\author{
UNI VERSIDADE DE SÃO PAULO \\ FACULDADE DE FILOSOFIA LETRAS E CIÊNCIAS HUMANAS \\ DEPARTAMENTO DE LETRAS CLÁSSICAS E VERNÁCULAS \\ PROGRAMA DE PÓS-GRADUAÇÃO EM ESTUDOS COMPARADOS DE \\ LITERATURAS EM LÍNGUA PORTUGUESA
}

MARI ANA CORTEZ

\begin{abstract}
Por linhas e palavras: o projeto gráfico do livro infantil contemporâneo em Portugal e no Brasil
\end{abstract}

São Paulo

2008 


\author{
UNIVERSI DADE DE SÃO PAULO \\ FACULDADE DE FILOSOFIA LETRAS E CIÊNCIAS HUMANAS \\ DEPARTAMENTO DE LETRAS CLÁSSICAS E VERNÁCULAS \\ PROGRAMA DE PÓS-GRADUAÇÃO EM ESTUDOS COMPARADOS DE \\ LITERATURAS EM LÍNGUA PORTUGUESA
}

\title{
Por linhas e palavras: o projeto gráfico do livro infantil contemporâneo em Portugal e no Brasil
}

Mariana Cortez

Tese apresentada ao Programa de PósGraduação em Estudos Comparados de Literaturas em Língua Portuguesa do Departamento de Letras Clássicas e Vernáculas da Faculdade de Filosofia, Letras e Ciências Humanas da Universidade de São Paulo, para obtenção do título de Doutora em Letras.

Orientador: Profa. Dra. Maria dos Prazeres Mendes Santos.

São Paulo

2008 
AUTORIZO A REPRODUÇÃO E DIVULGAÇÃO TOTAL OU PARCIAL DESTE TRABALHO, POR QUALQUER MEIO CONVENCIONAL OU ELETRÔNICO, PARA FINS DE ESTUDO E PESQUISA, DESDE QUE CITADA A FONTE.

Serviço de Biblioteca e Documentação da FFLCH/USP

Faculdade de Filosofia, Letras e Ciências Humanas da Universidade de São Paulo

Cortez, Mariana

Por linhas e palavras: o projeto gráfico do livro infantil contemporâneo em Portugal e no Brasil / Mariana Cortez; orientadora Maria dos Prazeres Mendes Santos. - São Paulo, 2008.

$407 \mathrm{f}$.

Orientadora: Profa. Dra. Maria dos Prazeres Mendes Santos

Tese (Doutorado - Programa de Pós-Graduação em Estudos Comparados de Literaturas em Língua Portuguesa do Departamento de Letras Clássicas e Vernáculas) - Faculdade de Filosofia, Letras e Ciências Humanas da Universidade de São Paulo.

1. Literatura infantil - livro-álbum 2. Semiótica discursiva 3. Portugal 4. Brasil 
MARI ANA CORTEZ

\section{Por linhas e palavras: o projeto gráfico do livro infantil contemporâneo em Portugal e no Brasil}

Tese apresentada à Faculdade de Filosofia, Letras e Ciências Humanas da Universidade de São Paulo, aprovada pela Banca Examinadora constituída pelos seguintes professores:

Profa. Dra. Maria dos Prazeres Mendes Santos FFLCH - Universidade de São Paulo Orientadora

São Paulo, de 
Aos olhos que nn Innro mo fitam

- created with nitro $^{\text {PDF }}$ professional download the free trial online at nitropod.com/profossional 


\section{AGRADECI MENTOS}

Gostaria de agradecer a todos que, por sua colaboração e incentivo, tornaram possível a realização desta pesquisa, em especial:

À CAPES, pela bolsa de estágio de doutoramento, oportunidade única de estudar em solo português;

À Profa. Dra. Maria dos Prazeres Mendes pela constante e dedicada orientação;

Ao Prof. Dr. Armindo Mesquita, pela orientação e acolhimento do outro lado do oceano;

À Universidade de Trás-os-Montes e Alto Douro pela recepção e acolhida;

À Profa. Dra. Teresa Colomer, por receber-me como aluna-ouvinte no Máster de Literatura para niños, na Universidade Autônoma de Barcelona;

À Profa. Dra. Ana Claudia de Oliveira por desenhar meu caminho;

À Profa. Dra. Diana Luz Pessoa de Barros por acompanhar meu trajeto;

Ao Colégio Santa Cruz - diretores, orientadores, professores do conselho de $8^{a}$. Série e alunos - pelo suporte tão necessário;

À minha mãe e aos meus irmãos (Paulo e Maristela) pelo amor sem palavras;

Ao Gusto, meu tio, por ensinar-me a estratégia de garrafas lançadas ao mar;

À Cláudia Trevisan, pela capa e conversas;

Ao amigo Ricardo por me ensinar o doce caminho português;

À Fantasia, à Pituca, aos pássaros e às plantas pela vida no novo lar. 


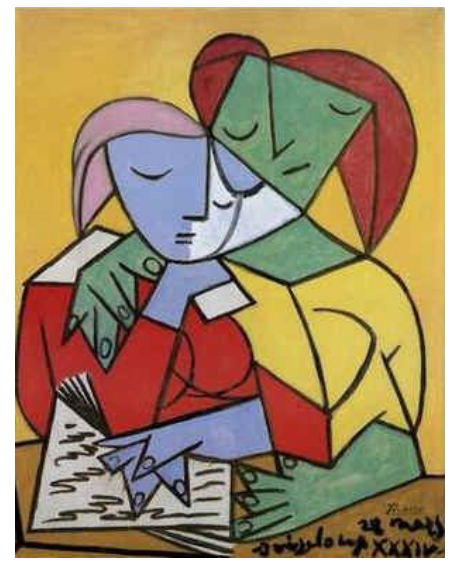

Viajar! Perder países! Ser outro constantemente, Por a alma não ter raízes De viver de ver somente!

Não pertencer nem a mim! I $r$ em frente, ir a seguir A ausência de ter um fim, $\mathrm{E}$ a ânsia de o conseguir!

Viajar assim é viagem. Mas faço-o sem ter de meu Mais que o sonho da passagem.

$O$ resto é só terra e céu.

(Fernando Pessoa)

O que me falta é esse eu que tu vês. E a ti o que falta é esse tu que eu vejo.

Por mais que avancemos no conhecimento um do outro, quanto mais nos refletirmos, mais seremos nutros. 
CORTEZ, Mariana. Por linhas e palavras: o projeto gráfico do livro infantil contemporâneo em Portugal e no Brasil. São Paulo, 2008. 407 f. Tese (Doutorado em Estudos Comparados de Literaturas em Língua Portuguesa) - Faculdade de Filosofia, Letras e Ciências Humanas, Universidade de São Paulo.

\section{RESUMO}

O trabalho que se apresenta tem por objetivo investigar a composição gráfica dos livros infantis. O corpus da pesquisa compreende as décadas de 1980 e 1990 e os primeiros anos do século XXI, em Portugal e no Brasil, a partir da seleção dos autores Manuela Bacelar (Portugal) e Roger Mello (Brasil). A escolha do corpus se justifica, pois ambos são, inicialmente, ilustradores para, em seguida, tornarem-se autores com dupla vocação, isto é, produtores de textos verbais e visuais. Além dessa característica, ambos desenvolveram uma produção literária voltada ao público infantil em que impera a diversidade de estratégias e relações entre sistemas semióticos, por exemplo: autores de livros de imagens, autoresilustradores de livros ilustrados e autores de livros-álbum. Essa última modalidade, em que há a integração dos textos verbal e visual, está no centro das discussões. A reflexão sobre o desenvolvimento desse gênero de texto à luz da Semiótica discursiva de linha francesa, a qual também fundamentará todas análises realizadas, compõe o primeiro capítulo deste trabalho de tese. Em seguida, abremse as portas para os livros infantis portugueses e o desenvolvimento do livro-álbum em Portugal, bem como serão realizadas análises minuciosas de três obras de Manuela Bacelar, a saber: O dinossauro (1990), A sereiazinha (1995) e Sebastião (2004). Cada uma das obras será abordada tendo em vista as diferentes relações entre palavra e imagem e a composição final em um projeto gráfico que deveria constituir um todo de sentido. Assim, as obras se diferenciam, pois O dinossauro é um livro-álbum, em que Bacelar é autora de dupla vocação; A sereiazinha é um livro-ilustrado, em que a autora portuguesa ilustra o clássico de Hans Christian Andersen e Sebastião exemplifica aquele gênero, em que, por meio de imagens, a artista plástica conta a história. No terceiro capítulo, o contexto brasileiro é colocado em foco e surge o trabalho em equipe, ou seja, uma equipe de profissionais é formada para criar o objeto-livro, e essa transforma-se em uma característica fundamental para a história do gênero livro-álbum no Brasil. Roger Mello é um autor bastante representativo dessa "corrente artística" e suas obras eleitas para análise se destacam pela produção em equipe e pela constituição de diferentes relações (ou grau de relações) entre palavra e imagem na composição do projeto gráfico. As seguintes obras serão analisadas com mais atenção: Jardins (2001) e Desertos (2006), texto verbal de Roseana Murray; Fita verde no cabelo: nova velha história (1992), em que Mello ilustra o conto de Guimarães Rosa e Vizinho, vizinha (2002), obra composta por uma equipe formada pelos artistas Mariana Massarani, Graça Lima e Roger Mello, e o último assina como autor do texto verbal. Finalmente, no quarto capítulo, é possível fazer um paralelo entre o contexto do livro-álbum e suas características nos cenários português e brasileiro, chegando a algumas invariantes, como a tendência ao traço pictórico em Portugal e ao grafismo no Brasil. Com isso, a partir de dois contextos particulares, vislumbra-se a importância do livro-álbum como um gênero cada vez mais presente no panorama da Literatura Infantil.

Palavras-chave: Literatura Infantil; Livro-álbum; Semiótica discursiva; Portugal; Brasil. 
CORTEZ, Mariana. Por linhas e palavras: o projeto gráfico do livro infantil contemporâneo em Portugal e no Brasil. São Paulo, 2008. 407 f. Tese (Doutorado em Estudos Comparados de Literaturas em Língua Portuguesa) - Faculdade de Filosofia, Letras e Ciências Humanas, Universidade de São Paulo.

\section{ABSTRACT}

The presented dissertation intends to investigate the graphic composition of children's books. The corpus of the research comprises the decades from 1980 to 1990 and the first years of the 21st Century, in Portugal and in Brazil, based on the selection of authors Manuela Bacelar (Portugal) and Roger Mello (Brazil). The choice of the corpus is justified because both were illustrators at first and then have become authors with double talent, that's to say, verbal and visual text producers. Besides this characteristic, both have developed a literary production dedicated to the juvenile public, based on the diversity of strategies and relations among semiotics systems, such as: picture books' authors, picture books illustratorauthors' and album formatted books' authors. This last mentioned modality of text, in which there is integration between texts (verbal and visual) is in the center of the discussions and the consideration about its development in light of the French discursive Semiotics, that will also validate every analysis made and constitute the first chapter of this thesis dissertation.Following, the door to Portuguese children's books and to the development of album formatted books in such country are opened; also, there will be a detailed analysis of three works by Manuela Bacelar: 0 dinossauro (1990), A sereiazinha(1995) and Sebastião (2004). Each of the works will be approached considering the different relations between word-image and final composition in a graphic project that should constitute a whole. So, the works differ one from the other, as $\mathrm{O}$ dinossauro is a album-book, in which Bacelar is a double talented author; A sereiazinha is an illustrated-book, in which the Portuguese author illustrates the Hans Christian Andersen's classic and Sebastião exemplifies the genre in which, by means of images, the plastic artist tells the history. In the third chapter, the Brazilian context is focused and the teamwork emerges, as in the production of comic books, and becomes a key characteristic to the album-book genre's history in Brazil. Roger Mello is an author quite representative of this 'artistic tendency' and the works chosen to be analyzed stand out by their team production and by their different relations' (or relation degrees') constitution between word and image in the composition of the graphic project. The following works will be analyzed with deeper attention: Jardins (2001) and Desertos (2006) verbal text of Roseana Murray; Fita verde no cabelo: nova velha história (1992), in which Mello ilustrates the tale of Guimarães Rosa and Vizinho, vizinha (2002), a work created by a team composed by the artists: Mariana Massarani, Graça Lima and Roger Mello and, still, the last signs it as its verbal text's author. Finally, in the fourth chapter it is possible to make a comparison between the album-book context and its characteristics in the Portuguese and in the Brazilian scenery, reaching some constants, such as the tendency to the pictorial trace in Portugal and to the graphism in Brazil. Therefore, from the two particular contexts, we can have a notion of the album-book as a genre increasingly present in the J uvenile Literature scene.

Key-words: Juvenile Literature; Album-book; Discursive semiotics; Portugal; Brazil. 


\section{STA DE I LUSTRAÇÕES}

Figura 1.1 - Reinações de Narizinho, J. Guillin (1930) 30

Figura 1.2 - A árvore que dava olhos, Maria Kheil (1954) 30

Figura 1.3 - De Morte! Angela Lago, 1992

Figura 1.4 - A raça Perfeita. Angela Lago e Gisele Lotufo (2004) 30

Figura 1.5 - Onde vivem os monstros? 46

Figura 1.6 - O pequeno azul e o pequeno amarelo 47

Figura 1.7 - Agora não, Bernardo $\quad 47$

Figura 2.1 - André Letria $\quad 60$

Figura 2.2 - João Caetano 60

Figura 2.3 - Gemeo Luís $\quad 60$

Figura 2.4 - Marta Torrão $\quad 60$

Figura 2.5 - Antony Browe 65

Figura 2.6 - Contracapa e capa $\quad 74$

Figura 2.7 - Contaminação cromática 76

Figura 2.8 - Contracapa $\quad 77$

Figura 2.9 - Klimt $\quad 77$

Figura 2.10 - Capa - fundo 77

Figura 2.11 - O Dinossauro $\quad 77$

Figura 2.12 - Chagall 77

Figura 2.13 - Inserção do P.S 80

Figura 2.14 - Situação inicial $\quad 81$

Figura 2.15 - Informações técnicas $\quad 82$

Figura 2.16 - Personagens instauram o narratário 84

Figura 2.17 - Transporte-monstro $\quad 84$

Figura 2.18 - Vizinhos trocam experiências pelas janelas 85

Figura 2.19 - Economia 86

$\begin{array}{ll}\text { Figura } 2.20 \text { - Profusão } & 87\end{array}$

$\begin{array}{ll}\text { Figura } 2.21 \text { - Alheio / Próprio } & 87\end{array}$

Figura 2.22 - Continuidade narrativa em duas páginar on

Figura 2.23 - Continuidade narrativa - quadro a quac 1 created with nitro $^{\text {PDF }}$ professional 
Figura 2.24 - Sua Alteza, a divinha! 92

Figura 2.25 - Abc doido $\quad 92$

Figura 2.26 - Linha da terra 93

Figura 2.27 - Consola-te - exemplo de linha da terra 95

Figura 2.28 - Comparação imagem de Bacelar e desenho infantil 97

Figura 2.29 - Desenho infantil - contorno 98

Figura 2.30 - Desenho infantil-linha da terra 99

Figura 2.31 - Silka, imagem de Manuela Bacelar 99

Figura 2.32 - Narrador-criança 101

Figura 2.33 - Narrador-adulto 101

Figura 2.34 - O professor na escola 105

Figura 2.35 - O professor 106

Figura 2.36 - Estudos de Leonardo Da Vinci 107

Figura 2.37 - Ruptura da fiç̧ão 108

Figura 2.38 - Situação inicial / Situação final 109

Figura 2.39 - Detalhe do título: fusão palavra/imagem 110

Figura 2.40 - Metáfora Visual 112

Figura 2.41 - Seqüência narrativa (virada de página) 112

Figura 2.42 - Capa e contracapa apresentam uma cena 113

Figura 2.43 - Passagem do tempo 114

Figura 2.44 - Sobrecapa 135

Figura 2.45 - Escultura em homenagem ao autor (Andersen) 137

Figura 2.46 - Desenho gráfico da página 143

Figura 2.47 - Quadrinho: anáfora da imagem da página seguinte 144

Figura 2.48 - Abstração (esquerda) $\rightarrow$ I cônica (direita) 145

Figura 2.49 - Paleta de cores de A sereizinha 148

Figura 2.50 - Página dupla 149

Figura 2.51 - Páginas simples 150

Figura 2.52 - Modelo de livro tradicional 151

Figura 2.53 - Modelo de livro 151

Figura 2.54 - Modelos de livros contemporâneos 152 
Figura 2.55 - Homologação do plano do conteúdo ao plano da expressão

Figura 2.56 - Percurso expressivo

Figura 2.57 - Influência de Trnka em Bacelar

162

Figura 2.58 - Influência de Chagall em Bacelar

164

Figura 2.59 - Cenário surrealista - Chagall

165

Figura 2.60 - Cenário Bacelar

165

Figura 2.61 - Detalhe de uma galinha no céu 166

Figura 2.62 - Detalhe de crianças (humanos) caindo

166

Figura 2.63 - Sereia com óculos de mergulho e uma figura de peixe

Figura 2.64 - Expressão do movimento/ Figura do pássaro negro

Figura 2.65 - Detalhe das figuras humanas caindo/ esqueleto de peixe

Figura 2.66 - Coruja de O dinossauro/ Coruja de A sereiazinha/Carcaça de rabo de peixe e figura humana

Figura 2.67 - A criança-sereia espia a príncipe 172

Figura 2.68 - Movimento ascendente 172

Figura 2.69 - Figura recorrente 173

Figura 2.70 - Ceci n'est pás une pipe 178

Figura 2.71 - Comparações: placa e muro 181

Figura 2.72 - Caixa com objetos não identificáveis 182

Figura 2.73 - Cena de rua: o protagonista é agressor 183

Figura 2.74 - Publicação francesa/espanhola 184

Figura 2.75 - As duas capas

Figura 2.76 - Uma das capas

Figura 2.77 - Outra capa

Figura 2.78 - Exemplo de Flip book 188

Figura 2.79 - Exemplo de Flip book II 189

Figura 2.80 - Histórias de um segredo (primeira página) 190

Figura 2.81 - Histórias de um segredo (segunda págir 
Figura 2.83 - A maior flor do mundo

Figura 2.84 - Detalhe do peixe

Figura 2.85 - Detalhe da intenção do bebê 192

Figura 2.86 - Detalhe da alteração dos objetos 193

Figura 2.87 - Detalhe das expressões faciais 194

Figura 2.88 - Detalhe da caneca com a inscrição S 194

Figura 2.89 - Oposição preto/branco versus colorido 195

Figura 2.90 - Oposição preto/branco versus colorido, em A flor do lado de lá

195

Figura 2.91 - Oposição linha da terra reta versus ondulada 196

Figura 2.92 - Oposição página vazia versus página preenchida 196

Figura 2.93 - Detalhe da expressão facial 197

Figura 2.94 - Quadrado semiótico 198

Figura 2.95 - Sebastião 199

Figura 2.96 - A sereiazinha 199

Figura 2.971 - Detalhe da instauração do narratário 199

Figura 2.98 - Mãe conduz o menino para a realidade 200

Figura 2.99 - Menino pendurado 200

Figura 2.100 - Detalhe da expressão facial 201

Figura 2 - Página de passagem 201

Figura 2.102 - El Gato que sonríe... (Eric Battut- França) 203

Figura 2.103 - Máquinas (Chloé Poizat- França) 203

Figura 2.104 - Detalhe da colagem 203

Figura 2.105 - Detalhamento (mãos, cabelo, olhos) 204

Figura 2.106 - Paleta de cores de Sebastião 205

Figura 2.107 - Sebastião - Manuela Bacelar 205

Figura 2.108 - Chagall 206

Figura 2.109 - Trnka 206

Figura 3 Detalhe da expressão corporal 206

Figura 2.112 - Detalhe dos retornos (narrativa A/narrativa B) 207

Figura 2.113 - As capas 207

Figura 3.1 - O pequeno azul e o pequeno amarelo (19 
Figura 3.2 - Le Petit Chaperon Rouge (1965)

Figura 3.3 - Flicts (1969)

Figura 3.4 - Mondrian 218

Figura 3.5 - Reinações de Narizinho - Votolino 220

Figura 3.6 - A bela borboleta 220

Figura 3.7 - Pedacinho de pessoa 220

Figura 3.8 - O homem no sótão 220

Figura 3.9 - Jardins de Versailles, criado por André Le Nôtre e construído para Louis XIV

231

Figura 3.10 - Kirstenbosch Botanical Gardens Table Mountain África do Sul

231

Figura 3.11 - Mirabell Garden, em Salzburg (Áustria) 231

Figura 3.12 - Parque Guell de Gaudí (Espanha) 231

Figura 3.13 - Apresentação da capa 234

Figura 3.14 - Página de abertura 234

Figura 3.15 - Página de rosto 235

Figura 3.16 - Exemplo de uma pasta de pesquisador 236

Figura 3.17 - Esquema da disposição das páginas 238

Figura 3.18 - Paleta de cores de Jardins 239

Figura 3.19 - Palavra se relaciona com a imagem 240

Figura 3.20 - Palavra como contraponto da imagem 241

Figura 3.21 - Imagem se relaciona com imagem 241

Figura 3.22 - I magem narrativa 242

Figura 3.23 - Matisse 245

Figura 3.24 - Jardins 245

Figura 3.26 - Referências interdiscursivas 246

Figura 3.27 - Henri Rosseau 247

Figura 3.28 - Jardins 247

Figura 3.29 - Escher 247

Figura 3.30 - Jardins 247

Figura 3.31 - Lagarto - Gaudí 247

Figura 3.32 - Jardins 
Figura 3.33 - Capa

Figura 3.34 - Caderno de viagem da artista Tarsila do Amaral

Figura 3.35 - Retângulo-moldura com título e autores da obra

Figura 3.36 - Etiqueta exemplo

252

Figura 3.37 - Detalhe do grafismo

252

Figura 3.38 - Página de falsa guarda

253

Figura 3.39 - Tapete Desertos

256

Figura 3.40 - Exemplo de tapete persa

256

Figura 3.41 - Detalhe da ficha e da lamparina

256

Figura 3.42 - Página de rosto de Desertos

259

Figura 3.43 - Detalhe tipografia mecânica e manuscrita

263

Figura 3.44 - Relação palavra-imagem improviso

264

Figura 3.45 - Detalhe de traços culturais

267

Figura 3.46 - Reprodução das provas litográficas de Picasso

268

Figura 3.47 - Seqüência da linha

270

Figura 3.48 - Oscar Niemeyer

271

Figura 3.49 - Linha e curvas

271

Figura 3.50 - Waltércio Caldas

272

Figura 3.51 - Linhas

272

Figura 3.52 - A Banguelinha 273

Figura 3.53 - A flor do lado de lá 273

Figura 3.54 - Moi j'attends $\quad 274$

Figura 3.55 - Releitura de Chapeuzinho Vermelho 288

Figura 3.56 - Voz de Rosa 301

Figura 3.57 - Voz de Rosa pela imagem 302

Figura 3.58 - Voz do texto-base 303

Figura 3.59 - Arquitetura colonial de Minas Gerais (luminária/guarda-corpos) 304

Figura 3.60 - Movimento ascendente e descendente das ruas de Minas Gerais

Figura 3.61 - Anjos barrocos

305

Figura 3.62 - Homem-lobo 
Figura 3.63 - Olhar de soslaio

Figura 3.64 - A flor do lado de lá 308

Figura 3.65 - Griso, o unicórnio 308

Figura 3.66 - Jardins 308

Figura 3.67 - Desertos 308

Figura 3.68 - Ver de ver meu pai, Celso Sisto 308

Figura 3.69 - La composición 309

Figura 3.70 - Irmãos Pretos 309

Figura 3.71 - Figura Hiper-realista 311

Figura 3.72 - Edward Hopper 312

Figura 3.73 - Hiper-realismo Hooper 312

Figura 3.74 - Cenas Surrealistas 313

Figura 3.75 - Situação inicial $\quad 314$

Figura 3.76 - Situação final 314

Figura 3.77 - Estratégia recorrente nas capas 316

Figura 3.78 - Sombra lobo (presença da morte) 316

Figura 3.79 - Sombra menina 316

Figura 3.80 - Sombra menina=lobo 316

Figura 3.81 - Ambigüidade espacial 317

Figura 3.82 - Capa $\quad 319$

Figura 3.83 - Detalhe das personagens 320

Figura 3.84 - Contracapa e capa 321

Figura 3.85 - Página de guarda 322

Figura 3.86 - Página de rosto 323

Figura 3.87 - Cenário sem fachada 327

Figura 3.89 - Divisão do cenário 328

Figura 3.90 - Capa 328

Figura 3.91 - Página de rosto 328

Figura 3.92 - Primeira Página 328

Figura 3.93 - Personagem no chuveiro 330

Figura 3.94 - Seqüência da personagem coadjuvante 333

Figura 3.95 - Portas-personagens 
Figura 3.96 - O menino quadradinho - Ziraldo

Figura 3.97 - Antes e depois da visita

Figura 3.98 - Espaços invadidos

Figura 3.99 - A volta à rotina

Figura 3.100 - Nova expectativa

Figura 3.101 - Debreagem enunciva

Figura 3.102 - Instauração do ele, lá, algures 344

Figura 3.103 - Construção das personagens 346

Figura 3.104 - As crianças 347

Figura 3.105 - Los abuelos 349

Figura 3.106 - Capa de El hilo de la vida 349

Figura 3.107 - Miolo de El hilo de la vida 349

Figura 3.108 - Citações pontuais 350

Figura 4.1 - Cântico dos cânticos 355

Figura 4.2 - O nascimento da Vênus, de Botticelli 357

Figura 4.3 - Eva, de Ziraldo 357

Figura 4.4 - Chiquita Bacana e outras pequetitas - Joãozinho e o pé de feijão - Obra de Picasso 358

Figura 4.5 - Apartamento da Vizinha povoado de histórias 359

Figura 4.6 - Máscaras observando $\quad 359$

Figura 4.7 - Referências intertextuais $\quad 359$

Figura 4.8 - Ricardo Azevedo 360

Figura 4.9 - André Letria 361

Figura 4.10 - Ar Penck 361

Figura 4.11 - A bela borboleta - grampos 365

Figura 4.12 - O personagem encalhado 365

Figura 4.13 - André Letria - História de um Segredo 366

Figura 5.1 - Relação metonímica 369

Figura 5.2 - Relação anafórica $\quad 370$

Figura 5.3 - Relação determinante de gênero 370

Figura 5.4 - Relação enigmática 371

Figura 5.5 - Relação formal 
Figura 5.6 - Edição portuguesa

Figura 5.7 - Lancelote \& Lampião

374

Figura 5.8 - No longe dos Gerais $\quad 374$

Figura 5.9 - Conto de escola 374

Figura 5.10 - Charadas macabras 375

Figura 5.11 - De morte! 375

Figura 5.12 - A maior flor do mundo 377

Figura 5.13 - Palavra para lavra 377

Figura 5.14 - O perfume do sonho, na tarde 377

Figura 5.15 - André Letria 378

Figura 5.16 - Danuta Wojciechowska 378

Figura 5.17 - Marta Torrão 378

Figura 5.18 - Sua alteza, a divinha $\quad 379$

Figura 5.19 - A raça perfeita 379

Figura 5.20 - André Letria 379

Figura 5.21 - Angela Lago $\quad 380$

Figura 5.22 - Marta Torrão 383

Figura 5.23 - Maria Kheil 383

Figura 5.24 - A exposição, em Portugal - imagem de Gemeo Luis 384

Figura 5.25 - A "boneca" - no Brasil - imagem da obra de Graça Lima 384

Figura 5.26 - João Caetano 385

Figura 5.27 - André Letria 385

Figura 5.28 - Angela Lago 385

Figura 5.29 - Gemeo Luis 386

Quadro 2.1 - Quadrado Semiótico 198

Quadro 3.1 - Quadrado Semiótico 336

Quadro 3.1 - Gradação acabada versus inacabada 315

Tabela 3.1 - Aproximações entre os projetos gráficos - Jardins e Desertos 280

Tabela 3.2 - Distanciamentos entre os projetos gráficos - Jardins e Desertos 
Tabela 5.1 - A capa e o material

Tabela 5.2 - As técnicas plásticas empregadas 380

Tabela 5.3 - Técnicas plásticas empregadas 387

Tabela 5.4 - Abordagens temáticas 390

Tabela 5.5 - Comparativo das características da literatura infantil contemporânea 390

Tabela 5.6 - Critérios para avaliação de um projeto gráfico 392 


\section{SUMÁRI O}

INTRODUÇÃO: APRESENTANDO O FAZER .......................... 21

Fios emaranhados e soltos: definições............................... 22

1 LITERATURA INFANTIL: UM DISCURSO ......................... 29

1.1 A imagem em pauta: a história ................................ 31

1.2 A história no espaço educacional: reflexos e implicações......... 34

1.3 A imagem, o livro e a sociedade: a construção de uma

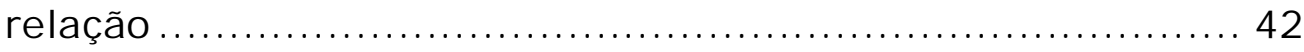

1.4 A imagem no mercado editorial para crianças: perspectivas .... 45

2 VIAGEM CERCADA POR CONTRADIÇÕES: O CONTEXTO

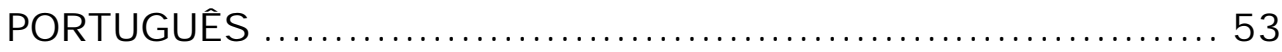

2.1 Os livro-álbuns para crianças em Portugal: destravando

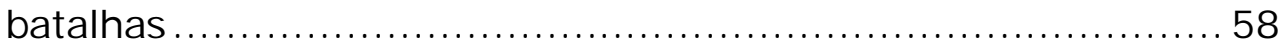

2.2 A obra de Manuela Bacelar: desbravando espaços .............. 67

3 CONTEXTO BRASILEI RO: ENTRECRUZAR DE CONFLITOS ........ 210

3.1 O livro-álbum no Brasil: um filho dos quadrinhos ................. 216

3.2 Roger Mello: explosão de experiências .......................... 222

3.3 Diálogos entre projetos gráficos: uma proposta poética .......... 224

3.4 Fita Verde no Cabelo - nova velha estória: emaranhados de

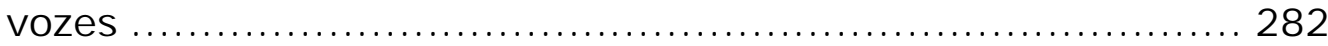

3.5 Desencontro para revelar encontros: Vizinho, Vizinha........... 319

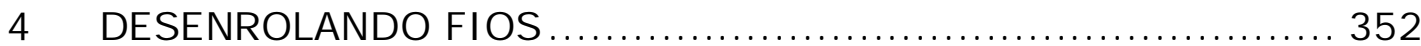

4.1 A Intertextualidade como uma Estratégia Literária: Um Fio Essencial........................................................ 352 
CONCLUSÃO: A SITUAÇÃO DO PROJ ETO GRÁFICO DOS LIVROS INFANTIS CONTEMPORÂNEOS EM PORTUGAL E NO BRASIL:

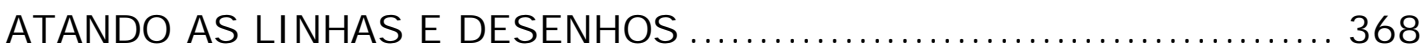

REFERÊNCI AS BI BLI OGRÁFICAS ................................... 395 


\title{
I NTRODUÇÃO
}

\section{APRESENTANDO O FAZER}

\author{
É muito fácil perder-se \\ Entre fios e tramas, \\ Basta um sopro \\ E já se desarruma o deserto, \\ Já se abrem suas portas \\ De luz e vento, \\ E a areia do tempo escorre \\ Para construir cidades. \\ (Roseana Murray)
}

Diante de diversos fios, ao mesmo tempo emaranhados e soltos, configura-se a tentativa de fazer deles um tecido bem tramado, para assim apresentar o livro destinado às crianças. O tema do tecer põe foco no texto em seu processo. Com essa característica, assume-se o trabalho de pesquisa que se apresenta. Um fazer reflexivo em processo. Sua urdidura consolidarse-á à medida do seu fazer.

O tecido-texto que se descortina para análise é aquele que implica fios-expressões provenientes de sistemas semióticos distintos - o verbal e o visual -, fios-contextos originários de territórios distantes - Portugal e Brasil - e, ainda, um olhar-mãos-tecelão que poderia ter nascido em diferentes campos de estudo - Educação, História, Psicologia, Literatura, Semiótica, entre outros.

Para continuar na isotopia da tecelagem, cabe eleger qual olhar será lançado sobre o dito tecido e quais serão as agulhas-metodológicas que tramarão os fios ora disformes em um tecido (com) forma.

Desatando a metáfora que abre este caminho investigativo, a imagem e a palavra (fios-expressões) serão abordadas na literatura infantil de Portugal e do Brasil (fios-contextos), mais que isso, o protagonista dessa empreitada é o projeto gráfico como um todo significativo. 
Antes, porém, de delinear a fundamentação teórica, revela-se a consciência sobre a complexidade do objeto, pois, de antemão, conhecem-se as prerrogativas determinadas pela eleição do corpus, a saber: a dificuldade de encontrar identidade, a eterna luta leitura-leitor, o estigma da imagem em oposição à educação escrita nas sociedades, entre outras. Estas são questões que, inicialmente, seguram os passos para não incorrer em conclusões apressadas.

Assim, obedecendo ao tempo em que as avós teciam cachecóis para o inverno, cada uma das questões virá à cena, para que, depois de os fios estarem desembaraçados, possa-se, novamente, uni-los em uma trama com formas e cores ordenadas ao gosto do analista-tecelão que ora expõe seu método e deseja confortar aquele que acompanha este fazer, ou seja, vislumbram-se as questões destacadas como inerentes ao presente objeto, mas como secundárias nas análises propostas.

\section{Fios Emaranhados E Soltos: Defi ni ções}

\begin{abstract}
Definir: 1. determinar a extensão ou os limites de; limitar, demarcar. 2. Enunciar os atributos essenciais e específicos de (uma coisa), de modo que a torne inconfundível com outra. 3. explicar o significado de; indicar o verdadeiro sentido de. 4. Dar a conhecer de maneira exata; expor com precisão; explicar.
\end{abstract}

(Dicionário Aurélio)

Definir não é uma tarefa fácil. Por vezes, o que se consegue é a aproximação, pela palavra, de um objeto. Tal aproximação pode garantir a totalidade do objeto que se vai definir ou apenas matizar a expressão, ou seja, tomá-la em parte. Como diria Clarice Lispector: “a aproximação do que quer que seja se faz gradualmente e penosamente...". Definir é nomear, é abranger algo em um nome, é dar col 
objeto. Entretanto, apenas um nome contemplaria uma expressão complexa? Eis a questão. A complexidade de um objeto determina muitas relações intrincadas na composição, eis a dificuldade imposta pelo livro para crianças.

Desta maneira se apresenta o objeto de leitura dado à criança. Como um universo complexo que resiste à definição, que não cabe em um espaço determinado, que se agita quando enquadrado em um nome. Para exemplificar a problemática manifesta, convoca-se um conto do aclamado Guimarães Rosa, Fita Verde no cabelo - nova velha estória, e perguntase: apenas por receber ilustrações em uma edição da Nova Fronteira poderia ser considerado literatura infantil? Apenas a ilustração alteraria o "status" de literatura? Além disso, pergunta-se: a quem caberia definir e catalogar as obras literárias destinadas ao público infantil? Existe tal distinção entre públicos? ${ }^{1}$

Aqui, há também problemas: a quem cabe a tarefa de analisar o objeto de leitura dado à criança? Ao crítico literário, ao pedagogo, ao psicólogo, ao lingüista? Sem dúvida, diante de um objeto complexo, todas estas disciplinas poderiam tomá-lo para o seu estudo. Cada estudioso, então, teria um rincão do objeto. Essa atitude, contudo, não minimiza o problema inicial - como definir o objeto? Ou cada área teria sua maneira de defini-lo? E usaria a obra literária conforme a designação da disciplina?

Um texto, segundo as teorias discursivas, poderia ser abordado a partir de diferentes perspectivas em relação interdisciplinar. A disciplina que o estuda não seria um critério para a definição. Talvez, dessa maneira, como texto, este objeto possa ser definido. Talvez, como discurso, possa ser analisado. Interessaria, então, a partir da semiótica discursiva, perceber o que o texto diz e como diz, para, assim, relacionálo à trama interdisciplinar que o compõe no nível discursivo, como postulado por Greimas e seus colaboradores. Portanto, o trabalho que ora

1 A obra citada, a saber: Fita Verde no cabelo: nova velha estória de fılıimarãec Rnca com ilustrações de Roger Mello, será analisada ao longo do cuidado, com o objetivo de desvendar as incógnitas esboçada 
se apresenta não pretende destacar os diferentes olhares sobre o objeto, antes, esclarece a fundamentação teórica norteadora das análises.

Vale pontuar como o conceito de texto é compreendido por este estudo; para isso, cita-se Diana Luz Pessoa de Barros, em Teoria semiótica do texto:

[...] o texto só existe quando concebido na dualidade que o define - objeto de significação e objeto de comunicação - e, dessa forma, o estudo do texto com vistas à construção de seu ou de seus sentidos só pode ser entrevisto como o exame dos mecanismos tanto internos quanto dos fatores contextuais ou sócio-históricos de fabricação do sentido (1999, p. 8).

Define-se, pois, neste trabalho, o livro que é dado à criança como texto e, por essa perspectiva, ele será analisado internamente, evidenciando suas relações intrínsecas de conteúdo e de expressão - que história é narrada e como ela é contada, seja pela expressão da palavra, seja pela expressão da imagem, e o projeto gráfico que guarda (envolve, organiza) a relação palavra-imagem será abordado como um texto que estabelece relações com o público, visto que, nesse discurso, como bem afirma Zohar Shavit, há o duplo destinatário:

Deste modo, ao contrário de outros textos que presumem um único leitor implícito e uma única (embora flexível) realização ideal do texto, o texto ambivalente tem dois leitores implícitos: um pseudodestinatário e um destinatário real. Não se espera que a criança, que é o leitor oficial do texto, realize o texto na sua totalidade, sendo muito mais uma desculpa para o texto do que o seu genuíno destinatário (2003, p.105).

Além disso, o conteúdo, nesse texto (obra literária destinada à criança ${ }^{2}$ ), é dado ora por um texto narrativo, ora por um texto descritivo

2 A questão do duplo destinatário será tratada por Shavit como a crianca (leitor ideal) e o adulto, que tem o poder de decisão; seja pai, professor literária destinada ao público infantil teria de atender tam 
ou informativo; obedecendo aos níveis das estruturas mais abstratas até as organizações mais concretas, como ensina a semiótica discursiva na abordagem analítica dos textos em geral.

A expressão pode, no entanto, dar-se por diferentes sistemas - o verbal, o visual, o sonoro. Eis mais uma questão solta. Como analisar tal expressão? Deve-se separar cada uma das expressões ou devem ser analisadas conjuntamente? Ainda, seria válido interrogar para que servem tais expressões ou como essas dizem o que querem dizer. Recorre-se novamente à Semiótica, que postula a seguinte metodologia:

A Semiótica sabe da necessidade de uma teoria geral do texto e reconhece suas dificuldades. Por isso mesmo, na esteira de L. Hjelmslev, propõe, como primeiro passo para a análise, que se faça abstração das diferentes manifestações - visuais, gestuais, verbais ou sincréticas - e que se examine apenas seu plano do conteúdo. As especificidades da expressão, na sua relação com o conteúdo, serão estudadas posteriormente (BARROS, 1999, p. 8).

Quando retomada a expressão, o projeto gráfico e suas implicações virão à tona, uma vez que interrogar sobre seu grau de comprometimento na significação é urgente, porque dali também brota o sentido da obra de literatura para crianças.

Além dos procedimentos metodológicos, a questão da identidade da literatura para crianças ainda perpassa pelo destinatário, como dito por Shavit (2003), visto que o livro será tomado, também, como objeto de comunicação, implicação da postulação teórica adotada.

Enquanto, para alguns, esse conflito sobre o destinatário de literatura infantil já está superado; para outros, será eterno. Aqui, definese o tecido como texto e como algo que se dá a ver aos sentidos de um sujeito que possui em seu repertório poucas informações, poucas imagens, poucas recorrências. Um sujeito com um olhar "quase" 
inaugural, não totalmente, mas um "quase" olhar inaugural. Passar, pois, da percepção das malhas do sensível para a cognição é o processo que se oferece, e, como afirmam Lajolo e Zilberman, em A Formação da Leitura no Brasil, o leitor se torna texto, corroborando a idéia de sujeito da enunciação delineado pelas teorias do discurso:

[...] o leitor empírico, destinatário virtual de toda criação literária, é também direta ou indiretamente introjetado na obra que a ele se dirige. Assim, nomeado ou anônimo, converte-se em texto, tomando a feição de um sujeito com o qual se estabelece um diálogo, latente mas necessário (1999, p.17).

O adulto, não se pode esquecer, é mediador da situação. Ele é quem oferece o livro: como pai, professor ou bibliotecário. A literatura infantil tem, pois, uma dupla função: atender à demanda e aos anseios da criança e às exigências do adulto mediador. Esses dois destinatários são textos em literatura infantil.

O texto será entendido, sobretudo, como um objeto que aciona e transforma o sujeito-criança por suas qualidades perceptivas. Tratar-se-á a literatura infantil, antes de um meio para educar (embora o faça), como um objeto estético que é sentido pelo corpo e, de alguma maneira, modifica este corpo perceptivo, fazendo que relações e redes outras se corporifiquem.

A semiótica do sensível ${ }^{3}$, proposta a partir de Da imperfeição, de A. J. Greimas, e nutrida pela fenomenologia de Merleau-Ponty, é base teórica para o desenvolvimento das pesquisas de Ana Claudia de Oliveira em seu artigo "A estesia como condição do estético", um dos que compõem a obra Do inteligível ao sensível, em que autora aborda o processo do sujeito diante do objeto sensível:

3 A semiótica do sensível vem sendo desenvolvida principalmente nelna necruicardnrea do Centro de Pesquisas Sociossemióticas (CNRS/ USP/ PI Landowski e Ana Claudia de Oliveira. 
O sentir está no texto, marcando, caso a caso, as mudanças de estado e passagens de isotopias. Quanto mais sensações são ativadas numa escritura, mais sensibilidade é requerida, sustentando a revelação em forma de "uma seqüência de modalidades aléticas e veridictórias.'

Incrustadas no nível da enunciação, as estratégias figurativas das sensações põem enunciador e enunciatário em sintonia, estado que possibilita ao último partilhar o conhecimento do primeiro e aprender com ele como adquirir competências que Ihe permitirão penetrar no segredo desse milagre que é o de se reunir ao mundo e apagar de vez, no tempo de duração da ocorrência, a separação entre sujeito e mundo (1995, p. 234).

Além da semiótica do sensível, também a teoria da leitura, em especial da literatura para crianças, deflagrou essa ocorrência sensível, cita-se Teresa Duran, em Leer antes de Leer:

Antes de saber 'leer' se ha de saber 'sentir'. Lo mejor es que nacemos sintiendo. Más que eso, sentimos antes de nacer, según dicen los especialistas. Así pues, la mitad del trabajo está hecho. Sentimos, percibimos los signos de nuestro entorno. Y tenemos la facultad de organizarlos siguiendo un orden significativo que puede ser valorado positivamente o negativamente, es decir, emotivamente $y$, por consiguiente, de manera afectiva. [...] I dentificarse al leer es establecer con lo que leemos una relación al mismo tiempo afectiva y enriquecedora (2002, p. 42).

Assim, o sujeito criança poderá formar seu repertório como leitor de obras de arte, sejam literárias ou plásticas. Os sentidos podem também apresentá-lo ao mundo percebido, ao mundo visível, constituindo-o, portanto, como indivíduo para atuar socialmente. Talvez seja mesmo essa a função da literatura e por isso agrade tanto os adultos como as crianças. Lygia Bojunga Nunes poetiza o fenômeno:

A gente bota essas experiências fortes de lado, mas elas ficam acontecidas dentro da gente; e os fragmentos delas formam um novo desenho lá caleidoscópio. Um caleidoscópio que

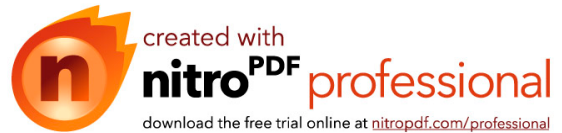


Só que no nosso caleidoscópio as imagens viradas - mesmo parecendo que nunca mais vão voltar, acabam aparecendo e de novo - porque a gente não deixa de ser cada desenho que criou (1990, p. 9).

Dessa maneira, pretende-se entender a concepção de projeto gráfico e suas implicações na leitura dos livros infantis nos dois países Portugal e Brasil -, a partir dos seguintes autores e obras: Manuela Bacelar (O dinossauro, A Sereiazinha e Sebastião) e Roger Mello (Jardins/Desertos, Fita Verde no cabelo: nova velha estória e Vizinho, Vizinha). Em cada projeto, os autores apresentam diferentes modos de presença, a saber: autor de palavra e imagem, de imagens de textos clássicos e de livro de imagem. A escolha de tais artistas se deve ao fato de serem bastante reconhecidos em seus países, seja pela crítica, pelo público ou por experimentarem a autoria do texto verbal mesmo sendo, por formação, artistas plásticos ou, ainda, por ousarem como produtores da concepção gráfica da obra.

A metodologia de análise parte do conteúdo, passando pela expressão e suas implicações discursivas que tangem à sensibilização do leitor e se encaminham para uma relação entre a obra literária inserida no campo das artes em geral e as outras artes, como as plásticas, cinematográficas, teatrais, entre outras, com o intuito de verificar a existência de interdiscurso e intertextualidade. 


\section{LITERATURA I NFANTI L: UM DI SCURSO}

Vale segurar os passos ansiosos e pontuar que o mundo não é composto apenas por palavras, como é sabido. O livro para crianças também não. Nele, há um alimentar constante, em que o mundo alimenta o livro, e vice-versa; sendo esse último, portanto, um objeto de comunicação, como dito anteriormente. Um discurso está sempre inserido em um contexto - refletindo-o e refratando-o, como postula Bakhtin, em Marxismo e filosofia da linguagem:

Cada signo ideológico é não apenas um reflexo, uma sombra da realidade, mas também um fragmento material dessa realidade. Todo fenômeno que funciona como signo ideológico tem uma encarnação material, seja como som, como massa física, como cor, como movimento do corpo ou como outra coisa qualquer. Nesse sentido, a realidade do signo é totalmente objetiva e, portanto, passível de um estudo metodologicamente unitário e objetivo (1981, p. 33).

Como signo ideológico, a literatura infantil se nutre dos movimentos discursivos de sua época, incorporando-os. Pulsam, portanto, as novas informações e, com elas, as novas linguagens neste mundo globalizado e conectado por imagens satélites. As obras literárias deste tempo constituem o corpus de análise desta pesquisa. Tanto Manuela Bacelar (Portugal) quanto Roger Mello (Brasil) pertencem a gerações pós1970 e acompanharam as transformações de sua época, em algumas obras com mais intensidade e em outras menos, mas, sem dúvida, são reflexo desse contexto.

Talvez hoje seja obsoleto abordar a crise gerada pela televisão nos anos 1950, mas aí está o despertar da questão da imagem no mundo adulto e no infantil. Ou seja, com os avanços tecnológicos, as linguagens se transformam e atuam sobre os sujeitos no mundo. A criança é, pois, um sujeito no mundo e está sensível aos estímulos que pairam no ar. 0 livro, para seduzir, atrair e convencer a criança, nãc 
discussão sobre a imagem e também de abarcá-la em seu corpo, visto que, como discurso, assimila o contexto, sem esquecer, obviamente, das demandas mercadológicas que visam a resgatar o leitor, que é, evidentemente, consumidor. A seqüência cronológica de imagens de obras literárias comprova as afirmações anteriores ${ }^{4}$.

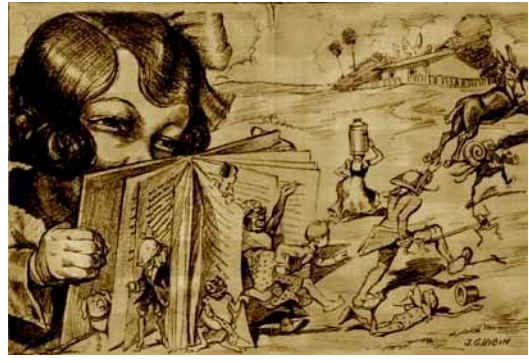

Figura 1.1 - Reinações de Narizinho, J. Guillin (1930)

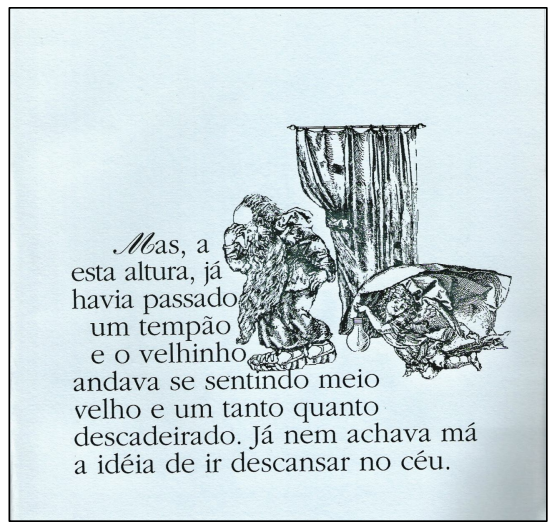

Figura 1.3 - De Morte! Angela Lago, 1992

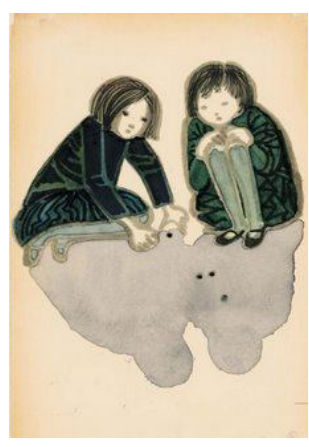

Figura 1.2 - A árvore que dava olhos, Maria Kheil (1954)

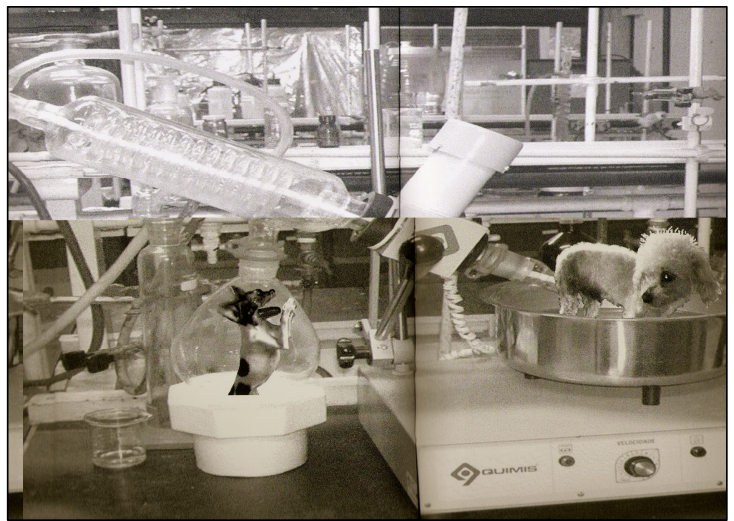

Figura 1.4 - A raça Perfeita. Angela Lago e Gisele Lotufo (2004)

Retomar o percurso histórico da imagem no livro para criança é o horizonte que desponta neste momento de reflexão. Esse trajeto é apenas um exercício para contextualizar as análises que seguirão como propósito dessa investigação.

4 Estas imagens são apenas exemplificações, não haverá anrofındamento na abordagem das obras citadas, apesar do seu grande valor infantil. 


\subsection{A I Magem Em Pauta: A Hi stória}

Para compreender a importância da imagem na sociedade, há que se olhar para a história da humanidade. O homem sempre utilizou a imagem como linguagem para contar sua vida, suas crenças, seus amores, enfim, para criar sua história, sua narrativa de vida. As artes primitivas, ou mesmo os murais dos templos renascentistas são exemplos deste fazer na História da Humanidade e, como conseqüência, na História da Arte. David Mc Kee conta o seguinte sobre o tema:

Cuando los primeros cristianos comenzaron a construir sus iglesias, hubo gran controversia acerca de las decoraciones interiores, especialmente con relación a los grabados. En el siglo VI, el Papa Gregorio Magno estableció un mandato que bien Ilevó a la I glesia Cristiana Occidental hacia una dirección. Dijo: 'La pintura puede hacer por los analfabetos lo que la escritura hace por aquéllos que leen' (2005, p. 159).

Seja por ignorância do sistema escrito, seja por desenvoltura na arte visual, uma vez que é uma habilidade inata ${ }^{5}$, o homem sempre se expressou por narrativas dadas aos olhos com o objetivo de atingir um maior número de pessoas. Assim, a religião e a educação tomaram a imagem para alcançar o público que não dominava o sistema escrito, porque essa linguagem sempre se comunicou com os não iniciados nas letras. A imagem tem sobre a escrita duas vantagens iniciais: a comunicação imediata e a facilidade de apreensão, que não exige, pelo menos este era o pensamento, o esforço do letramento.

Muito se passou em atos e conceitos, tendo a palavra, na contracorrente da facilidade de decodificação, se sacralizado. O sistema escrito elitiza na medida em que seleciona um público e, portanto, exclui os não-iniciados. Apesar disso, fez-se "grande e importante", ou seja, aquele que detinha sua decodificação pertencia ao mundo. Com esse

5 Ou se pensava que fosse. A imagem era entendida como portanto as possibilidades metafóricas dessa linguagem eram 
caráter, a escrita dominou as linguagens e todos desejavam iniciar-se nas artes das letras para fazer parte do grupo até como cidadão, uma vez que o analfabetismo exclui da vida pública.

Neste contexto, a imagem foi renegada ou mesmo excluída das prioridades educacionais e, por vezes, anti-heroína nessas discussões, pois a instituição escolar tinha por objetivo propiciar a aquisição do sistema escrito. Três argumentos sustentam a rejeição da imagem no cenário delineado: 1) a imagem como distração, diversão; 2) como facilitador da decodificação da escrita; 3) como delimitador do código escrito.

Esses três argumentos, muitas vezes, apareciam juntos, contudo, há que se pensar sobre cada um deles isoladamente, com o propósito de entender a rejeição da imagem e enaltecer a palavra e, assim, entender o papel da palavra e da ilustração no livro infantil, sendo este o objetivo deste capítulo.

No primeiro argumento - a imagem como distração -, essa, por suas qualidades sensíveis (cores, formas, texturas, planos), desviaria a atenção do leitor que, para decodificar as letras negras, deveria estar o mais centrado possível em seu fazer recém-aprendido.

O outro argumento - a imagem como facilitador - credita a ela a propriedade facilitadora. Enquanto a palavra exigiria esforço e aplicação para ser entendida e, sobretudo, demandava ensinamento e justificava a importância da instituição escolar; a imagem, por outro lado, era de compreensão inata, tendo em vista que sua função era retratar a realidade (uma linguagem referencial). Nesse discurso-argumento, a imagem é compreendida instantaneamente. Vê-se interligado a este argumento, o pensamento de que ela não necessita de leitura.

A partir da década de 1970, no entanto, essa idéia de habilidade inata é totalmente descartada, como bem declara Dondis em Sintaxe da linguagem visual (1997). A visão da estudiosa se desenvolveu a partir dos estudos da percepção - Gestalt e das abordagens discursivas da imagem - e da Semiologia. Essa visão, contudo, de a imagem necessitar de 
estudo, demorou a fazer parte dos currículos escolares dos países em foco nesta investigação - Portugal e Brasil.

Finalmente, no último argumento - a imagem como delimitador -, ela foi vista por muitos educadores como um elemento que cerceava a imaginação do leitor, constituindo-se este como o terceiro argumento contra a imagem na escola. A palavra, neste caso, seria polissêmica, enquanto a imagem, unívoca. Por isso, a última não deveria figurar na literatura infantil, visto que limitava a imaginação do leitor. Um exemplo deste discurso é dado por Manguel (2001), em Lendo imagens, o autor argentino remete ao século XIX e retoma as palavras de Flaubert:

Gustave Flaubert opunha-se de forma intransigente à idéia de ilustrações acompanharem as palavras. Ao longo da sua visa, recusou-se a admitir que qualquer ilustração acompanhasse uma obra sua porque achava que as imagens pictóricas reduziam o universal ao singular. 'Ninguém jamais me ilustrará enquanto eu estiver vivo', escreve ele, 'porque a descrição literária mais bela é devorada pelo mais reles desenho. Assim que um personagem é definido pelo lápis, perde seu caráter geral, aquela concordância com milhares de outros objetos conhecidos que leva o leitor a dizer: 'eu já vi isso', ou 'isso deve ser assim ou assado.' Uma mulher desenhada a lápis parece uma mulher, e só isso. A idéia, portanto, está encerrada, completa, e todas as palavras, então, se tornam inúteis, ao passo que uma mulher apresentada por escrito evoca milhares de mulheres diferentes. Por conseguinte, uma vez que se trata de uma questão estética, eu rejeito todo o tipo de ilustração (2001, p. 20).

Flaubert, como muitos autores e pesquisadores de seu tempo, entendia a imagem como cerceadora da imaginação do leitor. Diante de tais argumentos, a imagem ficou à margem do sistema educacional e a palavra desfilou, ainda, soberana pelos meios de comunicação, em especial no livro, o único legitimado pela instituição escolar até meados de 1970 nos contextos considerados por este estudo.

Esse quadro esboçado foi aos poucos se transformando. As artes plásticas deixaram de ser reprodução do real, no início do século XX. A fotografia, o cinema e a televisão adquiriram impc 
sociais e, por isso, a sociedade começou a ser rotulada como "sociedade da imagem". É, também, a partir desse contexto que o livro começa a ser pensado pela imagem.

\subsection{A Hı STÓRI A No Espaço Educaci OnAL: Reflexos E I MPLI CAÇões}

I nicialmente, no habitat educacional, o papel da imagem era de vilã, para, em seguida, tornar-se protagonista respeitada, apesar de permanecer sempre uma personagem polêmica ${ }^{6}$.

Desde o início, os livros para crianças utilizam imagens para ilustrar as histórias; essas, contudo, não eram percebidas pela crítica. Talvez não fossem também percebidas pelo próprio artista ou pelo próprio destinatário, pois todos entendiam a imagem como adorno da palavra. Segundo críticos e artistas do final do século XIX e até metade do século XX, a imagem deveria ser utilizada para transformar uma tarefa desgastante em algo mais prazeroso:

Un libro como éste, presentado de esta manera, podría (así lo espero) servir para atraer a los niños talentosos, para que el hecho de ir a la escuela no les parezca un tormento, sino más bien, una experiencia agradable. Pues, es obvio que los niños (aún desde su temprana infancia) se deleitan con las ilustraciones, y gustosamente se complacen con estas luces. Bien valdría la pena haber realizado tal obra si logramos ahuyentar a los espantapájaros de los Jardines de la Sabiduría (El Orbis Pictus, Comenius, 1657, In: MARANTZ, K., 2005, p. 15).

6 É possível que a polêmica se dê graças à transição de discursos. Como querem as teorias da análise do discurso: "Todo discurso define sua identidade em relação ao outro. Isso quer dizer que o discurso apresenta uma heterogeneidade constitutiva.' (Maingueneau, 1987, p. 81-93), ou seja, mesmo na ausência de qualquer marca de heterogeneidade mostrada, toda unidade de sentido, de qualquer tipo que seja, pode ser inscrita numa relação essencial com outra, a do ou dos discursos em relação às quais o discurso de que ela depende define sua identidade. [...] Um enunciado de uma formação discursiva pode então ser lido pelo 'direito' e peln 'avescn' nım ladn ele significa sua pertença a seu próprio discurso, no outro constitutiva que o separa de um ou vários outros discursos" ( 
Apesar dos avanços tecnológicos e da inserção de novas mídias, ainda hoje, este discurso, sobre a imagem como "diversão" ou "hora do recreio", circula nos estudos sobre a imagem destinada à criança. Vale ressaltar que esta idéia não é a única, mas coexiste com outras nesta corrente discursiva.

Isabel Calado, pesquisadora portuguesa contemporânea, é um exemplo dessa formação discursiva, pois adota a seguinte perspectiva:

Uma coisa me parece certa: não podemos prescindir das imagens [...] elas (re) introduzem-nos, de um modo muito especial, na instância do prazer e permitem-nos escapar ao esforço (de paciência e penosidade) que o trabalho de alinhamento e decifração da escrita normalmente acarreta ([s.d.], p. 117).

A partir das citações de tempos bastante distintos (uma de 1657 e outra do final do século $X X$ ), é possível vislumbrar um quadro em que a imagem no livro para crianças tem o status de leveza que, segundo ítalo Calvino, é uma exigência das artes no século XXI, como demonstra em seu tratado Seis propostas para o próximo milênio:

Depois de haver escrito ficção por quarenta anos, de haver explorado vários caminhos e realizado experimentos diversos, chegou o momento de buscar uma definição global de meu trabalho. Gostaria de propor a seguinte: no mais das vezes, minha intervenção se traduziu por uma subtração do peso; esforcei-me por retirar o peso, ora às figuras humanas, ora aos corpos celestes, ora às cidades; esforceime sobretudo por retirar peso à estrutura narrativa e à linguagem (1990, p. 15) ${ }^{7}$.

A função de diversão atribuída à imagem e apoiada pelos críticos de ontem e hoje, como já apontado, não inferioriza a imagem, mas, sobretudo, ressalta uma qualidade importante de tal linguagem: acionar

7 Apesar de Calvino não tratar da literatura infantil a sua cond século XXI é pertinente também ao gênero em questão. 
no sujeito-leitor ${ }^{8}$ a possibilidade de "entrar" na obra pelas vias sensíveis e experimentar o estético:

Se aproximo de mim o objeto ou se o faço girar em meus dedos para 'vê-lo melhor', é porque para mim cada atitude de meu corpo é um só golpe potência de um certo espetáculo, porque para mim cada espetáculo é aquilo que é em uma certa situação cinestésica (Merleau-Ponty, 1999, p. 406).

Por isso, é lícito reconhecer que com a explosão das chamadas novas tecnologias - entre elas, incluem-se o cinema, a televisão, os computadores, os jogos eletrônicos -, se por um lado a imagem foi vista como elemento de desvio - o "lobo" que desencaminhou a pequena menina do bom caminho - na leitura, por outro, pode ser entendida como um acréscimo na formação da sensibilidade dos aprendizes ou mesmo uma opção pela leveza, que foge ao peso da vida e da cotidianidade. Eis uma busca constante em literatura infantil: ela deve formar o leitor literário como é proposta demonstrar.

A obra de arte se aciona (ou se realiza) como um acidente. Se os novos meios forem retirados de seu uso habitual, existe a potencialidade do "acidente estético", como é o caso de uma instalação nas mostras de arte contemporânea e também do livro infantil contemporâneo:

A inserção na cotidianidade, a espera, a ruptura de isotopia, que é uma fratura, a oscilação do sujeito, o estatuto particular do objeto, a relação sensorial entre ambos, a unicidade da experiência, a esperança de uma total conjunção por advir, esses são os poucos elementos constitutivos da apreensão estética [...] (Greimas, 2002, p. 30).

8 É importante pontuar que a pesquisa que se apresenta entende n livrn infantil romn obra de arte, assim como a literatura para adulto. A compara outras manifestações artísticas será uma constante. 
Colomer, em artigo intitulado 'Apreciar el 'espesor' de las palabras y de las imágenes", reflete acerca do livro ilustrado como objeto artístico-estético:

Las palabras que se utilizan en un texto literario o las formas de una ilustración pueden ser las mismas que se hallan en cualquier otra comunicación o lugar, pero la manera de utilizarlas y recibirlas, no. Porque el escritor elige y combina las palabras y el ilustrador los colores o la perspectiva, para propiciar que el lector "se detenga en ellos", para que la lectura o la visión ingenuas y literales se sobrepasen y se puedan descifrar otros significados. Un escritor y un ilustrador pueden desarrollar una narración para transmitir una historia, pero eso no parece muy interesante si no eligen y combinan las piezas de manera que el conjunto se convierta en una oferta artística, en un objeto lingüístico y plástico que produzca una experiencia más intensa y más compleja. Cuando la lectura de esa narración dialoga con la anterior experiencia de vida y de lectura, verbal y plática, de los receptores es capaz de generar una experiencia artística, algo tan gratuito como placentero, ante lo que todos los humanos son capaces de reaccionar (2002, p. 83).

Colomer destaca a organização em discurso de palavras e imagens como meio para alcançar a experiência estética e fazer que o receptor reaja diante do evento. Ainda, Besty Hearne aponta a transformação dos livros para crianças como condutores à formação do repertório sensível do indivíduo para assim prepará-lo como leitor literário:

Del mismo modo que la apreciación del cartoon constituye una preparación para las formas de arte más profundas, así también las ilustraciones (e historias) de los libros-álbum son la preparación de los niños para formas artísticas más elevadas. Esto sin sugerir que los libros-álbum sean de ninguna manera formas artísticas inferiores 0 más primitivas, así como tampoco el folklore es una forma artística de menor importancia que la novela o la pintura de galería (2005, p. 211).

Apesar de tais afirmações ressaltarem as qualidades estéticas do

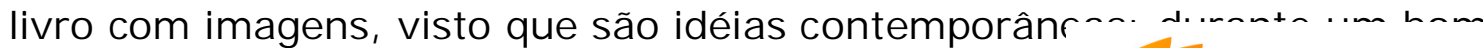
4 created with 
tempo, como vilão, o sistema visual roubou o espaço dos livros no tempo dos meninos e no próprio mercado editorial, visto que, por conseqüência da sedução das imagens, os editores, por um tempo, pararam de produzir literatura infantil. Isso porque, também, o mercado foi seduzido pelos artifícios da linguagem visual. Entre as décadas de 1930 e 1960, ao menos em Portugal e no Brasil, o mercado priorizou a produção de histórias em quadrinhos para alimentar a ficção na vida dos meninos.

Houve, então, a entrada triunfal (ou desastrosa, na visão de alguns) de tal expressão artística de massa - os quadrinhos (ou banda desenhada - como é chamada em Portugal) - nos mercados nacionais. Na maior parte, a expressão veio maciçamente como traduções da língua inglesa. Deixou-se de lado, portanto, a produção nacional para crianças e a opção editorial foi pela produção cultural de massa.

Algo semelhante é vislumbrado por Walter Benjamin, quando ele reflete a respeito da perda da "aura" artística. Solange Jobim e Souza em seu estudo sobre a infância e a linguagem, a partir das perspectivas teóricas de Walter Benjamin, Bakhtin e Vygotsky, afirma:

Com a multiplicação dos meios de reprodução técnica, sobretudo com o aparecimento da fotografia e, posteriormente, do cinema, a estrutura espaço-temporal da obra de arte se modifica. A partir do momento em que a obra fica excluída da atmosfera religiosa, que faz dela objeto de culto a ser consumido por poucos, a arte perde a sua "aura" e, na origem dessa dissolução, começa a se desenvolver o germe de uma política de transformação do real. Isso significa que o fim da aura na obra de arte não é, de forma alguma, arbitrário, mas condicionado socialmente. Por isso, Benjamin encontra no mundo massificado do capitalismo as causas do surgimento de um novo tipo de percepção voltado para o idêntico e para o contato direto com as coisas. [...]

Enquanto a arte clássica estava voltada para a contemplação individual, sendo, portanto, necessariamente elitista, a arte pós-aurática é condicionada por um tipo de recepção coletiva; esta irá mudar qualitativamente a relação entre obra e público, modificando a atitude da massa em relação à arte (1995, p. 47). 
Tomando a vertente crítica da produção cultural de massa trabalhada por Benjamin em meados do século XX, é interessante pontuar a distinção entre a recepção individual - livro -, e a coletiva - cinema, televisão. Instala-se, pois, a popularização da arte. Na contracorrente, é válido analisar os discursos da década de 1960 no Brasil, como documentos históricos, ideologicamente posicionados com fundamentos anti-história em quadrinhos, antiprodução cultural de massa. José Benedicto Pinto, estudioso brasileiro, pode ilustrar essa corrente discursiva:

O primeiro prejuízo causado pelas estórias em quadrinhos é este: afasta os leitores dos bons livros. Há quem afirme que através da estória em quadrinhos a criança aumenta o vocabulário. Acreditamos que isto é fato, mas, não podemos negar que, quem lê livros aumenta mais o seu vocabulário, pois a necessidade de procurar o vocábulo no dicionário, ou indagar o seu significado é maior em quem lê um livro do que naquele que lê a estória em quadrinhos pois estes, tem o quadrinho que facilita a compreensão da imagem mas, e os outros prejuízos? [...]

Nos Estados Unidos, em 1953 um menino de 13 anos cometeu um dos mais tremendos crimes de que se tem notícias naquele país. Matou com propósitos sexuais uma menina de seis anos, sob a influência de uma história em quadrinhos $[\ldots]$ (1969, p. 64-65).

Além de descartar os benefícios da produção quadrinizada, Pinto ainda associa essa expressão a atos de violência, exagerando seus efeitos. Tudo isso a fim de rejeitar a produção de história em quadrinhos para as crianças. Algo similar é vivido no século XXI com relação aos efeitos dos jogos eletrônicos.

Em Portugal, a literatura infantil também é abalada e ainda perde a batalha para as traduções da literatura quadrinizada e a exaltação da cultura de massa, como pontua Natércia Rocha:

Um balanço dos anos 40 revela que a produção editorial de qualidade assenta em meia dúzia de nomes. O facto mais representativo será talvez o recuo da nhm narinnal nnmantn 
o surto de jornais e livros vindos de produtores multinacionais que podiam apresentar a baixo preço [...]

As histórias em quadradinhos, de origem americana, espanhola e francesa, ocupam grandes espaços, firmando e alargando a posição já conquistada nos finais dos anos 30 (2001, p. 81-83).

Tal fenômeno ainda é agravado pela política autoritária da época ${ }^{9}$, pela sua ação sobre o sistema educacional e também pela censura editorial do período salazarista, que marcou uma estagnação na produção editorial portuguesa para crianças $^{10}$.

No Brasil, dá-se o mesmo com relação à avalanche dos gibis estrangeiros. No entanto, preserva-se a intensa produção nacional de tal expressão, por exemplo, O Tico-Tico (no início do século $X X$ ) e A turma do Pererê (em meados do século $X X)^{11}$ e ainda $A$ Turma da Mônica (em meados do século XX até os dias atuais), de Maurício de Sousa. Também alguns estudos sobre as histórias em quadrinhos, neste lado do oceano, apresentam um contradiscurso sobre o tema, em que há a defesa desse gênero artístico, negando, portanto, os discursos anteriores. Azis Abrahão, no artigo "Pedagogia e quadrinhos", publicado na obra Shazan!, apresenta o discurso favorável à história em quadrinhos:

Neste sentido, a literatura em quadrinhos, como veículo de aprendizagem para as crianças, não só é capaz de atingir uma finalidade instrutiva (ensino direto ou central), pela apresentação dos mais diversos assuntos ou noções. Mais do que isto, e principalmente, consegue preencher uma finalidade educativa (ensino concomitante), por um desenvolvimento, que produz, de ordem psico-pedagógica, isto é, dos processos mentais e do interesse pela leitura (1977, p. 147).

9 No item sobre os livros infantis em Portugal, este tema será aprofundado no estudo que ora se apresenta.

10 Autores como Natércia Rocha, Nelly Novaes Coelho, Lúcia Góes, entre outros apresentam trabalhos sobre essa questão.

11 A publicação das revistas citadas será mais aprofundada no brasileiro da imagem. 
Apesar de Azis figurar entre aqueles que já na década de 1970 valorizam a leitura da imagem, essa questão ainda é amplamente desprezada nos espaços educacionais. Os teóricos do passado ${ }^{12}$ não pensavam sobre uma pedagogia da leitura de imagem. Os professores se limitavam ao registro verbal.

Como já introduzido, em 1973, no entanto, Donis publica Sintaxe da linguagem visual, obra que marca uma transformação na maneira de pensar a imagem no espaço educacional, mas, em Portugal e no Brasil, apenas em 1991 se tem a primeira tradução para o português, ou seja, nestes países, essas idéias demoraram em vir à tona de maneira abrangente e institucional na escola ${ }^{13}$. Nessa obra, encaminha-se a questão sobre o alfabetismo visual da seguinte maneira:

Existe, porém, uma enorme importância no uso da palavra "alfabetismo" em conjunção com a palavra "visual". A visão é natural; criar e compreender mensagens visuais é natural até certo ponto, mas a eficácia, em ambos os níveis, só pode ser alcançada através do estudo (2003, p. 16).

A partir da compreensão da imagem como texto e com a necessidade de decodificação e interpretação, estabelece-se o princípio de que é válido educar para a imagem. Nas décadas de 1980 e 1990, os textos educacionais, tanto no que diz respeito à educação infantil quanto nos níveis mais avançados, introduziram o estudo e a leitura de imagem em seus currículos ${ }^{14}$.

O trabalho investigativo que ora se apresenta adota esta perspectiva, a saber: palavra e imagem constituem um todo discursivo, que merece decodificação no que tange a complementaridade entre essas

12 Entende-se passado como os anos anteriores a 1970.

13 Pode ser que os críticos dos países analisados já discutissem a questão nos meios universitários, no entanto, daí para a sala de aula houve um intervaln de temnn

14 Os parâmetros curriculares nacionais de Língua Portugues sobre a leitura de imagens. 
linguagens. Priorizar-se-á, ainda, o encontro de linguagens que desembocará no projeto gráfico ${ }^{15}$ proposto pela obra.

\subsection{A I magem, O Livro e A Sociedade: A Construção De Uma Relação}

Como agente social, a criança manipula, a todo o momento, a linguagem visual; de embalagem de biscoitos à imagem televisiva. E, ainda, devido ao contexto sócio-econômico, bem como à inserção dos discursos feministas na sociedade, cada vez mais cedo, a criança passou a ser introduzida no coletivo: ela sai do espaço familiar (privado) e ingressa, cedo, no escolar (público). Os pais se vêem "obrigados" a deixar o filho aos cuidados de uma creche ou escola, assim a criança compartilhará o espaço público precocemente.

Em A identidade cultural na pós-modernidade, Stuart Hall observa o que chamou de descentramento pós-moderno, ou seja, aquilo que leva à constituição de uma identidade pós-moderna. Entre eles, há o discurso feminista:

Mas o feminismo teve também uma relação mais direta com o descentramento conceitual do sujeito cartesiano e sociológico:

- questionou a clássica distinção entre o "dentro" e o "fora", o "privado" e o "público". O slogan do feminismo era: ‘o pessoal é político".

- abriu, portanto, para a contestação política, arenas inteiramente novas de vida social: a família, a sexualidade, o trabalho doméstico, a divisão doméstica do trabalho, o cuidado com a criança, etc.

- enfatizou, como uma questão política e social, o tema da forma como somos formados e produzidos como sujeitos generificados. Isto é, ele politizou a subjetividade, a identidade e o processo de identificação (como homens/mulheres, mães/pais, filhos/filhas) (2004, p. 44-45).

${ }^{15}$ A questão do projeto gráfico será tratada e definida ao longo 
Ali, nos espaços educativos, os educadores, e mesmo as outras crianças do grupo, vão interagir, como propõe Vygotsky, na postulada sócio-aprendizagem. A imagem, sem dúvida, é a linguagem em voga neste momento, assim como a música e a gestualidade.

Rapidamente, artistas e editores se deram conta desse nicho mercadológico:

Particularmente nos anos 70 , os designers passaram a fazer uso da imagem como construtora de sentido da narrativa, deixando de ser mera ilustração. Palavra e imagem, verbal e visual, integraram-se de tal maneira que o sentido do texto parece só se completar na leitura das expressões concomitantemente. Homem de Melo exemplifica quando diz que Ziraldo, em uma de suas capas "articula toda a composição gráfica. Texto e imagem formam um conjunto indivisível" (FERLAUTO, 2002, p. 74).

Antes de a mulher encontrar seu ambiente público, havia espaçotempo para a "contação" de histórias ao pé da cama ou no jardim; nos tempos globalizados, a dinâmica é outra, e é necessário deixar a nostalgia das "velhas" formas e interrogar sobre as "novas" maneiras de contar, pois algo é fato - o ser humano necessita de histórias, de momentos de ficção, seja para constituir a personalidade, seja para interagir no mundo. Benjamin explica a extinção da arte de narrar:

Uma experiência quase cotidiana nos impõe a exigência dessa distância e desse ângulo de observação. É a experiência de que a arte de narrar está em vias de extinção. São cada vez mais raras as pessoas que sabem narrar devidamente (BENJ AMIN, 1993, p. 197).

A narrativa, como o próprio Benjamin ensinou, contempla aspectos psicológicos e sociais. O autor-filósofo vai analisar a figura do narrador popular em oposição ao narrador do romance, no início do século XX. Muitos, nestes momentos de transição de discurso, anunciaram a chamada crise de leitura ou morte de livro. Em B 
narrador, se refere ao narrador popular. Chartie, no entanto, combate esse posicionamento e afirma:

Contra toda a nostalgia de uma idade de ouro, real ou imaginária, é preciso medir, analisar e entender o conjunto destas práticas de leitura e destes textos que não são precisamente o que se chama literatura. É preciso deixar para trás a nostalgia (literária ou política) e entender o fato de que agora se lê mais do que antes, sem esquecer que a produção de textos impressos é mais importante hoje do que no começo do século XX (2001, p. 126).

Resta perceber de que maneira a ficção toma conta do imaginário infantil no século $X \mathrm{XI}^{16}$.

O senso comum, apressadamente e com propriedade, dirá que pelos jogos eletrônicos a criança do século XXI supre a necessidade de ficção. Sem dúvida, a fonte de ficção mais atrativa ${ }^{17}$ para os meninos de hoje são jogos interativos, porém, tal recurso ainda está longe dos muros escolares e mesmo da preferência dos pais. Assim, ainda cabe ao livro, como fonte legitimada, o momento de ficção nos espaços educacionais.

Uma hipótese para o aumento visível e sensível da imagem na arte para crianças se deve a uma substituição de uma relação íntima, privada, de outros tempos e outros ritmos, por uma coletiva e pública, proporcionada pela imagem. É possível, hoje, desenhar-se a seguinte cena nos lares: o menino folheia o livro no chão enquanto a mãe trabalha à mesa e responde, em voz alta, às perguntas do filho sobre as figuras.

A questão do público e do privado, atualmente, transforma-se, uma vez que seus limites, nesta sociedade, são cada vez mais tênues. O livro proporciona uma relação privada, individual, por vezes, repleta de sentido, contudo, cada vez mais os espaços de socialização se constroem inusitadamente.

16 Há consciência que para explorar esta afirmação seria necescárin nıtra tece Parere no entanto, pertinente citá-la como forma de contextualizaçãı

17 Se não atrativa, pelo menos, bastante consumida. 
Por exemplo, no ambiente escolar, são feitos rodas e cantos de leitura, e, muitas vezes, o aluno é convidado a partilhar essa atividade. 0 papel da mediação de leitura é cada vez mais comum nas práticas pedagógicas, na medida em que este recurso atende a uma demanda social pela interação, por transformar uma relação privada em uma pública, pois entende-se que da socialização nasce a aprendizagem - o sócio-interacionismo.

Outro exemplo bastante significativo dessa socialização da expressão privada são as chamadas lan houses. Ali, os meninos transformam um jogo individual em coletivo. Tal estratégia cai no gosto dos garotos joysticks. Não raro, essas salas se tornam um mercado livre com disputas, emoções e muita troca de sensações projetadas, convencionalmente, para serem individualizadas. O jogo e a interação entre os jogadores substituem os narradores de outrora, já que ali eles criam as suas narrativas, os seus momentos de ficção.

Eis, então, alguns exemplos de como a produção artística é também conduzida pelas urgências sociais. Em contrapartida, não se pode deixar de lado o universo à parte que crianças e adolescentes constroem nos universos virtuais (salas de bate-papo, blogs, fotoblogs...). Privado e público/ individual e coletivo são conceitos ainda mais estremecidos no início do século XXI.

Este é o cenário em que se delineia a problemática do livro infantil hoje e se pergunta: qual o seu espaço neste panorama? O livro, neste contexto, atualiza-se?

\subsection{A I magem No Mercado Editorial Para Crianças: Perspectivas}

Quando a imagem entrou no mercado editorial para crianças, sendo reconhecida pelas instituições educacionais e legitimada pelo público-leitor, surgiram inúmeras formas de inserção. A mais popular e aceita de imediato, e que, por isso, nasce praticamente junto com a pr 
crianças, é a ilustração. Palavra e imagem, neste caso, praticamente constituem um discurso bivocal, a saber, ambos os sistemas contam a história, cada um com suas especificidades (literárias ou plásticas).

Aos poucos, no entanto, quando a criança passou a ter amplo acesso à imagem e, com isso, adquirir habilidades de decodificação muito eficientes, palavra e imagem começaram a estabelecer relações mais intricadas.

Pesquisadores e artistas como Uri Shulevitz, Ellin Greene, Teresa Colomer, Jane Doonan, Bárbara Kierfer, David Lewis, Leoni Lionni, Luís Camargo, Ziraldo, Isabel Calado, Lúcia Pimentel Góes, entre outros, a partir dos anos 1970, iniciaram a discussão sobre as diferentes formas de inserção da imagem na produção literária dedicada à criança. A experimentação começou como demonstram as imagens:

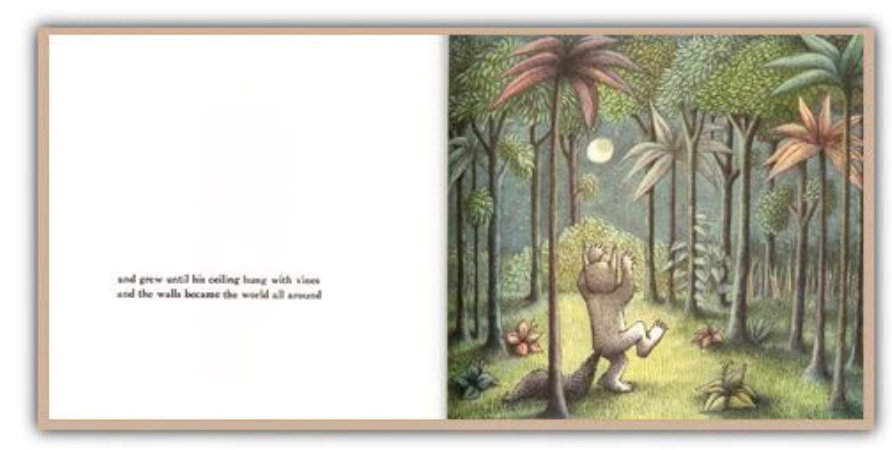

Figura 1.5 - Onde vivem os monstros? 


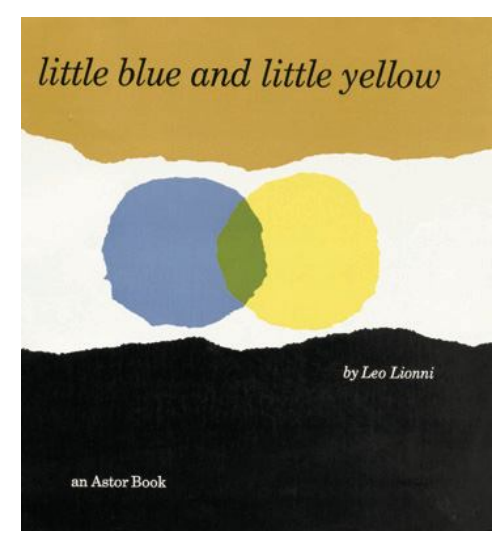

Figura 1.6 - O pequeno azul e o pequeno amarelo

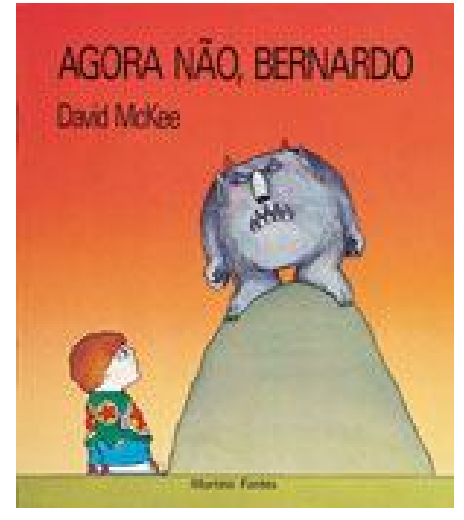

Figura 1.7 - Agora não, Bernardo

As tipologias surgiram da ousadia dos artistas no que diz respeito à forma de ilustrar, bem como a inovação de artistas plásticos que se dedicaram à produção gráfica de livros para crianças. Este último argumento pode ser sustentado pela listagem e pela justificativa que Betsy Hearne faz em seu artigo "Libros-álbum perennes sembrados por la tradicción oral":

El hecho de que todos los libros de la lista se siguen reimprimiendo y permanecen como modelos representativos por períodos que van desde trece hasta noventa y siete años (dependiendo de las fechas de su publicación), muestra que son perdurables en una época en que muchos libros quedan fuera de imprenta poco después de ser publicados. Se dice que hay pruebas reales para determinar la perdurabilidad de un libro: una, que los niños dejen de corretear 0 de golpearse unos a otros por suficiente tiempo como para escuchar la lectura, e otra, el número de veces que un adulto puede releer el libro en voz alta sin quedarse dormido o volverse loco [...] (2005, p. 209).

Além da exposição bem humorada de Hearne, a autora vai apontar uma qualidade dos livro-álbuns que interessam bastante a este estudo: "Veintiséis de los treinta y cinco libros son ilustrados por el autor, lo que quizás habla de la importancia de la unidad del arte y la narración" (2005, p. 209). 
Vale apresentar, inicialmente, duas tipologias dos livros oferecidos à criança e, em seguida, problematizá-las a partir da abordagem teórica que este trabalho pretende seguir, a saber, a semiótica discursiva.

A primeira é de Teresa Colomer. A investigadora catalã se detém à observação didática dos educadores e oferece as seguintes categorias: a) os livros de imagem (diz que normalmente são livros para indicar e nomear); b) os livros interativos (sobre estes, faz um percurso histórico e, em seguida, subdivide-os: aqueles que oferecem histórias a partir da sobreposição de folhas; aqueles em que um disco de papel gira para contar a história; aqueles em que a narrativa se desenrola como uma sanfona; aqueles que criam movimento e volume - pop-up; aqueles que empregam diferentes materiais para estimular os sentidos - tato, audição etc.; aqueles em que a criança deve desenhar ou passar um pincel mágico, por exemplo; assim, os livros interativos são: plastificados, popups, sanfona, com lingüeta, por sobreposição, com vazados, por tiras etc.); c) os livros informativos (que se dividem em de conceitos e de conhecimento); d) os livros de histórias sem palavras; e) os livros-jogos para maiores e, finalmente, f) os livros de histórias multimídias.

Em seguida, buscou-se uma pesquisadora brasileira, Lúcia Pimentel Góes, que oferece a seguinte tipologia: livro-objeto (pano, madeira, para acompanhar o banho); livro só com imagem em que a narrativa se constrói a partir da decodificação da narrativa visual (leitura de imagem) e, por fim, o diálogo palavra x imagem, em que a autora especifica: aquele em que um sistema amplia o outro; aquele em que um sistema contradiz o outro; e aquele em que se utiliza um contraponto lúdico, ou seja, em que um se torna charada para o outro.

As tipologias expressas auxiliam a entender o que o mercado editorial oferece ao público infantil, contudo resta investigar o que estes projetos editorias dizem e como dizem, tendo em vista o receptor da obra, ou seja, a qualidade de comunicação do texto - projeto gráfico.

Cabe a esta pesquisa a pergunta sobre a eficiência na comunicação desses projetos gráfico-literários oferecidos à crianç 
uso de técnicas, como grafismo, aquarela, óleo? O diálogo palavra $\mathrm{x}$ imagem não rompe a seqüência narrativa? Os discursos introduzidos no projeto comunicam-se com o público-leitor?

Neste momento, é importante definir como projeto gráfico é entendido por este estudo, para isso, cita-se María José Sottomayor:

Percibí que el proyecto gráfico era otro lenguaje del libro. Iba desde el gramaje del papel, el tipo y tamaño de letra usada, la forma como el espacio para el texto jugaba con la ilustración.... era otro lenguaje que iba también dialogando con la palabra escrita y la imagen, permitiendo otras lecturas de las obras. Estaba también el proyecto gráfico de las tapas de los libros y la forma como interactaban el título visual con el verbal, haciéndolos más apelativos para que los chicos se interesen en hojearlos (2005, p. 87).

Assim, para valorar o objeto-livro dado às crianças, é importante adotar uma perspectiva teórica, em que se possa analisar o diálogo palavra-imagem inserido no projeto gráfico. Este, em última instância, também é constituído como discurso. Não vale analisar este sistema semiótico sem ter em conta seu diálogo com a teoria da crítica literária, a da recepção, as das artes plásticas e as das artes gráficas. Todavia, sobretudo, propõe-se uma metodologia de análise em que tais teorias dialoguem.

Marantz, em seu ensaio "Com estas luces", alerta:

Según mi punto de vista, los libros-álbum deberían percibirse y valorarse como una forma de arte visual y no como arte literario. Insistir en estudiarlos como literatura, nos lleva a apreciar las ilustraciones, en primera instancia, desde su relación con el texto, más como simples asistentes que como símbolos con personalidad propia. Si permanecemos sujetos al texto, dejamos de sacar el máximo provecho a las propriedades visuales, que Comenius ${ }^{18}$ identificó como generadoras de nuestro deleite (2005, p. 15).

18 Autor citado anteriormente. 
E, ainda, a partir dessa perspectiva, lança a sua tipologia:

Por lo tanto, es fundamental estar muy claros acerca de qué es un libro-álbum. Para diferenciarlo de otros objetos similares, podría ser útil imaginarmos una línea que en uno de sus extremos tiene una novela típica, es decir, un libro cuyas páginas están exclusivamente llenas de palabras impresas. Al otro extremo de esta línea imaginaria, hay un libro totalmente carente de texto, uno que trasmite su mensaje (generalmente un cuento) utilizando sólo imágenes. En el medio de la línea, hay volúmenes que tienen una sola ilustración (en la portada), algunos que emplean viñetas a principio o al final de cada capítulo, otros que tienen imágenes ocasionales a página completa que realzan eventos particulares o delinean personajes presentes en la narrativa y unos pocos que insertan una variedad de ilustraciones y tener todavía una obra literaria coherente y completamente satisfactoria (2005, p. 17).

O que Marantz propõe em sua tipologia é uma gradação da relação palavra-imagem, em que os extremos seriam o livro sem imagem, de um lado, e o sem palavra, de outro.

Sobre isso, em dissertação de mestrado, Cortez (2001) ensaia uma tipologia que se seguiria da separação total entre as linguagens até a integração total entre elas, na última situação ocorreria no livro-álbum.

A imagem tem papel fundamental no projeto gráfico dos livros infantis, por isso, não pode ser rejeitada ou inferiorizada seja pela crítica ou pelos educadores. Muitas vezes, ela tem uma função determinante no projeto gráfico. Vale, então, observar o questionamento de Ricardo Azevedo sobre aquelas ilustrações que são tomadas fora do objeto-livro não podendo, portanto, ser avaliadas:

Exposições de grande tradição como a "Bienal de Ilustração de Bratislava" ou a "Exposição da Feira de Bolonha" costumam expor e premiar ilustrações sem tocar na questão do texto. Observamos lindos desenhos, mas não conhecemos os textos ilustrados. Como saber, então, se essas ilustrações são boas ou não? Como saber como dialogam, se é que dialogam, or ${ }^{-}$ texto? Como saber se acrescentan 
ao texto? Como saber, em que pese serem tecnicamente bem realizadas, se são óbvias ou não? Como saber a forma com que se relacionam com a mancha do texto dentro da página? Como saber como tal e tal situação, fundamental na estrutura do texto, foi resolvida? ${ }^{19}$

$\mathrm{Na}$ minha visão, se essas exposições são super interessantes no sentido de mostrar originais, apontar novas técnicas etc, são, por outro lado, incapazes de distinguir boas e más ilustrações.

Um desenho simples, feito com poucos traços, sem maiores pretensões técnicas pode ser, sempre a meu ver, infinitamente melhor ilustração do que um desenho rebuscado, construído a partir de uma técnica requintadíssima, mas que em relação ao texto só consegue ser redundante.

Nada contra, evidentemente, que ilustrações sejam expostas como pinturas. Esquecer, porém, as diferenças essenciais entre os dois gêneros me parece um tremendo equívoco. Pinturas não têm textos como referência, não foram feitas para serem impressas e nem para ocuparem, antes de qualquer coisa, páginas dentro de um livro (Disponível em: <www.ricardoazevedo.com.br>. Acesso em: 17 jun. 2008).

Define-se, pois, o olhar deste trabalho para o projeto gráfico que alia palavra e imagem em suas diferentes gradações, para isso, será necessário abordar os sistemas semióticos (palavra, imagem e projeto gráfico) como o mesmo instrumental metodológico, a saber, a teoria semiótica de linha francesa, tal qual apontado no capítulo introdutório desta tese.

A imagem é entendida, neste trabalho, como definida pelo Dicionário de Semiótica elaborado por Greimas e seus colaboradores. Ali, o verbete imagem apresenta a seguinte acepção:

Em semiótica visual, a imagem é considerada como uma unidade de manifestação auto-suficiente, como um todo de significação, capaz de ser submetido à análise. A partir dessa constatação geral, duas atitudes distintas se destacam. Enquanto a semiologia da imagem, que se refere à teoria da comunicação, a considera geralmente como uma mensagem constituída de signos icônicos, para a semiótica planar a imagem é sobretudo um texto-ocorrência (comparável, apesar da especificidade bidimensional de seu

${ }^{19}$ Grifo nosso. Destaca-se tal passagem haja vista que esta é a por este estudo. 
significante, aos de outras semióticas) que a análise pode explicar construindo-o como um objeto semiótico. Da mesma forma, enquanto para a semiologia da imagem a iconicidade dos signos faz parte da própria definição de imagem, a semiótica planar considera a iconicidade como um efeito de conotação veridictória, relativa a uma determinada cultura, que julga certos signos "mais reais" que outros, e que conduz, em certas condições, o produtor da imagem a se submeter às regras de construção de um 'faz de conta' cultural (1989, p. 276).

Assim, como revelado anteriormente, a imagem será tratada como texto passível de análise tanto do plano da expressão quanto do conteúdo, com relações internas e externas ao texto, mas, como uma "manifestação auto-suficiente", poderá ser questionada, pois, em alguns casos, o sentido se constrói somente na relação com a palavra, e este é o objeto de interesse desta tese. Em Semiótica, quando dois sistemas são acionados para compor um único discurso, diz-se objeto sincrético:

Mais recentemente, o estudo de diversos tipos de manifestações semióticas ditas sincréticas, isto é, que associam, por exemplo, como na publicidade, o texto e a imagem, permitiu apontar a existência de correspondências formais mais complexas que agem não só entre um plano e outro de uma mesma linguagem, mas também entre planos respectivos de duas linguagens simultaneamente em ação no caso, entre a organização do significante visual do anúncio publicitário e a organização dos significados assumidos na dimensão lingüística (1992, p. 147).

O que é válido pensar no livro para crianças ultrapassa as definições, já abordadas à exaustão, de texto e imagem; é importante investigar como se relacionam e se integram as linguagens no livro; essas expressões constituem um todo de sentido ou não? Esta integração é efetiva e eficiente na comunicação com o público e como objeto artístico? E, finalmente, o projeto gráfico contribui para essa interação ou fragmenta as linguagens? 0 projeto gráfico contribui para a formação de um leitor literário?

Tomando essas questões, restam as análises e decrnhertas. 


\title{
2 VI AGEM CERCADA POR CONTRADI ÇÕES: O CONTEXTO PORTUGUÊS
}

\begin{abstract}
A viagem não começa quando se percorrem distâncias, mas quando se atravessam as nossas fronteiras interiores. A viagem acontece quando acordamos fora do corpo, longe do último lugar onde podemos ter casa
\end{abstract}

(Mia Couto)

Viajar é descobrir o alheio. A viagem pode ser real ou metafórica. Pode ser um deslocamento físico ou uma viagem pelas linhas negras no papel branco.

$\mathrm{Na}$ literatura, a viagem parece ser a metáfora mais freqüente e diferenciada. Aí ela adquire muitos significados e muitas conotações. Talvez todas nasçam de uma viagem primordial e emblemática, mas são muitas as que se realizam e sonham ao longo das narrativas, das poéticas que constituem a literatura universal (IANNI, 2003, p. 28).

Viajar para investigar, no entanto, exige um olhar diferente, mas, muitas vezes, cercado por sensações emocionais obrigatoriamente deixadas de lado. Exige um olhar distanciado, objetivado; contudo, o corpo pulsa e, muitas vezes, trai a racionalidade e se deixa sentir. A pele, os olhos, o nariz, os ouvidos se movem como radares para descobrir o que há e como eles reagem diante do novo.

Um estrangeiro é como uma criança, declarou. Chegar a um sítio desconhecido é começar do início, aprender as palavras, ver como os outros se mexem, tropeçar. Assim a cidade revela-se despida e impoluta, pronta para ser descoberta (SUARÉZ, 2005, p. 135).

Há, no entanto, que se fazer pesquisador, guardar as veias sensíveis e percorrer o território alheio de maneira atenta e apurada - 
tudo e todos significam. Seria ingenuidade não ressaltar que sempre será um olhar com lentes estrangeiras.

É certo, ainda, que a viagem segue etapas. Talvez a primeira seja a preparação. Tanto o corpo como, sobretudo, a cabeça buscam imaginar o que será esse lugar. Um guia, leituras, vídeos, histórias de outrem ajudam a compor uma imagem sobre o desconhecido.

O espaço a ser desvendado neste caso, porém, não é totalmente desconhecido ou enigmático. Difícil seria, nos tempos globalizados, uma viagem como foram outrora as "descobertas do Novo Mundo", descritas com assombramento pelos viajantes do século XVI. Atualmente, as imagens que tomam as telas de cinema, as telas menores da televisão e as telas ainda menores dos computadores, todas elas, sem exceção, veiculam as imagens do exterior e neutralizam a sensação de total desconhecimento ou de êxtase da investigação in loco.

Para além das redes globalizadas, o espaço que interessa é também contemplado nos livros escolares, pois a ligação entre o próprio e o alheio é, praticamente, genética. Fala-se, portanto, de Portugal e do Brasil - metrópole e colônia em outros tempos. Sendo Brasil o que é próprio e Portugal o que é "quase" alheio. A modalização com o "quase" reflete a História. Portugal é, para o Brasil, um país distante geograficamente, que existe na memória, que pertence à História.

O brasileiro tem pouca proximidade com a imagem da terra lusitana. Talvez, como defesa ou negação do discurso do colonizador. A imagem, grosso modo, que se tem de Portugal é veiculada em rodinhas de piadas e anedotas contadas em praças e botequins. Assim, nem o ambiente, nem, muito menos, o conteúdo revelam a imagem efetiva do Portugal contemporâneo. Outra fonte de aproximação com a identidade portuguesa talvez seja a Literatura/História que se estuda nos bancos escolares. Ali, chega-se até o início do século XX. Talvez pela pena de Eça de Queiroz e Camilo Castelo Branco se desenhe uma idéia da terra de Camões no século XIX. Outro caminho, sem dúvida, é a aproximação da imagem portuguesa à imagem da Europa. Em opos 
contradiscursos, a imagem que se forma da pátria colonizadora é justamente a imagem da potência conquistadora, que pertence a um continente desenvolvido, protagonista dos principais acontecimentos do mundo político e cultural.

Uma possibilidade real é o brasileiro caminhar pelas ruas lusitanas perguntando-se onde estão as riquezas trazidas das colônias, não só do Brasil, mas das conquistadas pela dominação das terras africanas, asiáticas e indianas. Poder-se-ia imaginar um país repleto de riquezas e trocas étnicas. Apesar do cosmopolitismo de Lisboa, os intercâmbios culturais estão restritos à capital; nos demais sítios, verifica-se uma cultura voltada para sua própria origem, até mesmo a cultuada mescla racial, teorizada por Gilberto Freyre ${ }^{20}$, só se faz presente no território alheio, no território dominado, seja no Brasil como postulado, seja em Cabo Verde ou outro recanto colonizado.

A realidade portuguesa destoa, hoje, do mito de potência colonizadora cantado nos versos e nas prosas dos homens das letras. Vagar pelas margens do Tejo, do Douro, do Corgo revela um misto de ambientes, e, por vezes, vislumbram-se imagens paradoxalmente oníricas. A História está presente na arquitetura. Há traços de tradição na culinária e nos hábitos. Presencia-se certo déjà-vu nas senhoras com saias, meias grossas, chinelo, lenço na cabeça e conversas entre vizinhas na janela. Estabelece-se, contudo, a contradição entre acesso sem fio à internet em qualquer sítio (shoppings, cafés, rodoviárias etc.) e casas com cata-vento e horta, em clara produção para a subsistência, edifícios colossais e feiras de trocas que remetem ao cenário latino-americano.

Este retrato de contradição é definido por Boaventura Souza Santos como uma posição intermediária ocupada por Portugal:

[...] Portugal é uma sociedade de desenvolvimento intermediário, uma sociedade que, não pertencendo nem ao Primeiro Mundo nem ao Terceiro, tem características de

20 FREYRE, G. (1980). Casa-grande e senzala. Rio de Janeiro Olympio. A primeira edição da obra é de 1933. 
ambos. Esta posição intermediária ou semiperiférica é, por assim dizer, estrutural, isto é, dura há muito tempo [...] Ao contrário do que pode parecer à primeira vista esta duplicidade não ocorre apenas na economia; ocorre em todos os domínios da vida social, política e cultural (SANTOS, 2001, p. 83).

Talvez essa posição se justifique por estar e não estar em território próprio. Durante muito tempo, Portugal investiu em sua expansão territorial e se esqueceu de seu próprio território. Não raro, ainda hoje, escuta-se do português que seu país é pequeno e essa seria a causa de sua pouca projeção no cenário político, econômico e cultural. Ora, administrar um pequeno território, de certa maneira, pode ser mais simples, pois se tem tudo à mão e as demandas são reduzidas. Habita, contudo, o sentimento português um desejo de expansão e é perceptível o pesar da pequenez:

[...] a de esconder de nós mesmos a nossa autêntica situação de ser histórico em estado de intrínseca fragilidade. Não fomos, nós somos uma pequena nação que desde a hora do nascimento se recusou a sê-lo sem jamais se poder convencer que transformara em grande nação (LOURENÇO, 2005, p. 25).

Dominar território alheio não assegura, é sabido, a propriedade. É natural a todos os povos o sentimento de pertença. Com movimentos mais imediatos ou mais cautelosos, os naturais da região vão sempre reclamar a sua condição de donos da terra. Os dominadores, cedo ou tarde, serão "convidados" a deixar a terra alheia e a recusa ao "convite" gera guerras de independência.

Pois nem o colonialista nem o colonizado se comportam como se o sujeito e o objecto pudessem vir a ser conciliados. O primeiro saqueia e pilha; o último sonha com a vingança. Quando os nativos se revoltam numa insurreição violenta, não se trata de "uma confrontação racional de pontos de vista. Não se trata de um discurso sok 
afirmação impetuosa de uma originalidade colocada como absoluto (SAID apud SANCHES, 2005, p. 41).

A História apresenta sempre como vitoriosos os nativos do território; com isso, o movimento de abandono da terra conquistada requer gastos e desgastes econômicos, sociais e espirituais, considerandose a estima. Isso pode explicar a atual condição portuguesa no cenário mundial e seu perceptível atraso em relação aos países da União Européia.

O 25 de abril de 1974 rompe a ligação de Portugal com os territórios invadidos. Por pressões externas, é dada a Portugal a tarefa de voltar-se a si.

Chegou a hora de fugir para dentro de casa, de nos barricarmos dentro dela, de construir com constância o país habitável de todos, sem esperar de um eterno lá-fora ou lálonge a solução que, como no apólogo célebre, está enterrada no nosso exíguo quintal. Não estamos sós no mundo, nunca o estivemos. As nossas possibilidades econômicas são modestas, como modesto é o nosso lugar no concerto dos povos. Mas ninguém pode viver por nós a dificuldade e o esforço de uma promoção colectiva do máximo daquilo que adentro dessa modéstia somos capazes [...] (LOURENÇO, 2005, p. 52).

Destituído de colônias, o país teve de fazer um percurso solo, teve de retornar a casa. De um Estado autoritário e ditatorial, passou-se à democracia. Transformações radicais em restrito tempo histórico. Agregase a essa situação a nova ordem mundial. A queda de muros e de regimes implicou a formação do bloco da União Européia, e isso impôs aos lusitanos mais uma contradição. Enquanto, de um lado, destaca-se do português a qualidade de europeu, do outro, escancara-se a ferida da inferioridade. Se o parâmetro é o mundo, Portugal é Europa. Se o padrão é europeu, a realidade lusa está aquém das exigências, e há que se correr atrás.

Recorrendo a uma expressão brasileira, podemos dizer que a sociedade portuguesa está a cair dolorosamente de uma promessa fr 
fácil que nos prometeu um desenvolvimento igual ao dos países desenvolvidos da Europa e nos deixou vertiginosamente perto donde estávamos, a sociedade portuguesa vai aprendendo a conviver com a situação de estar muito mais integrada nos problemas da Europa do que nas soluções da Europa. O desemprego, a exclusão social, o racismo, a corrupção política, a insegurança batem-nos à porta - uma porta, afinal, escancarada, e sentam-se à mesa das nossas preocupações sem qualquer cerimônia (SANTOS, 2001, p. 167).

Os índices serão generosos se forem tomados os investimentos da comunidade européia para elevar o país às exigências do bloco ${ }^{21}$; os índices serão cruéis se a estima do português for considerada. Assim, pequeno e contraditório, o país se apresenta.

É com visada a este contexto sociopolítico, brevemente esboçado, que a pesquisa sobre a literatura infantil se constrói. Nesse panorama, há produção literária para crianças, resta voltar os olhos para o ambiente que se projeta.

Entre um período autoritário e a chamada crise da leitura ${ }^{22}$, delineiam-se o cenário da literatura infantil portuguesa e a tentativa de inserção do sistema visual nessa complexa expressão ofertada à criança. Os livros infantis como discurso refletem essa situação.

\subsection{Os livro-Álbuns para Crianças em Portugal: Destravando BATALHAS}

Em busca de compreender o fenômeno do livro-álbum em Portugal, chama-se à reflexão um pesquisador deste país, Gomes (2004), que

${ }^{21}$ Vale lembrar que do metrô da cidade do Porto à construção e planejamento de bibliotecas, Portugal fez uso dos recursos da União Européia.

22 Pontua-se que no capítulo 1, pelas palavras de Chartie contextualizada. 
justifica a ausência do chamado picture story book ou álbum narrativo ${ }^{23}$ no cenário português:

As dificuldades na publicação de álbuns prendiam-se, então, com os elevados custos de produção, os quais tinham repercussões no preço de venda ao público. Uma vez no mercado, o álbum defrontava-se com diversos problemas, o menor dos quais não era a escassa utilização do livro na educação pré-escolar e no 10. Ciclo do Ensino Básico. Outro obstáculo à proliferação deste tipo de obras residia na quase inexistência, em Portugal, de autores com a dupla vocação da escrita e da ilustração (situação que de algum modo perdura). Acrescia que raramente haviam surgido equipas, compostas por um argumentista/ escritor e por um ilustrador/designer gráfico, capazes de conceber um produto de nível globalmente satisfatório, em termos de articulação texto/imagem (GOMES, 2004, p. 17-18) ${ }^{24}$.

São três, portanto, os motivos enumerados por Gomes (2004) para a raridade da expressão do livro-álbum em Portugal, a saber: o econômico, o pedagógico e o humano-profissional.

A questão imediata é sempre de ordem financeira, seja em Portugal ou em qualquer outro lugar. Atribuído às editoras, o discurso se impõe: elevados custos em função da qualidade e variedade do material gráfico utilizado.

É, como se observa, uma constante a qualidade gráfica dos livros dedicados à infância em Portugal. Abaixo, demonstra-se a afirmação com ilustrações de uma edição comemorativa, em que os principais ilustradores portugueses e também de outras nacionalidades, como franceses e ingleses, são convidados a representar visualmente o conto Ervilha para as verdadeiras princesas, de Hans Christian Andersen. Temse, então, uma pequena amostragem da qualidade do livro português, no que diz respeito à gramatura do papel, qualidade de impressão,

${ }^{23}$ Gomes (2003), a partir de autores como Michaels e Walsh, define álbum narrativo ou picture story books como aqueles em que palavra e imagem estruturam em conjunto a significação. Pode ser um autor em parceria com o ilustrador ou um artista que manipula as duas linguagens. A definição desse gênero é fındamental an trahalhn como apresentado no capítulo 1.

${ }^{24}$ Grifos nossos. 
diversidade de técnicas empregadas (colagem, pastel, xilogravura...), além de os livros sempre se apresentarem em capa dura, uma constante no livro para crianças na Europa.

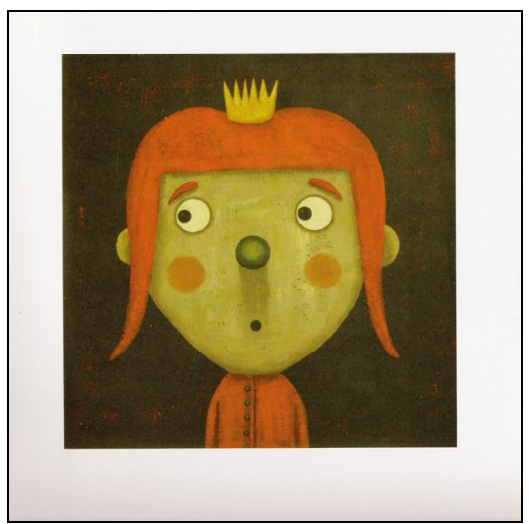

Figura 2.1 - André Letria

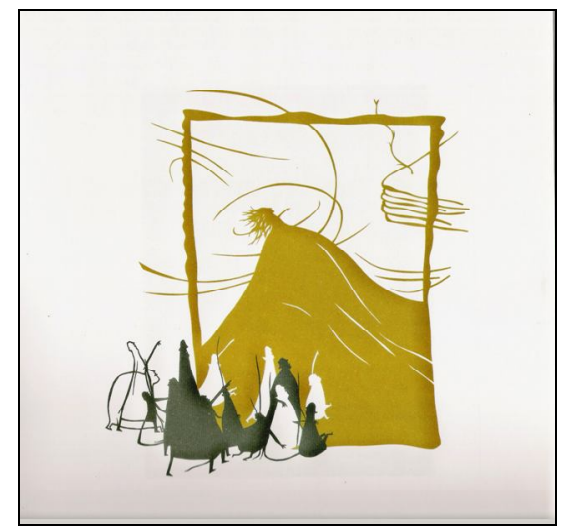

Figura 2.3 - Gêmeo Luís

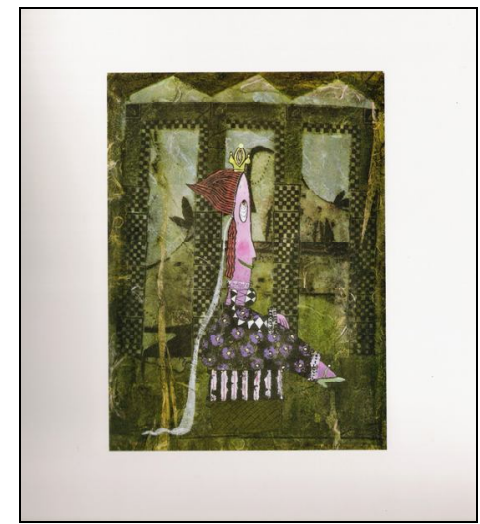

Figura 2.2 - J oão Caetano

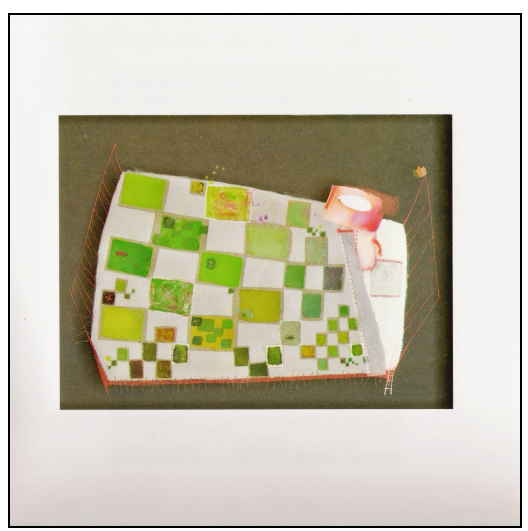

Figura 2.4 - Marta Torrão

Os livros dados às crianças têm capa dura, encadernação primorosa e acentuado cuidado plástico com as imagens. Por vezes, o leitor se encontra diante de um verdadeiro quadro com recursos como colagens, óleos, aquarelas de tal qualidade que é transportado para uma galeria de arte. Isso, evidentemente, custa, requer altos investimentos com a produção, seja para pagar o material, seja ao próprio artista e seus materiais.

A impressão gráfica com essa exigência deve ser fiel ao conceito do design gráfico da editora. Vale acompanhar e 
ponderação do pesquisador alemão Jan Tschichold, em 1975, sobre o artista gráfico de livros e questionar se tal definição se estende ao projeto gráfico do livro para crianças, visto que o pesquisador alemão trata da produção de livros em geral:

O trabalho de um designer de livro difere essencialmente do de um artista gráfico. Este está buscando constantemente novos meios de expressão, levado ao extremo pelo desejo de ter um "estilo pessoal". Um designer de livro deve ser um servidor leal e fiel à palavra impressa. É sua tarefa criar um modo de apresentação cuja forma não ofusque o conteúdo e nem seja indulgente com ele. O trabalho do artista gráfico deve corresponder às necessidades da época e, a não ser em coleções, raras vezes tem vida longa - ao contrário de um livro, que, presume-se, deve durar. O objetivo do artista gráfico é a auto-expressão, ao passo que o designer de livro responsável, consciente de sua obrigação, despoja-se desta ambição (2007, p. 31).

O autor de dupla vocação, ou mesmo o projeto gráfico do livro infantil, difere da definição e exigência de Tschichold, pois se trata de transformar o livro em um objeto em que os sistemas sejam organizados de maneira a convocar o leitor-criança para a leitura, então, é possível que o destinatário criança exija um objeto que acione tanto as vias sensíveis, quanto inteligíveis; além disso, torna-se "lugar-comum" que a criança obrigue a originalidade, pois, caso contrário, será um livro a mais nas prateleiras deste ambiente consumista, criado por livrarias e incentivado pelo mercado editorial.

Com isso, as nuances de cores, a gramagem do papel, o tamanho da folha fora da padronização, que podem determinar a chamada originalidade, geram custos elevados. Ao analisar a produção portuguesa para crianças a partir da década de 1980, salta aos sentidos a opção pela qualidade gráfico-artística.

Talvez esse fenômeno possa ser compreendido à luz de uma visada social dada por Saraiva (1981), quando o pesquisador define a "Personalidade cultural portuguesa": 
Para o camponês o dinheiro incorpora-se na terra e lá fica imobilizado, produzindo uma renda que traz a segurança e o bem-estar material ou ainda uma sobra para comprar mais terra; e este espírito encontra-se também nos emigrantes repatriados. Por outras palavras, o dinheiro tem uma finalidade concreta, o que é uma concepção pré-capitalista. Quanto ao citadino, que atingiu um certo nível entre nós, o dinheiro serve para comprar conforto, divertimentos e uma certa ostentação que inclui a liberalidade (1981, p. 100-101).

Para o homem português das cidades, como hipótese, no caso em exposição, a apresentação, a qualidade material do objeto livro é fundamental no momento de adquiri-lo. Tendo, obviamente, o homem português como consumidor, as editoras desse país primam por fazer do livro um objeto de "luxo" a ser exibido nas prateleiras, visto que este revela o poder de consumo. Torna-se, assim, o livro para crianças um produto caro, por vezes até inacessível ao português de classes baixas e médias.

Em momento algum, tal opção é passível de crítica; pelo contrário, a opção por destacar a qualidade plástica dos objetos só faz enriquecer o repertório do leitor, mas, como tudo, gera conseqüências que precisam ser pensadas e ponderadas, tendo em vista os objetivos de incentivo à leitura no país. Assim:

Em regra, e considerando o formato, as dimensões são superiores às de um romance, de uma coletânea de contos ou de um livro de poesia para adultos; a capa em geral é dura; o papel, por sua vez, tem uma gramagem elevada e é de boa qualidade [...] reduzido número de páginas e pelo facto de, profusamente ilustradas, serem estas quase sempre impressas em policromia (GOMES, 2003, p. 3).

Todos esses elementos destacados pelo pesquisador implicam o alto custo da produção gráfica, como já demonstrado, destinada às

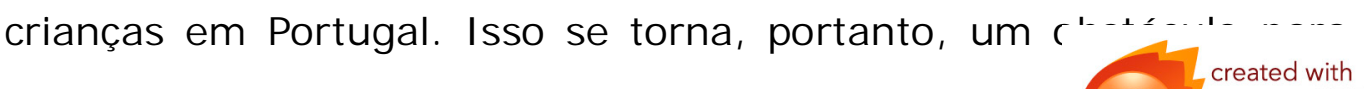


livro-álbum ganhe projeção no país, ficando, assim, circunscrito a um público determinado pelo poder aquisitivo.

Outra hipótese aventada é o fenômeno da influência da produção inglesa na Península I bérica. Na Inglaterra, os álbuns apresentam as mesmas características gráfico-plásticas encontradas em Portugal; como já apontado, a Europa, de maneira geral, adota essa perspectiva, instituindo o livro como um objeto de "oferta", isto é, pais, tios, padrinhos oferecem livros aos meninos em datas comemorativas. Hábito extremamente salutar. Vale, contudo, tomar o padrão financeiro médio de um inglês e o mesmo padrão de homem português ou espanhol e verificar se essa opção mercadológica é valida como incentivo à leitura ou se, em contrapartida, limita o acesso à leitura.

A justificativa de ordem pedagógica também vem à tona na reflexão de Gomes e deve ser pensada com cuidado, na medida em que é possível ser o livro para crianças uma ponte para a leitura canonizada, visto que é proposta da literatura infantil formar o leitor literário. É plausível pensar na passagem da imagem para a palavra como um processo de aquisição de leitura. Seria uma passagem da imagem própria ao aprendiz não-alfabetizado para a palavra, quando o sujeito adquirisse a competência leitora ${ }^{25}$.

O livro como objeto a ser manipulado estaria ali para que a criança com ele se familiarizasse, sentisse o prazer da descoberta, (ou por ele) aprendesse a relacionar-se com o mundo de outra forma, ampliando sua vivência e seu repertório ${ }^{26}$.

A escola deve preocupar-se com o livro em cada uma de suas etapas de escolarização, não apenas como algo que desenvolve o intelecto, mas também como um objeto artístico que se dá à contemplação:

${ }^{25}$ A obra brasileira O menino quadradinho, de Ziraldo, ilustra bem esta passagem das histórias em quadrinhos ao livro.

26 Essa é uma perspectiva a ser pensada tanto em Portugal co final desta tese, tal problemática será devidamente tratada. 
El libro infantil ilustrado es un camino hacia la apreciación de las artes visuales. Es un medio excelente para abonar la sensibilidad del niño, para abrir sus sentidos a modos diferentes de representar que trasciendan lo figurativo, lo explícito y lo obvio. Es una vía idónea para familiarizarlo con propuestas que sorteen el peligro del estereotipo, del clisé (ANDRICAÌ N, 2001, p. 4).

Para atingir esse objetivo, professores e bibliotecários devem ser formados para a leitura dos livros infantis de maneira a dar conta das qualidades estéticas do objeto ${ }^{27}$.

Tal necessidade não é, todavia, de total e única responsabilidade da escola, toda a sociedade deve ser envolvida na tarefa da leitura. É um confluir de ações que conduzem o leitor à leitura; isso não se fará por decreto ou com vara de condão, pelo contrário, é um processo e deve estar sempre em pauta.

O livro de imagem ou livro-álbum aproxima o leitor de um universo que também lhe é permitido. Se o livro-objeto pertence apenas a espaços proibidos, - como altas prateleiras da casa, organizadas e protegidas; estantes de bibliotecas impedidas para as crianças e mãos superprotetoras dos adultos -, a mensagem é de que aquilo não the pertence, não lhe é próprio e, portanto, deve-se manter à distância.

Já se o livro the é acessível, em forma e em conteúdo, como objeto manipulável e repleto de desencadeadores de sensações das mais prazerosas, ou mesmo das aterrorizantes, ele será sempre "sentido" como algo a ser explorado e sempre ao seu lado na vida. O corpo anseia por experiências sensíveis. Por isso, o parque de diversões é um "campeão de audiência", assim como os jogos eletrônicos, porque proporcionam ao corpo distintas sensações.

O livro tem possibilidade de ser um parque de diversões dos sentidos, resta ser bem trabalhado pelo mediador. Eis algumas obras-

27 Em Portugal, o Instituto Português do Livro oferece cıırcnc de formarãn anc professores e bibliotecários, como foi possível constatar investigação neste país. 
imagens que saltam aos olhos e clamam por relações com as artes plásticas - do surrealismo de Magritte a Pop Art de Warhol.
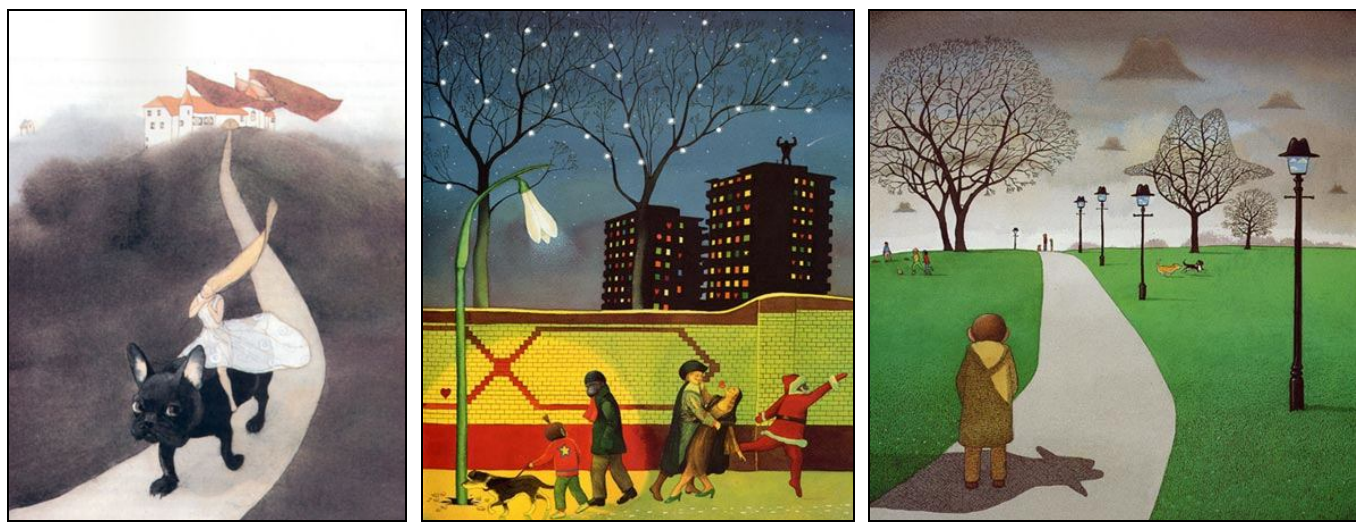

Figura 2.5 - Antony Browe

Voltando, no entanto, aos motivos enumerados por Gomes, o último revela a preocupação com a formação de recursos pessoais. A dupla vocação (escritor e ilustrador) só existe se for estimulada, como toda a produção. Em Portugal, não se percebe tal fenômeno evidente, por isso, como aponta Gomes, constituiu-se como uma prática pouco habitual. A ausência de incentivo, por parte de editores, livreiros ou leitores, pode ser uma hipótese tanto para raridade de artistas com a dupla vocação como para a inexistência de equipes de trabalho ${ }^{28}$.

A argumentação de Gomes tece reflexões encerradas no próprio contexto português, acerca da relação palavra-imagem. Compreender a raridade do fenômeno conjunto autor-ilustrador pode revelar outra forma de apropriação, ou mesmo de ação da literatura infantil. Por meio dessas constatações, assim começa-se a conhecer a literatura infantil portuguesa, a saber, como hipótese: uma literatura para crianças em que não há integração palavra-imagem no projeto gráfico.

${ }^{28}$ Vale ressaltar que o cenário no Brasil é outro, e essa cor capítulo final deste estudo. 
Manuela Bacelar, contudo, desponta como autora exceção no cenário português, pois se aventura pela dupla vocação, além de ser ilustradora de outros autores. Por ser um exemplo de ruptura na produção destinada à criança em Portugal, torna-se fundamental neste trabalho, porque, justamente, nega (ou negaria) a hipótese formulada.

A ousadia da autora, como ela própria afirma, deriva de sua formação fora do território português e, portanto, fora do cenário esboçado anteriormente:

Tenho uma formação além-fronteiras, que desde muito pequena tive livros para crianças. Meu pai era advogado, mas simultaneamente crítico literário, minha mãe era uma mulher muito ligada às artes, não como praticante, mas como apreciadora das artes, e, portanto, eu fui rodeada por livros. Desde miúda, habituei-me a ver que os livros para crianças muito pequenas tinham só um autor, era o autor do texto, o autor da ilustração, e ainda hoje é assim. De uma maneira geral, os livros ingleses, os livros franceses, os livros etc, etc... Em $80 \%, 70 \%$ o autor e o ilustrador são um só. Para crianças de idade menor, de 4, 5 anos. Portanto, eu sou autora de livros infantis, e normalmente um autor de livros infantis faz as duas coisas (BACELAR, M. Entrevista concedida a Mariana Cortez. Porto, 18 abr. 2006).

Gomes (2003) também destaca Bacelar no cenário de literatura infantil portuguesa e reafirma a formação além-fronteiras da artista, como justificativa para a sua excepcionalidade: “Familiarizada com o panorama da edição internacional, capaz de reunir os dois requisitos em causa, é natural que tenha sido a mais experiente das ilustradoras portuguesas uma das primeiras a abalançar-se ao projeto de conceber este tipo de obras" (GOMES, 2003, p. 18).

$\mathrm{Na}$ esteira desses argumentos, cumpre lançar os olhos à maneira de fazer da artista. Como a formação além-fronteiras contribui para sua singular produção? E, ainda, é válido perguntar se, no seu desbravar, outros a seguiram ou se, de fato, tal fenômeno não é fértil e não pertence ao espaço cultural português. 
Abrem-se, pois, as portas da aventura disposta em livro-objeto, destinado ao tatear, ao apalpar dos mais miúdos no contexto lusitano.

\subsection{A Obra de Manuela Bacelar: Desbravando Espaços}

É prática comum na literatura infantil, em qualquer lugar do mundo, a imagem acompanhar o texto. Portugal não foge à regra, como foi apresentado anteriormente. A produção de álbuns com autores de dupla vocação como já ponderado, no entanto, é uma prática mais rara nesse país. Manuela Bacelar é pioneira nesta expressão, se não a primeira $^{29}$, com certeza aquela que mantém regularidade em sua produção no final do século $X X$ e início do século $X X I$. Isso justifica a presença da autora na discussão que ora se propõe, além, é evidente, da qualidade de sua produção e de ser uma artista plástica por formação ${ }^{30}$.

Em 1990, destacam-se de sua autoria O dinossauro e O meu avô (ambos pertencem à coleção O Triciclo Voador), como bem aponta Gomes (1991) num balanço da produção para criança no início dos anos 90:

Num panorama editorial no qual escasseiam os álbuns de pequenas histórias para crianças dos quatro aos seis anos, é sempre de saudar o lançamento de obras originais de autores portugueses, como as de Manuela Bacelar editadas em 1990 (p. 69).

O crítico denomina álbum os livros em que palavra e imagem formam um todo de sentido. Não há sentido na leitura de apenas uma linguagem, ou seja, uma linguagem depende da outra, como foi definido no início deste trabalho de tese ${ }^{31}$.

29 Segundo Natércia Rocha, Maria Keil se destaca, em Portugal, como autora de textos e imagens: "Maria Keil [...] atinge uma carreira notável que abrange outras modalidades [...] com desenhos e textos seus, publicou três títulos" (2001 n 163)

30 A definição do gênero em questão foi abordada no capítulo 1.

31 Estes são os critérios apresentados na seleção do corpus dest 
Em seguida, houve a publicação da coleção $\operatorname{Tobias}^{32}$ (de 1989 a 1992), pela editora Porto, hoje esgotada. Finalmente, Bacelar publica, em 2004, Sebastião e, em 2005, Bernardino, ambas pela Edições Afrontamento. Outras publicações da autora existem em edições educacionais ou governamentais de menor tiragem e distribuição. Paralelamente a esse trabalho como autora-ilustradora, mantém-se, regular, sua produção apenas como ilustradora.

Em face da relevante produção no mercado editorial português, valida-se o estudo da obra de Manuela Bacelar como um fenômeno importante em seu país ${ }^{33}$, no que tange tanto à dupla vocação quanto à autoria de imagens.

Sobre a obra de Manuela Bacelar, três questões abrem perspectivas para a discussão sobre a relação palavra-imagem encadeadas pelo projeto gráfico no livro infantil português, segue o detalhamento da abordagem pretendida.

A autora assume, em sua produção, três distintos modos de presença ${ }^{34}$. Mesmo descartando, como ensina a Semiótica, a figura do autor de "carne e osso", a maneira de fazer do enunciador se distingue em cada modo de presença, independentemente de haver duas ou uma pessoa executando o texto. O projeto gráfico será tomado, então, para a demonstrar tal questão. Não é fácil essa tarefa, mas assegura-se o

32 Composta por Este é o Tobias (1989), Tobias e o leão (1990), Tobias, os sete anões e etc, Tobias encontra Leonardo (1991); Tobias do lado de lá do arco-íris (1992), Tobias, "o que eu passei para chegar até aqui" (1992). Esta é a coleção que autora mais prazer obteve, pois se sentiu livre para produzir (BACELAR, M. Entrevista concedida a Mariana Cortez. Porto, 18 abr. 2006).

33 Manuela Bacelar é também reconhecida no cenário internacional da ilustração, e isso pode ser comprovado por meio dos prêmios recebidos: "Maçã de Ouro - Bratislava 1989", "Prémio Octogones" - França - 1992, "Prémio Paolo Vergerio da Universidade de Pádua" - Itália - 1993, entre outros.

34 O termo "modos de presença" é empregado em referência à semiótica do sensível apresentada pelo pesquisador Eric Ladowski, em Presenças do outro, quando assume a seguinte perspectiva: “De fato, a semiótica não sendo para nós uma doutrina, mas uma prática, tentamos praticá-la: falá-la (a palavra de ordem está no aprendizado de segundas línguas) mais que falar dela. Pois bem, como todas as outras linguagens, não só ela está por natureza em devir, mas, sobretudo, deve permitir falar de outras coisa que não dela mesma: de textos:objetos, é claro, e de seus contextos, evidentemente, mas também das práticas reais nas quaic ectamn c diariamente envolvidos. Por exemplo, dessa prática semiótica em situaç⿳亠丷 produção da presença do outro, como tendo sentido (2002, p 
desafio. Os diferentes sistemas, as diferentes linguagens e, sobretudo, a articulação entre as expressões deixam ao analista frestas, para que um olhar atento e rigoroso possa espiar, vasculhar e, acima de tudo, trazer à luz plena as implicações interdisciplinares conseqüentes desse emaranhado que faz da obra de Bacelar para crianças um objeto sensível à contemplação artística. I mpõe-se, então, uma busca acurada sobre o projeto gráfico e se pergunta: ele (projeto gráfico) sofreria alterações devido ao modo de presença de um autor-ilustrador? Ou o projeto gráfico configura-se como enunciador? ${ }^{35}$

Assim, o primeiro modo de presença a ser analisado diz respeito à produção de Bacelar como autora de textos verbais, uma vez que nasceu no espaço das artes plásticas, muito embora em entrevista revele sua aproximação com as letras desde muito pequena ${ }^{36}$.

O segundo, de certa maneira, apresenta Bacelar como leitora de textos alheios e com a tarefa de transformar essa leitura de uma obra considerada clássica em imagens. Essa prática foi amplamente desenvolvida pela autora, como se pode comprovar pelo número de obras realizadas, e é mesmo o modo de presença habitual em sua literatura infantil.

Finalmente, o terceiro modo será o exercício de Bacelar como autora de livros de imagens, aqueles em que as imagens contam histórias, como já definido no capítulo anterior. Vale pontuar que essa não é uma

${ }^{35}$ É lícito lembrar que esta é a problemática pretendida por este trabalho de tese.

36 "Eu acho que escrever era uma coisa inata em mim, porque lembro-me de que quando criança eu não gostava muito de estudar, eu não gostava muito de teoria. Gostava muito de ler, era uma grande leitora. Minha mãe marcava a mim e aos meus irmãos horas certas para o estudo e, eu invés de estudar, eu escrevia. O simples diário eu tentava ter um estilo. Claro, naquela altura, eu era influenciada por A, B ou C. Passei minha adolescência, como a maioria dos adolescentes, a escrever poemas. Nas aulas de Língua Portuguesa, eu era péssima em gramática, embora dominasse intuitivamente, é claro, mas salvava-me sempre a minha classificação com a redação. No fim sempre havia uma redação. Isso foi uma coisa inata, tal e qual a visão, tal como gostar de música. Eu lembro-me de quando criança estar a desenhar, brincar de adivinhar o compositor da música que eu estava a ouvir no rádio. Quando era menor ainda, de descobrir qual era o instrumento. Acho que sempre gostei das artes todas, sem distinção. Mais tarde fiz balé, mais tarde fiz teatro, mais tarde nuic cer derlamadnra No meio de tanta confusão tive de optar e optei pelas artes $p$ (BACELAR, M. Entrevista concedida a Mariana Cortez. Porto, $1 \varepsilon$ 
prática constante de Bacelar, há apenas dois livros de sua autoria que apagam a palavra e dão voz às imagens ${ }^{37}$.

Tratando de (re)conhecer o livro infantil português e suas expressões constituindo o projeto gráfico, O dinossauro (1990) apresentará Manuela Bacelar como autora de textos verbais-visuais. A Sereiazinha, de Hans Christian Andersen (1995), revelará Bacelar como leitora e autora de um texto visual para as palavras de outro autor, um clássico. Sebastião (2005) dará conta de apresentar a narrativa sem palavras.

Assim, a partir da leitura da produção de Bacelar, aposta-se em três diferentes relações propostas no projeto gráfico de obras destinadas às crianças, eis a hipótese de trabalho. Então, trazer à luz a maneira como esses objetos significam em um projeto gráfico é a sugestão do capítulo.

Deslindar o sentido dessa produção gráfico-plástica trará à cena o objeto artístico com seu corpo-texto, que tem ação sobre o corpo-leitor, que se move por essas intrincadas veredas da palavra, da imagem e da composição. Lembrando que ambas as linguagens embalam o sujeito em uma experiência estética repleta de contribuições para a composição do indivíduo tanto na particularidade, o autoconhecimento, quanto na coletividade, o conhecimento do outro - mundo:

O enigma consiste em que o meu corpo é ao mesmo tempo vidente e visível. Ele, que mira todas as coisas, pode também olhar-se, e reconhecer então naquilo que vê o 'outro lado' do seu poder vidente. Ele vê-se vendo, toca-se tocando, é visível e sensível para si mesmo (MERLEAUPONTY, 2004, p. 20-21).

Diante de tais objetivos, descortina-se a produção portuguesa de leitura destinada a crianças - de um caso particular, a produção literária de Manuela Bacelar - para a extensão de outros autores de terras lusas;

37 Os livros de imagem de Bacelar são Consola-te e Sebastião. 
na conclusão, será apresentada uma amostragem do cenário da imagem infantil no projeto gráfico em Portugal.

\subsubsection{Como Autora-I lustradora: Experiência I naugural no Panorama Português em O Dinossauro}

Nunca me esquecerei desse acontecimento na vida de minhas retinas tão fatigadas. Nunca me esquecerei que no meio do caminho tinha uma pedra (Carlos Drummond)

Descobrir espaços, romper fronteiras, alterar sistemas é o exercício do artista à frente de seu tempo e espaço. Os lugares restritos, determinados, cerceados pelo estabelecido se convertem em prisão e há, por necessária conseqüência, que se sair em fuga. A esses sujeitos da inovação se conferem nomes-adjetivos: loucos, visionários, revolucionários, idealistas, mas, ao olhar para as estradas da história e, em especial, da história da arte, da literatura em particular, percebe-se que, ao fazer a revolução - ao se dar a volta -, deixa-se a marca, imprime-se sua personalidade e, acima de tudo, determinam-se os próximos passos.

Manuela Bacelar é um desses casos. A autora estaria entre aquele que Calvino (1993) definiu como clássico:

Os clássicos são livros que exercem uma influência particular quando se impõem como inesquecíveis e também quando se ocultam nas obras da memória mimetizando-se como inconsciente coletivo ou individual. [...]

Os clássicos são aqueles livros que chegam até nós trazendo consigo as marcas das leituras que precederam a nossa e atrás de si os traços que deixaram na cultura ou nas culturas que atravessaram (ou mais simplesmente na linguagem e nos costumes). 
Um clássico é uma obra que provoca incessantemente uma nuvem de discursos críticos sobre si, mas continuamente as repele para longe (1993, p. 9-13).

Em diálogo com esta abordagem, vale lembrar as palavras de Jorge Luis Borges: "El hecho es que cada escritor crea a sus precursores. Su labor modifica nuestra concepción del pasado, como ha de modificar el futuro" (1998, p. 309). Seria lícito pensar, então, sobre Bacelar como desbravadora de espaços no cenário português e, por isso, as críticas acompanham a obra da artista:

Aos mais desmemoriados vale pois a pena recordar o final dos anos oitenta e o princípio da década de noventa: quando da edição das colecções "Tobias" e "O Triciclo voador", vários escritores e críticos se apressaram a denegrir injustamente - a meia voz, como sempre - o trabalho de Manuela Bacelar como autora de textos, porque, em boa verdade, Ihe escapara o significado global do seu gesto artístico, e de certa forma pedagógico, que passava por envolvimento por inteiro na criação de álbuns para crianças pequenas. E recorde-se, a propósito, que Manuela Bacelar fora formada na antiga Checoslováquia e, nas décadas de 60 e 70 (período em que o álbum conheceu um boom decisivo em alguns países europeus e nos Estados Unidos), tinha contacto freqüente com a produção européia neste campo (GOMES, 2004, p. 17).

A autora em questão, como Gomes afirma, não foi compreendida em seu "envolvimento por inteiro na criação" em seu país. A crítica não percebia o gesto inovador da artista. Não entendia Bacelar como uma autora com formação além-fronteira: "Tenho uma formação alémfronteiras, $[\ldots]$ desde muito pequena tive livros para crianças" (BACELAR, M. Entrevista concedida a Mariana Cortez. Porto, 18 abr. 2006).

Essa autora traz, ao contexto português, a experiência do alheio. Esse ato, ontem e hoje, exige coragem e implica resistência diante do estabelecido.

Bacelar terá de abrir caminhos e romper preconceitos para ter sua obra reconhecida. A essa altura, a artista já ti 
ilustradora. Passar da imagem para palavra parece não ser possível, nesse momento, em Portugal. Entretanto, Bacelar se afirma como uma artista com dupla vocação.

Às letras, sempre são reservados os espaços sacralizados. Pergunta-se, como um "mortal", não dotado pelos "deuses da criação literária", poderia aventurar-se nessa arte? Esta voz ecoa dos muros acadêmicos das Letras.

$\mathrm{Na}$ contracorrente, com formação nas artes plásticas, Bacelar enfrenta os obstáculos para garantir espaço à sua obra, o que implicará, a dupla vocação.

\section{A capa: o convite à leitura}

Para entender um texto como poético, que cumpra a expectativa de trazer o leitor por meio das vias sensíveis, há que se ater tanto ao plano do conteúdo quanto ao da expressão e, ainda, demonstrar a correlação entre eles, como define a Semiótica, por meio do conceito de semi-simbolismo:

Para compreender, en su exacto sentido, el concepto de lectura, éste se debe delimitar, fundamentalmente, como una semiosis, es decir, como una actividad cuyo objetivo es poner en correlación un contenido con una expresión dada (VILCHES, 1995, p. 100).

Os caminhos entre o sensível e o inteligível devem estar cruzados, para que o leitor-criança possa experimentar as sensações da arte e, também, elaborar e ampliar sua compreensão/vivência do mundo, objetivo primeiro da arte literária no espaço educacional.

Percorrer as tramas desses planos na obra de Manuela Bacelar é a tarefa que se impõe, tendo a conquista do leitor como o objetivo que se 
mostra no horizonte. Sobretudo, entender se há eficiência no conjunto dos sistemas expressos no projeto gráfico é o desafio instaurado.

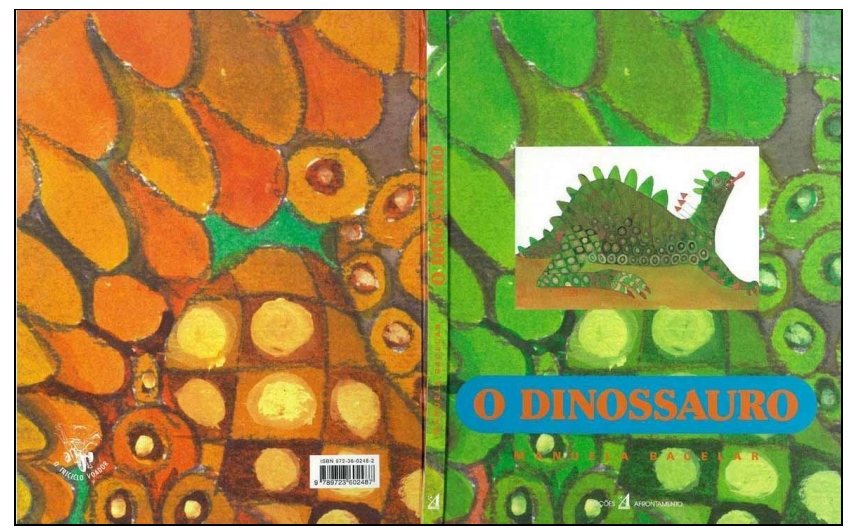

Figura 2.6 - Contracapa e capa

A narrativa apresentada em $\mathrm{O}$ dinossauro é uma descrição de acontecimentos. As cenas passam, literalmente, diante dos olhos dos leitores. Cada virar de página acrescenta um novo elemento à trajetória narrada, revelando-se surpreendente e evocando a fantasia.

Em uma pequena aldeia de Portugal, identificada pela maneira como aparecem as figuras ${ }^{38}$, um monte é coberto por uma suposta vegetação verde, sobre a qual existem casas.

A situação inicial, porém, é interrompida quando as casas começam a tremer, sacudir, pois o monte se revela um animal que desperta.

Diante do fato inusitado, os habitantes do "monte" procuram o professor, aquele que "tudo sabe", para, assim, entenderem o que se passa. O mestre sentencia que o "monte" é um animal pré-histórico despertado depois de muito tempo. O monstro se revela um dinossauro.

Duas questões se apresentam desta perspectiva, a saber: a capa como anáfora (indício) do que está por vir e a diferenciação entre enunciado e enunciação.

${ }^{38}$ Mais adiante, a referência a Portugal será tratada, levanc afirmação sobre as figuras estereotipadas que compõem a im 
Na capa, o verbal O dinossauro, redundado pelo desenho do animal, apresenta, de imediato, ao leitor, o protagonista da narrativa - o monte verdejante transformado em animal pré-histórico.

$\mathrm{Na}$ enunciação, o contrato entre enunciador e enunciatário se estabelece. "Eles" (leitores) detêm o segredo, na medida em que, no enunciado, os actantes (habitantes da aldeia) serão surpreendidos pela transformação do monte em dinossauro, informação que os leitores já receberam, antes mesmo de abrir o livro. Essa revelação só é feita às personagens no transcorrer da narrativa, ou seja, o enunciatário detém uma informação que o actante (personagem da narrativa) ignora. Evidencia-se, por meio dessa estratégia, o contrato enunciativo da obra. A imagem por associação de formas e cores leva o leitor ao imediato reconhecimento do protagonista representado pelo verbal e pelo visual na capa, isto é, o dinossauro.

Antes de virar a página, a capa se apresenta pelas qualidades da expressão: ela é composta por diferentes tons de verde (círculos) e cinza, que formam o pano de fundo dessa capa. No recorte ou janela branca, um retângulo apresenta a imagem da personagem título - o dinossauro mostrando a língua. Ele está bem no centro da capa, conferindo-lhe protagonismo e isso é reiterado pelo verbal.

O monstro nada tem de assustador, como se pode perceber, antes, parece uma dócil caricatura do monstro que atualmente aterroriza o imaginário em narrativas cinematográficas, como o sucesso de bilheteria Jurassic Park, de Steven Spielberg. O de Bacelar, contudo, não apresenta traços realistas, imprimindo o contrato da ficção logo no convite da leitura.

Alguns poderiam pensar que um monstro assustador afastasse o leitor-criança da leitura, e isso justificaria a opção enunciada, mas tal estratégia não se confirma. Primeiramente, porque o corpo anseia sensações positivas e negativas nas narrativas ficcionais, como bem demonstram as análises psicanalíticas: se for tomada, novamente, a imagem do parque de diversões, tanto o carrossel como o trem fantasma fazem sucesso, reforçando a teoria desenvolvida por 
também pelo sucesso de bilheteria, como afirmado, do filme de Steven Spielberg, que se tornou, mesmo, "mania" no imaginário infantil e, por vezes, até no adulto.

Assim sendo, a opção por um monstro dócil se dá na medida em que ele se mostra não como inimigo, mas, pelo contrário, como um auxiliar narrativo: dará poder ao actante coletivo ("toda gente") e ao actante indivíduo-professor, para realizar o percurso narrativo que levará ao conhecimento de espaços inexplorados (passeio pelo mundo todo).

Ainda, na capa, a personagem-título está deitada sobre a terra marrom; por semelhanças e escapes de cores, em que se observa uma contaminação cromática, ou seja, terra e animal se envolvem.

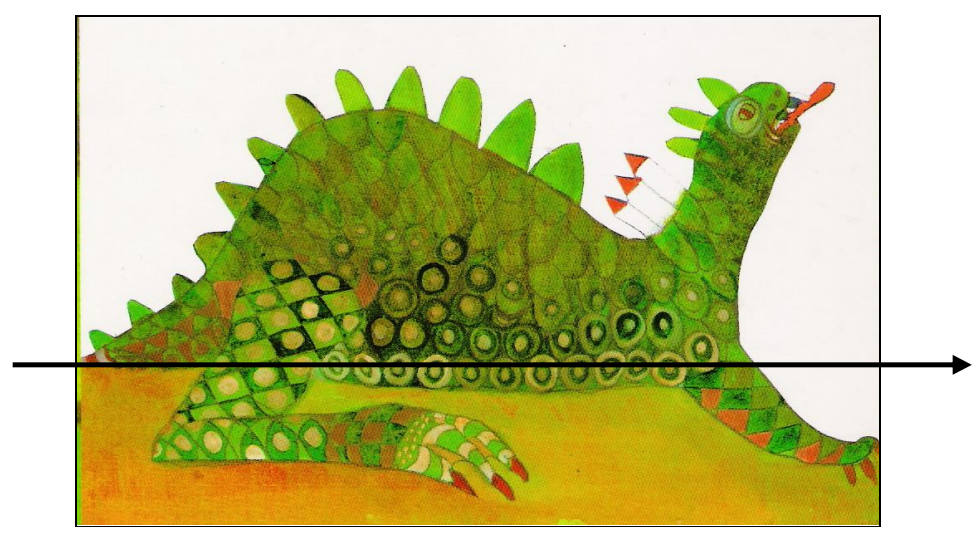

Figura 2.7 - Contaminação cromática

$\mathrm{Na}$ composição da pele do monstro, há influências artísticas que remetem ao universo de Klimt, que se tornam padrão por repetição como um pano de fundo para a capa. A pele perde a sua figurativização mais icônica e passa à abstração, no fundo da capa e em toda contracapa. 


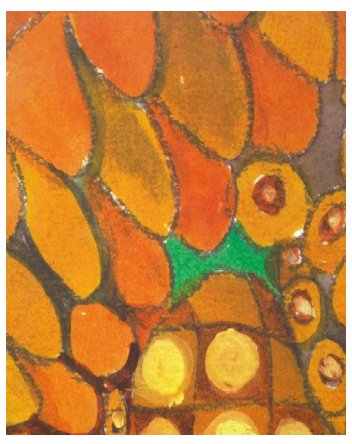

Figura 2.8 - Contracapa

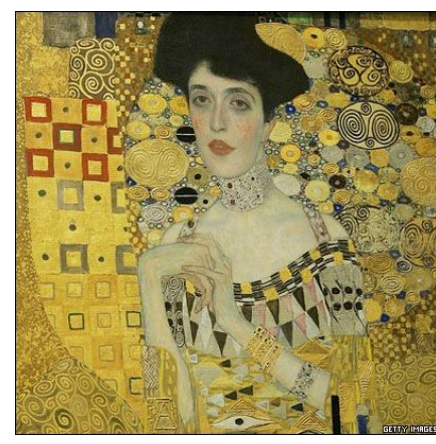

Figura 2.9 - Klimt

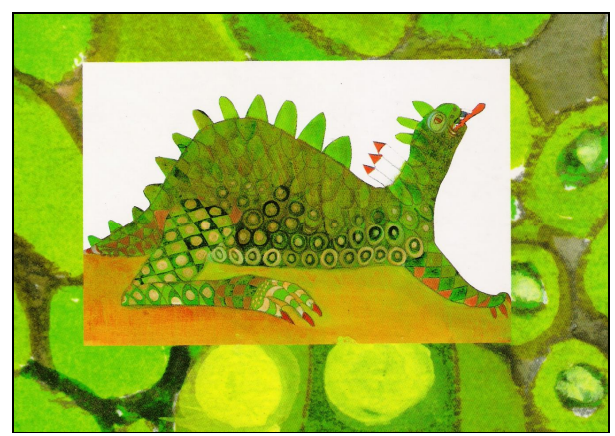

Figura 2.10 - Capa - fundo

Não é difícil reconhecer no traço das obras de Manuela Bacelar referências a outros artistas. Pessoas, animais e objetos voadores lembram Marc Chagall, influência nomeada pela própria autora e confirmada ao longo das análises de suas obras, como será demonstrado. Em O dinossauro, pode ser observada a relação a seguir:

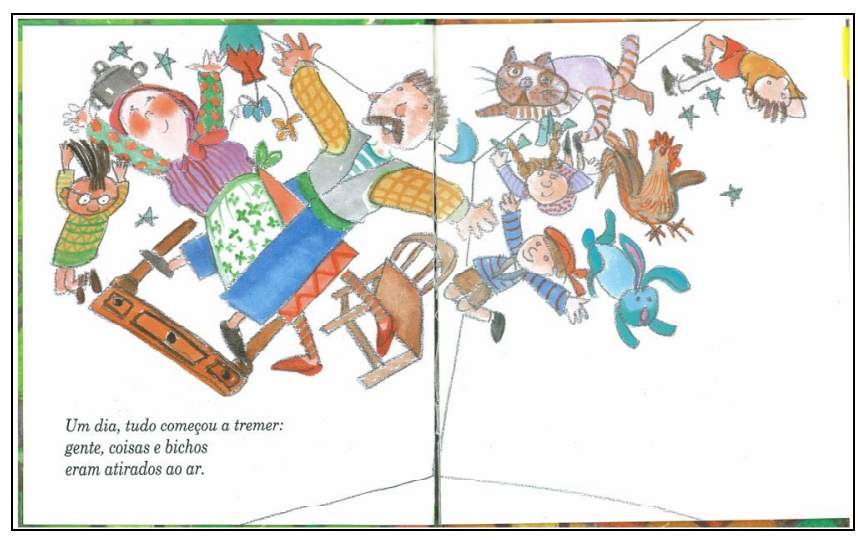

Figura 2.11 - O Dinossauro

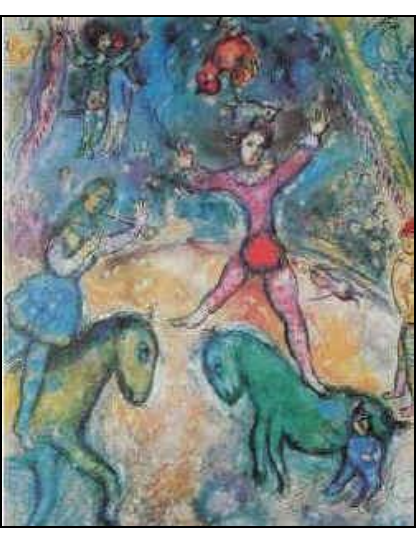

Figura 2.12 - Chagall 
O que influenciou meu trabalho... é tudo, porque eu tenho a princípio olhos para ver. Acho que olhar é saber ver, não é olhar, é saber ver. Há uma diferença entre olhar e ver. Ver é muito importante. A pintura influenciou o meu trabalho evidentemente. Eu vi pintura desde pequenina. Eu lembro que me contavam histórias de fadas oralmente e eu imaginava as meninas do Botticelli. As fadas eram as meninas do Botticelli. Mas é evidente que os meus pais também influenciaram, porque eu vivi numa casa em que não se ligava para que estivesse tudo ordenadinho, tudo regradinho, mas ligava-se para não ser tiroso, não ser cafona (BACELAR, M. Entrevista concedida a Mariana Cortez. Porto, 18 abr. 2006).

Conclui-se, então, que o diálogo entre textos é uma constante nos discursos, sendo-lhes mesmo inerente, como institui as teorias do discurso, formuladas por Bakhtin, inicialmente, e desenvolvidas por Kristeva $^{39}$. E que as obras destinadas à infância não fogem à regra, visto que se constituem, sobretudo, como discursos. Esse é uma das estratégias que será agente na formação do leitor literário.

Saindo do discurso e seguindo pela expressão, o nome da autora e o título estão na cor laranja. O título, no entanto, é destacado pelo contraste com o azul sobreposto à imagem, como um retalho, um recorte, daquele padrão que faz referência à pele do dinossauro. O nome da editora aparece ao pé da capa, em branco.

Tanto o nome da autora como da editora se confundem com o fundo, portanto, não há destaque nem para um nem para outro. Talvez se perceba, mesmo, uma fusão entre os universos - o da história e o do processo. O destaque, se desejado, deve ser conseguido pela oposição de cores (por exemplo, quente $X$ frio, vibrantes $X$ suaves, cores complementares). No caso analisado, no entanto, não há contrastes que possam ser identificados.

A obra é de capa dura, como a maior parte da produção portuguesa destinada ao público infantil não foge aqui à regra. A página de guarda é azul, recuperando o fundo, em que está escrito o título da obra.

39 Conforme BAKHTIN, M. Marxismo e Filosofia da linguagem. s e KRISTEVA, J. Introdução à semanálise.São Paulo: Perspecti 
Esses elementos reafirmam o cuidado gráfico presente na produção portuguesa, a saber: a qualidade do papel e a qualidade cromática. A página de guarda apresenta a oposição cromática: laranja (quente) $\mathrm{X}$ azul (frio).

Passada a página de guarda, já na história, adianta-se que o narrador, em primeira pessoa, não cumpre o papel normalmente atribuído ao narrador em primeira pessoa, ou seja, viver como personagem os dramas narrativos. Neste caso, ele observa a ação desencadeada pela transformação do monte em um animal pré-histórico (o dinossauro). É fato, no entanto, que o leitor acompanha sua emoção no transcorrer da narrativa, mas acompanha o relato de um observador da ação.

O efeito-surpresa, como bem observa Gomes (1991), perde-se para o leitor, como fora apontado:

Um único senão: para as crianças recém-chegadas à leitura, a presença do título da história, na mesma página em que se inicia a narração, anula o efeito surpresa preparado pelas oito primeiras páginas. De facto, associação imagem/título leva à conclusão imediata de que o monte não é mais do que o dorso do dinossauro (1991, p. 71).

Sobre essa ocorrência é necessária a reflexão acerca da palavraimagem. Por meio da palavra, são desfeitos o enigma e a surpresa. Aquela característica delimitadora da imaginação, tão insistentemente atribuída à imagem nos discursos pedagógicos de outrora, é assimilada, neste caso, pela palavra. Isso leva a crer que as linguagens podem anular-se no diálogo, mas que uma, não necessariamente, é delimitadora da outra, isto é, não é a imagem que tem em si qualidade de restringir o verbo. O que determina a redundância ou a originalidade é a concepção e organização gráfica de uma obra, ou seja, o papel do organizador do projeto gráfico é fundamental.

Assim, pondera-se que ser delimitador não é um traço inerente à imagem, pois, como demonstrado, a palavra também pode cumprir esse papel. A delimitação da imaginação pode dar-se quanNn n Niálnnn nslsurs imagem não for concebido como um todo significa 
acontecerá quando um diálogo ativo, em que uma linguagem nutre a outra, tornando-se um só sistema em um todo significativo: o projeto gráfico foi eficiente.

Na obra em análise, a imagem se sobrepõe à palavra, podendo esta ser quase descartada, não fossem alguns acontecimentos, como: o detalhamento sobre as características do dinossauro,- mas isso não é fundamental à narrativa- , e o caso da fotografia, ou melhor, da ausência dela, fruto do esquecimento do professor.

Sobre esse último elemento destacado, há um trabalho mais cuidadoso com a palavra e isso a torna fundamental neste álbum. O P.S. introduz um diferente gênero - a carta ou bilhete - abrindo caminho à isotopia metalingüística, ou seja, o que o leitor acompanhou ao longo das páginas é um registro em bloco de notas ou em diário de viagem. Essa isotopia pode ser reiterada pela imagem ao longo da história que parece feita às pressas ou como um rascunho. Isso se pretende demonstrar na edificação da análise.

Se essa isotopia for tomada, a crítica de Gomes ao efeito surpresa do dinossauro não se sustenta, visto que o projeto gráfico privilegia um contrato enunciador-enunciatário, a partir de um relato que reforçaria a subjetividade.

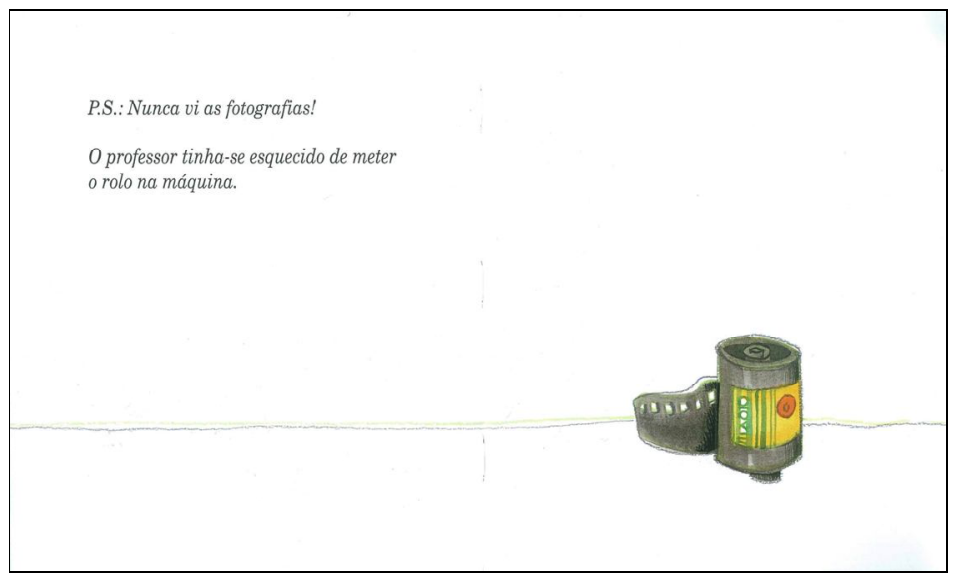

Figura 2.13 - Inserção do P.S 


\section{O miolo: da descrição à significação}

A situação inicial é apresentada na primeira página tanto pela imagem como pela palavra. A figura se localiza no lado esquerdo da página e transborda para o início da direita, já ocupando a página dupla; a imagem é sangrada, não há moldura. Ali, há o que se identifica como um monte verde, com árvores e casas.

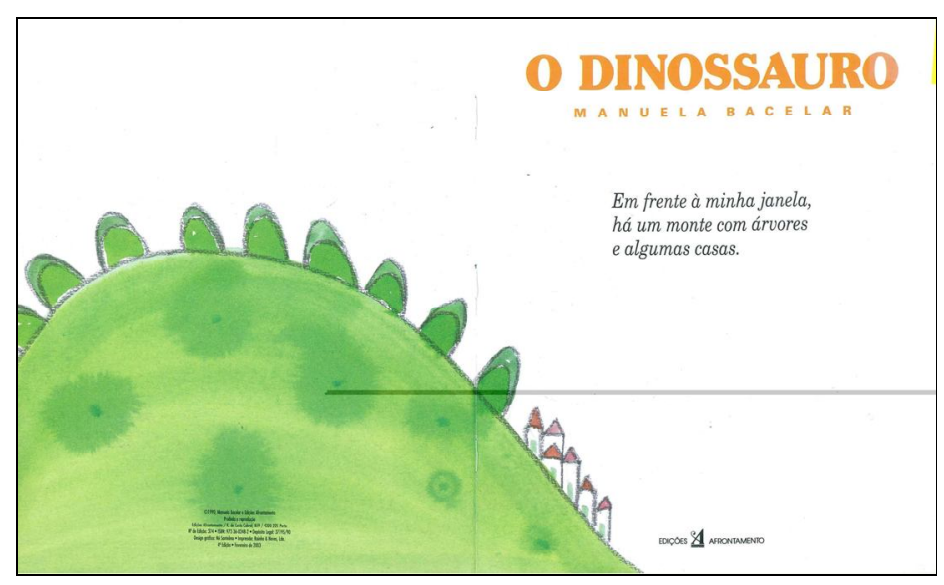

Figura 2.14 - Situação inicial

A palavra conta a história e também retoma o título, o nome da autora, o nome da editora, bem como a ficha técnica da obra. Coincidem, portanto, a página de rosto e o início da história. Não há, pois, divisão de espaços entre a realidade/enunciação (título, autor, ficha técnica, editora) e a ficção/enunciado (a história narrada), como é habitual nos livros, seja para o público adulto ou para criança, reafirmando o contrato enunciativo.

Esta apresentação é identificada por Gomes (1991) como também um problema. Segundo ele, parece haver um proposital desleixo no projeto gráfico, em que realidade e ficção não se separam. Pode-se, contudo, entender a presença de informações técnicas como elementos partícipes da significação da obra, corroborando a isotopia que se qiır nofandar 


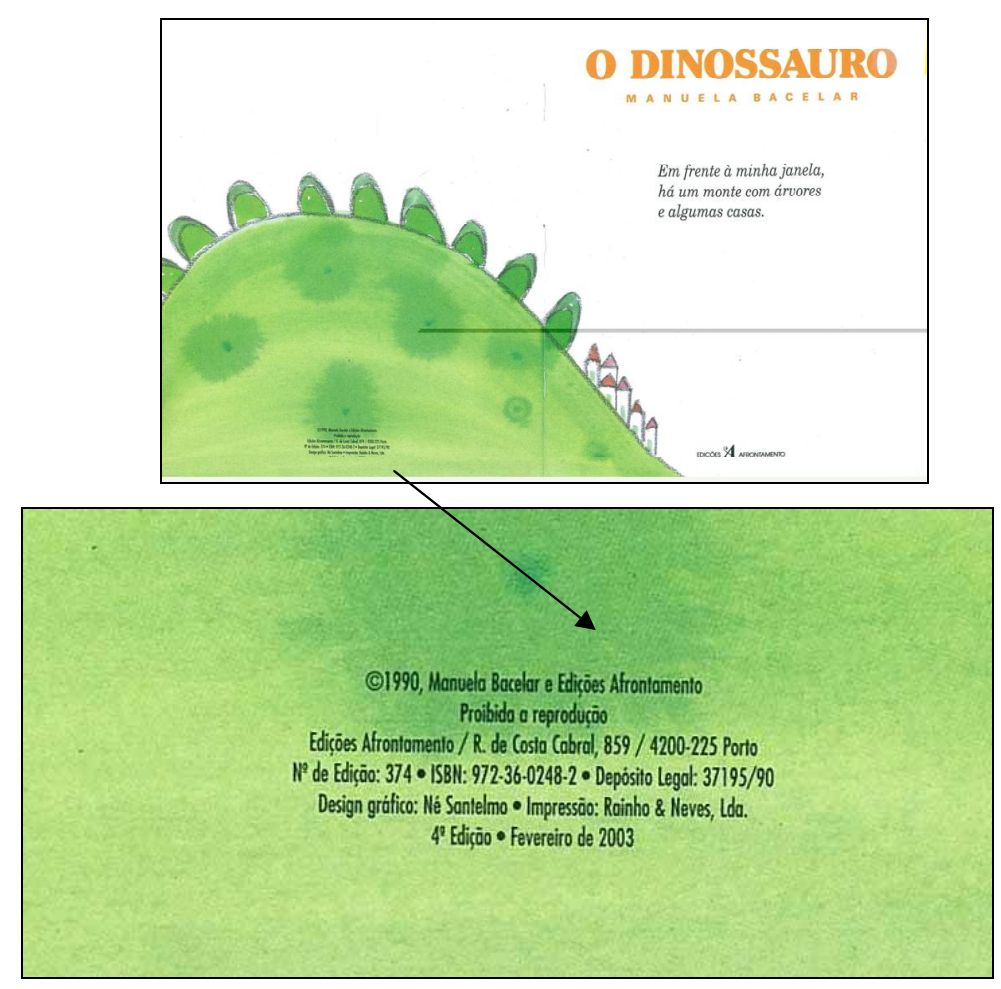

Figura 2.15 - Informações técnicas

De volta ao narrador: este é instaurado pelo pronome possessivo minha, em primeira pessoa, como já pontuado. Da janela, o narrador apresenta os fatos narrativos: "Em frente à minha janela, /há um monte com árvores/ e algumas casas". Da palavra casas, infere-se que haja gente. Com o virar da página, pessoas e animais são apresentados tanto no texto como na imagem.

À medida que se apresenta o narrador, o narratário também é instaurado. Será também pela janela, por meio dos olhos do narrador, que o leitor seguirá a história. Caminha-se, então, com um olhar subjetivo e, portanto, parcial dos acontecimentos, fato determinante quando o narrador está em primeira pessoa, considerando-se as implicações lingüísticas.

Para além da palavra que traz a condição de espectador ao leitor, a imagem também determina esse olhar pela janela, ou seja, fora de cena, fora da história. Como texto uno, palavra-imagem estabelece o foco narrativo coincidente - a função é do observador: 
La noción de texto excluye una pura multiplicación de elementos separados o el resultado de una suma de fénomenos independientes. Resalto, por el contrario, su unidad. Dicha unidad de los elementos situados en el interior de um texto es una propriedad semántica global de los mismos y recibe el nombre de coherencia que permite saber de qué cosa se está hablando o, en el caso de la imagen, qué cosa se está percibiendo o leyendo.

La coherencia textual en la imagen es una propriedad semántico-perceptiva del texto y permite la interpretación (la actualización por parte del destinatario) de una expresión con respecto a un contenido, de una secuencia de imágenes en relación con su significado. La coherencia no es solamente un principio de identificación semántica (qué se ve), sino que tiene también una función de distribución coordinada de la información visual en el nivel de la expresión (VILCHES, 1995, p. 34).

O leitor é passivo diante dos acontecimentos narrativos, mas isso não o exime de ser um agente ativo no preenchimento dos espaços comuns às narrativas elaboradas com imaginação e fantasia, como é o caso da que se analisa. Por isso, cabe ao leitor (re)construir o sentido. Compete a ele significar a obra. Este estar fora da cena, com um olhar por outros olhos, reitera a isotopia do relato, do registro parcial em primeira pessoa, corrobora o gênero de discurso - diário.

As pessoas e os animais que habitam as casas dos montes olham para fora, olham para aquele (ou aqueles) que os observam em uma situação de cumplicidade, como se fosse firmado um contrato. Cada actante cumpre o seu papel: os de "dentro" da história vivem, os de "fora" observam e talvez se emocionem, ainda não se sabe. O que se pode afirmar é que a cumplicidade é amistosa, visto as personagens olharem com bons olhos, olhos sorridentes, para os que estão à parte, na situação, agora, de narratários. 


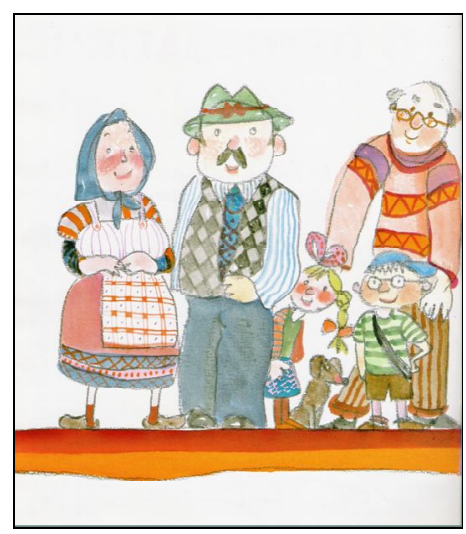

Figura 2.16 - Personagens instauram o narratário

Mesmo na página seguinte, quando o dinossauro desperta, as figuras humanas e animais estão, ainda, apesar da ruptura com a normalidade da pacata aldeia, olhando, sorridentes e tranqüilos, quase estáticos, para o leitor. Não há qualquer sinal de desespero e de inconformismo diante da situação inesperada. A cena é descrita por imagens que podem ser associadas a uma brincadeira, uma montanha russa, em que até o susto é prazeroso.

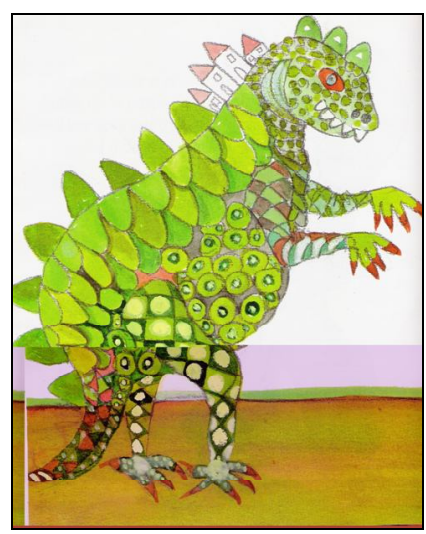

Figura 2.17 - Transporte-monstro

Mais uma vez, isso revela o olhar daquele que observa pela janela, envolto em toda a sua subjetividade, pois, para um adılto a situarãn seria, com certeza, desesperadora. Por isso, é po 
adulto não foi contemplado como leitor implícito, ou, no caso da Semiótica, como enunciatário presente nas malhas do discurso, constituindo o sujeito da enunciação.

Na página seguinte, a imagem recupera uma "cena portuguesa": pessoas estão à janela para observar o acontecimento e trocar experiências com os vizinhos. As janelas possibilitam a conversa entre vizinhos e tornam-se molduras desta cena. Cabe pontuar que a janela como moldura de conversa entre vizinhos é uma constante no imaginário sobre Portugal em terras estrangeiras. Essas janelas constituem a arquitetura portuguesa das aldeias do Norte, ou mesmo, no centro antigo de grandes cidades como Lisboa e Porto, assim tal associação é autorizada.

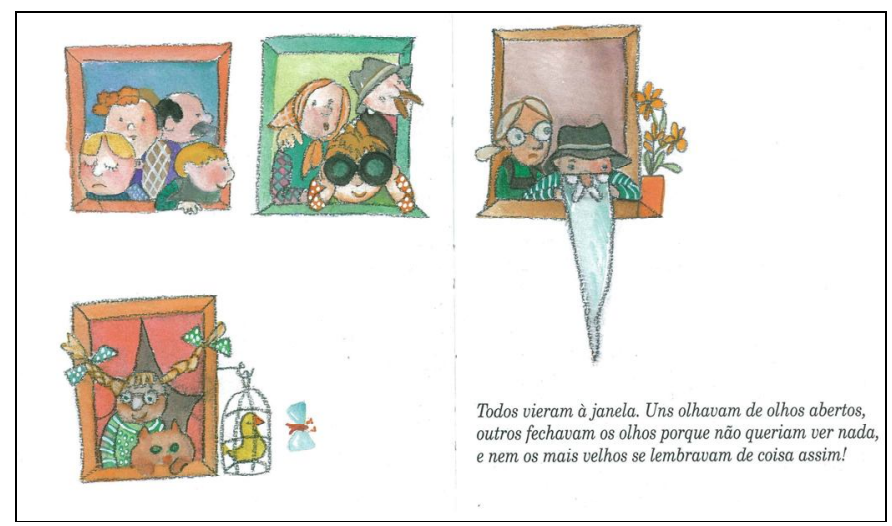

Figura 2.18 - Vizinhos trocam experiências pelas janelas

Vale ressaltar que a linha da terra que acompanhava a narrativa até então ${ }^{40}$ desaparece, o fundo é branco, vazado, de onde sobressaem janelas (quadrados coloridos) e, por estas, personagens, que conversam e observam.

Alguns elementos ultrapassam os limites do quadro. Não há perspectiva, há sobreposição de figuras. Cada janela é um quadro, recuperando até a idéia das histórias em quadrinhos.

40 A linha da terra será tratada mais adiante na análise desta ok 
Essa cena pode ser descrita da seguinte maneira: uma menina observa, e suas tranças escapam dos limites da janela, assim como sua gaiola e seu pássaro. Há, também, uma borboleta voando próxima à gaiola, não se sabe precisar de onde vem nem para onde vai o inseto; uma família - pai, mãe e dois filhos - compõe o quadro seguinte, em que o nariz e uma das mãos do filho estão fora da janela; outra família, agora com apenas um filho, surge de mais um quadrinho, e o que escapa são os bigodes e o chapéu do pai, e, finalmente, uma mulher mais nova e um senhor mais velho observam a aventura enquanto a longa barba branca do senhor escorre pela moldura da janela.

Apesar de elementos escaparem ao enquadramento da janela, a moldura persiste. O olhar, portanto, não está livre, mas sim determinado pelo limite da janela-moldura que cerceia o olhar do observador. O fundo da página é branco. O foco está nas ações simultâneas e interligadas que saltam das janelas.

Destaca-se a cena, descrita em detalhes, para refletir sobre um traço da imagem proposta nesta obra. Não há uma disposição regular da imagem na página, não há um padrão na apresentação das cenas.

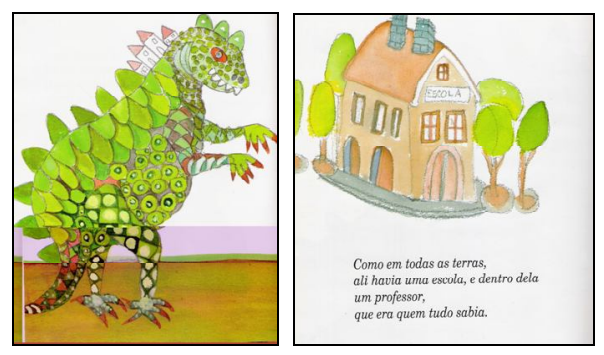

Figura 2.19 - Economia 

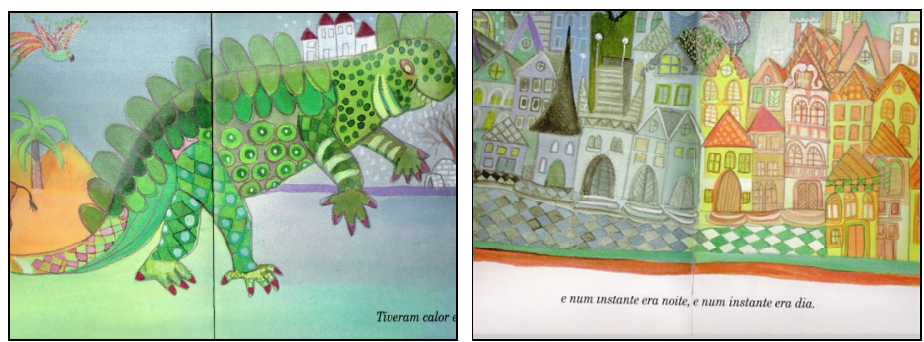

Figura 2.20 - Profusão

Essa organização casual (sem regra) revela a oposição entre profusão e economia ${ }^{41}$. Profusão de cenário (fundo), no que é alheio à cultura; economia de cenário (fundo), no que é próprio a essa. Com tal correlação, enfatiza-se pela expressão a idéia da viagem como aquisição de conhecimento e vivência. Por um lado, quando é desconhecido (alheio), há muitos detalhes; por outro, quando é conhecido, o espaço é vazio, não há detalhes, pois já se conhece, então, caso existisse detalhamento, este seria redundante do saber do leitor pretendido pela obra ${ }^{42}$. É, ainda, possível outra análise, essa a partir da pedagogia - as idéias são separadas para facilitar a leitura. Uma possibilidade, contudo, não invalida a outra, portanto, elas coexistem.
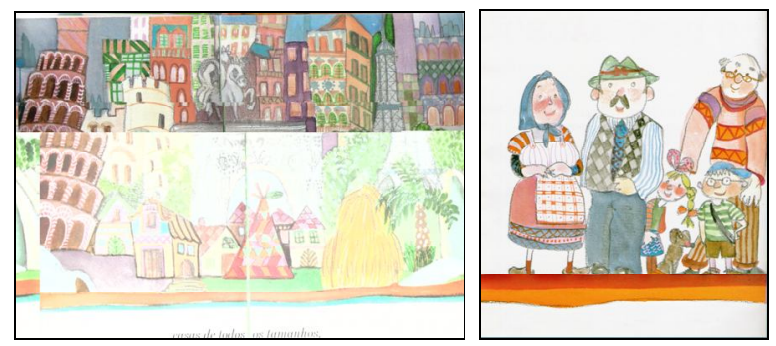

Figura 2.21 - Alheio / Próprio

${ }^{41}$ Oposição formulada em DONDIS, D. A. Sintaxe da Linguanem Vicııl Sãn Paıln. Martins Fontes, 2003.

42 Observa-se que o leitor pretendido são as crianças portugues 
Bacelar não segue um estilo linear, sistemático no sistema visual; ao contrário, impera o acaso, a simultaneidade. O suposto improviso marca seu estilo em $\mathrm{O}$ dinossauro.

O mesmo não acontece, contudo, no sistema verbal, sempre apresentado linearmente, seqüenciado ${ }^{43}$. Exceção feita à interferência do P.S., que rompe a linearidade narrativa para introduzir uma nova possibilidade de leitura, um novo gênero. Apenas na última página, no entanto, o verbal rompe a expectativa e, portanto, a previsibilidade, que o visual havia rompido há tempos.

\section{O formato: de um exemplo para a generalização}

Vale pontuar que, em O dinossauro, as páginas não são lidas como habitualmente o são em um livro, da esquerda para a direita obrigatoriamente, mas, a cada virada de página, tem-se um quadro com imagem e palavra. Se a leitura desse quadro é iniciada pela direita ou pela esquerda, de cima para baixo, é um critério do leitor, assim como nas artes plásticas.

As teorias da percepção visual exploram a temática de maneira a demonstrar tal afirmação:

Deve-se notar que o vetor direcional que torna as composições assimétricas tem pouco a ver com os movimentos dos olhos. Pelo traçado dos movimentos dos olhos, sabe-se que os observadores exploram a cena visual perambulando irregularmente e concentrando-se nos pontos de maior interesse. O vetor esquerda-direita resulta desta exploração, mas não provém da direção dos próprios movimentos dos olhos. Nem há qualquer evidência pronunciada de que a tendência lateral se relaciona com o uso de uma das mãos ou com o predomínio de um olho (ARNHEIM,1980, p. 27).

43 Oposição também formulada por op. cit. 
O álbum, contudo, não é como um quadro, pois a seqüencialidade existe e é dada pela própria natureza do objeto. É possível, então, recorrer, mais uma vez, à dinâmica das histórias em quadrinhos. Vilches (1995) reflete sobre a imagem em movimento do cómic em oposição à linguagem fílmica:

Tanto el cómic como la fotonovela pueden definirse como una unidad narrativa que se expresa tanto visualmente como por medio de un texto escrito bajo forma de diálogos, onomatopeyas, descripciones, comentarios y ruidos, que utilizan un mismo tipo de materia de la expresión: la prensa escrita. El trazo característico y definitorio del cómic y la fotonovela es la secuencialidad de las imágenes alineadas sobre el plano horizontal. La dirección de lectura de estas imágenes coincide con el sentido de la lectura de la línea escrita en la cultura occidental: de izquierda a derecha y arriba abajo (exactamente al contrario de la dirección de la lectura que se utiliza en los cómics de algunos países árabes, por ejemplo). Esta es la norma, aunque existen diversas tendencias que rompen la linealidad para introducir una complejidad mayor, sea por deformación del cuadro, planificación en cruz, en hélice o en diagonal. Un factor importante a señalar también dentro de la secuencialidad es el de que, con una cierta frecuencia, el lector del cómic o fotonovela se halla ante dos tipos de percepción narrativa: en primer lugar, se hace una lectura puramente icónica del cuadro o de la secuencia y, luego, se pasa al texto escrito (nunca a la inversa). En este caso, se dan dos tipos de códigos. Ambos niveles se hallan diferenciados discursivamente gracias a que existe una separación nata entre dos tipos de códigos (p. 70).

A obra que se oferece à análise, assim como inúmeros outros exemplos de literatura infantil, mostra-se, também, distinta do cómic. Impõe-se pensar sobre o objeto-livro, que, no caso da literatura com imagens, estabelece um sistema misto na condução do olhar. Existe a dinâmica impositiva do livro, o virar das páginas para acompanhar a seqüência narrativa, movimentando a imagem.

A cada virada, no entanto, há um quadro, sem uma seqüência do olhar preestabelecida, determinada. O leitor está livre para fazer seu percurso. 
No caso de $\mathrm{O}$ dinossauro, isso acontece, pois, na narrativa analisada, o percurso se faz pela aquisição de competência - o conhecimento (a volta ao mundo). Neste percurso, há a seqüência dos acontecimentos, já na história contada em cada quadro, há simultaneidade. A oposição continuidade versus pontualidade pode ser identificada no direcionamento da leitura ${ }^{44}$.

Buscou-se, contudo, outra obra da autora para exemplificar melhor a dinâmica. No exemplo a seguir, tem-se a obra Bernardino que segue os princípios das histórias em quadrinhos, como será demonstrado a partir da comparação com a primeira página da revista Tico-tico ${ }^{45}$, que traz, em sua capa, uma história em quadrinhos:
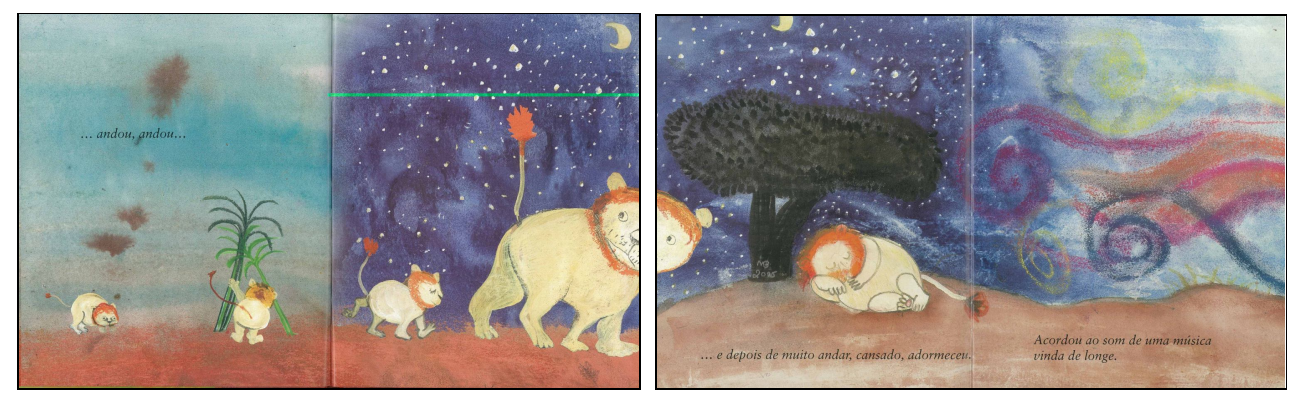

Figura 2.22 - Continuidade narrativa em duas páginas - É necessário virar a página.

${ }^{44}$ Esta é uma dinâmica de leitura bastante comum na literatura

${ }^{45}$ Poderia ter sido utilizado qualquer exemplo de histórias em qu 


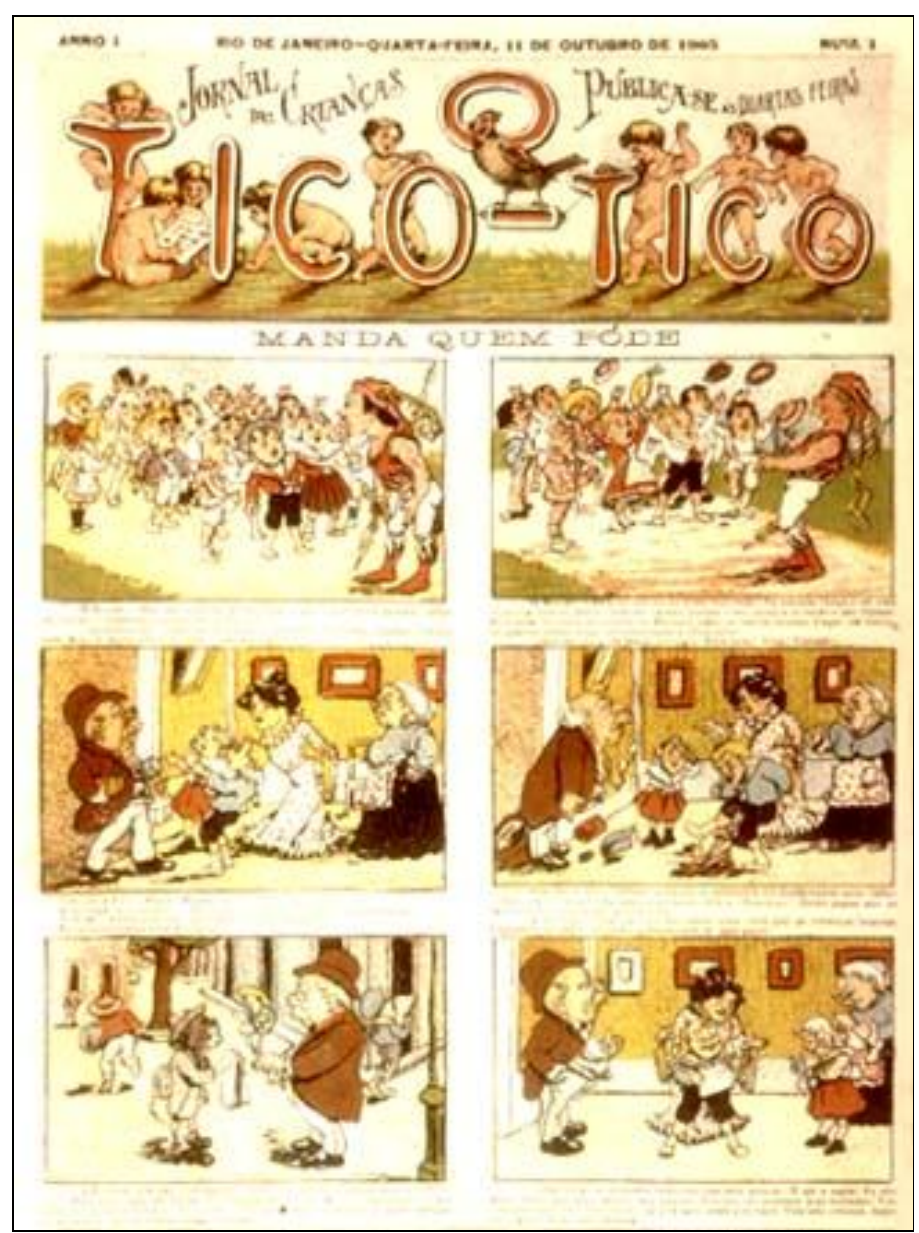

Figura 2.23 - Continuidade narrativa - quadro a quadro I magem seqüenciada em quadros e não na virada da página.

Em O dinossauro, a palavra também pode ser lida em momentos distintos - antes, durante, depois da leitura da imagem.

Existem outros exemplos da literatura infantil que corroboram a idéia de oposição da história em quadrinhos e da literatura infantil, também no que diz respeito a palavra como imagem, como nos exemplos a seguir: 


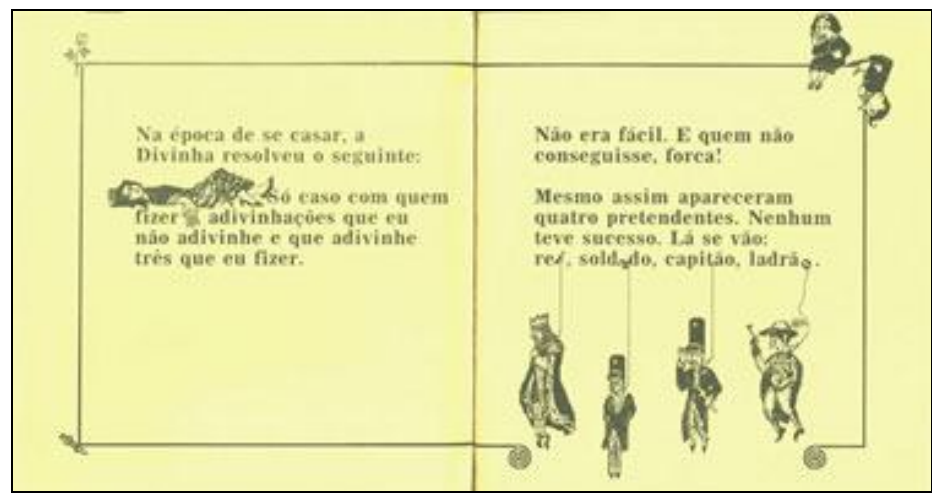

Figura 2.24 - Sua Alteza, a divinha!
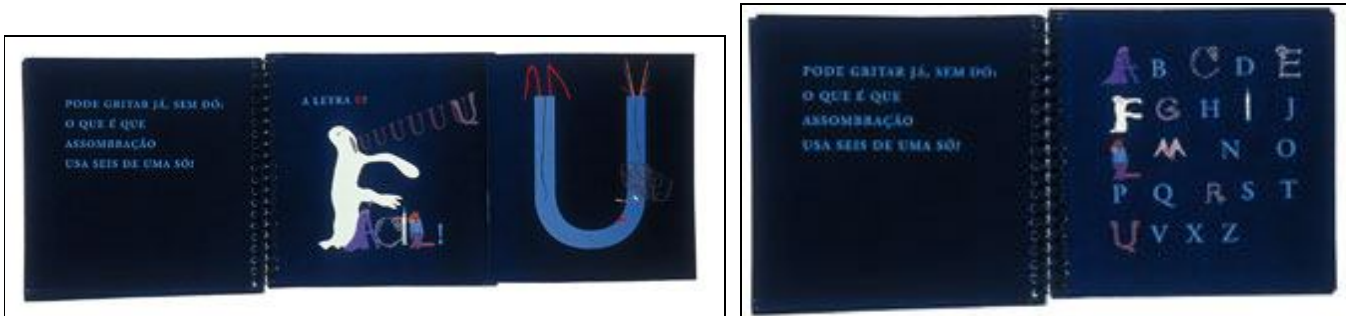

Figura 2.25 - Abc doido ${ }^{46}$

Os "tempos" de leitura e viradas de página para dar seqüência a narrativa são determinados pela urgência ou tranqüilidade na condução dessa e também dos enigmas propostos tanto pelo verbal, quanto pelo visual, como no caso da obra ABC, de Ângela Lago, em que o leitor deve desvendar uma charada a cada nova página.

Com isso, há que se pensar sobre o livro infantil em distinção daquilo que é proposto por Vilches para os cómics. Lá, o autor afirma que primeiro há a leitura puramente icônica do quadro e da seqüência, para depois se ler o texto verbal e nunca de maneira inversa. Essa metodologia do olhar, no livro infantil, não é uma verdade. Em particular no caso de $\mathrm{O}$ dinossauro, pode-se ler o texto e, em seguida, observar a imagem, ou o contrário, sem comprometer o entendimento do enredo, como já pontuado.

Há casos, que serão tratados mais adiante, em que ou a palavra ou a imagem não dependem um do outro, e isso implica a indiferença 
completa à ordem de leitura. Ou, ainda, como no caso da obra Jardins, de Roseana Murray, em que a casualidade se opõe a previsibilidade seqüenciada exigida pelo livro-objeto, cada página é independente ${ }^{47}$, ignorando até mesmo o suporte livro, como será objetivo demonstrar.

Assim, o necessário ao livro infantil é o diálogo efetivo, para que um sistema não se sobreponha a outro, neutralizando-o. O diálogo entre essas linguagens proporcionará um ir e vir entre palavra e imagem que ora palavra é imagem, ora imagem é palavra.

Além de o virar das páginas pontuar o ritmo da narrativa, que é uma forma de interação entre a criança e o livro, a linha da terra presente na obra $O$ dinossauro também contribui para o desenrolar narrativo, dando-Ihe, ou mesmo conduzindo para, uma seqüência narrativa.

\section{Linha da terra: elemento expressivo}

As figuras ${ }^{48}$ que estão na página descrita da obra em análise são pessoas e animais sobre uma linha.

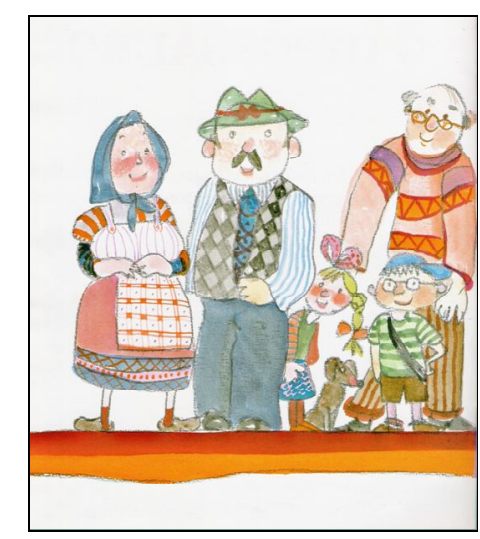

Figura 2.26 - Linha da terra

47 A análise da obra Jardins, de Roseana Murray será tratada no ranítıln 3

${ }^{48}$ Vale alertar que o termo figura está sendo empregado dentrc semiótica discursiva e não como sinônimo de imagem ou ilust 
A estratégia da linha da terra é uma recorrente na produção literária de Manuela Bacelar, em que ela exerce a dupla vocação, como observa Maia (2004), em artigo, que evidencia as "zonas marcantes" da produção de Bacelar:

Outra linha de abordagem às suas ilustrações e que gostaria que ficasse, aqui, bem marcada é a linha da terra. Se entendida como sinédoque do próprio planeta aí, a linha de terra é uma linha curva, se entendida como um terreno, onde estão às personagens, aí, a linha de terra é plana ou apenas levemente acidentada. [...]

A linha da terra separa aos nossos olhos aquilo que a ilustradora geralmente pretende que se junte nas nossas mentes: conjuntamente com tudo aquilo que nós sabemos pertencer à "zona celeste", sejam astros, aves, nuvens ou linhas de vento e de chuva, pairam, nos seus desenhos, corpos e objectos que nos entram pelos olhos e nos deixam a olhar para esses lugares de incerta existência, acima do horizonte. A sinuosa linha da terra que nos atira o olhar para os milhares de pontos de fuga dos fundos manchados, pontilhados, sarapintados, riscados, repincelados e marcados pela passagem do tempo, é uma linha condutora da acção, um fio do labirinto das histórias e também um elemento de ligação entre cada conjunto de páginas pares e ímpares que constituem um livro.

A linha da terra é um convite à visão frontal e esta panorâmica, que a ilustradora oferece aos nossos olhos, quase obriga cada elemento da composição a ser seqüencialmente dispostos em fila. Perante este facto, e como Manuela Bacelar não utiliza os códigos e os recursos dos seus colegas criadores de banda desenhada, necessitou de ir inventando soluções compositivas de estruturação espacial que acabam por ser uma espécie de marca d'água do seu trabalho (2004, p. 8-9).

O que foi destacado por Maia, ocorre na produção de Bacelar desde Consola-te, primeiro álbum de imagem da autora, mas não é uma constante quando a autora é ilustradora do texto verbal. 


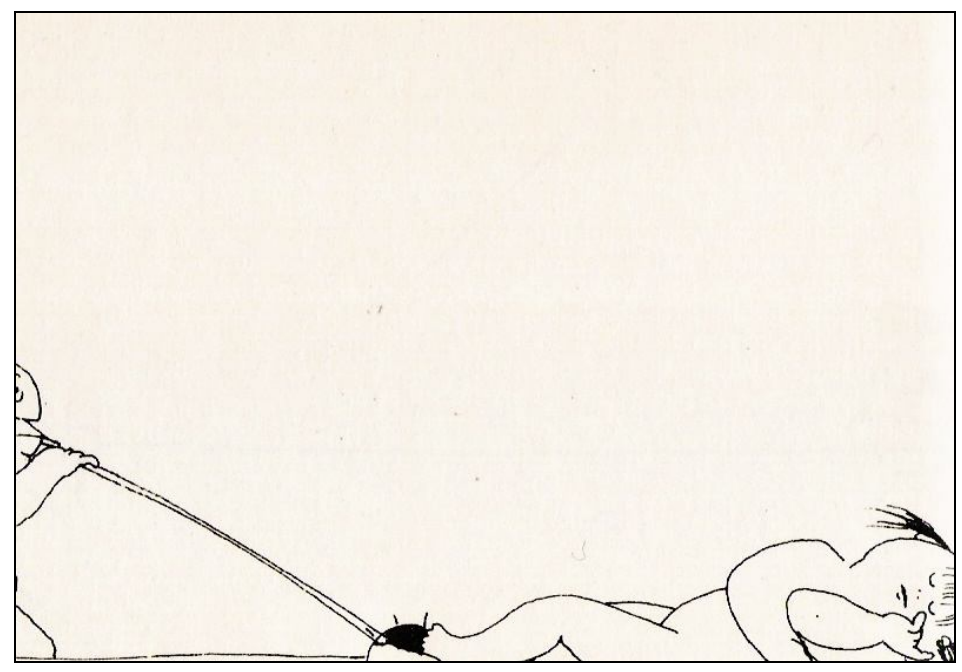

Figura 2.27 - Consola-te - exemplo de linha da terra

Em sua produção como autora de dupla vocação ou apenas autora de imagens, no álbum de imagem, a linha da terra aparece como marca registrada. Talvez a função desse recurso seja dar ao leitor a idéia da seqüência, como revela Maia (2004), corroborando a hipótese da imagem em movimento, aqui associado aos flip books ${ }^{49}$. Além de reforçar a seqüência, a linha da terra, em particular na obra $O$ dinossauro, apresenta-se como uma característica do desenho infantil.

À criança, normalmente, é necessário um solo para fixar suas personagens. Essa hipótese é autorizada a partir do aparecimento e desaparecimento da linha, ou seja, um traço distintivo da expressão é a presença e ausência da linha da terra, confirmando o tom da casualidade.

49 É importante definir os flip books: A passagem de uma imagem estática (livro) para imagens em movimento (cinema) faz do flip book uma mídia única e transitória.

Este, por sua vez, é ativo e completamente autônomo, determinando sem influências ou normas a velocidade com que o livro é visto. Pois é possível passar as páginas com calma, rapidez, desprezo, muita ou pouca delicadeza. Além disso, o flip book, ao contrário do cinema, permite ao observador/espectador determinar ele próprio a cronologia de recepção da obra: do começo ao fim ou de trás para frente.

"Os livros animados", diz Christoph Benjamin Schulz, curador da exposição em Düsseldorf, "são brinquedos infantis na forma de lidar e objetos filosóficos no que se refere à capacidade de expressão artística" (Disponível em. < www Deııctrhewelle.de/dw/article>. Acesso em: 17 jul. 2008 ) 
Antes de a linha da terra representar a própria Terra, um terreno, a aldeia, ela contribui para uma outra interpretação. Ela, neste caso, não figurativiza a realidade, não se aproxima do objeto em si. A sua presença ou a sua ausência revela um traço primário, apresenta um efeito de sentido de parecer pertencer ao universo do público pretendido pela obra, ou seja, a criança.

Busca-se uma identificação entre o estilo do autor e o "estereótipo" do estilo do desenho infantil. Outros traços reiteram essa afirmação. São eles: a formas humanas ou não, as cores primárias, a presença do traço do lápis, o vazar das cores pelas linhas desenhadas.

Pode-se afirmar, então, que se tem nas mãos um álbum metaficcional, em que o leitor se reconhece pela expressão de $O$ Dinossauro. Para sustentar a afirmação, vale definir 0 álbum metaficcional; para isso, convoca-se a pesquisadora venezuelana Maria Cecília Silva-Díaz, em seu artigo "La metaficción como um juego de niños - una introducción a los albumes metaficcionales":

Sin embargo, es conveniente deslindar ambos términos (postmodernismo y metaficción): mientras el postmodernismo es un concepto perteneciente a la historia literaria, que detona un tipo de literatura asociado a un momento cronológico - la época contemporánea -; la metaficción es una manifestación ahistórica que se ha registrado a lo largo de toda la historia literaria [...] Pero es un hecho que la presencia de la metaficción se ha intensificado en la literatura postmoderna, por lo que las variaciones metaficcionales se consideran características del postmodernismo literario (2005, p. 9).

Em O dinossauro, as formas são despojadas de toda e qualquer complexidade. Não há detalhamento, não há sofisticação no traço. O traçado a lápis não é apagado, as cores ultrapassam o limite da linha, não há qualquer tentativa de ser realista. A enunciação é revelada no enunciado (seja um detalhe ou completamente), caracterizando a 
proposta da metaficção que é quebrar o faz de conta imposto às artes de maneira geral ${ }^{50}$.

O tempo todo, o discurso das imagens insiste em dizer ao leitor que aquele é um desenho próximo ao seu, tornando-se, nesta medida, metalingüístico. Mais que isso, a metalinguagem é utilizada como forma de identificação e cumplicidade.

Quando se afirma que a expressão em $\mathrm{O}$ dinossauro assemelha-se ao desenho infantil, é importante recorrer aos teóricos do desenho infantil para não escorregar por caminhos inexplorados por esta pesquisa. Assim, Wallon (1979) define representação gráfica dessa forma:

A representação é uma fórmula estática, bem delimitada, que parece bastar-se mais ou menos a si própria no momento em que é pensada. [...] é a fórmula terminal em que se inseriram e delimitaram os aspectos do objeto (Disponível em: <www.rede-educacao-artistica.org>. Acesso em: 17 jul. 2008).

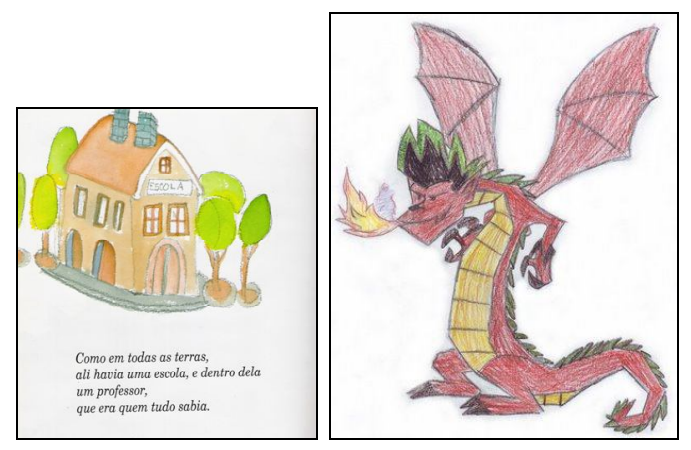

Figura 2.28 - Comparação imagem de Bacelar e desenho infantil

Em seguida, determina as fases do desenho; aquela identificada como "transcrição gráfica" atende à comparação desejada:

50 Esta caracterização do livro-álbum metaficcional vai acomr estudo de maneira a revelar uma tendência da literatura infar 
[...] uma forma ainda rígida, mais ou menos dispersa e estereotipada. [...] As variáveis inerentes às dessemelhanças entre as imagens visuais externas de um objeto [...] são excluídas. Trata-se de reconhecer o essencial e o elementar das coisas anulando-lhe a individualidade (Disponível em: <www.rede-educacao-artistica.org>. Acesso em: 17 jul. 2008).

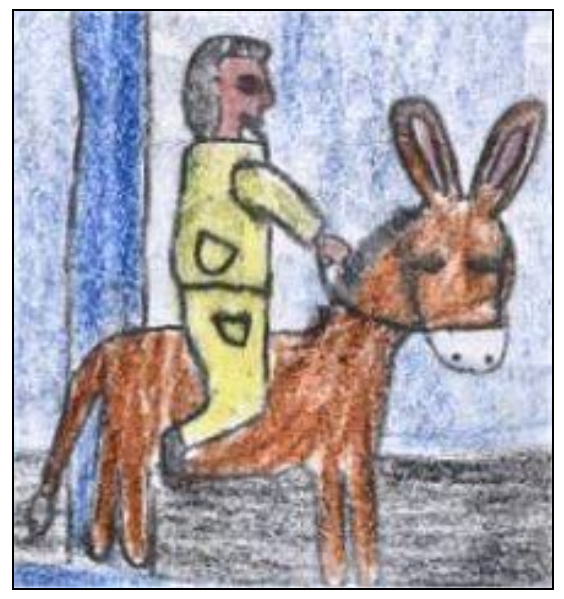

Figura 2.29 - Desenho infantil - contorno

Esse procedimento na obra de Bacelar é um efeito de sentido, por isso, é estilizado, diferente daquele apresentado pela criança. Em certa medida, é válido ressaltar que há um interdiscurso: Bacelar faz à maneira do desenho da criança, como um interdiscurso.

Finalmente, Duarte define os esquemas:

Casa, sol, nuvens, árvores, montanhas, passarinho, lagos, mares e rios, são representações gráficas que se repetem nos desenhos infantis. Estes esquemas aparecem grafados de modo quase invariável, isto é, com uma configuração praticamente idêntica, como recursos gráficos nos desenhos de todas as crianças [...] (Disponível em: <www.redeeducacao-artistica.org>. Acesso em: 17 jul. 2008). 


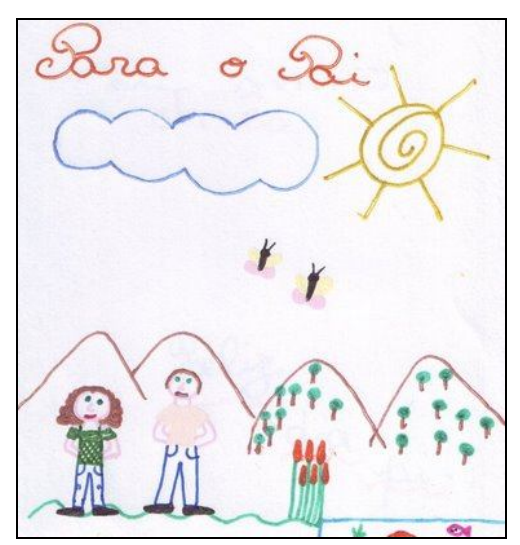

Figura 2.30 - Desenho infantil-linha da terra

A partir desta breve descrição teórica, observa-se o conjunto da obra de Bacelar. O único título da autora que leva ao extremo as características, ou melhor, a aproximação do modelo do desenho infantil é O dinossauro. Alguns outros apresentam tais traços de modo mais contido, como O meu avô. Há exemplos em que não existe qualquer semelhança com o desenho infantil, por exemplo, Silka, de Ilse Losa, com imagens de Manuela Bacelar:

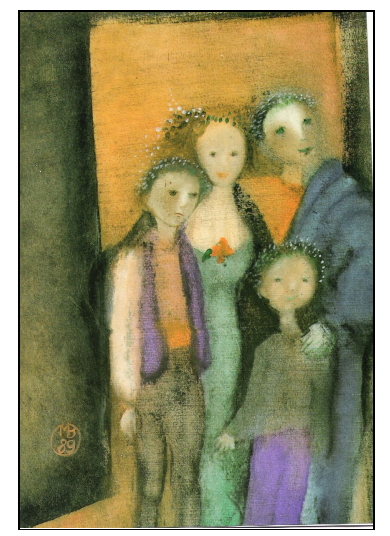

Figura 2.31 - Silka, imagem de Manuela Bacelar

No caso particular de $\mathrm{O}$ dinossauro, as figuras esquemáticas representam uma imagem mental que se arrisca 
social; nessa perspectiva, percebe-se o desenho como estereótipo. Tanto as personagens portuguesas como as originárias de outros países são representadas com o que há de padrão, de simbólico do país, seja na cor da pele, nos traços fisionômicos ou em acessórios.

Além disso, os símbolos são apresentados pelas imagens: as janelas, o bigode, o lenço na cabeça, o xale, o colete, o avental, a estampa xadrez territorializam a narrativa. Assim como a Torre de Pisa, o iglu, a oca indígena, a cabana africana, as pirâmides representam os espaços visitados.

Além das figuras esquemáticas, a opção por revelar os traços do lápis atribui ao desenho o aspecto inacabado, impreciso, em processo. A atmosfera criada pela expressão é a do registro provisório. Esse tom determinado pelo desenho conduz à leitura de aproximação do universo da criança, como já apontado, propondo um vínculo entre o que se lê e o que se produz, revelando, ainda, a integração entre palavra e imagem na composição do discurso, pois cria com o leitor (destinatário) um contrato de veridicção/identificação. O narrador/enunciador das imagens age à maneira da criança.

Vale lembrar o experimento de Ziraldo em $O$ menino mais bonito do mundo, em que o projeto gráfico é composto por dois ilustradores (Mariana Apoena e Ziraldo, respectivamente): um para representar o olhar infantil e outro para retratar o olhar amadurecido. Assim como é possível identificar e construir a imagem mental do narrador do sistema verbal, também o é no sistema visual. Os traços deixados na enunciação, sejam eles a utilização da primeira pessoa, de gírias ou diminutivos, podem ser identificados no visual pela perspectiva adotada dentro (narrador-personagem), fora (narrador-observador), pela escolha de cores, pela destreza do traço, pela complexidade da perspectiva etc. 


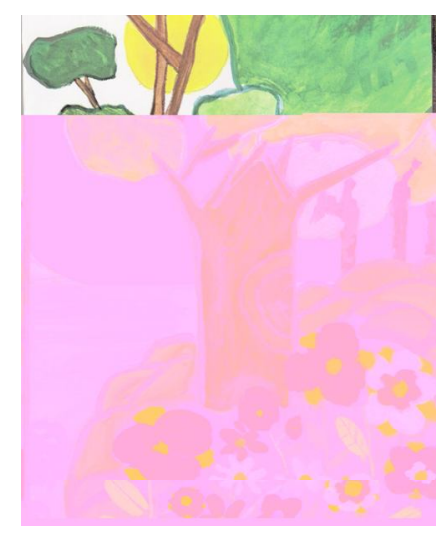

Figura 2.32 - Narrador-criança

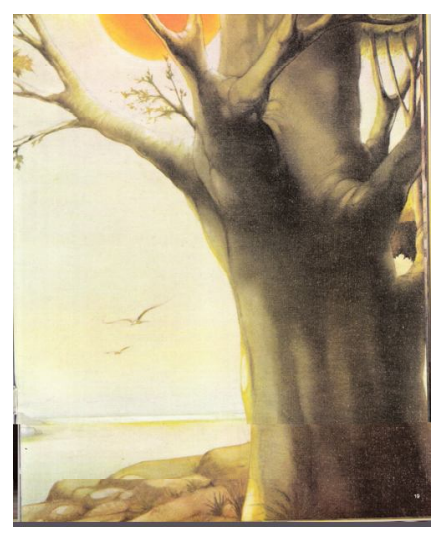

Figura 2.33 - Narrador-adulto

Valendo-se de Maia (2004), que afirma a presença do "acidente" na obra de Bacelar, comprova-se a leitura de que esse significa em sua produção, visto que propõe uma aproximação entre o narrador e o narratário no texto visual:

A representação gráfico-plástica [de Bacelar] segue, então, padrões de recriação de uma linguagem própria em sintonia com a sua liberdade. O seu trabalho não só deixa nu as imperfeições (ou por outras palavras, os acidentes de percurso) como principalmente as usa como matéria prima indispensável (1991, p. 9).

A obra O dinossauro propõe-se, portanto, como um experimento, visto que, até a ruptura modernista, sempre foi tarefa da arte - e, mais ainda, da literatura para crianças - buscar a mimesis aristotélica para, assim, estabelecer o contrato entre enunciador e enunciatário, ou seja, a tentativa era fazer-crer o leitor na ficção desenvolvida. A tentativa do discurso de Bacelar é, ao desfazer-se o "faz de conta", estabelecer um novo contrato entre aquele que diz e aquele que escuta (lê): a liberdade de expressão e experimentação com o intuito de aproximar os mundos e apresentar a realidade, como esclarece Silva-Díaz (2005): “Una característica de las obras metaficcionales que se consideran adecuadas 
para los niños es que le ofrecen al lector un balance entre lo conocido y lo nuevo; es decir, entre las convenciones y su vulneración" (p. 22).

Entretanto, o pesquisador não reconhece o procedimento tal como a análise que se apresenta e o analisa da seguinte maneira:

Manuela Bacelar não receia tirar partido do estereótipo. Muitas caras e animais, tal como muitas flores e plantas, são representados através de uma utilização mecânica e simplificada. Este esquematismo, a meu ver, resulta naquelas ilustrações em que a força da espontaneidade se sobrepõe ao automatismo, conseguindo deste modo, que a frescura de traço transporte a veracidade expressiva (MAIA, 2004, p. 7).

O pesquisador reforça o aspecto da expressividade do desenho em detrimento de um automatismo, mas caberia interrogar o efeito de sentido de tal expressividade, ou seja, esse caráter primário, não no sentido pejorativo. Esse aspecto, propositadamente elementar, fala de perto à linguagem do público pretendido pela obra. A significação se estabelece a partir da identificação entre enunciador e enunciatário, identificação esta que diz respeito ao estilo discursivo colocado à mostra.

A obra apresenta um tom como se o enunciador das imagens falasse a mesma língua do leitor. Há um acordo entre as partes do processo comunicativo, como é esperado, contudo, o acordo desse caso, se dá pela identificação.

Esse procedimento discursivo pode ser explicado por Fábio Lucas (1985), pelos fios ideológicos que subjazem ao texto de literatura infantil:

O primeiro contacto com a literatura infantil irá dar-se no período escolar. O adulto, ao elaborar a mensagem dirigida à criança, assume postura semelhante à do tradutor. O produtor do texto procura trasladar-se à situação infantil, valendo-se de sua experiência, e tenta mimetizá-la, a fim de alcançar o interesse do destinatário da mensagem. No sentido e na forma, o adulto busca equiparar-se à idade infantil, enquanto veicula um tipo de conhecimento que é, ao mesmo tempo, afectivo e racional (1985, p. 21 ). 
Este "falar a mesma língua do público" é muito comum à literatura juvenil. Álvaro Magalhães, autor português de literatura infantil e juvenil, em entrevista, destaca esse traço:

Quando um leitor meu lê um livro de aventura, um romance de espião, costuma dizer que ele não vê ali um narrador, uma pessoa adulta, distante que está ali a contar uma história; ele percebe que aquilo lá é deles, uma coisa com eles; eles percebem que sou um dos deles, pelo ponto de vista que estou ali para narrar. É como se fosse escrito por um deles (BACELAR, M. Entrevista concedida a Mariana Cortez. Porto, 18 abr. 2006).

A aproximação de estilos - enunciador e enunciatário (narradornarratário) - está presente, no caso de O dinossauro, na imagem, como apontado. Já no texto verbal, não há traços da linguagem da criança. As imagens revelam um olhar ingênuo, que observa um fato inusitado, fantástico, com naturalidade e vê de maneira positiva aquele percurso. A fantasia $^{51}$ se estabelece no acontecimento: um monte se torna um dinossauro e sai para descobrir o mundo.

A maneira de fazer do verbal, no entanto, não reitera essa atmosfera, não há marcas lingüísticas mais livres que possam revelar o propósito de aproximação com o leitor infantil. As palavras não carregam marcas do enunciatário, como seria pertinente pensar.

Percebe-se sempre a linearidade, o padrão, a língua correta. Não há traço de oralidade, não há diálogo. A palavra está instaurada no narrar alheio, não expressa afetividade nas escolhas lexicais. As palavras são frias, distantes. Não há excesso de adjetivos ou diminutivos. As palavras pertencem, resta concluir, ao mundo da narração, ao lá, ao distante. O verbal está, pois, afastado do público. A palavra está longe, muito longe da perspectiva da criança. Não fosse pela ordem direta, pelo vocabulário simples, pelas construções sintáticas facilitadas e pela ingenuidade do tema, esse discurso teria como destinatário o adulto, apesar do uso da $1^{\underline{a}}$

${ }^{51}$ Os termos fantástico e fantasia são utilizados, neste momento, c 
pessoa, que como pontuado por Fiorin (1996), em As astúcias da enunciação, gera o efeito de sentido de maior subjetividade. Posto isto, é válido pensar que a palavra, pelo plano da expressão, também poderia estabelecer um contrato de identificação com o leitor.

Caberia, neste momento, tomar a discussão formulada por Zohar Shavit sobre o duplo destinatário (adulto e criança), que, segundo proposto pela pesquisadora israelense, é revelado pelo discurso. Na obra em questão, há a predominância de um sobre o outro, no sistema verbal. O discurso verbal do adulto vence.

Além disso, outra figura discursiva que endossa tal leitura é a do professor como aquele que tudo sabe, visto que se tem a equação: professor = saber. Insere-se uma voz institucional. Assim, o discurso da literatura infantil como veículo para educação vem à tona.

O primeiro aspecto ideológico a destacar na literatura infantil é a posição hegemônica do adulto em relação à criança na materialização da obra a ser consumida. O invólucro ideológico que norteia o adulto infiltra-se na obra por ele produzida e confirma, para a criança, a atmosfera de consenso que a ideologia requer (LUCAS, 1985, p. 20).

Vale registrar que a consulta sobre a natureza do monstro poderia ser feita ao sábio da aldeia, ou a uma feiticeira, ou à própria natureza, ou até ao dinossauro, mas o discurso de valorização da escola e do saber instituído se faz presente, introduzindo um discurso autorizado, que não é próprio à criança, mas sim àquele que a educa.

Mesmo com a tentativa de aproximação do universo da criança que se constata nas características dos desenhos, os fios ideológicos submergem e, traiçoeiramente, escapam ao controle do discurso. É sensível um enunciador traído pela ideologia subjacente. Isso que fere os seus princípios estéticos de superfície, no caso, apresentado pelo sistema visual.

A imagem (desenho) do professor é algo que também deve ser destacado, pois enfatiza a ideologia do discurso instituído. O professor representado no verbal como sábio é, por meio da ir 
atrás de sua mesa, com óculos e maçã. As figuras são arranjadas de modo estereotipado, e o professor é visto como aquele que pensa, no lugar para pensar - a escola.

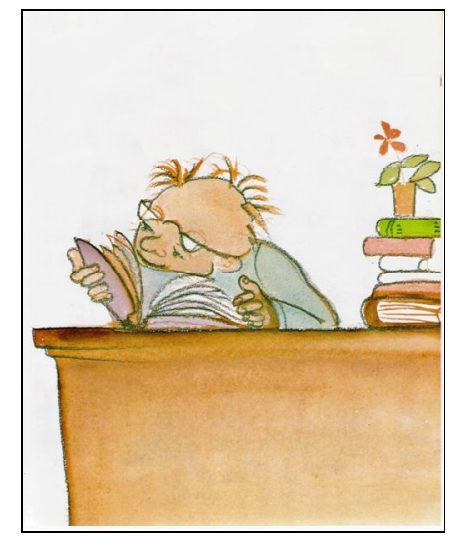

Figura 2.34 - O professor na escola

Uma figura discursiva, contudo, um conector de isotopia, inverte ou acrescenta sentido à leitura. Em duas cenas, a figura do professor faz cena solo: durante a reflexão sobre a identidade do monstro e durante a viagem, quando fotografa. A forma de rascunho é novamente e, talvez, de maneira ainda mais enfática, tratada. A enunciação é mostrada e abre caminho para uma leitura em sentido oposto.

No primeiro momento solo, tem-se a oposição figura vazia versus cheia. A linha da terra, o caminho circular e o lápis são figuras vazias. O corpo, a camisa, a calça, o colete e os sapatos são figuras cheias. Essa oposição traz a idéia do desleixo, do estar por fazer, do feito às pressas e, assim, reitera a leitura do bloco de notas, do diário de viagem, realizado por um olhar-criança.

O espaço circular, que representa o caminho do professor, é reforçado pela cor traçada sobre o traço do lápis. Este movimento gera o efeito de continuidade, de duratividade no caminhar do mestre. O professor refletiu por um bom tempo para chegar 
identidade pré-histórica do monstro. O tempo, o espaço e a formação autorizam a personagem a refletir e a concluir. O professor é o único capaz de solucionar o enigma. Chave que foi dada ao leitor antes mesmo do início da história.

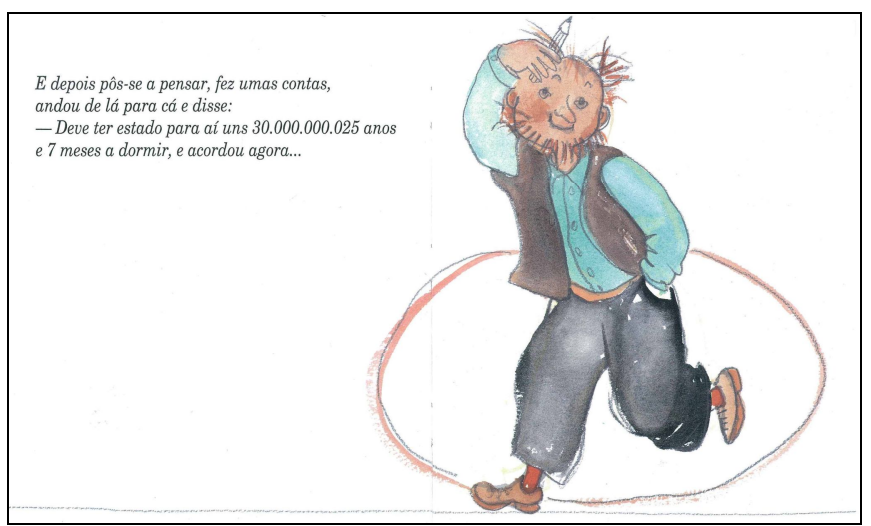

Figura 2.35 - O professor

Na segunda cena, a idéia do rascunho também é reiterada, mas por outras vias: há uma flecha a lápis que aponta para a cabeça de uma das posições do professor, e as diferentes posições apresentam a marcação temporal, mas sem as molduras, ou quadrinhos, como em outra cena.

Apesar da simultaneidade da imagem, a idéia da passagem de tempo está presente, visto as alterações realizadas. Como num estudo de arte, por exemplo, os de Leonardo da Vinci, que, se sabe, são um processo e, portanto, obedecem a uma seqüencialidade não aparente, mas inferida: 

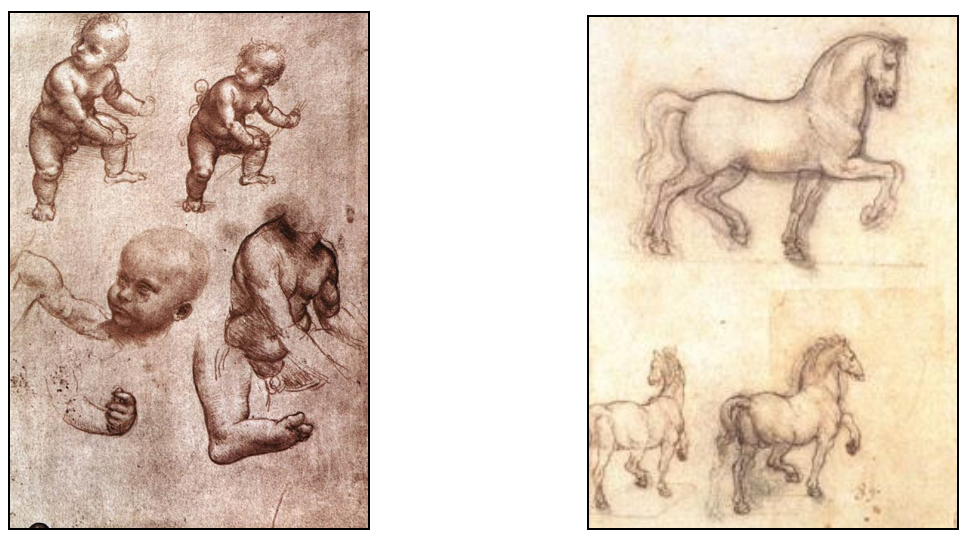

Figura 2.36 - Estudos de Leonardo Da Vinci

Esse recurso de mostrar o fazer, de trazer a enunciação ao enunciado, de tratar a imagem como rascunho provoca o distanciamento da ficção. Se, por um lado, a figura estereotipada e a ligação com o estilo de desenho infantil aproximam o leitor, por outro, a ruptura da ficção distancia o receptor do dito, da ficcionalidade. Eis a imagem ambígua, caracterizando um dos procedimentos poéticos na imagem do livro infantil.

Armas (2003) teoriza sobre essa questão:

Algunas de las más sorprendentes rupturas de los límites de espacio establecido llegan a rozar lo metaficticio, pues tienden a crear un efecto de distanciamiento: señalan la ficcionalidad de sus recursos, rompen los límites entre la realidad y la ficción, como ocurre de una manera evidente en aquellos libros que se incluyen a sí mismos en la ficción [...] Aquí nos referiremos a la ruptura literal del marco en que se encuadra la ilustración y que es procedimiento que quiere revelar mediante el distanciamiento su carácter ficticio. A este respecto, es interesante observar que ruptura del marco es el nombre que recibe uno de los procedimientos más comunes en la metaficción contemporánea, y consiste en romper las convenciones del relato (2003, p. 178). 


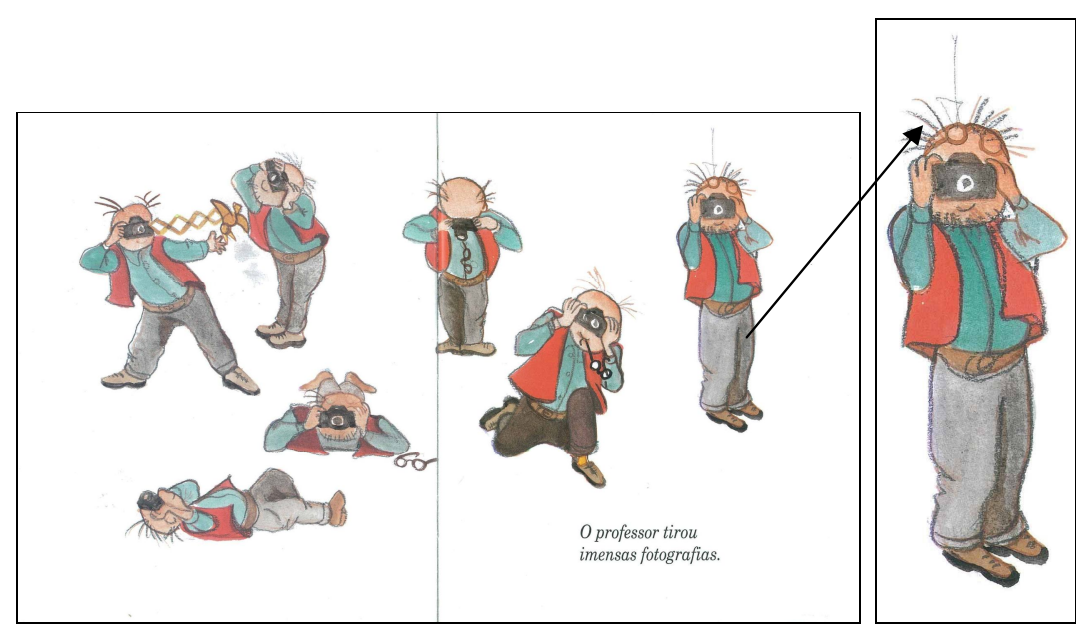

Figura 2.37 - Ruptura da ficção

O experimentalismo de Bacelar se aproxima da ficção contemporânea. Observa-se essa tendência em autores como Saramago, José Cardoso Pires, Guimarães Rosa experimentam (ou experimentaram) essa tendência em suas obras literárias. Magritte, Fellini experimentaram em outras expressões poéticas, as artes plásticas e o cinema, respectivamente - eis a inserção e exploração do discurso metaficcional na literatura infantil, traço característico da, ainda em formulação, literatura pós-moderna:

[...] o sócio-código do pós-modernismo baseia-se numa preferência pela não selecção ou por uma quase-nãoseleção, numa rejeição de hierarquias discriminadoras e numa recusa da distinção entre verdade e ficção, entre passado e presente, entre relevante $e$ irrelevante (FOKKEMA, [s.d], p. 66).

Finalmente, a narrativa termina como começou, ou seja, é cíclica a imagem de encerramento é a mesma da introdução: 

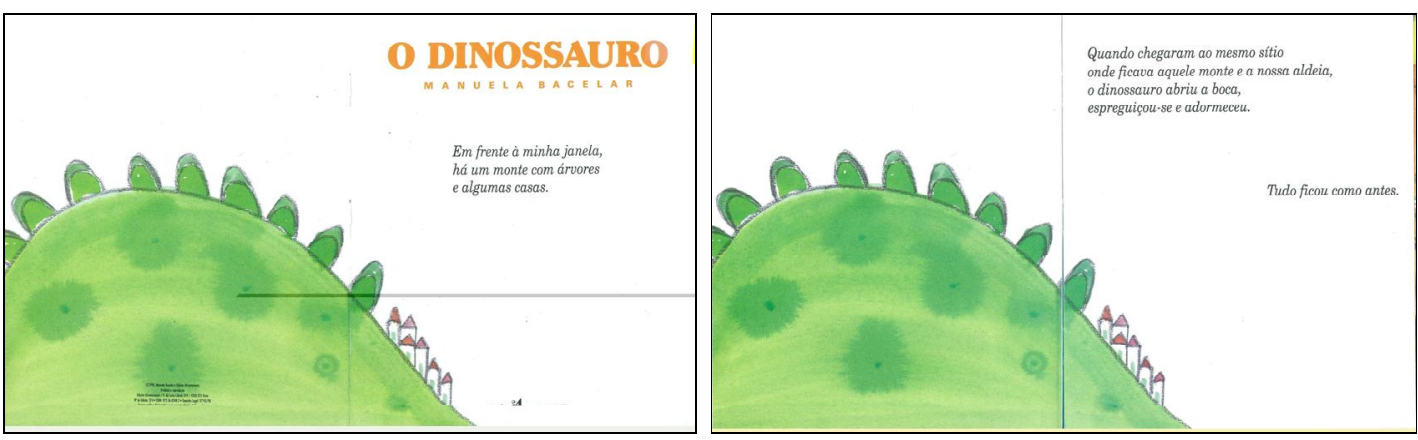

Figura 2.38 - Situação inicial / Situação final

\section{Relações: tramando os fios}

O dinossauro e O meu avô, de Manuela Bacelar, são as primeiras aventuras da autora no exercício da dupla vocação. Assim, todo o trabalho é, antes, uma busca de linguagem própria, de identidade. Há, evidentemente, deslizes, como uma proposta de aproximação com o público infantil apenas no visual, isolando do projeto gráfico a contribuição do verbal, como foi demonstrado., Há, no entanto, com maior freqüência, acertos, como o recurso do P.S., a ruptura com a ficção, entre outros avanços expressivos, a aproximação com o desenho infantil.

É natural que, com o passar do tempo, a técnica de Bacelar como autora-ilustradora tenha se aprimorado. Isso é perceptível à leitura de Bernardino (2005). Algumas questões são de relevo para o estudo que ora se propõe e, por isso, há a necessidade de se explicitarem os avanços nesta obra de 2005, quinze anos após a publicação de 0 dinossauro. Interessam à pesquisa as diferentes relações entre palavra-imagem englobadas pelo projeto gráfico. Destacam-se, por isso, algumas diferenças da primeira para última publicação acerca do entrecruzar de sistemas expressivos.

Há mais liberdade na apropriação dos espaços. As linguagens não são confinadas em um espaço predeterminado. Assim, palavra e imagem 
se entrelaçam e se tornam, cada vez mais, um todo indissociável, como demonstra o título da obra, cumprindo efetivo papel de livro-álbum:

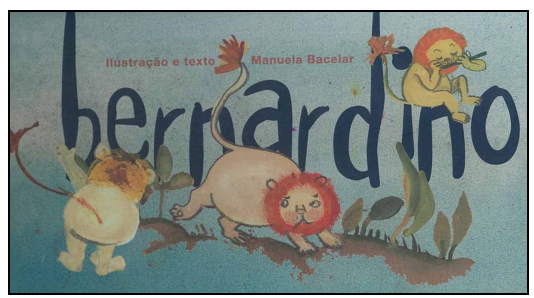

Figura 2.39 - Detalhe do título: fusão palavra/ imagem

Seguindo a mesma perspectiva, o texto passa a acompanhar a imagem, sem um lugar predeterminado para um e para o outro. Na obra analisada anteriormente, a palavra ocupava sempre o mesmo lugar na página. A variação espacial da palavra na página desautomatiza o olhar, obrigando o leitor a correr por toda a superfície da imagem para chegar, ou não, à palavra, seja qual for o desejo dele. No design gráfico de Bernardino, opõem-se previsibilidade e espontaneidade.

Ainda, em $O$ dinossauro a palavra sempre aparecia em itálico, reforçando o gênero do relato subjetivo em primeira pessoa, observador distante da ação. Ao instaurar o narrador, cabe ao narratário o mesmo papel distanciado, visto que este olhará pelos olhos daquele, reforçando a subjetividade como efeito de sentido. Já em Bernardino, haverá a inserção do diálogo. Há, portanto, a instância da interlocução. A voz é atribuída à personagem, não há filtro do narrador como no caso anterior. A observação do leitor é, por conseqüência, mais objetiva. O olhar desse já não coincide com o daquele.

A palavra, em interlocução, adquire um estilo também diferenciado, uma vez que não está em itálico. A letra, portanto, passa, na última obra, a significar e, por conseguinte, ser partícipe na construção do texto. Ainda que timidamente, a palavra é imagem. O título em minúscula na capa da obra reforça esse raciocínio. 
Outro dado importante é a identificação do leitor-criança com a personagem principal (protagonista), também criança, que enfrenta dificuldades semelhantes às encaradas por qualquer um nessa faixa etária: o amor dos pais, a aceitação social, a busca da identidade.

$\mathrm{Na}$ obra O dinossauro, a identificação enunciador-enunciatário somente era possível graças à expressão da imagem. Neste outro exemplo, a imagem continua a revelar o fazer estereotipado próprio ao desenho infantil (reforçado também pela linha da terra sempre presente neste caso), contudo, o tema proposto também estabelece o contrato discursivo entre leitor-texto. Pode-se mesmo afirmar que o contrato se estabelece no plano da expressão e no do conteúdo, no sistema verbal e no visual, autorizando a afirmação de que com o passar do tempo, a obra de Bacelar amadureceu em direção ao livro-álbum.

$O$ texto poético exige ainda o trabalho com a linguagem, a saber, o desvio do sentido denotativo da palavra. Na primeira obra analisada, o monte que se transforma em dinossauro rompe a realidade e explora a ficção. Tal ruptura é possível visto a metáfora visual: monte verde - dorso verde do dinossauro, ou seja, a metáfora permanece na imagem, pois os traços comuns - forma e cor - autorizam a associação metafórica.

Em contrapartida, Bernardino avança e apresenta a metáfora tanto na imagem quanto na palavra. Diz o texto: “[...] e abrir uma porta que o pai trazia, a tapar o coração".

A insensibilidade do pai diante da personalidade diferente do leãofilho faz que ele traga uma porta fechada no coração. Metáfora do aprisionamento do sentimento, da afetividade entre pai e filho. A imagem representa um coração preso numa gaiola, e a flauta de Bernardino será instrumento de libertação e está posta entre as grades da gaiola, como se pudesse abri-la. A imagem não descreve literalmente a palavra, mas acrescenta uma metáfora com o mesmo sentido, construindo um diálogo efetivo entre palavra e imagem, reforçando a idéia do livro-ábum. 


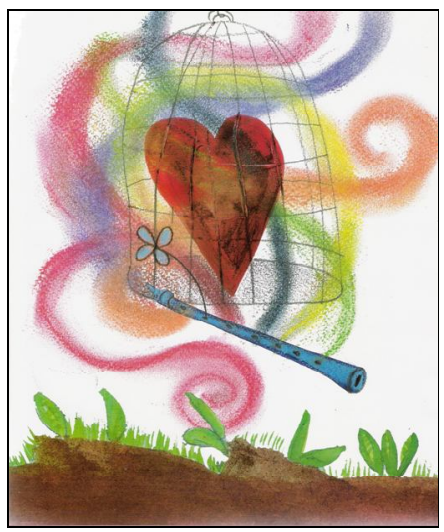

Figura 2.40 - Metáfora Visual

A ruptura da linearidade expressiva presente em $O$ dinossauro se dá a ver por outro recurso em Bernardino. Aqui, a imagem recorre à continuidade na página dupla ou na virada da página. Como Armas (2003) revela:

[...] las ilustraciones se extenden durante cuatro o cinco páginas, y aprovechan las interrupciones del texto pictórico para crear una atmosfera [...], para mostrar acciones y movimientos [...], para configurar espacios y sugerir secuencias temporales [...] o para crear efectos anticipadores [...] (2003, p. 175).

Na obra de 2005, o recurso sugere o movimento e a passagem temporal:
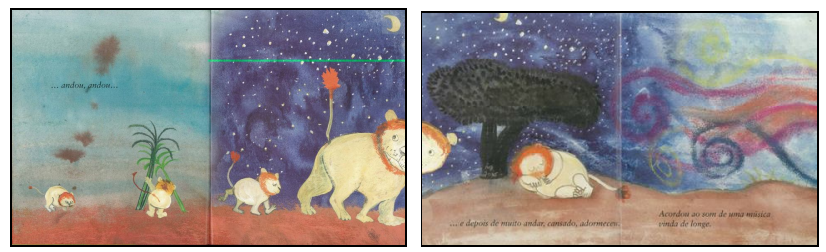

Figura 2.41 - Seqüência narrativa (virada de página) 
Tanto o tamanho do leão como as cores do fundo contribuem para a mudança espaço-temporal da personagem. Este procedimento também pode ser observado na capa, na contracapa e na lombada do livro:

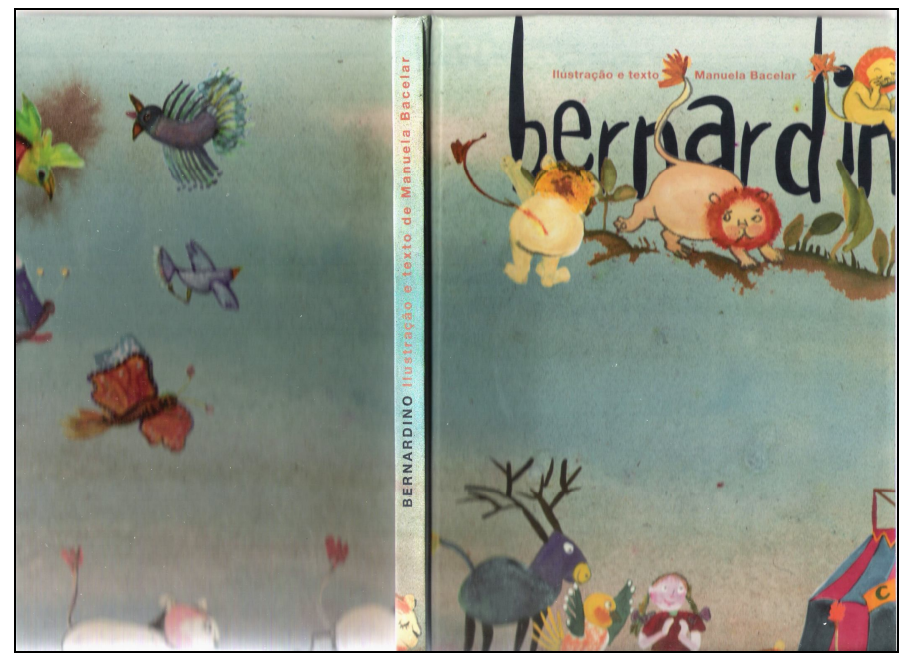

Figura 2.42 - Capa e contracapa apresentam uma cena

Além das capas externas, as páginas de ante-rosto de início e final agregam sentido à narrativa. Sobre esse procedimento, recorre-se novamente a Armas (2003):

Las estrategias van incluso más allá de la página, desbordando los límites establecidos convencionalmente para la ilustración en el propio libro. Es cada vez más habitual, por ejemplo, encontrar ejemplos de sobreinformación en portada y contraportada del libro, formando parte del contrato o pacto de lectura que el texto firma con el lector: proporcionando información genérica o temática, por ejemplo, pero prestándose también a la interpretación por parte del lector. [...]

Portada y contraportada pasan entonces a tener un papel narrativo que ha empezado antes de leer el texto, al coger el libro y contemplarlo como objeto, o que termina después de la lectura iluminando retrospectivamente el sentido de la historia (2003, p. 176). 
A contribuição teórica de Armas se ilumina com Bernardino, uma vez que todos os espaços são utilizados, sejam eles internos ou externos à obra, sejam usuais ou não.

Assim, Bernardino tem, nas páginas de ante-rosto de início, o nascer do sol e, nas páginas de ante-rosto finais, o luar. Mais uma vez, reiterando a passagem de tempo e a esperança de reconciliação com o pai, visto que, no fim da história, resta a esperança, não há o final feliz tão presente no conto para criança, principalmente, aqueles em que os ensinamentos são obedecidos.
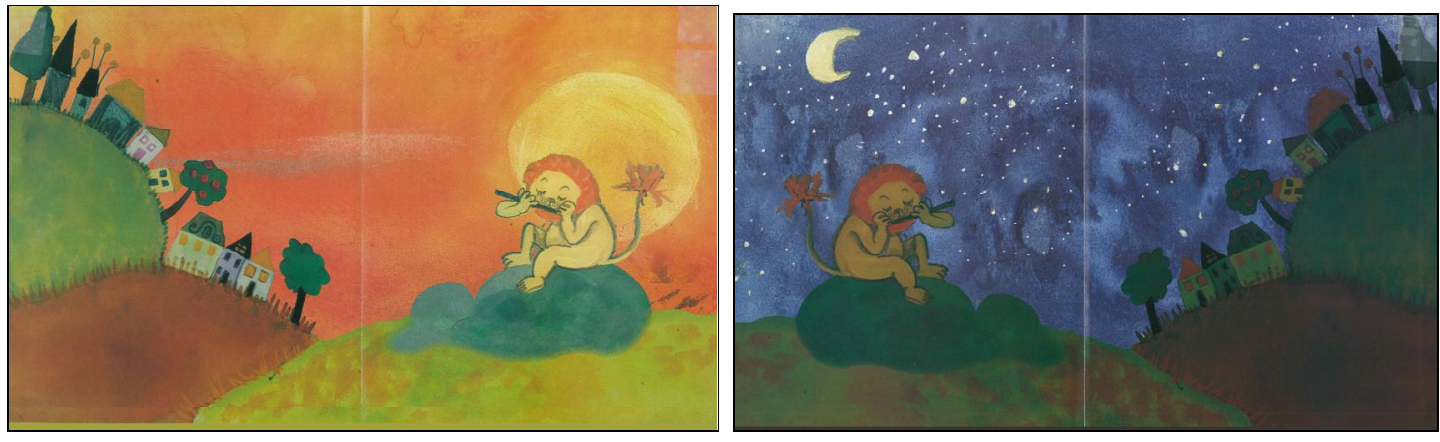

Figura 2.43 - Passagem do tempo

O final, como é particularmente singular às obras de Bacelar, não é feliz nem triste, simplesmente não existe, desfaz-se no ar, como bastante próprio às narrativas contemporâneas, que fogem ao maniqueísmo tradicional dos contos para crianças.

O leitor pode, nas obras dessa autora, terminar apropriando-se do contar e do papel passivo de leitor, tornar-se ativo como narrador, assim como quer Bojunga Nunes: "[...] eu sou leitora, logo, eu participo intimamente desse jogo maravilhoso que é o livro; eu sou leitora, logo, eu crio" ([s.d.], p. 22). Eis a interação proposta como meta na literatura pós-moderna. 


\subsubsection{Como Leitora-Autora: Experiência com o Clássico A Sereiazinha}

Terror de te amar num sítio tão frágil como o mundo

Mal de te amar neste lugar de imperfeição

Onde tudo nos quebra e emudece Onde tudo nos mente e nos separa. (Sophia de Mello Breyner Andresen)

\section{Tecendo objetivos e implicações: o objeto clássico}

Um relevo sinuoso surge para análise. A análise busca entender em que medida o projeto gráfico contribui para a leitura e formação do leitor literário e justifica essa travessia arriscada. Há ciência da dificuldade a ser percorrida, tendo em vista os problemas abordados anteriormente. Também não está descartada uma volta ao ponto inicial sem ter tido respostas ou ter chegado a conclusões. Vale, porém, pontuar as dificuldades e destacar as implicações do diálogo entre os dois sistemas semióticos. Nesse caminho, os atalhos, as paisagens vislumbradas, os pequenos oásis já são jóias raras e pontos de luz na escuridão reinante.

Antes, a dupla autoria de palavra e imagem na obra de Manuela Bacelar era a questão perseguida pela trilha da pesquisa; agora, uma questão bastante controversa se oferece. Um texto instituído, consagrado, conhecido - lido e relido - existe. É independente, livre, autônomo. A palavra se basta. De que serve a imagem? É a pergunta que se impõe. É possível um livro-álbum nessas condições, ou seja, sem que palavra e imagem nasçam juntas?

Hans Christian Andersen assina a autoria. De geração a geração, da voz à escrita, a história da sereia encontrou abrigo no imaginário infantil. Sempre, ou quase sempre, as linhas negras foram acompanhadas por imagens. A palavra ficou, a imagem não. Constata-se e, mais uma vez, pergunta-se: as imagens também contavan 
desenhos contribuíram para eternizar o conto? Por que morreram as imagens? Havia conversa entre palavra e imagem quando esta história foi apresentada em objeto-livro?

Deixando de lado a diacronia e acelerando o tempo, em um salto, o calendário se impõe no final do século XX, mais precisamente em 1995, a história da Pequena Sereia, ou A sereiazinha, ali está em um objeto-livro, nas mãos das crianças, dos professores, dos pais. A palavra permanece e é a mesma de outrora. A sereia é a mesma, o príncipe também. A imagem, no entanto, "desfez-se no ar", não existe mais, foi substituída. Imediatamente, escapam mais e mais perguntas: por que a imagem não se eternizou junto com a palavra? É função da imagem atualizar, contextualizar a palavra e, por isso, ela não permanece? As artes gráficas se transformaram, e isso implica mudança da imagem?

Uma angústia impera diante dos espaços a serem descobertos. Apresenta-se o "novo mundo", com seus mistérios e perigos. Com método e sistemática, avança-se sobre o caminho repleto de obstáculos e enigmas que turvam imenso o olhar. Contudo, aventurar-se pelo desconhecido é inerente ao humano. Assim, segue-se.

Uma primeira lâmpada se acende. A imagem pode durar. A palavra pode durar. O objeto-livro também pode com aquela palavra e aquela imagem $^{52}$. Contudo, o mundo está em movimento, cientistas há tempos comprovaram. As leituras e releituras de textos acompanham esse ritmo, como constatam os analistas do discurso. Eis um axioma do mundo da literatura ou das artes: os textos estão em constante diálogo e renovação.

[...] o grande vigor dos estudos folclorísticos na União Soviética apenas se explica através do interesse pelas produções artísticas populares não só como herança de antigas eras, mas como algo que continuamente se renova e se cria (CALVINO, 1999, p. 144).

52 Justificam as afirmativas as reedições de clássicos com o r imagem de outros tempos. 
A obra à cabeceira da cama e sobre a mesa de análise é A Sereiazinha, de Hans Christian Andersen ${ }^{53}$, ilustrada por Manuela Bacelar. Autor dinamarquês (1805-1875), ilustradora portuguesa, de 1995 - data da edição. A publicação da Edições Afrontamento tem Portugal como terreno e nas crianças deste tempo potenciais leitores. Encontro inusitado de leituras ou, quem sabe, releituras. Fato é que houve necessidade de ouvir mais uma vez a história e esta ação vem acompanhada da imagem recontextualizando a narrativa. O que motivaria uma leitura de retomada? Valeria criar um álbum em que a história é antiga, conhecida e as imagens inéditas? É possível, ainda, fazer deste conjunto de sistemas semióticos um todo de sentido eficiente e coeso para a leitura?

\section{O Status do Texto}

Passado tanto tempo, como a história-lenda de uma sereia pela escrita de Andersen interessa aos miúdos desta era informatizada com seus joysticks e conversas além-mundos? Das prateleiras empoeiradas da biblioteca, Calvino esclarece: "Andersen é um clássico". Pronto, o clássico tudo vence. É o supermam dos discursos. Entretanto, o que é clássico afinal? Que propriedades ele possui? Calvino elucida:

1) Os clássicos são aqueles livros dos quais, em geral, se ouve dizer: 'Estou relendo...' e nunca 'Estou lendo...'

2) Dizem-se clássicos aqueles livros que constituem uma riqueza para quem os tenha lido e amado; mas constituem uma riqueza não menor para quem se reserva a sorte de lê-los pela primeira vez nas melhores condições para apreciá-los.

3) Os clássicos são livros que exercem uma influência particular quando se impõem como inesquecíveis e também quando se ocultam nas dobras da memória, mimetizando-se como inconsciente coletivo ou individual.

4) Toda releitura de um clássico é uma leitura de descoberta como a primeira.

53 O texto da publicação é a versão integral e original de Hans tradução de Ribeiro da Fonseca (cortesia de Círculo de Leitore 
5) Toda primeira leitura de um clássico é na realidade uma releitura.

6) Um clássico é um livro que nunca terminou de dizer aquilo que tinha para dizer.

7) Os clássicos são aqueles livros que chegam até nós trazendo consigo as marcas das leituras que precederam a nossa e atrás de si os traços que deixaram na cultura ou nas culturas que atravessaram (ou mais simplesmente na linguagem ou nos costumes).

8) Um clássico é uma obra que provoca incessantemente uma nuvem de discursos críticos sobre si, mas continuamente as repele para longe.

9) Os clássicos são livros que, quanto mais pensamos conhecer por ouvir dizer, quando são lidos de fato mais se revelam novos, inesperados, inéditos (1993, p. 9-13).

Quais são os elementos da história A sereiazinha que a qualificam como um clássico? É possível que em literatura, em particular a infantil, mais que a obra possa ser considerada um clássico, os autores se tornam clássicos e fazem História. Assim como Grimm e Perrault, que fizeram recolhas de histórias populares, Andersen também o fez e é um clássico. Seus contos se eternizaram. Do século XIX à era da globalização e comunicação de massa dos medias, o que faz a sereia descrita por Andersen se renovar?

De entre todos los géneros a los que Andersen dedica su actividad literaria, son los cuentos los que le proporcionan el reconocimiento mundial. Andersen se inspira en los relatos populares. Escribe 164 cuentos para los que toma prestados personajes y argumentos del mundo de la leyenda, de la Historia o de la vida. Los cuatro primeros son publicados en 1835. Aunque estos cuentos están destinados a los niños, también resultan atractivos a los adultos por su imaginación poética $y$, sobre todo, por el sentido moral y filosófico que se esconde detrás de cada anécdota (Disponível em: <http:// www. ricocheteunes.org/es/biblio/base9/andersen. htm>. Acesso em: 17 jun. 2006).

Para entender melhor o que é essa anedota filosófica e moral, Calvino (1999), quando se debruçou sobre os contos de fadas, constatou, a partir de estudos como o do formalista russo $P$ 
mantêm o mesmo esquema presente na estrutura narrativa de diversas regiões, das mais próximas às mais longínquas:

O que na história humana é narração e imagem - desde as cosmogonias dos índios do Brasil até à mitologia grecoromana, e ao Capuchinho Vermelho - aparece hoje como manifestação de um processo mental único, que de um século para outro e de um continente para outro repete os mesmos esquemas. Algumas escolas interpretativas identificaram nos motivos dos contos de fadas as fases dos ritos de iniciação; outras reconheceram neles os símbolos dos sonhos; ou também foram reduzidos a fórmulas esquemáticas como operações lógico-matemáticas. O debate entre as várias escolas continua, e os contos de fadas, em toda a sua elementar simplicidade, permanecem uma das mais misteriosas expressões da cultura humana (1999, p. 79).

Tal fato revela a necessidade do humano de retomar a essência dos contos de fadas, e esse é o sentido da anedota filosófico-moral, que, de certa maneira, atende à demanda entrevista como fundamental pelo adulto, estabelecendo-se como critério de escolha de narrativas oferecidas para os pequenos. Daí a necessidade da reedição ou releitura ${ }^{54}$.

Não é, obviamente, fácil uma obra partilhar o gosto de pais e filhos simultaneamente. Shavit (2003) teorizou sobre o que designou ambivalência do texto da literatura infantil. Também refletiu sobre a conseqüência dessa ambivalência com relação à canonização da obra. A autora israelense afirma que a literatura infantil tem como condição o propósito de atender aos interesses dos adultos (pais e professores) e das crianças. As obras que atendem a esse duplo encargo são aquelas canonizadas.

[...] o texto ambivalente tem dois leitores implícitos: um pseudodestinatário e um destinatário real. Não se espera que a criança, que é o leitor oficial do texto, realize o texto em sua totalidade, sendo muitas vezes mais uma desculpa para o texto do que o seu genuíno destinatário (2003, p. 105).

${ }^{54}$ Os estudos psicanalíticos como de Bruno Bettelheim, em A । fadas, evidenciam a questão. 
De acordo com esta visão, o crítico e autor Calvino reitera o duplo encargo no caso dos contos de fadas:

Na nossa seleção tivemos em conta as exigências de um público infantil como destinatário natural dos contos de fadas, mas também o facto de habitualmente serem pessoas adultas a ler ou a contar as histórias às crianças; para facilitar a mediação dos adultos, as nossas secções apresentam-se como uma amostra dos vários filões contidos no livro (1999, p. 83).

Uma vez publicada a obra, resta interrogar que aspecto cabe à criança e quais elementos convencem ao adulto na obra A sereiazinha para assim formular a necessidade e atualidade desse enredo hoje. Como hipótese, à criança caberia a imaginação, a ficcionalidade; ao adulto, o fundo moral dos contos, pois a ele cabe a eleição de um conto, a partir do critério "o que é bom para o meu filho?" ou "o que meu aluno deve aprender?". Interessa, mais uma vez, ouvir o que a história diz, para, então, perceber (sentir) como ela diz e assim, mais profundamente, enredar-se nos planos do conteúdo e da expressão dessa publicação. Destaca-se, de antemão, que a expressão popular atua sobre o homem de uma maneira singular, não o popular regionalizado, mas universalizado, por isso, clássico.

\section{Releitura da tradição popular: lenda ou conto?}

Este clássico de Andersen, assim como seus outros contos, é uma releitura da tradição popular: “En lo que se refiere a Andersen, éste se limita a tomar prestadas ideas de los cuentos populares que le proporcionan un punto de partida para poner su imaginación en marcha" (Disponível em: <http://www. ricochetjeunes.org/es/biblio/base9/andersen.htm>. Acesso em: 17 jun. 2006). 
Trazer o popular à narrativa implica enveredar pelos confins do imaginário coletivo. A sereia é uma figura lendária. Aquelas comunidades que têm forte vínculo com o mar, como Portugal, Brasil e Moçambique, para citar algumas, acompanham (ou são acompanhadas por) sereias em diversas narrativas. De Camões, no século XVI, em continente europeu, a Mia Couto, em continente africano, no século XXI. Por si, o tema já habita a fantasia do homem e como lenda, história narrada, renova-se de enunciação a enunciação.

A sereia, com seu canto sedutor, hipnotiza os marinheiros, fortes guerreiros e os atraem para as profundezas do mar. Explicam-se, com isso, os naufrágios ou as mudanças inesperadas de rotas ou possíveis fugas da terra natal. A lenda, muitas vezes, explica o que não tem, em princípio, explicação: “Por vezes, aparecem classificadas como lendas narrativas que se propõem explicar a origem ou razão de um fenômeno ou de um facto geográfico" (REIS e LOPES, 2002, p. 224-225).

Em A sereiazinha, tem-se a lenda, mas, sobretudo, a releitura da lenda transformada, possivelmente, em conto. Este é caracterizado por Reis e Lopes (2002):

[...] o conto esteve originalmente ligado a situações narrativas elementares: nelas, um narrador, na atmosfera quase mágica instaurada pela expressão 'era uma vez', suscitava num auditório fisicamente presente o interesse por acções relatadas num único acto de narração e que não raro tinham, para além dessa função lúdica, uma função moralizante (2002, p. 79).

Da justificativa oral ao universo da ficção, a sereia se faz presente nos relatos das gerações. Passa-se, então, à história com o intuito de explicitar a sua estrutura e sua ação sobre o interlocutor - um sujeito distante dos valentes capitães do mar e próximo dos shoppings e dos jogos eletrônicos, que em nada remetem às aventuras marítimas. 


\section{Das profundezas: a história}

Andersen conta que, nas profundezas do mar, um viúvo, pai de seis filhas, é rei. A avó exerce o papel da mãe. São lindas meninas-sereia que encantam aquele já encantado território. Ali, vivem as pequenas sereias na expectativa de completar quinze anos e poder descobrir a superfície das águas. A caçula é mais calada, ensimesmada e também a mais bonita. Sonha com a possibilidade de explorar o desconhecido, a saber: o proibido reino da superfície. Sonha em desvendar as distantes paisagens "alémáguas". A menina-sereia se assemelha em muito aos próprios marinheiros que anseiam pelo novo e aventuram-se pelos perigos do mar.

As irmãs, por serem mais velhas, uma a uma, vêem o sonho realizado. Atenta, a Sereiazinha ouve os relatos sempre com a frustração de não serem tão maravilhosos como o seu desejo. Quando completa quinze anos, a protagonista recebe autorização e sobe à tona. Maravilhada, depara-se com um navio e avista um lindo rapaz. Ao contrário do que se passa nas narrativas-lendas sobre sereias, é ela, a hipnotizada pelo humano. Anteriormente, a história aponta um indício do seu desejo de conhecer o ser mortal:

Era uma criança estranha, calada e pensativa ${ }^{55}$. Enquanto as outras irmãs decoravam os seus canteiros com várias coisas provenientes de navios afundados, o único ornamento que ela escolheu foi uma bela escultura de mármore representando um lindo rapazinho, feita de pedra branca proveniente também de um naufrágio ( $p .7$ ).

Suspendendo o narrar e exercitando o fazer metalingüístico, um traço há que se destacar. Nas histórias tradicionais de amor, de Branca de Neve à aprisionada Rapunzel, a mulher tem por função (condição) esperar o príncipe encantado. Esse é um motivo-tema nos contos populares, como atesta Propp pelas palavras de Calvino (1999): “O motivo difundidíssimo

${ }^{55}$ Grifo nosso. 
da princesa prisioneira corresponde à clausura a que eram submetidas as raparigas durante o período menstrual" (1999, p. 143).

Em A sereiazinha, por outro lado, a princesa dos mares é caracterizada como inconformada e, por isso, age. Esse traço distintivo de sua personalidade é reiterado ao longo da narrativa de Andersen, como em: "Era uma criança estranha, calada e pensativa... o único ornamento que ela escolheu foi uma bela escultura de mármore representando um lindo rapazinho [...]" (p. 7). Pergunta-se, então: O conto seria, portanto, ideologicamente feminista? Isso seria possível no século XIX ou seria um anacronismo? Andersen é caracterizado por trabalhar com o universo feminino e, principalmente, por atribuir às mulheres papéis que destoam da tradição:

En los cuentos de Andersen las mujeres ocupan un lugar preponderante hasta el punto de que en algunos no encontramos la presencia masculina. [...] Las mujeres juegan a menudo el papel tradicionalmente masculino: ellas tienen el poder, la fuerza (la Reina de las Nieves y la Virgen de los hielos) y socorren a los hombres (Disponível em: <http://www.ricochetjeunes.org/es/biblio/base9/andersen.htm>. Acesso em: 17 jun. 2006).

É possível que, nesse traço distintivo, esteja a autorização para a releitura contemporânea da narrativa. Entender a atualidade da história por sua essência é uma possibilidade aberta na literatura.

De volta à história, o ficcional conduz o fio da história. Uma tempestade se forma e o navio do príncipe naufraga. A Sereiazinha rompe os padrões sociais e morais e, com mãos e cauda de peixe, salva o seu príncipe encantado. Há, pois, neste momento, uma inversão de papéis sociais, ou, deixando-se de lado os costumes da sociedade, há a quebra de um dos componentes do paradigma tradicional do conto de fadas, reiterando a idéia apresentada anteriormente: “La Pequeña Ondine (1835): los hombres están casi ausentes en este cuento. Incluso el príncipe, que debería ser un personaje importante, 
autónoma" (Disponível em: <http://www.ricochetjeunes.org/es/biblio/base9/andersen.htm>. Acesso em: 17 jun. 2006).

Senhora da situação e do destino, a princesa dos mares deixa o seu amado desacordado à margem do continente e espera que alguém o encontre. Assim como desejava a pequena sereia, outra linda moça o encontra. A princesinha dos mares se tranqüiliza e volta para casa de seu pai, mas nunca esquece aquele rapaz que teve nos braços.

Depois de algum tempo angustiada, a heroína narra a história para as irmãs, e estas a ajudam a encontrar seu amado.

Com a alma inquieta que tem, a pequena sereia não se conforma em apenas observá-lo de longe; quer estar ao seu lado. Mais uma vez, vislumbra-se a mulher que parte para a ação, manipulada por seu querer estar conjunta ao objeto de desejo figurativizado pelo príncipe e também pelo desejo de ser humana, expresso anteriormente.

É importante evidenciar que não apenas o objeto de desejo amoroso manipula a Sereiazinha, mas também o desejo da imortalidade da alma pregada por uma corrente discursiva judaico-cristã:

- Oh, sim - respondeu a velha senhora -, eles [humanos] também morrem e as vidas deles ainda são mais curtas do que as nossas. Nós podemos viver trezentos anos, mas quanto chega a nossa altura transformamo-nos em espuma do mar. Mas os seres humanos têm uma alma, que continua a viver depois de o corpo se tornar em pó. Voa para o céu, até às estrelas brilhantes. Tal como nós subimos até à superfície para olhar para o mundo humano, também eles sobem até lugares desconhecidos que nós nunca alcançaremos (p. 30).

Justifica-se, então, a busca por uma alma, já que esta Ihe traria a imortalidade. Para realizar seu objetivo, ela age. Pede ajuda, procura a competência que lhe falta.

Nos "contos de fadas", a presença da bruxa é recorrente. Eis a personagem das poções e feitiços. À bruxa cabe, normalmente, o papel de obstáculo à realização da performance do sujeito. A 
também esse papel. A bruxa doará competência à princesa. Pode perguntar aquele habituado aos contos: “Esta não é a função da fada, com sua varinha de condão?". A bruxa, neste caso, fará algumas exigências, e isso justifica o doador de competência ser figurativizado por ela. É instaurada a troca, e não puramente a doação, como proposto no esquema proppiano. A condição não é das mais favoráveis à princesa. Há um acordo entre as partes. A princesa negocia friamente a sua felicidade com a bruxa - "Dá-me sua voz e dou-te o príncipe" -, ou melhor, a bruxa vai dar-Ihe condições para ter o príncipe, mas exige pagamento.

O comércio se estabelece. Não é uma ação solidária própria às comunidades regidas pelo trabalho coletivo: é uma comunidade mercantilizada, refletindo as relações de trabalho do final do século XIX, ou pré-capitalismo.

Duas questões clamam pelo olhar da análise. A primeira é aquela em que a princesa assume sua vida, apesar dos riscos, como sujeito do fazer. Ela quer e faz, independentemente dos obstáculos. A pequena Sereia não terá mais a encantadora voz e sentirá dores terríveis nas pernas. Nada the importa, no entanto. Troca seus dotes e atributos pelo amor (ou possibilidade de amor) do príncipe. A segunda questão diz respeito à humanização. O que a bruxa tira da sereia é justamente o seu poder mágico. Ela terá de seduzir o príncipe como humana, com as mesmas armas e artimanhas das outras humanas, possíveis candidatas ao coração do amado. A personagem mágica dará vida ao humano.

A Sereiazinha, despojada de magia, reencontra seu príncipe. Ele se encanta com ela, mas com um olhar fraterno; ela não parece ter atributos sensuais. Não é reconhecida como mulher. Desprovida de elementos mágicos, a Sereiazinha assume o papel de companhia do príncipe. Ele até Ihe dá roupas de homem e Ihe faz confidências, como a um amigo. Ele não tem olhos apaixonados para ela, mesmo porque se revela apaixonado por outra moça, aliás, aquela que o salvou do naufrágio, a quem ele deve a vida. O príncipe não reconhece sua verdadeira heroína, a Sereiazinha, pois ela não parece sê-lo, portanto, sua identidade está ma 
No dia do casamento do príncipe, num ato mágico, as irmãssereias fazem um pacto com a bruxa a fim de salvar a irmã mais nova. A bruxa fica com os lindos cabelos das princesas e elas recebem um punhal, com o qual a Sereiazinha deve matar o príncipe. O amor ao humano, contudo, é maior que por sua família e por si mesma. Sem realizar o seu desejo, porque o príncipe se casa com outra, o seu amor por ele sobrevive. Matá-lo não seria possível, pois o amor a impede.

Tem-se como percurso narrativo a manipulação das irmãs, mas a princesinha não possui um querer realizar a performance da salvação, pois a liberdade não é um objeto-valor para ela. A Sereiazinha, então, diante do trágico destino, joga-se ao mar e se transforma em espuma branca. Esta figurativiza a morte no universo das sereias. Assim, todo o percurso da Sereiazinha é sancionado negativamente. É um percurso de frustração e não-reconhecimento, que só não chega a ser totalmente negativo, pois é oferecido à Sereiazinha um caminho para imortalidade, mas esta depende da ação (comportamento) da criança.

Das entrelinhas às linhas, a moral e o discurso judaico-cristão maniqueísta são explicitados, reafirmado:

- Não precisamos do amor de um humano para nos tornarmos imortais. [...] Quando tivermos tentando fazer todo o bem possível [...] conseguimos uma alma imortal e a felicidade eterna. [...]

Sem nos verem, deslizamos para dentro de casas de seres humanos onde há crianças, e sempre que encontrarmos uma criança boa, uma que torna os pais felizes e merece o seu amor, Deus encurta o nosso tempo de experiência ${ }^{56}$. [...] mas, se encontramos uma criança realmente má, então temos de chorar lágrimas de pena, e cada lágrima acrescenta um dia à nossa espera (p. 60-61).

Algumas leituras desse conto são possíveis. A didático-moralizante, em que é dito ao leitor que ele seja bom, pois disso depende a vida da Sereiazinha, personagem bastante carismática. Uma leitura sociológica ou

56 Grifo nosso. Vale destacar que a questão da ideologia i। conclusão deste estudo. 
psicanalítica, em que há necessidade de a mulher ficar à espera, pois, quando assume para si a conquista, a ação, o amor não se realiza. Triste é o caminhar daquela que determina o seu destino. Triste é a condição da mulher nos contos de fadas.

Em oposição, a reconhecida heroína é a princesa do reino vizinho. O sonho dos reis, pais do príncipe, é promover o casamento entre os herdeiros dos dois reinos. Dessa forma, são reiterados os valores sociais de uma época.

Como teorizado por Propp e Bakhtin, texto e contexto são intrínsecos. O discurso reflete e refrata a sociedade, neste caso, com valores capitalistas, ideário moral judaico-cristão e hierarquização das classes sociais, visto que o príncipe se casa com a princesa de um reino vizinho, como quer o seu pai.

Sereia, magia, amor, príncipe, frustração são figuras que alimentam e compõem o imaginário humano. Vivenciando a narrativa, o homem experimenta as emoções. O objeto estético atua sobre a sensibilidade e também sobre as estruturas psíquicas do indivíduo. Por meio da narrativa, há o descobrir-se. Na linha estruturalista e fenomenológica:

E o próprio adulto descobre na sua vida o que a sua cultura, o ensino, os livros, a tradição Ihe ensinaram a ver. O contato de nós mesmos conosco faz-se sempre através da cultura, pelo menos através da linguagem que recebemos [...] e que nos orienta no conhecimento de nós mesmos. Pelo que, finalmente, o puro si, o espírito, sem instrumentos e sem história, embora seja como que uma instância crítica que opomos à pura e simples intrusão das idéias que nos são sugeridas pelo meio, só se realiza em liberdade efetiva mediante $o$ instrumento da linguagem e participando do mundo (MERLEAU-PONTY, 2002, p. 51).

Da ação do discurso sobre o homem e a sociedade, passa-se ao plano da expressão. O "portão aberto" conduz à maneira de fazer com relação ao que se conta na obra $A$ sereiazinha e às provocações sensíveis criadas pelas imagens agregadas à palavra poética 
Nas mãos, a análise leva os valores fundamentais da narrativa de Andersen para homologá-los à expressão.

\section{Palavra e imagem: implicações e entraves}

Analisar a relação palavra-imagem articulada pelo projeto gráfico é a proposta deste estudo. É pertinente perguntar, então, que função a imagem exerce (ou deveria exercer) no diálogo com a palavra. Que espaço tem aquela em um texto completamente autônomo? Seria o papel do ilustrador preencher as entrelinhas deixadas pelo autor? Contudo, se for afirmativa a resposta dada à pergunta anterior, sendo o livro preenchido pelas ilustrações, o que sobraria para o leitor completar?

Para aproximarnos al libro-álbum, de lo primero que debemos hablar es de su particular relación entre el texto y la imagen. Cuando tenemos un libro-álbum en nuestras manos nos vemos sorprendidos por la presencia notable de la ilustración. Contrapunteo de imagen y palabra, donde la imagen narra lo no dicho por la palabra, o la palabra dice lo dejado a un lado por la imagen. Un libro-álbum no se entendería sin sus ilustraciones, así como la ilustración sin el texto perdería también su sentido. En un libro-álbum la imagen supera el lugar de mero adorno o compañía del texto; la imagen es narrativa, portadora de la historia en sí misma y en diálogo con la palabra (BAJOUR e CARRANZA. Disponível em: <http://www.imaginaria.com.ar/10/7/libroalbum.htm>.

Acesso em: 4 abr. 2006).

Bajour e Carranza definem o livro-álbum, que tem por condição a fusão da palavra e da imagem no contar, idéia já explicitada e trabalhada no capítulo 1. A sereiazinha, de Andersen não se enquadra nessa definição de livro-álbum. O texto existia antes da ilustração e tinha sentido completo. Não depende, portanto, da imagem para significar; essa relação não lhe é intrínseca. Entretanto, a pergunta continua sem resposta: de que serve a imagem neste texto? Por que a opção por 
ilustrá-lo? São muitas as perguntas, e talvez as respostas sejam mais escassas, como advertido de início.

Pesquisas francesas e inglesas ${ }^{57}$ se debruçaram sobre uma possível tipologia de subgêneros dos livros de literatura infantil, a partir de características recorrentes. Às vezes, tomando-se a relação palavraimagem como critério, outras, o tipo de texto, definem-se os subgêneros. Assim, retomando a discussão realizada anteriormente, pois este é o objetivo deste trabalho de tese, vale deitar olhos sobre a tipologia, uma vez que a análise tem em mãos, propositalmente, uma obra com relações distintas da estudada anteriormente:

a) livros com narrativas duais: são aqueles em que imagem e palavra se constituem como duas narrativas que correm simultaneamente e não se interseccionam.

b) livros ilustrados: são aqueles em que a imagem é cenário para a palavra;

c) livros interativos: são aqueles em que a narrativa é assegurada por uma estreita relação entre a imagem e a palavra; chamado, também, de livro-álbum;

d) livros sem palavras: são aqueles em que há uma sucessão de imagens que formam a narrativa, sem necessidade da palavra.

Essas investigações incluem ainda os livros artísticos, em que o texto verbal é poético, e os de estilo, que veiculam as histórias em quadrinhos ou os cartoons. Nestes últimos subgêneros, o critério é o tipo de texto. Essa mudança de critério poderá ser vista positivamente se a abrangência de textos for considerada, mas, se há rigor na formalização dos subgêneros, tal fenômeno não pode ocorrer. Opta-se por deixar de lado, neste estudo, os últimos tipos de livros e retomar o critério da relação palavra-imagem; assim, é possível acrescentar, pelo menos e por enquanto, três outros tipos de livros:

57 José Antonio Gomes, em artigo intitulado “O conto em forma (to) de álbum: primeiras aproximações" (Revista Malasarte, Porto, novembro, $2003 \mathrm{n}$ 1) $\mathrm{n}$ 3-6l fa> referência aos seguintes autores para traçar os subgêneros Hepler, Claude Le Manchec, Renée Léon, Wendy Michael e Maı 
e) livros escritos a partir de imagens $^{58}$ consagradas, por exemplo, as narrativas sobre artistas de renome (Frida Kahlo, Portinari, Klimt, entre outros);

f) livros em que o texto verbal é cenário da imagem ${ }^{59}$;

g) livros sem imagem: são aqueles em que a palavra prescinde da imagem.

Esses sete tipos de livros podem ser encontrados na seção destinada às crianças nas livrarias e bibliotecas, em qualquer parte do mundo. Vale ressaltar que a faixa etária não foi considerada nesta tipologia, pois, ao longo do estudo que se apresenta, muitas contradições e imprevistos surgiram com relação a esse tipo de classificação por idades $^{60}$. Por isso, a imagem não está associada à fase pré-escolar, ou seja, às idades iniciais não alfabetizadas.

Trazendo a obra de Andersen às mãos novamente, A sereiazinha seria exemplo, então, dos livros ilustrados, ou seja, aqueles em que a imagem é adorno do texto? A imagem não acrescentaria nada à palavra? Esse cuidado com a fidelidade à obra é uma marca do livro ilustrado?

Ricardo Azevedo, autor e pesquisador de literatura infantil, não concorda com esta possibilidade de ausência da cooperação entre palavra e imagem:

É impossível negar que todo o texto ilustrado vai, necessariamente, receber interferência de suas ilustrações. A energia, a leitura (ilustrar é interpretar), o imaginário, a linguagem, as cores, o clima, a técnica, as referências icônicas, tudo o que o ilustrador fizer, vai alterar e interferir na leitura (e no significado) do texto.

Mal comparando, é como um pianista acompanhado pelo contrabaixo. Os dois instrumentos, as idéias dos dois músicos, as referências e a cultura musical de cada um, tudo vai entrar na construção do som. Dependendo da música, o

58 Alguns exemplos: no México, Frida, de Jonah Winter (texto) e Ana Juan (ilustração). Trad. André J enkino do Carmo. São Paulo, Cosac Naify; na Itália: Apresento-vos Klimt, de Octavia Mônaco. Lisboa, Livros Horizonte; no Brasil, há com esta mesma proposta sobre Tarsila do Amaral, Cândido Portinari, entre outros.

59 Exemplos são as obras de Angela Lago: O personagem encalhadn editnra lê e Chiquita Bacana e outras pequetitas, editora Formato, ambas

60 Esta reflexão voltará à tona em outros momentos do trabalhc 
solo predominante será de um ou de outro instrumento. Mesmo quando o solo é feito pelo piano tendo por trás o contrabaixo este, de repente, cresce enquanto o piano fica só na base. De repente, parece que ouvimos dois contrabaixos tocando. É o piano imitando o baixo. Outras vezes, o baixo vai para o agudo e finge ser um violão.

Algo parecido pode acontecer, em graus diferentes, entre o texto e as imagens de um livro.

Um autor ou editor que pretenda publicar um texto sem interferências deve publicá-lo sem ilustrações. O texto, em todo caso, continuará sujeito às influências do formato, do papel, do tipo de letra (um livro sobre computação e outro sobre floricultura exigem, em princípio, tipologias diferentes), da capa, da qualidade de impressão etc. (Disponível em: <www.ricardoazevedo.com. br>. Acesso em: 5 jan. 2007).

Para Azevedo, tudo interfere na significação de um texto. Como a lingüística ensina, nada é arbitrário, e até a ausência significa. MerleauPonty (2002) reitera o postulado:

Perante um quadro, não se trata, pois, de multiplicar as referências ao tema, à circunstância histórica, se é que ela existe, que está na origem do quadro; trata-se, sim, tal como na percepção das próprias coisas, de contemplar, de perceber o quadro segundo as indicações mudas de todas as partes que os traços de pintura depositados na tela me proporcionam, até que todas, sem discurso e sem raciocínio, se compõem numa organização estrita onde se sente que nada há de arbitrário, mesmo se não se consegue explicar (2002, p. 58).

Vislumbra-se, portanto, a impossibilidade de um sistema semiótico não interferir no outro. Não se descarta, contudo, a existência de livros em que há duas narrativas paralelas: a da imagem e a da palavra, as quais, mesmo sem pontos aparentemente comuns, constroem um único texto, às vezes apresentado sob diferentes pontos de vista, às vezes com pontos de contato entre figuras discursivas.

Ainda, levando-se em conta os desenvolvimentos teóricos sobre a imagem na literatura infantil, a relação entre as mídias sempre é pensada como um regime de cooperação, e, se há presença de dois sistemas, então, existe a reciprocidade: 
Durante mucho tiempo, los ilustradores que producen libros ilustrados han estado sometidos al texto. Eso era fruto del proceso de creación del libro ilustrado - un texto para ilustrar - y de la visión que se tenía de la infancia.

Hoy día es cada vez más raro encontrar ilustradores cuya función, determinada en general por editores covencionales, sea decorar las páginas de un texto para embellecer el libro; la ilustración que resulta de esta visión tiene una función puramente pasiva, no juega ningún papel en la lectura del texto. Así, en la actualidad predominan los artistas que ponen su talento al servicio de un texto para transformarlo en imágenes; la ilustración nace, por tanto, como una recreación del contenido textual; tiene ya una función activa, pues abre al joven lector la posibilidad de una lectura doble, incluso plural, que es fuente de reflexiones e interrogantes. Se puede decir que el rasgo más característico de la ilustración actual radica en el hecho de que posibilita una lectura autónoma del texto: a través de la sucesión de ilustraciones, el joven lector puede crear su propio relato (ESCARPIT, 1979, p. 23).

Escarpit (1979) se detém sobre outro aspecto, o pedagógico, diante da recepção da obra. Deita olhos ao leitor, enquanto a outra mirada incidia sobre o objeto, sobre o texto e sua significação, sem considerar a recepção. A autora francesa focaliza a contribuição da imagem para o enriquecimento da leitura da criança, reforçando o caráter polissêmico da expressão. Tanto a perspectiva pedagógica quanto a Semiótica endossam as transformações e a tendência atual da relação palavra e imagem na literatura infantil. Contudo, mesmo a análise proposta não sendo diacrônica, vale lembrar que os contos de fadas foram ilustrados, e essa ilustração marcou o imaginário de gerações:

As ilustrações a cores, extraídas de quadros do pintor flamengo quinhentista, Pieter Brueghel, o velho, serviram para sublinhar através de uma livre associação de imagens o ritmo que rege o mundo realista-grotesco da fantasia camponesa nórdica. O achado de ilustrar Grimm com Brueghel foi de Giulio Bollati, que, juntamente com Elio Vittorini, se divertiu a selecionar os pormenores e a determinar as sua associações [...] (CALVINO, 1999, p. 81-82). 
E mais:

É claro que na nossa memória desempenha um papel importante a fantasia dos desenhadores que ilustraram como Ihes deu na gana os livros que lemos em crianças, e, antes ainda, a dos escritores que coligiram os contos tradicionais e Ihes deram forma literária (CALVINO, 1999, p. 141)

Como Escarpit, Calvino também destaca o papel do editor de uma obra, quando se pensa a imagem. Assim sendo, o texto A sereiazinha é autônomo, então, a imagem deve buscar o seu espaço nessa relação. A visão abrangente e a sensibilidade do editor são fundamentais para promover o diálogo entre os sistemas semióticos. Cabe a ele a organização dos sistemas. É tarefa do editor harmonizar os textos para promover uma leitura articulada entre um e outro. Em casos como este, o papel do editor é condição fundamental para a produção da obra, como reflete Vaz no artigo "Ilustre ação: embalar textos com letras e margens":

Contrariamente à fácil suposição de que boas ilustrações bastam para atrair os olhos do leitor, a resposta a essa questão encontra-se no trabalho do intermediador "artista gráfico" que faz a programação visual de um livro. [...] um artista gráfico [...] sabe como: configurar as palavras impressas; diagramar as páginas; destacar os títulos; eclipsar notas e numeração de páginas; compor bloco de palavras, formando linhas, compor blocos de linhas, formando páginas; definir margens, compondo seu desenho gráfico; escolher o tipo de letra adequado; definir o corpo tipográfico, isto é, o tamanho de letra ideal; programar um bom contraste entre tinta de impressão e papel, de modo a não cansar nem exigir esforço do leitor; adotar sinalização clara para início e término de capítulos; achar a forma de se favorecer a leitura continuada do texto (1998, p. 43).

A partir desse esclarecimento técnico, o próximo passo para compreender a relação palavra-imagem no caso de A sereiazinha é, sem dúvida, analisar a própria obra, ou seja, o projeto gráfico e, a partir disso, confirmar (ou negar) as propostas teóricas alinhadas nt 
que palavra e imagem desempenham papéis de cooperação no projeto gráfico desta obra. De olhos abertos para as imagens e ouvidos atentos à leitura, segue-se a história com especial cuidado sobre o ofício do editor.

\section{Palavra e imagem: continuidades e rupturas}

Pode-se pensar, inicialmente, na imagem como o cenário do texto na obra dada à análise. Para isso, é de se supor que o texto não dê atenção à descrição. Essa suposição não é verdadeira na obra de Andersen. No texto em questão, há descrições primorosas do espaço, das personagens, dos sentimentos, as quais convocam o imaginário do leitor por meio de figuras sinestésicas. O sabor, a cor, o perfume, o som são delineados pela palavra:

[...] as descrições, são facilmente destacáveis do conjunto textual: tendencialmente estáticas, proporcionam momentos de suspensão temporal, pausas na progressão linear dos eventos diegéticos (REIS e LOPES, 2002, p. 93).

A pena de Andersen cuida especialmente das descrições. $O$ exercício se configura, então, em perceber e determinar o que cabe à imagem e o que cabe à palavra, sem, de antemão, determiná-lo, ou que espécie de cooperação se cria entre os sistemas. Descarta-se a imagem como cenário e sem "pré" conceitos, mergulha-se na produção.

É importante ter no horizonte a relação palavra-imagem e, ao final da análise, refletir sobre a pertinência e validade de tal relação encadeada pelo projeto gráfico. Isso poderá ser pensado a partir do leitor pretendido pela obra e suas implicações pedagógicas, como bem abordado por Escarpit, e, também, no que tange à teoria Semiótica ${ }^{61}$. Aquela coloca foco

${ }^{61} \mathrm{O}$ que se propõe não é separar a teoria pedagógica da teoria Semiótica, mesmo porque a Semiótica pode compreender a pedagogia enquanto dicrırcn $\cap$ mus se pretende é, tão-somente, focalizar ora o texto, ora o leitc marcar a distinção entre uma e outra. 
na polissemia da imagem e na necessidade da dupla leitura - a verbal e a visual; esta, em constante diálogo com o discurso anterior, desvenda as tramas discursivas - suas coerências e rupturas no enunciado e, ainda, desfaz as tramas discursivas e expõe a enunciação, ou seja, a ação do leitor sobre o livro, implicando, necessariamente, a interdiscursivização texto/contexto: neste caso, a obra A sereiazinha e sua pertinência pedagógica como objeto-livro dado às crianças no Portugal contemporâneo.

Resta observar, com bastante astúcia, o objeto-livro e as implicações ou as provocações que ele proporciona ao leitor tanto no enunciado quanto na enunciação.

Posto isso, na edição da Afrontamento de A sereiazinha, o livro apresenta uma sobrecapa ilustrada com uma imagem retirada do miolo da obra, ou seja, antecipa-se a imagem, deslocando o contexto em que está inserida e atribuindo-Ihe outra fruição.

O que se lê-observa na sobrecapa é: uma sereia sobre uma pedra ao mar, com o título em laranja, em fonte maior que as demais palavras, centralizado. Ao lado da figura da sereia, há o nome do autor em branco, em fonte menor, e abaixo a chamada: ilustrações, em laranja, e o nome de Manuela Bacelar, em branco, com fonte menor que a do nome do autor.

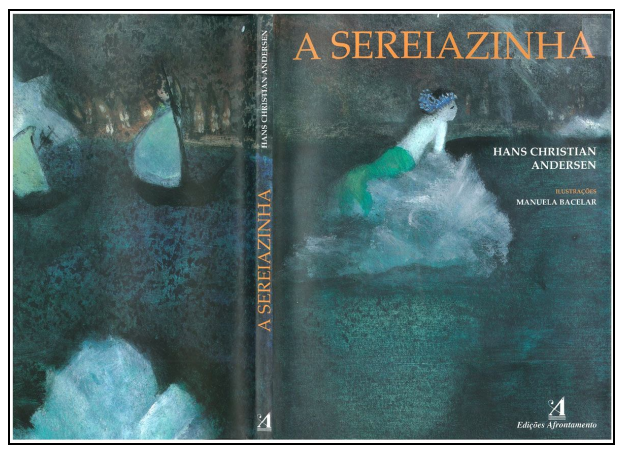

Figura 2.44 - Sobrecapa 
Vale pensar na hierarquização das tarefas dos artistas. Na seqüência: o título, o autor, a ilustradora e, finalmente, ao pé da página, o nome da editora: Edições Afrontamento. Ressaltam-se ou atenuam-se os elementos que têm importância segundo aquele que elaborou o projeto gráfico.

Sobre o projeto gráfico de uma obra, três caminhos podem ser traçados, e a opção por um deles é tarefa da editora: o editor elabora o projeto ou o ilustrador propõe ou, ainda, uma terceira pessoa é responsabilizada por essa produção, o diretor de arte, ou designer gráfico. Neste caso, em particular, coube às Edições Afrontamento tal trabalho.

Assinala-se que a sobrecapa tem função de mercado. Deve manipular o leitor, para que este compre o livro. Além disso:

\footnotetext{
As sobrecapas consistem em uma folha de papel dobrada em quatro páginas, com lombadas e orelhas. Recobrem o livro de capa dura, com dupla função: de um lado suportam a impressão de letras, imagem e cores sem outra limitação, o que a do bom gosto e moderação; em segundo lugar, evitam (ou pelo menos retardam) o desgaste do material que reveste a capa dura (COLLARO, 2000, p. 20).
}

A presença da sobrecapa agrega o valor de reconhecimento, de prestígio de uma obra, algo que deve ser estimado, guardado. O nome de Andersen leva a uma imediata relação com a obra clássica, acrescentando ainda mais valor ao objeto, visto que é um autor de excelência reconhecida. A imagem escolhida, a sereia sobre a pedra, reporta à imagem também clássica da escultura em homenagem ao conto presente na cidade de Copenhague, onde se encontra o museu dedicado ao autor. 


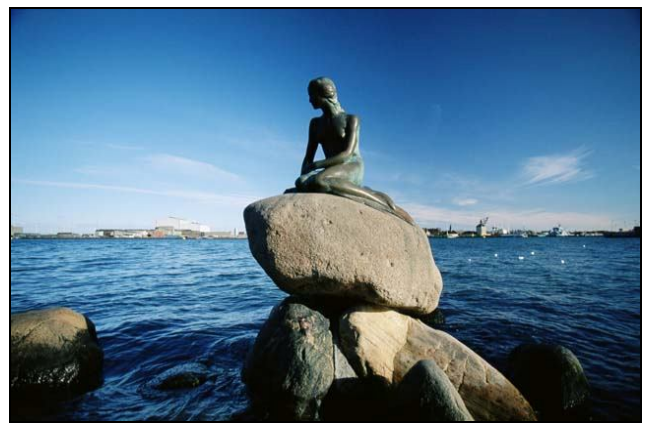

Figura 2.45 - Escultura em homenagem ao autor (Andersen)

A sobrecapa provoca o reconhecimento do status clássico da obra, presente nas figuras do nome do autor em destaque e na alusão à imagem de homenagem. Além disso, a componente plástica, ou seja, a imagem com suas cores diluídas e formas desfeitas, deixa de lado a iconicidade $^{62}$ máxima para trazer à cena certa subjetividade. Essa recorrência plástica agrega à obra a idéia do clássico modificado, uma vez que torna o conhecido alterado, não subvertido, mas (re) trabalhado, ou seja, uma possível releitura.

Para o leitor, aquela não é a obra conhecida, mas sim outra leitura dela. As imagens dão uma nova atmosfera, um novo ritmo, um novo sentido ao texto consagrado de Andersen:

É um outro assunto vasto e sedutor, acerca do qual me limito a deixar uma pergunta: são também estas imagens funcionais? [...] Sendo a fruição o seu principal destino, cabe nessa idéia de um serviço? [...]

E, por outro lado, há na contemplação, essencialmente, uma razão passiva? Ou a contemplação - com as suas exigências de estado (de espírito...), de tempo (de deleite), de 'quietude' das leituras e das interpretações, ou ainda (admitamo-lo) de regressão do olhar para os indizíveis do inconsciente e do tempo onírico... - pode ser um trampolim?... [...]

62 Iconicidade/iconização são termos definidos pela Semiótica Discursiva da seguinte maneira: "é o investimento figurativo exaustivo da última face do nroredimento de figurativização, com o objetivo de produzir ilusão referencial 1999, p. 87). 
A partir deste poder da imagem podemos (e talvez devamos) reflectir a questão do Imaginário e da Imaginação. São temas especialmente caros ao pensamento sobre a ilustração que tocam, amiúde, a questão de saber se as imagens, acrescentadas aos textos, interferem ou não com a capacidade de imaginação que um texto literário, por definição, activa [...] (CALADO, [s.d.], p. 115).

Sem dúvida, a imagem da sobrecapa atua sobre o leitor. É ela que faz o convite à leitura. Quais são os argumentos utilizados? São: 1. a recorrência ao clássico; 2. o clássico com nova "roupagem"; 3. apesar do adjetivo "novo", a narrativa original é preservada, visto que existe a referência ao autor e à imagem clássica.

A verdadeira capa dura é toda de tecido verde-escuro. É curioso, pois a sobrecapa vem colada à página de ante-rosto, ou seja, para tirá-la, há que rasgar. A capa e sobrecapa perdem, pois, a função: a sobrecapa, de proteger e ser descartável, e a capa, de ser neutra e mais resistente ao tempo para compor a biblioteca da casa. A sobrecapa serviria apenas para seduzir o leitor e, portanto, seria descartada assim que fosse adquirida, para, dessa forma, a capa, neutra, permanecer nas prateleiras das bibliotecas privadas. A impossibilidade de descartar a sobrecapa destitui as funções da capa e da sobrecapa. Perde-se, ainda, a sensação tátil que o tecido provocaria. Trazer um novo material à capa revela a originalidade editorial, mas não é dado o prazer ao leitor, a menos que ele rasgue o livro e retire a sobrecapa.

A página de guarda é verde, dando continuidade à cor de fundo da sobrecapa e à do tecido da capa. Se a sobrecapa for descartada, a página de guarda também será rasgada, assim aquela ganha uma função fixa, neutralizando a capa e sua função. A continuidade cromática - sobrecapa, capa, página de guarda - envolve o leitor, remetendo-o ao universo das águas. A cor não é homogênea, há variações, como o mar.

A opção editorial por sobrecapa, a menos que a análise não tenha percebido o sentido, não é eficiente, uma vez que não cumpre sua função nem propõe uma outra leitura, o que poderia ser umi 
criativa. Há obras em que rasgar a página agrega sentido ao texto, a saber: descobrir um segredo ou estabelecer interação com uma personagem. A obra O Escrivão, da editora Cosac Naify, propõe essa ação, para chegar à leitura é necessário rasgar as páginas ${ }^{63}$. Já, no caso de $\mathrm{A}$ sereiazinha, parece um recurso mal aproveitado e descontextualizado.

Dando seqüência à análise, a primeira página é toda branca e traz o título em fonte minúscula, em preto. Uma apresentação bastante sóbria, recuperando a idéia do tradicional. Essa página é chamada de ante-rosto e tem a seguinte definição: “[...] a primeira página ímpar impressa chama-se ante-rosto (ou falsa folha de rosto ou falso frontispício) e traz impresso apenas o título da obra, em corpo pequeno" (COLLARO, 2000, p. 18). Este recurso dá o tom da obra original e institui a voz clássica, instaura-se a formalidade.

A página seguinte distribui o nome do autor centralizado em cinza, o título maior, em vermelho e um pequeno quadro de $3 \times 3 \mathrm{~cm}$, com imagem abstrata que remete às cores de fundo da sobrecapa. Ainda, há a chamada: ilustrações e o nome da ilustradora e, ao pé da página, o nome da editora. Todo esse texto aparece centralizado nesta página.

Chega-se, pois, à narrativa, já na página 5; ali, há apenas texto, iniciado por uma iluminura ${ }^{64}$ vermelha. A obediência a todas as normas gráficas, incluindo a iluminura, reforça o estatuto clássico à obra das Edições Afrontamento. A presença da iluminura remete ao conto, ao gênero dos contos de fadas ou contos populares.

Como toda narrativa tradicional, esta também obedece à estrutura narrativa mais ou menos fixa do conto popular: apresentação, criação do conflito, clímax, resolução do conflito e desfecho. Deveria, então, o conto ser introduzido por um "era uma vez". A iluminura, neste caso, substitui esse recurso.

63 O projeto gráfico se inspira na personagem: a história se esconde em folhas duplas que precisam ser "rasgadas" para que se possa ter acesso ao texto. A encadernação é artesanal e a capa deve ser descosturada para se abrir o livro

64 Segundo o dicionário de língua portuguesa, iluminura é: "n com que se ilustravam pergaminhos e manuscritos" (2006, $p$ 
Apesar de ser narrativo, o texto está fortemente pautado na descrição, como já apontado. Este procedimento é necessário à narração para delinear os elementos narrativos, como: personagens, tempo, espaço e, por vezes, até o narrador. O gênero conto, porém, se caracteriza por não se ater ao detalhamento. Entretanto, Andersen nega esta invariante, característica do conto, e, artesanalmente, produz figuras, imagens tão ricas que ofuscam o olhar, reiterando a idéia que a análise pontuou anteriormente.

A primeira descrição desloca o leitor para o universo ficcional, inicialmente, pela iluminura (palavra que é imagem e vice-versa) e, depois, pelas belas descrições do ambiente mágico:

Longe, lá longe no mar alto, a água é tão azul como as pétalas da mais bela centáurea e tão límpida como o vidro mais transparente; mas é profunda, muito profunda, tão profunda que nenhuma âncora jamais lá chegou. Seria preciso colocar inúmeras torres de igrejas umas sobre as outras para chegarem do leito do mar até a superfície. Nessas profundezas vivia o povo das águas (p. 5).

Alguns pontos merecem destaque, para que a relação palavraimagem seja pensada. O narrador, como na maioria dos contos de fadas, está em 3ạ pessoa. Isso implica um modo de narrar mais distanciado e, portanto, mais objetivo. O tempo instaurado é o passado vivia e o espaço é o do lá, lá longe. O "era uma vez" é, pois, substituído graficamente pela iluminura e, lingüisticamente, por uma marca espacial que também remete à ficcionalidade Longe, lá longe no mar alto... ou seja, no universo da ficção - atemporal e universal, a debreagem enunciava, como postula a Semiótica Discursiva.

As suspensões narrativas vão criar aquilo que Greimas $^{65}$ chama de fraturas, conceito derivado da fenomenologia, em que sujeito e objeto se

65 Greimas, em Da imperfeição, analisa a obra Continuidade dos Parques, de Julio Cortazar, e propõe a seguinte reflexão acerca da leitura: "F ce hnıver nrazer necsa leitura, ele será encontrado não na aproximação do obj contrário, no distanciamento progressivo do que é 'realidad 
fundem, levando ou elevando ao prazer estético. Tanto a palavra quanto a imagem têm propriedades para provocar esses momentos de suspensão temporal, em que o leitor é transportado pelos sentidos. Em A sereiazinha, a palavra encanta e abre fendas para a sensibilidade do leitor.

Posto isso, volta-se à questão da descrição, uma vez que chama a atenção. O texto descritivo na obra em questão é bastante detalhado e cria figuras inesperadas, aproximando-se da linguagem poética, campo fértil à contemplação estética. Um dos exemplos está na descrição do mar, em que é utilizada uma bela comparação: "a água é tão azul como as pétalas da mais bela centáurea e tão límpida como o vidro mais transparente". A descrição oferece ao leitor dados para que ele possa realmente imaginar. Esses são referenciais: "Seria preciso colocar inúmeras torres de igrejas umas sobre as outras". Assim, o leitor pode ter a medida da distância e há dados para que a imaginação possa voar. Imagens são minuciosamente construídas pela palavra, como Colomer explica a partir da lembrança que se tem de uma obra literária:

Ciertamente, es difícil para la mayoria de nosotros recordar el argumento completo de una obra al cabo de un cierto tempo, por más que nos hayamos sentido absolutamente arrastrados por ella durante la lectura. En cambio la atmósfera creada o el tono de la narración se mantienen de forma mucho más estable en nuestra evocación. Y sin duda, al recordar o hablar de las obras, partimos casi siempre de escenas y detalles que nos impactaron especialmente (2000, p. 10).

Por meio da descrição, o narratário também é instaurado, ele é chamado à narrativa: "Não se deve pensar, nem por um único momento, que não há nada lá em baixo senão areia branca" (p. 5). Há, ao utilizar essa estratégia, o desejo de trazer o leitor para a narrativa, como faz o contador de histórias na instância da oralidade, berço da narrativa em questão. Percebe-se, então, que alguns recursos da expressão oral 
"sobram" quando estas são escritas. Tal "sobra" é característica do gênero conto de fadas ou conto popular. O leitor é completamente envolvido pela palavra, pelo contar, pela ficção.

Todos os recursos descritivos destacados são obstáculos para presença da imagem, pois o que resta à imagem revelar? Como é possível estabelecer diálogo com algo que já disse tudo e já elevou os sentidos do leitor? Pergunta-se novamente.

Na página seguinte, a imagem se apodera do espaço. As perguntas elaboradas anteriormente devem ser respondidas pela observação direta da expressão plástica, e, por essa trilha, segue a análise neste momento.

Como padrão editorial, as páginas serão apresentadas sempre com o texto em preto, justificado e com entrada de parágrafos. A iluminura desaparece nas páginas seguintes. A imagem fica a cargo do quadrinho, que foi apresentado anteriormente na página de abertura, de $3 \times 3 \mathrm{~cm}$ como um recorte, e é um recurso de antecipação da imagem, revela parte do que está por vir, ou seja, tem a função de envolver o leitor no ambiente, no clima da obra. O desenho gráfico da página (figuras, mancha de texto e disposição) também remete ao padrão tradicional das histórias antigas, dos livros antigos, corroborando a idéia de manutenção do status do texto original. 


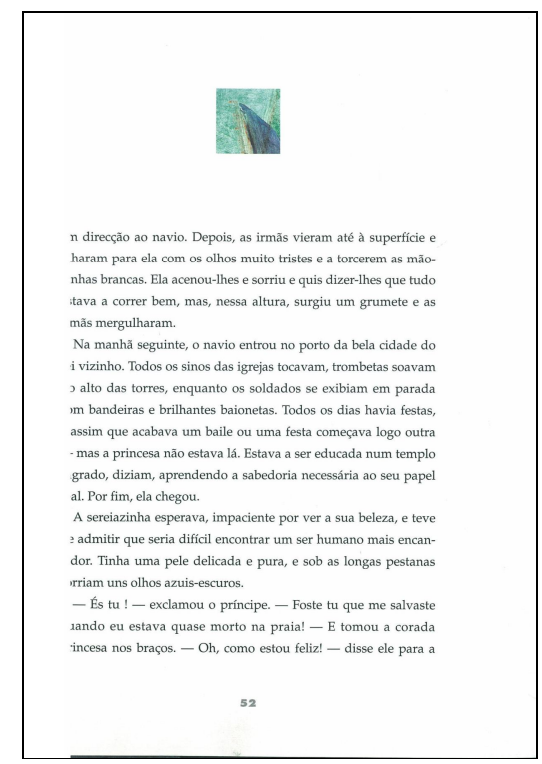

Figura 2.46 - Desenho gráfico da página

Olhando cuidadosamente para o quadrinho, ele faz lembrar dois recursos lingüísticos: a anáfora, que recupera uma figura de linguagem, ou o indício, que recupera uma estratégia descritiva. Com o intuito de compreender a presença deste quadrinho que acompanha todas as páginas da obra, para além da reiteração da idéia de clássico, dois percursos distintos serão realizados. Primeiramente, para definir anáfora, recorre-se ao dicionário de língua portuguesa: "anáfora: figura de estilo que consiste em repetir a mesma palavra no princípio de duas ou mais frases" (2006, p. 51).

De fato, a recorrência insistente do quadrinho ilustrado, no alto da página, parece utilizar um procedimento semelhante ao lingüístico definido pelo dicionário. Mas ainda está suspensa a conclusão. Passa-se, então, à segunda definição; no caso, o conceito de indício será esclarecido pelo dicionário de narratologia formulado por Reis e Lopes: "indício remete premonitoriamente para um certo desenvolvimento da intriga, ao nível das funções cardinais" (2002, p. 202). O indício lingüístico também pode ser transportado para a imagem, no caso apresenta 
na medida em que o quadrinho é um recorte da imagem que ocupará a página dupla mais adiante.

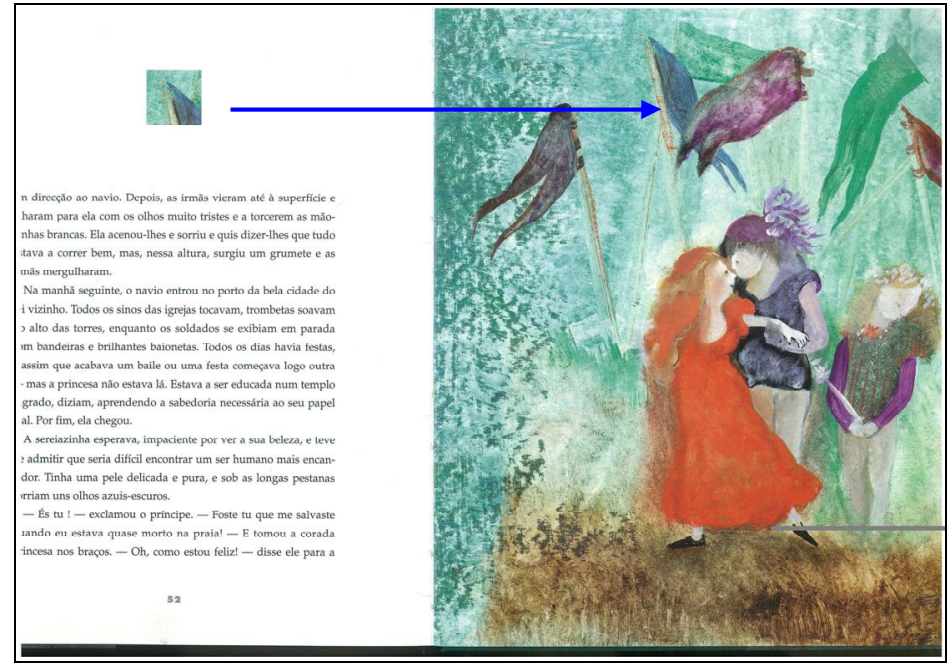

Figura 2.47 - Quadrinho: anáfora da imagem da página seguinte

No entanto, recorrer a essa estratégia seria utilizar um instrumental analítico de um sistema expressivo para outro, do verbal para o visual. Isso, por um lado, pode ser muito importante, pois permite a comparação entre as linguagens, visto que se percebe as mesmas categorias na descrição do efeito, e, por outro lado, pode ser arbitrário, uma vez que o sistema semiótico não foi analisado a partir de suas próprias qualidades. Novamente, suspende-se a conclusão para se inserir outro problema.

Outra questão que se impõe é que os quadrinhos apresentados no alto da página não são figurativos, ou seja, há uma imagem abstrata. Sair da imagem com maior grau de iconicidade para um menor é aventurar-se nos sentidos incertos da mídia visual: 


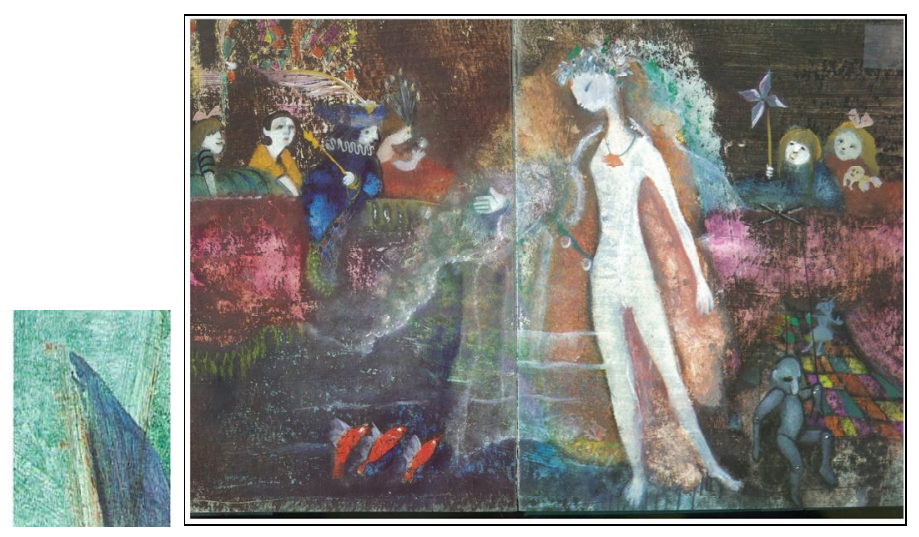

Figura 2.48 - Abstração (esquerda) $\rightarrow$ I cônica (direita)

Definiríamos a polissemia como uma interrogação sobre o sentido (podendo ir da incerteza à inquietação, ou mesmo ao trauma e ao pânico). Barthes (1964 a) chega a falar do 'terror dos signos incertos'... Vimos como, na imagem, esta polissemia é sempre maior que no verbo; vimos também que, sendo embora a cadeia de significados visuais uma cadeia flutuante, há técnicas destinadas a fixá-la, ancoradouros de sentido (CALADO, 1994, p. 62).

$\mathrm{Na}$ arte abstrata, ou com menor grau de iconicidade, o que se pretende é o estímulo aos órgãos sensoriais ${ }^{66}$. Com isso, conclui-se que são duas as funções dos quadrinhos abstratos: criar uma atmosfera para os sentidos e cumprir uma função de marcação do desenvolvimento narrativo. Sobre esta última, a sua função seria muito semelhante àquela da linha do tempo ${ }^{67}$, a saber: marcar a continuidade narrativa pela repetição da estratégia discursiva. Cumpre-se, portanto, uma função similar a que tem a anáfora na poesia que estabelece o ritmo poético. $A$ Semiótica também pensou sobre a anáfora com relação ao texto visual:

La anáfora puede ser homologada a la figura retórica de la repetición en el caso del texto icónico, si la consideramos como una reiteración de una forma visual mediante figuras que funcionan como sinónimos o con variaciones expresivas. La anáfora, en este caso tendría una intencionalidad

${ }^{66}$ Ao longo deste estudo, a abstração será mais detalhada.

67 Este elemento plástico-narrativo foi trabalhado na anális Manuela Bacelar. 
persuasoria directa en la medida que, valiendose de la noción de focalización, sirve para llamar la atención sobre un TEMA, al mismo tiempo que lo amplifica (VILCHES, 1995, p. 297).

Assim, por meio da Semiótica, é possível entender o quadrinho abstrato como uma anáfora, em que a repetição chama atenção para a imagem, para o texto, para a história narrada, imprimindo-lhe ritmo e, portanto, progressão.

O trabalho plástico abstrato e a construção da atmosfera de uma obra são destacados por Bacelar em entrevista. Nestes termos, recuperase a idéia de atmosfera, pois este não é um conceito do arcabouço da Semiótica; procurou-se, no entanto, trazê-lo para a teoria que fundamenta este estudo. Vale revelar a reflexão de Bacelar acerca do conceito discutido:

A parte complicada surge mais quando o texto é de uma outra pessoa... não é chata, é complicada. Porque primeiro eu tenho que encontrar a atmosfera do livro. Atmosfera é uma coisa que se fala muito pouco em Portugal, seja no teatro, seja no que for. A atmosfera como um todo. Não é que as pessoas não tenham a atmosfera presente, mas o que eu não ouço é pronunciar a palavra. A atmosfera é muito importante - se um livro é poético, se é um livro de humor, é de uma maneira; se a escrita é mais pesada, eu ilustro de outra maneira. Eu não ilustro muito o que lá está, o que lá está lá. Eu gosto de ilustrar o que não está lá ou o que lá está mais a minha maneira. Não é aquela ilustração: a menina pôs um vestido vermelho - a menina com vestido vermelho; a menina pôs o sapatinho, deixa eu ver se a menina é loira... É claro, às vezes o autor põe tanto pormenor no texto, que uma pessoa não pode fugir a esta regra. Mas eu gosto mais de sugerir, gosto de deixar um espaço para imaginação, ou para uma terceira imaginação que é a do leitor. Porque também lá está a minha imaginação e lá está a imaginação do autor (BACELAR, M. Entrevista concedida a Mariana Cortez. Porto, 18 abr. 2006). ${ }^{68}$

${ }^{68}$ Grifos da análise. 
Rui de Oliveira dialoga e concorda com esta perspectiva quando utiliza o termo "método de abordagem". O ilustrador brasileiro, em entrevista para o site de literatura infantil Doce de Letra, diz que não gosta do conceito de estilo, mas que a cada obra que recebe para ilustrar se detém sobre o "método de abordagem" a fim de chegar à maneira de ilustrar aquela obra.

Das falas de Bacelar e de Rui de Oliveira, pode-se extrair a questão de que a imagem se apropria da palavra do outro. Essa apropriação se daria por meio da já referida atmosfera e também do olhar que a ilustradora tem como leitora do texto que deve ilustrar. Sem se esquecer do espaço deixado à imaginação do leitor.

O quadrinho, presente em todas as páginas, é uma maneira de envolver o leitor na atmosfera da obra, no clima proposto pela história de encantamento. Sempre com tonalidades variantes entre o azul e o verde, remete ao mar, ao céu, à natureza e, portanto, ao universo da protagonista - a sereia, metade humana, metade peixe. Esta personagem vive o conflito de sua natureza (origem) ser sua "prisão". Ela é determinada pelo espaço em que vive, suas qualidades e sua cauda de peixe revelam essa essência. Para humanizar-se, contudo, ela deve abandonar a sua origem, o seu lar, a sua família, os seus costumes naturais ${ }^{69}$.

A oposição liberdade versus opressão marca a história, assim como natureza versus cultura, oposição absolutamente relacionada à nãohumano versus humano.

Tem-se, pois, o seguinte percurso do sujeito: natureza $\rightarrow$ nãonatureza $\rightarrow$ cultura. A sereia pertence ao natural; quando se transforma, está no não-natural, mas não consegue atingir a cultura, que estaria ligada a total humanidade.

A natureza corresponderia ao estado opressivo, pois ali ela não concretiza o seu amor, enquanto a cultura, à liberdade, na medida em que

69 Está, pois, a protagonista, como Rapunzel, aprisionada. 1 alcançar o amor. 
é condição para o amor e, como revelado, para a imortalidade da alma. Eis o percurso temático apresentado pela obra.

Além de remeterem ao mar e ao problema da personagem, as cores dos quadrinhos atuam sobre o leitor por suas vias sensíveis, reforçando o clima de encantamento e mistérios das profundezas do mar. A paleta de cores pincela simbolicamente o mar, mas tem em si a qualidade de pertencer predominantemente ao grupo das cores frias, com exceção do vermelho (alaranjado - vermelho com amarelo):

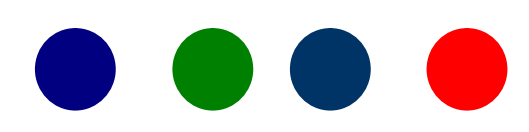

Figura 2.49 - Paleta de cores de A sereizinha

Além disso, a anáfora marca e o indício conduz a narrativa. Ambas as funções atribuem ritmo à essa pela visualidade, envolvendo ou reforçando o envolvimento do leitor com a obra.

Quando se tem diante da análise um texto de natureza poética, as categorias profundas destacadas devem encontrar correspondência nos traços da expressão.

Os objetos que assediam os nossos sonhos são, de igual modo, significativos. A nossa relação com as coisas não é uma relação distante, cada uma delas fala ao nosso corpo e à nossa vida, são revestidas de caracteres humanos (dóceis, doces, hostis, resistentes) e, inversamente, vivem em nós como outros tantos emblemas das condutas que apreciamos ou detestamos. O homem está investido nas coisas e as coisas estão nele investidas. [...] É o que pretendia dizer Cézanne, ao falar de um certo 'halo' das coisas, que importa restituir pela pintura (MERLEAU-PONTY, 2002, p. 36). 
O "halo" destacado por Ponty no discurso de Cézanne assemelhase a definição de atmosfera apresentada pela autora portuguesa.

Da narrativa, volta-se à expressão, para que seja possível homologá-los. Vale destacar que Bacelar utiliza, neste trabalho, técnicas mistas, mas existe a predominância do óleo sobre tela sempre com cores entre o azul e o verde e ainda o branco e o preto, criando cinzas e marrons. Há também alguns pontos, todavia, mais raros, vermelhos. Todas as imagens estão sobre fundo escuro, com exceção do casamento do príncipe. As imagens ocupam a página dupla na maior parte dos $\operatorname{casos}^{70}$.

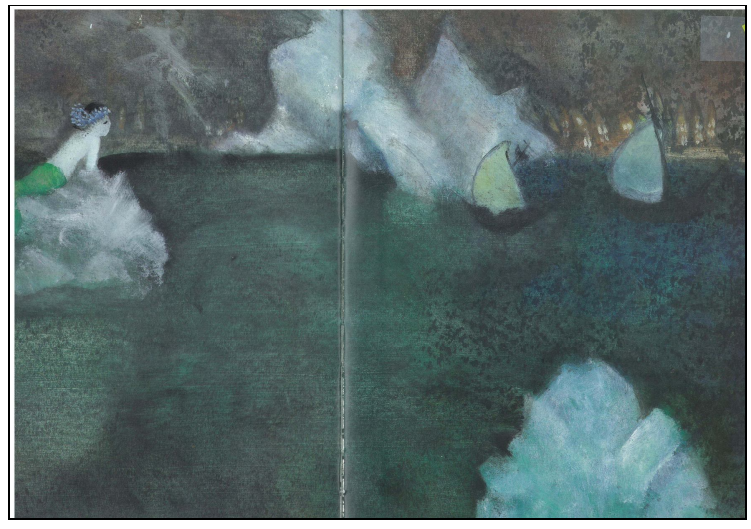

Figura 2.50 - Página dupla

Apenas duas cenas são representadas em página simples; como formulado por García em "Como leer el álbum ilustrado", a definição entre a página simples e a dupla depende do efeito de sentido desejado, neste caso: o contar das irmãs sobre o mundo na superfície e o casamento do príncipe com outra mulher revelam momentos em que a protagonista não está presente na cena: 

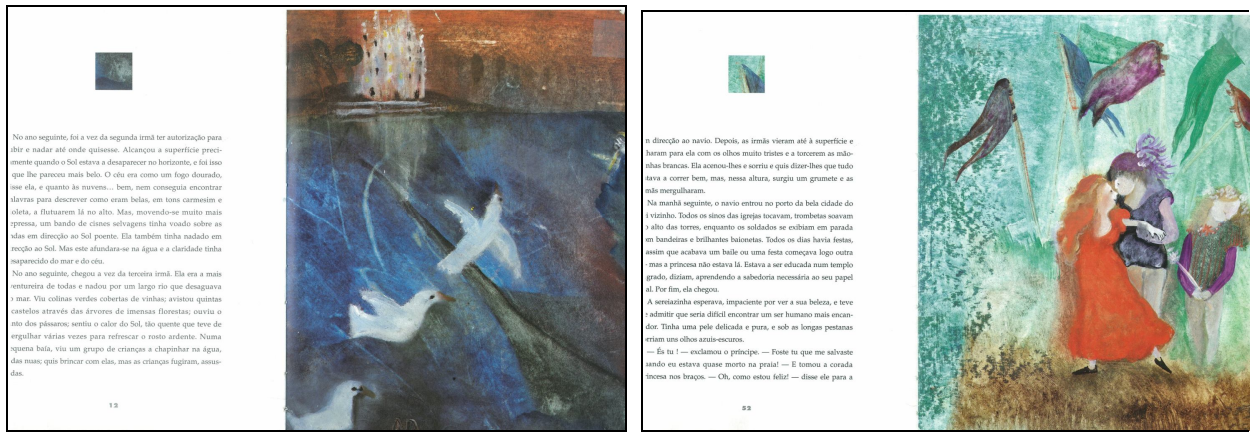

Figura 2.51 - Páginas simples

Assim, o texto visual, em A sereiazinha, tem, na maneira de apresentar-se, as seguintes categorias: contenção versus expansão. Com relação à ocupação da página pelo verbal e visual, pesquisas sobre o designer do livro infantil ${ }^{71}$ apontam que essa ocupação espacial na página da ilustração em relação ao texto pode se dar de três maneiras principais: a ilustração é aplicada numa área separada do texto - modelo tradicional; a ilustração é aplicada parcialmente em união ao texto - modelo intermediário; o texto é aplicado de modo a intermediar ou se relacionar com a forma da ilustração - modelo contemporâneo.

Os primeiros livros infantis obedeciam a uma configuração em que a ilustração era aplicada numa área separada do texto. Durante algum tempo, por questões técnicas, o livro impresso teve o espaço para as ilustrações separado do texto. Esses livros não continham tantos eventos ilustrados, e a área ocupada pelo texto era maior do que a das ilustrações. A partir de processos industriais de impressão, como a litografia no século XIX, essa rigidez pôde ser quebrada: 


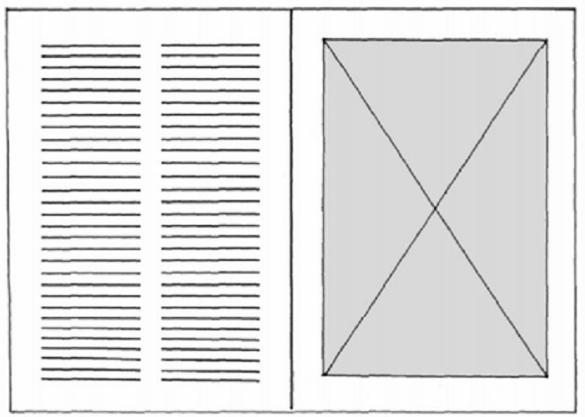

Figura 2.52 - Modelo de livro tradicional

$\mathrm{Na}$ atualidade, ainda subsiste esse tipo de aplicação, no entanto, essa separação pode se dar também por áreas isoladas da imagem, em aplicação lateral ou inferior à ilustração, como:

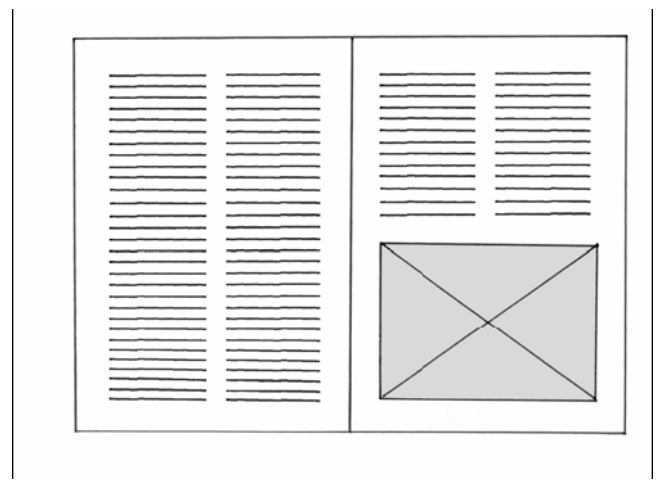

Figura 2.53 - Modelo de livro

Quando a ilustração é aplicada parcialmente em união com o texto, configura-se determinado estado, o qual continua a ocupar uma área delimitada num retângulo, mas dentro da mancha de texto, ou seja, parcialmente unida. A conformação do retângulo ocupado pela ilustração pode variar entre retângulos compridos, retângulos largos e retângulos "quebrados" como um " $L$ ".

A terceira forma de relação espacial ocorre quando o texto é aplicado de modo a intermediar ou se relacionar com : 
A relação espacial entre texto e ilustração, estabelecida nesse tipo de aplicação, constitui um elo visual entre o elemento verbal e o textual texto e imagem apresentam-se visualmente unidos. Essa forma evidencia a dimensão gráfica do texto. Alguns modelos são exemplificados abaixo:
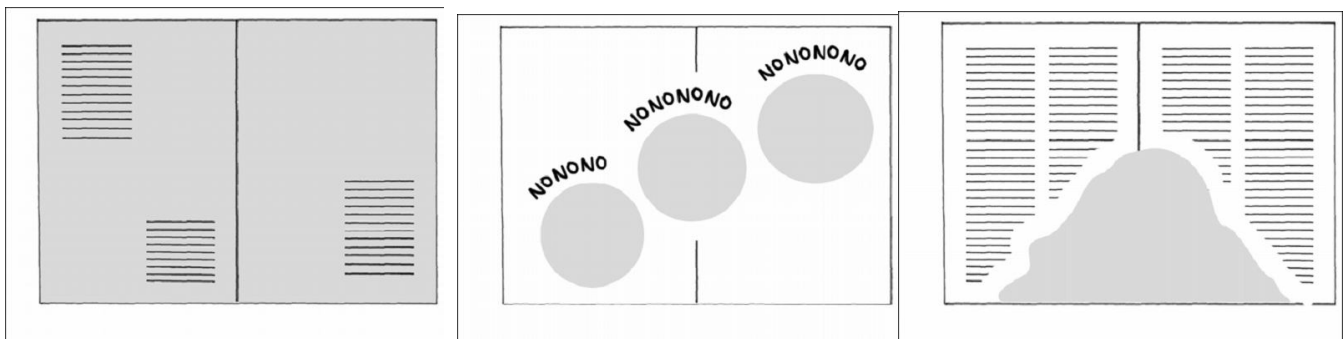

Figura 2.54 - Modelos de livros contemporâneos

Vale lembrar que esses modelos não dão conta de todas as modalidades de diagramação do mercado, pois a cada nova publicação o eles são alterados. Ângela Lago e Ziraldo podem ser citados como exemplos de subversão, pois inserem imagem e palavra na dobra do livro para aproveitar o seu movimento ( $O$ personagem encalhado e A bela borboleta, respectivamente) ${ }^{72}$.

A editoração de A sereiazinha, no entanto, obedece ao modelo tradicional de inserção da ilustração na página, gerando o efeito de sentido, mais uma vez, da publicação tradicional.

Existe, porém, uma relação que merece ser abordada: nos quadrinhos delimitados, haveria a contenção da imagem; na página dupla, expansão dessa e, na meia página, sua não-contenção. A naturezaopressão, no plano do conteúdo, seria homologada à contenção; a nãonatureza-não-opressão à não-contenção. Finalmente, cultura-liberdade homologada à expansão.

Para alguns, seria lícito pensar que, como no percurso não se atinge a cultura-liberdade, então, a categoria expansão também não se

${ }^{72}$ Estas obras serão apresentadas no capítulo final deste estudo 
concretizaria ou não deveria se concretizar. Porém, o que se observa nas páginas expandidas, é a busca da princesa-sereia por sua liberdade, senão revela a liberdade total, ao menos a Sereiazinha está lutando por ela. O esquema abaixo ilustra a questão:

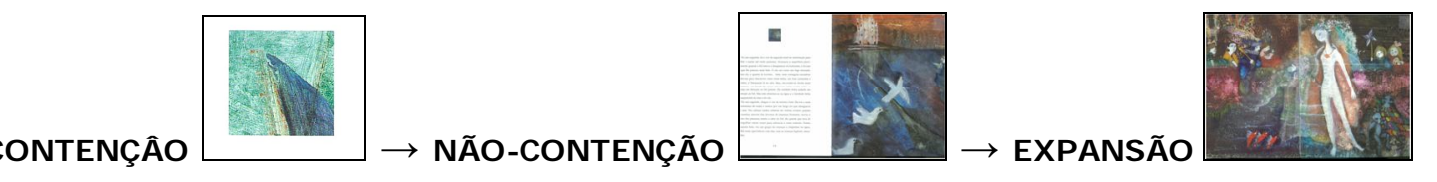

Figura 2.55 - Homologação do plano do conteúdo ao plano da expressão

Além dessa relação expressão-conteúdo, surge mais uma, os diferentes graus de iconicidade sugerem abstração homologada à opressão-natureza (o quadrinho abstrato) e figuratividade homologada à liberdade-cultura. Ponderando-se que não haverá a figurativização total próxima ao icônico, pois não se atinge a cultura, visto que o percurso é frustrado. Os únicos quadros abstratos são aqueles contidos nos quadrinhos e, por isso, a relação com a opressão, como anteriormente analisado.

ABSTRAÇÃo (opressão-natureza)

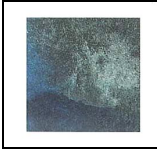

FI GURATIVI ZAÇÃO ( liberdade-cultura)

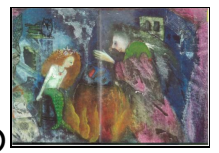

Figura 2.56 - Percurso expressivo 
Voltando à questão dos quadrinhos abstratos, eles, de alguma maneira, suprem a "timidez" da imagem em relação à palavra, cumprindo, no projeto gráfico, outra função. Percebe-se um enorme "respeito" pela palavra, e a imagem nunca interfere na constituição do texto, não altera o espaço designado para a palavra, que é sempre fixo. Utiliza-se o adjetivo "timidez" para a imagem, pois esta é inserida na obra com a enorme preocupação de preservar a palavra e o estatuto clássico desse texto. Há a idéia de que, se a imagem ocupar o lugar da palavra, alterará o texto original. Sabe-se, todavia, que de qualquer maneira a imagem dará um novo sentido à obra, como demonstrado, mas se nota o "respeito" ao texto clássico, corroborando a idéia de sobriedade imprimida pela capa.

Esta opção editorial não passa despercebida ao leitor atento , ainda mais, se tal estratégia implica desarmonia na relação palavra-imagem, rompendo o fluxo de leitura. Para constatar a afirmação, passa-se à análise do ato enunciativo, ou seja, a comunicação autor-leitor pelo e no livro. Pensa-se, por conseqüência, no exercício do editor, ou seja, aquele que arranja os elementos gráficos no objeto-livro.

\section{O projeto editorial como agente da relação palavra-imagem}

Como referido anteriormente, a função do editor na relação palavra-imagem, quando o texto, seja um clássico ou não, faz parte do repertório de uma comunidade, é fundamental e bastante delicada.

A obra espontânea perde por ser modificada segundo os imperativos de um editor? Por vezes, sem dúvida, sobretudo no caso em que os arranjos pedidos afectam uma obra ininterrupta e que "conta uma história": romance, conto ou novela. Isso explica-se: um tal tipo de texto forma, com efeito, um bloco que possui a sua unidade interna, o seu equilíbrio, a sua harmonia própria. É então difícil que umas modificações não resultem, ora numa mutilação se se deve abreviar, ora numa 'diluição' se é preciso, pelo contrário, desenvolver (HELD, 1978, p. 138). 
Como revelado por Held, adaptar um texto com coerência interna à imagem é uma tarefa arriscada que exige muito cuidado, pois uma inadequação, como a ruptura da progressão narrativa, comprometeria demasiadamente o projeto gráfico como o todo de sentido.

É função do editor, assim, criar harmonia entre a palavra e a imagem atribuindo sentido ao objeto-livro que será desvendado pelo leitor. Essa competência tem responsabilidade redobrada se o texto apresentado já existe, é conhecido, inúmeras vezes recontado, ou seja, um clássico. No caso em análise, em que a história recebeu inúmeras releituras ou mesmo faz parte daquele grupo de histórias que habitam a tradição oral, é possível que uma mãe conte esta história para o seu filho adormecer. $O$ editor, neste caso, terá como dever, se esse for o desejo ${ }^{73}$ da editora, preservar intacto o clássico, assegurando uma boa leitura e também uma ilustração que não descaracterize a obra. Nesse momento, descarta-se a idéia de a imagem traduzir o texto verbal, pois:

Sentidas e pensadas mais como 'honestidade' ou mais como 're-interpretações', o certo é que as ilustrações redimensionam os textos: as imagens são, na narrativa, gestalts que a pontuam e a digerem; criam momentos de alternância e por vezes mesmo de desvio relativamente ao eixo linear do discurso. Nunca se trata, apenas, de traduzir: a imagem possui um conjunto de repertórios e de códigos e uma retórica particulares; o próprio contexto que a recebe pode ser entendido como próprio e diferenciado, na medida em que texto e imagem criam leitores diferentes [...] (CALADO, [s.d.], p. 116).

O editor não possui uma tarefa fácil. Alguns cuidados são necessários para colocar em diálogo a palavra e a imagem, pois, do contrário, não seria necessário recorrer a outro sistema semiótico. Feita a opção, há que se ater a ela e pensar sobre o diálogo entre os sistemas semióticos, ou melhor, na maneira mais adequada de estabelecer esse diálogo.

73 Pode, também, ser opção da editora (ou do autor) parodiar o te 
Esta afirmação é possível, porque muitas vezes não é dada chance ao leitor de contemplar a imagem neste projeto gráfico. O diálogo, ou melhor, a ausência de diálogo entre palavra e imagem pode implicar uma leitura truncada, interrompida, gerando não o envolvimento pretendido, mas o oposto. A conseqüência pode ser o afastamento do leitor:

As imagens apercebidas num instante, mensagens visualmente inteligíveis, são, por exemplo, a maioria dos cartazes; estes são - em princípio - concebidos com esse fim: o conjunto da sua mensagem pertinente deve ser "digerido" pelos olhos e pelo cérebro no tempo global que a situação do espectador que passa diante pode consagrar-Ihe (4 a 10 segundos, em geral); pelo contrário, os 'textos' longos, os quadros de certos pintores (Brueghel, Bosch, etc.) são destinados a serem explorados (CALADO apud MOLES, 1981).

No caso de A sereiazinha, das Edições Afrontamento, o texto é interrompido e compromete a fluidez da leitura. A editoração não proporciona diálogo entre palavra e imagem, antes, se for observado, o projeto gráfico implica ruptura na seqüência narrativa. Quando o texto é abruptamente interrompido para a inserção da imagem, corta-se o fio da narrativa, a linha de raciocínio, uma vez que as imagens ali inseridas exigem um olhar para a fruição, pois são quadros a serem contemplados com mais vagar, com deleite. A conversa entre palavra e imagem, nesta obra, está truncada.

Essas rupturas acontecem de distintas maneiras, com maior ou menor intensidade. Os exemplos seguem, gradativamente, da menor à maior forma de ruptura:

a) No meio de uma idéia - texto: “Mas a sereiazinha não precisou de fazer isso, porque os pólipos se afastaram assustados quando viram a poção a brilhar-lhe na mão como uma estrela. De maneira que atravessou [a Sereiazinha] sem demoras o pântano e depois a floresta e os remoinhos". Inserção da imagem: a bruxa preparando a poção. Esta ação já havia sido narrada no texto verbal, não sendo mais necessário ilu 
- que estava no texto verbal era a transformação da Sereiazinha. Há, pois, um atraso entre a narração verbal e a imagem da narração. Propõe-se designar essa relação como descompasso de sentido na relação palavra-imagem;

b) No meio da sentença - texto: "Pedia à velha avó que lhe...". Inserção da imagem: as sereiazinhas brincando. Texto: “... contasse tudo sobre navios e cidades, pessoas e animais". Para o leitor dar seqüência à idéia, deve ler o texto e depois voltar à imagem para contemplá-la. A sentença (idéia) é interrompida pela diagramação para inserir a imagem, truncando o pensamento. A proposta é nomear essa ocorrência como interrupção de sentido na relação palavra-imagem;

c) No meio da palavra - texto: "Nem conseguiam apreciar nunca o paraíso do fundo do mar, porque quando o navio se afundava eles [humanos] morriam afoga-..." Inserção da imagem: uma das sereias em uma pedra observando um navio. Texto: “... dos. Só homens afogados é que chegavam por vezes ao reino das profundezas do mar." Dividir uma palavra para inserir a imagem é quebrar totalmente a harmonia da leitura, por isso, sugere-se: ruptura de sentido na relação palavra-imagem.

As relações palavra-imagem explicitadas relevam um problema na editoração. Não houve diálogo harmônico entre autor, ilustrador e editor, por conseqüência, falhou a relação cooperativa entre palavra, imagem e projeto gráfico.

O que se verifica, portanto, em A sereiazinha é uma perda das qualidades da releitura do clássico, pois o projeto gráfico, a partir da inserção das imagens, comprometeu a progressão narrativa. A imagem, neste caso, passa a atrapalhar a leitura, e não contribuir para a polissemia dos sentidos da obra. O papel do editor (ou designer) é fundamental na execução da proposta gráfica, visto que a inserção inadequada das imagens pode desautorizar o diálogo. 
É importante ressaltar que as imagens produzidas por Bacelar foram premiadas, e isso revela a sua qualidade plástica. O que poderia ser repensado é o projeto gráfico, uma vez que dois momentos merecem cuidado maior: a função capa-sobrecapa e a inserção da imagem ao longo da narrativa.

\section{Tecendo valores: a imagem}

As imagens propostas por Manuela Bacelar, em A sereiazinha, são pinturas. A palavra "pinturas" é recuperada para expressar e ressaltar as qualidades plásticas ali empregadas. Com maestria, a artista proporciona ao leitor uma visita à galeria de arte. A cada virada de página, o leitorapreciador deve parar para contemplar a riqueza de detalhes e a pujança de cores e estilo. Ao leitor, é dada a oportunidade de experimentar os sentidos. Chamados à percepção, os formantes plásticos (a cor, a forma, a disposição dos elementos na tela e o material) são tramados e arranjados para compor a atmosfera do conto de fadas. Não só a narrativa lingüística cria o cenário da fantasia, mas também a percepção visual conduzirá ao universo dos contos, ampliando as possibilidades estéticas e estésicas da obra.

A sereiazinha é um objeto estético e como tal promove uma inversão de papéis no jogo enunciativo. Neste processo, o objeto se torna sujeito e atua sobre os órgãos sensoriais do, antes sujeito, agora, transformado em objeto. É no momento de fratura da regularidade narrativa que há a suspensão temporal, e sujeito e objeto se fundem em nome do prazer estético. Este prazer estético proporcionado pela leitura é o elemento de sedução. A entrada da criança no universo literário se dá também por essa via, por vezes, pouco explorada nas instâncias educacionais. Ana Claudia de Oliveira se ateve a esta questão no artigo "Visualidade, entre significação sensível e inteligível": 
A semiótica trabalha com as axiologias, e toda a sua descrição dos procedimentos de estruturação visa à determinação dos sistemas de valores que circulam nos objetos. A relevância da semiótica no ensino justifica-se assim inteiramente, uma vez que ela capacita o sujeito para a construção da significação, ao mesmo tempo em que, ao fazê-lo, faz descortinar-lhe as possibilidades para assumir posicionamentos críticos e de reflexão. Entre o que vê e aquilo que é visto engendram-se os mecanismos contratuais a ser ou não partilhados entre os parceiros da interação, mas que, em todo caso, são recursos de argumentação que apontam ao destinatário uma trajetória para que, assim se direcionando, torne-se sujeito competente para realizar o desbravamento textual (OLIVEIRA, 2005, p. 117).

Assim, caminha-se pelas habituais linhas negras e, em alguns momentos, se é tomado pelos sentidos. Pelos recantos da galeria-livro, a análise opta por destacar traços comuns às imagens da obra e também por evidenciar o que há de variante, singular, especial neste trabalho de Bacelar. Algumas idéias anteriormente apresentadas serão retomadas, com o compromisso de ampliar tais análises e interpretações. É objetivo mostrar as qualidades estéticas do fazer da artista portuguesa, com o propósito de auxiliar o formador a entrar na obra e explorar os caminhos do sentido.

\section{Das invariantes}

Uma constante na proposta da artista plástica é a presença da data e assinatura em todos os quadros, no caso, MB - 93. Enfatiza-se o traço da assinatura e datação na obra dos portugueses, pois isso thes confere um status, uma maneira de fazer-se visível ("quere-ser-visto") pela comunidade, em que a obra circulará. O artista se afirma nesse processo como o autor presente, visível da obra a ser lida ${ }^{74}$.

74 É possível que esse procedimento revele a constatação da desvalorização do artista português e isso implique contratos editorias desfavoráveis à classe. Contudo, para a análise aqui apresentada, interessa perceber a assinatura rnmn 1 ım elementn de constituição do sentido, um modo de presença do autor voltará à discussão ao longo do trabalho que ora se apresenti 
No Brasil, pelo menos nos autores contemporâneos, não existe essa prática. Se o percurso diacrônico for convocado, é possível verificar a assinatura como uma prática comum no início do século $X X$, que, gradativamente, será apagada ${ }^{75}$. Pode parecer detalhe insignificante, mas o procedimento revela a maneira como o artista se relaciona com o seu fazer e ainda como a comunidade o vê. Para ele, ilustrar não é distante de produzir uma série de telas para uma exposição. Durante muito tempo, e talvez ainda, associou-se a ilustração à produção de telas. Isso acontece tanto com Bacelar quanto com outros autores portugueses.

No caso da obra em questão, Bacelar deve dividir, se assim for encarado, o espaço com Andersen. A sua afirmação como "co-autora", portanto, ou mesmo como uma segunda voz discursiva, não tem equivalência dentro dos padrões canonizados. Se o contexto português, por outro lado, vier à tona, Bacelar será um nome bastante respeitado. Há, assim, a afirmação, por meio da assinatura para marcar a segunda voz, para instituir o diálogo de fato, pois o nome de Andersen, ou a sua obra clássica, poderia, de certa maneira, apagar o fazer de Bacelar. Essa é uma hipótese, a outra seria o nome/assinatura de Bacelar ser utilizado como um motivo (argumento) para a aquisição de um texto já conhecido, ou seja, as qualidades atribuídas de antemão à artista faria que o leitor se aproximasse do livro. Em artigo da Revista Solta Palavra, Bacelar conta que tem predileção por ilustrar clássicos e, ainda, que Trnka, ilustrador tcheco, foi seu mestre e exerceu forte influência sobre seu trabalho: a ele também agradava dar imagens aos clássicos. Sobre esta e outras influências, a artista esclarece:

As minhas influências? Acho mais fácil para quem está de fora vê-las. No entanto nunca lutei contra elas. Também nunca copiei. Tenho contacto com a arte desde muito pequena. Por outro lado sou como uma esponja: se gosto muito da imagem ela fica "arquivada numa qualquer gaveta das que tenho na cabeça" que se pode abrir de um momento para outro. No entanto, ao selecionarmos essas imagens que

${ }_{75} \mathrm{Na}$ conclusão deste trabalho de tese, esta questão será aprofı 
vamos pôr na tal "gaveta" estamos a fazer o "caldo" de onde nasce o nosso "estilo".

Na ilustração, ao contrário do que me acontece na pintura, é um pouco como no teatro: interpreto uma idéia, um estilo literário, uma atmosfera, o texto e o subtexto.

Por vezes e com o prazo de entrega a apertar, rasgo tudo o que fiz e começo do zero. Outras vezes rodeio-me de livros de arte e de extracção e passo um dia assim, sem pegar num pincel.

Tiveram influência em mim o Trnka, Miloslav Jagr e a pintura, principalmente a pintura renascentista e flamenga. Por vezes nem se vê, mas a pintura que me dá coragem para cada dia, para cada ilustração (BACELAR, [s.d], p. 4).

Deslindar as influências sobre o trabalho de Bacelar é um caminho para (re) conhecer a sua proposta artística. Na ordem contrária ao seu texto, parte-se da influência de Trnka, seu professor, para depois (re) conhecer outras hipóteses de influências. Assim, a sistemática da análise parte do extratexto, artigo da autora sobre seu fazer e depois, aguça o olhar sobre a própria obra e dela extrai possíveis intertextos e interdiscursos.

O artista tcheco referido por Bacelar também ilustrou clássicos da literatura infantil, como já destacado. Ilustrar as obras de autores como La Fontaine, Grimm e mesmo Andersen fez parte de sua trajetória artística, que inclui também a imagem em movimento - o cinema animado:

Sus ilustraciones para Bajaja, de Vladimír Holan, libro de 1955, están consideradas uno de sus trabajos más perfectos en el terreno de la recreación del folclor checo. Ese mismo año da a conocer su interpretación de los cuentos de Hans Christian Andersen (Disponível em: <http:// www. cuatrogatos.org/ dossiertrnkapoetadelaimagen. html>. Acesso em: 17 jun. 2006).

Assim como influenciou Bacelar, Trnka, como ilustrador, tem forte presença nessa arte da imagem para livros, e seu trabalho é bastante representativo e valorizado pela crítica: 
Sus ilustraciones, en las que plasmó una concepción estética y una figuración muy personales, han influido fuertemente en muchos artistas posteriores. En 1968, la International Board on Books for Young People (IBBY) le concedió a Trnka la medalla Hans Christian Andersen de ilustración por el conjunto de su obra. (Disponível em: <http://www. cuatrogatos.org/dossiertrnkapoetadelaimagen. html>. Acesso em: 17 jun. 2006).

Além do interesse comum pelos clássicos, o estilo da imagem de Bacelar dialoga com o estilo de Trnka, compondo o que se designa como interdiscurso. Uma invariante na obra da artista portuguesa é o diálogo com as obras de outros artistas ou com o próprio mestre. Demonstra-se :
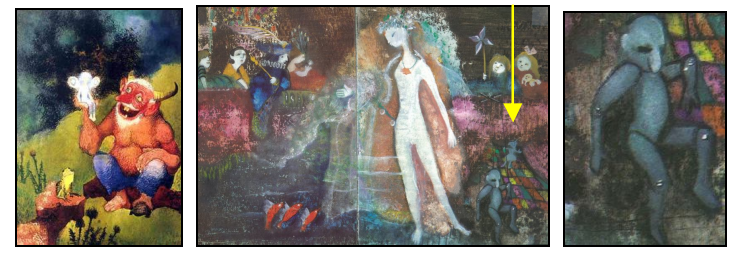

Figura 2.57 - I nfluência de Trnka em Bacelar

As cores e a técnica de luz-sombra podem ser destacadas como uma recorrência de Trnka em Bacelar. Ambos reforçam idéias ou sentimentos pelo contraste cromático. A fada, em Trnka, e a Sereiazinha, em Bacelar, são destacadas pela luz em oposição à sombra que ocupa toda a tela. A inserção da fantasia na figurativização das personagens também pode ser observada em ambos, Reforçada, ainda, pela aproximação "estereotipada" das feições das personagens, às vezes animais, às vezes bonecos. Essa estratégia aproxima o público da obra. Como sempre, também, em todas as produções, está claro que a ficção é ingrediente da alma infantil, e a cultura alimenta essa característica, atribuindo vida ou traços humanos aos animais ou bonecos. Chama a atenção, na cena da sereia dançando, também a presença da marionete, que pode ser uma alusão ao seu professor, mestre 
bonecos, inserindo o intertexto, nesse caso a citação de outrem, como postula Bakhtin ${ }^{76}$.

Da influência declarada às impregnadas ao texto, percebe-se como uma constante o diálogo. A arte de Bacelar se encontra com as produções dos grandes nomes das artes plásticas. Talvez a "conversa" mais insistente se estabeleça com as obras surrealistas, em especial a de Marc Chagall $^{77}$, por isso, caracteriza-se o estilo de Chagall como uma invariante em sua produção. A temporada da artista portuguesa na antiga Tchecoslováquia, agregada então à URSS, contribuiu para a aproximação.

Não é de menor relevo fazer nota à vanguarda russa antes e depois da Revolução de 1917. O cenário revolucionário trouxe ao palco inúmeros artistas, sejam poetas, músicos ou pintores, e, ainda, é dessa frutífera época a contribuição teórica dos formalistas russos, entre eles Propp, amplamente aplicado às análises deste estudo, por ele mesmo ou por seus seguidores, Barthes ou Greimas.

Chagall figurava entre esses artistas da vanguarda russa. Com o endurecimento do regime comunista, muitos foram obrigados a deixar seu país. A França, Paris em especial, soube receber os "exilados" e integrá-los ao universo artístico de então. As vanguardas européias cubismo, expressionismo, fauvismo - estavam presentes nas alamedas parisienses. Chagall participou desse intenso fluxo criativo. O surrealismo é o tom de seu discurso.

É a fase final deste artista, que já superava os 90 anos de vida, a fonte de inspiração da artista portuguesa. Ambos empregam técnicas mistas em seu fazer, pelo menos durante um período de sua produção. A diferença entre os materiais proporciona o destaque ou apagamento de formas, primeira aproximação possível: "As técnicas que uso começaram por ser os marcadores, depois e durante muito tempo usei técnica mista. Neste momento uso técnicas puras como o óleo e o guache ou têmpera" (BACELAR, [s.d], p. 3).

\footnotetext{
76 Este procedimento será bastante explorado pela análise das c

77 Essa relação já foi percebida na obra O dinossauro.
} 
Para exemplificar essas influências, apresentam-se, a seguir, três imagens (as duas primeiras de Chagall e a terceira de Bacelar) em que o traço, seja do lápis ou do carvão, é deixado à mostra.
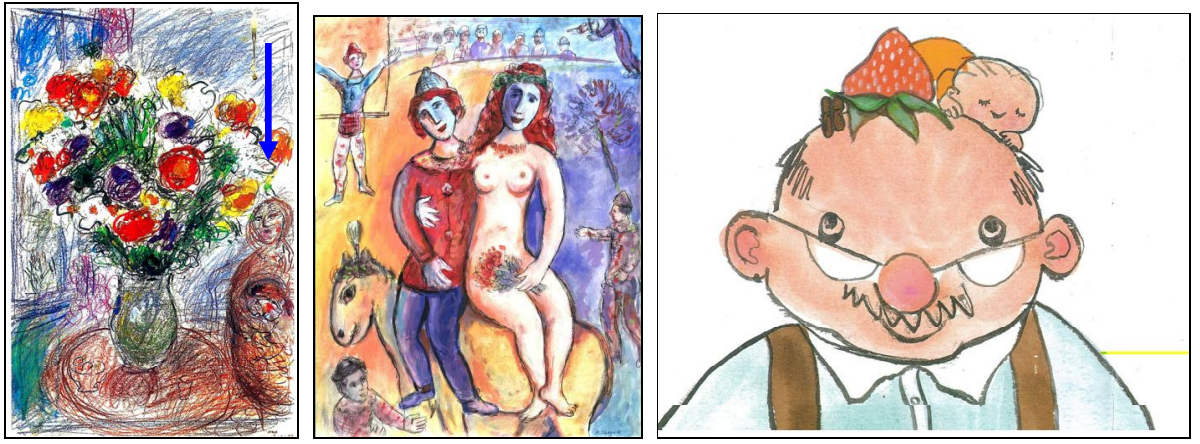

Figura 2.58 - Influência de Chagall em Bacelar

Também a recorrência ao universo onírico é uma temática partilhada por esses artistas. Em uma das apresentações da última fase de Chagall, o crítico explica:

Que no se trata de una situación real, sino de un sueño lo atestigua la presencia de algunos animales fantásticos, símbolo de su universo poético y presencia constante en sus creaciones. Ya no nos sorprendemos de que las gallinas o la vaca vuelen ligeras por el cielo [...] (CREPALDI, 2001, p. 71).

Nota-se na imagem última imagem, um morango e um bebê como chapéu na cabeça do avô, tais figuras rompem a coerência realista, instaurando a ficção.

Retomando-se os formantes cromático, eidético, topológico e matérico como critério para observação dos artistas, será possível perceber ainda outras aproximações entre eles: 


\section{1) Elementos estranhos:}

Destaca-se, de Chagall e Bacelar, a figura do peixe. No primeiro, o peixe voa agarrado às pernas de uma mesa; no segundo, entre as meninas-sereia, há uma cabeça de peixe, o corpo se dilui na água e se tem o elemento estranho.
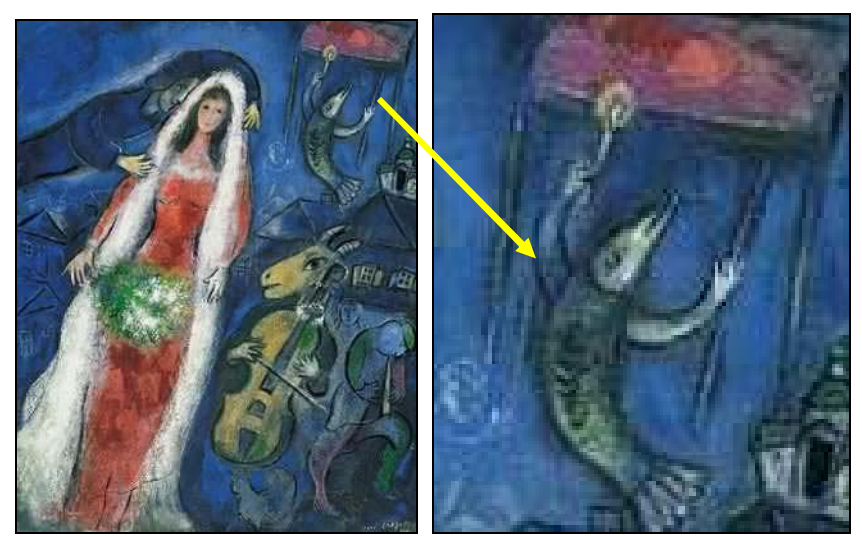

Figura 2.59 - Cenário surrealista - Chagall
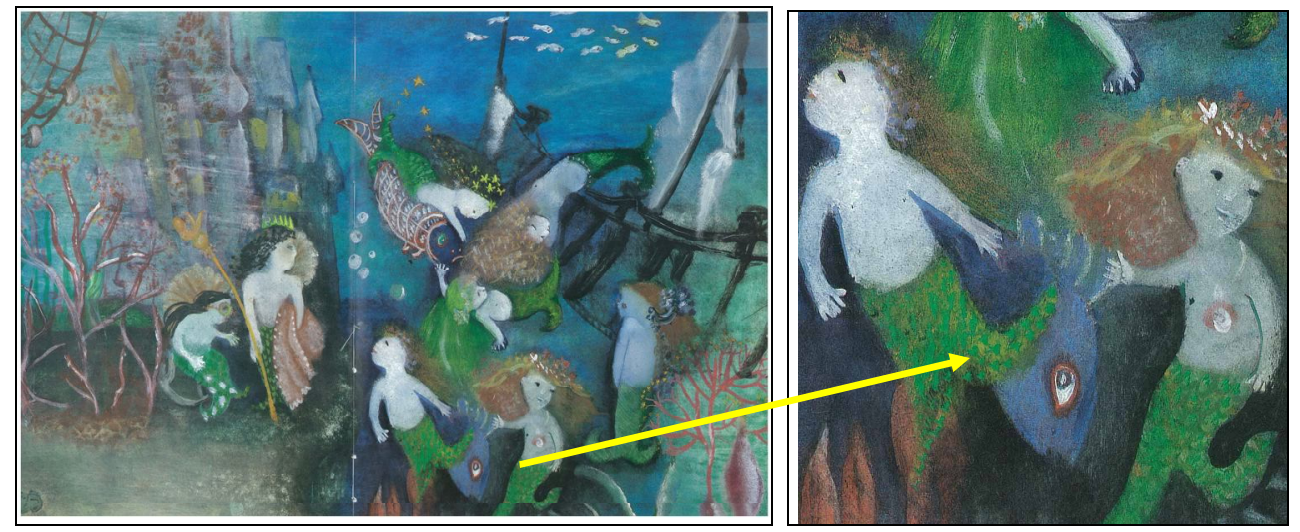

Figura 2.60 - Cenário Bacelar

\section{2) Figuras descontextualizadas:}

Em Chagall, como bem destacou o crítico citado anteriormente, a galinha voa sobre a cidade. Na ilustradora portuguesa, corpos humanos caem no esconderijo da bruxa. Como ressaltado, na análise de $\mathrm{O}$ dinossauro, a recorrência a Chagall parece ser uma constante em toda a obra de Bacelar. 


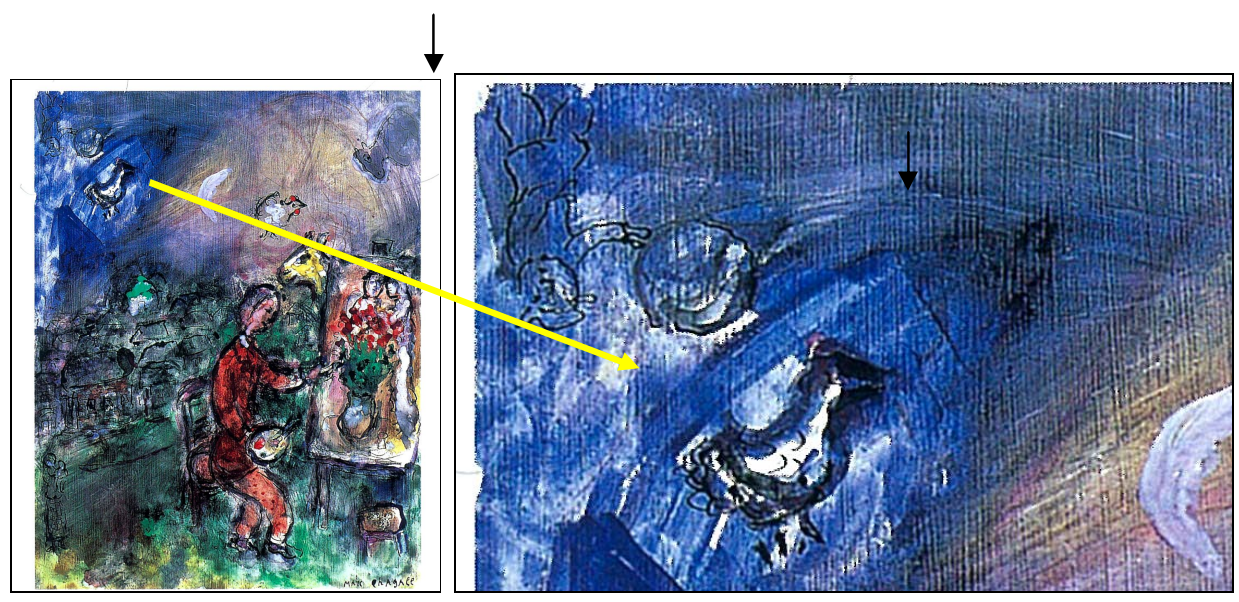

Figura 2.61 - Detalhe de uma galinha no céu
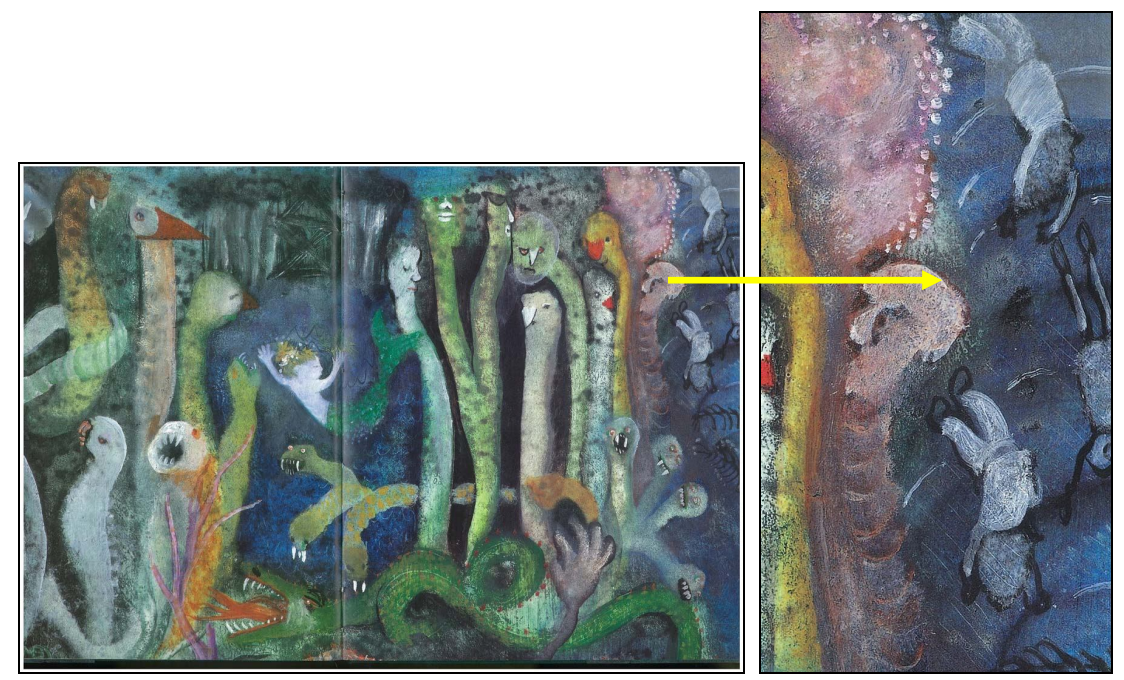

Figura 2.62 - Detalhe de crianças (humanos) caindo

Vale registrar que em A sereiazinha a técnica empregada é óleo, mas, constantemente, a artista lança mão do desenho sobre a pintura, traçando figuras vazias, como o caso apresentado, utilizando, portanto, a técnica mista, como afirmado pela própria artista. 


\section{Das variantes}

Opta-se por voltar e destacar algumas relações entre palavraimagem para revelar um fazer singular de Bacelar. Como apontado anteriormente, a técnica utilizada é mista - o óleo sobre tela e marcadores. Da tela, passa-se à impressão, este é procedimento comum entre os artistas portugueses e Ihes confere uma qualidade plástica bastante sofisticada. As imagens-pinturas criam uma atmosfera envolvente e oferecem ao leitor um mergulho profundo até o universo encantado das sereias, com cores do azul ao preto, o pincel delineia a onda, em que embarca o olhar do leitor. No ir e vir das páginas, o balanço do livro transporta o viajante pelo mar das letras e desenhos.

\section{Cena 1:}

Palavra: revela a brincadeira comum das seis irmãs sereias com restos de naufrágios.

I magem: a) há oito sereias, e não seis como narrado. Este procedimento se assemelha ao utilizado em $O$ dinossauro quando 0 professor fotografa em várias posições e sua imagem se multiplica, gerando o efeito de movimento;

b) a sereia posicionada na extrema esquerda traz no rosto uns óculos parecidos com os de mergulho, rompendo a atemporalidade proposta pelo conto de fadas. O objeto moderno pertence aos tempos atuais;

c) entre as duas sereias, no centro à direita, existe a metade de um peixe, recorrência surrealista da obra;

d) inserção de figuras traçadas, mas não preenchidas, como o caso da carcaça de um navio naufragado à direita, em preto, procedimento reincidente da antiga técnica mista. 

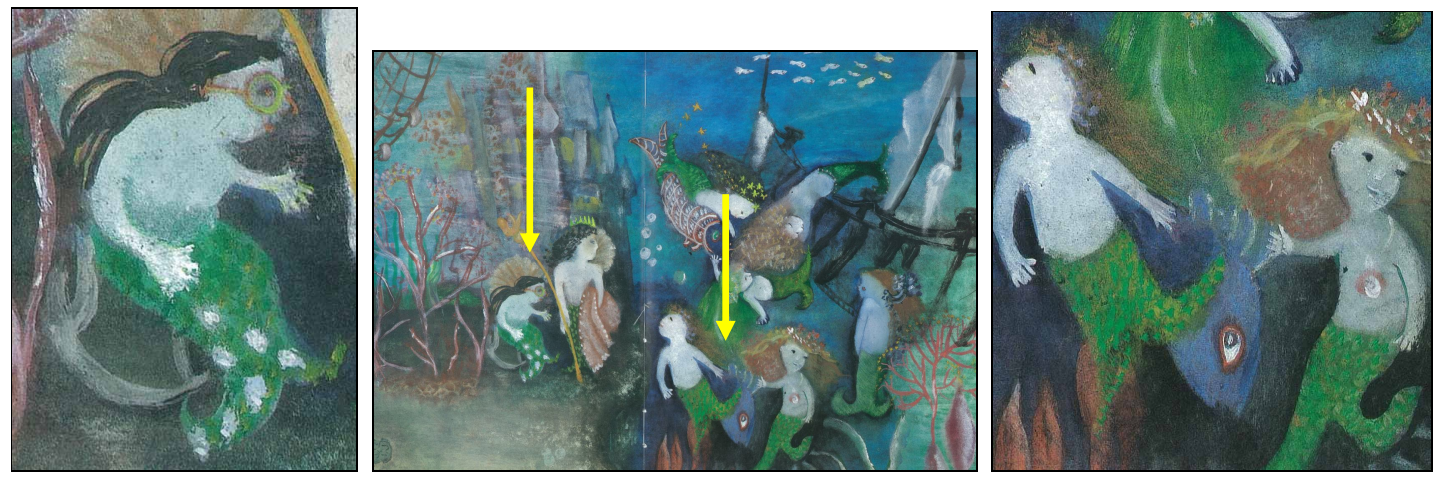

Figura 2.63 - Sereia com óculos de mergulho e uma figura de peixe

\section{Cena 2:}

Palavra: a transformação da sereia em humana.

I magem: a) não há utilização da perspectiva como recurso plástico, essa ausência cria a ambigüidade: mar-terra, mas em função da posição descendente - alto-baixo. Gera a idéia de que a figura humana submerge, e não emerge como deveria pela lógica narrativa. Esse recurso enriquece a interpretação da obra, na medida em que revela a ambigüidade própria ao discurso poético;

b) a correlação criada é céu-mar (azul, preto e branco) e terraareia (marrom, amarelo e branco), insistindo na ambigüidade proveniente da ausência de perspectiva, corrobora a idéia expressa no item anterior;

c) o elemento estranho é um pássaro negro do mesmo tamanho da figura humana que sobrevoa a Sereiazinha. Um indicativo de mau agouro em lendas populares;

d) a Sereiazinha já tem pernas, mas continua desprovida da sensualidade. Os seios e as genitais são apagados, fazendo o observador não saber se a personagem está de frente ou de costas para a cena. Isso demonstra como a autora entende o seu fazer. A ambigüidade novamente vem à tona: 
Eu não ilustro muito o que lá está. Eu gosto de ilustrar o que não está lá ou o que lá está, mas a minha maneira. Não é aquela ilustração: a menina pôs um vestido vermelho - a menina com vestido vermelho; a menina pôs o sapatinho, deixa eu ver se a menina é loira...É claro, às vezes, o autor põe tanto pormenor no texto, que uma pessoa não pode fugir a esta regra. Mas eu gosto mais de sugerir, gosto de deixar um espaço para imaginação ou para uma terceira imaginação que é a do leitor. Porque também lá está a minha imaginação e lá está a imaginação do autor (BACELAR, M. Entrevista concedida a Mariana Cortez. Porto, 18 abr. 2006).

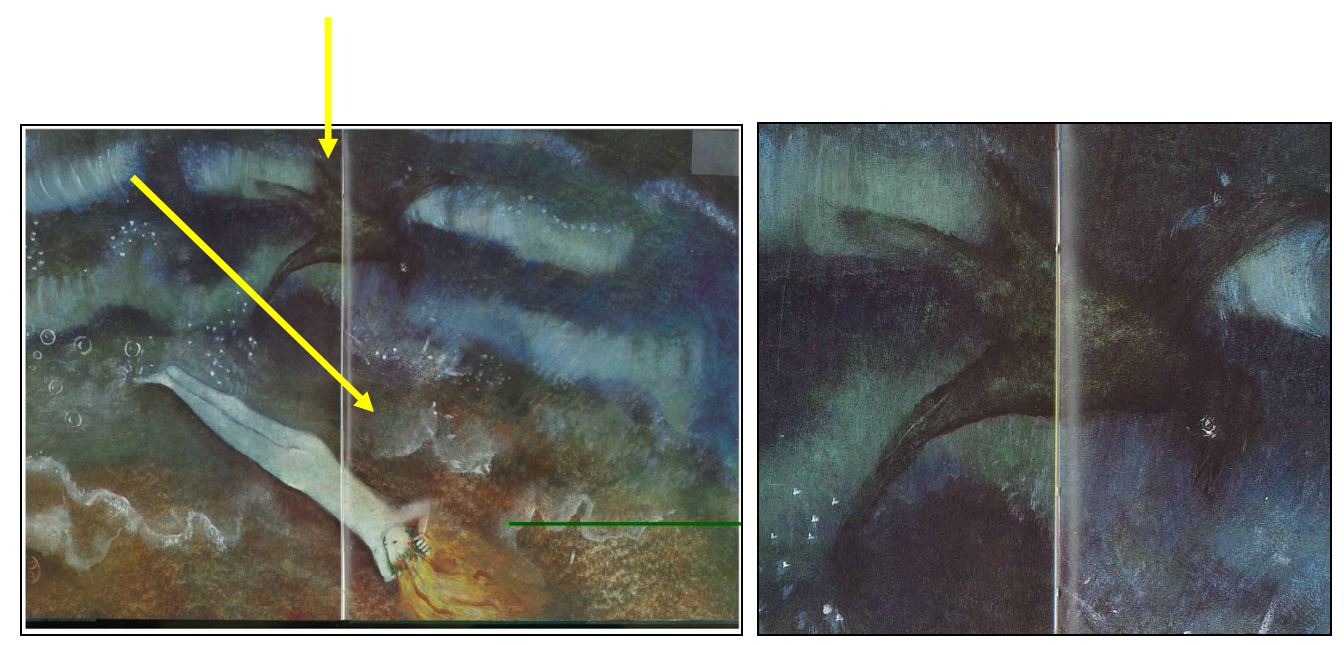

Figura 2.64 - Expressão do movimento/ Figura do pássaro negro

\section{Cena 3:}

Palavra: a entrada da sereia no universo da bruxa.

I magem: a) a figura central da sereia caindo recupera a idéia do fundo do poço, idéia reiterada na obra. A busca da sereia pelo príncipe é, por vezes, representada pelo movimento descendente, ou seja, conteúdo e expressão estão homologados;

b) os pólipos, antes de serem maus, são cômicos. Não há idéia de assustar. Palavra e imagem criam sensações diferentes. Óculos, língua para fora, rostos humanos são traços que dão suavidade à palavra, que descreve o ambiente de maneira assustadora. Esta característica de "suavizar" os pontos de terror já foi percebida na ani" 
na expressão facial dos personagens diante do terror do dinossauro, animal pré-histórico;

c) No canto direito, há figuras enigmáticas: esqueletos de peixe e humano, figuras vazia de humanos, como em Chagall, quando se tira partido da técnica mista.
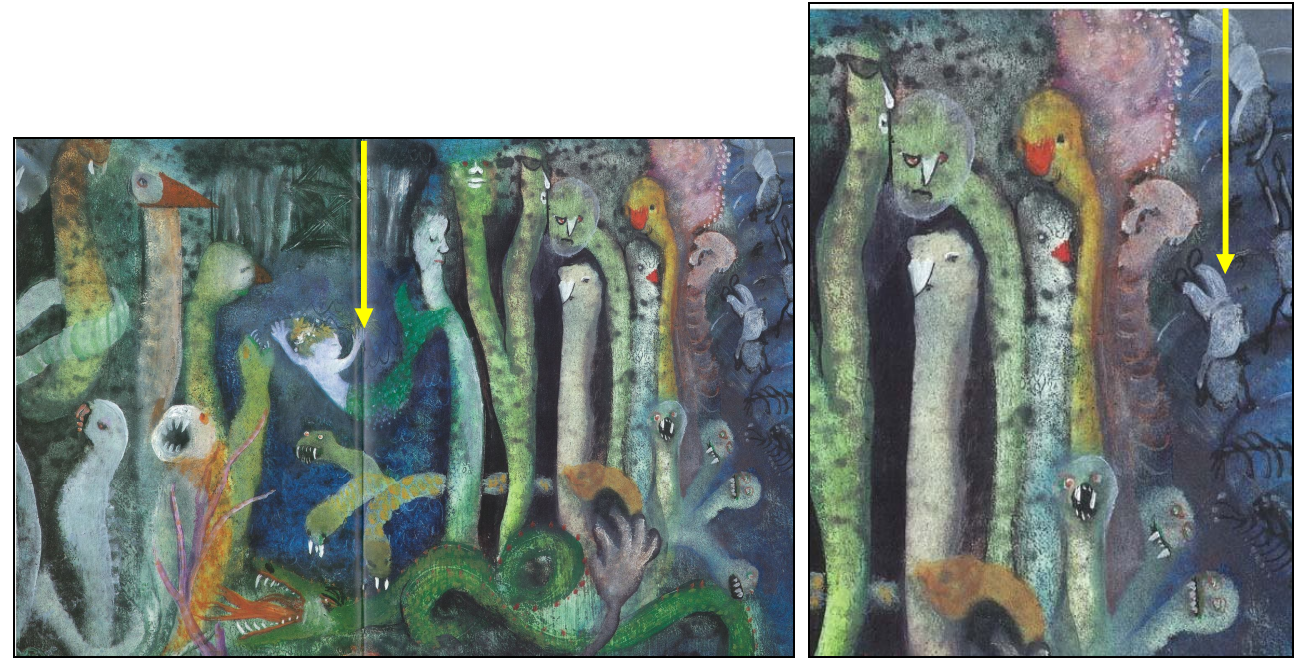

Figura 2.65 - Detalhe das figuras humanas caindo/ esqueleto de peixe

\section{Cena 4:}

Palavra: trato da bruxa com a sereia.

I magem: a) a sereia aparece pela primeira vez com atributos sensuais: cabelo, seios a mostra. Nota-se que, em outras leituras da personagem, seus "dotes" sensuais sempre foram ressaltados ${ }^{78}$;

b) a presença da luz nos rostos da sereia e da bruxa e a desproporcionalidade da mão da feiticeira demonstram a característica de dar destaque aos elementos importantes à narrativa, independentemente do compromisso com a realidade;

c) no canto esquerdo superior, há novamente a presença de figuras enigmáticas: coruja, rabo de sereia e um perfil desconhecido, sempre

\footnotetext{
78 Ver a Pequena Sereia, de Walt Disney, ou mesmo a escul
} conto, que figura entre as imagens deste estudo. 
promovendo diálogo com outras histórias, outros tempos ou outras narrativas, que podem ser criadas a partir de uma "dica". A coruja que está aí já apareceu na obra O dinossauro.
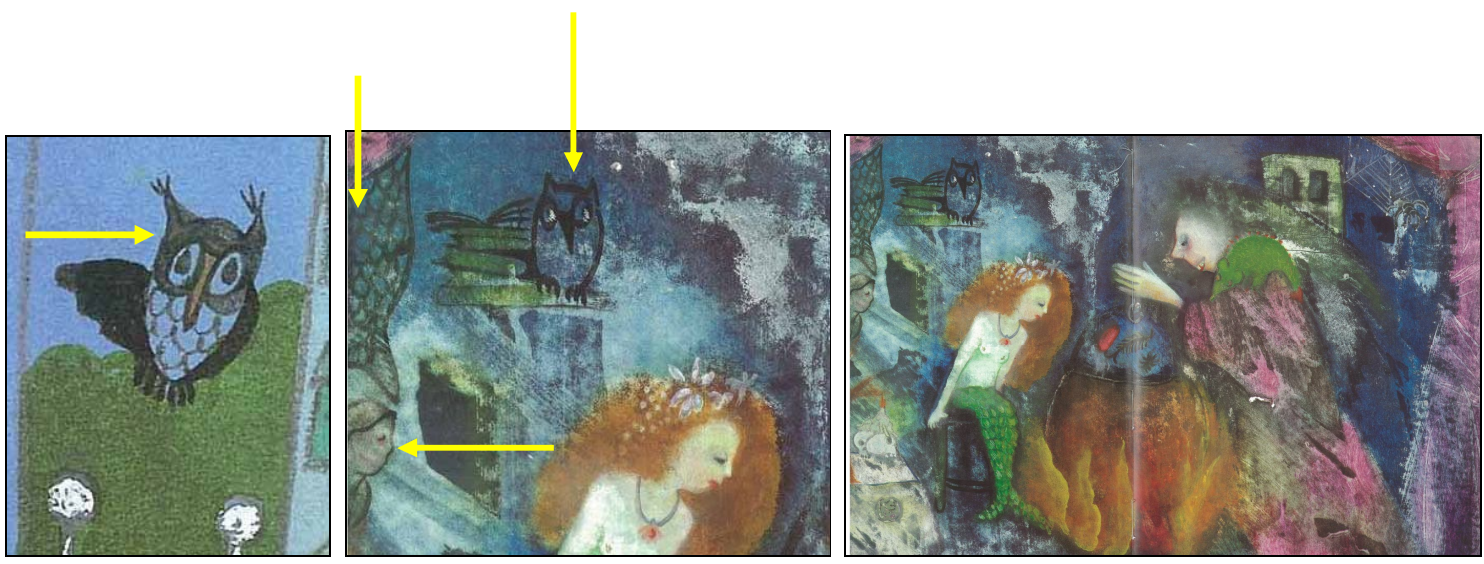

Figura 2.66 - Coruja de O dinossauro/ Coruja de A sereiazinha/ Carcaça de rabo de peixe e figura humana

\section{Cena 5:}

Palavra: a sereia vê o príncipe no navio pela primeira vez.

I magem: a) a luz incide sobre o príncipe, que é a personagem destacada; é a primeira aparição da personagem. Ressalta-se, mais uma vez, que a luz imprime expressividade à imagem da autora;

b) entre as duas personagens sentadas no chão, há uma terceira que parece um bebê, com um capuz, também enigmática, contribuindo para a atmosfera onírica;

c) a imagem da Sereiazinha é vista pela janela no navio, e suas mãos e rosto são de criança, jamais de uma jovem de quinze anos;

d) há, à frente à direita, uma caneca traçada, bem como a garrafa que o príncipe segura, o instrumento que a figura toca e o barril que tem o candelabro sobreposto. 

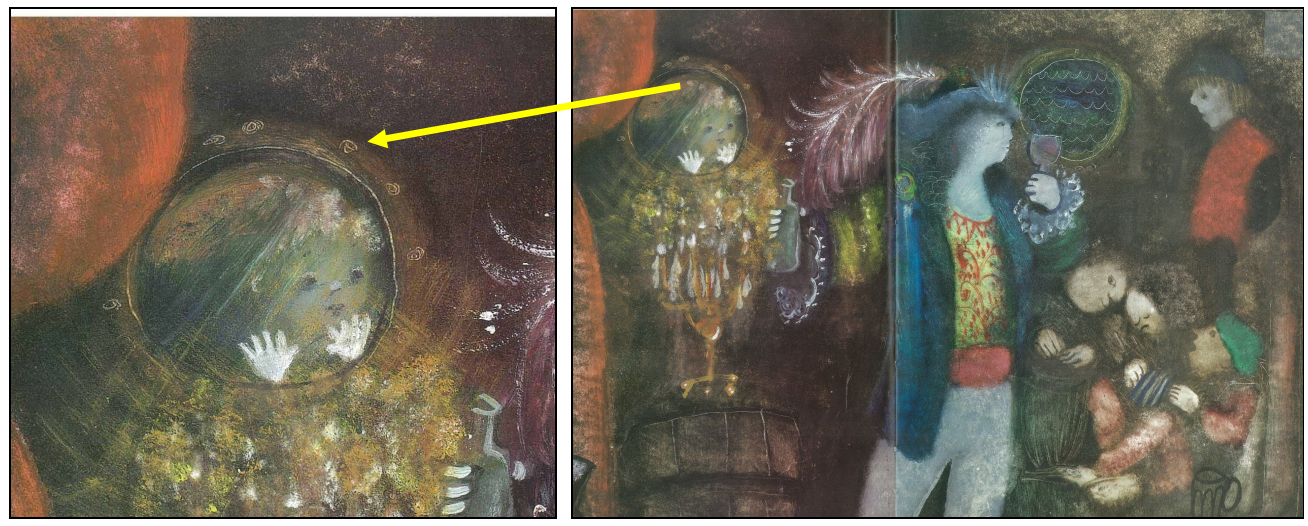

Figura 2.67 - A criança-sereia espia a príncipe

\section{Cena 6:}

Palavra: resgate do príncipe.

I magem: a) a idéia da sereia-menina despojada da sensualidade da jovem é negada na cena de resgate. Aí, tem-se o envolvimento sensual: o encaixe dos corpos, a proximidade entre os lábios, o contraste luz-sombra conduzem ao tema da sensualidade, o contato sensual homologado ao sentido ascendente;

b) o desenho ascendente contraria as outras imagens, afirmando a diferença desta imagem.

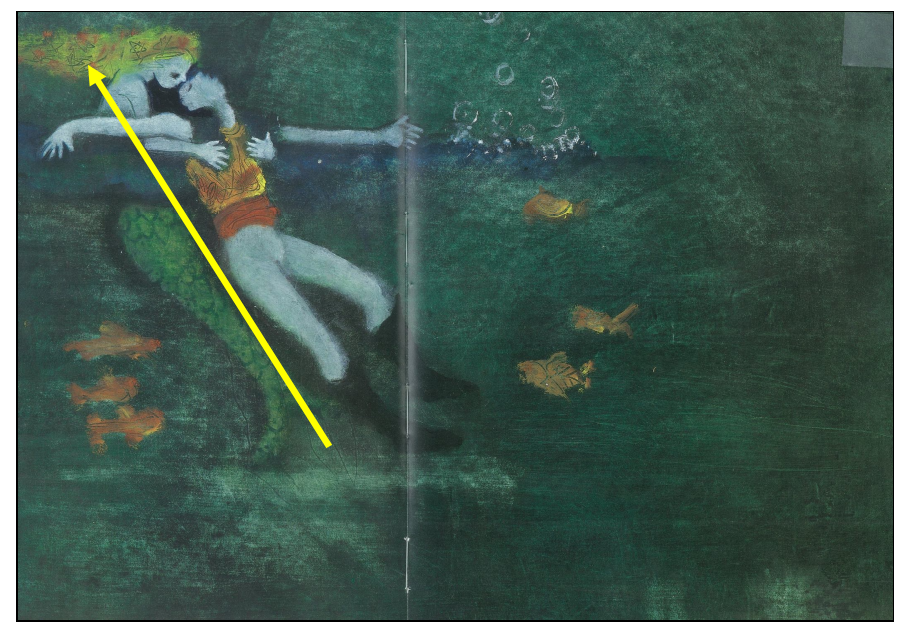

Figura 2.68 - Movimento ascendente 


\section{Cena 7:}

Vale destacar a utilização de imagens recorrentes ao longo da obra. As irmãs sereias são representadas por pássaros em duas ocasiões: a) quando há a narração sobre a aventura de descobrir a superfície, existe a metáfora, mas o leitor não a reconhece, pois o texto narra a presença de gaivotas: "Tinha visto navios, mas tão longe que pareciam gaivotas" (p. 14).

b) quando as irmãs oferecem o punhal para que a Sereiazinha mate o príncipe. A metáfora reincide, e é possível para o leitor associar os termos comparados: irmãs-gaivotas. Nota-se que a pintura é a mesma. Isso autoriza a leitura proposta.

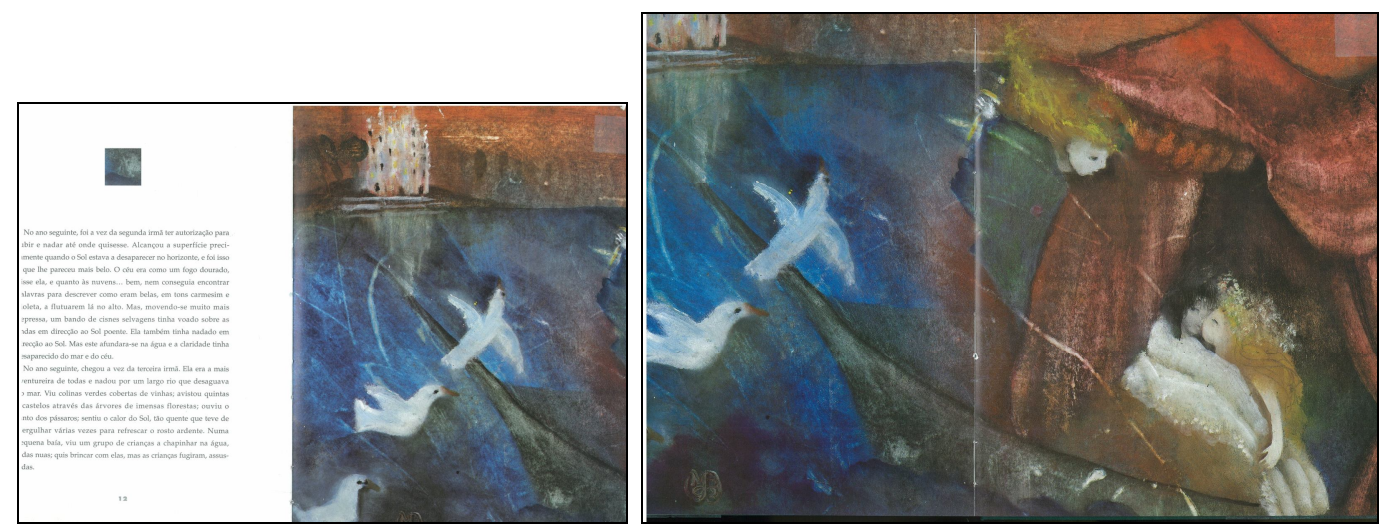

Figura 2.69 - Figura recorrente

\section{Atando os nós}

As pinturas da obra contam também, de maneira autônoma, a saga frustrada de A sereiazinha. Repleta de polissemia, dada por ambigüidades, metáforas, inserções de outras narrativas, além da rica e estimulante presença de influências num fluxo contínuo de discursos, a imagem se revela não apenas como adorno ou cenário da palavra, pois é inegável que acrescenta elementos. 
Apesar do acréscimo, mantém-se fiel ao texto, também não subverte ou atualiza as linhas de Andersen; aliás, as imagens apresentam marcas temporais do século XIX mescladas com figuras do século XX, dialogando e atualizando o conto.

O que a imagem propõe são caminhos para novos diálogos, gerando no observador questões, reflexões, como queriam Escarpit (1979) e Calado (1994). Este procedimento é enriquecedor e estimulante para o jovem leitor. Os constantes diálogos que a narrativa oferece conferem-Ihe atualidade, e isso renova cada leitura do conto. Tal característica dialógica é recuperada pela imagem. Há entre palavra e imagem uma relação de essência (natureza) comum. Assim, agrega-se mais um tipo de texto, o dialógico: aquele em que a palavra e a imagem conduzem a textos outros (em ausência), como em um jogo de caça do tesouro, em que uma pista leva a outra.

Do ponto de vista pedagógico, este texto é fundamental, pois dá ao educando a possibilidade de entender o texto em rede, procedimento tão louvado pela "modernidade" na era informatizada, mas tão antigo e inerente ao mundo das artes - como bem revela a história das Mil e uma noites, por exemplo. 


\subsubsection{Como Autora de I magens Narrativas}

\section{O livro de imagem narrativa em Portugal: um exemplo em Sebastião}

Debaixo d'água tudo era mais bonito

Mais azul, mais colorido

Só faltava respirar

Mas tinha que respirar

$[\ldots]$

Debaixo d'água por encanto sem sorriso e sem pranto

Sem lamento e sem saber o quanto

Esse momento poderia durar

Mas tinha que respirar

(Arnaldo Antunes)

Em Portugal, não há prática habitual na produção de livro de imagem. Manuela Bacelar, mais uma vez, destaca-se por introduzir o álbum de imagem em seu país, mas também não possui vasta produção nesse gênero. Seu trabalho exclusivo com a imagem se limita às obras Sebastião e Consola-te.

Sebastião será a obra analisada neste estudo, uma vez que, apesar de ser um texto que prescinde da palavra, é possível estabelecer relações entre as linguagens verbal e visual, como será objetivo demonstrar.

Algumas definições, todavia, são necessárias nesta etapa, em especial sobre o gênero álbum de imagem. É válido lembrar que o livro de imagem surge no mercado editorial com o propósito de atender à demanda de um grupo de não-alfabetizados, como bem pontua Colomer (1999):

Se trata de libros que desarrollan una historia completa utilizando únicamente una sucesión de imágenes. Son particularmente útiles para el deserrollo del lenguaje y del esquema narrativo ya que se ofrecen como un estímulo para que el niño narre la historia por sí o en combinación con el adulto. Al relatar el cuento el niño aprende a integrar las imágenes en una estruntum annmanta ." 
aprende a apoyarse en la información del libro para construir su interpretación (1999, p. 147).

Existem duas formas de nomear este objeto, são elas: livro de imagem ou álbum de imagem. Adotar a palavra álbum pode impor uma abordagem mais quadro a quadro, sem, portanto, privilegiar a continuidade narrativa, enquanto o uso da palavra livro implica a mecânica imposta pelo objeto, a saber: a linearidade e uma sistemática de leitura.

A abordagem realizada a partir da análise de Sebastião leva a compreendê-lo como um livro de imagem ou ainda um objeto-livro ${ }^{79}$. A adoção dessa perspectiva conduz à pergunta: é possível um objeto-livro ser completamente desprovido de palavras? Tal questionamento é pertinente graças ao termo livro: será que a palavra designa o texto verbal? Com o intuito de descartar essa relação preestabelecida, cabe investigar quais características da palavra permanecem nos livros de imagens ou, ainda, em que medida esses remetem ao universo das palavras?

É possível observar que o livro de imagem leva a criança a estabelecer o primeiro contato com o objeto-livro, pois muitas vezes a palavra aparece como imagem ou mesmo o sistema de escrita é reproduzido na expressão plástica, como é proposta demonstrar. Caminha-se, pois, com vistas à articulação da imagem e da palavra, sobretudo, quando essa última está ausente graficamente, como é o caso do objeto analisado, mas que, a partir da relação com a palavra ausente, edifica um todo de sentido articulado pelo projeto gráfico da obra.

Independentemente de se considerar a palavra necessária ou não ao livro, o que pode ser percebido é que, mesmo em ausência, ela processa significação neste objeto. Resta evidenciar de que maneira isso se processa. As possibilidades são:

79 Livro-objeto será definido, neste estudo, conforme a seguinte citação: "A unidade semântica é dada, em português, principalmente pelo uso de hífen, como o apóstrofo e a aglutinação em inglês, por exemplo (artist's book e bookwork). Do mesmo modo, o objeto livro (o objeto de uso cotidiano ao qual denominamos livro) e o objeto-livro (como uma proposta de especificação conceitual do objeto artíctirn)" (Dicnnnível em. <http://www.artewebbrasil.com.br/marcelo/livro_objeto.htm>. 2008). 
1) Em que medida a palavra, apesar de restrita, está presente graficamente (como imagem) e significa no processo de decodificação da narrativa, podendo limitar ou ampliar o sentido do texto visual, neste caso, entendido como um objeto sincrético?

2) Em que medida a palavra permanece inerente ao discurso como intertextualidade, contribuindo para a significação da narrativa?

3) Em que medida a "mecânica" do livro, ou seja, o formato, o suporte, determina a leitura de um livro de imagem, impondo a mesma dinâmica ditada pelo texto verbal?

Tais questões iluminam o caminho de análise da obra Sebastião, e, ainda a partir da análise, é possível perceber a representatividade do álbum de imagem no cenário de literatura infantil em Portugal.

\section{O livro de imagem: arte literária e arte plástica}

A primeira questão a ser investigada no livro de imagem é a presença do título e, como conseqüência, a capa, pois é onde esse aparece. Verbal e Visual interagem para apresentar a obra ao público, seja na estante da biblioteca, seja na vitrine de uma livraria, seja, mesmo, nas mãos do mediador. Inevitavelmente, no livro de imagem, a capa exige a leitura tanto verbal como visual, visto que, mesmo priorizando a imagem, o título é verbal.

Ora, a capa exerce a função de convite à leitura e pode aproximar ou afastar o pequeno leitor. Mesmo com a tarefa de introduzir os nãoalfabetizados na leitura, os livros de imagem apresentam um título, isso, de antemão, prevê um mediador que deverá ler esse para a criança não iniciada na leitura verbal ou, por outro lado, o descarte do título se não houver a mediação.

Sem a mediação do alfabetizado, a criança poderá eleger seu livro pela imagem da capa ou depois de folhear as imagens do miolo, nestes dois 
exemplos, o título seria insignificante como elemento de sentido, o que para Semiótica, fundamentação teórica adotada nesta pesquisa, seria impensável.

Assim, o título existe e significa, daí olhar para a capa como um texto sincrético no livro de imagem. Para discutir sobre a importância e pertinência do título no livro de imagem, recorre-se às teorias das artes plásticas, na medida em que neste universo é possível vislumbrar uma obra, intencionalmente, sem título.

Posto isso, vale pontuar que a arte moderna questiona a própria representação. Movimentos como impressionismo, o cubismo, o surrealismo, para citar alguns, têm por proposta não imitar a realidade, mas, por vezes, o tema mesmo é a representação, por exemplo, a famosa obra de Magritte (1898 - 1967), Ceci n'est pás une pipe (1928-1929), em que o artista nega a representação:

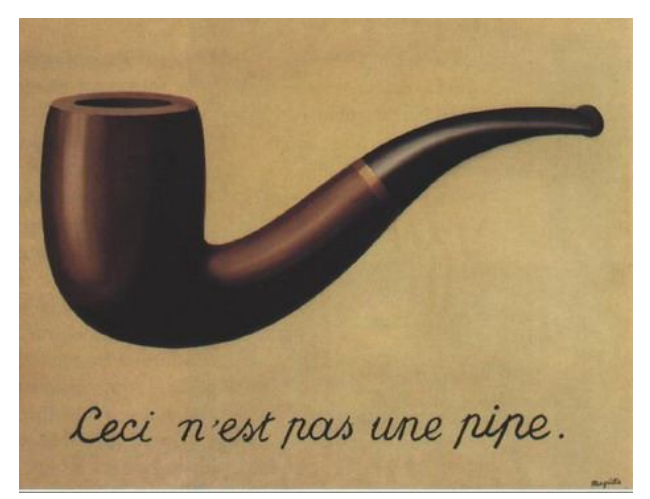

Figura 2.70 - Ceci n'est pás une pipe.

Oliveira (2004), em seu artigo "As semioses pictóricas" duas questões bastante significativas para este estudo. A primeira versa sobre o fenômeno da abstração na pintura, a segunda focaliza a problemática do título na obra de arte. As duas questões nascem no universo das artes plásticas, mas, aqui, adaptam-se de maneira reveladora aos livros de imagem. Sobre a representação, Oliveira observa:

80 Publicado na obra Semiótica Plástica, que tem sua organizaçã 
A pintura não é um espelho do mundo natural, mas uma codificação outra, que se organiza pelo e no ato de o pintor concebê-la no espaço bidimensional, ou seja, no modo em que ele se assume enunciador de um enunciado montado, na relação entre esse e a enunciação, um contrato comunicacional que expõe ao enunciatário as relações estabelecidas entre o plano da expressão e o plano do conteúdo (2004, p. 126)

Ambas problemáticas (ausência de título e abstração) estão relacionadas, uma vez que, dentre os movimentos, um, em especial, pôs à prova o título, a saber, o abstracionismo.

A pintura denominada abstrata é a que procura expor um médium pictórico, ou seja, seu objetivo é tornar visível não a relação entre o objeto pictórico e as coisas do mundo, mas as possibilidades de codificação de seu próprio código, a sua realidade plástica. Refletindo sobre o seu próprio médium, que é inclusive convertido em um tema da pintura, os pintores se lançam numa busca não mais de recobrir a tela através de ilusões óticas para, por exemplo, conseguir, na sua inerente bidimensionalidade, a tridimensionalidade do mundo natural, mas de descobri-la na sua planitude plano sob plano, plano no plano (2004, p. 126).

Não raro, em exposições de arte abstrata, o apreciador é tomado pela decepção quando os seus olhos e intelecto não encontram abrigo no título de um quadro que pouco ou nada dá a "entender". Alguns artistas plásticos atribuem ao título uma natureza delimitadora, ou seja, frente à arte abstrata o título daria um sentido indesejado para uma obra aberta. Por vezes, os artistas optam mesmo por não atribuir títulos às suas obras, e o apreciador, quando busca o "porto seguro" da palavra, pode depararse com "sem título".

Resta ainda um aspecto a ser observado que é o das pinturas não intituladas. A impossibilidade de criar um título, ou seja, de nomear verbalmente a pintura, é um reconhecimento da sua intradutibilidade em outro sistema. Nesse sentido, o não nomear ou a aurn̂nris Nım nnmn num outro sistema já é por si mesmo um 
guia o observador na tarefa de re-construir a significação da obra (2004, p. 129).

Essa mesma preocupação e, por conseqüência, esses mesmos conflitos são gerados pelo título no livro de imagem. Se, por um lado, pode oferecer conforto ou relações concretas ao leitor, por meio da intertextualidade ou da metonímia ou do protagonismo, por outro, pode restringir a polissemia da imagem.

Para tratar da problemática dos títulos nos livros de imagem, buscou-se um exemplo no que se refere à tradução. A hipótese aventada é que a alteração do sentido original do título implicaria modificação no conteúdo da obra, pois o título no livro de imagem atribui sentido às imagens em seqüência narrativa.

\section{O título como condição de sentido}

O exemplo é a obra Cena de rua, de Angela Lago. No título, a palavra "cena" remete às linguagens do teatro, do cinema, da teledramartugia, em que as personagens desenvolvem uma ação em um tempo e em um cenário. Para reforçar o sentido da palavra, destacam-se, ainda, três acepções do dicionário: 1) Nos palcos, o principal espaço de representação; 2) Cada uma das situações ou lances no decorrer da evolução da intriga de uma peça, novela, romance; 3) Acontecimento dramático, ou cômico ${ }^{81}$.

A palavra cena, neste título, vem acompanhada pela locução adjetiva "de rua", que transporta o leitor para o cenário, onde a ação se desenvolve. Há, também, a generalização imposta pela ausência do artigo ( a ou uma). Tem-se, portanto, uma ação qualquer em um cenário, a rua.

O título, no entanto, não está só. A imagem está ali. Aliás, sobreposta a ele. O título é englobado pela imagem, além de, por si só, gerar imagens, tornando-se também imagem, como postulado por Otávio Paz em Signos em 
Rotação ${ }^{82}$. Na capa, há ainda a sobreposição de quadrados: o negro, o branco, os coloridos em tamanho menor. Reconhecem-se, nesta montagem, três elementos do mundo: uma placa tipo claquete, um muro e a pichação. Incluído na placa ou muro, está o título, que, pela grafia, sugere a pichação ou inscrição manuscrita em uma placa. Este título autoriza a leitura tanto da placa como do muro, deixando ao leitor diversos significados para recobrir a figura: um filme? Um muro?
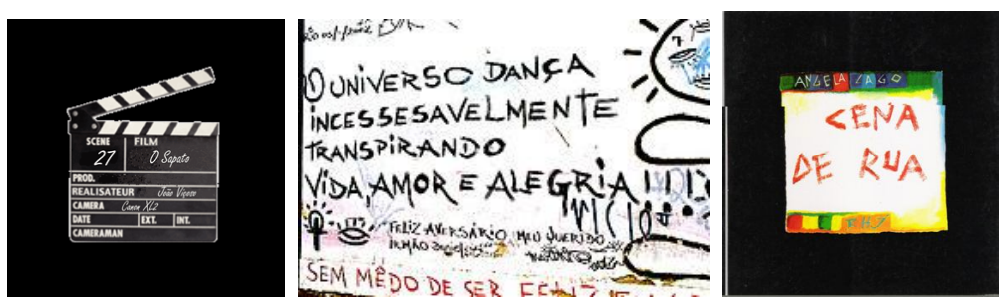

Figura 2.71 - Comparações: placa e muro

Para compreender a capa e lhe atribuir sentido, é necessário recorrer não só ao título, mas ao miolo da obra, ou seja, o jogo está posto, dado que o leitor é convidado a entrar na obra. A capa tem, pois, a propriedade de propor a leitura ao leitor, de manipulá-lo para leitura. Cláudio Ferlauto afirma que a capa é criada para "provocar, despertar e induzir a imaginação e a curiosidade do consumidor. Vender idéias. Seduzir olhos e mentes" (2002, p. 75).

Nesta narrativa, Lago conta com imagens que mostram a "condição" circular de um menino de rua de uma grande cidade, que pode ser São Paulo, Rio de Janeiro, Belo Horizonte ou Lisboa, Madrid, Londres, como demonstrado pela ausência do artigo (a ou uma). Ali, há uma seqüência de ações que revela a narratividade do texto ${ }^{83}$.

82 Esta propriedade de a palavra gerar imagens (criar imaṇenc) cerá tratada maic adiante neste estudo.

83 O termo narratividade é utilizado conforme a teoria da semióı 
As cenas urbanas são exibidas a cada virada de página. O menino vende ou oferece objetos que não são figurativos, podem, por isso, ser recobertos por doces, frutas, brinquedos.

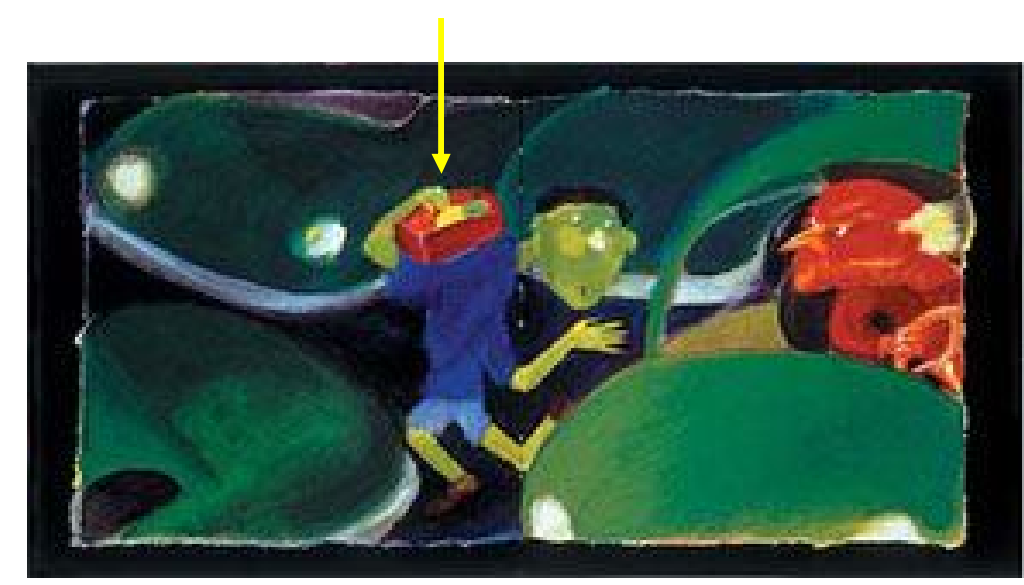

Figura 2.72 - Caixa com objetos não identificáveis

Vale ressaltar que é possível haver a venda ou doação dos objetos, não se sabe. A narrativa se desenrola com um ir e vir de agressões (sem contato físico), das pessoas, dos homens-animais e dos animais que estão dentro do carro, mas também do menino que está fora, na rua. Ele também agride, pois furta um objeto de um carro. Na maior parte das cenas, no entanto, apresenta a gestualidade que figurativiza a humildade, a subserviência, contudo, quando o menino resolve pegar algo dentro de um dos carros, a ação revela também agressividade por parte do protagonista, trazendo à tona a ambigüidade das relações diante da desigualdade social, tema posto pela narrativa.

Há, então, um misto de medo, pena e ira, sentimentos próprios aos moradores das grandes cidades, onde a exclusão social é recorrente. Destacam-se as cenas em que o menino é carente de dinheiro (representado pela bolsa) e carinho (representado pelo filho nos braços da mãe) em oposição à cena de furto, em que o menino também expressa agressividade. Ele é, portanto, agressor e vítima. 


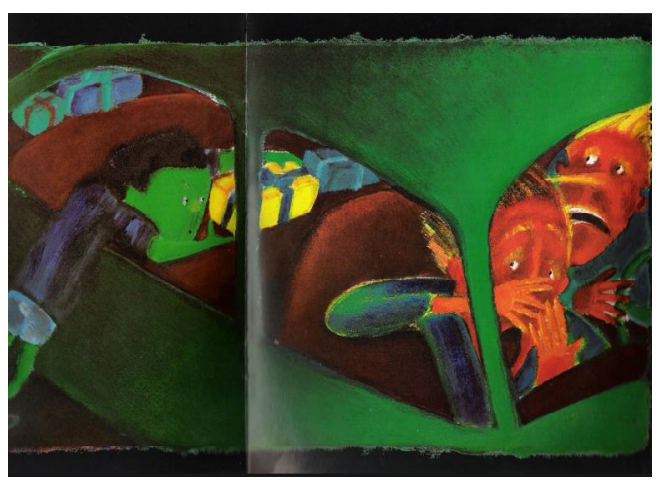

Figura 2.73 - Cena de rua: o protagonista é agressor

O aspecto mais interessante na obra é a ambigüidade: seja dos sentimentos, das funções do protagonista e dos antagonistas ou ainda da circularidade sugerida pelo final, que retoma a cena inicial.

Voltando ao título, Cena de rua reafirma-se como ambíguo, polissêmico, deixando ao leitor diferentes possibilidades de preenchimento até para gerar o efeito de sentido daquele sentimento contraditório (medo, pena, raiva), que essa cena de rua gera em quem participa dela ("dentro da obra", personagens, e "fora da obra", leitores).

Para abordar a importância do título no álbum de imagem, utilizamse duas traduções da obra de Lago: em espanhol, editado pela Ekaré (Venezuela) e, em francês, editado pela Editions Rue du Monde (França).

$\mathrm{Na}$ tradução para o espanhol, a obra recebeu o título de De noche en la calle. Há, pois, uma diferença importante entre os títulos, em português e em espanhol. Explica-se: o fundo negro que contribuía para a polissemia da obra: noite, cena de cinema, apresentação teatral, recorte de uma cena da realidade, foi restringido pelo sentido da palavra noite, ou seja, o negro do fundo da cena só pode ser entendido como noite na obra em espanhol.

Já na tradução francesa, Le petit marchand des rue mantém a idéia da abertura de sentido das cores, não explorada pela tradução em espanhol, porém a ambigüidade da função do menino-protagonista não permanece, uma vez que ele, nesta tradução, somente será visto como vendedor e não como doador, negociante ou até 
agressor, como foi aventado anteriormente. Nesta edição, uma cena do miolo da obra compõe a capa, isso reforça o estado de submissão da personagem na tradução francesa. Enquanto a capa original explora a ambigüidade, em uma capa ambígua, a versão francesa utiliza o recurso anafórico, como será categorizado na conclusão deste estudo.
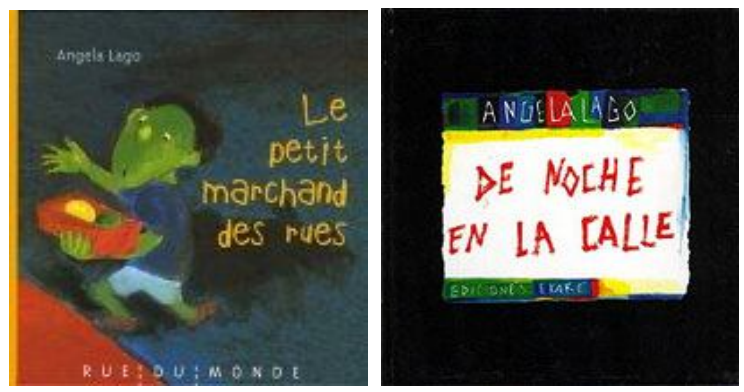

Figura 2.74 - Publicação francesa/ espanhola

Pode parecer simples traduzir um livro de imagem, pois apenas o título deve ser vertido, mas a tarefa exige muita atenção, dado que, durante muito tempo, atrelou-se a função delimitadora à imagem nos livros para crianças, em que se percebe o caráter delimitador que um título pode assumir. Conclui-se, então, que no diálogo palavra/imagem a propriedade limitadora de um sistema sobre outro é um risco constante, ao qual o editor deve estar atento.

Como o verbal é restrito ao título do livro de imagem, ele deve ser pensado a partir de duas possibilidades: como contextualizador e ambíguo, no caso de Cena de rua, ou gerador de intertextualidade, como Sebastião, tal qual será demonstrado a seguir.

Por essa mesma razão, dar título ao livro de imagem não é fácil, a menos que ele se enquadre na categoria de livro informativo (seja de conceito, seja de conhecimento), pois, como demonstrado, o título compõe a significação da obra e torna-se mesmo condição para a significação.

Do exemplo brasileiro, passa-se para a obra portuquesa: Sebastião (2004), de Manuela Bacelar, editado pela Edições Afrc 


\section{Uma história ou duas histórias: o enlace narrativo no livro de imagem}

Depois de comprovar a importância do título no livro de imagem, toma-se a capa e contracapa com relação ao título, na obra Sebastião, de Manuela Bacelar. Observando o livro de frente ou ao contrário, percebe-se a presença de duas capas: a capa e a que deveria ser a contracapa. Nesta edição, contudo, essa adquiriu status daquela, anulando, portanto, a sua função. Abaixo, apresenta-se o livro aberto, expondo as duas capas e interroga-se: há duas histórias neste livro de imagens? A personagem representada é a mesma nas duas capas, ou seja, Sebastião?

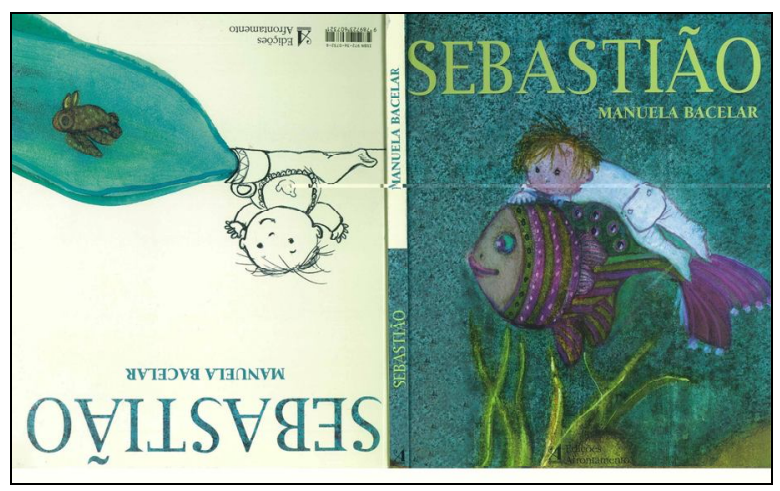

Figura 2.75 - As duas capas

Para iniciar a análise, optou-se por uma das capas, ponderando que essa é uma estratégia da análise e não uma determinação do objeto, isto é, normalmente a capa do livro estabelece a entrada do leitor na obra. Neste caso, por serem duas capas, o leitor deve optar por um dos lados para iniciar a leitura, ou seja, o objeto-livro começa por questionar a própria dinâmica que lhe é inerente.

Assim, em uma das capas, há um bebê em branco e preto que deixa derramar o conteúdo de uma caneca. O conteúdo colorido da caneca remete ao universo das águas pelas cores azul e verde e $p r$ 
assemelha a um peixe. Aparece o título Sebastião em azul manchado de cinza. Sebastião é a personagem, no caso o bebê, pois é quem age. Colomer discute a questão de como a imagem pode conferir protagonismo:

\begin{abstract}
"De quién trata una historia" es una información tan básica para adentrarse en una narración, que a menudo el título o la portada ya se encargan de sumistrarla. La ilustración tenderá a destacar a sus protagonistas y a recordar al lector la importancia de cada personaje. No tendría mucho sentido, por ejemplo, que el primer plano estuviera ocupado por un personaje secundario sin mayor relevancia, a no ser que quisiera crearse algún efecto especial. Pero las formas de indicar la jerarquía entre los personajes pueden ser más variadas que simplemente el hecho de situar al protagonista en el centro (2002, p. 28).
\end{abstract}

O bebê seria o protagonista: Sebastião? Ou o peixe seria Sebastião? Ou outra personagem que aparecerá ao longo da narrativa se chama Sebastião? Vale, no entanto, investigar o título sem conhecer o miolo? Apenas, sabe-se que trata de uma personagem do sexo masculino, mas palavra e imagem não dialogam a ponto de, pela hierarquização, distinguir-se o protagonista ${ }^{84}$, porque entre o peixe e o menino não há hierarquização por tamanho, luminosidade ou forma (ou até mesmo outro recurso plástico).

Assim, há, de um lado, o fundo preenchido por cores azul, verde e manchas em tons de cinza, a figura de um peixe e, sobre ele, uma criança, o que se verifica como uma quase fusão entre as personagens. Há o título: Sebastião. Eis a imagem:

${ }^{84}$ Nos livros infantis, talvez nas obras de arte em geral, é difícil ectahelecer renrac nara o conteúdo e estratégias discursivas predeterminadas, pc designers gráficos estão sempre tentando romper a expectati 


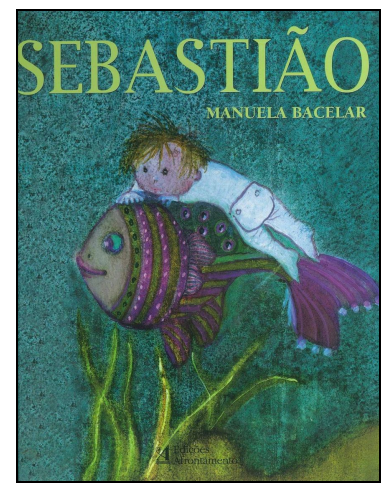

Figura 2.76 - Uma das capas

Pelo outro lado, o fundo é branco, e o bebê é maior que o peixe, como se verifica:

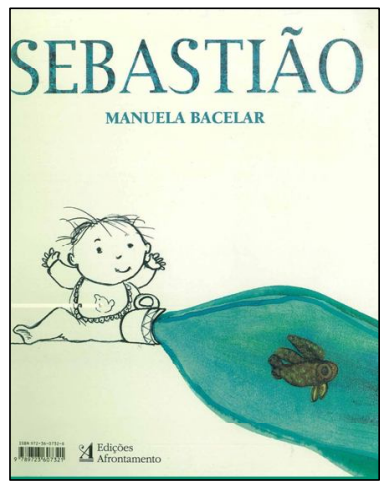

Figura 2.77 - Outra capa

As capas apresentam uma diferença: uma é caracterizada pelos vazios de cor, e a outra, pelo preenchimento de cores. Para avaliar a pertinência desta diferença, passa-se ao miolo da obra, destacando-se alguns questionamentos que devem nortear a análise.

O título estaria na categoria da ambigüidade ou sugeriria relações intertextuais?

Se intertextual, é válido interrogar em que medida a mensagem verbal (dada pelo intertexto) interfere na construção da narrativa visual, 
ou seja, gera ambigüidade ou acrescenta dados à ela? Ainda, qual o sentido da dupla entrada?

Explicitadas as questões que iluminam a trilha, inicia-se a análise por um dos lados para tentar respondê-las. A opção é pela capa que apresenta vazios, lembrando que a escolha não segue nenhum critério algum predeterminado.

\section{Um dos lados em análise}

Seguindo uma das histórias $A^{85}$, a técnica utilizada por Bacelar, mais uma vez, é mista: aquarela para a cor e nanquim como marcador.

Assim como em $\mathrm{O}$ dinossauro, obra analisada anteriormente, em que a linha da terra leva à condução da seqüência das imagens e, mais uma vez, a idéia do flip books é retomada. Volta-se, pois, à técnica da animação. A técnica empregada tende mais ao gráfico que ao pictórico ${ }^{86}$. A cada virada de página, o bebê se movimenta em direção à caneca. Abaixo, exemplifica-se a técnica do Flip book, pois esse procedimento será um traço característico da obra de Manuela Bacelar:

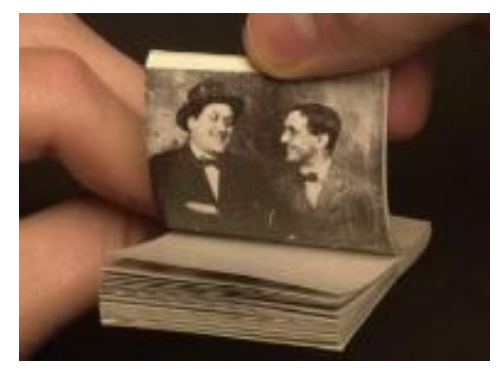

Figura 2.78 - Exemplo de Flip book

85 Para se referir às diferentes histórias ou percursos, A será utilizado para designar a primeira história analisada e B, para a segunda. É possível comerar tantn nor ı ıma romn por outra, assim, a designação, primeira e segunda, é apenas u

86 Esta oposição gráfico/pictórico será trabalhada ao longo da pє 


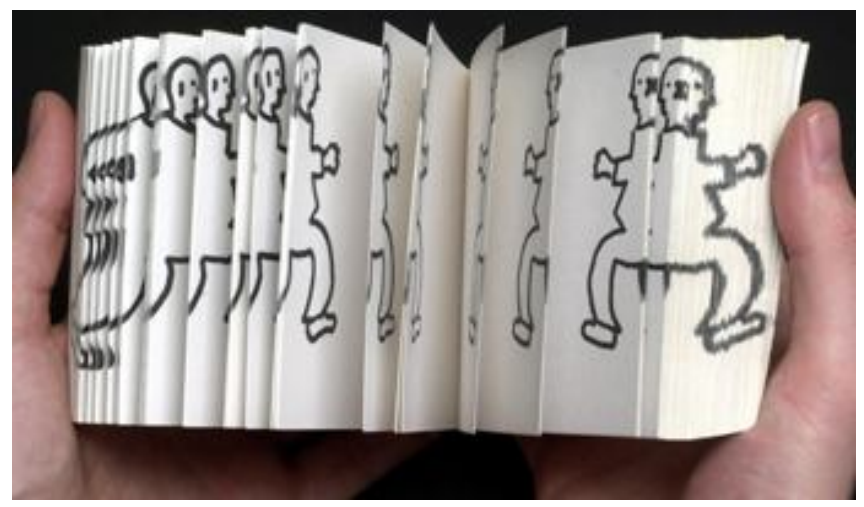

Figura 2.79 - Exemplo de Flip book II

Inicia-se, então, a história. Um bebê, personagem principal, está do lado esquerdo da página, e uma caneca, do lado direito. Esses elementos estão ligados pela linha da terra que cria a idéia de solo e, ainda, o elo entre eles. $\mathrm{O}$ ato de virar as páginas gera o movimento da personagem.

O desenho não é realista, e sim apenas um esboço, ou seja, não obedece às cores naturais, nem às proporcionalidades do ser humano. Como a imagem é vazia, vem à tona a idéia do esboço, do inacabado. O traçado é vazado e está a mostra. Tem-se a enunciação enunciada. O enunciador não tem a intenção de apagar ou disfarçar seu fazer, pelo contrário, este é mostrado. Este é um traço presente na produção pósmoderna. Durante bom tempo, as técnicas plásticas tinham por objetivo a fidelidade ao objeto representado; na modernidade, os artistas abandonaram essa idéia e imprimiram maior subjetividade às criações; já na pós-modernidade, a idéia da metalinguagem, ou melhor, a idéia da metaficção toma a cena, como declaram Gonzáles e Zaparín: “[...] La inclinación posmoderna a que los mismos dibujos interactúen con el álbum: el argumento de la historia está en la manipulación del proprio médio" (2005, p. 14).

Ainda, Maria Cecília Siva-Díaz reafirma a característica metaficcional como determinante da literatura infantil pós-moderna: 
En la literatura llamada postmoderna abundan los experimentos literarios arriesgados y complejos que buscan desenmascarar la ilusión de realidad que crea la literatura a través de convenciones que quizá en otra corrientes, menos audaces, permanecen ocultas. Estos experimentos revelan que toda narración es una construcción hecha de palabras, de acuerdo a convenciones muy codificadas. De este modo las historias metaficcionales colocan a los lectores en una posición distanciada, en la que no pueden "sumergirse" puesto que no se les permite perder de vista el carácter artificial y convencional del texto y al problematizar la lectura [...] les hacen consciente de que están activamente implicados en la construcción de sentido (2005, p. 4).

$\mathrm{Na}$ literatura infantil portuguesa contemporânea, são raros procedimentos audazes com relação à metaficção, como será demonstrado na conclusão deste estudo, de qualquer modo, dois exemplos são destacados: Histórias de um segredo, de João Paulo Cotrim e André Letria, e A maior flor do mundo, de José Saramago e ilustrações de J oão Caetano, nesta ordem:

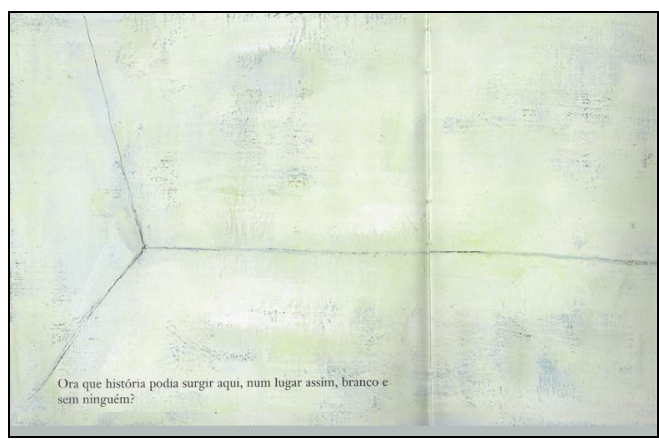

Figura 2.80 - Histórias de um segredo (primeira página)

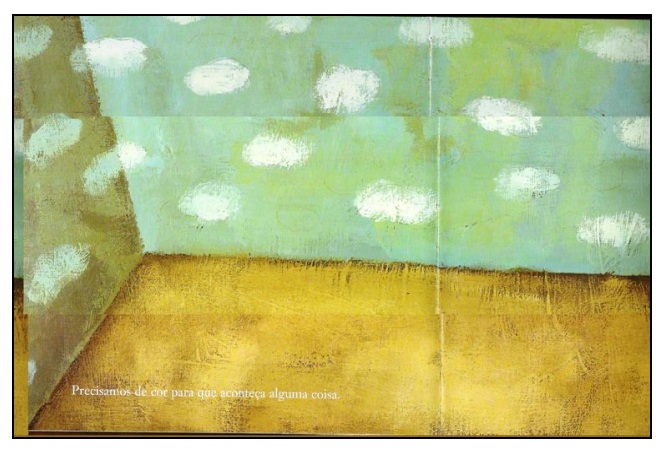

Figura 2.81 - Histórias de um segredo (segunda página) 


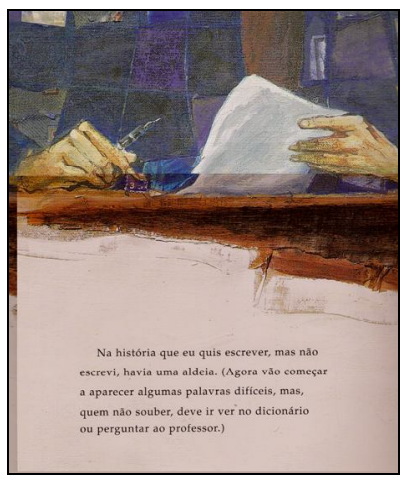

Figura 2.83 - A maior flor do mundo

Nas obras de Manuela Bacelar, o desenho vazado é tomado como uma possibilidade metaficcional, esse procedimento marca o estilo da autora. Assim, o marcador, em nanquim, desenha o bebê que está cercado por brinquedos com formas geométricas, como cubo, triângulo, losango e uma bola, e já tem, em suas mãos, um peixe, que não é totalmente mostrado. As mãos da personagem escondem partes do peixe, mas é possível identificar o rabo, a barbatana e as escamas.

Pergunta-se: o bebê quereria devolver o peixe ao seu habitat, o mar ou o rio? Este seria o conflito da narrativa?

O peixe está disjunto de seu objeto-valor, a água. $\mathrm{O}$ bebê adquiriria, com isso, a função de personagem-auxiliar ou doador de competência. O peixe não pode voltar para o mar, pois não consegue locomover-se fora d'água. O bebê tem competência para ajudá-lo, então, a narrativa segue.
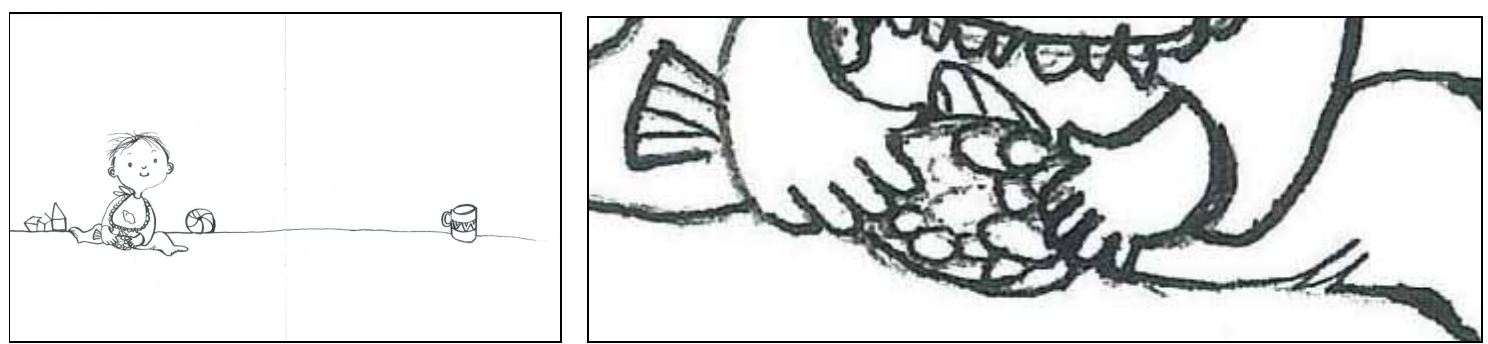

Figura 2.84 - Detalhe do peixe created with 
O bebê carrega o peixe em direção à caneca. A ação é do bebê. Ele quer fazer-se conjunto ao objeto-valor: caneca ou conteúdo dela.

A expressão do bebê é de contentamento e curiosidade, virar a página é, assim, natural, pois a expectativa narrativa foi criada no leitor (o protagonista quer "salvar" o peixe ou saber qual é o conteúdo da caneca?).

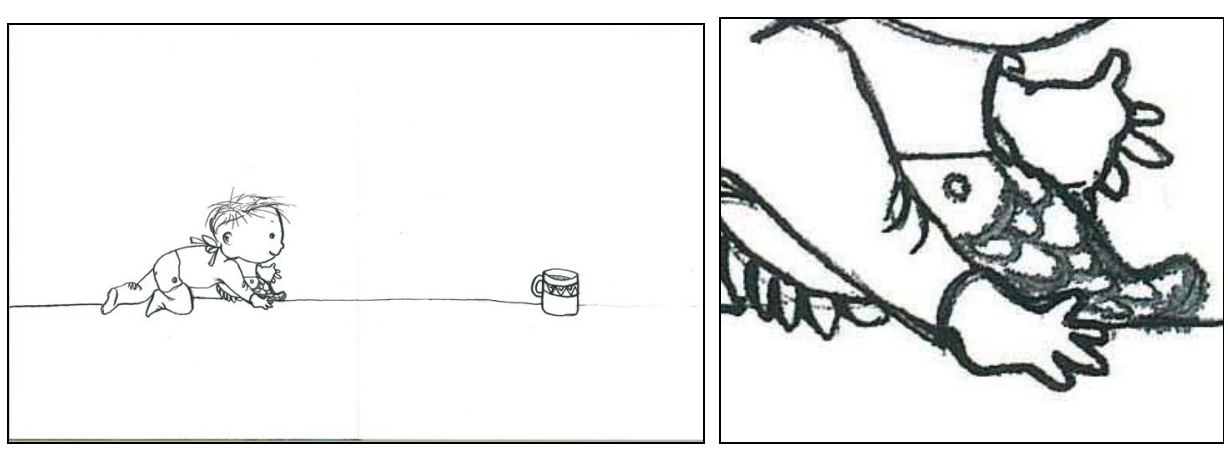

Figura 2.85 - Detalhe da intenção do bebê

Há uma transformação na cena seguinte. A disposição dos brinquedos é alterada, rompendo com a idéia do flip book, que, como demonstrado, deve alterar os elementos visuais progressivamente para que as figuras adquiram movimento com o folhear das páginas. Esse tipo de livro exige a manutenção do cenário, e, para dar movimento à imagem ${ }^{87}$, somente é possível movimentar a personagem. Com isso, o cenário deve ser fixo, a fim de que a personagem possa ganhar mobilidade.

${ }^{87}$ Este tipo de texto já foi trabalhado na análise da obra O dinossa 

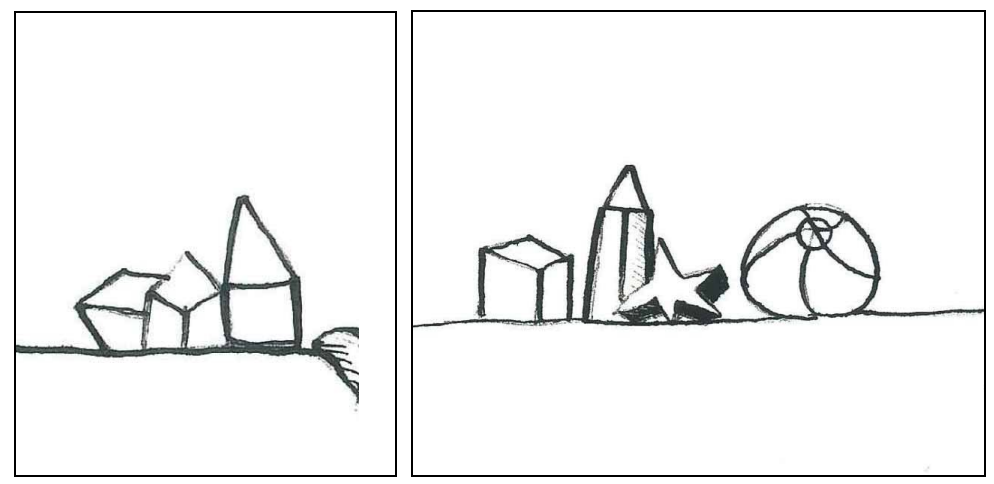

Figura 2.86 - Detalhe da alteração dos objetos

O livro de imagem não exige tanto rigor, visto que a intenção não é a animação como no Flip book, e o leitor pode passar lentamente pelas páginas, além disso, a alteração "misteriosa" dos elementos do cenário oferece dados à imaginação do leitor.

O menino-protagonista, na seqüência, introduz o peixe na caneca. O azul é derramado sobre a linha da terra. Tem-se, pois, a idéia da água. Como conseqüência, a cor aparece, e é autorizada a entrada do bebê no universo da ficção.

No que diz respeito à estrutura narrativa, até este momento foi possível identificar: situação inicial e conflito narrativo. Assim, na situação inicial, o bebê estava disjunto do universo mágico, a partir da introdução do peixe na caneca, o sujeito-bebê faz-se conjunto com um campo ficcional desenhado pela tinta azul. Assim, evidencia-se o peixe como doador de competência ao bebê, é ele quem o auxilia a se fazer conjunto com o universo ficcional, ao contrário daquilo que foi aventado como hipótese inicial: então, o doador de competência é o peixe. O que ocorre, na verdade, é a reciprocidade - o menino doa e recebe, o peixe doa e recebe, ambos se fazem conjuntos ao objeto de valor: água - mundo ficcional.

Tanto o bebê como o peixe têm demonstram contentamento, que é revelado pelas expressões faciais. 


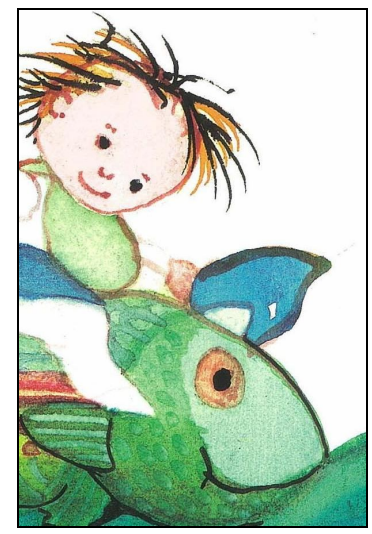

Figura 2.87 - Detalhe das expressões faciais

A conjunção com o universo do maravilhoso é eufórica, assim como a devolução do peixe ao seu cenário/habitat. O contentamento seria por que ambos encontraram o seu ambiente: peixe-água, bebê-mundo ficcional?

Além disso, é possível, também, ler na caneca um $\mathrm{S}$, talvez um indício do nome da personagem, um pertencimento: essa caneca pertence ao Sebastião protagonista da narrativa: o peixe? Ou o menino?

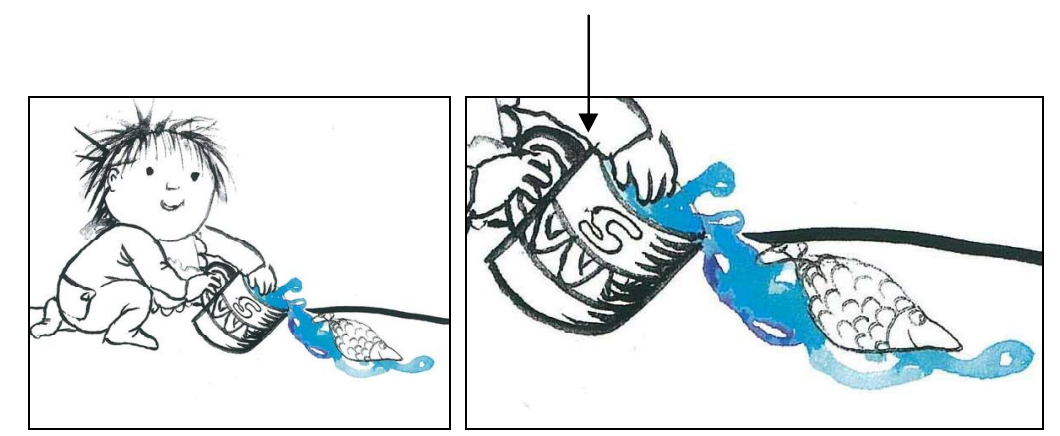

Figura 2.88 - Detalhe da caneca com a inscrição S

O líquido escorre, aumenta de volume e começa a tomar conta da página, alarga-se. Eis a magia em colorido. A cor apresenta o universo irreal, ficcional, e, assim, o bebê vai descobrir as águas e viajar sobre o peixe. O ser marítimo é transporte do bebê para esse mundo da 
fantasia ${ }^{88}$, reforçando a idéia do peixe como doador de competência ao bebê. Nesta nova atmosfera, o menino e o cenário ganham cor.

Uma relação muito utilizada em literatura infantil é a seguinte: preto e branco (ou ausência de cor) para a realidade e cores para a fantasia. Roger Mello, em seu A flor do lado de lá, utiliza, também, esse recurso. Um procedimento usual não desqualifica o valor estético da obra, pelo contrário, pode ser uma característica do sistema, do gênero livro de imagem, como a utilização dos balões nas histórias em quadrinhos.
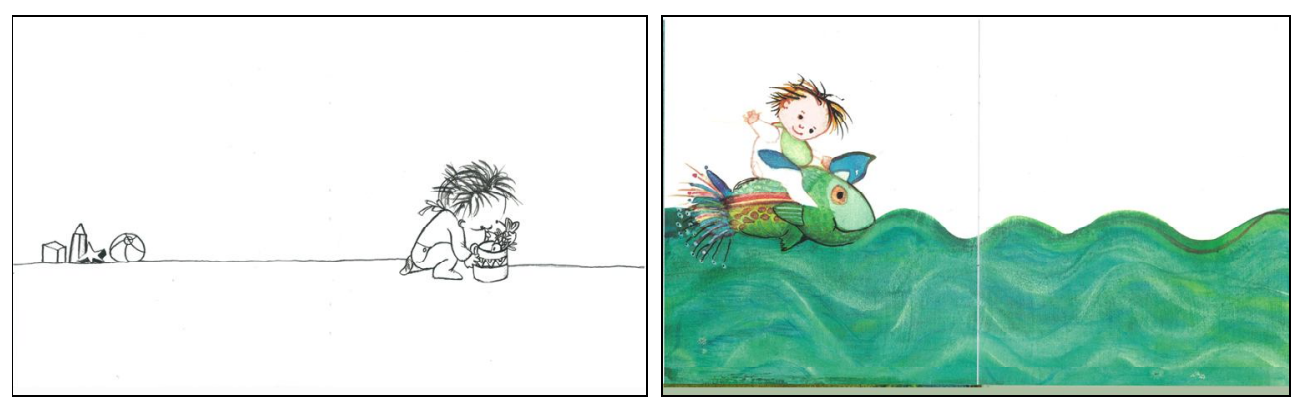

Figura 2.89 - Oposição preto/ branco versus colorido
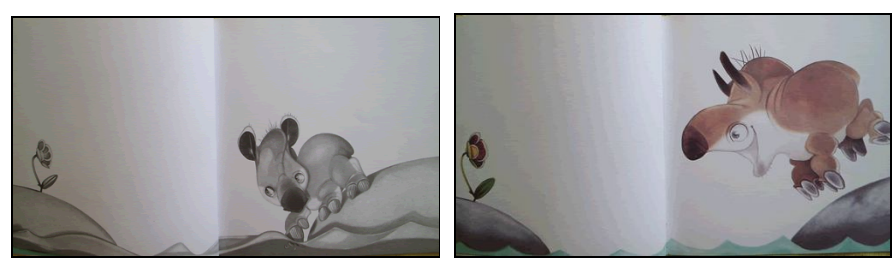

Figura 2.90 - Oposição preto/ branco versus colorido, em A flor do lado de lá

Outra oposição é: a linha reta versus a ondulada, também associada ao real e à fantasia, respectivamente. Entretanto, não é possível afirmar que a oposição seja uma convenção do gênero, como a relação preto/colorido analisada. 


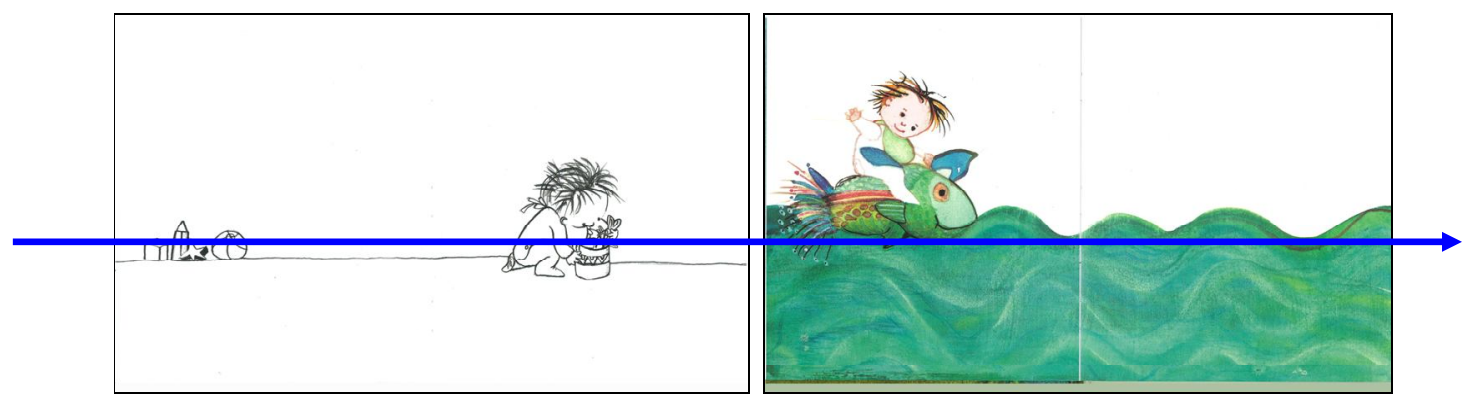

Figura 2.91 - Oposição linha da terra reta versus ondulada

A criança vai até o reino das águas e conversa com as sereias, os peixes, os cavalos-marinhos. As misteriosas profundezas compõem o cenário. Sempre envolvido por muita cor, muitas formas e muitas figuras distintas, estranhas, mas nunca assustadoras, elas são, pois, sempre amistosas.

As páginas são completamente preenchidas, sangradas. Ali, não há espaço para o branco. Instaura-se outra oposição: página vazia versus página preenchida. Homologam-se, respectivamente, a realidade (fundo - vazio de cores) versus fantasia (página sangrada - em profusão de cores).
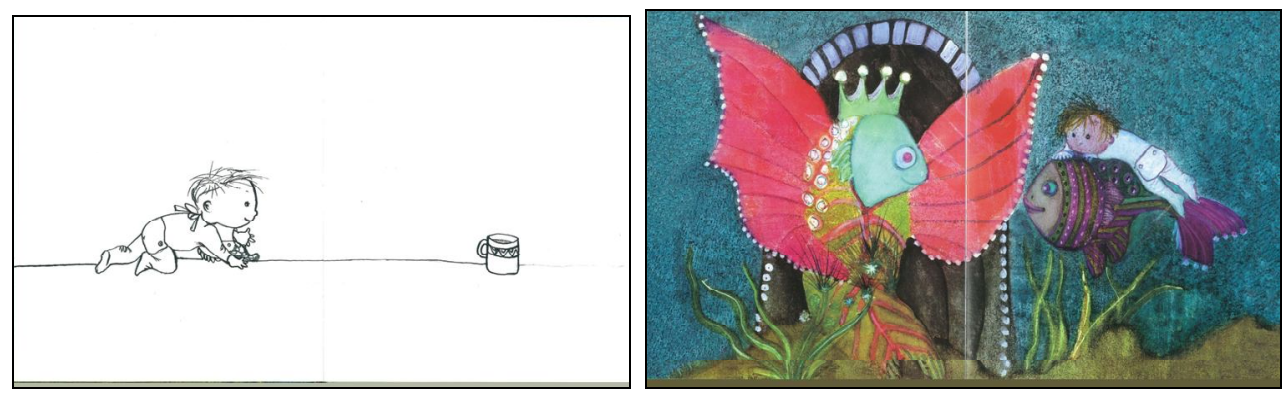

Figura 2.92 - Oposição página vazia versus página preenchida

Na cena-página seguinte, o bebê está totalmente envolvido pelo universo das sereias quando há uma interrupção. Introduz-se a palavra. Sebastião é chamado à superfície. 
A palavra aparece como característica da imagem, remetendo à linguagem das histórias em quadrinhos. Um balão exclamativo traz o título da obra ou, agora sim, nomeia o protagonista. Os olhos da personagem evidenciam que está sendo chamado. Ele se chama, portanto, Sebastião.

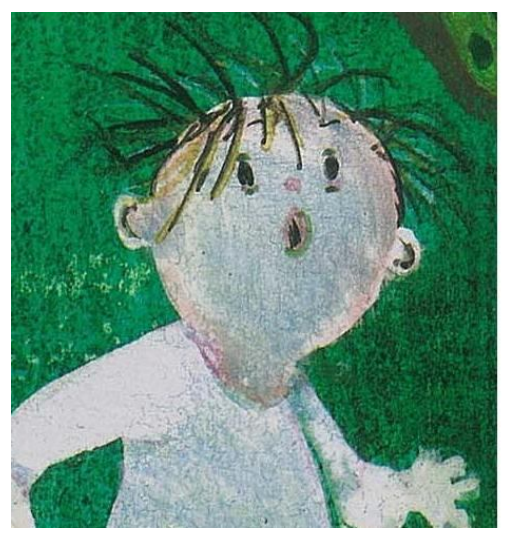

Figura 2.93 - Detalhe da expressão facial

Se a palavra vem em balão, por reconhecer a linguagem, o leitor sabe que há o interlocutor daquela fala. Alguém chama o menino Sebastião, pensa o leitor. Essa voz, provavelmente, vem da superfície. Sebastião, agora, deve voltar à tona, à realidade. Deve deixar o sonho, o espaço do maravilhoso.

Nota-se que nesta cena há a predominância de uma cor, o verde, em oposição às cenas anteriores, em que eram utilizadas cores diversas. A monocromia pode ser homologada a um estágio intermediário, nem realidade (preto e branco) nem fantasia (colorido), mas a não-realidade. Este percurso é proposto pelo quadrado semiótico, em que as categorias da expressão são homologadas às categorias do conteúdo. 


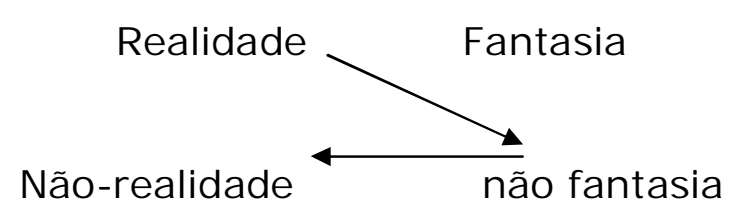

Quadro 2.1 - Quadrado semiótico

Além da relação semi-simbólica ${ }^{89}$, demonstrada pelo quadrado semiótico, observa-se que a cena das sereias remete ao intratexto (relação entre textos do mesmo autor), porque A Sereiazinha, outra obra analisada por este estudo, é citada. Existe o diálogo do ponto de vista temático, o mundo das sereias, e do ponto de vista expressivo, uma vez que a disposição das figuras na página remete um a outro texto da mesma autora, retomando inclusive o mesmo estilo, o que caracteriza o interdiscurso. Oliveira trata do tema, no artigo já mencionado, quando analisa a tela de Pablo Picasso intitulada As meninas, em releitura da obra de Velásquez:

\begin{abstract}
A esteria desse procedimento corrente nas artes, 0 tratamento que a semiótica propõe para dar conta das semioses textuais e discursivas não é nenhuma inovação ou ruptura com os fazeres próprios dos pintores. Ele, como se vê, parte do estudo da linguagem pictórica com base nos procedimentos semióticos que a estruturam, se a operação é entre textos, ela é abordada como intertextualidade e se ela é entre discursos, como interdiscursividade (2004, p. 133).
\end{abstract}

Há, pois, o intertexto, no primeiro caso explicitado, e o interdiscurso, no segundo. As sereias (personagens retomados) são citadas e a maneira de fazer (cores, formas, traço, disposição) é retomada.

${ }^{89}$ Semi-simbolismo, pela definição dada pela semiótica discursi as categorias do conteúdo e da expressão 


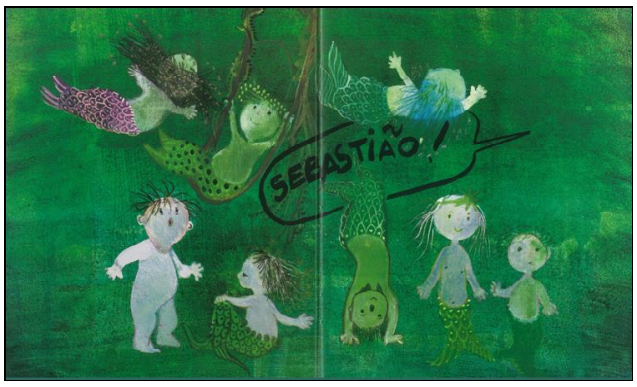

Figura 2.95 - Sebastião

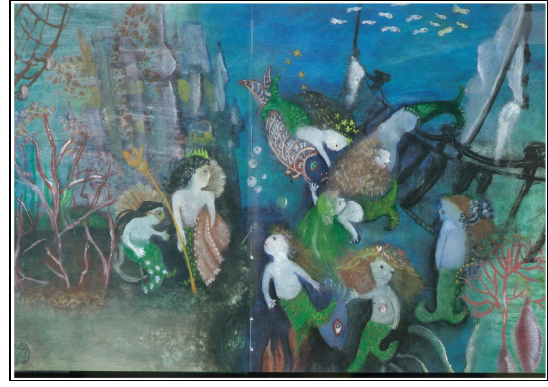

Figura 2.96 - A sereiazinha

Nesta cena, também, pode-se perceber o narratário instaurado, visto que as sereias olham para frente, para o interlocutor. Este "olho no olho" busca a cumplicidade, bem como corrobora o recurso metalingüístico, já observado anteriormente, pois rompe o espaço aqui (narrativa) e lá (enunciação), na medida em que convoca o leitor como partícipe da história, outro elemento metaficcional.

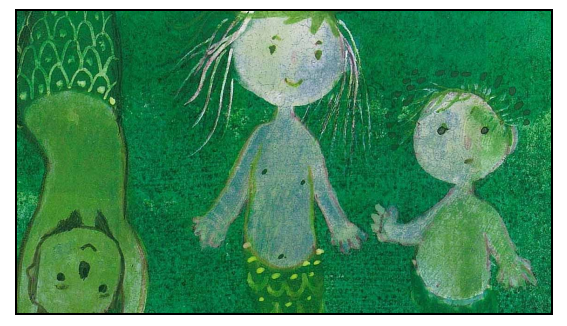

Figura 2.974 - Detalhe da instauração do narratário

A narrativa termina com humor quando a suposta mãe (figura feminina) tira o bebê da água e o coloca no varal. A cena volta a perder o colorido. 


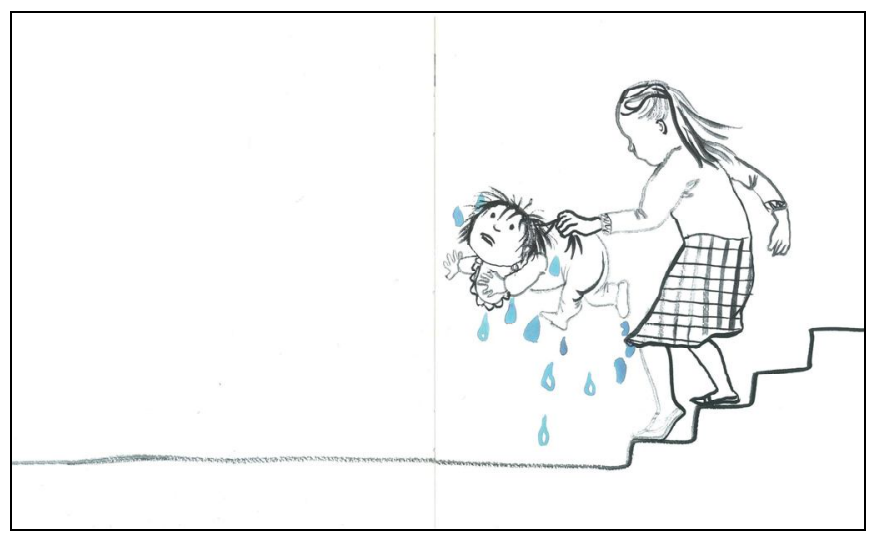

Figura 2.98 - Mãe conduz o menino para a realidade

Esta cena também é caracterizada como intermediária, remetendo ao quadrado semiótico esquematizado, pois há traços da realidade: varal, calcinha, meia, plantas, pássaro, mas o bebê está pendurado, o que não é usual nem possível, além disso, a cor azul das gotas rompe o preto e o branco homologado à realidade.

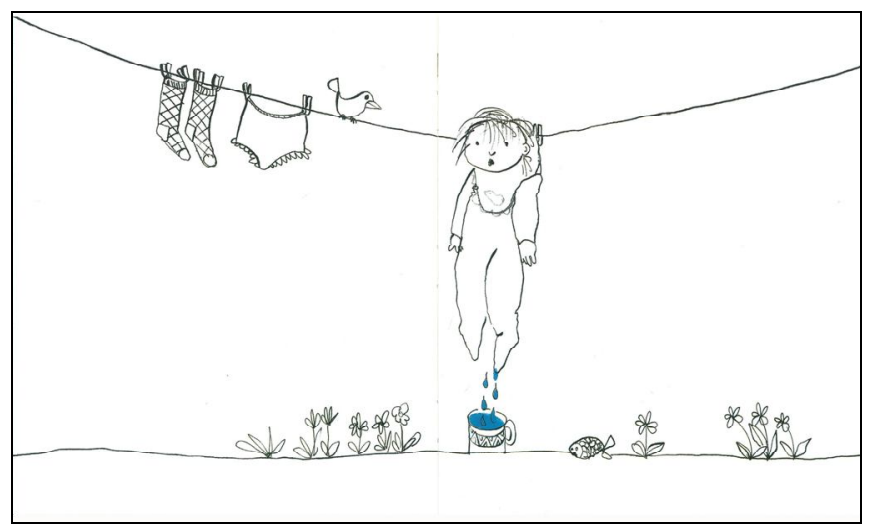

Figura 2.99 - Menino pendurado

Com isso, a narrativa termina na não-fantasia como se houvesse uma intersecção dos dois universos - fantasia e realidade. O bebê não está triste, nem feliz, mas surpreso, perplexo, o que é revelado pela expressão facial. "Preso" ao varal para "secar-se" da aventura 


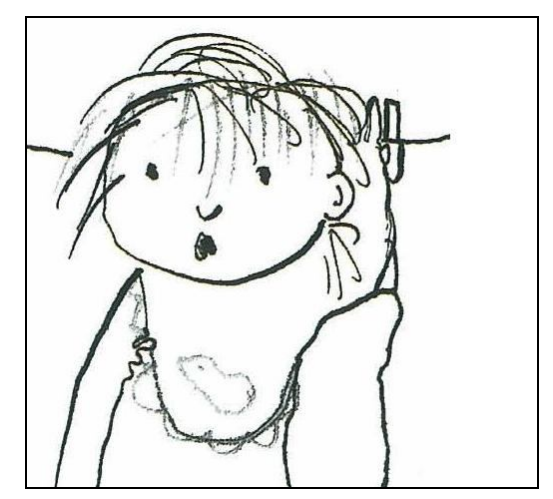

Figura 2.100 - Detalhe da expressão facial

Há, pois, o seguinte programa narrativo: sujeito-bebê é manipulado a querer-fazer (estar conjunto ao universo ficcional), figurativizado pelas águas e lendas (sereias) que envolvem este "misterioso" ambiente. Ali, o sujeito interage e se faz conjunto com a fantasia. Até que, por intimidação, o sujeito-adulto (mãe) manipula o bebê, e este sai do universo ficcional e volta à realidade, mas está encharcado da água da caneca, e resta a dúvida: é realidade ou imaginação? Eis a figura ambígua, elemento caro às obras literárias.

Virando a página, a narrativa é interrompida, graças à ausência das personagens ou mesmo de qualquer referência a elementos reconhecíveis do mundo natural. É uma página em que os elementos não são figurativos, há apenas cor:

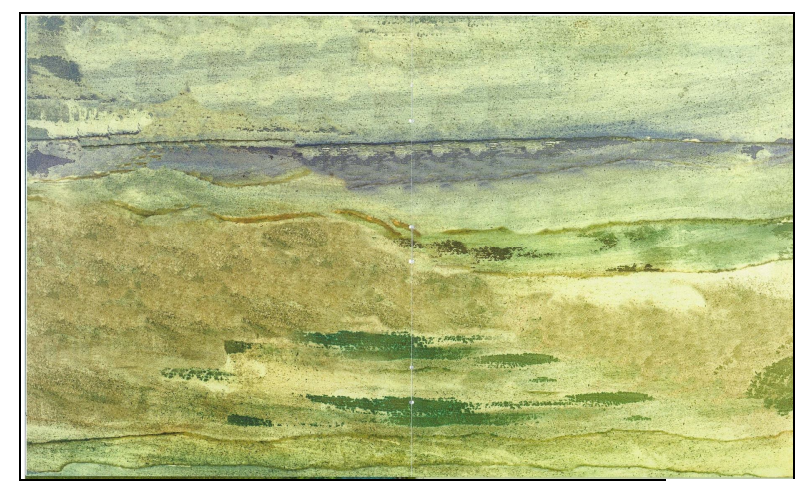

Figura 5 - Página de passagem 
Então, ao leitor é dada a oportunidade de recomeçar a história pelo outro lado.

\section{Pelo outro lado: outra história?}

A narrativa $B$, contudo, é muito semelhante à anterior, exceção feita à figurativização do cenário, dos elementos e da personagem. A variação discursiva e expressiva aparece da seguinte maneira:

1) A técnica empregada é mista: aquarela, marcadores e colagem. A colagem é a técnica acrescentada. Esse procedimento leva a crer em algo fora do contexto, visto que explicita para o leitor a ação de ter sido recortado de uma situação e colado em outra. O menino nesta narrativa não está, portanto, em seu contexto original. Ele foi recortado de um texto e colado em um novo, em uma nova história. Nessa técnica, a enunciação é percebida no enunciado. O recurso metaficcional é explorado pela enunciação mais uma vez. Isso se dá pela técnica empregada implicando o formante matérico na significação da obra. Segundo González e Zaparín, a colagem surgiu, na literatura infantil, quando se buscava imprimir maior subjetividade às descrições do espaço:

En la historia del arte, después de los primeros collages se produjo un paso más cuando, a base de una superposición de imágenes que no fuera una mera yuxtaposición, se intentaba desdoblar el espacio y aprovechar la profundidad de campo mental (2005, p. 13). 
Destacam-se, abaixo, exemplos de colagem em literatura infantil:

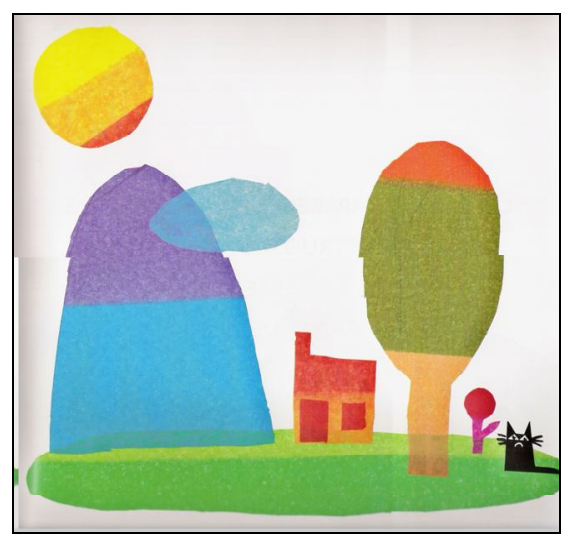

Figura 2.102 - El Gato que sonríe... (Eric Battut- França)

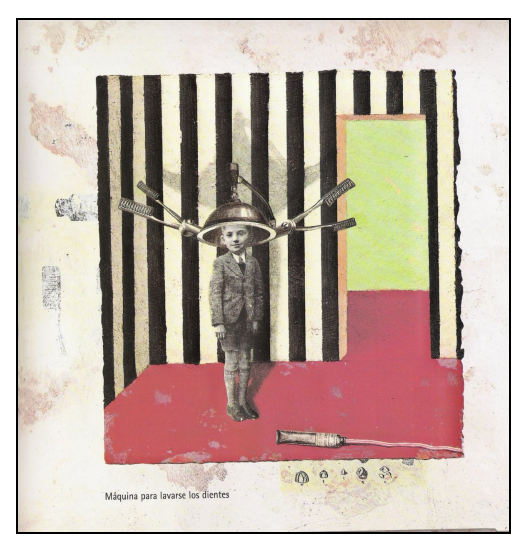

Figura 2.103 - Máquinas (Chloé Poizat- França)

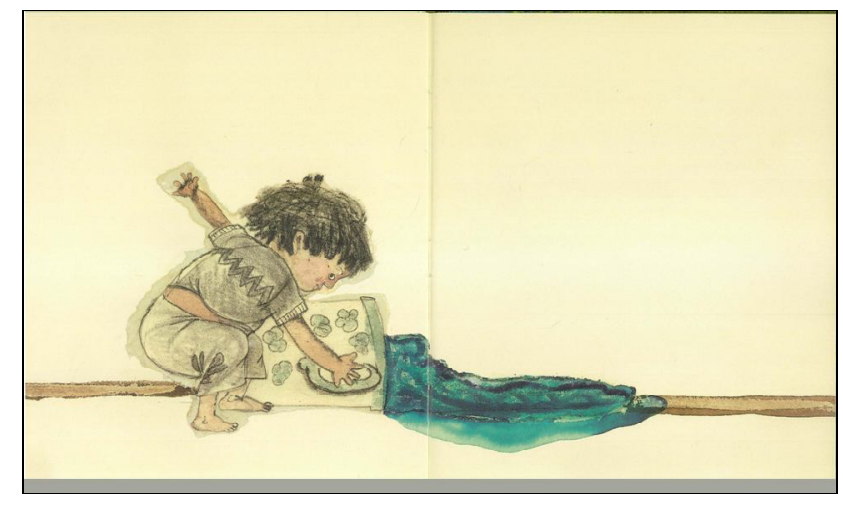

Figura 2.104 - Detalhe da colagem

Aponta-se que, no entanto, a técnica empregada por Bacelar simula a colagem quando sombreia o contorno da personagem Sebastião, distintamente dos exemplos apresentados, em que o recorte é mais evidente.

2) A personagem possui traços mais realistas, pois são mais detalhados, mas, com a simulação da técnica mista, reforça-se a ruptura com a realidade do traçado e a fidelidade com relação ao desenho das mãos, dos pés, dos olhos. Além disso, pela vestimenta (short e camiseta) e pelo andar, ao invés de engatinhar, percebe-se que a crianç 


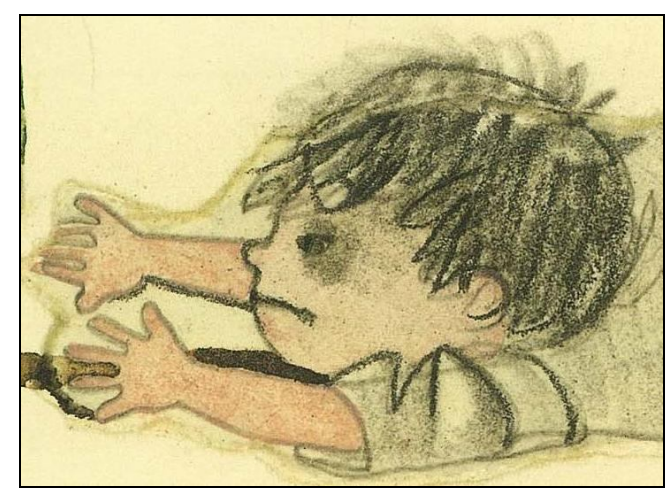

Figura 2.105 - Detalhamento (mãos, cabelo, olhos)

3) Há cores desde o início em tons de terra. Não existe, portanto, a oposição entre preto-branco, realidade, e colorido, fantasia, como na história do outro lado. Uma nova oposição é criada, homologando expressão e conteúdo, ficção versus metaficção, sendo aquela o colorido e essa os tons terra e a técnica da colagem. Simbolicamente, o formante cromático gera a idéia do envelhecido, corroborando o sentido de "fora de contexto", anteriormente ressaltado pelo matérico.

4) Nota-se que não há o peixe, o elemento desencadeador como na outra narrativa. O peixe era um elemento concreto, coerente naquela história. Nesta, a subjetividade será mais explorada. Um exemplo é a caneca ganhar proporções à medida que o menino a deseja ou a teme.

6) A principal ruptura, no entanto, está no plano da ficção. Enquanto na narrativa $A$, a recorrência era ao plano da fantasia, em um estilo de desenho mais "ingênuo"; nesta, há a recorrência ao surrealismo, que, conforme o Dicionário de pintura moderna, pretende:

Tratava-se da ocorrência de temas fornecidos pelo inconsciente, o acaso, a loucura, os sonhos, as alucinações, o delírio ou o humor, ou outros tantos estados psíquicos capazes de criar na imaginação do artista as zonas de "deslocamento sistemático", que precisava, depois, identificar e povoar. [...] torna-se para logo evidente que a principal contribuição da obra plástica [...] o imprevisto, pelo

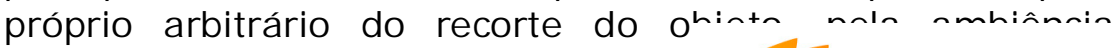
surreal que se desprende dela, a 
surrealistas trouxeram mistério angustiante a fixidez desconcertante (1981, p. 331-331).

Observam-se as mesmas características do surrealismo na obra de Manuela Bacelar, em que os elementos voam, e os objetos pertencentes a cenários diferentes são inseridos em novos contextos; também o cromatismo assemelha-se. Segue a paleta de cores para comprovar a afirmação:

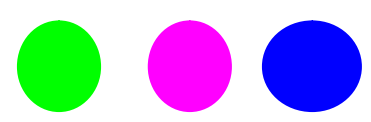

Figura 2.106 - Paleta de cores de Sebastião
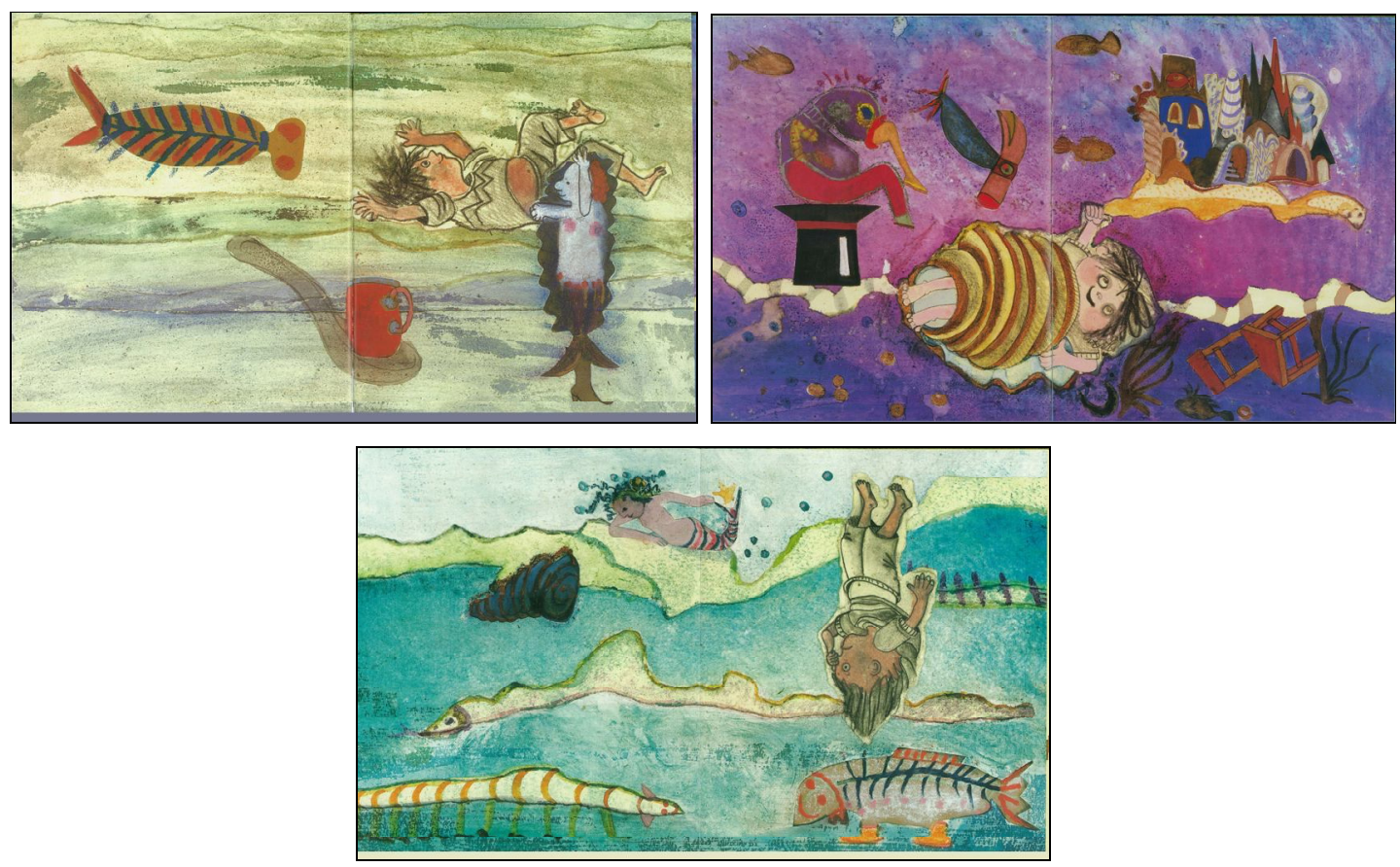

Figura 2.107 - Sebastião - Manuela Bacelar 


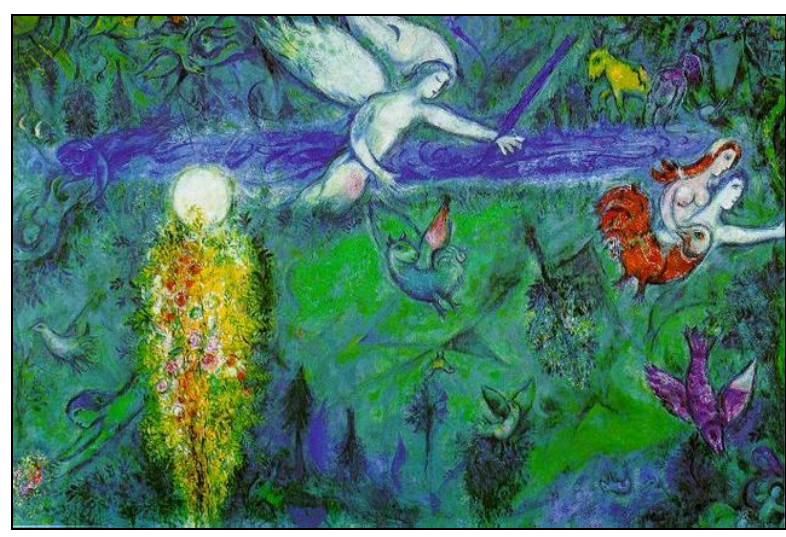

Figura 2.108 - Chagall

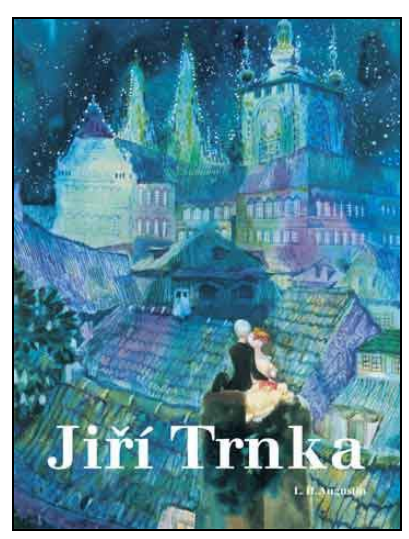

Figura 2.109 - Trnka

7) Não há a figura da mãe, mas há o chamado. O menino chega a uma praia e ele mesmo sai da água, deixando para trás a caneca, como se já tivesse vivido esta situação outras vezes. Ele já conhece o caminho e, portanto, é autônomo em seu processo. Sai d'água cabisbaixo; pela expressão corporal, visualiza-se a insatisfação:
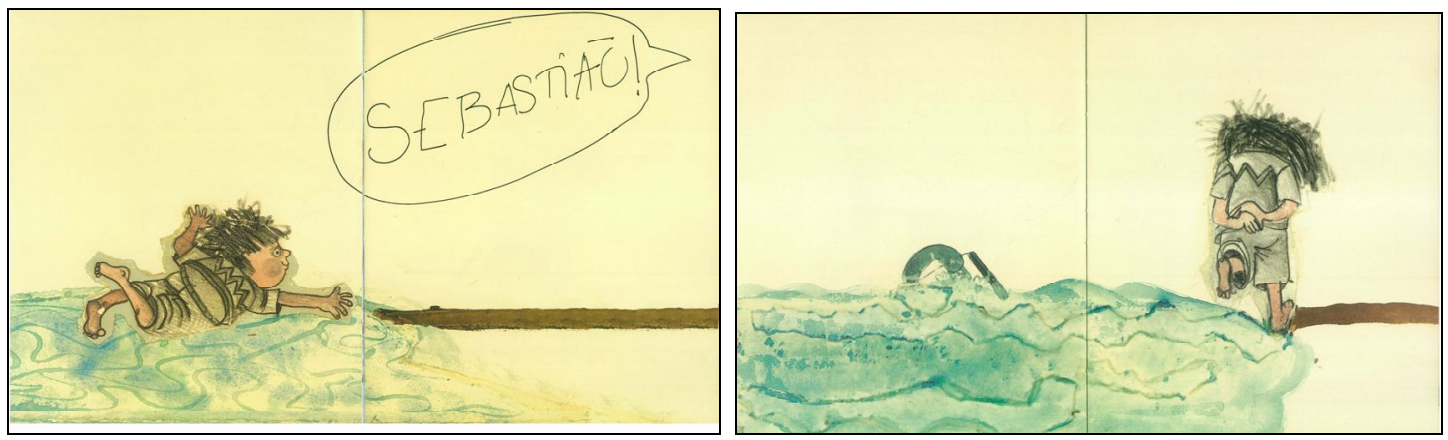

Figura 6 - Detalhe da expressão corporal

8) A última cena é muito semelhante à narrativa anterior, no entanto, o grau de autonomia permanece. Suas ações são individuais, não há a necessidade do outro, ele mesmo se pendura no varal. 

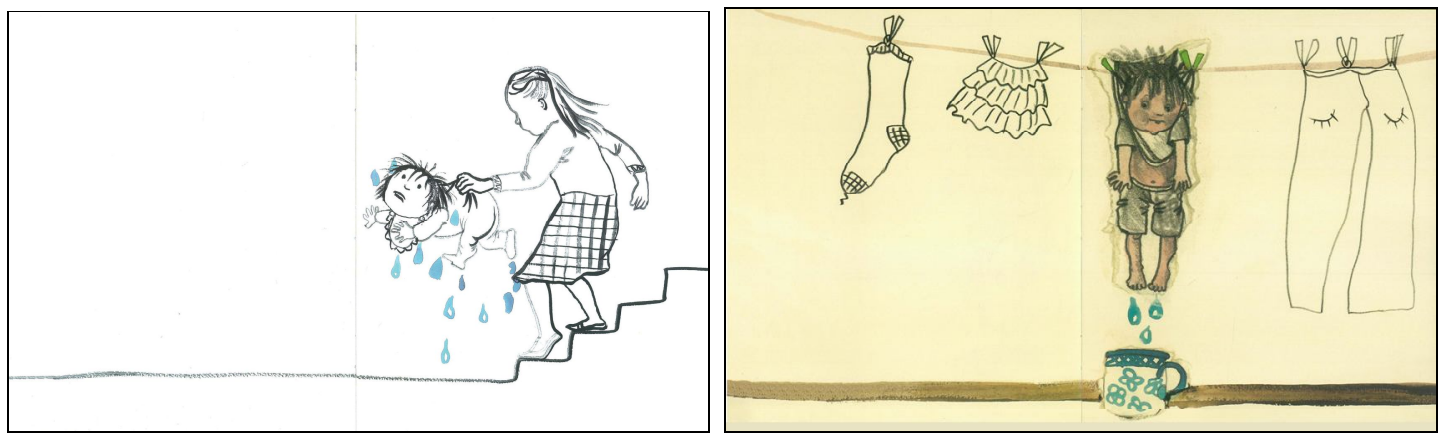

Figura 2.112 - Detalhe dos retornos (narrativa A/ narrativa B)

\subsubsection{O enlace das histórias: um livro de imagem}

As capas

As capas são recortes das imagens da história A. Nelas, não há referência à história B. Isso pode autorizar a leitura da junção de duas histórias como uma única narrativa.

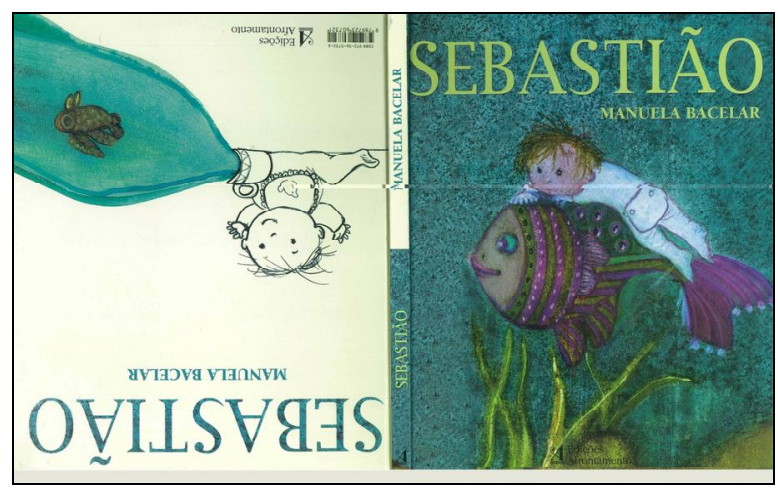

Figura 2.113 - As capas 


\section{A diferente caracterização dos protagonistas}

Apesar do mesmo nome, Sebastião, os protagonistas apresentam características distintas. O protagonista da história A é um bebê, já da história $\mathrm{B}$ é um menino. O cromatismo da história B pode criar a atmosfera do envelhecimento, assim, propõe-se como uma leitura possível que a entrada do garoto no universo da fantasia é recorrente, tanto que o menino mais amadurecido já conhece seu itinerário e está habituado a ele. Há, portanto, uma circularidade que, aos poucos (pela cor, pelas formas, pela proporcionalidade), envelhece, amadurece, torna-se autônomo.

\section{A intertextualidade verbal (a palavra em ausência)}

No contexto português, é inevitável pensar sobre o nome Sebastião e não associá-lo ao mito-lenda da volta do Rei Sebastião que, depois de se perder nas águas, voltaria a Portugal para salvar seu povo. O mito dá nome ao fenômeno do sebastianismo que é definido como:

Termo proveniente da civilização portuguesa que, originariamente (final do século XVI), designava a crença muito difundida no retorno de um de seus reis, D. Sebastião (155-1578), morto na batalha de Alcácer-Quibir (1578), em luta contra os mouros. Posteriormente, o termo reapareceu por ocasião de crises nacionais [...] D. Sebastião encarnava o Encoberto que voltaria para livrar o reino lusitano do jugo espanhol (SERRÃO, 1985, p. 509).

A obra em questão apresenta um Sebastião que entra e sai do mar de forma circular e recorrente, chegando mesmo a envelhecer. O mar é representado como um universo fantástico, o espaço da liberdade, mas existe sempre alguém que chama e quebra o sonho.

A obra de Bacelar seria, então, uma releitura do mito do Rei Sebastião. Ler a narrativa sem recorrer ao intertexto 
no entanto, a ausência da alusão gera uma narrativa com humor, pelo inusitado do varal, mas sem sentido entre as histórias. A ligação não tem relação do ponto de vista da seqüência narrativa. Elas não se cruzam, afinal contam a mesma história. São histórias paralelas, mas, pela circularidade que impõe traços temporais, graças ao envelhecimento, os recursos plásticos autorizam a ligação em uma única história associada pelas categorias da expressão.

Com a ajuda da intertextualidade, a obra Sebastião reitera a idéia de objeto-livro, dado que a manipulação, para além da mecânica do livro, torna-se fundamental para a significação deste texto. No cenário português, sabe-se, pois é lenda, que Sebastião mantém um ir e vir (marterra) dado ao chamado do povo português, que sempre que está em perigo pode recorrer ao seu rei Sebastião.

A lenda não fica circunscrita à mediação do adulto em Portugal, visto que é uma história corrente na tradição oral. 


\section{CONTEXTO BRASI LEI RO: ENTRECRUZAR DE CONFLITOS}

Quem parte treme, quem regressa teme. Tem-se medo de se ter sido vencido pelo Tempo, medo de que a ausência tenha devorado as lembranças. (Mia Couto)

Ao trilhar veredas conhecidas, duas questões cobram o pesquisador: o distanciamento necessário à análise crítica e o cuidado com a tendência a julgar com maior condescendência (ou, talvez, com maior rigor) o que é local. Assim, para um estudo que se pretende comparativo, esse é o desafio imperioso ao qual se propõe. Lobato aposta que a distância aguça a crítica:

Vejo ao longe a ave exotica: a Europa. Não mais o projeto antigo da aldeia minhota, mas Paris. Acho que só de lá posso ver bem e bem estudar este Brasil. Cá dentro somos um pau da floresta, e os paus das florestas não podem fazer ideia das florestas em conjunto. Falta-lhes o longe da perspectiva aerea. Aquele soldado de Stendhal que andou perdido uma porção de tempo, muito se admirou mais tarde quando the disseram que "aquilo" havia sido a famosa batalha de Waterloo. Tenho de colocar-me longe para olhar e ver se o Brasil é coisa que mereça consideração (LOBATO, 1946, p. 167).

Sem poder seguir os ensinamentos do pai do sítio, cabe à análise deitar olhos sobre o que the pertence. Desde já, portanto, adota-se inversamente a postura anterior àquela sobre o território alheio. Visto que o solo agora é local, abrem-se as veias sensíveis para tocar, cheirar, apalpar a realidade brasileira, que, por vezes, ofusca por suas desigualdades e seus contrates, que geram sobretudo a violência - ao ser humano, à natureza, à vida, aos sonhos. Ser brasileiro é viver um paradoxo: olhar e não querer ver a sua condição de miséria e olhar e querer ver a beleza impingida a esse território. 
Em entrevista ao Roda Viva - Flip em 2007, o autor moçambicano Mia Couto citou Agualusa, autor angolano, quando afirmou que ser pessimista diante da miséria é um luxo. Tomando o ensinamento daqueles que partilham problemas similares, o pesquisador olha, como dizia outro poeta, com "olhos livres", apesar da certeza da perspectiva utópica e da crueza da realidade, para aquela miséria sofrida, porque própria.

Viver no Brasil é estar em constante desafio. Andar por alamedas com casas cinematográficas e cair em ribanceiras que depositam seu lixo em córregos ao ar livre; trafegar por largar avenidas com carros importados e observar famílias que vivem em sofás-sucatas e utilizam fogueiras de papelão como aquecedor nas noites frias: este é o retrato de um Brasil urbano, que se vangloria por abrigar todos os povos, mesmo que isso se dê em porões em situação subumana, como no caso dos latino-americanos e dos africanos em situação ilegal nas confecções do Bom Retiro.

\begin{abstract}
Ah, São Paulo, São Paulo! E as suas caras diferentes, caras rosadas e pretas, caras satisfeitas e caras deprimidas, sujas e malcheirosas, perfumadas e gordurosas. Todas as cidades são muitas dentro de uma só, tal como acontece com as pessoas: todas são uma merda e poesia (SUAREZ, 2005, p. 36).
\end{abstract}

Entretanto, mais adentro, no interior, há abundância de águas que correm por todos os lados (Solimões, Amazonas, Paraná, Cuiabá, Tietê, Negro, São Francisco...), entrecruzam-se em bacias e geram vida e geram morte - ciclo natural, eis a beleza. Água que cura, água que mata. Das secas às enchentes, a natureza governa o país tropical, em que as mães d'água, os sacis, os minhocões habitam e ensinam o imaginário popular, mas que pouca credibilidade adquiriram diante dos homens que planejavam retificação de rios, asfaltos, metrôs, barreiras, hidrelétricas. 0 país tem pressa e há de ser o país do futuro! As questões culturais são deixadas de lado em detrimento do crescimento acelerado que o sistema capitalista demanda. Condição inexorável desde o séc 
Por outro lado, há vida na margem esquerda do rio. Vida precária de roçado nos grandes latifúndios. Vida de colonos, assim chamados por seus senhores, apesar da independência datar do início do século XIX. Abundância de verde, em que o Boitatá era lenda da proteção das matas, mas a ganância venceu o mito, e o progresso, com suas queimadas e colhedeiras, substitui os homens e seus sonhos nas lavouras. Crescimento acelerado para os produtores de soja, que devem abaixar a calha do rio para escoar seu produto com rapidez. Parece que o discurso uniformizado do crescimento sustentável invade até as pequenas comunidades ribeirinhas que viviam de pesca e artesanato, mas que hoje, por ação midiática, articulam com fluência as imposições de um país globalizado.

Olhar para o Brasil é viver a natureza em constante batalha com o humano. As cores infinitas da Mata Atlântica, do Cerrado, da Amazônia, do Pantanal abafadas pelo cinza do progresso e do crescimento acelerado. Há muita gente e essa gente precisa sobreviver, precisa de emprego. Indústrias, comércio e tecnologia são as soluções à mão: o capital move o país, esta é a lei de mercado.

Não se pode esquecer mais outro lado, aquele que chamou atenção dos portugueses quando do "achamento" da Terra de Santa Cruz, ou seria Pindorama? - o litoral. Ali, estão as maravilhas e a vastidão do mar e das serras que compõem o cartão postal nacional: a cidade maravilhosa, a Veneza brasileira, a cidade com atabaques, berimbaus, ritos e crenças. Atrativos turísticos de primeira linha no mercado comercial, claro que aliados à exploração sexual das Lolitas sonhadoras de um país com grandes dimensões.

País multicultural, multirracial, multi para não se entender, e dificuldade imensa para olhar o que o cerca, afinal tanta diversidade o cerca. O pai, a metrópole, chora por sua pequenez, e a colônia, o filho, angustia-se por sua imensidão.

Apesar de tudo, ou por isso, a educação ainda está desacelerada nas escolas multiseriadas, em que o professor leigo trabalha em três 
períodos e cursa a faculdade obrigatória, à distância, instituído pelo Normal Superior. Talvez, uma conquista diante de cenário tão macabro.

A escola e os livros constituem-se como opressores diante da diversidade, como revela o narrador machadiano em Conto de Escola, o qual aprendeu nesse lugar somente duas coisas: a corrupção e a delação. Cenário escolar do século XIX que perdura até o início do século XXI. Todavia, como é bordão nacional: a vida ensina! A vida no morro, a vida na favela, a vida na rua, todas essas ensinam.

Além da dificuldade fronteiriça natural e aquela demarcada pelo homem e sua democracia em castas, também a fronteira geográfica atropela a nacionalidade. Os limites latino-americanos existem. Determina-se o país selvagem de língua portuguesa como a potência do cone sul. Apaziguador e gerador de conflitos: Colômbia, Venezuela e Bolívia. Todos tremem diante desse colosso multirracial. E sua internacional Amazônia torna-se, a cada dia, mais internacionalizada, como todos querem: a união dos povos! Contudo, este país tão alegre e receptivo, em momento algum, sente-se parte da América Latina e, por vezes, até rivaliza, como nos momentos em que a bola rola nos gramados, ou, de maneira mais científica, como revela Eduardo Lourenço:

Tudo se passa como se o Brasil, em confronto com a herança européia, ou da miragem européia, usufruísse de um estatuto completamente diferente à parte no conjunto da América Latina. Muito cedo começou a existir o dispositivo que devia dar à cultura brasileira a tonalidade única que a iria distinguir no mundo, hoje sobretudo. Há entre todas as antigas colônias espanholas, nascidas da conquista, ou se uma ocupação menos sangrenta, um ar de família que não existe entre elas e o Brasil (2005, p. 93).

Tantos problemas vividos, no entanto, aproximam os países vizinhos: invasão e colonização européia, desigualdade social, golpes militares, busca da identidade, torturas, "invasões bárbaras", influências culturais dos irmãos milionários, entre outros. A condicão social avanca sobre a imposição lingüística e balança as fronteiras 
querem aqueles que pregam a união latino-americana, pela similaridade da situação, a América Latina vive nos brasileiros:

Sin embargo, frente a la opresión, el saqueo y el abandono, nuestra respuesta es la vida. Ni los diluvios ni las pestes, ni las hambrunas ni los cataclismos, ni siquiera las guerras eternas a través de los siglos y los siglos han conseguido reducir la ventaja tenaz de la vida sobre la muerte. Una ventaja que aumenta y se acelera: cada año hay 74 millones más de nacimientos que de defunciones, una cantidad de vivos nuevos como para aumentar siete veces cada año la población de Nueva York. La mayoría de ellos nacen en los países con menos recursos, y entre éstos, por supuesto, los de América Latina. En cambio, los países más prósperos han logrado acumular suficiente poder de destrucción como para aniquilar cien veces no sólo a todos los seres humanos que han existido hasta hoy, sino la totalidad de los seres vivos que han pasado por este planeta de infortunios (Discurso de Gabriel Garcia Marquez quando recebeu o prêmio Nobel de Literatura, $1982 . \quad$ Disponível em: <http://www. ciudadseva.com/textos/otros/ggmnobel.htm> Acesso em: 27 jul. 2008).

Abandona-se o contexto sociopolítico-geográfico para mergulhar na ficção. Todavia, ela está sempre na realidade, como ensina Antonio Candido:

A literatura é essencialmente uma reorganização do mundo em termos de arte; a tarefa do escritor de ficção é construir um sistema arbitrário de objetos, atos, ocorrências, sentimentos, representados ficcionalmente conforme um princípio de organização adequado à situação literária dada, que mantém a estrutura da obra. [...]

Nos países da América Latina a literatura sempre foi algo profundamente empenhado na construção e na aquisição de uma consciência nacional, de modo que o ponto de vista histórico-sociológico é indispensável para estudá-la. Entre nós, tudo se banhou de literatura, desde o formalismo jurídico até o senso humanitário e a expressão familiar dos sentimentos. Por isso é difícil delimitar esse universo insinuante e multiforme (2003, p. 179 -180). 
Segundo Alcântara Machado, em romance do início do século XX, a nacionalidade brasileira nasceu do encontro entre três raças: "Durante muito tempo a nacionalidade viveu da mescla de três raças que os poetas xingaram de tristes: as três raças tristes" (Brás, Bexiga e Barra Funda. São Paulo: Moderna, 2006). Mas, como se sabe, ela não parou por aí e a mestiçagem caracteriza a nacionalidade, como as bricolagens artísticas.

Diante de tanta diversidade e capacidade de assimilação, talvez o Brasil tenha perdido a habilidade de olhar para fora. Este reflexo da diversidade e da imensidão sentidas está em discurso.

No que diz respeito à literatura, havia urgência em se definir a brasileira, que não desejava ser um modelo europeu.

No Brasil, ao contrário dos países americanos que conheceram grandes civilizações pré-colombianas, é impossível pensar num processo civilizador à margem da conquista européia, que criou o país. [...] A nacionalidade brasileira e as suas diversas manifestações espirituais se configuraram mediante processos de imposição e transferência da cultura do conquistador, apesar da contribuição (secundária em literatura) das culturas dominadas, do índio e do africano, esta igualmente importada (CANDIDO, 2003, p. 177).

A mestiçagem transculturada marca a nacionalidade brasileira e suas manifestações artísticas. Em literatura infantil, um fenômeno marca a nação tupi iletrada: Monteiro Lobato, e este polêmico artista faz seu "auto-retrato", que é mesmo o da arte brasileira depois do modernismo:

Ando com varias ideias. Uma: vestir nacional as velhas fabulas de Esopo e La Fontaine, tudo em prosa e mexendo nas moralidades. Coisa para crianças. Veio-me diante da atenção curiosa com que meus pequenos ouvem as fabulas que Purezinha Ihes conta. Guardam-nas de memoria e vão reconta-las aos amigos - sem, entretanto, prestarem nenhuma atenção à moralidade, como é natural. A moralidade nos fica no subconsciente para ir se revelando mais tarde, à medida que progredimos em compreensão. Ora, um fabulario nosso, com bich exoticos, se for feito com arte $\epsilon$ 
preciosas. As fábulas em português que conheço, em geral traduções de La Fontaine, são pequenas moitas de amora do mato - espinhentas e impenetraveis. Que é que nossas crianças podem ler? Não vejo nada. Fabulas assim seriam um começo da literatura que nos falta. Como tenho um certo jeito para impingir gato por lebre, isto é, habilidade por talento, ando com ideia de iniciar a coisa. É de tal pobreza e tão besta a nossa literatura infantil, que nada acho para iniciação de meus filhos (1946, p. 104).

O modernismo trouxe à literatura o desejo de ser nacional, de fazerse própria. Com o fenômeno Monteiro Lobato, a literatura infantil ganha forças de expressão nacional. Este grande visionário da arte editorial, desde sempre vislumbrou a inserção das imagens em suas produções literárias para crianças, porque ele mesmo era autor literário e artista plástico, mas nunca se aventurou a ilustrar suas próprias obras, para essa tarefa, tinha em mãos Belmonte e Votolino. De seus livros ilustrados e suas invencionices, desenvolvem-se os livros para a meninada brasileira.

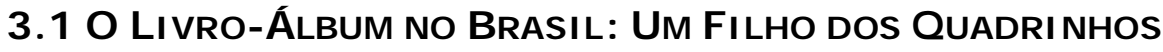

No Brasil, o livro infantil ilustrado nasce das influências da revista O tico-tico, de 1905, segundo Mokarzel, em artigo para o site de literatura infantil Doce de letra:

Um dos exemplos da existência do novo público consumidor infantil é o surgimento da revista O tico-tico, em 1905. Essa revista será um sucesso desde o seu lançamento e permanecerá no cenário editorial até os anos 60 . Ela foi responsável pela criação de personagens e histórias que contribuíram na construção de um imaginário infantil mais afinado com a realidade brasileira (Disponível em: <www. docedeletra.com.br>. Acesso em: 15 set. 2006).

O tico-tico dialoga com os personagens do sítio, e o imaginário infantil avança. Já nos anos de 1960 aparece uma nova revista em quadrinhos brasileira bastante inovadora, Pererê,

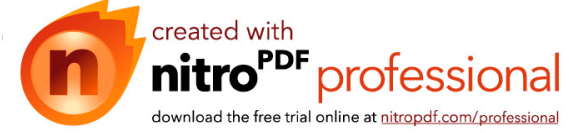


retirada precocemente do mercado no golpe militar de 1964, pois figurava entre a imprensa subversiva.

Ziraldo, no entanto, permanece e passa a ser um grande nome da ilustração no Brasil. Ele é um autor que migra das artes plásticas, sua carreira de formação, para as letras, e publica o primeiro livro-álbum brasileiro, Flicts (1969), que, além de articular palavra e imagem em total integração, agrega algo novo no cenário da literatura infantil brasileira, pois possui imagens que tendem à abstração. Por ser um artista reconhecido e em freqüente intercâmbio com outros artistas, vale lembrar que surgem, na mesma época, na I tália e na França, os álbuns O Pequeno azul e o pequeno amarelo, de Leo Lionni (1959), e Le Petit Chaperon Rouge, de Warja Honergger-Lavater (1965), este último sem palavras. Em ambos, é possível reconhecer o diálogo com a obra de Ziraldo, bem como associá-las ao movimento abstracionista de Mondrian, por exemplo:

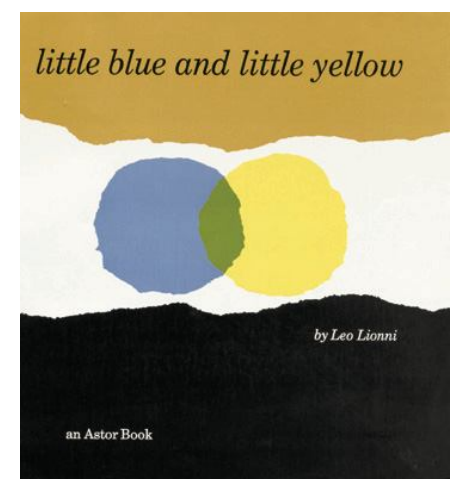

Figura 3.1 - O pequeno azul e o pequeno amarelo (1959)

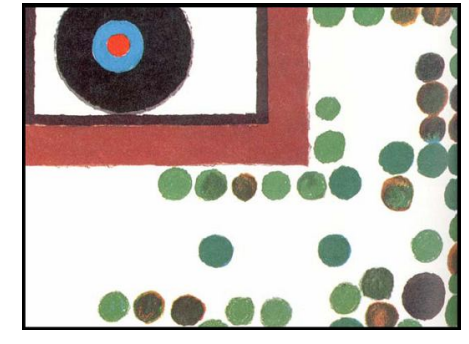

Figura 3.2 - Le Petit Chaperon Rouge (1965) 


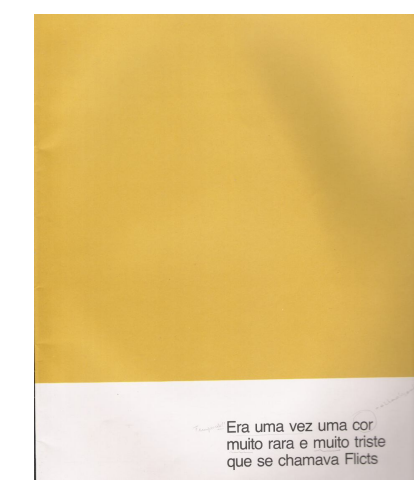

Figura 3.3 - Flicts (1969)

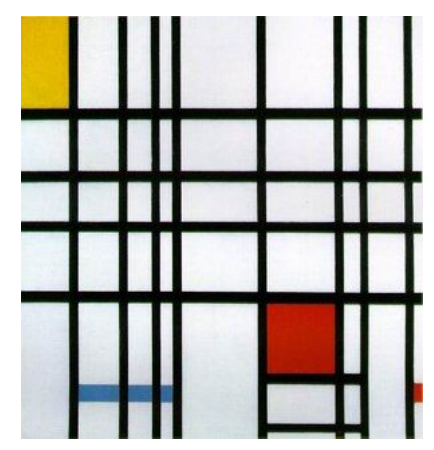

Figura 3.4 - Mondrian

Contudo, será em 1980 que a literatura infantil brasileira experimentará um boom no mercado editorial no que diz respeito ao livroálbum, visto que o momento de grande força da literatura infantil aconteceu na década de 1970, como marcam pesquisadores deste gênero de literatura - como Nelly Novaes Coelho, Marisa Lajolo, Regina Zilbermman, entre outros. Sobre a ilustração, área de interesse deste estudo, Morkazel afirma:

Mas, na verdade, a ilustração se difundiu no Brasil, principalmente na década de 80 , quando um novo visual pode ser percebido. Foi nesse período que a ilustração tornou-se mais ousada e o livro recebeu um tratamento gráfico que revelou maior preocupação com a estética. E o trabalho do ilustrador começou a ser reconhecido (Entrevista concedida ao site Doce de Letra. Disponível em: <www.docedeletra.com.br>. Acesso em: 15 set. 2006).

Assim como Portugal tem Manuela Bacelar com formação alémfronteira e desbravadora do livro-álbum em seu país, destacam-se, no cenário brasileiro, além de Ziraldo: Rui de Oliveira, Gian Calvi, Jô de Oliveira, Helena Alexandrino, Ângela Lago, Eva Furnari, Ricardo Azevedo, entre outros.

Uma nova geração surge no final dos anos de 1980 e início de 1990 dentro do estúdio de Ziraldo, ou seja, bastante marcada pelo processo de criação em equipe, como é próprio da natrínin- anma - 
Zappin, de Ziraldo ou os estúdios de Maurício de Sousa. Ali, os artistas aprendem a fazer à maneira do artista "principal", no caso Ziraldo ou Maurício de Sousa.

Roger Mello e Graça Lima surgem neste contexto, e a última artista nomeada conta, em entrevista, sobre o início de sua carreira:

Eu aprendi muita coisa com ele (Ziraldo). Ele foi o pai dessa geração gráfica. Quem não trabalhou diretamente no escritório tem algum tipo de contato com Ziraldo e certamente aprendeu muito com esse contato. [...]

Quem viu ele trabalhando, quem observou o que ele fez tanto em termos gráficos quanto em termos de processo e análise, soube aproveitar. Quase todos nós passamos por ele, de uma maneira ou de outra. Ele tem um trabalho que foi muito baseado nos grafis, nas revistas internacionais, na vanguarda da imagem; ele trabalhou muito com a imprensa alternativa e os trabalhos dessa época foram importantes para a cultura visual desses ilustradores que estão aí agora (Entrevista concedida ao site Doce de Letra. Disponível em: $<w w w$. docedeletra.com.br>. Acesso em: 15 set. 2006).

Graça Lima não só é ilustradora, mas também pesquisadora de literatura infantil e possui dissertação de mestrado defendida na PUC/RJ na área de designer gráfico, aliás, lá existe um centro de pesquisa que vem formando inúmeros pesquisadores na área do designer do livro infantil, como Guto Lins ${ }^{90}$.

Voltando ao trabalho de Roger Mello, autor selecionado no corpus do trabalho que se apresenta, verifica-se a sua origem no estúdio de Ziraldo e o trabalho em equipe como algo que marca o seu fazer e será explorado pela análise de Vizinho, vizinha.

As artes gráficas são uma grande influência da ilustração do Brasil, distintamente do que se verificou na ilustração de Portugal, como já pontuado. Eis alguns exemplos que justificam a afirmação, nesta ordem Votolino, Ziraldo, Ricardo Azevedo e Ângela Lago. Percebe-se,

90 Como revela a obra LINS, Guto. Livro infantil? - projetc subjetividade. Rio de Janeiro: Rosari, 2003. 
principalmente, nas últimas imagens apresentadas, um traçado próximo das artes gráficas/ da arte impressa:

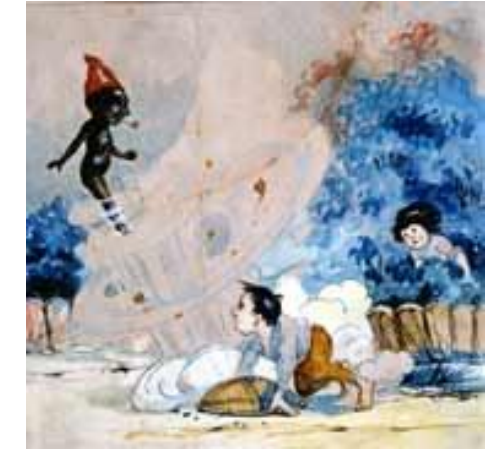

Figura 3.5 - Reinações de Narizinho - Votolino

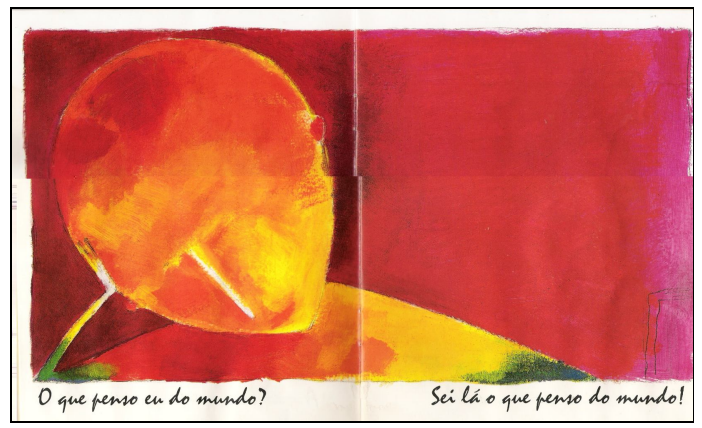

Figura 3.7 - Pedacinho de pessoa

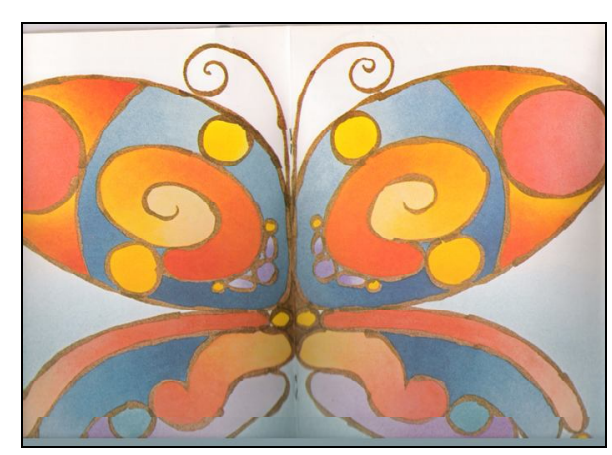

Figura 3.6 - A bela borboleta

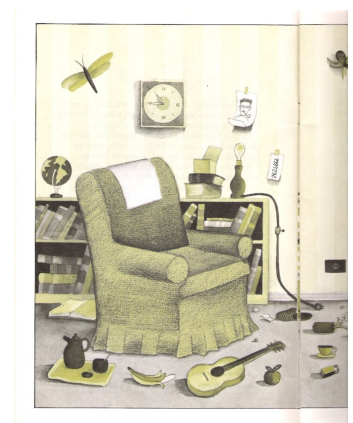

Figura 3.8 - 0 homem no sótão

Além disso, pelas imagens destacadas, percebem-se os estilos variados e as diversas técnicas empregadas. No último capítulo deste trabalho de tese, pretende-se detalhar a comparação entre Portugal e Brasil com relação às técnicas e aos "modos de fazer" suas obras literárias para o público-criança.

Para terminar este breve percurso histórico sobre o livro-álbum no Brasil, vale ressaltar que, desde a obra Flicts de Ziraldo, já se entende o autor com dupla vocação. Talvez, por influência das histórias em quadrinhos ou de Ziraldo ou dos dois ao mesmo tempo, nunca houve no Brasil o estranhamento de um autor artista plás 
literário, como foi relatado no cenário português, pelo pesquisador Gomes $^{91}$.

A autora Graça Lima, ainda em sua entrevista, destaca o valor artístico de Roger Mello, e, com as suas palavras, passa-se à análise de suas obras, que serão fundamento para as afirmações apenas esboçadas neste momento:

Eu não entendia o que o Roger estava fazendo ali. A gente trabalhava com o traço de Ziraldo, desenvolvendo os produtos dele, e o Roger já tinha um traço próprio maravilhoso e muito bem desenvolvido.

A viagem termina quando encerramos as nossas fronteiras interiores. Regressamos a nós, não a um lugar. (Mia Couto)

${ }^{91}$ Quando o contexto do livro-álbum português é trabalho, descrever a situação. 


\subsection{Roger Mello: Explosão De Experi ÊnCias}

Caminante, son tus huellas el camino, y nada más; caminante, no hay camino, se hace camino al andar. Al andar se hace camino, y al volver la vista atrás se ve la senda que nunca se ha de volver a pisar. (Antonio Machado)

\subsubsection{O Artista e suas Metamorfoses: Alterando o Cenário}

Roger Mello é um artista que pode receber o adjetivo de inovador. Formado em desenho industrial e programação visual, aproximou-se, primeiramente, da produção de histórias em quadrinhos, quando trabalhou ao lado de Ziraldo, na Zappin. Também experimentou a criação de desenho animado, fazendo cursos com o grupo Animation (equipe da National Film Board, do Canadá), isso revela a constante busca criativa pelo objeto artístico destinado ao público jovem.

Roger Mello é ilustrador, escritor, diretor de arte e designer num só profissional. Sua obra literária apresenta facetas desse caminho entrecruzado, muitas vezes bifurcado e, portanto, experimental no que diz respeito às suas propostas visuais e verbais.

O trabalho do artista sempre apresenta algo inusitado, novo, original; seja no estilo, seja na prática da própria composição do projeto gráfico. O artista produz arte em diversas linguagens, meios e com diversas possibilidades de diálogo entre artes.

Começou um trabalho autoral em literatura infantil com A flor do lado de lá, um álbum de imagem bastante interessante ${ }^{92}$. Ao longo de seu percurso, foram impondo-se desafios de criação que tangem desde o

92 Esta obra foi e será abordada em dois momentos neste trabalhn a caher nn canítıln "O livro de imagem em Portugal: um exemplo em Sebastião" no Cabelo - nova velha estória: emaranhados de vozes". 
estilo até a experimentação autoral em equipe, como no caso da obra Vizinho, vizinha, em que o artista convida outros dois ilustradores para partilharem a produção gráfica da história.

Ainda, suas produções para crianças propõem diálogos variados com a linguagem fauvista de Matisse, a arte africana, o Näif e o folclore popular brasileiro ${ }^{93}$, promovendo uma relação discursiva que tem expressão máxima na obra Griso, o unicórnio ${ }^{94}$.

O objetivo desse trabalho de tese é também, como já apresentado, investigar a produção gráfica contemporânea brasileira, para tanto, Roger Mello torna-se fundamental ao corpus deste estudo, tendo em vista seu caráter experimental e, pode-se dizer, ousado. A ousadia na experimentação das linguagens, além das propostas de composição com vários artistas e do enfrentamento inusitado do livro como objeto o diferenciam e autorizam um olhar atento sobre sua produção artística para crianças.

Três relações propostas por Mello interessam, em especial, à investigação, a saber: a relação do texto visual com a poesia, constituindo dois projetos gráficos interligados e com processos de criação diferenciados - Jardins, obra escrita por Roseana Murray e com desenhos de Roger Mello95, e Desertos desenhos-poéticos, de Roger Mello, que foram "ilustrados" pelas palavras-poemas, Roseana Murray. Apesar de esse processo de criação ter pontos de partida distintos, os projetos gráficos dialogam, pois apresentam pontos de aproximação na concepção gráfica das obras, como será demonstrado ao longo da análise.

A segunda obra de especial interesse ao estudo é em que o artista se propõe como ilustrador de um dos escritores mais estudados e importantes no Brasil: Guimarães Rosa, em Fita Verde no cabelo: nova velha estória. Tal proposta artística o aproxima de Manuela Bacelar na experiência com o clássico A sereiazinha, de Andersen.

93 Estas influências poderão ser reconhecidas ao longo das análises.

94 Griso é uma personagem em busca de sua identidade que, an nerrorrer nc ecnarn incorpora a tendência daquele lugar ou época.

95 Utiliza-se a palavra desenho, pois é assim que a obra apreser 
Para finalizar essa explosão de experiências, a obra já citada Vizinho, vizinha será analisada. Nela, Roger Mello é responsável pelo texto, pela ilustração de uma das personagens e pelo projeto gráfico; além disso, os outros dois personagens são desenhados por Graça Lima e Mariana Massarani, compondo, portanto, uma equipe de criação que exige diálogo entre as concepções sem causar impacto ou prejudicar a organização narrativa, pelo contrário, produzindo uma obra bastante original.

Diante dessa amostragem, pretende-se interrogar sobre os efeitos de suas experimentações e ousadias, no que diz respeito à eficiência de um projeto gráfico de literatura infantil, ou seja, as questões perseguidas pelo estudo que se apresenta continuam sendo aquelas ligadas ao diálogo palavra-imagem, à organização gráfica e ao projeto gráfico como elemento significativo do texto literário destinado às crianças.

\subsection{Diálogos entre Proj etos Gráficos: uma Proposta Poética}

Monteiro Lobato, no início do século XX, em cartas ao amigo Rangel desabafa que o universo da criança é bastante distinto do adulto, principalmente, no que se refere à literatura. O autor vai declarar que a memória da criança sobre as histórias é infinitamente maior que a de um adulto, pois esse já experimentou muito a vida. Daí as obras literárias da infância marcarem tanto a formação do indivíduo e serem lembradas pela vida toda ${ }^{96}$.

Apesar de muitos autores (pesquisadores ou literários) insistirem no fato de não haver distinção entre escrever para o público adulto e para as crianças, Zohar Shavit demonstrou bem que os autores adotam esta posição devido a uma auto-imagem fragilizada, isto é:

96 Referência à obra A barca de Gleyre - cartas trocadas entre c 
O ponto comum a todos estes escritores é a sensação de que escrever para crianças significa algo inferior, algo diferente de "literatura" tal como ela é entendida pelos intelectuais. Eles sentem que, como escritores para crianças, estão condenados a um estatuto inferior como escritores e que se encontram injustamente limitados na sua escrita devido à atitude da sociedade para com a literatura para crianças. Assim devido à fraca auto-imagem da literatura para crianças, os escritores tentam libertar-se do sistema infantil e desejam ser considerados simplesmente escritores (ou potenciais escritores) para adultos e com a negação de qualquer distinção entre escrever para adultos e escrever para crianças (2003, p. 68-69).

Lobato, como artista e intelectual "antenado", vislumbra sua vocação para a escrita destinada ao público infantil e já em sua época, início do século $\mathrm{XX}$, afirma-se como escritor para crianças:

Ah, Rangel, que mundos diferentes, o do adulto e o da criança! Por não compreender isso e considerar a criança 'um adulto em ponto pequeno', é que tantos escritores fracassaram na literatura infantil e um Andersen fica eterno. Estou nesse setor há vinte anos, e o intenso grau da minha "reeditabilidade" mostra que o meu verdadeiro setor é esse. A reeditabilidade dos meus livros para adultos é muito menor. Não posso dar a receita. Entram em cena imponderaveis inapreensiveis (1946, p. 346).

Além disso, o pai do sítio antevê a importância da recepção do livro na infância e os efeitos que aquele objeto estético vai desempenhar e é feliz em sua proposição quando afirma que a criança tem de morar no livro e não apenas lê-lo e colocá-lo fora:

Ando com ideias de entrar por esse caminho: livros para crianças. De escrever para marmanjos já me enjoei. Bichos sem graça. Mas para as crianças, um livro é todo um mundo. Lembro-me de como vivi dentro de Robison Crusoe do Laemmert. Ainda acabo fazendo livros onde nossas crianças possam morar. Não ler e jogar fora; sim morar, como morei no Robinson e n' Os filhos do Capitão Grant (1946, p. 293). 
A idéia de morar é a possibilidade de se tornar familiar, de pertencer, vivenciar a experiência estética, como Regina Zilbermman revela na proposta da Teoria da Recepção edificada por Jauss:

Caracterizando a experiência estética, Jauss explica por que é lícito pensá-la como propiciadora da emancipação do sujeito: em primeiro lugar, liberta o ser humano dos constrangimentos e da rotina cotidiana; estabelece uma distância entre ele e a realidade convertida em espetáculo; pode preceder a experiência, implicando então a incorporação de novas normas, fundamentais para a atuação na e compreensão da vida prática; e, enfim é concomitante antecipação utópica, quando projeta vivências futuras, e reconhecimento retrospectivo, ao preservar o passado e permitir a redescoberta de acontecimentos enterrados (1989, p. 54).

Morar em um livro seria conviver com os personagens, emocionarse com as aventuras e descobertas, enfim, acompanhar uma narrativa com altos, baixos, expressões de sentimentos e desenlaces felizes. Em literatura, contudo, a prosa narrativa não é a única possibilidade do artista literário. Eis que surge também no universo para crianças a poesia, mas essa não pode perder as características inerentes à literatura infantil, como formulado por Lobato.

A pergunta que desponta, no entanto, é: a criança tem meios e habilidades para decodificar esse signo tão complexo que é o poema? José Paulo Paes, um dos maiores poetas para crianças no Brasil, dedicou-se a esclarecer:

No meu modo de entender, a prosa e a poesia atuam de maneiras diferentes na sensibilidade infantil. As narrativas em prosa, com personagens, peripécias e desfechos, estimulam os mecanismos de identificação imaginativa. Durante a leitura de uma história desse tipo, a criança se enfia na pele dos heróis e vive com eles, e por eles, as aventuras narradas. Com isso, o mundo da simulação literária se torna indistinguível, durante o tempo da leitura, do mundo da realidade cotidiana. Já a poesia tende a chamar a atenção da criança para as surpresas aue podem estar escondidas na língua que ela fal 
dar conta delas. Por exemplo, a rima, ou seja, a semelhança dos sons finais entre duas palavras sucessivas, obriga o leitor a voltar atrás na leitura. Esta passa então a ser feita não linha após linha, sempre para frente, como na prosa, sim num ir e vir entre o que está adiante e o que ficou atrás. Com isso, desautomatiza-se a leitura e se direciona a atenção para o conjunto de significados do texto, não apenas para a seqüência deles. O que é um convite e uma ajuda à memorização (1996, p. 24-25).

A poesia, então, traria o exercício com a palavra. O significante levando ao significado e à descoberta da própria iconicidade da palavra ${ }^{97}$.

Se o próprio significante leva à imagem poética, valeria ilustrar poesia? E se isso fosse feito, qual seria o objetivo? Explicar o poema, ornar o texto, distrair o leitor do hermetismo da poesia ou, até mesmo, limitar as possibilidades imaginativas sugeridas pela poesia? Ou, ainda, envolver o leitor de modo a ativar todos os órgãos de sentido? Roger Mello apresenta sua concepção ao ilustrar poesia:

Ilustrar poesia se trata de trabalhar o vazio, e não de preencher os vazios. É claro que alguns poemas são mais narrativos, e toda prosa, tem um pouco de prosa poética. A poesia e a imagem têm muitos elementos semelhantes entre si: ritmo, forma, cor, movimento, silêncio... Se por um lado, o corpo do poema é por si uma forma, toda palavra, toda letra é também uma imagem. As letras são imagens que viraram signos que geram imagens para o leitor. Talvez por isso eu viva confundindo letras e imagens, e sons também ( $O$ diálogo de

Roseana

Murray e Roger Mello com Jardins e Desertos. Tigre Albino. [S.I.], v. 1, n. 3, 15 jul. 2007. Entrevista concedida a Annete Baldi. Disponível em: <www.tigrealbino.com.br>. Acesso em: 17 maio 2008).

97 Vale lembrar, que, ao longo desse trabalho, utilizou-se a denominação imagem para texto visual, aqui, imagem adquire a conotação de imagem poética, pois a palavra leva à imagem, como quer Octávio Paz em Signos em Rotação (1976):

"O poeta não descreve a cadeira: coloca-a diante de nós. Como no momento da percepção, a cadeira nos é dada com todas as suas qualidades contrárias e, no ápice, o significado. Assim, a imagem reproduz o momento da perrenrãn e forra o leitor a suscitar dentro de si o objeto um dia percebido. O vers ressuscita, desperta, recria" (p. 46). 
Há na concepção apresentada por Mello um encontro com a proposta de Octávio $\mathrm{Paz}^{98}$ : palavra é imagem. E o artista ainda percebe a sua real confusão entre letras e imagens, o que revela seu modo de fazer, em que as linguagens não obedecem a limites absolutamente demarcados, tanto do momento de concepção quanto na recepção.

Martin Salisbury acredita no caráter poético próprio também ao texto visual e, assim, propõe a ilustração da poesia como um diálogo subjetivo:

Abordar la ilustración de poemas es una empresa muy distinta a responder visualmente a la prosa narrativa. Un poema es un todo del que el lector puede extraer muchas modalidades de gozo personal, y es importante que el ilustrador no adopte un planteamiento demasiado literal. Normalmente, la buena ilustración de poesía pide que el artista sea más subjetivo de lo habitual. Forma un todo visual paralelo, un contrapunto a las palabras, sobre todo cuando la poesía es de tono lírico (2005, p. 104).

Diante deste novo desafio, isto é, investigar a relação palavraimagem (texto visual) na poesia, as obras Jardins e Desertos, de Roseana Murray, serão analisadas com o intuito de se observar se poema e desenho compõem um projeto gráfico coeso de modo a constituirem-se como um todo de sentido. Além disso, a obra deve ainda privilegiar aquilo que deveria ser inerente à obra literária: a sensibilização, o contato estético/estésico. Como observa Landowski, o cotidiano, por vezes, automatiza o olhar e a poesia seria um acidente neste cotidiano:

Na maior parte de nossas atividades cotidianas, das mais triviais às mais cientificamente sofisticadas, privilegiamos a eficácia prática, o poder-fazer ou saber fazer em detrimento de outros modos de relações possíveis com o nosso ambiente. Esquecemos que um outro olhar é possível, um olhar que ao nos fazer ver o mundo por ele mesmo, nos permitiria também ter conhecimento dele, mas de um modo menos imediatamente interessado: como objeto de contemplação e não como campo de ação, ou, na ação,

98 Ver nota de rodapé anterior. 
como parceiro antes do que como meio ou instrumento (LANDOWSKI, 2005, p. 94).

José Paulo Paes concorda com a abordagem semiótica quando reflete acerca da condição de a poesia desautomatizar o cotidiano:

Objetivo fundamental da poesia: mostrar a perene novidade da vida e do mundo; atiçar o poder de imaginação das pessoas, libertando-as da mesmice da rotina; fazê-las sentir mais profundamente o significado dos seres e das coisas; estabelecer entre estas correspondências e parentescos inusitados que apontem para uma misteriosa unidade cósmica; ligar entre si o imaginado e o vivido, o sonho e a realidade como partes igualmente importantes da nossa experiência de vida (1996, p. 27).

Uma obra literário-poética seja para adultos ou crianças deve agir sobre a sensibilidade daquele que a toma, que a manipula. A eficiência do projeto gráfico estaria em compor um todo de sentido coeso entre as mídias (verbal e visual) que proporcionasse ao enunciatário o acidente anunciado por Valéry no artigo "Questões de Poesia":

Coloquemo-nos no estado para o qual nos transporta uma obra, daquelas que nos obrigam a desejá-las mais, quanto mais as possuímos, ou quanto mais elas nos possuem. Encontramo-nos então divididos entre sentimentos nascentes, cuja alternância e contrastes são bem notáveis. Sentimos, por um lado, que a obra que age em nós convémnos tão proximamente que não podemos concebê-la de outra forma. Mesmo em alguns casos de supremo contentamento, sentimos que estamos nos transformando de alguma maneira profunda para sermos aquele cuja sensibilidade é capaz de tal plenitude de delícia e de compreensão imediata. Mas sentimos com a mesma intensidade, e como através de outro sentido, que o fenômeno que causa e desenvolve em nós esse estado, que nos inflige sua força, poderia não existir, e até que não deveria existir, classificando-se no improvável.

Enquanto nosso prazer ou nossa alegria está forte, forte como um fato, a existência e a formação do meio, da obra geradora de nossa sensação parecem-nos acidentais. Essa existência parece o efeito de um acası dom suntuoso do destino, e é ond $\epsilon$ 
observá-lo) uma analogia particular revela-se entre este efeito de uma obra de arte e aqueles de certos aspectos da natureza: acidente geológico ou combinações passageiras de luz e vapor no céu da noite (1999, p. 168).

Unir natureza à poesia ou mesmo dar a ver a poesia da natureza são os objetivos que envolvem essa travessia por alamedas floridas e desérticas, em que palavra-imagem/imagem-palavra estão soltas ao vento e são ordenadas conforme o desejo e sensações dos artistas. Roseana Murray explica:

Sou uma poeta da imagem. Eu vejo as imagens antes de tudo e tenho que correr atrás delas muito depressa para que elas não escapem, e tenho que dar conta disso com palavras. É um processo de concentração superintenso. Também há uma musicalidade natural na minha poesia, talvez porque tenha passado a maior parte da minha vida dentro da natureza, com os sons da natureza e porque amo o silêncio, me alimento de silêncio e sou muito contemplativa. Também amo as palavras e sua sonoridade e principalmente seus sentidos, é isso que é maravilhoso na poesia, uma palavra vai se desdobrando, gosto muito de ambigüidades, sinuosidades. Não gosto de certezas nem de nada fechado. Às vezes a palavra que a gente quer está escondida e pode levar até muito tempo para ela aparecer [...] então sim, tenho que revisar o poema, até reescrever, mas a imagem que vi está lá, preservada (Entrevista concedida à Revista Poiesis, 2007).

\subsubsection{Olhar(Es) I nusitado(s): J ardins de I magens Poéticas}

A palavra jardim, segundo o dicionário Aurélio, quer dizer: "Terreno, em geral com alamedas, onde se cultivam plantas ornamentais, úteis, ou para estudo" (1988, p. 375). O título da obra em questão traz o plural Jardins, ou seja, a obra poética apresentará mais de um jardim: "Ao fazer o Jardins: .. eu estava livre e sozinha. Mergulhei num jardim interno, em todos os jardins que carrego comigo e também nos impressionistas" ( 0 diálogo de Roseana Murrav

e Roger Mello com Jardins e Desertos. Tigre Albino. [S 
2007. Entrevista concedida a Annete Baldi. Disponível em: $<$ www.tigrealbino.com. br>. Acesso em: 17 maio 2008).

Além da informação a partir de fonte lingüística de referência e da própria proposta da autora, se a História for recuperada, muitas imagens de jardins importantes surgem ali, dentre eles: os Jardins Suspensos da Babilônia, o Jardim de Versalhes, os jardins japoneses com seus bonsais. Eternos jardins que são lembrados e esquecidos conforme tempos e estilos. Não esquecendo que muitas vezes os jardins são retomados, pois habitam os discursos interiores dos indivíduos. Eis alguns que ilustram a beleza e a vivência entre as flores: formas, cores e composição, que individualizam e dão sentido a um pedaço de terra.

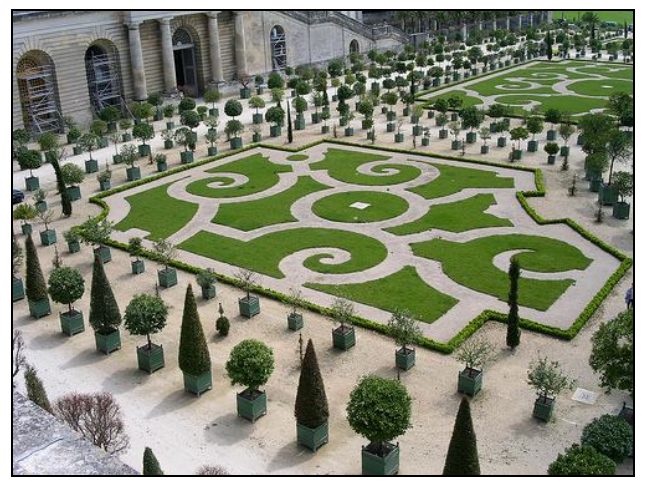

Figura 3.9 - Jardins de Versailles, criado por André Le Nôtre e construído para Louis XIV

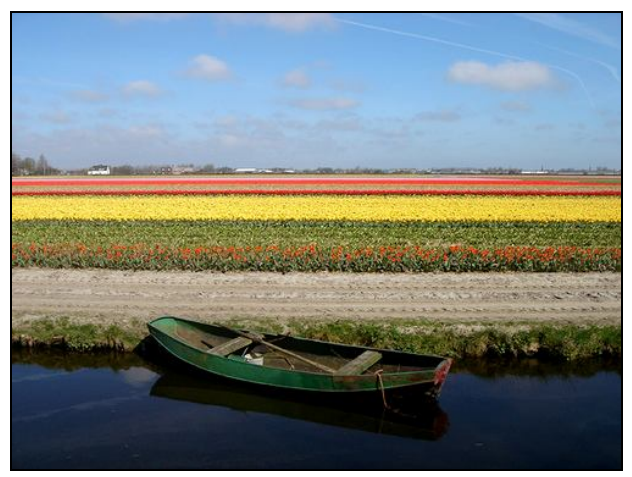

Figura 3.11 - Mirabell Garden, em Salzburg (Áustria)

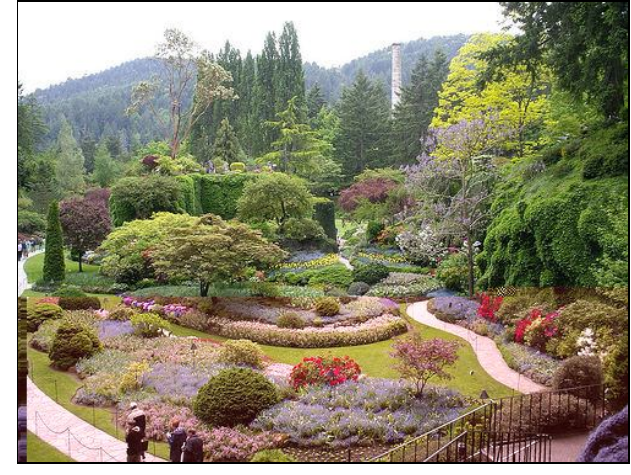

Figura 3.10 - Kirsten bosch Botanical Gardens Table Mountain - África do Sul

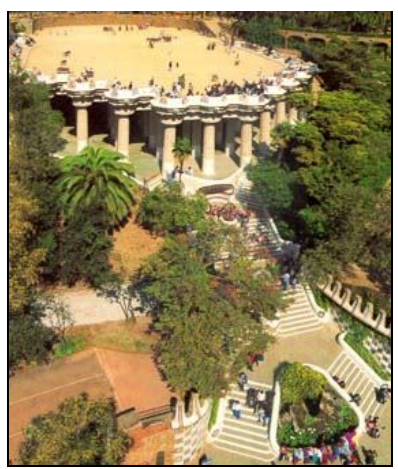

Figura 3.12 - Parque Guell de Gaudí (Espanha)

FONTE: <www.Cybervida/doze-dos-mais-belos-jardins.com. $b$ 2006 
O jardim, portanto, adquiriu sentido na sociedade graças à beleza, à afetividade e, às vezes, à funcionalidade, tendo em vista que imprimem identidade às cidades ou às regiões. Eles se organizam como discursos que revelam a presença do eu (individualidade ou coletividade). Pode ser o jardim do Bonifácio ou o jardim de estilo inglês concebido, por exemplo, para o Parque da Luz, na cidade de São Paulo. Assim, recortes, formas, cores e aromas serão distintos e diferentemente distribuídos, no entanto, os recortes, as formas, as cores e os aromas são essenciais à composição, ao arranjo e, sem dúvida, apresentam a subjetividade daquele que os organiza, como em um discurso lingüístico.

Os jardins colocados em papel permitem que o leitor avance pelos caminhos em busca de variantes e invariantes que desenham esse acidente em meio ao quase sempre preto e branco do cotidiano das letras e da vida:

Como a percepção diária está por demais viciada, o espelhamento realista confundir-se-ia com o dejá-vú e perderia o efeito; por isso, cumpre investir no diferente, que não precise coincidir necessariamente com o novo; pode ser o que permaneceu escondido ou reprimido, conforme faz Proust, cuja obra romanesca funda-se na recordação (ZILBERMMAN, 1989, p. 56).

Na obra que se apresenta, o jardim (ou jardins, como quer o enunciador) aparece instalado no discurso verbal e no discurso visual. Além disso, há um englobante que é o projeto gráfico. Esse já é apresentado na sobrecapa que envolve o objeto-livro.

Verde, alaranjado e branco com suas nuances apresentam o título, a autora, o autor dos desenhos e a editora. Também, graficamente, as cores e as formas criam imagens visuais de plantas (árvores) geometrizadas, envolvendo e convidando o enunciatário a olhar pelas frestas deixadas, recortes curvos que não representam nenhum objeto identificável, em princípio. 
A sobrecapa está recortada de maneira a deixar ver outro jardim, aquele que está na capa. Esse de cores mais intensas e vibrantes: vermelho, amarelo, azul, branco, preto e verde. Dentro, há brilho, fora, opacidade. A forma retangular do objeto livro se opõe às formas curvas das frestas, que delineiam formas abstratas muito características da natureza que, em geral, não obedecem à geometrização. Percebe-se uma oposição entre as formas e cores da sobrecapa (duas cores e tonalidades destas), uma geometrização, o que remete a uma arte mais "ingênua" ou, como querem alguns estudiosos, mais "primitiva" (associação com a arte própria ao continente africano) e, na capa (policromia), intensidade e desenhos mais delineados sugerindo maior complexidade.

A sobrecapa, ainda, apresenta uma figura plástica, tátil: um laço, que são duas fitas vermelhas, acetinadas e amarradas, desencadeando uma possível isotopia. Este não é um jardim em si, mas um álbum que apresenta Jardins: “Esbocei um caderno, com uma capa que envolvia o miolo, como uma pasta de desenhista que faz aquarelas de plantas" ( $O$ diálogo de Roseana Murray e Roger Mello com Jardins e Desertos. Tigre Albino. [S.I.], v. 1, n. 3, 15 jul. 2007. Entrevista concedida a Annete Baldi. Disponível em: $<$ www.tigrealbino.com.br>. Acesso em: 17 maio 2008).

A partir do convite, o enunciatário é manipulado a desamarrar as fitas e vasculhar este álbum, que também, pelo tato, sugere as texturas dos Jardins: maciez x aspereza. Esta capa apresenta a relação, que é determinante do gênero, como será demonstrado no capítulo final deste estudo.

O objeto livro constitui-se como algo a ser tocado, visto, cheirado, sentido, como um jardim. O objeto cultural - livro -, acidentalmente, expõe os elementos naturais para a fruição do leitor, como analisa Landowski (2005): 
Na experiência estésica [...] as coisas se revelam na sua "essência", "sem buscar outra justificação que a sua própria perfeição -, pode ocorrer que a realidade faça sentido de um modo quase fusional, como se o contato com o "perfume" dos objetos bastasse para tornar o sujeito plenamente presente ao mundo - e o mundo imediatamente significante (p. 94).
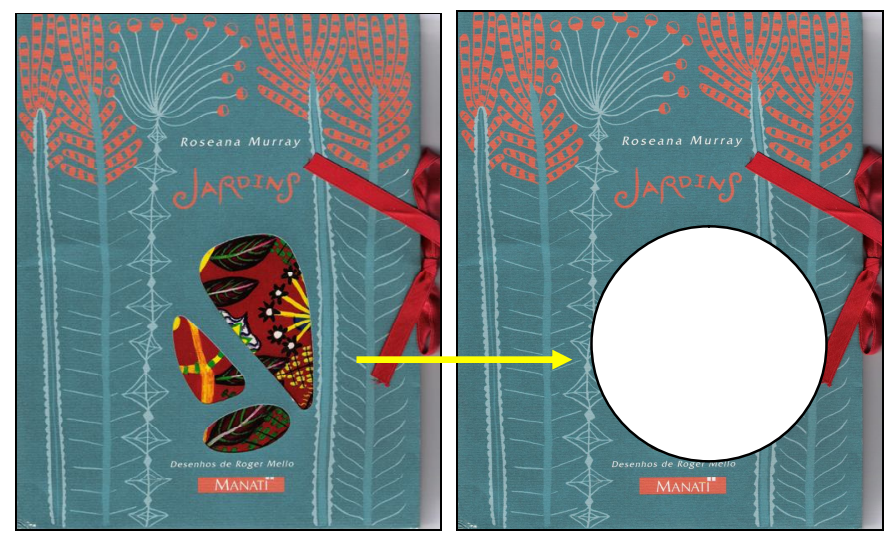

Figura 3.13 - Apresentação da capa

A página de rosto traz uma figura: uma pequenina rã, que possivelmente remete ao se habitat, mais uma vez, o jardim, impregnado de belezas: animais e insetos, formando o ciclo natural da vida.

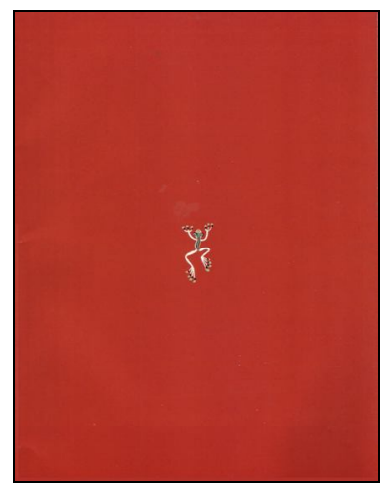

Figura 3.14 - Página de abertura 
Na página seguinte, a leitura da obra como álbum é reforçada, pois se identificam desenhos de folhas/plantas coladas com fitas adesivas, remetendo ao universo da pesquisa. Há um exemplar de cada espécie: folhas mais próximas do real, mais geometrizadas, estilizadas, mais abstratas. Nesta página, há a inserção de texto. Em uma das folhas à esquerda, Manoel de Barros faz uma espécie de prefácio da obra, enfatizando as qualidades da poeta:

Querida poeta Roseana, Gostei do seu Jardins. De suas guirlandas de palavras. Gostei de ler seu verbo e prender os perfumes, as cores, as formas e o sol sobre as flores. Há por certo uma poeta sensível às coisas da natureza neste Jardins. Isso eu vi e senti. Meus parabéns, cara poeta, um abraço afetuoso do Manuel de Barros (Campo Grande, agosto de 2001).

Na página direita, o título é retomado, bem como os nomes de Roseana Murray (autora), Roger Mello (autor dos desenhos) e Manati (editora). O fundo da página é de cor ocre, remetendo, mais uma vez, ao caderno de pesquisador, colecionador, que faz do papel tipo Kraft o depósito de seus exemplares. A cor neutra do fundo destaca as cores e formas diferenciadas de sua coleção, como é próprio em um álbum de pesquisa, em que as "vedetes" são as espécies diversificadas e raras.
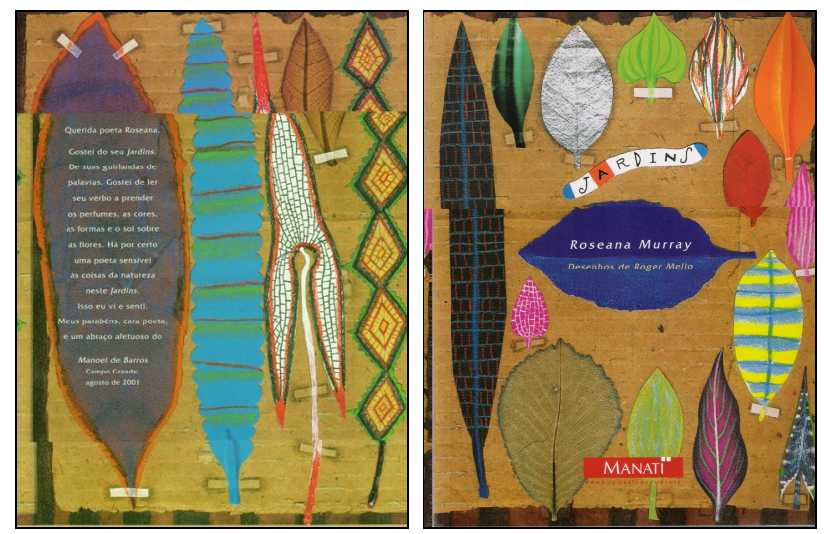

Figura 3.15 - Página de rosto 
Segue um modelo de álbum (pasta) de pesquisa, em que a coleta de espécies, observações, análises são fundamentais para as etapas seguintes da investigação ou da produção artística, não se sabe.

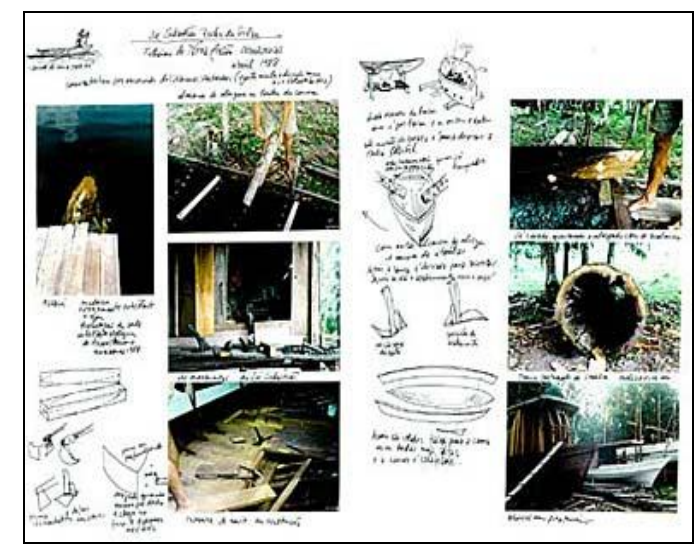

Figura 3.16 - Exemplo de uma pasta de pesquisador

O percurso vislumbrado pelo leitor é de que ele acompanhará a coleta de espécies de um pesquisador/colecionar/artista, dado que esse enunciatário está folheando um álbum. O leitor habituado à seqüência narrativa verá frustrada sua expectativa. A narrativa imaginada pelo leitor não se realiza, pois ele tem diante de seus olhos poemas que não apresentam a esperada seqüência narrativa. Não há história, não há personagens em conflito, não há tempo determinado (ou mesmo indeterminado).

Resta, porém, o cenário. Este sim é o elemento protagonista, ou seja, o leitor "recebe", "passeia" pelos Jardins de onde, possivelmente, foram retirados os exemplares colocados na primeira página. O leitor seguirá por jardins em busca de espécies, como um pesquisador/artista e, assim, percorrerá "jardins-mundo" em sua diversidade de formas, cores, aromas, organizações, deixando entrever os seus sentidos pelas palavras poéticas.

Palavra e imagem organizados pelo projeto gráfico convidam o leitor a um estudo de meio, em que a palavra criará s imsnam nnótirs o o texto visual contribuirá para a própria sensação । 
Palavra poética e imagem poética pretendem um todo de sentido que rapte o leitor para este universo. O enunciatário será instalado no vagar sensível da natureza e percorrerá uma seqüência narrativa: S1 (não conhece 0 jardim/percurso) $\rightarrow$ manipulação estética/estésica $\rightarrow$ performance $\rightarrow$ sanção positiva $\rightarrow$ conhecer os jardins e percursos do artista, pesquisador ou colecionador. Este é o programa narrativo proposto pelo projeto gráfico.

\section{Ordenador(es) : cor, flor, fruta, fantasia - traços de subjetividade}

As páginas da obra são divididas ora em página simples, ora em dupla, mas não numeradas, pois não sugerem ordem de leitura, José Paulo Paes destaca esta característica da arte poética:

Esta passa então a ser feita não linha após linha, sempre para frente, como na prosa, sim num ir e vir entre o que está adiante e o que ficou atrás. Com isso, desautomatiza-se a leitura e se direciona a atenção para o conjunto de significados do texto, não apenas para a seqüência deles (1996, p. 25).

As páginas simples e as duplas adquirem funções diferentes no projeto gráfico e, como formula Francisco Gutiérrez García, no artigo "Como leer el álbum ilustrado": “[...] ambos formatos de página colaboran activamente con el lector en la construcción del "texto", ya que le ofrecen una guía para ordenar, diferenciar e interrelacionar las proposiciones o ideas que contiene" (2002, p. 21).

Vale, então, pontuar que no álbum Jardins existem 28 páginas. A maioria (dez) é simples que conjuga palavra e imagem: 


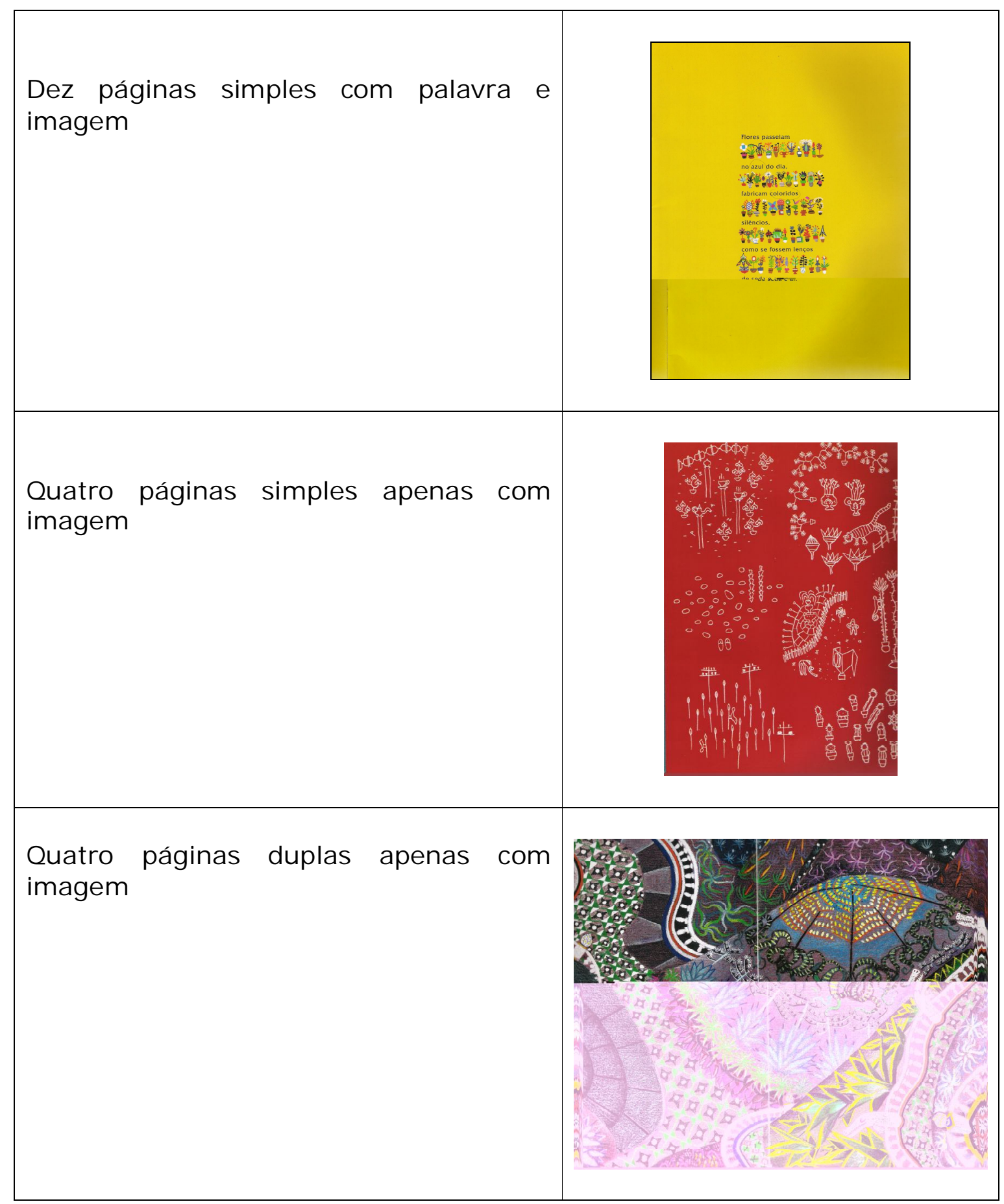


Três páginas duplas com palavra e imagem

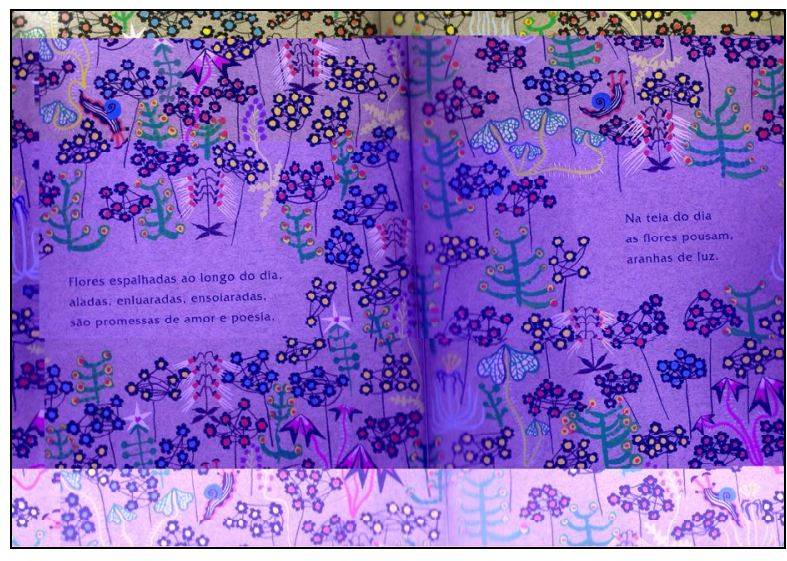

Figura 3.17 - Esquema da disposição das páginas

A partir deste levantamento, pode-se entender que não há obrigatoriedade de ler a obra em seqüência linear, como é mesmo característica das obras poéticas. Não existe hierarquia entre palavra e imagem, ou seja, os sistemas semióticos se apresentam da mesma maneira para a fruição. Não existem páginas apenas com palavras. Ora elas são tomadas completamente por formas, cores e palavras, ora deixam as formas concretas ou abstratas de lado para enfatizar a cor. Cada página simples ou dupla apresenta cores distintas. Essas são sempre vibrantes-intensas. A luz promove o constante brilho e vivacidade das imagens. Seguindo a seguinte paleta:
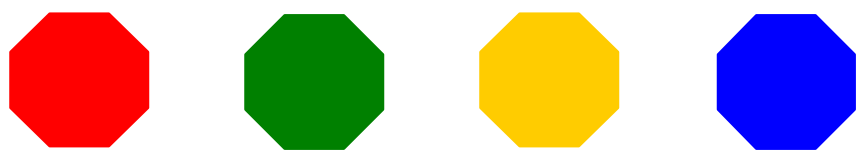

Figura 3.18 - Paleta de cores de Jardins 
Também, há momentos em que a palavra dialoga com a imagem acrescentando um novo elemento ou retomando um elemento tratado pelo poema. Como no caso do seguinte poema: "Flores pintam/norte e sul/ em todos os timbres/ e tons de azul.", em que a página é toda azul, à direita e à esquerda linhas verticais caem, como cortina, também azuis:
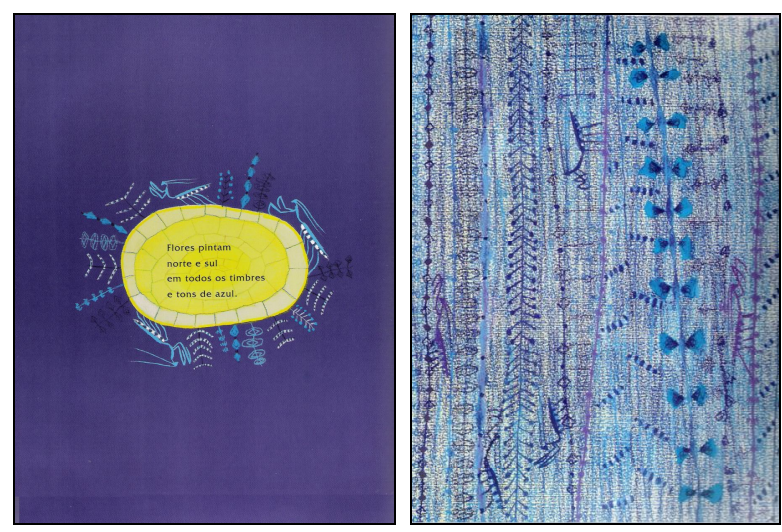

Figura 3.19 - Palavra se relaciona com a imagem

Há espaço em que palavra e imagem traçam discursos paralelos, ou seja, não há ponto comum. No poema: “Entre no jardim secreto,/ é lá que vive o eterno luar,/ as assombradas caravelas,/ as flores imperfeitas do amor.", a imagem que emoldura o poema forma guirlandas, rendas de flores e mulheres com saias longas e, ainda, aves que se assemelham às araras, as figuras remetem à cultura oriental, mas só há sugestão. O jardim secreto de que trata o poema está aberto à esquerda na imagem. Neste caso, a palavra e a imagem criam um contraponto: 


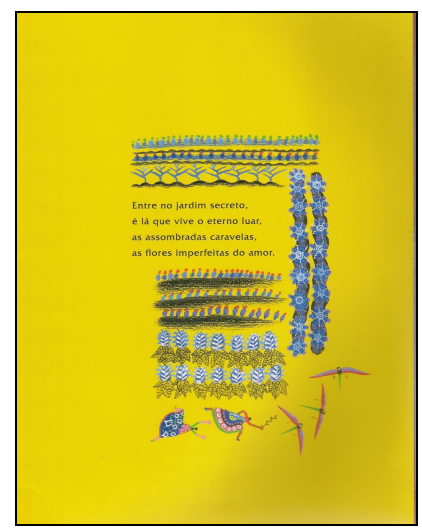

Figura 3.20 - Palavra como contraponto da imagem

Existem casos em que a imagem dialoga com a imagem da outra página (ao lado), mas não com uma parte específica do conteúdo do poema, como por exemplo: página da esquerda - "Para que o dia/seja todo de estrelas/e magia,/estranhas flores/ao pé da estrada."; página direta - "Flores alimentam sonhos/ dão de comer aos olhos,/ arrumam e desarrumam/ formas e cores." A mídia visual insere insetos que literalmente alimentam-se das plantas e das flores. São formigas e lagartas que, sem dúvida, habitam os jardins e compõem formas e cores deste caleidoscópio natural que é um jardim. Faz-se referência ao brinquedo infantil:

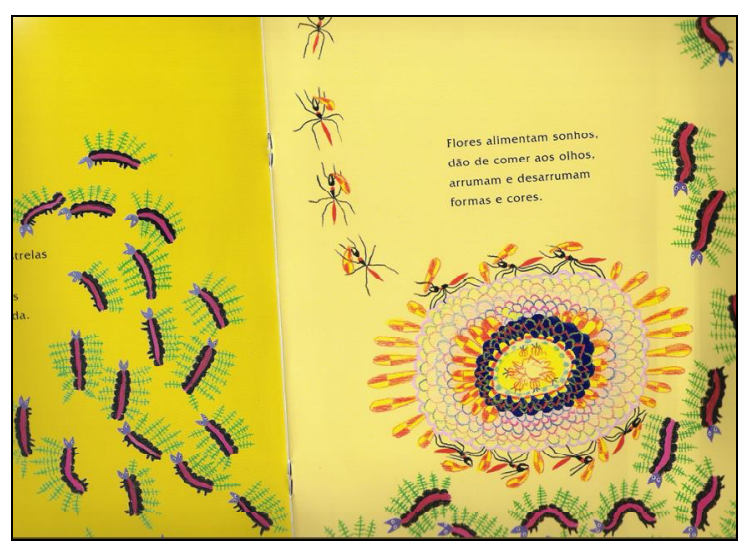

Figura 3.21 - I magem se relaciona com imagem 
Ainda, há momentos em que o espetáculo é apenas da imagem na página dupla, que pode até apresentar um grau de narratividade maior que o próprio texto verbal, pois esses são quase exclusivamente expositivos. Eis um labirinto com a figura humana, a gaiola e pássaros alguns presos nas gaiolas, outros livres. Ao aproximar a imagem, ela se confunde, ao distanciá-la, percebe-se que o labirinto formado é a copa de uma árvore.

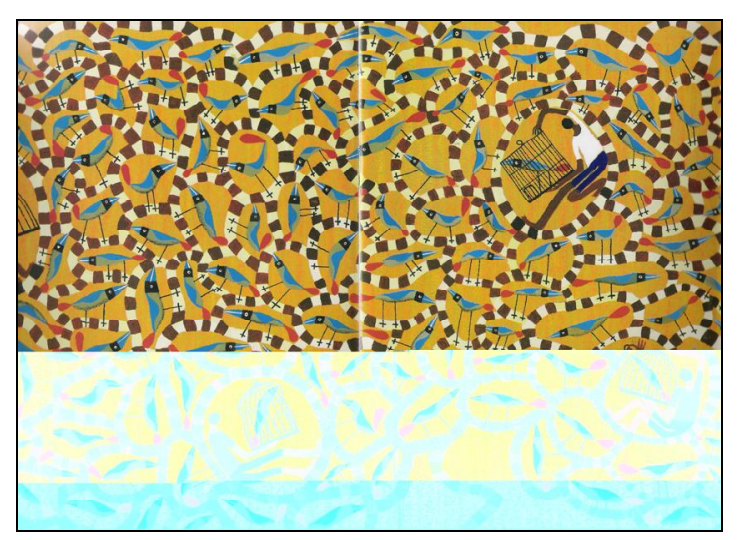

Figura 3.22 - I magem narrativa

A partir da descrição, percebe-se a diversidade: os poemas figurativizam as fases do dia - manhã, tarde, noite - as flores, as cores, as formas e as sensações geradas por cada um dos elementos naturais. As imagens figurativizam formas, cores, flores, animais, insetos.

Palavra e imagem alinham-se para apresentar seus jardins, mas não redundam esse retratar. As subjetividades de traços, cores, adjetivos constituem universos discursivos particulares que dialogam em sua diversidade para compor o projeto gráfico da obra Jardins, e esse último sim interliga os elementos expositivos a fim de propor um percurso narrativo, como já apresentado, sugerindo um caminho-aprendizado ao leitor, quem, afinal, irá decidir sobre o caminho. 
O diálogo palavra-imagem vai além, pois está envolvido por um projeto gráfico que o embala, assim, cabe atentar para esta proposta. A contracapa anuncia:

Fazer poesia é arrumar palavras pra transmitir sentimentos indizíveis... um sentimento que humaniza os homens.

A mais linda poesia desperta esse sentimento como se fosse música ou imagem. Suas palavras são tão precisas e necessárias que desaparecem, como as notas da música ou os traços da imagem, no momento em que surge o indizível. Criar um jardim é arrumar elementos da natureza para produzir uma emoção plena, indecifrável.

No mais lindo jardim o indizível germina como se a natureza fosse só poesia. As formas, as cores e a vida são tão precisas e necessárias que desaparecem, no momento em que os homens o penetram e vivenciam uma emoção indecifrável, aproximando-se dos outros seres da natureza. Neste livro repousam a mais linda poesia e os mais lindos jardins, à espera de que o leitor os penetre com a mais singela delicadeza. ${ }^{99}$

\section{Um projeto gráfico coeso: o destinatário em pauta}

O projeto gráfico, portanto, ao integrar palavra-imagem apresenta ao leitor o indizível próprio à natureza poética da imagem e da palavra.

Há, no entanto, que se questionar sobre o destinatário. A criança teria meios (habilidades) para decodificar tão intrincado e complexo projeto gráfico, graças às suas insinuações e suas nuances e diversidades de imagens poéticas visuais? Daniela Padilha, em artigo "Percepções do ser: o endereçamento da poesia de Cecília Meireles e Roseana Murray", afirma que apenas o suporte definiria o endereçamento, no caso de Jardins, a ilustração atribuiria ao objeto as qualidades para a obra ser destinada à criança. Na teoria da recepção, e mesmo em Semiótica, sentir e compreender são faces de uma mesma moeda:

${ }^{99}$ Grifo nosso. 
J auss não acredita que o significado de uma criação artística possa ser alcançado, sem ter sido vivenciado esteticamente: não há conhecimento sem prazer, nem a recíproca, levandoo a formular um par de conceitos que acompanham suas reflexões posteriores: os de fruição compreensiva e compreensão fruidora, processos que ocorrem simultaneamente e indicam como só se pode gostar do que se entende e compreender o que se aprecia (ZILBERMMAN, 1989, p. 53).

O trabalho com o sistema verbal, o recriar as palavras ou sentido das palavras, a proposição de rimas/ritmos, estranhamentos leva à criança, justamente, ao "acidente" na cotidianidade. O experimentar um uso inabitual da palavra. O exercício de inúmeras possibilidades.

O mesmo acontece com o sistema visual que propõe formas e diálogos que inserem o destinatário no universo das artes, na medida em que oferecer à criança acesso à arte deve ser condição da literatura infantil, visto que o repertório está em formação:

En cualquier caso, resulta incuestionable que mientras más imágenes creadas por auténticos artistas ingreses a ese archivador, más disímiles y amplios serán nuestros referentes, más posibilidades tendremos de juzgar con acierto qué es hermoso o no, qué es de buen gusto o no. Generalmente, esas imágenes no son estáticas, no permanecen quietas en el archivador, todo lo contrario: dialogan y riñen entre sí, se asocian y disocian, se niegan o aceptan, se asienten o contradicen, se transforman mutuamente, y transforman, con esa interrelación, nuestras concepciones y juicios estéticos.[...]

De ahí la importancia de enriquecer, desde la infancia más temprana, el reservorio de referentes visuales de los niños con obras de reconocida calidad, de diferentes artistas, épocas, escuelas, estilos, tendencias, intenciones (ANDRICAì N, 2001, p. 2-3).

Assim como a palavra conduz a diversos jardins, a imagem também propõe diálogos entre artes diversas, como as cores vibrantes e intensas do fauvismo de Matisse podem ser contempladas na capa e na página central do miolo. 
Há no fazer discursivo da visualidade uma referência e, portanto, o interdiscurso. Elemento característico da literatura infantil pós-moderna, como já trabalhado na análise da obra Sebastião, de Manuela Bacelar, e em outras obras que ainda serão analisadas ao longo desse estudo. A ligação entre as expressões se dá na intensidade do vermelho, amarelo, azul e verde, nas formas bem delineadas e sinuosas no fundo da pintura de Matisse e na própria figura em Jardins; estes são alguns elementos plásticos que autorizam a aproximação.

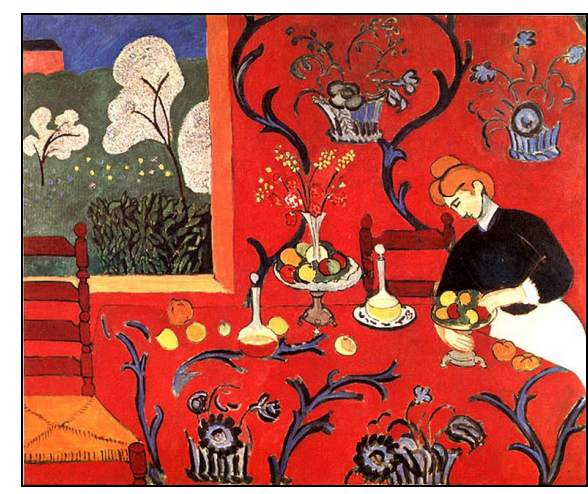

Figura 3.23 - Matisse

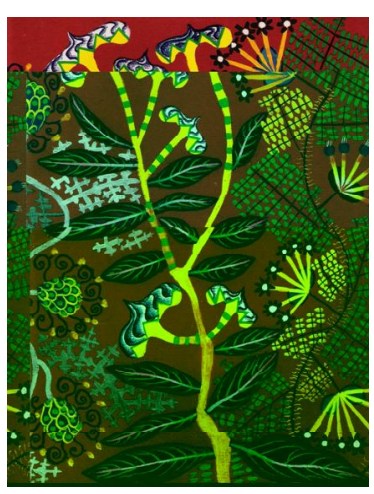

Figura 3.24 - J ardins

Outra referência trazida pelas imagens é um diálogo intenso com os traços da arte africana contemporânea: formas, cores, organizações dos elementos no espaço e, ainda, a forma despojada das figuras humanas e da natureza. Vêm à tona também, nesse estilo de arte, os retratos e cantares das lendas populares: 


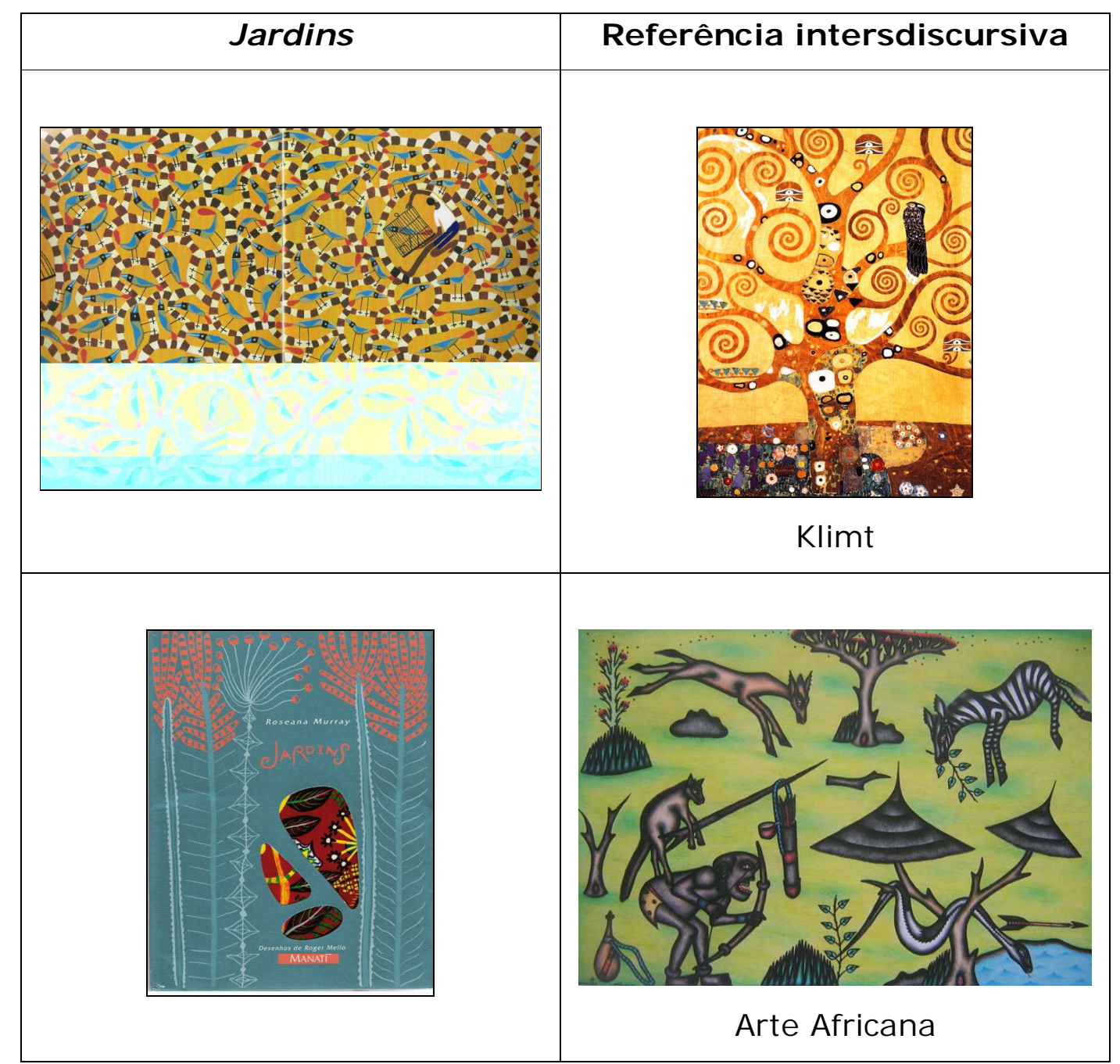

Figura 3.26 - Referências interdiscursivas

Os temas e figuras comungam para apresentar o popular. As cantigas e olhares ingênuos, deslindados dos requintes das artes clássicas como perspectivas e mescla de cores, e Henri Rosseau, com seu estilo Näif, fazem-se presente no Jardins, de Roger Mello. Os traços recorrentes são a ausência de perspectiva - sobreposição de imagens - , uso de cores puras e recorrência figurativa à natureza: 


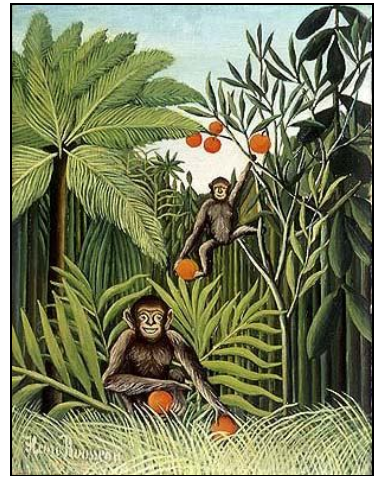

Figura 3.27 - Henri Rosseau

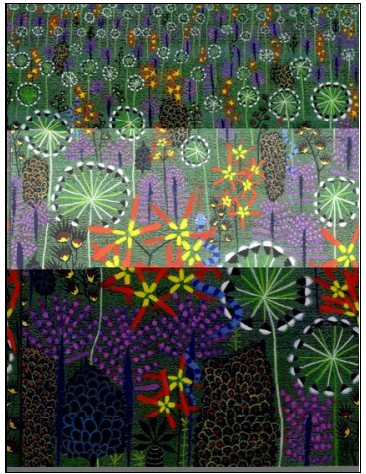

Figura 3.28 - Jardins

Ainda, as referências à repetição de imagens e a ilusão criada a exemplo do caleidoscópio guiam para o artista gráfico Escher, recorrência importante na literatura infantil brasileira, como bem revelam as obras de Angela Lago:

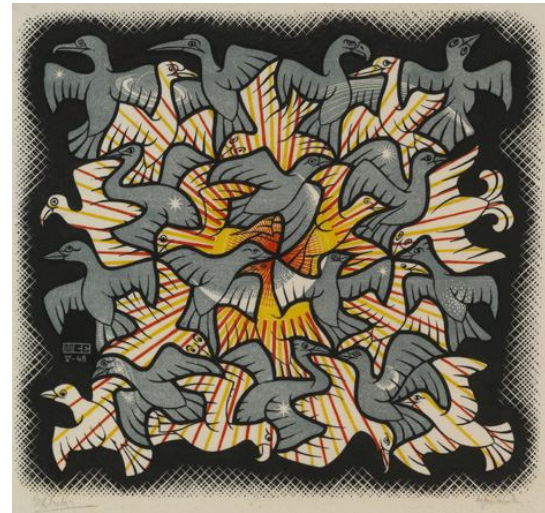

Figura 3.29 - Escher

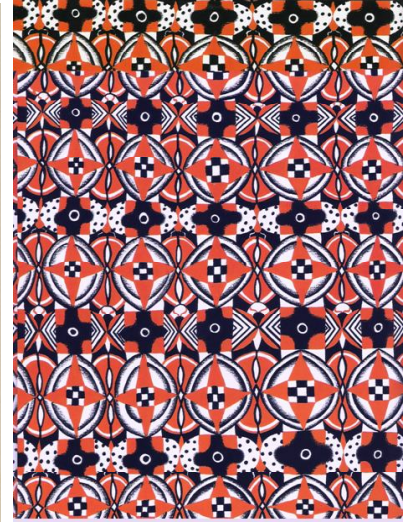

Figura 3.30 - Jardins

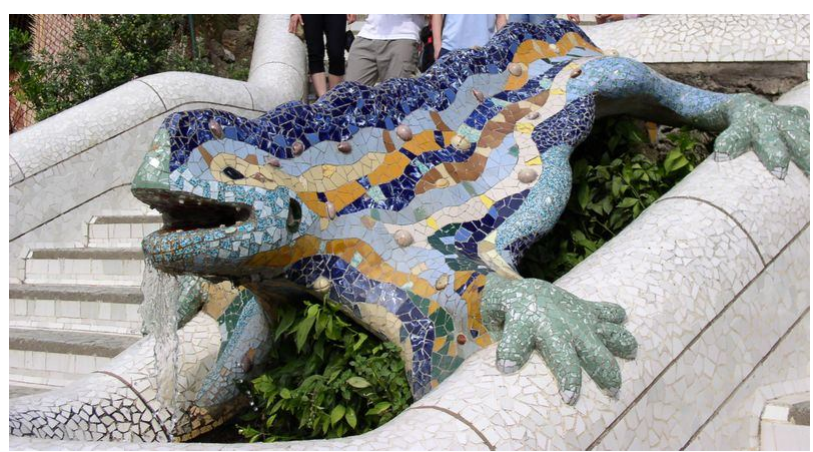

Figura 3.31 - Lagarto - Gaudí

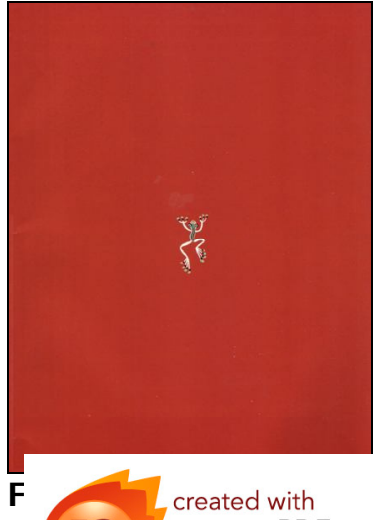

nitro $^{\text {PDF }}$ professional 
A última relação construída se refere ao Parque Guell de Gaudí em Barcelona, a idéia do trabalho em mosaicos é bastante retomada por Mello em seu jardim.

Com isso, é possível afirmar que, apesar de ser um projeto gráfico muito eficiente, caberia ao educador ou mediador ${ }^{100}$ a apresentação de uma pasta de pesquisador, um trabalho com a vocalização dos poemas e um olhar cuidadoso sobre as imagens e suas referências. Por exemplo, o fauvismo, de Matisse - nas cores vibrantes - ; a tematização do ingênuo e de natureza próprio do chamado Näif e, ainda, um passeio pela arte africana que dialoga com o folclore e a arte popular brasileiros.

\subsubsection{Objeto-Livro: Corporificação dos Desertos}

Ao observar a capa da obra Desertos, de Roseana Murray e Roger Mello, a sensação é imposta pelas nuances cromáticas do marrom. Os matizes, ora mais claros (alaranjado), ora mais escuros, levam o leitor à sensação de um papel de gramatura alta, que produz efeito de sentido ao tato, sugerindo certa rugosidade. As diferentes tonalidades criam a sensação de textura no papel, com relevos e reentrâncias:

A textura é o elemento visual que com freqüência serve de substituto para as qualidades de outro sentido, o tato. $\mathrm{Na}$ verdade, porém, podemos apreciar e reconhecer a textura tanto através do tato quanto da visão, ou ainda mediante uma combinação de ambos. É possível que uma textura não apresente qualidades táteis, mas apenas óticas, como no caso das linhas de uma página impressa, dos padrões de um determinado tecido ou dos traços superpostos de um esboço ${ }^{101}$ (DONDIS, 2003, p. 70).

\footnotetext{
${ }^{100}$ No capítulo de conclusão deste estudo, serão propostos critérios de avaliação de um projeto gráfico, por meio do quadro apresentado é possível n mediadnr identificar nc aspectos que merecem destaque durante o trabal ho em sala । ${ }^{101}$ Grifo nosso. 


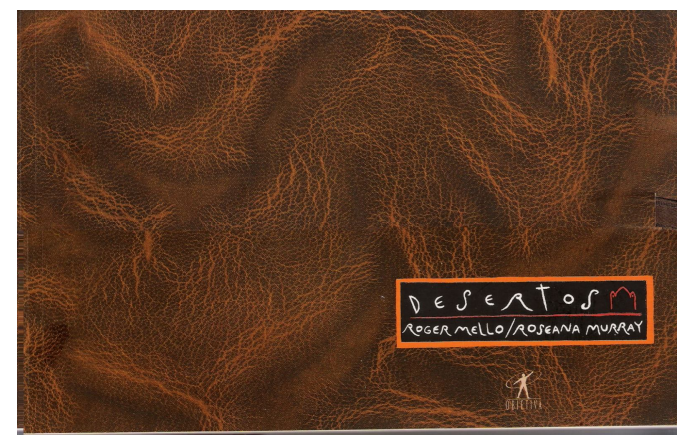

Figura 3.33 - Capa

A definição apresentada por Dondis corrobora a apreciação da análise, visto que é possível, a partir dessa descrição, verificar que a capa propõe uma comparação com os desenhos na areia - aquelas curvas traçadas pelo vento em ambientes desérticos. Impõe-se, então, a metáfora visual: ondas de areia no deserto em associação à capa de um caderno de modelo antigo. Tal aproximação se explica graças ao cromatismo, como apontado, que lembra a areia do deserto trabalhada pelos ventos; já o formante eidético, ou seja, a forma do objeto-livro, remete aos antigos cadernos de anotações, além também de o cromatismo contribuir para se estabelecer essa última relação.

$\mathrm{O}$ tato sugerido pelas cores revela a sensação proposta pela visão e faz crer nos grãos de areia, que são também nervuras do papel. Além de deslindar o deserto, o leitor aciona suas lembranças e eis o caderno de anotações, e a figura ambígua se instala no discurso, constituindo-se como conector de isotopias.

Assim, pelo sensível, isto é, pelas qualidades plástico-sensoriais tem-se a textura do deserto; pelo inteligível, pelas qualidades mnemônicas, por associação de formas e cores: o caderno de anotações. Essa última estratégia de reconhecimento é reforçada pelo laço - duas fitas marrons acetinadas que fecham os segredos do Desertos ${ }^{102}$ : "O deserto abriga segredos e tesouros, abriga as primeiras civilizações do mundo, as primeiras cidades [...]" (MURRAY, 2006). Abaixo, apresenta-se 
um modelo de caderno de viagem, para que a comparação proposta pela análise se sustente.

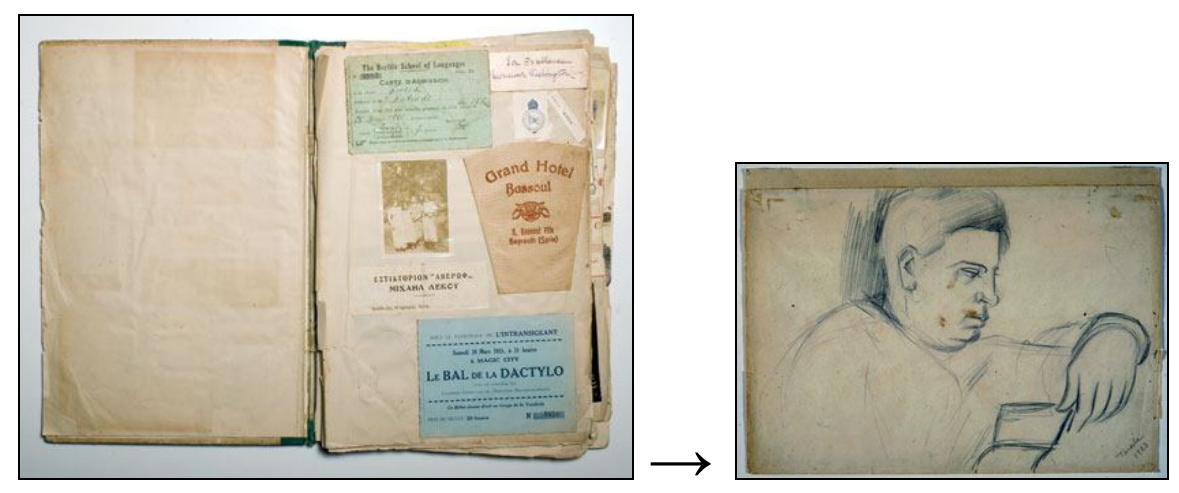

Figura 3.34 - Caderno de viagem da artista Tarsila do Amaral ${ }^{103}$

Até a metade do século passado viajar era difícil, o mundo era imenso e com vastos espaços ainda desconhecidos. Viajantes partiam de suas aldeias ou cidades para conhecer novas terras, hábitos ou em busca do conhecimento e inspiração. Partiam a pé, em barcos, a cavalo, em trens a vapor. Os aviões como transporte de massa chegariam depois da Segunda Grande Guerra.

Os cadernos de viagem, os diários, as anotações, faziam sonhar os que ficavam. Marco Pólo, Stevenson, Maupassant, Guimarães Rosa, há toda uma linhagem de escritores viajantes, e seus cadernos de viagem nos levam juntos, nas entrelinhas, nas margens, entre um adjetivo e uma exclamação de assombro. Há sempre um espaço para o leitor. E, pelos olhos dos viajantes, empreendemos também nossa longa viagem rumo a lugares ermos ou desconhecidos, rumo a nós mesmos. De cada viagem voltamos transformados (MURRAY, 2006, Prólogo).

A capa desta obra e a apresentação da autora levam o leitor a acreditar que tem diante dos olhos um caderno de viagem, e, mais, pelas qualidades sensíveis, o cenário é apresentado ao leitor - o deserto. O cromatismo corporifica as qualidades visuais do deserto - a cor e

${ }^{103}$ No destaque, o perfil de Oswald de Andrade; palavra e imanem rnnatitıem $n$ exemplo. Este caderno pode ser tomado como um ex corrobora a leitura proposta. 
tonalidades ocre e a textura em grãos e nervuras. O livro-objeto revela o gênero; a sensorialidade propõe o cenário visitado, que é desvendado também pelo verbal: Desertos, título da obra que ora se analisa.

Oliveira, em artigo intitulado "Visualidade entre significação, sensível e inteligível", vislumbra a possibilidade de as qualidades sensíveis constituírem o gênero de discurso:

[...] as particularidades assumidas nessa estruturação do visual são guiadas pelos propósitos do texto, os quais têm também implicações na duração de sua captação, pois os modos distintos de organizar um texto de relato, de reportagem, de entretenimento, de reflexão, de arte, marcam também em suas formas e gêneros discursivos, os distintos modos de apreensão, percepção e significação de cada um deles (OLIVEIRA, 2005, p. 112-113).

O verbal é visual na obra em questão, visto que a tipografia utilizada e a moldura englobante das palavras reforçam as expressões que autorizam a identificação do gênero e, mesmo, determinam a maneira de olhar-ler, como postula Oliveira, naquele caso com relação à organização diagramática dos jornais. A figuratividade do discurso associada à expressão do formante cromático (preto, branco e vermelho), eidético (retangular) e topológico (abaixo, canto direito da página) remetem às etiquetas escolares, reforçando a lembrança dos cadernos de anotações. O retângulo-moldura impresso no caderno introduz o título e os autores.

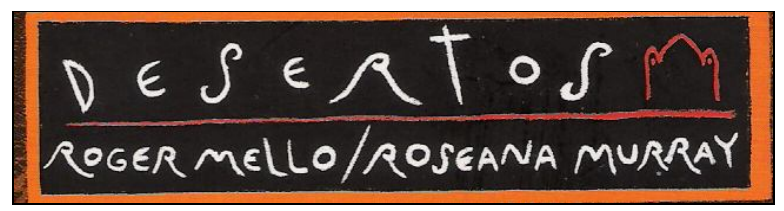

Figura 3.35 - Retângulo-moldura com título e autores da obra 


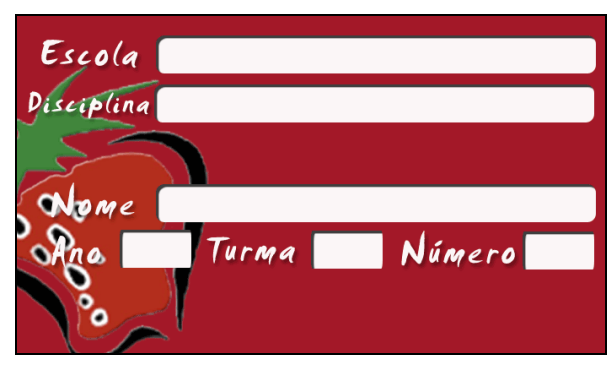

Figura 3.36 - Etiqueta exemplo

$\mathrm{Na}$ etiqueta da capa, há uma espécie de logotipo com a representação gráfica de algo que pode ser uma representação de castelo, montanhas ou janela. O grafismo pode ser considerado uma anáfora do que está por vir - a arquitetura das cidades do oriente, ou algo que o leitor ainda descobrirá. O traço (estilo) do grafismo também será retomado ao longo da narrativa visual, como marca do estilo empregado nos desenhos ${ }^{104}$ - a linha é personagem central nesta expressão.
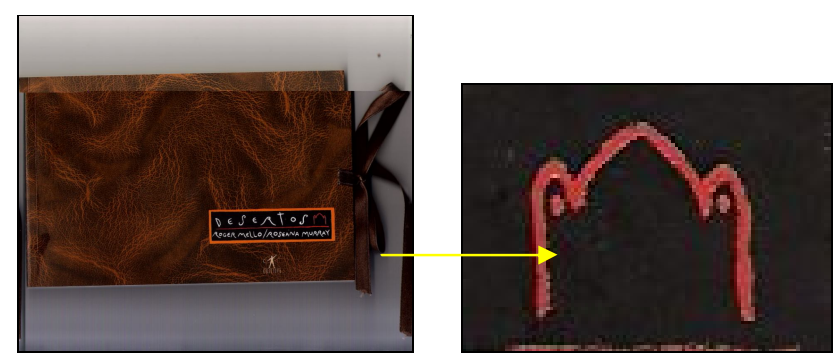

Figura 3.37 - Detalhe do grafismo

Seguindo o percurso natural, desfaz-se o laço, e a capa se abre para um papel de alta gramatura e aspecto mais rugoso, este sim guarda as características apenas sugeridas pela capa - aquelas que convocam as sensações táteis.

104 Mais adiante, a questão do estilo será detalhada. 


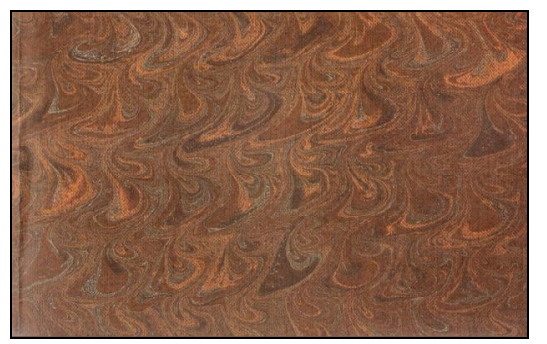

Figura 3.38 - Página de falsa guarda

A sensação tátil, neste caso, não é dada apenas pela visão; as mãos, de fato, tocam algo mais rugoso (áspero), que a página anterior. Tem-se, portanto, a oposição entre ser versus parecer. Antes, parecia, agora, é. Se for tomada a qualidade matérica da areia no deserto, essas alterações de textura serão constantes e também podem ser sentidas ao longo da leitura de Desertos.

A página de "falsa guarda" é dupla com desenhos curvos e pinceladas que remetem ao padrão de tecidos orientais. O leitor toca (sente) o ambiente que será percorrido. A dupla página também retoma as tonalidades da página de guarda das antigas encadernações.

É importante ressaltar que, nesse caso, não são páginas de guarda, mas a falsa página de guarda, pois aquelas só existem em encadernações de capa dura, e essas, apenas em capa mole, mas o emprego desse recurso gráfico cria o simulacro da capa dura, mais uma vez, a oposição ser versus parecer vem à tona.

Guto Lins indica a função da página guarda e, ainda, cita Roger Mello, autor em discussão nesta análise:

Em livros com capa mole e com acabamento canoa (com grampo) pode-se utilizar uma "falsa guarda". A falsa guarda também corresponde às primeira e última páginas e são geralmente impressas somente com imagens, aplicação de texturas ou motivos (patterns) repetidos.

No caso de livros infantis, o seu uso é por questões estéticas ou até poéticas. Segundo o autor e ilustrador Roger Mello "O livro é tão importante que tem um guarda na entrada e outro na saída" (LINS, 2003, p. 57). 
A "falsa guarda" é um recurso recorrente nas obras de literatura infantil brasileira, pois essas dificilmente aparecem em capa dura, quase sempre são encadernadas em capa mole e com "falsa guarda"105. Talvez esteja aí uma primeira diferença entre a produção gráfica de livros infantis do Brasil e de Portugal, uma vez que naquele país, como apresentado, as obras aparecem envolvidas por capa dura. Pontua-se ainda que, no caso de Desertos, o acabamento não é feito com grampos, entretanto a capa é mole, e isso autoriza a referência.

Na página de rosto, o título é retomado com uma moldura que experimenta as cores dos lápis empregados no miolo da obra: verde, azul, preto, vermelho, amarelo - cores primárias que acompanharão o percurso deste viajante que registra a viagem por meio de desenhos, esboços. As cores dos lápis reforçam a paleta de cores disponível ao enunciador, isso indica a escassez de possibilidades cromáticas, como será tratado mais adiante pela análise. A escassez de cores é revelada, em entrevista, pelo próprio autor:

Fazia meses que eu não conseguia esboçar um desenho sequer, uma história sequer, então resolvi me dedicar ao vazio. Consegui 4 lápis de cor e um "livro blanco" na Espanha, antes de embarcar para o Marrocos. Dessa maneira surgiu um diário gráfico, o primeiro que eu fiz, durante essa viagem em 2002, com elementos muito simples (Entrevista concedida à Revista Poiesis, 2007).

O "improviso", elemento característico da viagem e, mais especificamente, do registro durante a viagem, vem à enunciação e, portanto, torna-se enunciado, enfatizando o gênero de discurso: diário de viagem. Este gênero é caracterizado por texto descrito-narrativo de caráter informativo, em que devem existir marcas lingüísticas como indicação de

\footnotetext{
${ }^{105}$ Vale pontuar que a "falsa guarda" é um recurso muito utili: autores como Ziraldo que não utilizam o recurso.
} 
local e data e o uso de primeira pessoa do singular ou do plural com "eu" incluído, atribuindo à descrição a subjetividade, que lhe é fundamental ${ }^{106}$.

A obra em questão não tem no título a palavra viagem, nem mesmo a palavra diário é incluída. O título Desertos não localiza o leitor, pelo contrário, uma vez que está no plural ${ }^{107}$. Essa estratégia imprime um cenário vago, impreciso. Este diário não dará a ver um deserto em particular, porque não é o do Atacama, nem o Dakar, mas sim, todos os desertos ou, pelo menos, alguns. Dessa forma, não é uma obra que se intitule como diário de viagem, apesar de apresentar características que encerram neste gênero.

Ainda é válido reforçar que o percurso registrado será manifestado por dois sistemas semióticos distintos: o verbal e o visual. O enunciador dará a possibilidade de conhecer o deserto por diferentes mídias, que podem ou não ser interdependentes. O objetivo da análise é justamente demonstrar como o projeto gráfico associa os sistemas semióticos e cria um todo de sentido. Para isso, a descrição grão a grão se faz necessária para atribuir sentido ao ambiente que desponta no horizonte da análise e, então, propiciar uma segunda etapa - a aproximação entre a obra Desertos e Jardins, dado que elas são construídas pelos mesmos autores e por eles mesmos relacionadas.

Seguindo os meandros analíticos, a cena seguinte aponta para o universo oriental, introduzindo o leitor nessa cultura. A referência está nos famosos tapetes, com padrões geométricos. O sistema verbal, mais adiante, apresentará o tapete como sentinela do deserto, ou seja, segundo o dicionário Aurélio: "Qualquer coisa elevada em lugar deserto. Ato de guardar, vigiar ou espiar; guarda" (1988, p. 594). Reforça-se, com essa referência, a entrada no ambiente a ser descrito. Vale recordar dos tapetes "persas" que proliferam na cultura ocidental com status de preciosidade.

\footnotetext{
106 BAKHTIN, 2006, p. 207.

107 Nota-se que o plural foi um recurso lingüístico empregado n finalidade de ampliar possibilidades.
} 


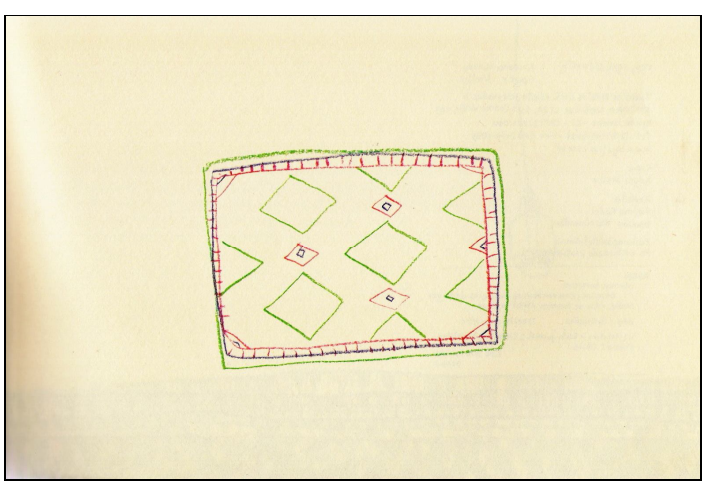

Figura 3.39 - Tapete Desertos

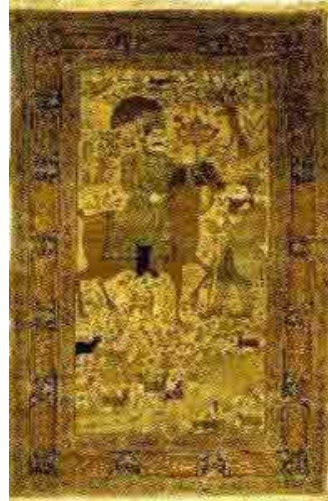

Figura 3.40 - Exemplo de tapete persa

A ficha catalográfica vem na página seguinte acompanhada por um muro-moldura, com padrões geométricos e cores: verde, amarelo e azul e, ainda, uma lamparina para acender o caminho a ser percorrido pelo enunciatário ou para acender, no produtor dos textos, os relevos e reentrâncias do deserto. O sistema visual incorpora as referências catalográficas de maneira a inseri-las, também, no ambiente visitado. Não há, portanto, distinção nesta apresentação entre enunciado e enunciação. Nas análises realizadas, a obra O dinossauro, de Manuela Bacelar empregou o mesmo recurso.

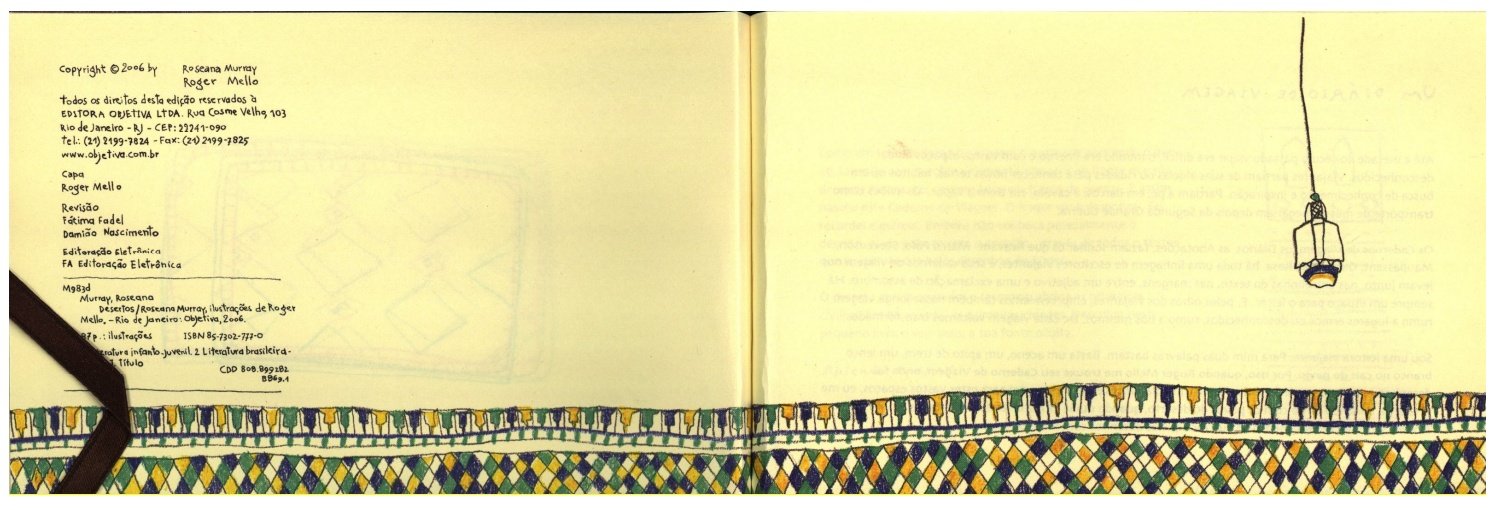

Figura 3.41 - Detalhe da ficha e da lamparina 
Estes elementos (tapete, muro e lamparina) criam o ambiente, onde o viajante-leitor passará e por onde o viajante-autor passou. Um diário de viagem tem por pressuposto que o leitor deve acompanhar uma viagem já realizada: seu percurso, suas revelações e suas constatações, mas não são imagens fotográficas que se mostram, pois a técnica eleita imprime maior subjetividade ao registro passado e essa subjetividade interessa ao leitor potencial.

Pressupõe-se, com isso, que o leitor acompanhe um registro subjetivo, isto é, a expressão de um sujeito que percorre espaços desconhecidos e registra tais momentos com suas alegrias e seus percalços. Além de ser a expressão de um indivíduo, a palavra diário sugere não só o registro dia-a-dia, mas também impõe uma reflexão sobre quem seria o enunciatário: o próprio produtor do texto ou um desconhecido? O diário, por ser fechado, não pertence somente àquele que o produziu e, portanto, é um texto-segredo? ${ }^{108}$

O diário é um registro íntimo para ser realizado e lido pelo mesmo sujeito, isto é, um gênero reflexivo em definição. Esse caráter do segredo/ do secreto vem sendo alterado ao longo do tempo, uma vez que o diário de viagem tornou-se um gênero muito publicado e apreciado. É um meio dado ao leitor, para que ele conheça lugares inatingíveis ou inimagináveis e alguns se tornaram best-sellers visto o interesse despertado. Todavia, não apenas o lugar visitado interessa, mas também a perspectiva daquele viajante é fundamental, como revelam: Darwin, em Galápagos, ou LévisStrauss, no Brasil, Che Guevara, na América Latina, entre outros.

No caso da obra Desertos, o gênero de discurso envolvido pelo projeto gráfico (tamanho, forma, cores, tipo de papel, imagens de abertura) confere ao leitor (enunciatário) o contexto em que será inserido pelo registro da viagem. O corpo do leitor-viajante sentirá o caminho visível e grão a grão construirá o seu deserto. Oliveira formaliza esta percepção sensível da seguinte maneira:

${ }^{108}$ Vale lembrar que esta obra não se intitula como diário, dado 
Desse sentir o sensível, uma experiência vivida, o olho - que não pode apreender tudo de uma só vez - de certa maneira nas suas movimentações repete ações, precisando-se até conseguir atingir contornos mais estáveis e duradouros. Assim, das atmosferas sensíveis, os formatos de coisas, objetos, figuras, pelas suas qualidades, vão se fixando e ganhando cristalização, que os tornam perceptíveis. Nessa outra etapa, é sobre uma sintagmática que o sujeito da visão atua e, com o seu corpo todo, depreende a corporiedade do outro corpo visível, percebendo-o na relação que entretece. Da apreensão à percepção, passa-se a discriminação de impressões das qualidades às diferenciações distintivas entre elas (OLIVEIRA, 2005, p. 110).

Com tais ensinamentos na bagagem, a análise avança.

\section{Processo revelado: enunciação enunciada}

Desertos apresenta-se como diário na materialidade do objetolivro, apesar da omissão das palavras diário ou mesmo viagem, isso faz que o leitor viva um segredo.

O enigma se torna ainda maior quando se pergunta: se um diário, como proposto pela materialidade, é um percurso de um sujeito, como pode, então, este "diário" apresentar dois produtores de texto, a saber: "Roseana Murray para desenhos de Roger Mello"? Como apresentado na página de rosto: 


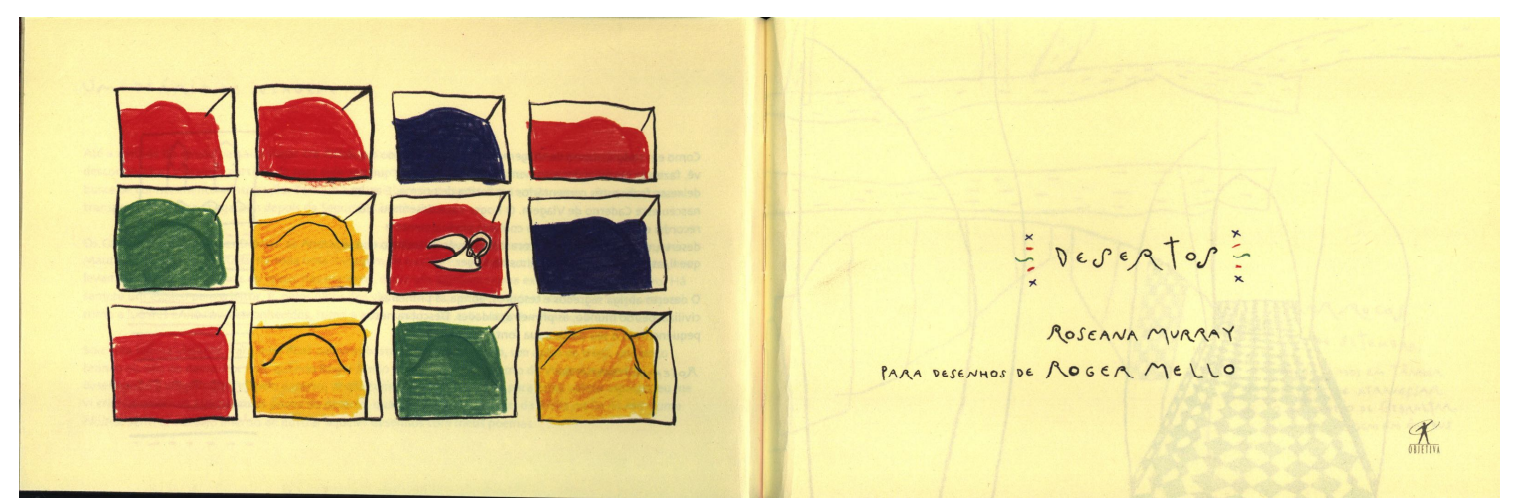

Figura 3.42 - Página de rosto de Desertos

Nesta página, no verbal, há o título Desertos e o nome do autor Roseana Murray e se pergunta: foi ela quem viajou?; "para desenhos de Roger Mello" refere-se àquele que não viajou, mas ilustrou o relato visual? Ou os autores viajaram juntos? Rompe-se, portanto, o padrão imposto pelo gênero e o processo criativo vem ao enunciado pelas palavras de Murray no prefácio:

Sou uma leitora viajante. Para mim duas palavras bastam. Basta um aceno, um apito de trem, um lenço branco no cais do navio. Por isso, quando Roger Mello me trouxe seu caderno de Viagem, onde foi desenhando a viagem que fez pelo deserto [...] Senti um desejo imenso de ilustrar aqueles desenhos com meus poemas (MURRAY, 2006, Prólogo).

Este prefácio-aviso revela o fazer dos autores e autoriza o analista a questionar a eficácia de um projeto que tem o verbal como ilustração do sistema visual, pois é esse o exercício proposto pelos autores, contrariando o usual em literatura infantil, em que o verbal é ilustrado pelo visual. Talvez esteja aí a justificativa para obra não se intitular como diário de viagem.

A tarefa dos artistas exige um fazer muito integrado, no que diz respeito à concepção e aos efeitos de sentido desejados, visto que inúmeros pesquisadores alertam para uma composição gráfica em que os artistas não dialogam e, em pior situação, quando os 
se relacionam, às vezes, até comprometendo o sentido da obra ou de um dos sistemas semióticos. Devem conversar, portanto, autor e ilustrador ou designer que será o articulador do projeto gráfico:

Um problema, contudo capital quando encaramos o nascimento dum livro para crianças, foi até aqui apenas aflorado: é o papel do ilustrador. Pode acontecer, temo-lo dito, que um livro nasça primeiro da iniciativa do ilustrador. É o que acontece por vezes com os álbuns sem texto por um lado, por outro como obras que se dirigem geralmente aos mais pequenos em que o texto, contraponto da figura, se encontra reduzido à sua mais simples expressão.

Existe uma outra possibilidade deixada de lado até aqui: um livro pode ser, uma primeira etapa, o resultado de uma estreita cooperação entre um autor e um ilustrador que elaboram e precisam juntos um projecto: tema geral, eventualmente intriga e personagens, depois realizam em conjunto uma pré-matriz que ambos propõem ao editor, sendo este primeiro projecto em seguida afinado, discutido, revisto. Aí está, creio, uma forma de trabalho apaixonante e sempre muito enriquecedora para cada um dos participantes (HELD, 1978, p. 143).

Held prevê alguns modos de relação entre palavra-imagem ou entre autor e ilustrador e, já na década de 1970, vislumbra a possibilidade de o visual "nascer" antes do verbal, contudo, as expressões indicadas pela pesquisadora francesa se atêm ao livro de imagem ou ao álbum, em que a palavra está restrita a explicar o visual para o público-leitor iniciante - não alfabetizado. A proposta que a análise tem em mãos é distinta daquelas formuladas por Held, uma vez que mesmo o processo tido como ideal: total integração na gênese da obra entre autor (verbal) e ilustrador (visual) não é atendido. Roseana Murray revela que, quando propôs ilustrar com poemas o diário de imagem de Mello, ele já estava concluído; a declaração da autora é feita no próprio prefácio da obra, como esta pesquisa, o projeto-livro é abordado como todo de sentido, assim, o prefácio não pode ser descartado da análise. Pergunta-se, então: como fazer desta obra um todo significativo neste contexto, com essa proposta inusitada? Esta tarefa cabe de imediato à editoração, 
É possível, como hipótese, que o contrato firmado por esta obra seja similar aquele em que o ilustrador se propõe a desenhar sobre um texto clássico, como Manuela Bacelar para A sereiazinha, de Hans Christian Andersen. Ali, a tarefa era criar imagens para uma narrativa partilhada socialmente, porque um clássico. Em Desertos, Murray deve criar textos para uma narrativa visual não partilhada socialmente, ou seja, existe o desafio de comunicar ao leitor o percurso do viajante, por isso, a proposta artística em foco não se assemelha à anteriormente tratada.

Algumas questões devem, por isso, acompanhar a análise de um objeto suis generis: 1) O texto visual se constitui como uma narrativa visual, a exemplo do álbum de imagem, ou seja, o visual é independente, não "precisaria" do verbal? 2) O verbal deveria compor uma narrativa para interligar as imagens "avulsas", isto é, proporia uma interdependência entre as duas mídias de maneira a constituir-se como um livro-álbum?

Resta "desconstruir" o projeto gráfico e interrogá-lo sobre as questões que desafiam e, em seguida, edificar a significação da obra que se mostra no horizonte da pesquisa. Vale, contudo, esclarecer de antemão, como demonstrado, que o texto visual introduz o leitor pelo convite expresso na capa e nas páginas iniciais.

\section{Ver para crer: imaginar para existir}

Roseana Murray não omite o fato de fazer os poemas sobre o deserto sem nunca ter estado lá. A autora revela seu processo de busca intertextual: "imediatamente me transportei para estes vastos espaços, eu me vi criança andando junto com os povos do deserto, quando ouvia as histórias da Bíblia ou lia As mil e uma noites" (MURRAY, 2006, Prefácio).

O diálogo constitutivo da obra vem à expressão, pois se identificam vozes provenientes de diferentes interlocutores. É possível que esta seja a chave interpretativa para identificar a dependênc 
entre os sistemas semióticos. Cada interlocutor evidencia sua voz, no entanto, há uma englobante que faz do discurso bivocal um unívoco, isso se forem tomadas as marcas discursivas, como formulado por Bakhtin. Apagam-se, portanto, os autores de "carne e osso", para que saltem as vozes do discurso.

Segundo o teórico russo, o discurso é social e o texto é individual, assim continua o raciocínio que mesmo o individual corresponde (ou responde) às coerções sociais - falando ou calando sobre aquilo que ditam as manifestações sociais de seus espaços e de sua época ${ }^{109}$. O estudioso formula, ainda, que todo discurso apresenta uma heterogeneidade constitutiva e, como conseqüência, o bivocalismo - dialogismo. Essa heterogeneidade constitutiva pode ser mostrada e marcada, mas pode ser mostrada e não marcada, isso dependerá de marcas expressas em discurso.

No livro infantil, se for considerado o projeto gráfico como sujeito da enunciação, idéia defendida por este trabalho, então, a heterogeneidade constitutiva será mostrada e não marcada na maior parte dos casos e mostrada e marcada, na minoria.

No caso em análise, Desertos, que por estratégias verbo-visuais, que não as aspas e o verbo de dizer (como apresentado para os textos verbais, pois Bakhtin se ateve a esses), mas pela tipografia gráfico-visual, marcará a diferença de vozes discursivas, inserindo-se naquela heterogeneidade mostrada e marcada.

A bivocalidade virá à cena pela diferença tipográfica conferida, de um lado, pela letra manuscrita e, de outro, pela tipografia mecânica. 

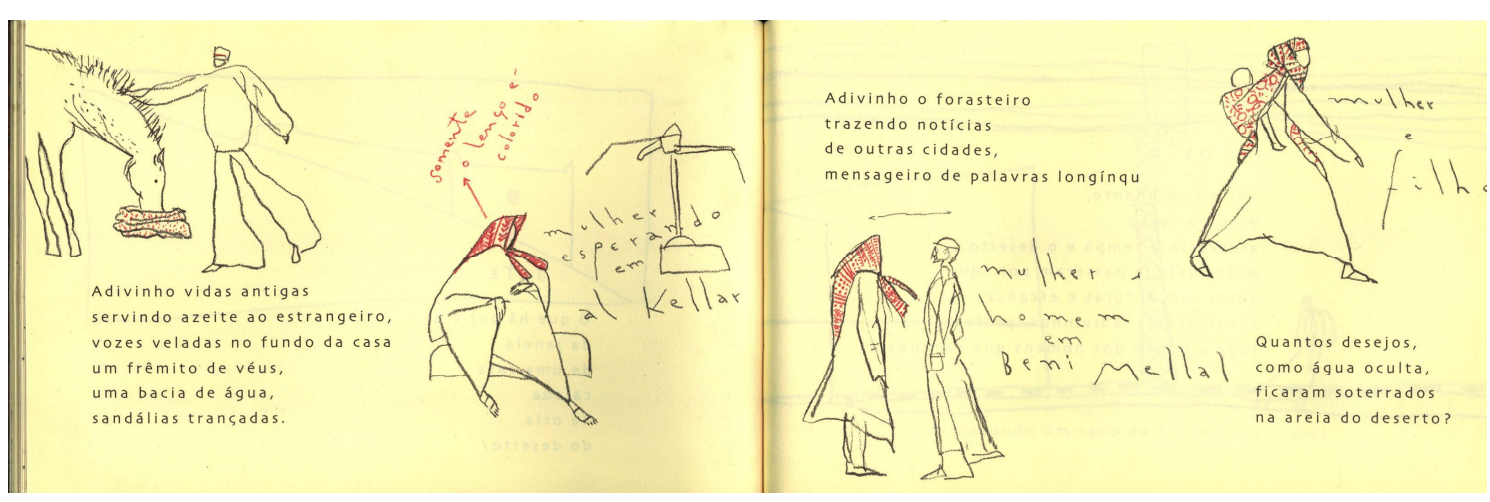

Figura 3.43 - Detalhe tipografia mecânica e manuscrita

Ao manuscrito, cabe a seguinte aspectualização de tempo/pessoa/espaço: agora/aqui/nós inclusivo, ou seja, não é o nós da ciência que busca o efeito de sentido impessoal, mas aquele que tem um nós, que destaca o "eu", pessoalizando o discurso:

"Marrocos - 22 de setembro, Aportamos em Tânger/ depois de atravessar/ os estreito de Gibraltar/ Seguimos viagem em ônibus."

Esta tipografia também apresenta uma descrição-narração, que não pode ser entendida como uma descrição detalhada, mas sim como simples apontamentos descritivos, anotações de viagem improvisadas. Além disso, o manuscrito faz a marcação numérica seqüencial dos textos verbais (esses registrados pela tipografia mecânica) - UM a VINTE E QUATRO - e a indicação espacial (os lugares visitados, por exemplo: Marrakesh, Serrat, Marrocos...). Faz também algumas anotações como descrições que traduzem o desenho ("mulher e filho"), que complementam o desenho ("somente o lenço é colorido") e que alteram os desenhos (em losangos pretos, há uma fecha com a indicação: "azul”). Lembra-se que, nas páginas anteriores, havia desenhos em cor azul, supõe-se, então, que não havia, naquele momento, a disponibilidade do azul, caracterizando aquilo que anteriormente foi denominado "improviso" próprio ao registro de viagem, qualidade do gênero em questão. 


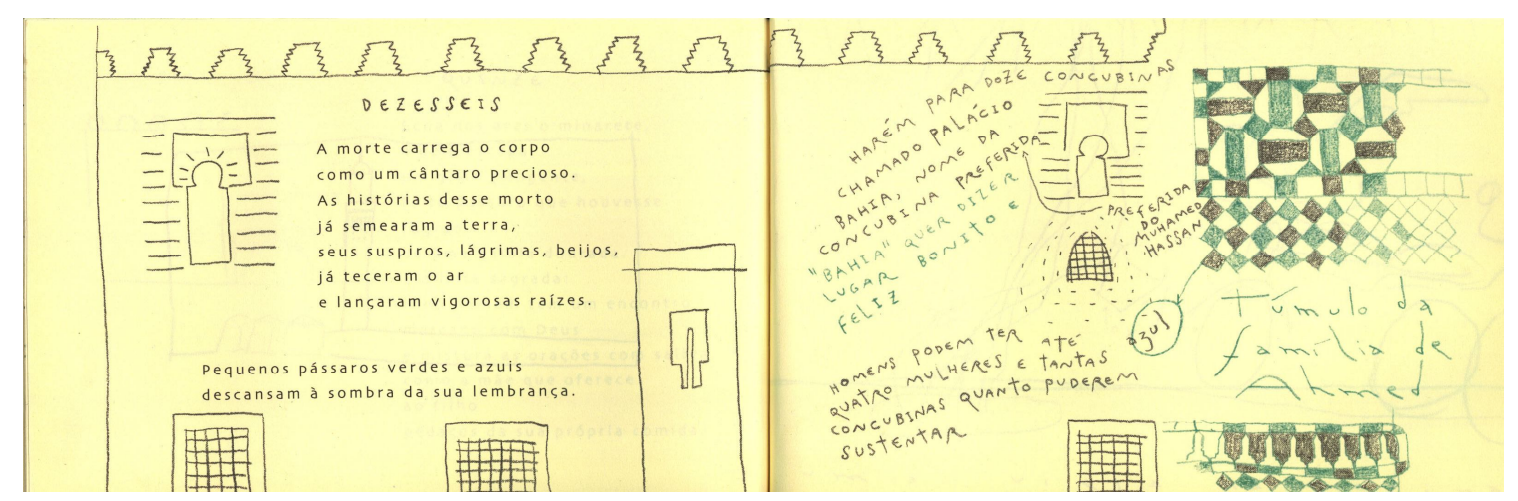

Figura 3.44 - Relação palavra- imagem improviso

Já a tipografia mecânica apresenta uma seqüência de poemas descritivos que compõem um todo narrativo, pois o poema UM revela o seguinte conteúdo: “De muito longe me vejo/ ajoelhada no fundo da caverna,/possuidora de palavras mágicas,/sultana de um reino invisível/ as mãos cheias de tesouro." Tem-se, portanto, um "vejo" (1a. Pessoa do singular), "ajoelhada" (feminino). No poema VI NTE e QUATRO, o conteúdo apresenta: "Três palmeiras na fronteira/ entre passado e futuro./ Já desaparecem, pouco a pouco,/ o deserto,/ suas caravanas, cactos, beduínos/ já os anjos e suas mensagens/ cifradas adormecem,/ já se recolhem todos/ ao sono da areia./ (outra página) O deserto agora são desenhos/ num caderno,/ são rabiscos de poemas,/ a fotografia revelada,/ um último adeus num cibercafé,/ a lembrança de um grande silêncio." O tempo verbal é presente (agora), mas enquanto no poema UM o tempo está por "acontecer", no poema VINTE E QUATRO, há a despedida, o encerramento, o que ficou para trás naquele momento, "fecham-se as vozes do deserto" e fim da viagem. Conclui-se que o poema UM apresenta a tarefa de uma personagem feminina que detêm o poder das palavras e têm em suas mãos tesouros-desenhos. Ela está dentro da caverna (escuridão-silêncio), está longe, mas tem "competência" para dar voz aos tesouros desenhos. A sultana, de um reino invisível (sem imagens), deve atribuir palavras mágicas que transformarão a escuridão em luz e o silêncio em voz. 
No poema VINTE E QUATRO, a imagem pouco a pouco se apaga e se torna registro, "rabiscos de poemas", e se faz o silêncio novamente. Será, a partir desse silêncio, que a sultana receberá o tesouro, e, portanto, é o fim da viagem e o começo da palavra, do registro verbal que tem como propriedade eternizar os momentos com marcas subjetivas. Lembra-se da passagem: "In principio erat verbum". A enunciação, por esta demonstração, está enunciada.

O discurso bivocal está instaurado tanto na palavra como na imagem. Existem duas vozes e essas não são determinadas pelos limites entre expressões (verbal e visual), mas pelas próprias marcas gráficas à semelhança da heterogeneidade mostrada e marcada pelo uso das aspas e do verbo de dizer.

Enquanto o manuscrito se mantém mais fiel ao que é visto, e, a partir das intervenções, comentários aproximam-se da objetividade desejada à descrição; a tipografia mecânica utiliza a heterogeneidade marcada e não mostrada quando estabelece relações mais subjetivas, pois há imprecisões, comparações, metáforas e o recurso intertextual é constante, revelando uma faceta muito mais subjetiva e outras vozes saltam à enunciação, como acontecerá também às imagens.

Essa opção enunciativa parece contrariar a expectativa simbólica do senso comum, pois o manuscrito é simbolicamente instituído como pessoal, enquanto a tipografia mecânica imprimiria um caráter mais impessoal. Essa expectativa simbólica é rompida pelo sujeito da enunciação como uma opção discursiva, instaurando aquilo que a Semiótica de linha francesa denominou semi-simbolismo ${ }^{110}$, recurso próprio dos textos poéticos. O dialogismo existe na expressão e no conteúdo, criando uma obra semi-simbólica:

Aceitando-se reservar o nome de semiótica semi-simbólicas para esse tipo de organização de significação - que se define pela conformidade entre dois planos de linguagem reconhecida como se dando não entre elementos isolados,

${ }^{110}$ Conceito definido anteriormente, mas reapresentado nesta ar 
como acontece nas semióticas simbólicas, mas entre suas categorias - perceber-se-á que tais organizações se encontram não apenas na linguagem gestual (na qual encontramos, por exemplo, a disjunção/conjunção homologada ao movimento das mãos no eixo da lateralidade, efetuando-se em sentidos opostos, ou a atração/repulsa expressas pelos movimentos do tronco e dos braços no eixo prospectivo), mas também nas línguas naturais e, mais particularmente, na elaboração secundária desta que é a linguagem poética (com as categorias prosódicas como a entonação frasal, a rima e o ritmo) (GREIMAS, 2004, p. 93).

\section{Vozes da imagem: a linha em silêncio}

O percurso trilhado pelo Desertos tem início na Espanha, passando pelo Estreito de Gibraltar para, finalmente, aportar no Oriente. Marrocos, Serrat, Tamalet e Marrakesh são alguns dos lugares indicados pelos manuscritos. A tipografia em manuscrito e os desenhos esboçados formam uma voz discursiva, que será descrita pelas linhas que seguem.

No horizonte da travessia, pela janela do ônibus, a linha acompanha o trilhar. No entorno, só há o vazio, o silêncio, mas, como é lugar-comum afirmar, "uma imagem vale mais que mil palavras". O discurso visual se impõe e, com ele, sua característica, que também constitui a heterogeneidade, mostrando suas "mil vozes". Então, vale pontuar que tanto o verbal quanto o visual se propõem como dialógicos, condição inerentes aos discursos, como postula Bakhtin.

O discurso visual que se revela é marcado pelo essencial. Linhas, contornos, figuras geométricas criam o cenário, e, em alguns momentos, a figura humana é protagonista, mas essa também é retratada apenas pelas propriedades que a identificam, ainda, só se tornam protagonistas quando um traço cultural é destacado. Evidenciam-se, então, características do romance de viagem, como descrito por Bakhtin: "Daí a percepção - característica de tais romances - dos grupos sociais estranhos, nações, países, modo de vida etc. no espírito do "exotismo", 
isto é, a percepção das diferenças nuas, dos contrastes, das estranhezas" (2006, p. 207).

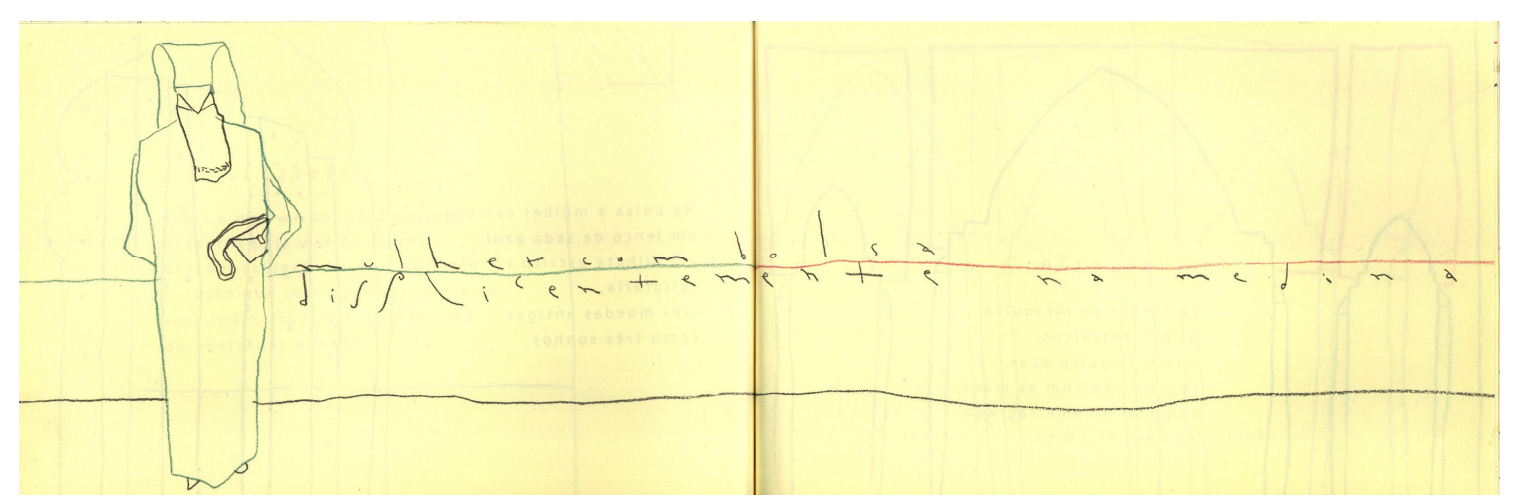

Figura 3.45 - Detalhe de traços culturais

No mais, o discurso visual organiza a narrativa por uma seqüência de imagens essenciais que, quadro a quadro, descortinam o cenário - Desertos.

A exemplo daquilo que se conhece como esboço (ou, em alguns casos, da arte final), deve restar, nos desenhos, a essência.

O diálogo inerente ao discurso se dá, a partir da voz da arte moderna, tangendo seus precursores, como Pablo Picasso. O registro da essência como fundamento do desenho do viajante conduz a um texto muito bem humorado, que tem Picasso como protagonista. A narrativa a seguir ilustra a busca pelo essencial, proposta artística do século XX, quiçá XXI:

E Célestin conclui a sua história: "Na última prova só restavam algumas linhas. Eu olhava o artista (Picasso) trabalhar. Ele suprimia, suprimia. Pensei no primeiro touro, e disse comigo: é curioso; ele terminou por onde normalmente devia começar, Mas Picasso procurava o seu touro. E para chegar ao touro de um único traço passou por todos aqueles outros touros. $E$ quando se vê esse traço único não se pode imaginar o trabalho que o artista teve."

"Há pinturas que parecem não ter nada mas têm tudo", disse Corot. 0 processo seguido por Picasso para chegar a esse touro é um exemplo magnífico. Cada etapa tem sua carga de realidade, e cada realidi verdade. E a versão definitiva leva er 
vem à mente quando dizemos a palavra touro (Disponível em: $\quad<w w w . I m c . e p . u s p . b r / p e o p l e / j c y r o /$ index5724.htm>. Acesso em: 15 jun. 2008).

A narrativa verbal sobre o processo de criação de Picasso pode ser acompanhado pelas provas litográficas, que demonstram exemplarmente a busca pela essência, restando apenas a linha - o essencial:

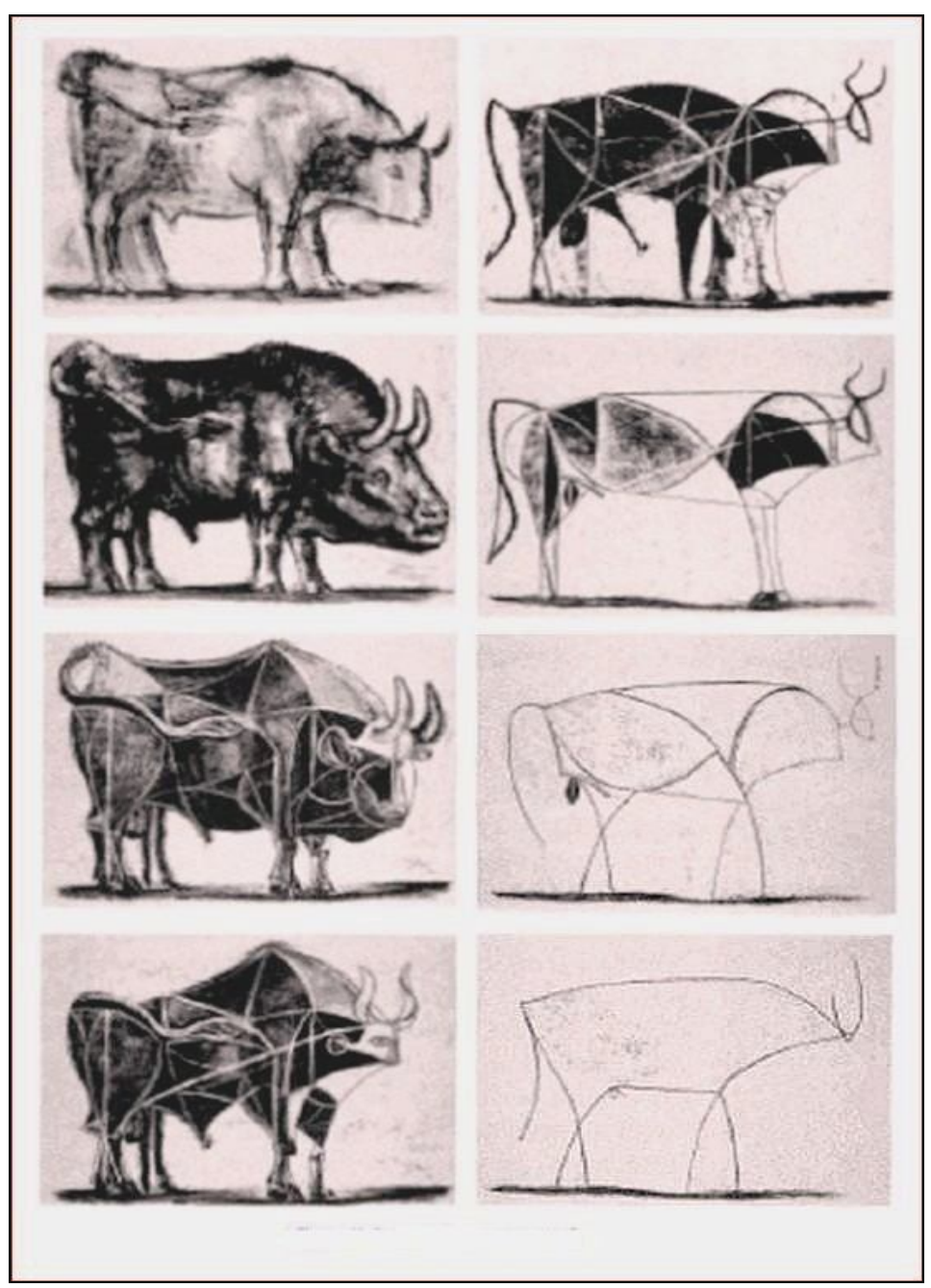

Figura 3.46 - Reprodução das provas litográficas de Picasso 
Os desenhos do deserto apresentados pela obra em análise também guardam apenas a essência, cumprindo os ensinamentos do artista espanhol. A seqüência visual propõe um estilo associado àquele dos registros manuscritos, corroborando a idéia do gênero - durante a viagem não há tempo para preencher, a imagem deve representar o essencial, pois, quando retomada, será preenchida pelo observador: "E a versão definitiva leva em si a imagem que nos vem à mente quando dizemos a palavra touro" (Disponível em: <www.Imc.ep.usp.br/people/jcyro/index5724.htm>. Acesso em: 15 jun. 2008).

Nas artes visuais, a função da linha é a edificação do essencial, como Dondis aponta, sustentando a argumentação proposta:

Nas artes visuais, a linha tem, por sua própria natureza, uma enorme energia. Nunca é estática; é elemento visual inquieto e inquiridor do esboço. Onde quer que seja utilizada, é o instrumento fundamental da pré-visualização, o meio de apresentar, em forma palpável, aquilo que ainda não existe, a não ser na imaginação. Dessa maneira, contribui enormemente para o processo visual. Sua natureza linear e fluida reforça a liberdade de experimentação. Contudo, apesar de sua flexibilidade, a linha não é vaga: é decisiva, tem propósito e direção, vai para algum lugar, faz algo definitivo (DONDIS, 2003, p. 56).

A imagem, as linhas traçadas, contudo, não são estáticas, como alertou Dondis. Pelo contrário, a linha no horizonte se transforma em movimento, a exemplo do que ocorre com a linha da terra nas animações, em que ela, a cada virada de página, modifica-se: ora personagem, ora edifício, ora montanha ${ }^{111}$. Além disso, as linhas em Desertos estão traçadas em cores primárias, conduzindo o caminho e delineando, como já apontado, o cenário. Como em um percurso, em uma viagem, o leitor segue o caminho, a estrada dada pelo desenho que transmuta pela janela do ônibus:

111 Por este perfil, é possível relembrar da capa da obra, e caracterizado como anáfora do conteúdo expresso no miolo. 

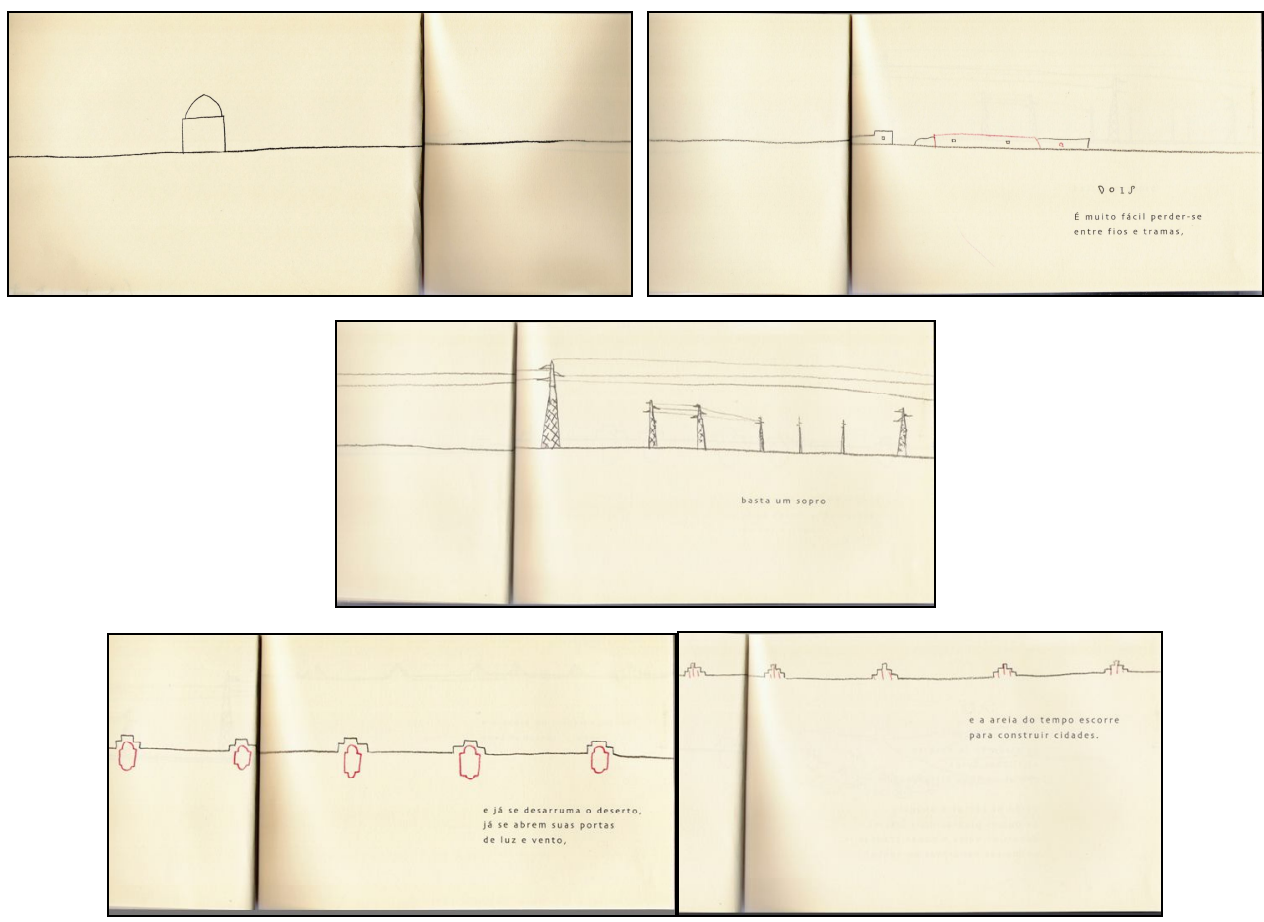

Figura 3.47 - Seqüência da linha

Aproveitei o balanço do ônibus pra atenuar o desenho das linhas. O vazio da região semidesértica seria um estímulo? A paisagem na janela do ônibus mudava constantemente: montanhas, ovelhas, postos, refinarias, letreiros, palmeiras, sacos plásticos, aquedutos, mulheres esperando ônibus, mulheres com sacolas, campos de futebol e a repetição de todas essas coisas ( $O$ diálogo de Roseana Murray e Roger Mello com Jardins e Desertos. Tigre Albino. [S.I.], v. 1, n. 3, 15 jul. 2007. Entrevista concedida a Annete Baldi. Disponível em: <www.tigrealbino.com.br>. Acesso em: 17 maio 2008).

Este traço deixa espaço para a imaginação, o esboço exige a finalização que, neste caso, cabe ao leitor. A imaginação, o repertório são convocados. A imagem (discurso visual) abre possibilidades de preenchimento com lembranças, recorrências, sonhos, enfim, diálogos. A linha pode ser as curvas da natureza, que, esculpidas pelo arquiteto, tornam-se monumentos; pelo escultor, obras-prima; pelo desenhista, sugestões. 
Em Desertos, o enunciador cria cenários arquitetônicos, que remetem às criações de Oscar Niemeyer, estabelecendo relações com o seu repertório - um artista brasileiro contemporâneo que registrou nos grandes centros o seu estilo, que acompanha as próprias curvas do relevo sinuoso de seu país:

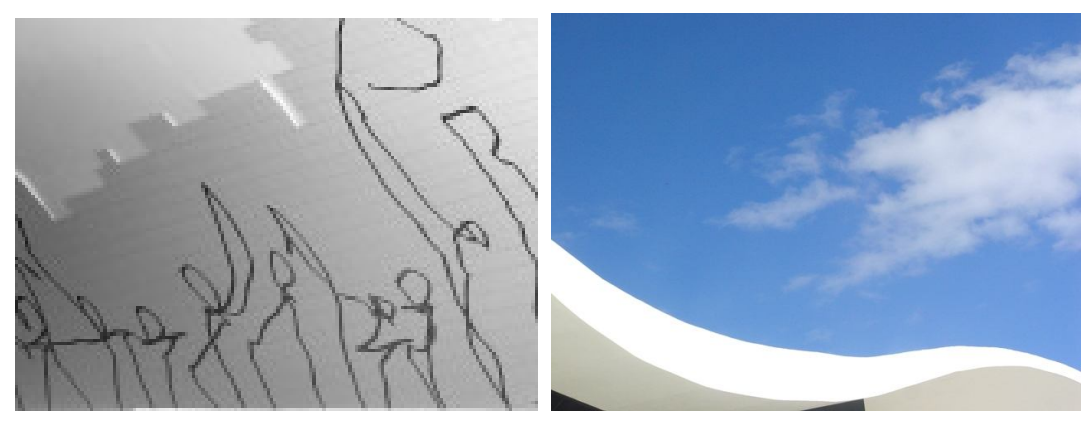

Figura 3.48 - Oscar Niemeyer

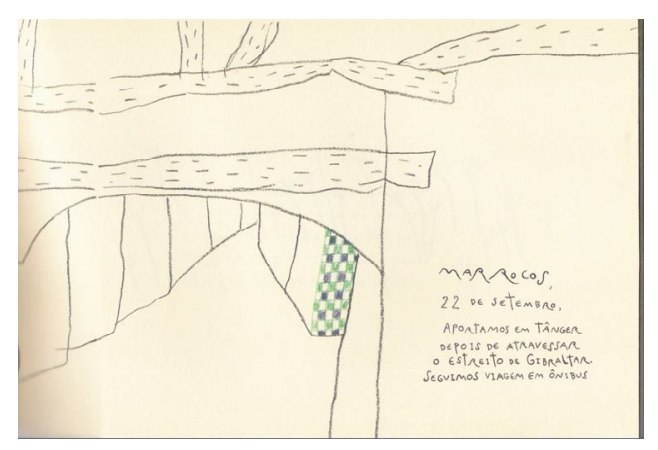

Figura 3.49 - Linha e curvas

Ainda, em Desertos, bordam-se esculturas que lembram o emaranhado de linhas essenciais de Waltércio Caldas, outro artista brasileiro contemporâneo que por um tempo tomou a linha à semelhança de novelos para edificar suas esculturas. A forma, à semelhança da arquitetura, confere característica para aproximar as obras: 


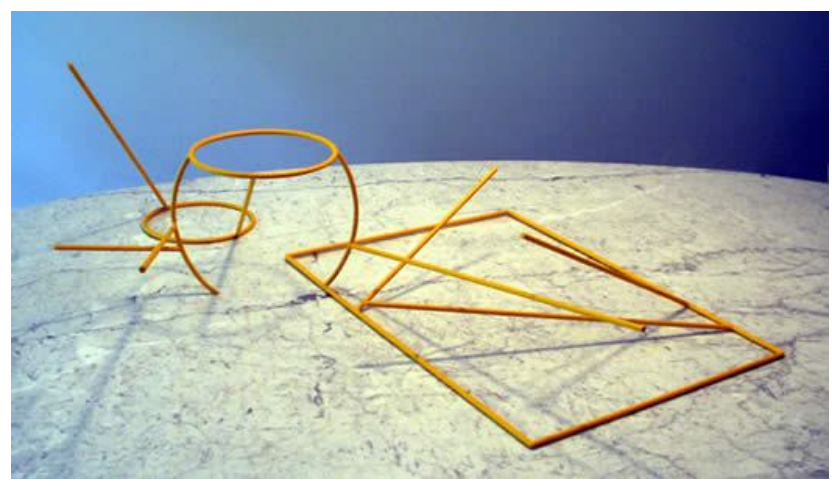

Figura 3.50 - Waltércio Caldas

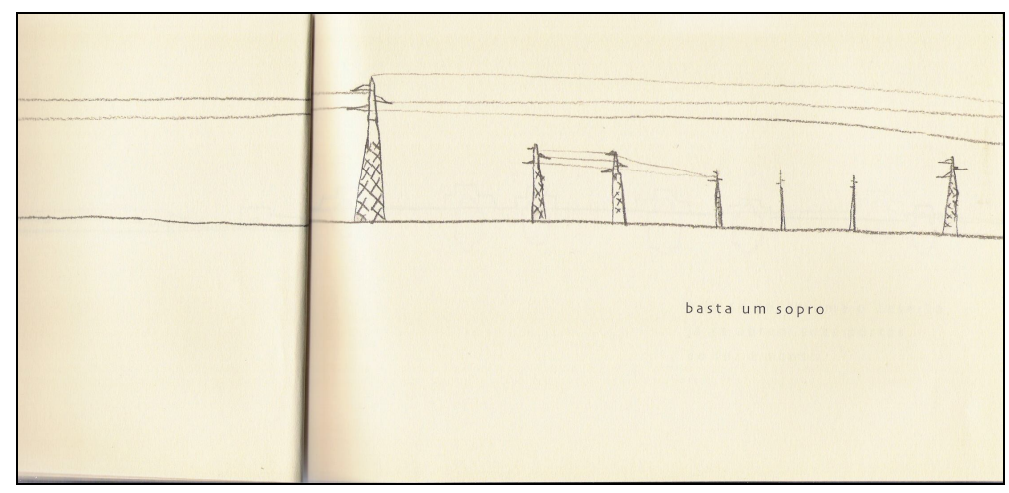

Figura 3.51 - Linhas

Além das referências a nomes-obras em particular, o trabalho de Roger Mello dialoga com seu tempo e seu espaço, sem dúvida deixando a marca de seu estilo (individualidade), mas, sobretudo, refletindo as suas referências contextuais.

Apesar de o estilo gráfico das imagens partir de uma escolha pessoal e ser produzido por um ilustrador, não pode ser classificado como uma assinatura absolutamente particular deste último. Por mais que o traço estilístico de um artista possua personalidade, faz parte de uma visão de mundo coletiva, conforme postulado por Bakhtin:

A literatura é parte inseparável da cultura, não pode ser entendida fora do contexto pleno de toda a cultura de uma época. É inaceitável separá-la do restante da cultura e, como se faz constantemente, ligá-la imediatamente a fatores socioeconômicos, por assim dizer, paccandn nnr rims Na cultura (2006, p. 360). 
Ainda, em literatura infantil, o estilo proposto deve dialogar com a concepção da obra, como explica Rui de Oliveira, em entrevista ao site de literatura infantil Doce de Letra:

[...] Qualquer trabalho que faço passa antes por uma fase de referências e pesquisas. Quando começo a ler um texto e esboçar as ilustrações, já penso logo qual o estilo apropriado àquelas palavras, e onde está este estilo. Melhor dizendo: onde está o modo de fazer. Não gosto de usar a palavra estilo (Disponível em: <www.docedeletra.com.br>. Acesso em: 15 set. 2006).

Vale demonstrar a afirmação, a partir de três obras contemporâneas que reafirmam a influência do contexto cultural em que está inserido e suas tendências. O estilo do autor carrega características que revelam as marcas e estilo de seu tempo: A Banguelinha (2002), de Angela Lago, A flor do lado de lá (1999), de Roger Mello, e Moi j'attends $(2005)^{112}$, de Davide Cali e Serge Bloch, respectivamente:

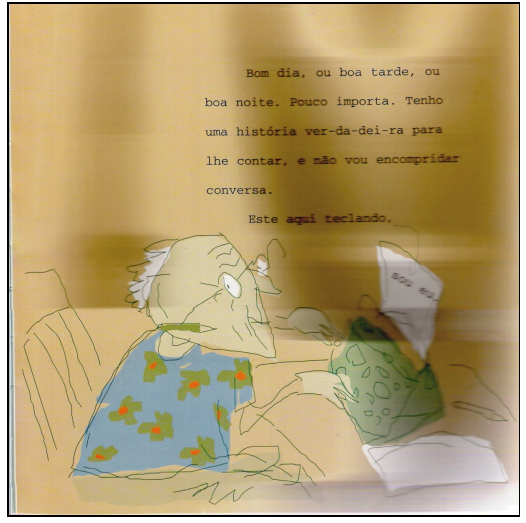

Figura 3.52 - A Banguelinha

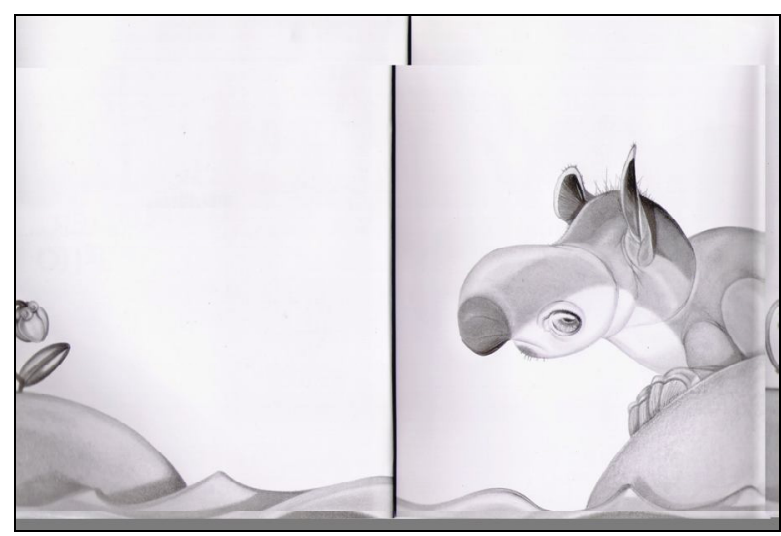

Figura 3.53 - A flor do lado de lá

112 Esta obra foi publicada no Brasil em 2006, a versão apresent 


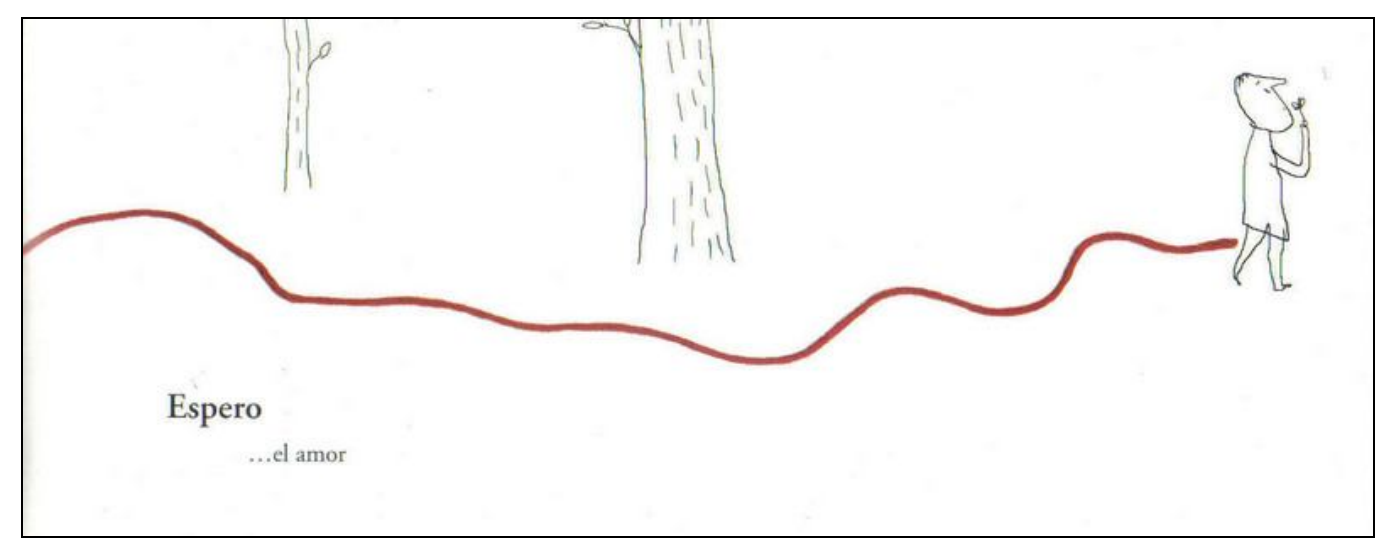

Figura 3.54 - Moi j'attends

Pela linha (elemento gráfico comum), cada um dos artistas conduz sua narrativa visual, imprimindo um diálogo que é próprio ao tempo e à expressão da literatura infantil, no entanto, cada autor capta a tendência da época a sua maneira. Lago recheia as linhas com cores, construindo formas a partir da linha essencial, suas formas são figurativas e podem ser associadas ao estilo do rascunho. Mello, a partir da linha da terra, constrói as distâncias entre as personagens (anta - protagonista e objeto de desejo - flor), essa ligação estabelece o diálogo da obra que será um traço recorrente no próprio estilo do autor. Já Cali e Bloch costuram com lã o elo entre personagens e vida.

Todos estes encontros discursivos revelam a voz presente no silêncio pretendido pelos desenhos do Desertos. Apesar da ausência aparente, as vozes das artes se mostram apenas, na linha, posta no horizonte do leitor, e tais vozes autorizam a semelhança e total fusão entre os diferentes sistemas semióticos, como será demonstrado a seguir, pois o verbal também liberta vozes nas profundezas das palavrashistórias, estabelecendo constantes diálogos. 


\section{Silêncios da palavra: as vozes do discurso}

O discurso verbal também é constituído por vozes mostradas e não marcadas, a exemplo do discurso visual, imprimindo uma característica discursiva que se manifesta por meio de dois sistemas semióticos. Murray revela, de antemão, que conhecera o deserto pelas vozes das histórias, então, já impõe ao leitor as relações intertextuais. As seguintes relações são identificadas: o mito da caverna (Platão), a estátua de sal (Bíblia), Lilith (histórias árabes) e as histórias de Sherazade e Ali Babá (narrativas populares).

A partir da numeração proposta pela tipografia manuscrita (UM até VINTE E QUATRO), acompanha-se uma narrativa composta por poemas que formam um todo de sentido, em tipografia mecânica, como já ponderado. Por meio dos poemas, formula-se a narrativa que será detalhada a seguir:

Poema 1: uma personagem feminina, com poderes mágicos das palavras, está em uma caverna e tem em mãos tesouros - aqui está a referência ao Mito da Caverna, de Platão, em que se questiona a aparência e a essência; o mundo inteligível e o mundo sensível, além de remeter a existência de vozes - o eco, no espaço da caverna. Trazer as palavras à luz é a tarefa do actante;

Poema 2: faz-se um alerta sobre os perigos do caminho; caso algo se altere, pode haver a perda do rumo determinado e de poderes atribuídos. Pressupõe-se, então, que o actante deve cumprir seu percurso, determinado pelos desenhos-tesouros, visto que possui competência e foi manipulada para tal, mas deve atentar para os perigos de outras possíveis manipulações;

Poema 3: existe um questionamento sobre a identidade do deserto - o actante deve realizar sua performance no intuito de passar de um estado inicial de desordem com relação ao sentido (identidade) do deserto para um estado final, em que o sentido esteis nrrsnissdn a nu 
portanto, o leitor possa reconhecer a identidade desse deserto ou do próprio deserto em essência;

Poema 4: a descrição inicial do cenário: o tapete é o sentinela e avisa o viajante de sua entrada no universo desconhecido - a idéia do guarda (guardião) do deserto que anuncia a proximidade com o objeto a ser descrito, o tapete tem a função de destinador do sujeito da ação;

Poema 5: há a oposição entre o oculto e o revelado - este jogo é proposto ao viajante e também ao leitor - o enigma é o que pertence (em essência) ao deserto. No entanto, será revelado o que pertence à cidade, pois não é possível esquecer que ela guarda subjacente a gêneses do deserto. Afirma-se que o deserto, por suas histórias, constitui as cidades, então, estas não estão opostas ao deserto, mas em relação dialética;

Poema 6: revela-se a relação entre cidade e deserto - no entanto, a força deste está nas Histórias que compõem a cidade, ou seja, há oposição e relação de interdependência entre as figuras;

Poema 7: o estrangeiro, o forasteiro, a palavra longínqua é expressa, reafirma-se a existência do viajante, aquele que tem como objetivo reconhecer a identidade do lugar desconhecido ${ }^{113}$ e que será o elo entre o deserto e a cidade;

Poema 8: o caminhante é retratado com sonhos nas costas - todo ser também tem suas histórias (passado, vivência), isso determinará o reconhecimento deste novo espaço que se apresenta, o lugar, será, portanto, (re) conhecido;

Poema 9: descrição da passagem do tempo - anoitecer. A passagem do tempo marca a aprendizagem;

Poema 10: o futuro impõe que não se olhe para o passado, esta imagem recupera a cena bíblica da mulher de Ló que fora transformada em estátua de sal por desobedecer e olhar o (ou ficar preso ao) passado;

\footnotetext{
${ }^{113}$ Destaca-se que a palavra longínqua aparece sem a letra a final n nı node nerar algum sentido que escapa à análise ou pode ser fruto $c$ composição do livro.
} 
Poema 11: no meio do caminho, existe uma pousada entre passado e futuro, talvez, uma referência ao próprio presente como um abrigo entre esses - lugar de acolhimento, lugar conhecido;

Poema 12: Marrakesh - a cidade se impõe, mas o deserto sussurra, o passado também, como apontado anteriormente, constitui a cidade;

Poema 13: Lilith - a condição da mulher no território, a figura demoníaca, o pecado ou obstáculo que poderia "segurar os pés" do viajante, para que ele não seguisse o caminho determinado - manipulação - destinador, como alertado no início;

Poema 14: Sherazade e Ali Babá representam o poder da palavra, contrariando o lugar comum da força da imagem, a palavra tiraria o desenho do silêncio e, portanto, daria sentido ao deserto, a partir de suas recorrências intertextuais;

Poemas 15, 16, 17, 18 e 19: imagens mais preenchidas que demonstram a cultura local, como: especiarias, minarete (grafismo presente da capa), casa das doze concubinas, mulher com véu, mesquita (os desenhos e os manuscritos preenchem as palavras e vice-versa, podese afirmar que a complementaridade entre os sistemas semióticos nestes versos é bastante efetiva);

Poema 20: o verso se refere à música, ao poema como expressão;

Poema 21: chave para descobrir a essência do deserto - o enigma novamente é colocado ao leitor e ao viajante, pois, com suas memórias do ocidente, deve (re) conhecer o oriente;

Poema 22: o verso seguinte aponta o homem como elo (chave) entre o Oriente e o Ocidente, aquele viajante citado anteriormente;

Poema 23: a palavra especiarias trará à tona a lembrança do deserto, com o seu aroma, suas cores e seus sabores;

Poema 24: o último verso apresenta a linha divisória entre Oriente - passado - e Ocidente - futuro (cibercafé).

Pela descrição narrativa, é possível estabelecer a seguinte relação: 
Situação inicial: Conhecido (futuro) - cidade - histórias recontadas - releitura versus Situação final: (re) conhecido (passado) deserto - "histórias antigas", que constituem as novas histórias.

\section{Desertos: redes de silêncios e vozes}

Há, portanto, em Desertos, um entrecruzar de histórias, em que conhecer e (re) conhecer se confundem, remetendo, sem dúvida, à rede narrativa arquitetada por textos como As Mil e uma noites, em que a narrativa principal gera outras histórias.

Nos lugares em que se pretendia o silêncio, saltaram vozes intertextuais. Os discursos tramados por este projeto gráfico apagam as figuras de "carne e osso", apesar de o prefácio trazer a voz da autora, para impor vozes do passado e do futuro, que são "encarnadas" pela diversidade tipográfica, ora manuscrita, ora mecânica. Assim, não existe demarcação entre o que pertence ao verbal e o que pertence ao visual, logo, constrói-se um todo de sentido edificado por dois sistemas semióticos que se tornam apenas um - o livro-álbum:

el género del libro-álbum tiene entonces una naturaleza intrínsecamente dual que nos lleva a relacionar la diversidad de elementos que conforman su lectura. Leemos las imágenes a través de las palabras y las palabras a través de las imágenes. En términos de Bakhtin, cada una de ellas está "dialogizada". Por otra parte, el libro-álbum se dirige a una audiencia para la cual el mundo en general (y la literatura en particular) se encuentran en un estado de cambio perpetuo. En esta estampa, no hay una noción concreta de lo que es la lectura (LEWIS, 1990, p. 98).

Para discorrer sobre este objeto, não foi necessário reconstruir seu processo de criação, mas, pelos próprios arranjos discursivos e composições plásticas dispostas em enunciado, o dialogismo saltou aos olhos e ouvidos para que o leitor acompanhasse a via 
melhor, Desertos, uma vez que não apresenta apenas um, mas vários que habitam (ou habitaram) as artes narrativas ao longo dos tempos.

\subsubsection{O Diálogo entre os Dois Projetos Gráficos}

O objetivo deste trabalho de tese é verificar em que medida o projeto gráfico dos livros infantis se constitui como todo de sentido e, ainda, se a articulação entre os sistemas semióticos contribui para uma leitura rica, que implica ampliação de repertório e inserção no universo das artes, sejam plásticas ou literárias, formando um leitor literário. Assim, cabe à análise, neste momento, a tarefa desafiadora de descortinar dois projetos gráficos relacionados, pois apresentam um encontro bastante recorrente no cenário da literatura infantil brasileira, a saber: o fértil diálogo entre os artistas Roseana Murray e Roger Mello.

A proposta era um risco, pois a pesquisa fundamenta-se nas teorias semiótica e discursiva que deixam de lado o processo de criação e focalizam o produto (texto e discurso) em si. Por isso, de certa maneira, as palavras de Roseana Murray apaziguam os anseios da análise:

O efeito dos livros, se olharmos os dois juntos, é impressionante. O Jardins é uma explosão, o Desertos é uma arquitetura feita de vazios e silêncios. Na verdade o livro Jardins é do Roger, meus poemas apenas pontuam a maravilha que é o seu trabalho. E o Desertos, apesar do Roger ter viajado sozinho, é como se fosse meu também, viajei junto com ele, mas depois (O diálogo de Roseana Murray e Roger Mello com Jardins e Desertos. Tigre Albino. [S.I.], v. 1, n. 3, 15 jul. 2007. Entrevista concedida a Annete Baldi. Disponível em: <www.tigrealbino.com.br>. Acesso em: 17 maio 2008).

A autora, em entrevista a Revista Poesis, descaracteriza totalmente a autoria, quando revela que em Jardins seus poemas pontuam os desenhos de Mello e que em Desertos, apesar de apenas Mello ter viajado, a poeta se manifesta como autora, a partir de relaçõ€ 
A análise com relação a essas obras, que têm processos de criação, de certa maneira, opostos, autoriza a elaboração de que o sujeito da enunciação, como ensinam os conceitos semióticos, não revela os sujeitos autores, mas se constroem por meio da própria enunciação, deixando claro que o projeto gráfico, se bem articulado, como nas obras em análise, funciona como um único mecanismo de significação, ou seja, um discurso.

Posto isso, evidenciam-se os pontos de aproximação e os pontos de distanciamento entre os dois projetos gráficos em análise:

\section{Tabela 3.1 - Aproximações entre os projetos gráficos - Jardins e Desertos}

\begin{tabular}{|c|c|}
\hline \multicolumn{2}{|c|}{ Aproximações } \\
\hline CAPA & Identificação do gênero \\
\hline AUTORES & Equipe verbo-visual \\
\hline PREFÁCIO & Introdução da obra \\
\hline $\begin{array}{c}\text { TI PO DE TEXTO } \\
\text { VERBAL }\end{array}$ & Poemas \\
\hline $\begin{array}{c}\text { PLURAL NO Tí TULO } \\
\text { RECORRÊNCI AS } \\
\text { INTERTEXTUAIS }\end{array}$ & Subjetividade \\
\hline $\begin{array}{c}\text { DESCRI ÇÃO DE } \\
\text { AMBI ENTES }\end{array}$ & Diversas vozes \\
\hline
\end{tabular}



Desertos

Tabela 3.2 - Distanciamentos entre os projetos gráficos - Jardins e

\begin{tabular}{|c|c|c|}
\hline \multicolumn{3}{|c|}{ Distanciamentos } \\
\hline & Jardins & Desertos \\
\hline PÁGI NAS & Preenchidas & Vazias \\
\hline EXPRESSÃO & Profusão & Escassez \\
\hline CORES & Diversidade & Restrição \\
\hline AMBI ENTE & Conhecido & (Re)Conhecido \\
\hline TI POGRAFI A & Manutenção & Alternância \\
\hline SOBRECAPA & Presença & Ausência \\
\hline POEMAS & Descritivos & Narrativos \\
\hline I MAGENS & Pontuais & Seqüenciadas \\
\hline PREFÁCIO & Manoel de Barros & Roseana Murray \\
& (alheio) & (próprio) \\
\hline
\end{tabular}

Os esquemas revelam mais pontos de distanciamento que de aproximação, mas a investigação valida a experiência da equipe de produção na composição da obra de literatura infantil. 


\subsection{Fita Verde no Cabelo - Nova Velha Estória: Emaranhados de VOZES}

De muito longe me vejo/ ajoelhada no fundo da caverna,/ possuidora de palavras mágicas,/sultana de um reino invisível/ as mãos cheias de tesouro.

(Roseana Murray)

Fita Verde no cabelo - nova velha estória, de Guimarães Rosa, editada pela Nova Fronteira, apresenta em seu título a problemática a ser abordada por esta análise. Interessa investigar a presença do discurso do outro na obra de Guimarães Rosa, tanto a voz da "velha estória" como a "voz" das imagens, pelas ilustrações de Roger Mello. Assim, a intertextualidade e a relação palavra-imagem são as questões que norteiam o estudo.

Quando Guimarães Rosa, autor do conto, introduz o subtítulo "nova velha estória", antecipa a inclusão de uma voz, a da "velha estória" que será recontada. Tem-se, pois, uma releitura, uma relação intertextual no texto verbal.

A "velha estória" reelaborada por Rosa é o tradicional conto Chapeuzinho Vermelho. O objetivo que se impõe é o de verificar as relações de permanências e transformações entre 0 texto-base (Chapeuzinho Vermelho) e conto de Rosa (Fita Verde no cabelo) para, assim, perceber os pontos de interação entre os textos verbais. Cabe identificar pontos de interação tanto no plano do conteúdo, tangendo a estrutura de ações do actante Chapeuzinho Vermelho e as manifestações de temas e figuras no nível discursivo, quanto o plano da expressão para revelar a linguagem poética.

Contudo, além disso, o trabalho de tese que se apresenta tem por objetivo "ir mais para lá" das relações verbais, pois seu foco, sobretudo, recai sobre relação entre palavra e imagem, articuladas 
Então, o conto de Rosa, editado pela Nova Fronteira é o objetolivro dado à análise, visto que Roger Mello, autor selecionado no corpus desta pesquisa, aceitou ilustrar esse intrincado recontar. A pertinência deste adjetivo se dá pela exploração da linguagem poética, característica do autor mineiro e também do artista brasiliense.

Posto isso, adota-se como metodologia desfazer os emaranhados verbais para, em seguida, tramar os fios dos sistemas semióticos (verbal e visual) e, finalmente, entender os procedimentos da composição gráfica, sem perder de vista o público pretendido pela obra, a saber: a partir da análise que se propõe, é lícito perguntar se o público-criança é realmente aquele pretendido pela edição.

Mais uma vez, diante de um texto clássico da literatura infantil, recontado inúmeras vezes, caberá verificar-se a pertinência da releitura "atualizada" (ao menos transformada) e, ainda, a função da imagem neste projeto gráfico. Vale, então, perguntar: se todo o trabalho poético de Rosa, que não é um autor de literatura infantil, mas que recorre ao conto maravilhoso como base de sua criação, não afasta sua versão do público pretendido pelo texto original - Chapeuzinho Vermelho? A função da imagem seria justamente aproximar o leitor, endossando aquela visão de que a imagem esclarece o texto verbal? E, também, cabe, mais uma vez, indagar: se o texto existia antes da imagem, essa, portanto, não seria desnecessária? Questionar-se-á, portanto, o gênero da obra: livro-álbum, álbum ilustrado, conto ilustrado?

Só é possível trabalhar as relações destacadas graças à edição da editora Nova Fronteira, porque a problemática de retomada do discurso alheio se dá tanto no texto verbal quanto no visual, possibilitando reflexões sobre a interação entre os dois sistemas semióticos, como se pretende demonstrar. 


\subsubsection{A Nova Fronteira I mposta ao Clássico}

A edição da Nova Fronteira foi ilustrada em homenagem a Guimarães Rosa, quando dos 25 anos de sua morte e, como Glória Pondé, coordenadora da edição, relata na contracapa, a obra pretende o público em geral: "O conto, rico por si mesmo, escrito com um ritmo e uma forma de apresentação de cenas e imagens que muito o aproximam da poesia, encanta o público de qualquer idade" (PONDÉ, 1992, contracapa).

Pontua-se que o texto de Guimarães Rosa não sofreu qualquer alteração para se adaptar a uma faixa etária específica - a infância, por exemplo. A edição apenas colocou o texto verbal em diálogo com o visual para compor uma nova edição do conto de um autor brasileiro que é clássico e, assim, homenageá-lo. Ainda, se a apresentação de Ponde destaca o público-alvo, como generalizado: "encanta o público de qualquer idade", isso se impõe como um alerta ao leitor, pois, se fosse uma obra destinada ao público adulto, não haveria a necessidade da ressalva. É senso comum entender a obra ilustrada como um livro destinado à criança, além disso, a retomada do conto maravilhoso reforça a sugestão do público-alvo.

A retomada do conto maravilhoso Chapeuzinho Vermelho fica clara para o leitor já em seu título, então, não haveria necessidade de adaptação na linguagem. O leitor-criança, por meio da identificação entre as histórias, compreenderia o recontar de Guimarães Rosa.

O conto Chapeuzinho Vermelho mora no universo infantil, logo, a identificação é imediata. Tal afirmação é possível tendo em vista que esse conto, a partir da Revolução Francesa, foi utilizado para ensinar às crianças, portanto, muito difundido a partir de então em todos os cantos do mundo, até no Brasil. Nelly Novaes Coelho reflete acerca do percurso do conto maravilhoso a partir de seu "nascimento" na França: 
Uma coisa, porém, é indiscutível: tal redescoberta do popular, em plena crise dos valores clássicos/aristocráticos, na França de Luís XIV, está [...] ligada à Querela dos Antigos e Modernos (que dividiu a Academia Francesa e marcou, historicamente, o crepúsculo do Classicismo). [...]

Parece que, com a redescoberta dessa literatura popular, autenticamente francesa e, portanto, moderna, Perrault pretendia provar a identidade de valores entre a criação dos novos povos e a produção dos antigos (gregos e romanos), tidos como modelos superiores de cultura oficial (1987, p. 66-70).

Se a história de Chapeuzinho Vermelho é um clássico, o seu recontar é inevitável na esteira do que revelara Ítalo Calvino sobre os clássicos ${ }^{114}$. Posto isso, resta identificar o que do texto-base se mantém, o que se transforma e, ainda, os porquês dessas permanências e transformações. Quais são os efeitos de sentido gerados pelas modificações?

$\mathrm{Na}$ edição em análise, a relação palavra-imagem não pode permanecer em segundo plano, e isso, obviamente, também agrega sentido.

Além das indagações expressas, formulam-se outras duas questões que intrigam na mídia visual, a saber: 1) as imagens como voz do outro e 2) as referências a outras vozes no próprio discurso visual.

Enquanto o texto verbal dialoga com outra história, como se sabe, o visual dialoga com outras técnicas das artes plásticas, como será demonstrado: o surrealismo, o hiper-realismo, o barroco, entre outros. Estaria, pois, nesta característica do discurso visual, o diálogo com a palavra, uma vez que essa incorpora ao seu discurso as estratégias utilizadas pelo discurso verbal. É importante verificar quais estratégias o discurso visual lança mão para constituir um todo de sentido com a palavra.

Quando um artista ilustra determinado texto, estabelece com este um diálogo que pode ser totalmente redundante com relação ao verbal, agregador, ou mesmo, um dissipador de sentido, caso não se estabeleça relação de novos sentidos, hipótese que este trabalho descarta. Por isso, interessa à investigação entender a função da imagem nesta edição e os 
emaranhados de vozes formados por este encontro entre dois poetas, Guimarães Rosa e Roger Mello.

\subsubsection{Vozes da "Nova Velha Estória": Permanências e Transformações}

A narrativa de base é o antigo conto de tradição oral Chapeuzinho Vermelho, registrado posteriormente por Perrault e pelos Irmão Grimm. Cada um desses autores é influenciado por sua época. A história tem suas alterações e, portanto, diferentes versões. Benjamin Abdala Junior aponta que “o que ocorre, neste sentido, (é) uma apropriação 'natural' das articulações literárias sem que o próprio futuro escritor se aperceba de sua situação de ser social e de 'porta voz' de um patrimônio cultural coletivo" (2003, p. 112).

Discini explica que Chapeuzinho Vermelho, em particular, é um conto maravilhoso com traços míticos, e isso lhe garante os atributos clássicos:

[...] pode-se concluir que Chapeuzinho Vermelho é um conto que apresenta traços míticos. Não poderia ser mito, porque mantém a especificidade do conto maravilhoso, que é, segundo Mieletínski (1979, p.54), “a invenção poética consciente", a "transformação da imaginação 'etnográficaconcreta' numa imaginação poética generalizada (em certa medida até mesmo convencional" (2004, p. 141-142).

Guimarães Rosa também deixa entrever em sua obra, como não poderia deixar de ser, o seu tempo e o seu espaço, e, por isso, impõe-se uma releitura do conto, e não um contar a história-base simplesmente. É uma retomada livre ${ }^{115}$ da história base. Caracteriza-se, pois, como um vôo que tende à originalidade narrativa. Discini (2004) afirma a linguagem poética de Rosa:

115 O adjetivo livre é usado, pois Guimarães Rosa não tem por nhietivo rnmo fira clarn em seu conto, transmitir o conteúdo do conto popular Cha sim dar novo sentido, novo mote à narrativa original. 
Fita-verde, de todas as amostras do nosso corpus, é aquela em que a função estética atinge sua máxima e plena realização, beirando à poesia. As figuras são as do texobase; os temas são os do texto-base; o sistema sintático enuncivo é o do texto-base; as seqüências narrativas são as do texto-base; as relações sintático-semânticas básicas são as do texto-base. Acontece que tudo se resolve numa ambigüidade discursiva, que é conseqüência de ambigüidades que se vão tecendo desde as profundezas [...] do nível fundamental [...]

Fita-verde esconde, sob uma linguagem trabalhada, Chapeuzinho Vermelho, a qual Ihe dá a matéria-prima, fazendo com que significante veicule um novo significado, de tal maneira que se torne impossível desvincular o conto de Rosa do modo como ele é contado. [...]

Rosa não mostra o texto-base, com o qual conflui e que está na base da construção do significado de seu conto (2004, p. 239).

O texto-base Chapeuzinho Vermelho surge como uma estruturabase que será transformada pelo novo discurso, a qual habita o imaginário (repertório) popular e, por isso, pode ser preenchida, recheada por outro conteúdo, por outras temáticas, sem que a sua estrutura-base seja alterada e sem modificar o que o enunciatário já guarda em seu repertório sobre ela.

Neste momento, é possível remeter a outras duas leituras do conto, uma francesa, um livro de imagem, com figuras discursivas mais abstratas (HONEGGER-LAVATER, W. Le Petit Chaperon Rouge, 1965) ${ }^{116}$, e outra brasileira (HOLANDA, F. B. Chapeuzinho Amarelo. Ilustração de Ziraldo. Rio de Janeiro: José Olympio, 1984), um livro ilustrado ${ }^{117}$ :

${ }^{116}$ Verifica-se, nesta versão, que, apesar de as figuras tenderem à abstração, o leitorcriança facilmente depreende o enredo narrativo, pois o título ancora a abstração, como foi demonstrado na análise da obra Sebastião, de Manuela Rarelar

117 Esta obra também foi analisada como uma variação do con realizado por Norma Discini em Intertextualidade e o conto $\mathrm{m}$ 

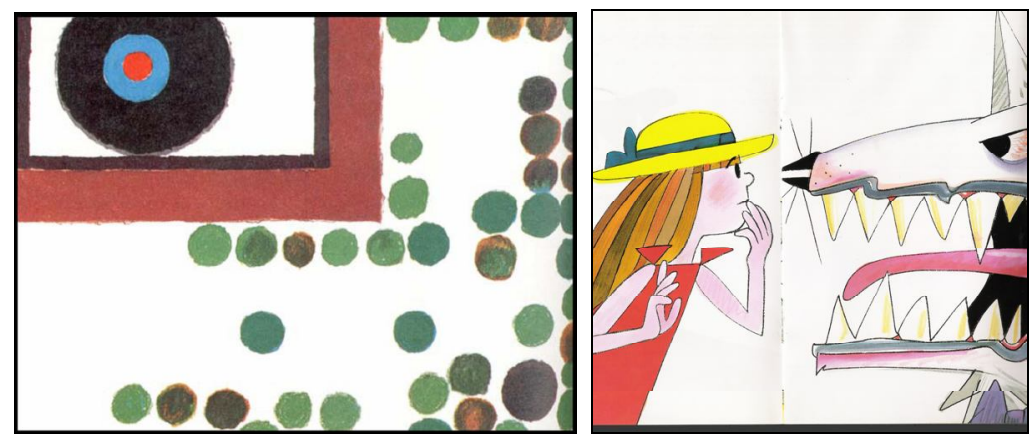

Figura 3.55 - Releitura de Chapeuzinho Vermelho

A hipótese criada, então, é a de que Rosa recupera a estrutura narrativa com suas seqüências e contratos a fim de preenchê-la com o universo que lhe é característico. Um discurso no entrelugar do local (sertão) e do universal (mundo). O autor parte, pois, de algo estrangeiro (conto maravilhoso) para imprimir a marca nacional. Tendo tal hipótese como ponto de partida, evidenciam-se alguns pontos de aproximação e outros de distanciamento entre as obras colocadas em relação.

\subsubsection{O Texto-Base}

A protagonista de Chapeuzinho Vermelho é uma menina "sem juízo", desobediente, assim caracterizada pelo narrador do conto maravilhoso. Apesar disso (ou por isso), recebe uma missão, a saber: ela é incumbida pela mãe a levar doces e frutas à avó, que está doente. A menina, como antecipado pela caracterização, quebra o contrato estabelecido quando rejeita o caminho mais seguro indicado pela mãe e segue a sua escolha: o percurso mais curto, reforçando o traço de desobediência. Lá, neste caminho "proibido", para surpresa da menina, está o Lobo (antagonista), que a engana e, antes dela, corre para a casa da avó da menina. Ali, come sua primeira vítima - a própria avó. Algum tempo depois, a menina encontra o Lobo disfarçado de vovó. Há, então, um conflito entre ser versus. parecer, visto que a $\mathrm{m}$ 
sua avó. Neste ínterim, o caçador salva ambas as vítimas: avó e menina. Chapeuzinho Vermelho não chega a ser devorada, a avó é retirada inteira da barriga do lobo, e o final é feliz e traz uma moral da história.

A temática dos contos maravilhosos registrados nos tempos de ascensão da classe burguesa tem por objetivo educar. Com este propósito, Chapeuzinho Vermelho ensina à infância as "conseqüências" da desobediência. Seria essa a proposta educativa presente neste conto maravilhoso, como pontua Discini:

Conclui-se, disso, que Chapeuzinho Vermelho, a menina tão delicada e frágil o que é atestado pelo duplo diminutivo, também ancestral, o que subentende de todos os tempos. Com esse arcaísmo, o discurso fortalece o caráter de conto exemplar. Quando a menina é designada por "le petit chaperon rouge", não é descrita, não é conhecida por traços fisionômicos individualizantes. O petit chaperon, o duplo diminutivo, é a sua identidade, e é arcaico, e é "próprio para as mulheres velhas", trazendo consigo a significação de tempo muito antigo.

Aí está uma menina "exemplar", que pode ser qualquer menina, ou, até, qualquer adulto. Um ator, enfim, construído com traços de generalidade, de imprecisão, para que, nele, o enunciatário mais facilmente se reconheça, assim como, por meio dele, mais facilmente aprenda a lição (2004, p. 149).

Depois de descrever, brevemente, o texto-base, passa-se ao universo "perigoso", porque repleto de lacunas e sobressaltos de Guimarães Rosa e sua leitura do conto de tradição oral.

\subsubsection{O Sertão Universal como Base para a Leitura}

Guimarães Rosa tem o sertão como cenário recorrente em sua produção literária. Um sertão que é o mundo, segundo as palavras de Riobaldo, narrador de Grande Sertão: veredas: “Enfim, cada um o quer aprova, o senhor sabe: pão ou pães, é questão de opiniães... O sertão está em toda parte" (1986, p. 1). 
Vale perguntar se a história de Chapeuzinho Vermelho poderia ser "espacializada" no sertão, visto que, originalmente a menina se perde em uma floresta densa e fechada própria a outro bioma que não o sertanejo. Parte-se, contudo, da hipótese de que o texto-base seria apenas uma estrutura narrativa nas mãos de Rosa, isto é, a estrutura narrativa com seus contratos e a performance é mantida, já a "cobertura" própria ao plano da expressão seria a grande mudança no conto do autor mineiro.

Na obra Fita Verde no cabelo, o cenário não dá pistas do sertão roseano. O sertão universal de Guimarães Rosa está à margem neste conto, pelo menos no que se refere à caracterização do espaço físico, em que os acontecimentos narrativos se dão. Essa afirmação é possível graças a termos como "O pote continha um doce em calda, e o cesto estava vazio, que para buscar framboesa". "Divertia-se com ver as avelãs do chão não voarem [...]"118. Avelãs e framboesas deslocam o cenário sertanejo e aproximam outro espaço, um ambiente de clima temperado, próprio para tais frutos. O cenário dado pelos frutos distancia do sertão, mas como este é universal, cria-se a ambigüidade discursiva. Avelãs e framboesas são conectores de isotopia que conduzem o leitor ao texto-base. No sertão, deveriam destacar-se cactos, buritis, pequis; plantas e frutas próprias do sertão mineiro.

Isso, contudo, não descaracteriza a linguagem que consagrou Rosa, pois seu narrar sertanejo ${ }^{119}$ permanece: "Havia uma aldeia em algum lugar, nem maior nem menor, com velhos e velhas que velhavam, homens e mulheres que esperavam, e meninos e meninas que nasciam e cresciam". O uso de neologismos inspirados nos falares do povo continua e marca a produção criativa do autor em questão. Tal escolha lexical e sintática conduz o leitor, novamente, para o sertão mágico e universal de Guimarães Rosa.

${ }^{118}$ Grifo nosso.

119 Quando se trata do narrar roseano, verificam-se duas questões, uma que se refere ao linguajar que retoma a fala do homem sertanejo e outra à prónria ectrıtıtıra de diálnan com outras histórias, de uma estrutura com vazios, de referências à tradição popular, oral. 
A marca do sertão na obra de Rosa é uma constante. Por isso, podese afirmar que essa recorrência lingüística marca o seu estilo, não por meio das figuras do conteúdo, mas pelas marcas da expressão que levarão ao discurso poético recheados por aliterações, polissíndetos, metáforas, comparações, ambigüidades recriadas do sertão de Minas Gerais.

Quanto às duas questões tratadas, a primeira aproxima a obra original da obra de Rosa, quando o ambiente que abriga a narrativa apresenta características de países temperados, ou seja, espaço onde surgiu a obra original; a segunda, no entanto, distancia a obra original de sua releitura, pois o narrador narra ao modo sertanejo. Sua linguagem tem características do contar roseano. Marca o estilo do produtor do texto.

A obra Fita Verde no cabelo apresenta, no conteúdo figurativo do discurso, uma aproximação com o texto-base, enquanto, no plano da expressão do discurso, o modo de narrar, o estilo do contar propõe um distanciamento do texto-base. Rosa imprime seu estilo ao narrar, e sua marca poética faz o sertão emergir do conto maravilhoso.

Como ensina Bakhtin: "A maneira individual pela qual o homem constrói seu discurso é determinada consideravelmente pela sua capacidade inata de sentir a palavra do outro e os meios de reagir diante dela" (1981, p. 197).

A caracterização do cenário, que aponta para um lugar fora do sertão, mas que é conduzido por um narrar sertanejo, ascende, assim, a possibilidade intertextual do conto Fita Verde no cabelo. Reafirma-se esse conto como uma releitura estilizada de Chapeuzinho Vermelho:

Dissemos anteriormente que a estilização resulta de um acordo entre a enunciação enunciada e o enunciado enunciado, na medida em que o texto-base, implícito na enunciação, é assimilado pelo enunciado da variante intertextual $[\ldots]$

O texto-base, segundo o que foi dito, fica, também, ideologicamente confirmado, ainda que uma leve sombra recaia sobre ele.[...]

Rosa chamou-a nova velha história: nós. estilizacão (DISCINI, 2004, p. 216). 
Havia, ou mesmo há, uma tendência grande em "cuidar" da integridade das grandes obras de arte com algo sagrado, intocável. O movimento modernista do início do século passado no Brasil por inspiração européia, "dessacralizou" a obra de arte, pois com ela estabeleceu diálogos, ora parafraseando, ora parodiando ou estilizando, como será defendido por Discini ${ }^{120}$. Diferentemente do "respeito" ao texto clássico que Bacelar manteve ao ilustrar a obra de Andersen, Rosa toma o conto maravilhoso como seu, apropria-se dele e o transforma, exercendo o reflexo modernista em seu discurso.

Verifica-se, então, que Rosa elege um cenário que não territorializa, mas sim universaliza. A universalização é dada por meio da inserção de uma voz que não é a sertaneja no seu conteúdo, mas sim em sua forma: "Havia uma aldeia em algum lugar, nem maior nem menor, com velhos e velhas que velhavam, homens e mulheres que esperavam, e meninos e meninas que nasciam e cresciam".

O conteúdo apresentado é a história de uma menina que desobedece às ordens da mãe. Ação idêntica ao texto-base, enquanto os neologismos e as construções sintáticas apontam para uma busca dos padrões lingüísticos regionais, nacionais e, portanto, frisa-se que a obra de Rosa está no entrelugar do local e do universal. Essa é uma expressão utilizada pelo crítico Silvano Santiago, em Uma literatura dos trópicos (1978), quando focaliza a literatura latino-americana. Para justificar a referência, cita-se:

O escritor latino-americano brinca com os signos de um outro escritor, de uma obra. As palavras do outro têm a particularidade de se apresentarem como objetos que fascinam seus olhos, seus dedos, e a escritura do texto segundo é em parte a história de uma experiência sexual com o signo estrangeiro (1978, p. 21).

${ }^{120}$ A autora, em Intertextualidade e o conto maravilho, discute $\bar{c}$ 


\subsubsection{O Conto de Ensinamento: O Recontar Roseano}

Outro aspecto relevante, depois de abordar a questão da espacialização e o modo de narrar, diz respeito ao que se aprende neste conto Fita Verde no cabelo, pois também isso foge da proposta do conto maravilhoso. Enquanto neste, a desobediência leva à aprendizagem do respeito às normas; naquele, de Rosa, a desobediência - "Todos com juízo, suficientemente, menos uma meninazinha, a que por enquanto." leva ao encontro, à descoberta da morte.

Para fundamentar e sustentar essa afirmação, focaliza-se a personagem antagonista, que no texto-base é o Lobo. Essa personagem símbolo do medo, do mal, para alguns, é o retrato do masculino, da sensualidade para outros ${ }^{121}$. Instala-se como mal (mau), no texto-base, na medida em que, pela desobediência, chega-se a ele. Essa é a moral do texto-base. Contudo, e a moral na obra Fita Verde no cabelo?

$\mathrm{Na}$ voz do narrador roseano, a figura do lobo assume outro sentido, pois esse perde seu lugar, não será, ele, o antagonista. Este é figurativizado pela própria consciência da menina. Pode-se dizer que o "lobo" (da outra narrativa) está dentro dela, ou seja, em sua consciência. O lobo não existe na leitura de Fita Verde no cabelo, pois é a própria oposição humana: vida versus morte. "Daí, que, indo, no atravessar o bosque, viu só os lenhadores, que por lá lenhavam; mas o lobo nenhum, desconhecido nem peludo. Pois os lenhadores tinham exterminado o lobo." Está, portanto, descartada da leitura de Guimarães Rosa a figura do Lobo, como um antagonista, ou seja, o opositor que impede o herói de realizar sua ação.

${ }^{121}$ Como em A psicanálise dos contos de fadas, de Bruno Bettelr 
Discini faz a seguinte análise a este respeito:

Observemos um pouco mais o actante do enunciado, FitaVerde, que, com Chapeuzinho Vermelho, constituem um único sujeito com o mesmo percurso narrativo, como foi dito. Aliás, é bom que se acrescente que, na sintaxe narrativa, o texto-base é citado com fidelidade. Poder-se-ia argumentar que, no lugar da manipulação contraditória do lobo, que é deduzível do texto-base, aqui há a automanipulação contraditória da própria menina, estando aí, uma diferença entre a variante e o texto-base. [...] Acontece que, por meio do jogo dos pressupostos, o lobo intertextual está citado; faz-se presente pela "ausência", diluindo-se, dessa maneira singular, a possível diferença narrativa (2004, p. 221).

Partindo da análise semiótica desenvolvida por Discini, vale lembrar que as descobertas interiores, as tomadas de consciência fazem o percurso dessa menina, que, por vezes, distrai-se, muda de caminho, mas chega à casa da avó, onde esta está convalescendo, morrendo. E, por fim, falece na presença de sua neta: "Mas a avó estava lá, sendo que demasiado ausente, a não ser pelo frio, triste e tão repentino corpo."

Os momentos de paradas para reflexão, de distração com os elementos da natureza parecem compor a personalidade da menina. O que o leitor acompanha metaforizado é o processo de amadurecimento da personagem - "sem juízo, por enquanto" - para se transformar: "FitaVerde mais se assustou, como se fosse ter juízo pela primeira vez."

Os trechos destacados a seguir apresentam passagens que evidenciam a leitura do amadurecimento da protagonista:

A decisão:

A aldeia e a casa esperando-a acolá, depois daquele moinho, que a gente pensa que vê, e das horas, que a gente não vê que não são.

E ela mesma resolveu escolher tomar este caminho de cá, louco e longo e não o outro, encurtoso. Saiu, atrás de suas asas ligeiras, sua sombra vindo-Ihe correndo, em pós. 
Nessa passagem, apreendem-se as figuras espaciais do acolá (da ilusão - "pensa que vê" e da ignorância "que a gente não vê que não são") e do cá ("louco e longo", perigoso que exige amadurecimento). Há a transformação do texto-base quando a protagonista opta pelo caminho mais longo; naquele, a opção é pelo caminho mais curto, mais rápido. A alteração da figura temporal (longo versus curto) representa a necessidade de um tempo maior para concluir o percurso, a fim de que, assim, o actante adquira competência para o seu fazer, que, neste caso, é tematizado pelo amadurecimento. Ressalta-se que, como no texto-base, a escolha é da protagonista, havendo, então, um ponto de aproximação: ambas desobedecem às ordens das mães e optam pelo caminho: "E ela mesma resolveu escolher tomar este caminho de cá, louco e longo, e não o outro, encurtoso".

As distrações:

Divertia-se com ver as avelãs do chão não voarem, com inalcançar essas borboletas nunca em buquê nem em botão, e com ignorar se cada uma em seu lugar as plebeinhas flores, princesinhas e incomuns, quando a gente tanto por elas passa. Vinha sobejadamente.

O narrador constrói a sentença a partir do recurso poético da aliteração, na repetição sonora do fonema /v/. A menina se perde na brincadeira, no lúdico, na infância. A protagonista permanece criança. Este é um obstáculo, evidente, para atingir a maturidade.

A demora: "Demorou, para dar com a avó em casa..."

Assim, termina o percurso de aquisição de competência do sujeito, que será legitimado somente pela perda da fita verde do cabelo. Aquela fita que a identifica, nomeia, que é verde, ou seja, não está madura.

A falta de prontidão é representada simbolicamente pelo verde: "Aquela, um dia, saiu de lá, com uma fita verde inventada no cabelo"; a personagem Fita-Verde perde seu adereço (a fita verde) ao longo da travessia, ou seja, deixou de estar/ser "verde" para : 
concluir seu percurso narrativo: "[...] de ver que perdera em caminho sua grande fita verde no cabelo atada".

Retomando a questão, o antagonista não está figurativizado fora do protagonista, mas nele mesmo, como apontado anteriormente. É um processo que se dá na própria consciência da personagem. Um crescimento/amadurecimento individual. O que Discini analisa é que, em "ausência", o lobo está presente e, na análise que ora se apresenta, é a própria consciência da menina.

Há, pois, dois textos distintos: um conto maravilhoso (narrativabase), que tem por proposta educar, e uma narrativa que não tem como preocupação a educação. Com isso, no primeiro, é importante separar bem e mal; no segundo, na narrativa moderna, eles coexistem e compõem a personalidade do indivíduo. A identidade do sujeito se revela por suas escolhas. As diferentes tomadas de posição da protagonista entre as duas versões revelam uma postura diante da maneira de persuadir o leitor. Segundo Bruno Bettelhein, em A psicanálise dos contos de fadas, essa distinção ocorre da seguinte maneira:

É característico dos contos de fadas colocar um dilema existencial de forma breve e categórica. Isto permite à criança aprender o problema em sua forma mais essencial, onde uma mais complexa confundiria o assunto para ela. O conto de fadas simplifica todas as situações. Suas figuras são esboçadas claramente; e detalhes, a menos que muito importantes, são eliminados. Todos os personagens são mais típicos do que únicos.

Ao contrário do que acontece em muitas estórias infantis modernas, nos contos de fadas o mal é tão onipresente quanto a virtude. Em praticamente todos os contos de fadas o bem e o mal recebem corpo na forma de algumas figuras e de suas ações, já que bem e mal são onipresentes na vida e as propensões para ambos estão presentes em todo homem. É essa dualidade que coloca o problema moral e requisita a luta para resolvê-lo (2000, p. 15). 
Nota-se que, no conto de fadas, há a necessidade da distinção em duas figuras (menina e lobo), já na narrativa moderna, de Rosa, o conflito é interno, ou seja, não há necessidade de separá-lo, bem e mal existem, em luta, no próprio homem.

Os aspectos apresentados, cenário, ausência do lobo e escolha do caminho mais longo, distanciam as narrativas (base e releitura), contudo, - percurso trilhado pelas protagonistas continua em relação de manutenção, no que diz respeito às etapas percorridas. Essas podem ser suprimidas à seguinte seqüência narrativa: contrato (mãe - filha); quebra de contrato - novo percurso estabelecido (novo contrato firmado); surpresa / conseqüências (sanção negativa).

Ambas as protagonistas têm uma missão - levar doces, frutas para a avó que está doente - atribuída pela mãe, que reforça a necessidade da obediência - devem seguir o caminho mais seguro: uma o mais longo, tradicional; outra, o mais curto, moderna. Como já foi destacado, as meninas são caracterizadas por não terem juízo. Esse adjetivo autoriza a coerência dos acontecimentos na narrativa, pois a personalidade das personagens antecipa a possibilidade de desobediência. Posto que, as duas desobedecem às ordens das mães.

As duas protagonistas, no lugar do juízo que lhes falta, levam algo na cabeça, um enfeite, uma proteção. Esses elementos têm destaque, visto que as meninas são nomeadas por esse adereço: Chapeuzinho Vermelho e Fita-Verde ${ }^{122}$.

O texto Fita Verde no cabelo nasce de Chapeuzinho Vermelho. A relação de complementação do ponto de vista das cores das figuras está, sem dúvida, posta em questão. Na "cartela de cores" o vermelho opõe-se e complementa o verde, reforçando a ligação entre os textos e, ao mesmo tempo, distanciando-os.

Dessa reflexão, afirma-se a perspectiva temática de Fita Verde no cabelo como a descoberta ou o contato com a morte. Sobre essa

\footnotetext{
${ }^{122}$ Outra interpretação para a opção da cor em Fita Verde é a ceauinte: "Anagramaticamente os verbos fitar e ver estão presentes e vez nosso olhar é requisitado para ver/ler uma nova travessic 
abordagem, a obra oferece duas possibilidades de interpretação. Na primeira e mais comprovável, a morte seria de um ente próximo, a avó; mas, não há como descartar, como segunda possibilidade, a morte da própria inocência da menina ${ }^{123}$ : "Mas agora Fita-Verde espantava, além de entristecer-se de ver que perdera em caminho sua grande "Fita Verde no cabelo atada [...]". Na narrativa de Rosa, há o percurso como metáfora do amadurecimento da menina, que descobre a morte, condição daquele que vive.

Com relação aos objetos, em Chapeuzinho Vermelho, o chapéu envolve a menina, agasalha, quiçá protege; já em Fita Verde no cabelo, a fita é apenas um adorno que se desprende no percurso da garota. Há, como se nota, uma diferença relevante entre os objetos - um acompanha, envolve; o outro enfeita e se perde. O primeiro tem uma função essencial, o segundo é provisório, acessório, um estado que pode ser alterado. Aí, é possível afirmar que o objeto é uma metáfora do grau de proteção sobre as meninas. Chapeuzinho Vermelho é mais protegida, agasalhada, enquanto Fita-Verde está ligada apenas por uma fita à autoridade do adulto.

A desobediência às ordens das mães, para que seguissem o caminho mais seguro, é um tema de aproximação. As duas meninas quebram um contrato estabelecido. Chapeuzinho Vermelho e Fita-Verde escolhem o caminho mais perigoso, porém é o que possibilita as descobertas. Todavia, sobretudo, o que há é uma afirmação como sujeito autônomo: agora quem escolhe os caminhos sou eu! Eis o amadurecimento e autonomia e, por isso, elas devem sofrer as conseqüências de seus atos.

Quando chegam, enfim, à casa da avó, o susto com o que encontram aproxima as histórias novamente, pois os diálogos são bastante parecidos:

${ }^{123}$ Esta leitura poderá ser justificada a partir da análise do diálogo com a imagem. Do amadurecimento, chega-se à morte: as mãos (velha/nova) encontram-se, na retomada, talvez renascentista de Michelângelo. Na cena seguinte, a menina está entre anjos, referência ao barroco; em seguida, a personagem aparece só, retomada da arte contemporânea e, na última cena, a aldeia se desfaz pelos ares, sugestão surrealista. Na leitura das figuras, tem-se o sofrimento, a snlidãn a nascanem nara outra fase - o amadurecimento. 
Em Chapeuzinho Vermelho:

Então ela foi até a cama da avó e abriu as cortinas. A vovó estava lá deitada com sua touca cobrindo parte do seu rosto e, parecia muito estranha...

- Oh, vovó, que orelhas grandes a senhora tem! Disse então chapeuzinho.

Em Fita Verde no cabelo:

Mas agora Fita Verde se espantava, além de entristecer-se de ver que perdera em caminho sua grande "Fita Verde no cabelo" atada; e estava suada, com enorme fome de almoço. Ela perguntou: /

- Vovozinha, que braços tão magros, os seus, e que mãos tão trementes! /

- É porque não vou poder nunca mais te abraçar, minha neta... - a avó murmurou /

-Vovozinha, mas que lábios, tão arroxeados! /

- É porque não vou nunca mais poder te beijar, minha neta.... - a avó suspirou. /

- Vovozinha, e que olhos tão fundos e parados, nesse rosto encovado, pálido? /

- É porque já não te estou vendo, nunca mais, minha netinha... - a avó ainda gemeu.

Apesar de diálogos similares, as descobertas são diferentes. $\mathrm{Na}$ primeira, a protagonista terá de viver as conseqüências de seus atos; na segunda, a menina terá de viver com a condição humana: a morte. O conto de Rosa oferece uma nova maneira de ver os conflitos humanos que acontecem não só exteriormente, mas também, em grande medida, no interior humano. 


\subsubsection{Vozes da I magem: O ( Re) Contar de Mello}

Roger Mello é convidado a ilustrar o conto Fita Verde no cabelo: nova velha estória, de Guimarães Rosa, em edição comemorativa da editora Nova Fronteira, como anteriormente observado.

Nesta edição, o ilustrador vai propor um diálogo com a palavra, que remete tanto ao seu conteúdo quanto à sua expressão. As interações tangenciam tanto a história contada por Rosa como a leitura pessoal do conto maravilhoso e o texto-base do contar do autor mineiro.

A proposta de trabalho de Roger Mello é estética, poética, por isso agrega novos sentidos ao texto verbal, isso é importante demonstrar. Vale, pois, identificar como essas imagens compõem com as palavras um todo de sentido, gerando um projeto gráfico coeso.

Por revelar a preocupação de ordem estética, Mello instaura vozes neste discurso: a intertextualidade e a interdiscursividade são a tônica de seu projeto artístico.

Assim, esclarece-se que a análise entende a organização das vozes da seguinte maneira: a primeira voz inserida na narrativa é a da releitura de Guimarães Rosa, ou seja, existem traços nas imagens que revelam a relação com o texto verbal de Rosa; a segunda voz diz respeito ao texto-base, há figuras que remetem à história-base - Chapeuzinho Vermelho; a terceira compõe um misto de vozes que se pode entender como as diversas leituras realizadas ao longo do tempo em torno da narrativa-base, por exemplo, a análise psicanalítica proposta por Bruno Bettelhein, em que o estudioso propõe um paralelo do percurso da protagonista com a iniciação sexual das meninas adolescentes; e, finalmente, a quarta voz é aquela em que narrativa visual se apresenta como um discurso e, por isso, existe a proposta de interdiscurso na própria maneira de produzir as imagens.

Todo esse complexo jogo de vozes vem à tona por meio das figuras e dos temas revelados no nível discursivo do sistema visual e também no plano da expressão. Explicita, pois, a organização $n$ Nictinrãn No unsnc para sustentar a proposta analítica: 


\section{Voz da imagem - palavra da narrativa de releitura (Rosa):}

Palavra: a morte - "Mas a avó estava lá, sendo que demasiado ausente, a não ser pelo frio, triste e tão repentino corpo."

Imagem: a menina com o cabelo sobre o rosto, ajoelhada. Esta cena reflete o vazio, não há fundo na imagem. A figura da avó também está ausente. A menina é o foco da cena, que está entrecortada pelos fios que alinhavam a narrativa ${ }^{124}$. A protagonista realiza seu percurso de amadurecimento sozinha, não há antagonista. É um percurso individualizado, como já foi discutido.

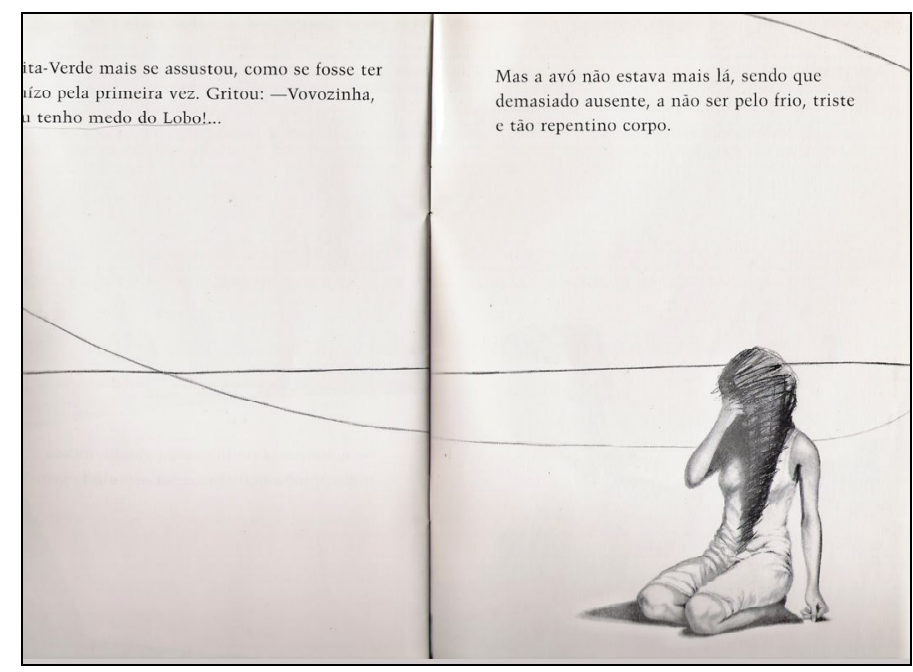

Figura 3.56 - Voz de Rosa

Palavra: o modo de narrar sertanejo - "Então, ela, mesma, era quem se diziam:

- Vou a vovó, com cesto e pote, e a 'Fita Verde no cabelo', o tanto que a mamãe mandou."

${ }^{124}$ Mais adiante, a análise deter-se-á aos fios que entrecortam a 
Imagem: No canto da página, abaixo do texto, há uma menina com traços verdes acima da cabeça como se fossem rasuras, uma vez que não está realistamente atada, muito menos é uma fita propriamente dita.

o cenário que envolve a menina é uma mata, um pouco mais atrás, em perspectiva, existe um animal que se assemelha à jaguatirica ${ }^{125}$, animal próprio ao bioma brasileiro e da América Meridional. A menina usa um vestido despojado de adereços ou bordados e está descalça, figura característica do viver sertanejo. Esses elementos apóiam a afirmação sobre o reflexo do narrar roseano inserido na voz da imagem.
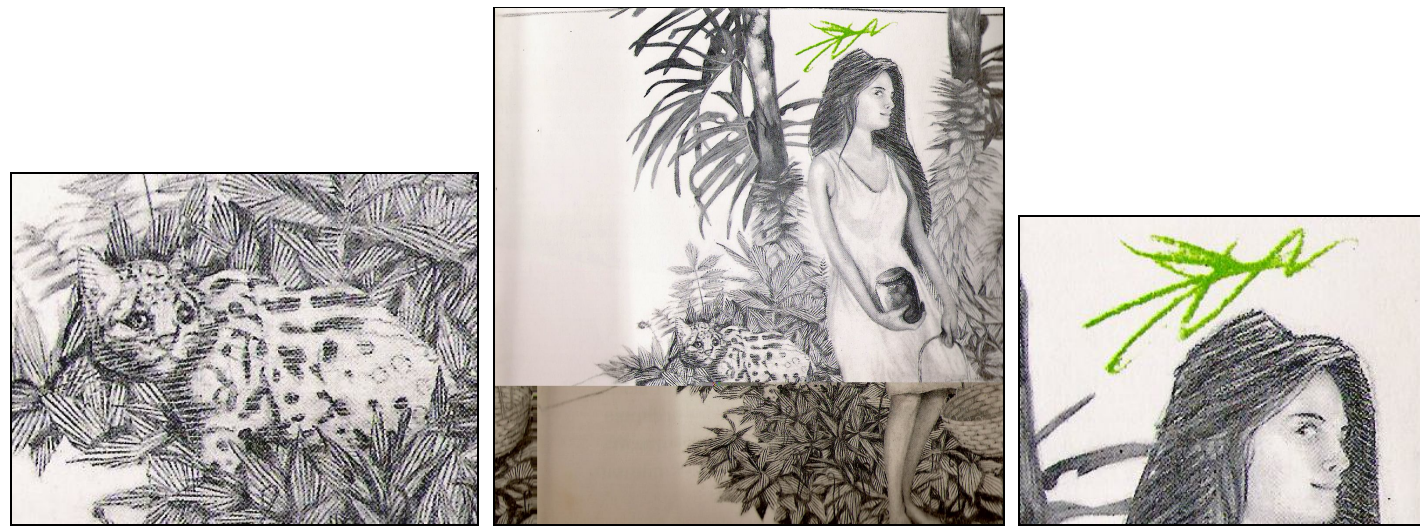

Figura 3.57 - Voz de Rosa pela imagem

\section{Voz da imagem - palavra do texto-base (Chapeuzinho Vermelho):}

Palavra (o diálogo similar):

a) “- Vovozinha, que braços tão magros, os seus, e que mãos tão trementes!

- É porque não vou poder nunca mais te abraçar, minha neta... - a avó murmurou.

${ }^{125}$ Segundo o dicionário Aurélio: “jaguatirica: Mamífero carnívoro, fissípede, que atinge cerca de $85 \mathrm{~cm}$ de comprimento e $40 \mathrm{~cm}$ de altura. Cor ruivo-amarelada rom manchas redondas orladas de preto; na nuca apresenta cinco ou seis todo o Brasil e América Meridional; vive em matas e banhados 

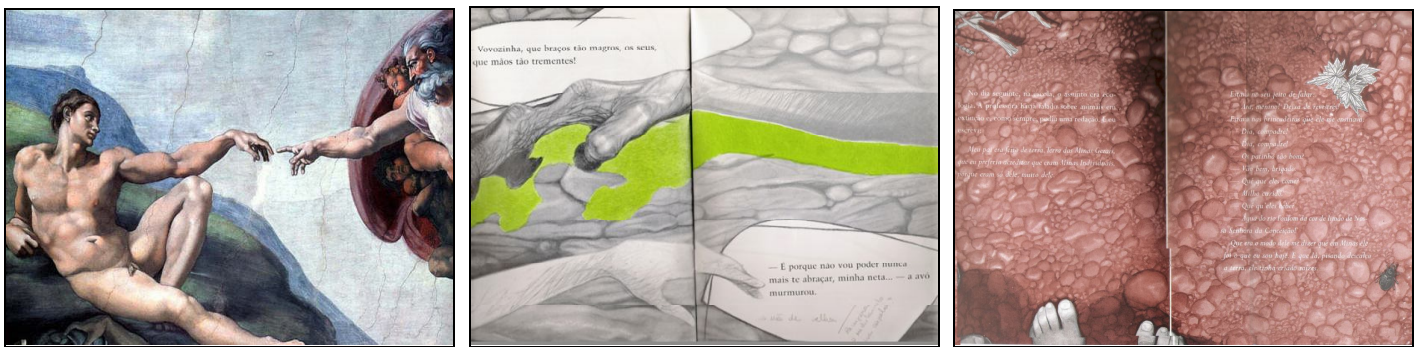

Figura 3.58 - Voz do texto-base ${ }^{126}$

A imagem mostra os dois braços: da menina (mais baixo), da avó (mais acima) em nítida comparação com a mão do lobo (lobo=morte). O verde é a sombra do lobo ou da própria menina, visto que esta é nomeada como verde. Eis a ambigüidade posta anteriormente em palavra e, agora, em imagem. Nesta cena há figura versus fundo nos termos de Wölffing, nele é possível visualizar o chão típico do sertão (árido, seco), mas também rachaduras do envelhecido, ou até formas abstratas e, por isso, a abertura de possibilidades interpretativas, reiterando a ambigüidade como um recurso utilizado pelo sistema verbal e pelo visual. Além da ambigüidade, é possível retomar a cena de Deus em comunhão com o filho, visto o destaque aéreo das mãos e braços.

b) - “Vovozinha, mas que lábios, tão arroxeados!

- É porque não vou nunca mais poder te beijar, minha neta....

- a avó suspirou."

${ }^{126}$ Nesta imagem, da obra Ver de Ver meu pai, de Celso Sisto, Mello, por meio da comparação, é possível visualizar o chão $c$ 


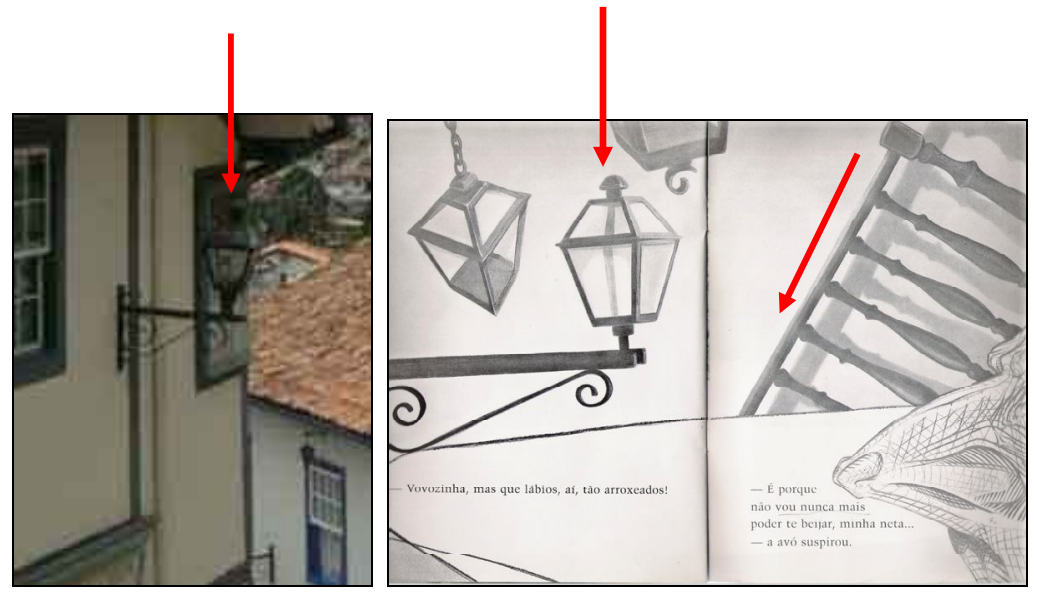

Figura 3.59 - Arquitetura colonial de Minas Gerais (luminária/ guarda-corpos)
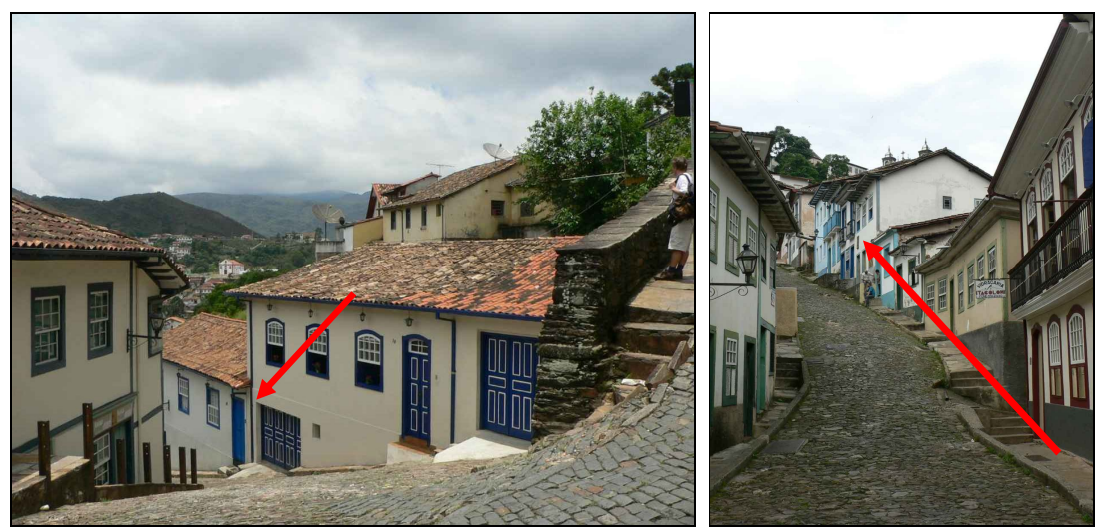

Figura 3.60 - Movimento ascendente e descendente das ruas de Minas Gerais

Cena que remete à corrente artística do hiper-realismo ${ }^{127}$, em que as figuras de luminárias (realistas) e guarda-corpos (realista) são identificáveis como característicos da arquitetura colonial mineira, cenário do autor Guimarães Rosa. Esses elementos invadem as imagens alterando a isotopia com relação ao texto-base e inaugurando uma nova com relação aos dados sobre o próprio autor do conto. Além disso, a disposição das figuras no plano altera a perspectiva realista, gerando, mais uma vez, ambigüidades.

Também o perfil da avó, mais uma vez, aparece em junção ao do lobo, portanto, metáfora e metonímia, neste momento, unem-se para compor a cena. Aquela por similaridade e essa por contigüidade, como se sabe.

${ }^{127}$ O hiper-realismo virá à cena mais adiante. 
c) " - Vovozinha, e que olhos tão fundos e parados, nesse rosto encovado, pálido?

- É porque já não te estou vendo, nunca mais, minha netinha... - a avó ainda gemeu."
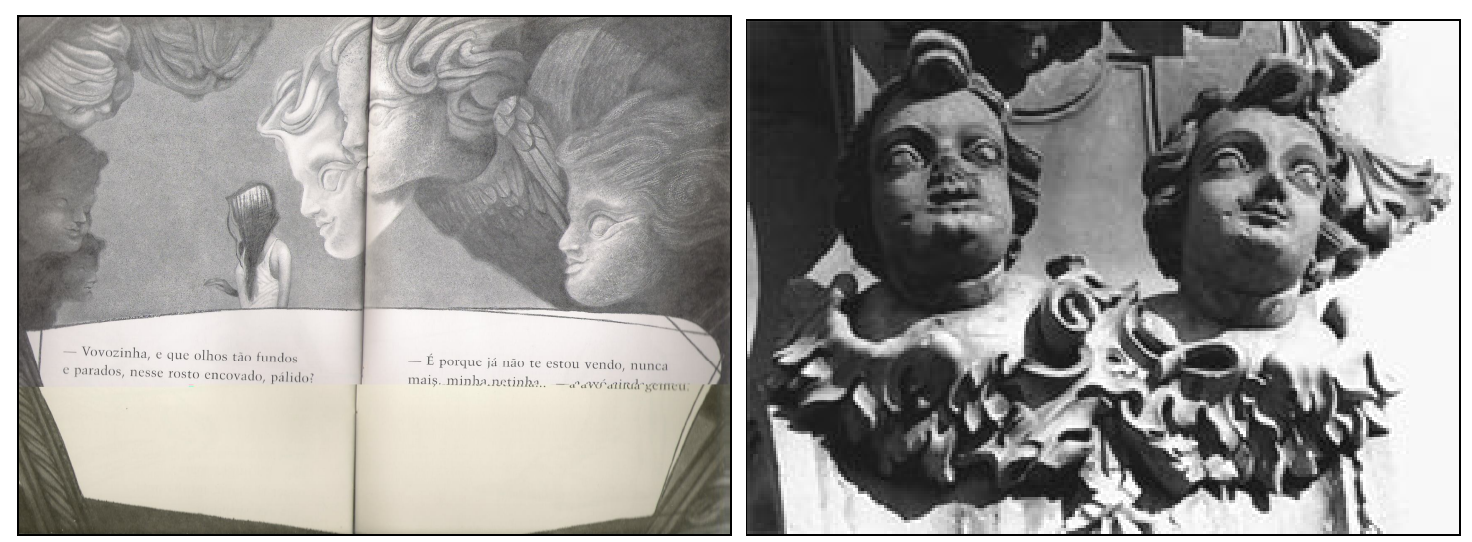

Figura 3.61 - Anjos barrocos

Apesar de a voz da avó estar expressa no sistema verbal, ela não aparece representada na imagem. A referência aos anjos (próximos aos anjos barrocos, mais uma influência da arquitetura mineira, agora de cunho religioso) insere a avó em outro plano, a morte, o céu. Os anjos têm dimensões aumentadas em proporção ao tamanho da protagonista e, portanto, rompe-se a proporcionalidade realista, na medida em que eles ocupam toda a cena e saem de uma construção, sendo, por isso, possível associá-los aos anjos barrocos que pertencem às igrejas mineiras, como já apresentado. Um universo pelo outro, impõe-se a metáfora visual, afirmando este sistema com os mesmos recursos utilizados pelo sistema semiótico verbal. 


\section{Voz da imagem - palavras das diversas leituras}

\section{Palavra: leitura psicanalítica- o lobo é visto como homem e} remete à iniciação sexual da menina - "Daí, que, indo, no atravessar o bosque, viu só os lenhadores, que lenhavam; mas o lobo nenhum, desconhecido nem peludo. Pois os lenhadores tinham exterminado o lobo."
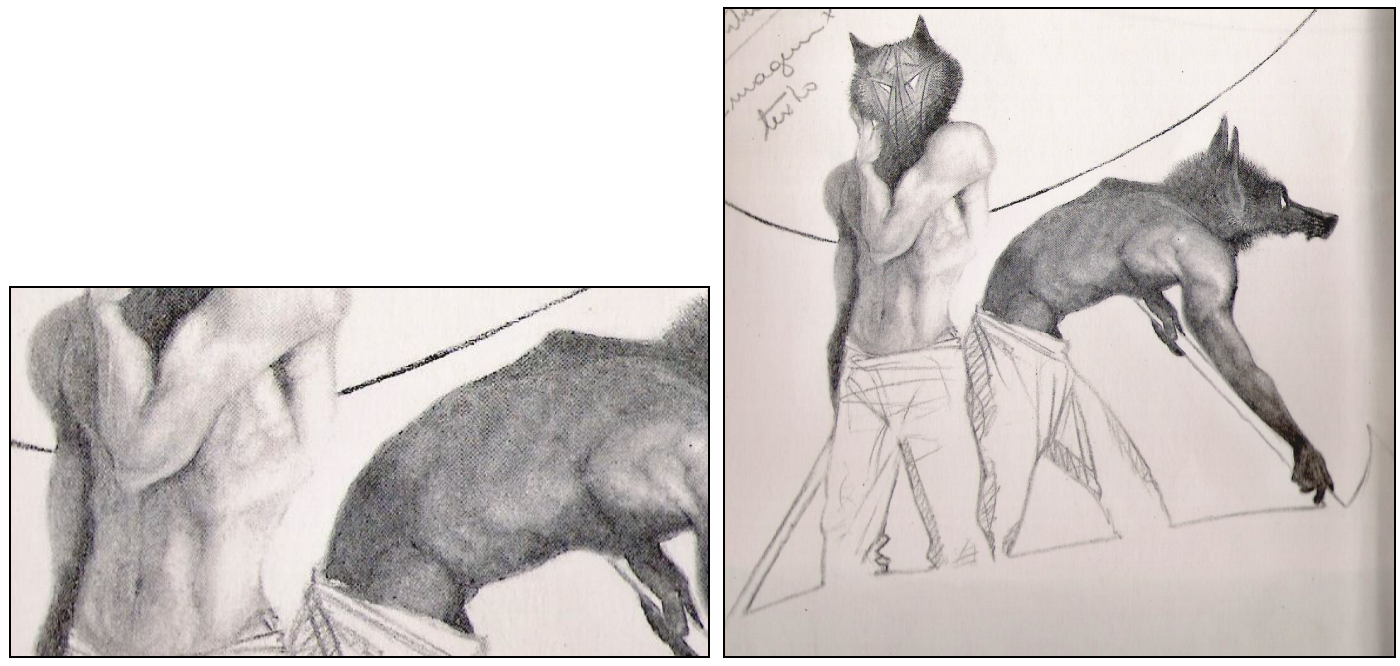

Figura 3.62 - Homem-lobo

Imagem: na página da esquerda, seres são metade homens, metade lobos. Os tórax estão nus e os músculos são bem delineados, explicitando características sensuais, a menina, por sua vez, não os encara, mas os observa de soslaio, o que implica, pela expressão facial, um interesse dissimulado ou proibido. Os corpos, agora, não remetem ao barroco que tem como característica a desproporcionalidade em oposição à escultura clássica, em que a simetria é uma exigência, como revela Davi, de Michelangelo, por exemplo. 


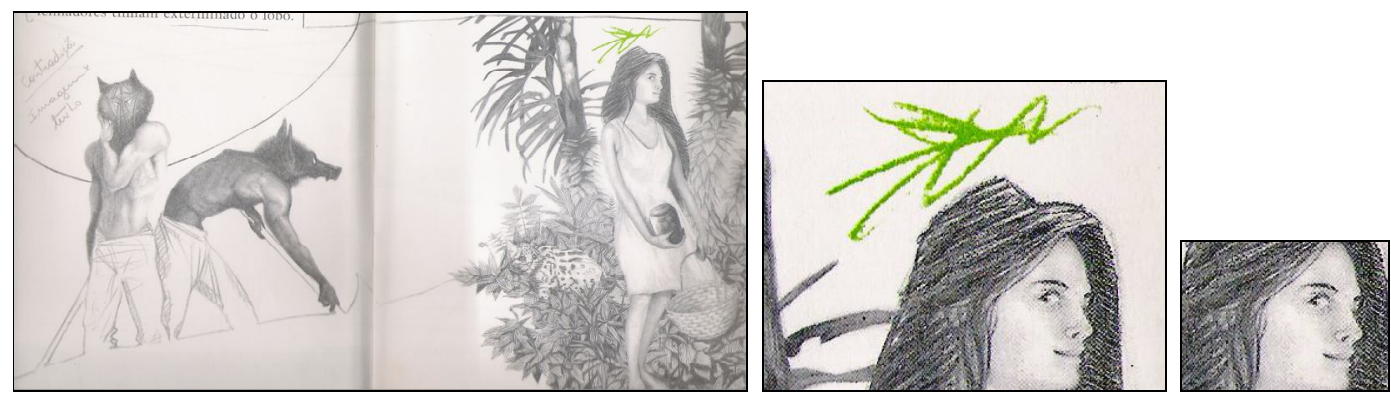

Figura 3.63 - Olhar de soslaio

\section{A voz da imagem - referências discursivas}

No verbal e na relação verbal-visual, há a retomada de vozes textuais, criando um estilo de contar. Tal estilo pode ser verificado também entre discursos visuais, se se pensar que, além dos diálogos entre verbal e visual, há um entre discursos, maneiras de fazer, como já trabalhado em análises anteriores deste estudo.

O discurso de Mello, ao longo de sua produção de literatura infantil, define-se pela "metamorfose" de estilos, corroborando Rui de Oliveira em afirmação anterior ${ }^{128}$.

Neste momento da análise, é necessário retomar a discussão sobre o estilo das ilustrações de Mello; para isso, exemplifica-se a metamorfose de estilos do autor, em quatro trabalhos, A flor do lado de lá, Griso, o unicórnio, Desertos e Jardins, nesta ordem - cronológica:

${ }^{128}$ Em entrevista, Rui de Oliveira declara que o estilo, ou melhor, "modo de fazer" da ilustração é determinado pelo que sugere a narrativa (OLIVEIRA Rıi de Artinn nnline Como vejo a arte de ilustrar $e$ as intenções do meu $t$ <http://www.docedeletra.com.br/ruideoliveira/ >. Acesso em: 


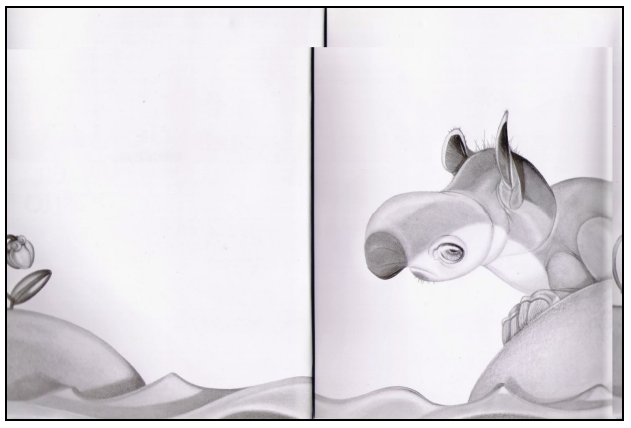

Figura 3.64 - A flor do lado de lá

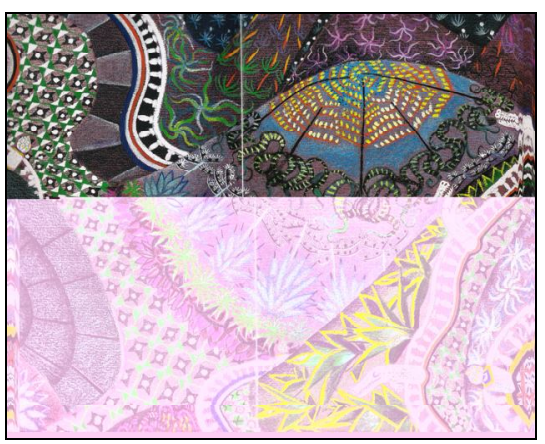

Figura 3.66 - J ardins

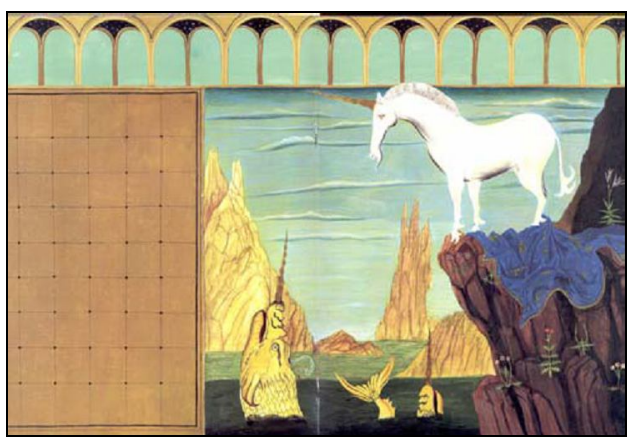

Figura 3.65 - Griso, o unicórnio

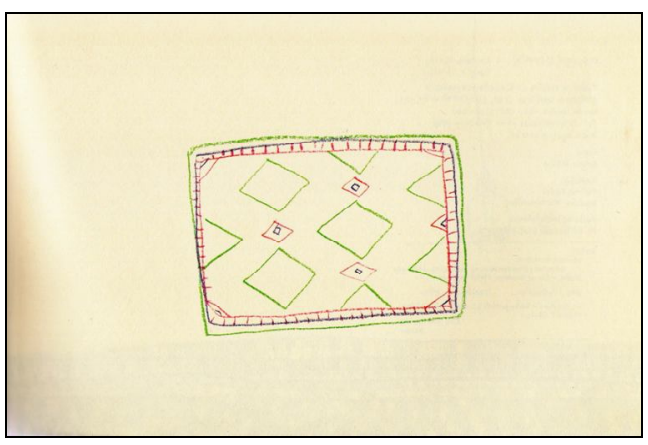

Figura 3.67 - Desertos

O artista, nas imagens para a obra Fita Verde no cabelo, não retoma um estilo utilizado anteriormente, mas antecipa um que será empregado em Ver de ver meu pai, de Celso Sisto, da mesma editora (Nova Fronteira), como é possível observar:
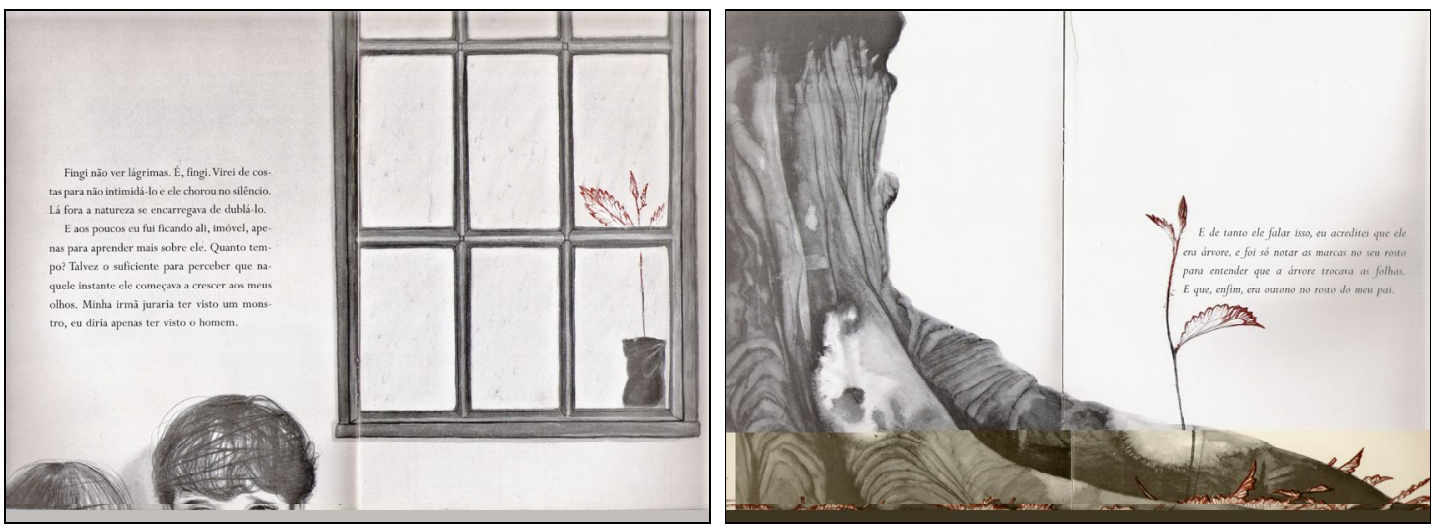

Figura 3.68 - Ver de ver meu pai, Celso 
As referências (figuras) e a técnica empregada (expressão) convocam o realismo, mas um realismo próximo do contar roseano, que extrapola as exigências puramente realistas para deflagrar a situação, como no realismo mágico ou nas artes plásticas com o hiper-realismo.

Se forem pensadas as ilustrações realistas, dois exemplos vêm à memória:

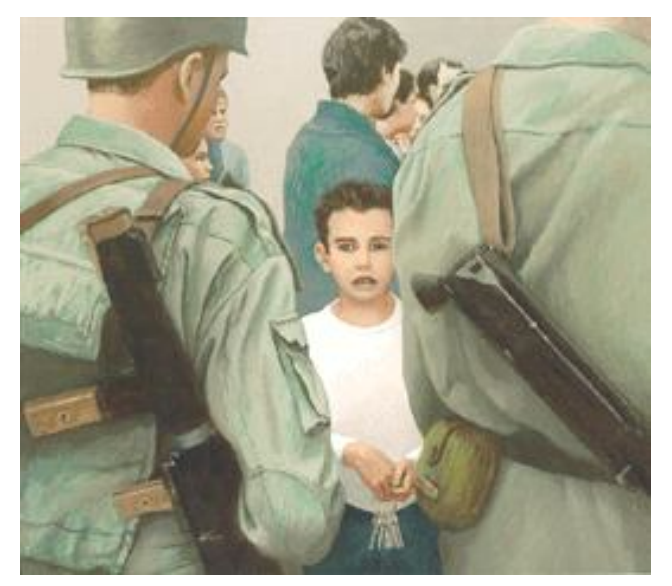

Figura 3.69 - La composición

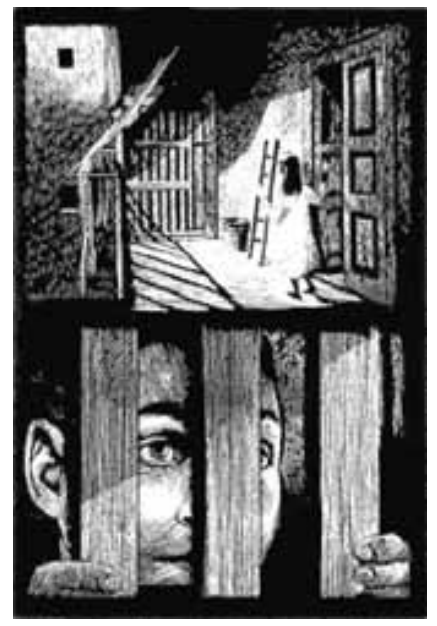

Figura 3.70 - I rmãos Pretos

Há, portanto, uma diferença entre as imagens apresentadas em La composición e Irmãos Pretos e as ilustrações de Mello, como em A flor do lado de lá, que também é distinta de Jardins ou Desertos, como foi demonstrado neste trabalho de tese. Em A flor do lado de lá, recorre-se a elementos lúdicos - feições do animal e traços arredondados na flor; já em Desertos/Jardins as imagens criam os ambientes descritos (a saber o próprio deserto e o jardim) e, por isso, tornam-se quadros. Em Fita Verde no cabelo e nos exemplos dados em La composición ou em Irmãos Pretos, há a distinção de outro gênero do discurso, que Salisbury denominou livro ilustrado: 
En el libro-álbum, casi toda la comunicación corre a cargo de las imágenes, y existe una dependencia entre las palabras e imágenes. El funcionamiento de los libros de cuentos es completamente distinto. En su caso, lo primero son las palabras, que pueden haber sido escritas sin pensar en ninguna ilustración. El hecho de que la ficción para adultos carezca de ilustraciones suele justificarse con el argumento de que las imágenes se interponen entre el escritor y el lector, y distorsionan el proceso personal de evocar imágenes mentales. La buena ilustración, tanto si es para adultos como si es para niños, debería ser un acicate visual, una contrapartida visual del texto. Su función es aumentar la comprensión del lector y su disfrute (2005, p. 94-95).

Esta distinção entre o livro-álbum e o livro ilustrado é válida, pois apresenta dois pontos discutidos por esta análise: 1) a necessidade da imagem em um texto que prescinde deste sistema semiótico; 2) o público adulto como leitor pretendido pelo livro ilustrado, nos termos apresentados por Salisbury. Além disso, a relação descrita entre palavra-imagem se aplica, exatamente, à obra de Mello, a saber - a ampliação e a ambigüidade:

En puridad, ningún texto de imaginación debería "necesitar" que lo ilustren. La función de las imágenes no es repetir ni aclarar las palabras. Sin embargo, las imágenes pueden enriquecer la experiencia del lector y estimular la sensibilidad del niño. [...]

Hace poco, uno de mis alumnos tuvo la inspiración de realizar una serie de dibujos llenos de fuerza basados en la visión, aparentemente cotidiana, de un solo guante tirado en una cuneta. Este tipo de ambigüedad y sugestión constituye una parte importante de la ilustración de cuentos (2005, p. 95 -97).

Esses dois elementos (ampliação e ambigüidade) são fundamentais à obra poética e exigem, obviamente, uma leitura mais complexa, em que metáforas e metonímias são mais profundas à trama discursiva. Talvez isso possa revelar que a obra em análise, de fato, exija um público adulto. Por ora, abandona-se a questão, mas ela permanece inquieta. 
As imagens narrativas apresentadas por Mello dialogam com alguns movimentos artísticos, como o hiper-realismo ou o surrealismo. Sustentase essa afirmação a partir das seguintes cenas:

a) $\mathrm{Na}$ primeira cena-exemplo, há um jogo de luz e sombra representado nas figuras de uma porta, em um aparador e em um vaso vazio. A dobra do livro é aproveitada para fazer a dobradiça da porta, o que revela uma preocupação com detalhes realistas ${ }^{129}$. Nesse quadro desenhado pelo artista brasiliense, percebe-se a sugestão do movimento hiper-realista ${ }^{130}$. Esse movimento tem as seguintes características:

- Aproximación nueva y radical al mundo real;

- Carácter distanciado y frio;

- Afirmación de la realidad mediante sus plasmación tal como la vería una câmara fotográfica (Disponível em: $<w w w$.arteuniversal.com>. Acesso em: 10 jul. 2008).

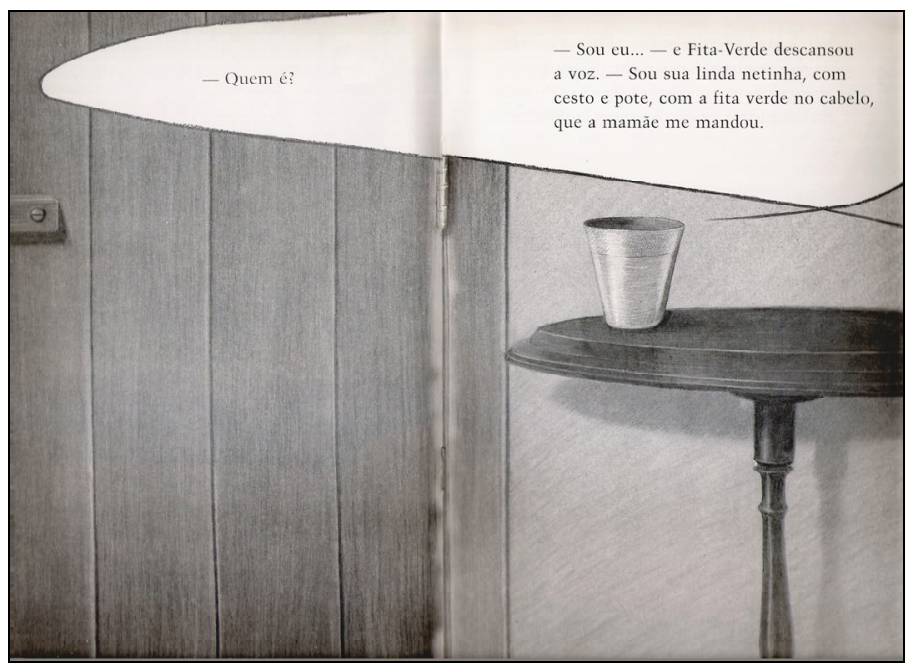

Figura 3.71 - Figura Hiper-realista

${ }^{129}$ Vale estabelecer um paralelo entre a utilização da dobra da página e dos grampos em A Bela Borboleta, de Ziraldo, Personagem encalhado e Cena de rua, de Angela Lago, e a obra de Mello, nesta última, não há a linguagem voltada ao próprio código, mas a utilização do objeto para gerar o efeito de "ilusão realista".

${ }^{130}$ Este movimento apareceu pela primeira vez na exposição "The nhotonranhir I manec" em Nova York, em 1966. Ganhou força na década de 70, Kassel", em 1972. 

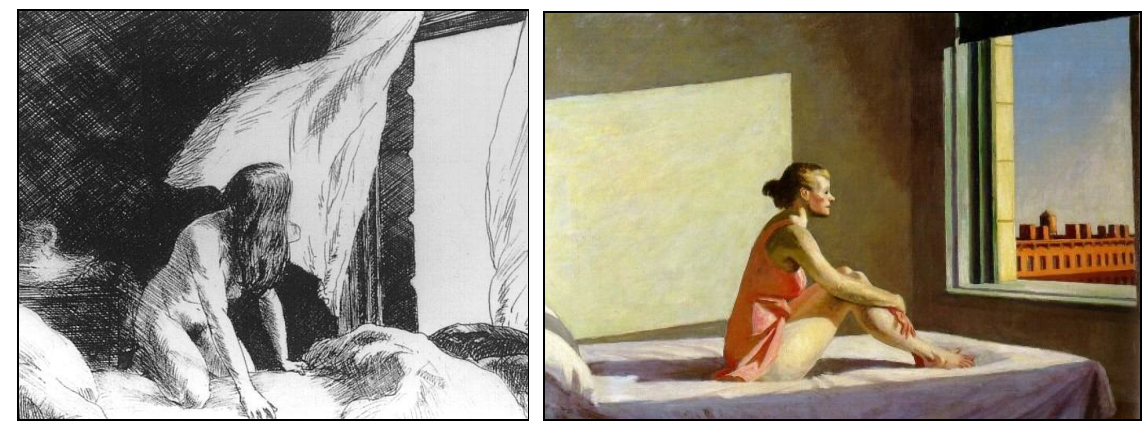

Figura 3.72 - Edward Hopper

Na primeira imagem de Hopper, há a monocromia de preto e branco, como em Mello; na segunda, os destaques estão nas sombras delineadas na parede, como a que aparece abaixo do aparador, reforçando a idéia de referência ao hiper-realismo, movimento, no qual a obra de Hopper se insere.

Nas imagens a seguir, a similaridade está na presença surrealista (apesar de a obra exemplo pertencer ao hiper-realismo) das borboletas (avelãs ou galhos de árvores) e também das linhas verticais, em Fita Verde, e das linhas horizontais na imagem ao lado para destacar a realidade (ou efeito de sentido de) da construção em madeira.
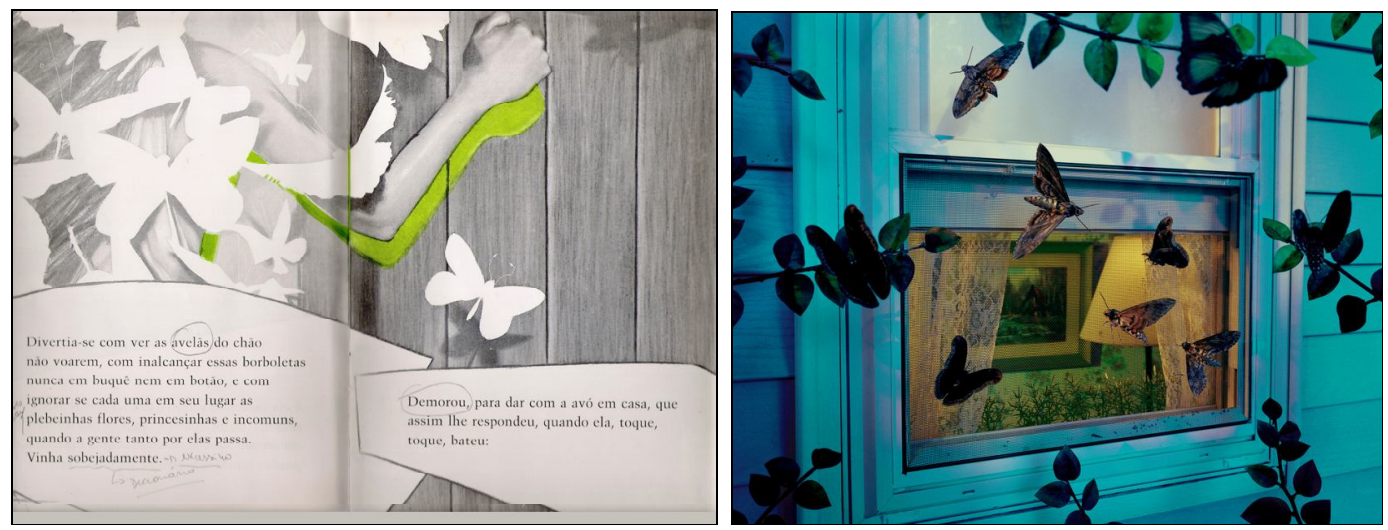

Figura 3.73 - Hiper-realismo Hooper 
b) Com relação ao outro movimento, a última cena do livro revela o surrealismo ${ }^{131}$. Nela, a menina está no alto de uma montanha e a aldeia, figura que abre a narrativa visual, desfaz-se pelos ares. É interessante notar que não há palavra nessa cena. O conto de Guimarães Rosa já chegou ao fim na página anterior. A narrativa visual, porém, continua. Esse recurso evidencia que a ilustração não é mero adorno, mas conduz a uma proposta estética de agregar sentido à narrativa verbal, criando metáforas e ambigüidades próprias à linguagem poética, como apontado anteriormente. Neste caso, até ampliando o texto verbal que já acabou e segue a coerência narrativa proposta por Rosa.
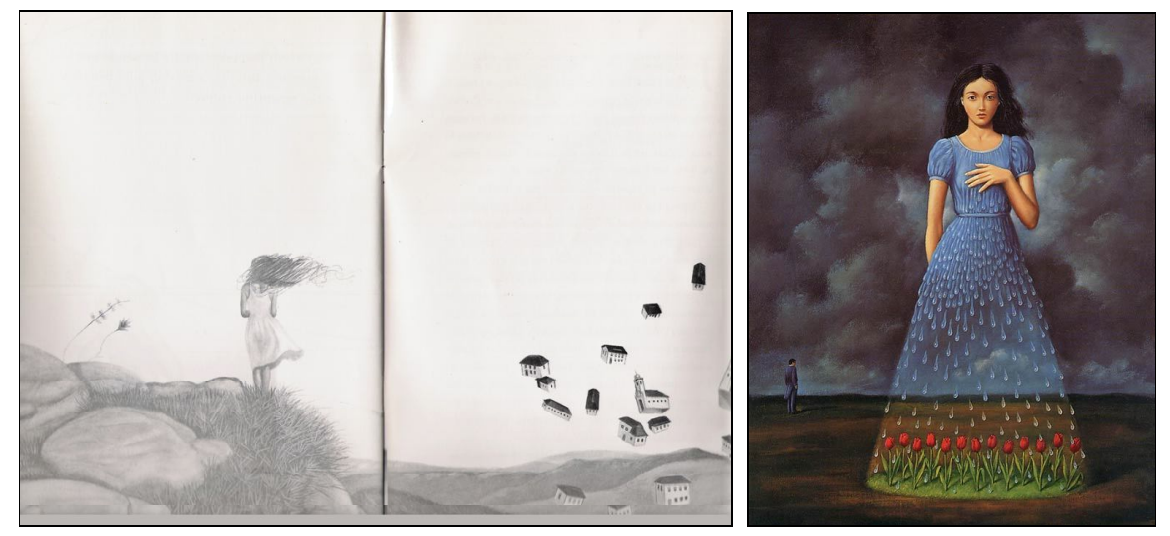

Figura 3.74 - Cenas Surrealistas

\subsubsection{Encontro de Vozes}

Deixou-se de lado, até então, outro recurso utilizado pela narrativa visual. Em todas as páginas, aparecem fios, linhas que ora estão soltas, ora envolvem o texto verbal, parecendo os balões das histórias em quadrinhos. Esses fios conduzem à leitura de uma metáfora: o contar. Muitas vezes, o contar é associado ao tecer na literatura infantil, não são

\footnotetext{
${ }^{131}$ Este conceito já foi definido anteriormente.
} 
raras as associações entre escritor e tecelão ${ }^{132}$. Eis também uma referência à tradição oral, em que uma história lembra a outra, constituindo uma rede de histórias interligadas e, porque não, um emaranhado de vozes como quer sustentar esta análise.

O texto visual está disposto da seguinte forma na página: na parte superior, está o texto verbal circundado por fios (linhas) que lembram os "fios das histórias" ou o "fio narrativo", expressões que legitimam a associação descrita acima. Esses fios vão permanecer em todas as páginas, a exceção da última, em que a protagonista está "livre" de tudo, até de sua fita verde. Ela, finalmente, amadureceu e completou o seu percurso.

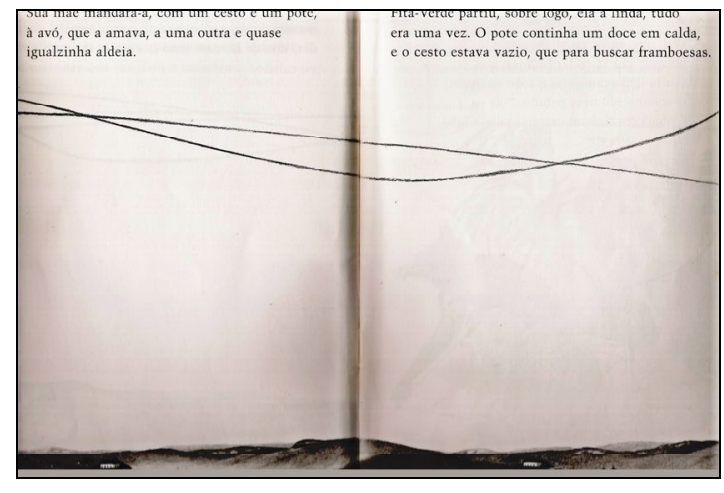

Figura 3.75 - Situação inicial

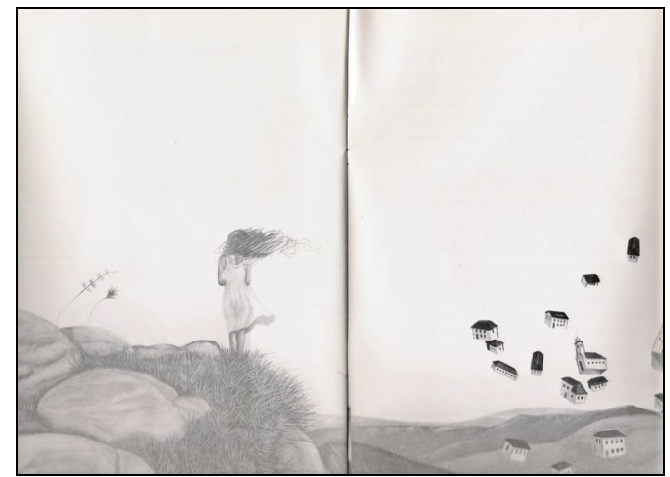

Figura 3.76 - Situação final

Outro recurso constante no modo de narrar do visual é que muitas das imagens do livro deixam entrever o seu fazer. Tem-se a enunciação eninciada. O material é o pastel preto sobre o papel branco, e, em alguns momentos, há a interferência do verde. A oposição se dá entre figuras em processo versus finalizadas que deixam aparente o traçado do pastel sobre o papel; há uma gradação entre a mais finalizada e a menos finalizada, como o quadro abaixo apresenta ${ }^{133}$ :

\footnotetext{
${ }^{132}$ Obras como As mil e uma noites e Feito à mão, de Lygia Bojunga Nunes, dentre outras, utilizam a mesma metáfora.

${ }^{133}$ Este quadro não revela uma ordenação temporal, porque ela
} 


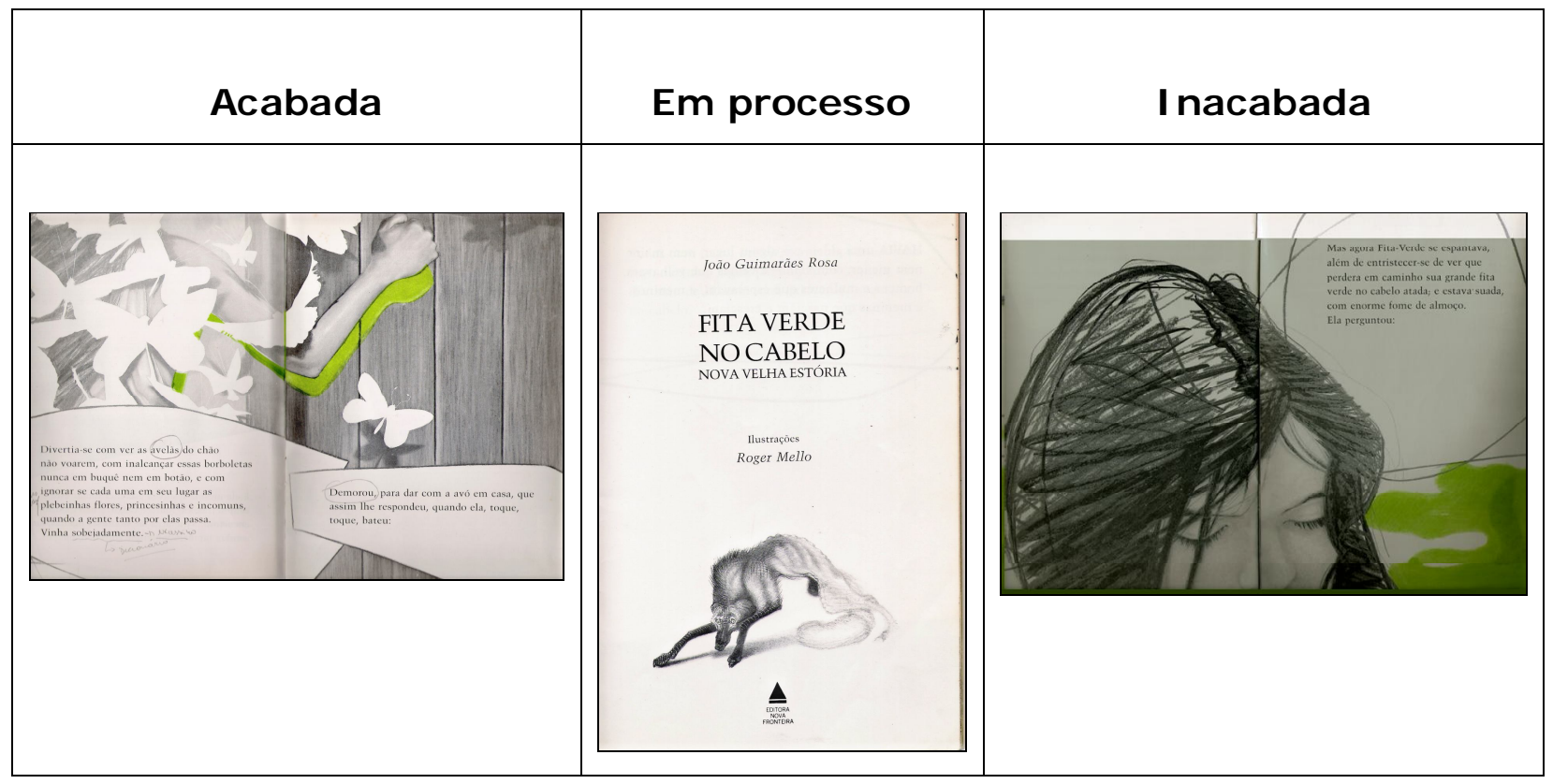

Quadro 3.1 - Gradação acabada versus inacabada

As imagens presentes nesta obra vão, por um lado, criar o efeito de proximidade com a realidade, apagando as marcas da enunciação, e, por outro, distanciar-se do efeito de sentido de realidade, deixando-se ver a enunciação, rompendo o encanto da ficção. Dessa forma, há a metaficção nos desenhos de Mello.

Vale pontuar, ainda, que a capa retoma o estilo empregado por Mello em outras obras, tais como A flor do lado de lá ou Ver de ver meu pai.

A imagem da menina de olhos baixos é retirada do miolo da obra. Além disso, a concepção gráfica da capa envolve frente e contracapa e deve ser observada como um todo que compreende o objeto-livro e já antecipa a narratividade ${ }^{134}$. A capa é caracterizada como anafórica, como será desenvolvido mais adiante.

134 Pontua-se que este tipo de capa difere daquela apresentada na nhra Sehactiãn Anı impõe duas narrativas interligadas, como foi demonstra narrativa está envolvida pela capa. 

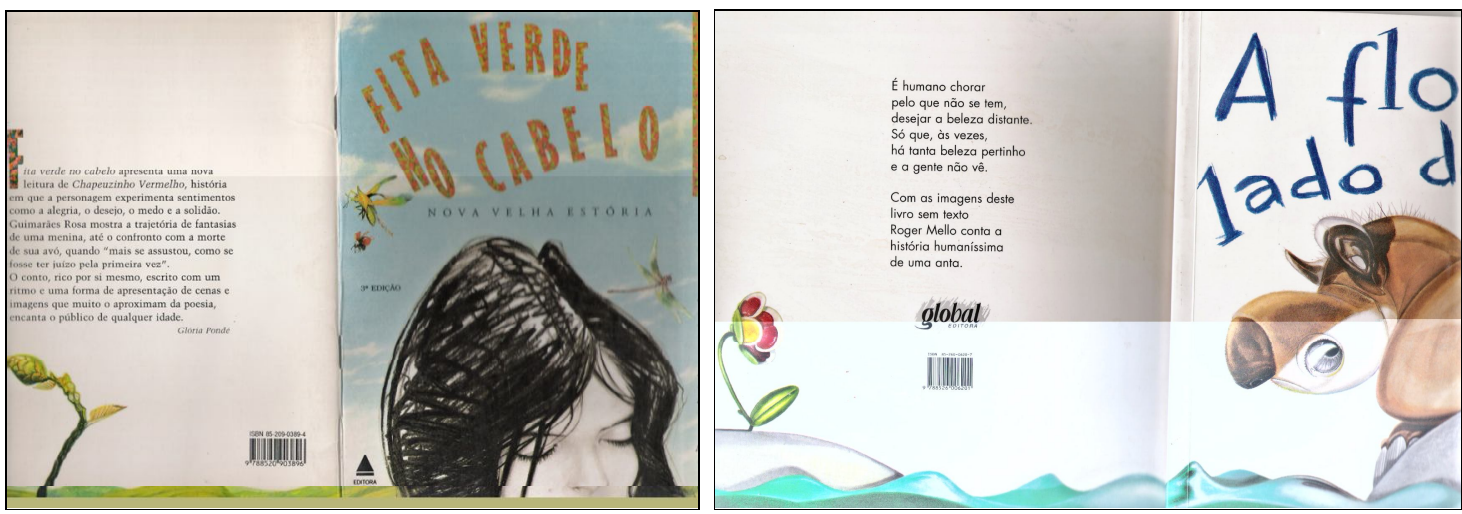

Figura 3.77 - Estratégia recorrente nas capas

Ainda, a sombra verde cria metáforas que ora são a sombra da menina, ora a do lobo, ora a da avó, ora a fusão entre as personagens lobo=menina; lobo=avó/presença da morte:

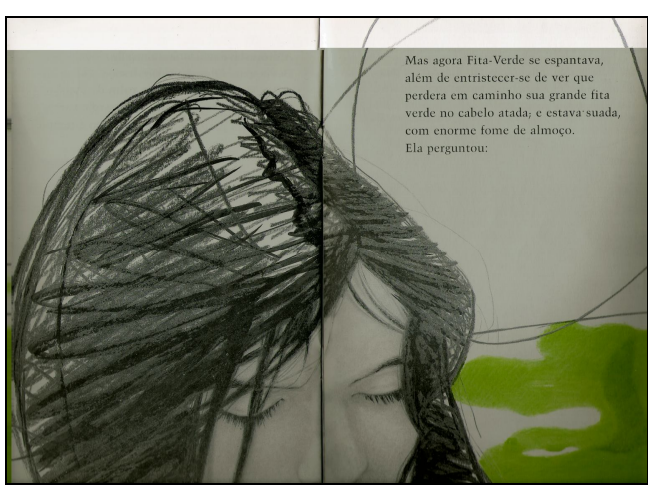

Figura 3.78 - Sombra lobo

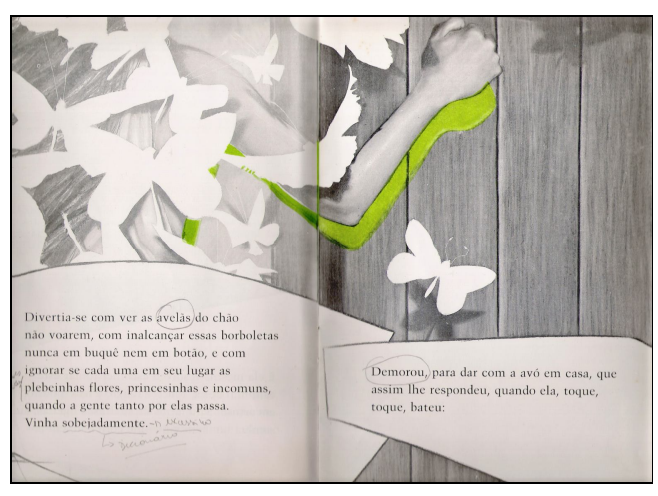

Figura 3.79 - Sombra menina

(presença da morte)

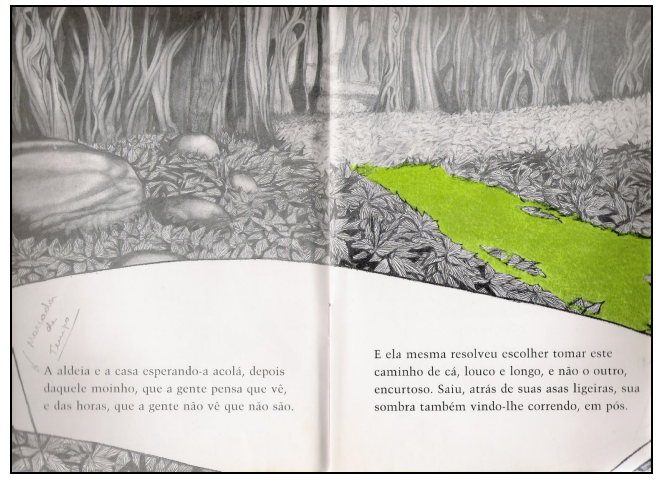

Figura 3.80 - Sombra menina=lobc 
Além da metáfora desenhada pelo verde, há uma ambigüidade espacial proposta pelas imagens, não se sabe se está em um ambiente interno ou externo, como pode ser demonstrado pelas cenas a seguir:
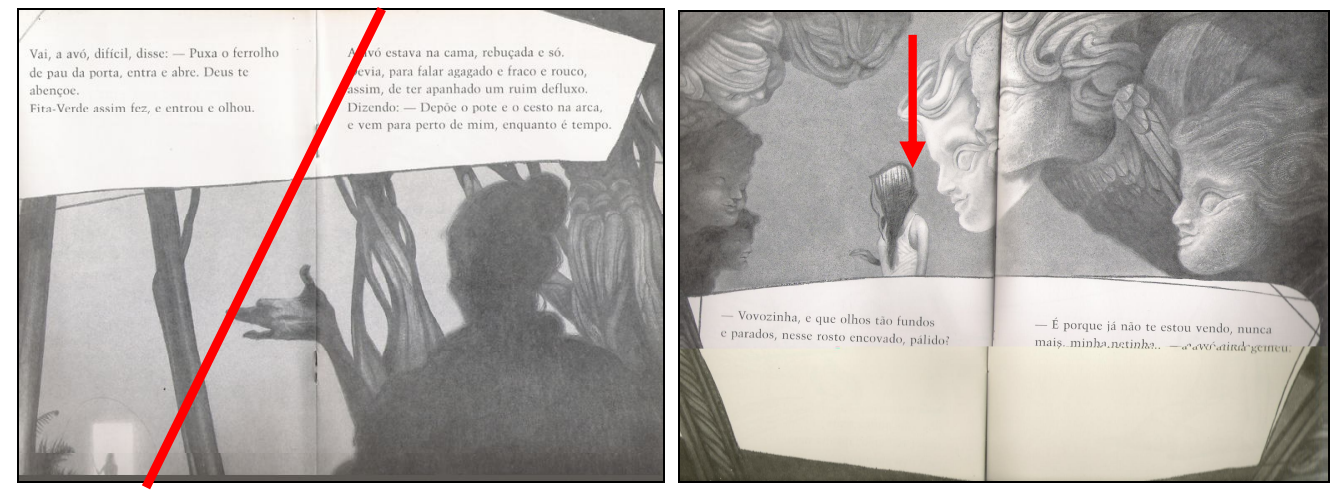

Figura 3.81 - Ambigüidade espacial

Interno ou externo: floresta ou

casa? A avó já é lobo=morte
Interno ou externo: igreja ou céu?

Assim, demonstrou-se que, a exemplo dos fios, as vozes discursivas envolvem a trama discursiva, tecendo um novo texto impresso pelo projeto gráfico que une palavra e imagem:

O texto é o que se vê, um campo, um deserto. A análise semiótica contribui para que se veja, sob o solo do discurso, um subsolo movediço de relações dinâmicas que, construindo as diferenças do próprio solo, dão-lhe significado. O deserto significa em oposição a um campo gramado (DISCINI, 2004, p. 82). 


\subsection{8 $\operatorname{Re}($ contando) o Emaranhado de Vozes: Um Livro para Crianças}

Resta, finalmente, responder a quem se destina a obra em análise. Para isso, recorre-se à voz de Norma Discini e de outros pesquisadores por ela citados a fim de justificar que a arte não determina a faixa etária, e que a poesia é fundamento da ludicidade:

Rosa é o mais lírico de todos os textos deste corpus, portanto, o mais lúdico, pelo próprio percurso temático da imprevisibilidade, que se realiza num jogo de figuras inéditas, pela musicalidade, pelas aliterações, pela ambigüidade, pelo sentido do inacabado, pelo indizível, pelo poético, enfim. Justamente ele, que não parece ser conto infantil, é o que deixa livre um observador-interno-menina para que este possa emergir do tom narrado; logo, Rosa é o que mais se aproxima, apesar de não parecer, desse universo infantil. [...] Castagnino acrescenta: "A literatura é um jogo espiritual; nela, as coisas têm outro aspecto que na 'vida habitual' e, quando está carregada de lirismo, até pode mover-se em meios alógicos. [...] O poeta joga da mesma forma que a criança. Por isso se disse, com grande verdade, que para captar as essências poéticas é preciso ser capaz de revestir o espírito como essa magia infantil, é preciso virar criança e recuperar a disposição para penetrar no mundo do maravilhoso. (2004, p. 240)

Eis a prosa poética de Rosa inserindo a criança num ambiente que é todo dela. Mello utiliza os mesmos mecanismos da linguagem poética em suas linhas realistas, hiper-realistas, surrealistas. Este é um rico projeto gráfico para dar à criança aquilo que ela deseja: a brincadeira para o desenvolvimento. Assim, encerra-se a análise como a definição de poesia para crianças de José Paulo Paes:

[Poesia] Podia ser a linguagem da surpresa diante dos mistérios do mundo, o mundo fora e o mundo dentro da gente; a linguagem em que eram formuladas as grandes perguntas fundamentais acerca do sentido da vida e da morte (1996, p. 11). 


\subsection{Desencontro para ReVelar Encontros: Vizinho, Vizinha}

Soledad, Aqui están mis credenciales, Vengo llamando a tu puerta Desde hace un tiempo, Creo que pasaremos juntos temporales, Propongo que tú y yo nos vayamos conociendo.

(Jorge Drexler)

\subsubsection{As Apresentações}

Cidade grande: prédios, antena parabólica, asfalto e pessoas... Duas personagens são destacadas do fundo e seguem em direções opostas.

A cidade compõe o fundo da cena. A cor predominante é o amarelo. Um, dentre muitos edifícios, tem dois andares com sacada e está em destaque pela cor rosa. Amarelo e Rosa são as cores em oposição na obra em análise.

Os outros prédios desta cidade são delineados em cor preta e o fundo vaza pelos contornos e os faz amarelos. A rua, que também é uma linha da terra, é preta. Em cores, a obra se apresenta ao leitor.

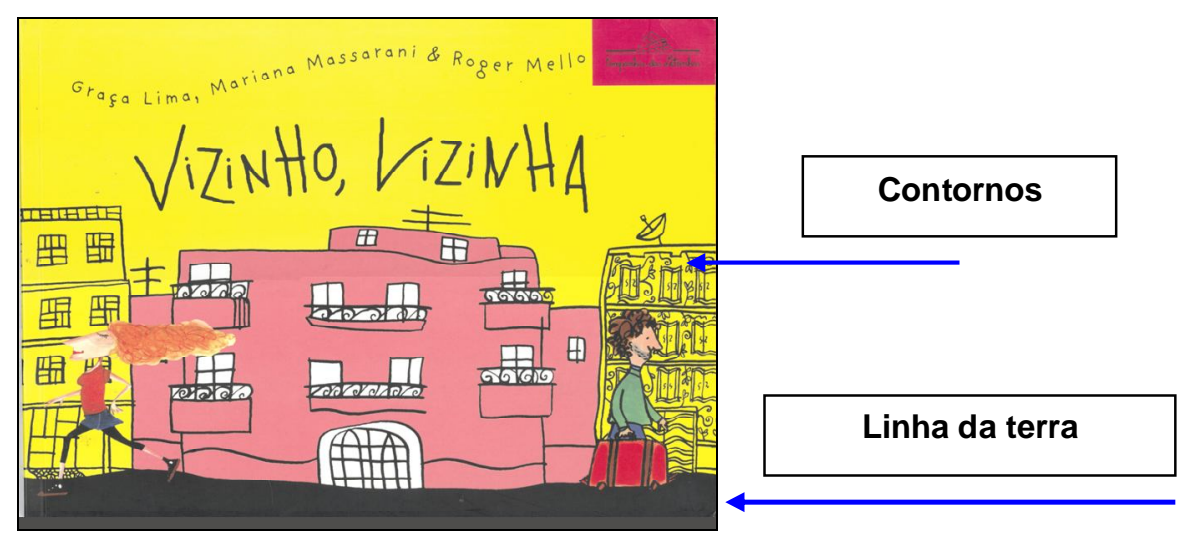

Figura 3.82 - Capa 
As duas personagens destacadas dão a impressão de terem sido coladas, ou seja, pertenciam a outros contextos, mas foram retiradas e inseridas neste fundo que acabou de ser descrito ${ }^{135}$, visto que ela apresentam técnicas plásticas distintas da utilizada no fundo da cena. Elas (Vizinho, Vizinha) são coloridas, e se percebem traços de estilos distintos com relação às formas corporais e as expressões faciais, cada uma tem o seu "estilo", a sua individualidade. Essa estratégia é reiterada pela técnica empregada, a saber: no homem, desenho com marcador e preenchimento em aquarela, na mulher, óleo, como pode ser comprovado pelo detalhe da cena:
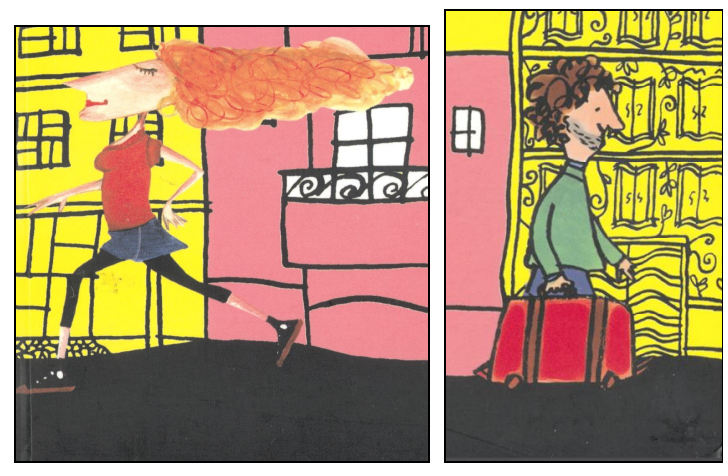

Figura 3.83 - Detalhe das personagens

Estas personagens, além das cores, são impregnadas pela técnica utilizada: mista. González e Zaparín apontam para a tendência em utilizar técnicas mistas nos álbum contemporâneos, no artigo intitulado "Entusiastas de la fusión - Aproximaciones al lenguaje de los álbumes":

Parece que lo que ahora pide el sofisticado mercado occidental es la combinación de elementos, y nada más. Lo importante es que por encima de eso nos encontramos con cualificados recursos gráficos y narrativos, propios de una

${ }^{135}$ Relação similar à descrita na análise da obra Sebastião, de $M_{i}$ 
manera de hacer y un género cada vez más consolidados (2005, p. 10).

Há, então, uma indagação: por que as personagens não revelam um estilo próprio, personalizando o artista que as produziu e uniformizando o projeto gráfico, como nas outras obras analisadas por este trabalho de tese? A questão se finca como "pedra no meio do caminho", como dizia o poeta. Entretanto, segue-se.

Pelo sistema verbal, a capa apresenta, nesta ordem: os autores, Graça Lima, Mariana Massarani e Roger Mello; o nome da editora, Companhia das Letrinhas; e o título, Vizinho, Vizinha (dois substantivos separados por vírgula ${ }^{136}$ ). Além disso, vale pontuar que a imagem da capa continua na contracapa, a estratégia como um estilo, "modo de fazer" do artista Roger Mello ${ }^{137}$.
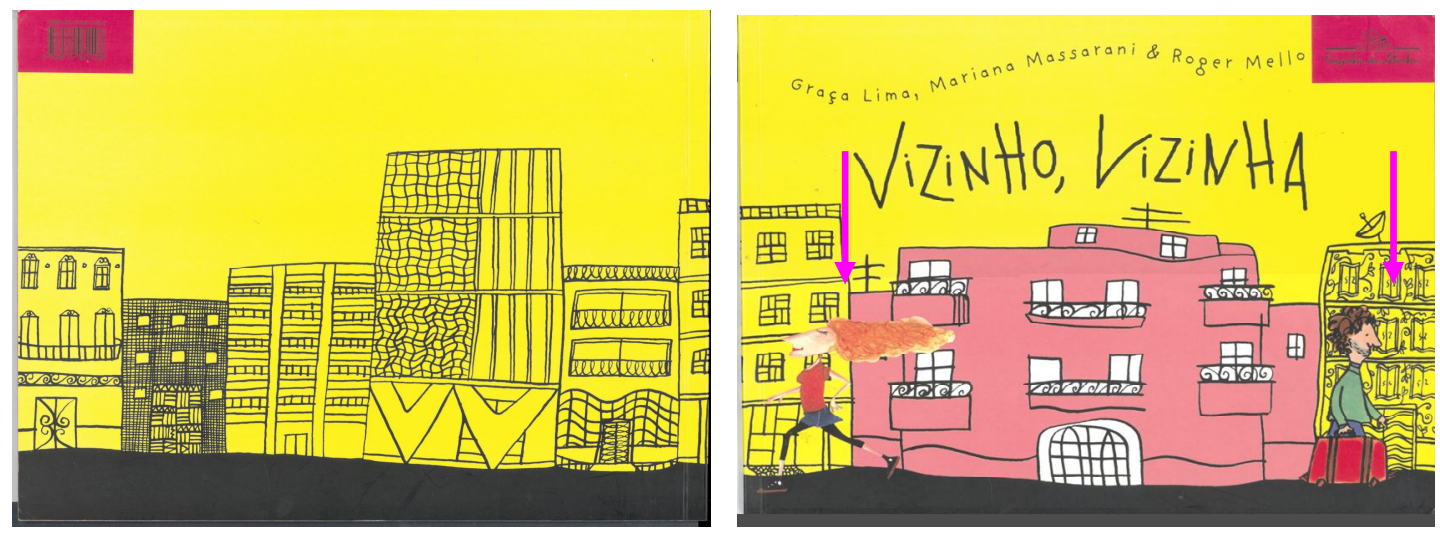

Figura 3.84 - Contracapa e capa

A página guarda apresenta fundo preto e figura (desenho) branca. O desenho é de uma cidade, o traço empregado é estilizado, pode-se dizer até caricatural. Isso pode ser comprovado por quadras absolutamente definidas, um patinho na Lagoa, o naviozinho no mar, entre outros. Uma

${ }^{136}$ Este sinal gráfico será analisado ao longo do estudo, pois caberia outro conectivo (palavra) em seu lugar: e, por exemplo. Caberá à investigação revelar o efeito de sentido gerado pela opção.

137 Tal afirmação é possível, visto obras citadas por este estudk lado de lá, Fita verde no cabelo - nova velha estória. 
busca de identificação com o público-leitor ou um traço do artista? Outras questões que surgem para análise.

Ainda, é possível identificar alguns símbolos e monumentos que revelam de que cidade se trata: o mar à esquerda, mais ao centro Lagoa (Rodrigo de Freitas), morros, chafariz, monumentos, Maracanã, Jardim Botânico, a Candelária, os Arcos da Lapa. Logo, diante dos olhos está a cidade maravilhosa: o Rio de Janeiro.

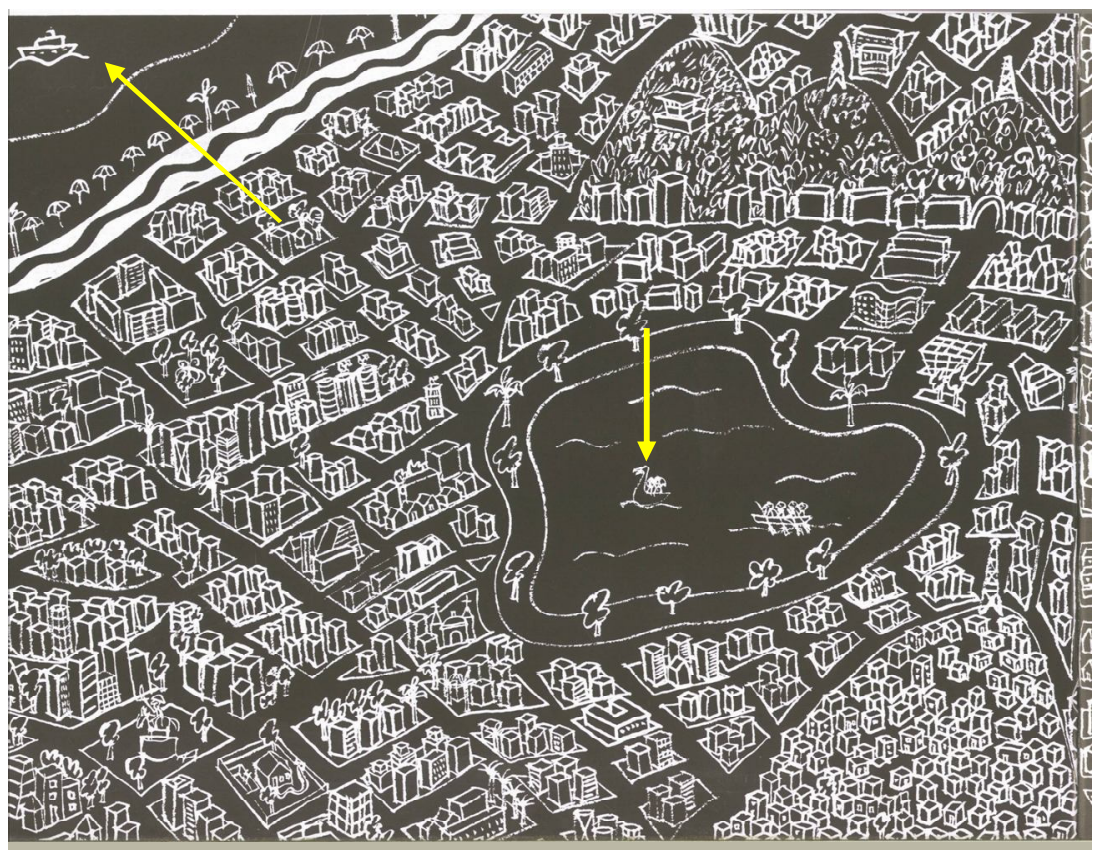

Figura 3.85 - Página de guarda

Alguns esclarecimentos para análise já surgem na capa: a história será protagonizada por um Vizinho e por uma Vizinha de um prédio na cidade do Rio de Janeiro. Como em outros projetos gráficos ${ }^{138}$, a capa deve ser amplamente utilizada na seleção ou não de uma determinada obra pelo agente de mediação; o que se quer afirmar é que o projeto

${ }^{138}$ Como demonstrado na análise das obras neste estudo. 
gráfico inclui a capa, se ela não estiver em sintonia com o miolo, pode ser um critério para a desvalorização da obra.

Também, sobre a produção, a página de rosto reitera os dados já apresentados. Em cor de rosa, a página de rosto traz uma figura menor (como se fosse um logotipo) do prédio destacado na capa, e o sistema verbal, mais uma vez, revela o título: Vizinho, Vizinha - texto de Roger Mello; ilustrações de Graça Lima, Mariana Massarani; participação especial (com letras menores) Roger Mello. Ainda, abaixo do logotipo está o nome da editora: Companhia das Letrinhas.

Caracteriza-se a página de rosto como bastante tradicional, exceção feita à opção de cor, pois, no padrão, a opção é por preto e branco.

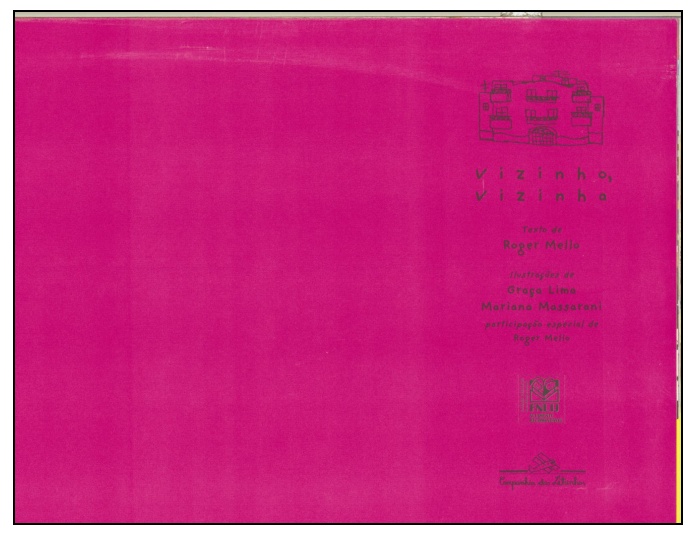

Figura 3.86 - Página de rosto

Antes de passar ao enredo, vale ressaltar que a normalidade no encontro autor do sistema verbal, autor do sistema visual, nos livroálbuns, foi rompida, pois a obra em questão apresenta um autor verbal, dois autores das imagens e ainda uma participação especial na imagem, aliás, do próprio autor do texto verbal. Assim, percebe-se que Vizinho, Vizinha será uma produção em equipe ${ }^{139}$. Denomina-se equipe, pois, nas análises anteriores, havia um diálogo entre o sistema verbal e o visual,

\footnotetext{
${ }^{139}$ Estes autores (Mariana Massarani, Graça Lima e Roger Mello) ๔ãn nronrietárinc de ı ıma empresa de trabalhos gráficos chamada Capa Dura em Ci habituados ao trabalho conjunto. 
como foi demonstrado, ora com um único autor, ora com dois autores, cada um responsável por um dos sistemas semióticos presentes no objeto-livro.

Agora, nasce uma nova relação: mantêm-se os diálogos entre os sistemas semióticos, no entanto, na obra que se apresenta, é lícito verificar se o autor e o estilo se mostram na enunciação ou se não importa para análise saber que são três autores do sistema visual, pois este fato não agregaria sentido ao enunciado? Como afirma Bakhtin, em A estética da criação verbal:

De fato, o artista trabalha a língua mas não como língua: como língua ele a supera, pois ela não pode ser interpretada como língua em sua determinidade lingüística (morfológica, sintática, léxica, etc), mas apenas na medida em que ela venha a tornar-se meio de expressão artística (a palavra deve deixar de ser sentida como palavra). O poeta não cria no mundo da língua, ele apenas usa a língua. No que diz respeito ao material, ao desígnio do artista, condicionada à tarefa artística fundamental, pode ser expressa como superação do material. No entanto, essa superação é de natureza positiva e não visa absolutamente à ilusão. Supera-se no material uma possível determinação extra-estética dele: o mármore deve deixar de persistir como mármore, ou seja, como um determinado fenômeno físico; ele deve exprimir plasticamente as formas de um corpo, mas sem criar a ilusão de corpo; tudo o que é físico no material se supera precisamente como físico. Devemos sentir as palavras em uma obra de arte precisamente como palavras, ou seja, em sua determinidade lingüística [...] (2003, p. 178).

Diante desta situação, pergunta-se se o material leva à identificação de um estilo ou, ainda, se isso deve ser deixado de lado, por se considerar fundamental a história narrada e não a forma como este conteúdo se apresenta. A Semiótica, no entanto, postula que o texto poético é aquele em que o plano da expressão está homologado ao plano do conteúdo. Posto isso, é consenso que a obra literária oferecida para as crianças deve primar por sua especificidade poética, assim, a poeticidade seria um critério de avaliação da obra de literatıra infantil Racta investigar se a obra Vizinho, vizinha se caracteriza pe 
Também o visual, isso inclui a materialidade, não compõe o enunciado no livro-álbum, uma vez que este é definido como um livro, em que as mídias verbal e visual se organizam para contar uma história, formando um todo significativo? Convoca à análise, então, a questão do estilo aliado à técnica e interroga-se: haverá apenas um estilo, e Lima, Massarani e Mello, tal qual nos estúdios de Ziraldo ${ }^{140}$, trabalharão a partir de um mesmo traço ou cada um vai deixar a mostra o seu estilo, visto que este traço distintivo dará o tom da narrativa, como acontece em obras como O menino mais bonito do mundo, de Ziraldo e Mariana Apoena, em que há dois ilustradores, ou Griso, o unicórnio, em que Roger Mello "personifica" diferentes estilos ${ }^{141}$ ? Se a segunda hipótese for verdadeira, como fazer a obra ser um todo de sentido? Haverá, portanto, ruptura do sentido do discurso e isso comprometerá o projeto gráfico, visto que a inteligibilidade estará comprometida? Valerá, então, discutir sobre algo que não é comum em literatura, a saber: uma obra escrita (desenhada) a três mãos, reiterando uma característica da literatura infantil brasileira que é a de estar atrelada à história em quadrinhos, ou mesmo, como afirmado anteriormente neste trabalho, ter nascido deste gênero de discurso no cenário brasileiro ${ }^{142}$ e, ainda, qual é o efeito de sentido gerado a partir da proposta do processo de criação, ou seja, este pode ser percebido no enunciado?

Estas questões são colocadas no horizonte da análise, e segue-se a narrativa a fim de observar as surpresas que ela guarda e, assim, responder às indagações formuladas. E, se for o caso, rejeitar ou valorizar uma maneira de produzir livros para crianças.

\footnotetext{
${ }^{140}$ Roger Mello e Graça Lima trabalharam juntos no estúdio de Ziraldo. Esta informação já foi tratada por meio de entrevista em análise anterior.

${ }^{141}$ Outras obras poderiam ser citadas como exemplo.

${ }^{142}$ Alerta-se, ainda, para a freqüência com que tal estratégia ( histórias em quadrinhos ou nas animações. 


\subsubsection{A Construção da Personagem: Técnicas e Materiais}

A primeira página da narrativa é toda amarela, e a narração é feita em off, como no teatro, o narrador não aparece, pois está em terceira pessoa, como narrador observador distanciado, mas é ele quem introduz a história, tal qual os personagens-narradores nas peças de Shakespeare, por exemplo. Instaura-se a debreagem enunciva: ele - lá - algures, como elucida Fiorin, em As astúcias da enunciação:

A debreagem enunciva é aquela em que se instauram no enunciado os actantes do enunciado (ele), o espaço do enunciado (algures) e o tempo do enunciado (então). Cabe lembrar que algures é um ponto instalado no enunciado; da mesma forma, o então é um marco temporal inscrito no enunciado, que representa um tempo zero, a que se aplica a categoria topológica concomitância vs. não-concomitância. [...]

A debreagem enunciativa e a enunciva criam, em princípio, dois grandes efeitos de sentido: o de subjetividade e o de objetividade. Com efeito, a instalação dos simulacros do ego - hic - nunc enunciativos, com suas apreciações dos fatos, constrói um efeito de subjetividade. Já a eliminação das marcas de enunciação do texto, ou seja, da enunciação enunciada, fazendo que o discurso se construa apenas com enunciado enunciado, produz efeitos de sentido de objetividade. Como o ideal de ciência que se constitui a partir do positivismo é a objetividade, o discurso científico tem como uma de suas regras constitutivas a eliminação de marcas enunciativas, isto é, aquilo a que se aspira no discurso científico é construir um discurso só com enunciados (1996, p. 45).

Toda a obra Vizinho, Vizinha é narrada como discurso científico: “Quem passa pela rua do Desassossego, número 38, nem percebe, mas....."

A narração deixa no ar a continuidade narrativa, "obrigando" o leitor (narratário instaurado) a virar a página. Cria-se a expectativa narrativa que também é dada pelo nome da rua, uma vez que, 
segundo o dicionário Aurélio, desassossego quer dizer: falta de sossego; inquietação, perturbação. (1989, p. 205).

Assim, falta algo para aquela rua. Isso impõe um percurso de busca. Ela (personificada) deve sair em busca de suprir sua falta, ou os desassossegados, moradores de tal rua, devem partir em busca do sossego? Para o enunciatário ver respondidas suas dúvidas, ele deve, mais uma vez, virar a página e seguir a narrativa.

A página seguinte é toda colorida e compartimentada, isto é, cada elemento tem o seu lugar. Assim, o leitor tem a impressão de um corte longitudinal na maquete que fora apresentada na página de guarda. Como acontece em cenário para filmes, novelas e, às vezes, peças teatrais, a fachada do prédio rosa foi tirada e o leitor pode acompanhar a vida do morador da esquerda e da moradora à direita:

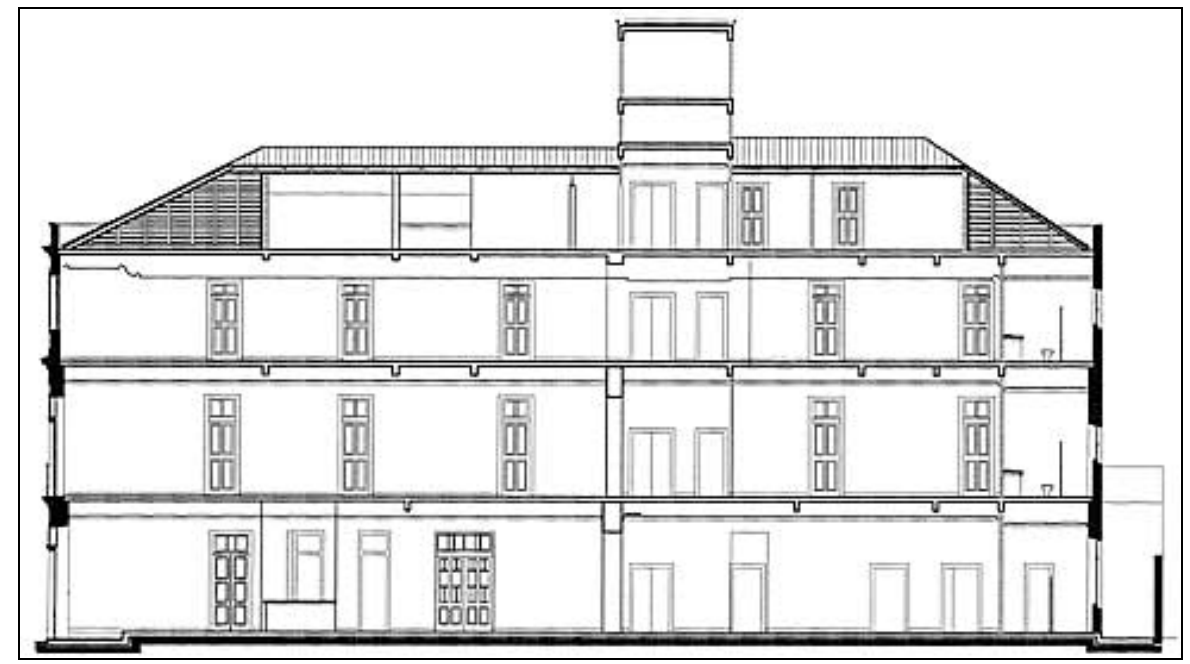

Figura 3.87 - Cenário sem fachada

Pelo "buraco da fechadura", será dada ao leitor (enunciatário) a realidade, aproximando o discurso de um estilo "realista", em que há necessidade de dar a luz aos problemas que afligem a sociedade, isso, cabe pontuar, no que diz respeito à aspectualização de pessoa, tempo e espaço do discurso. No conteúdo do sistema verbal, esta afirmnñ̃n ń mantinnn+n nn 
entanto, pela expressão do sistema visual, outra proposta virá à tona, essa mais subjetiva. Eis o objeto revelado por todas as suas facetas.

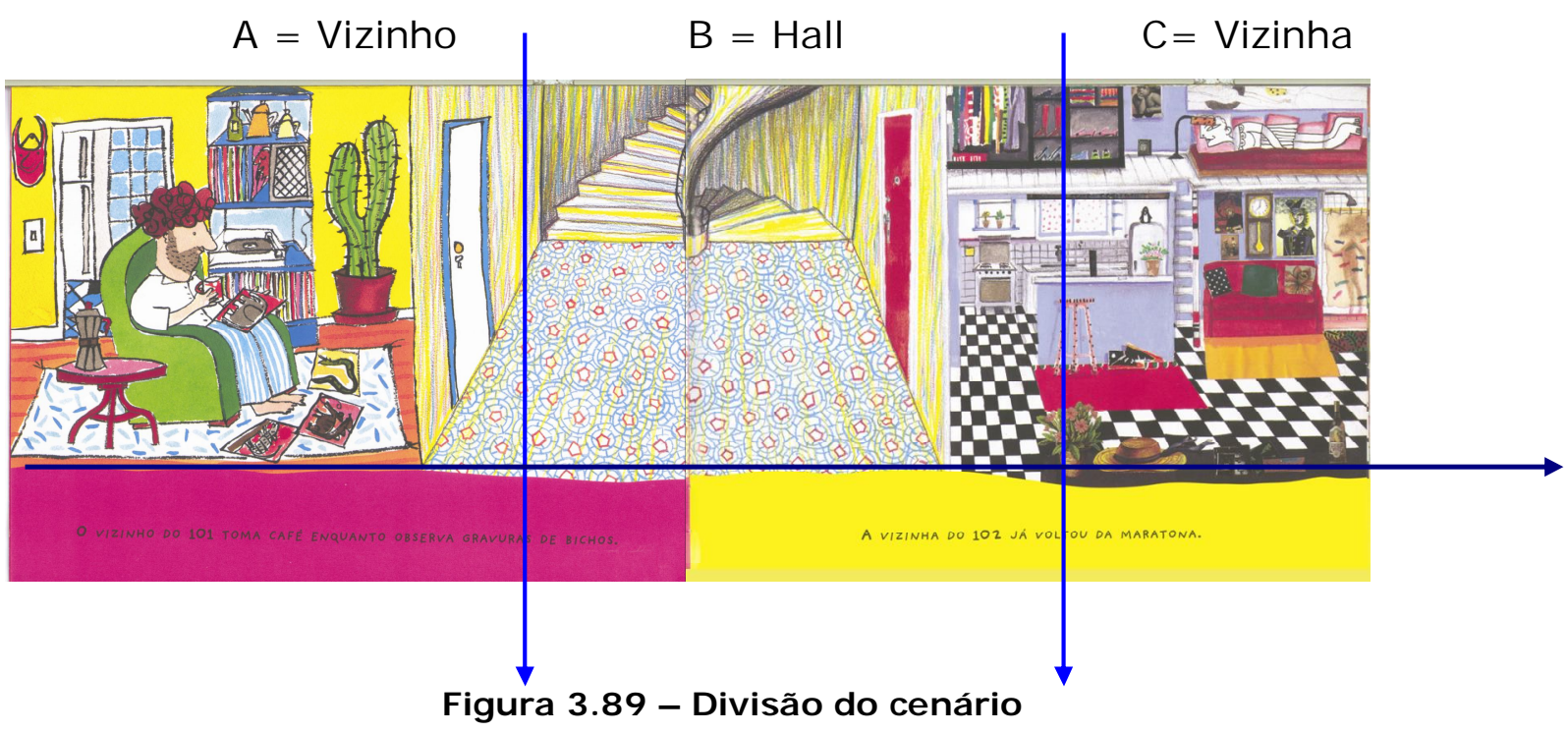

O morador da esquerda tem a sua legenda preenchida pelo rosa, a moradora da direita tem a sua preenchida pelo amarelo. As cores acompanham a narrativa desde a capa e seguem até o fim da história. Como mostra a seqüência abaixo:

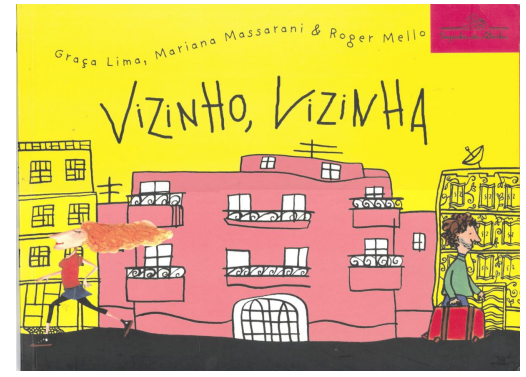

Figura 3.90 - Capa

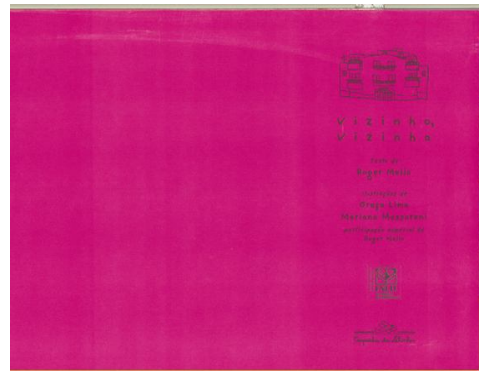

Figura 3.91 - Página de rosto

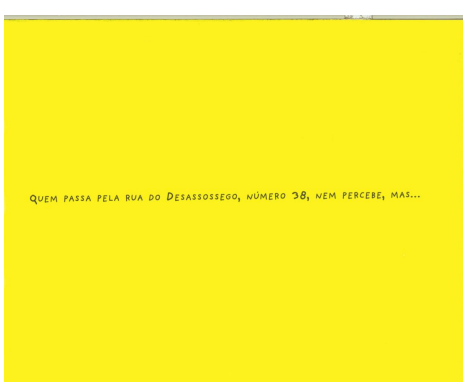

Figura 3.92 - Primeira Página 
Pontua-se que o projeto gráfico em análise foge ao simbolismo das cores, em que o rosa representaria o feminino e, provavelmente, o azul, o masculino. Neste caso, a oposição masculino versus feminino não é fundamental e está bastante atenuada, leva-se em conta as relações humanas, independentemente do gênero.

As cores cumprem outro papel, não são, pois, símbolos convencionais. Elas funcionam como guias da leitura, na medida em que é possível seguir o caminho traçado por elas no projeto gráfico da obra, demonstrando continuidade e coerência na composição gráfica e também instituindo uma marcação (passagem) temporal, reforçando a comparação com a função da legenda nas histórias em quadrinhos e autorizando a aproximação entre o livro-álbum em análise e o gênero de discurso já citado.

$O$ texto verbal diz à esquerda: "O vizinho do 101 toma café enquanto observa gravuras de bichos". Do outro lado, "A vizinha do 102 já voltou da maratona". As personagens não têm nome ${ }^{143}$. A ausência do nome é uma estratégia discursiva que gera o efeito de sentido de generalização: não é Maria ou J oão, são todos os habitantes das cidades grandes.

No centro da página, há um hall. Destaca-se este espaço, pois, apesar de ele não abrigar ninguém, tem o mesmo tamanho do espaço deixado para a personagem da esquerda que está sentada em sua poltrona, bebendo café e observando gravuras e para a personagem do outro lado que está escondida na cena:

\footnotetext{
${ }^{143}$ Impossível não se lembrar da crônica de Rubem Braga, sitıada na mecma cidade grande - o Rio de Janeiro -, Recado ao senhor 903. In: $20 \mathrm{C}$ de Janeiro: Record, 2003.
} 


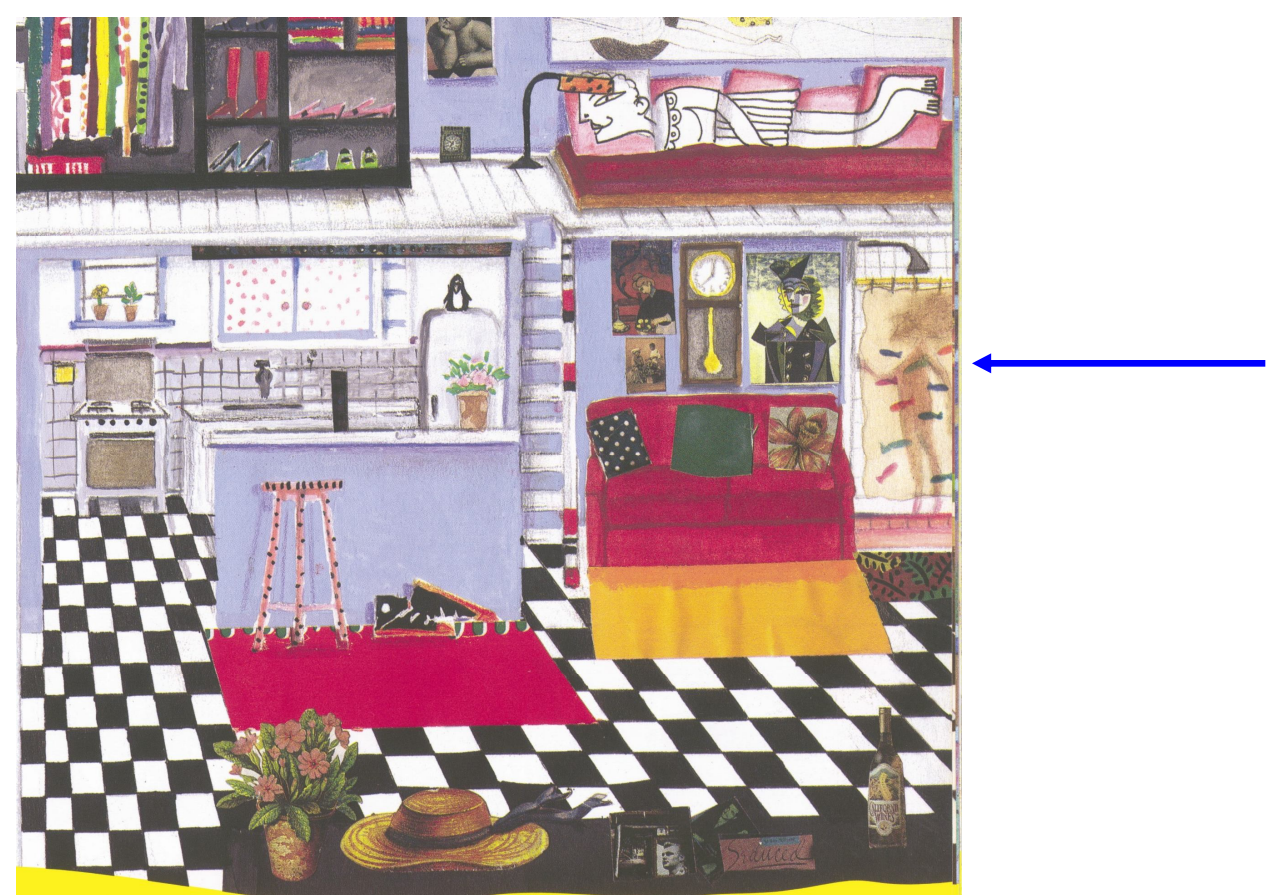

Figura 3.93 - Personagem no chuveiro

A técnica empregada para separar o espaço dos vizinhos é o pastel. Cada espaço será a continuidade das técnicas, dos materiais utilizados para a caracterização das personagens.

Assim, além do espaço reservado para cada um dos elementos apartamentos, hall e legendas -, as técnicas empregadas em cada um dos espaços também os diferencia: apartamento da esquerda, contorno preenchido por aquarela; apartamento da direita, óleo com colagem; hall, pastel; e narrador/legenda, cor de impressão, apagam-se as marcas do material e só há o preenchimento da cor. Como já observado na capa, o miolo reitera o que já havia sido sugerido por essa.

Tem-se, portanto, uma obra que manipula a técnica mista e ainda, dentro da mistura, organiza as técnicas, para que elas atribuam personalidade aos ambientes e, por conseqüência, às personagens, marcando as subjetividades ${ }^{144}$ :

${ }^{144}$ A questão da subjetividade versus objetividade, como efeitos discurso, será tratada mais adiante. 
Dicho en pocas palabras, se entró en crisis (da obra de arte) por el agotamiento del modelo verosímil, tras su extensa vigencia y por la demanda de mayor subjetividad, que prefería el universo interior e individual a la muy conocida representación del mundo exterior. Esta revolución se tradujo en nuevas formas de representación que, resumiendo mucho, podríamos distinguir según el binomio de razón y sentimiento. La gran aportación de los sistemas de representación racionales, siempre a la busca de una mayor subjetividad, fue el cubismo (2005, p. 8).

A técnica da colagem utilizada na caracterização da personagem da direita corrobora a idéia da referência cubista como um estilo impregnante na construção da protagonista.

\subsubsection{Enredo de Desencontro}

Também, pelo conteúdo do texto verbal, o leitor poderá descobrir que as personagens reveladas têm gostos diferentes: "o vizinho coleciona discos da velha guarda. A vizinha guarda coisas velhas que depois não encontra. Ele já viajou o mundo inteiro. Ela tem uma estante de livros do tamanho do mundo. Ele molha as plantas no parapeito, vestido com um escafandro, e quando lê quadrinhos, sempre perde a noção das horas. Ela ainda vai aprender a tocar clarineta e seu relógio não funciona há muito tempo". A descrição das ações das personagens revela: personagens com gostos próprios, personalidades, mas com detalhes que poderiam ser partilhados.

Em seguida, vem a descrição da rotina dos protagonistas: "quatro e quarenta: ele sai com o canário para um passeio. Vinte para as cinco: ela finalmente leva o relógio ao conserto".

É, então, o momento em que estas duas personagens se encontram (ou se desencontram). Todos os dias, é isso que acontece: "só se encontram a esta hora. No corredor: Boa tarde, boa tarde, como tem passado? Como está o tempo? E é só". Indaga-se: qual o projeto de vida destas pessoas? Elas trabalham? Qual a 
família? Amigos? Eis o retrato da imposição das grandes cidades. Otávio Ianni reflete acerca da condição nas cidades:

Cidade rima com modernidade e pós-modernidade; e muito mais quando se trata da grande cidade, metrópole, megalópole ou cidade global. Esse o excepcional laboratório de todas as possibilidades, práticas e ideais, reais e imaginárias (2000, p. 133).

A narrativa se apresenta como a laboratório da vida cotidiana, que não particulariza a problemática, uma vez que as personagens não são nomeadas, mas generaliza e, por isso, pode revelar, desmascarar a vida nas grandes cidades, como quer Ianni.

$\mathrm{Na}$ cidade de Vizinho, Vizinha, ninguém conhece ninguém. Eles parecem ter tempo para se conhecerem, então, por que não se conhecem? A falta de relação entre as pessoas é o tema proposto pela obra, e isso caracteriza a cidade retratada.

Enquanto as duas personagens eram descritas por seus gostos, rotinas, outra surgiu no espaço vazio, no hall.

A obra, ao fazer o corte longitudinal na fachada, traz à tona outra técnica das histórias em quadrinhos, a saber: a simultaneidade da leitura 145, que, oposta à linearidade, é uma questão própria ao projeto gráfico em análise, que deve ser descrita e discutida mais adiante.

O hall é preenchido por uma personagem "muda", ou seja, o narrador do texto verbal não a descreve. Ele existe apenas no texto visual, a menos que seja a metáfora de algo revelado no verbal, mas a associação ainda não foi estabelecida. A personagem desce a escada caracol e leva um balde na mão. Ela é o faxineiro, pois, na cena seguinte, além do balde, tem uma vassoura, uma garrafinha com produto de limpeza e um pano que passa do chão.

\footnotetext{
${ }^{145}$ Apesar de utilizar períodos curtos no texto verbal, não mensagens simultâneas ou instantâneas pelo sistema verba sistema visual amplia a história contada pelo verbal.
} 
Seguindo a ação (percurso do coadjuvante), o faxineiro deita no chão para "tirar uma soneca". Toda ação executada por ele não é descrita pelo texto verbal, como já apontado. Depois da "soneca", o responsável pela limpeza segue para o andar debaixo. Eis a seqüência visual:

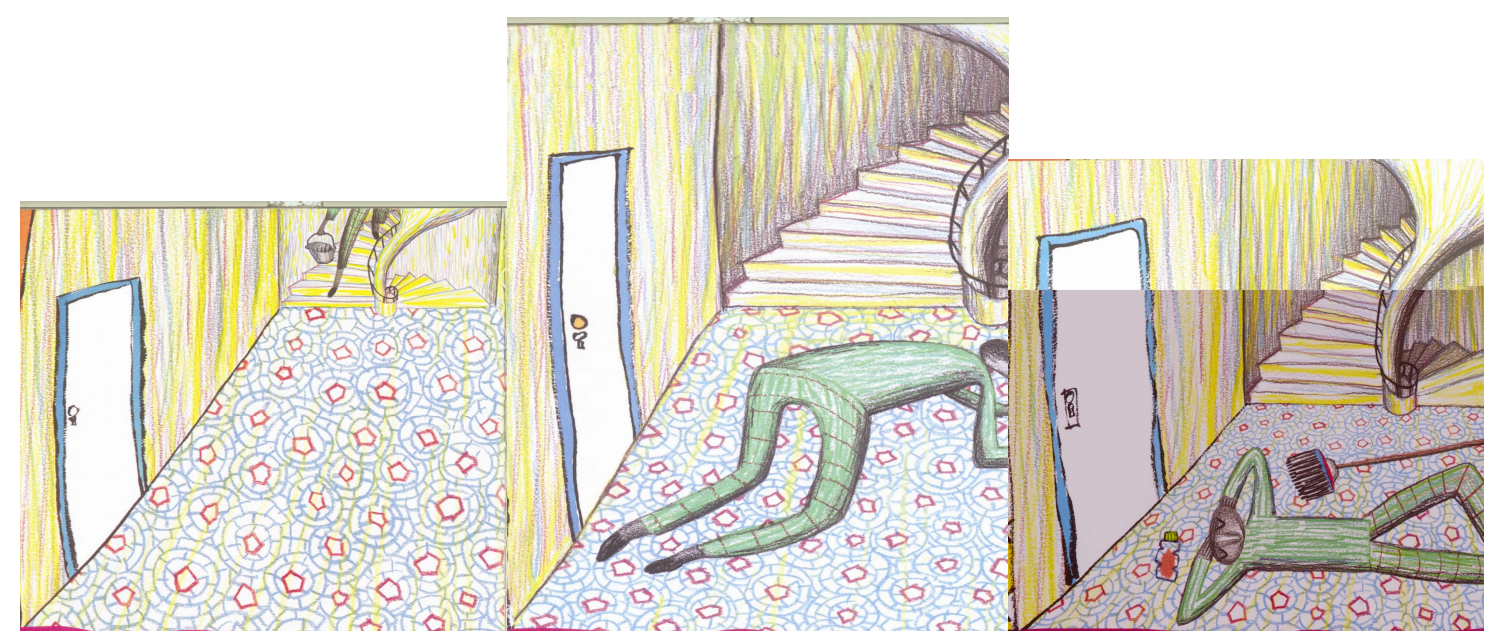

Figura 3.94 - Seqüência da personagem coadjuvante

Todavia, mais uma vez, voltam-se os olhos aos protagonistas. No encontro rotineiro, apesar de nada falarem, além de cumprimentos fáticos, o visual, novamente, amplia o verbal, visto que, pelas expressões faciais, as personagens deixam transparecer interesse uma pela outra, mas não revelam tal sentimento. Mesmo o corpo falando, as palavras calam. Esta é a condição das cidades grandes, e a "falta de tempo", uma desculpa para a distância, pois até agora as personagens não se apresentaram "ocupadíssimas" e, portanto, "sem tempo" para conhecer o vizinho "de porta".

É na grande cidade que aparece a multidão, a massa ou a turba, assim como o líder, dirigente, demagogo, condottiere. Aí se formam o cidadão e a cidadania, o solitário e a solidão, o radical e o fanático, o suicida e o profeta, o artista e o cientista, assim como o aventureiro. o blasé. o flâneur (2000, p. 125). 
As pessoas se camuflam na multidão. É personalidade na generalização (multidão). Face ao desenho citadino, fica fácil se esconder, não se viver as relações intersubjetivas. Assim, nesse rápido encontro vazio de palavras, o hall ganha proporções maiores, pois os apartamentos somem da cena, somente as portas aparecem, e elas, de maneira sugestiva, corporificam, pela técnica, pela materialidade empregadas, o estilo de seus donos, como todo o apartamento. A porta é a metonímia de seus donos, que, por contigüidade, carregam a personalidade dos protagonistas.

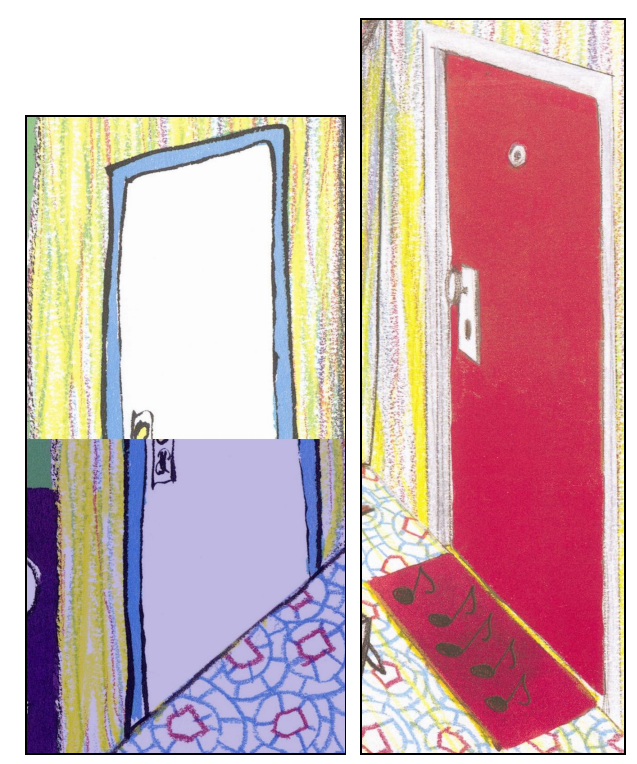

Figura 3.95 - Portas-personagens

Na página seguinte, só o apartamento do vizinho aparece: "vinte para as seis: ele está de volta, construindo uma cidade de papel. Seis e pouquinho: ela trouxe um"Manual do químico moderno", o conserto do relógio, paciência, ficou para amanhã"146. Os espaços na cena se ajustam na medida em que os sentimentos são relevantes, ou seja, há uma hierarquização na distribuição deste espaço. Ele não é estático, como 
nas maquetes ou cenários, mas móvel como os espaços dos quadros nas histórias em quadrinhos.

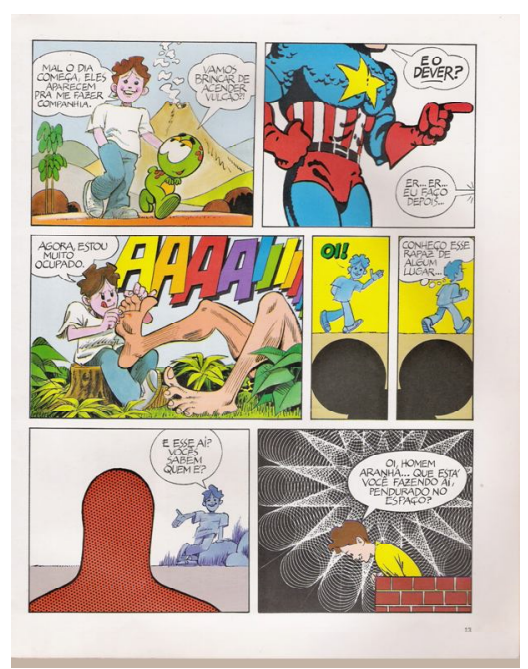

Figura 3.96 - O menino quadradinho - Ziraldo

A vizinha sobe a escada já lendo seu livro, e o narrador, aqui, ganha a palavra do discurso indireto livre, uma vez que a expressão: "paciência" revela um sentimento que não se sabe se é do narrador ou da personagem, ou talvez pertença aos dois. Instaura-se a ambigüidade verbal própria ao discurso indireto livre, como esclarece Fiorin (1999):

O discurso indireto livre mescla a fala do narrador com a do personagem. Do ponto de vista gramatical, o discurso é do narrador; do ponto de vista do significado, o discurso é do personagem. Isso é possível pela queda dos elos subordinativos e dos verbos de dizer presentes no discurso indireto. Por isso, o discurso indireto livre cria um efeito de sentido que fica a meio caminho entre a subjetividade e a objetividade. Nele, são duas vozes que se expressam, a do narrador e a do personagem (1999, p. 185). 
A cena volta à sua antiga disposição, cada um no seu espaço e em seu mundo. "Ele inventou uma máquina de fazer chover, e a vizinha não sabe. Ela alimenta um rinoceronte debaixo da pia, e o vizinho nem desconfia". Configura-se o seguinte quadro semiótico da relação intersubjetiva mantida pelos protagonistas:

\begin{tabular}{|ccc|}
\hline Verdade & $\leftrightarrow$ & Mentira \\
Segredo & $\leftrightarrow$ & Falsidade \\
\hline
\end{tabular}

\section{Quadro 3.1 - Quadrado Semiótico}

Além disso, o conteúdo das ações desempenhadas pelas personagens revela um universo imaginário, próprio à criança ou, também, podem demonstrar figurativamente que os atores nada têm a fazer ou, ainda, que máquinas de chuva e rinocerontes são metáforas dos obstáculos impostos ao encontro. Todas as possibilidades são pertinentes, reiterando a leitura plurissignificativa, condição da obra literária.

O segredo instaurado, ainda, estabelece-se, pois as personagens estão encerradas no próprio universo. Elas não se conhecem, não compartilham os desejos, os sonhos, os obstáculos, os problemas, como I anni define a cidade moderna ou pós-moderna:

É desde a grande cidade que se difundem a modernidade e a pós-modernidade, como estilos de vida e visões de mundo. São as luzes da cidade que iluminam praticamente todas as outras partes do mundo. Quando se fala em modernidade e pós-modernidade, tendo-se em conta o local, o nacional, o regional e o mundial, não se pode esquecer que uma e outra modulações ressoam desde a grande cidade. É aí que se radicam as relações, os processos e as estruturas que organizam, movimentam e transformam o mundo (IANNI, 2000, p. 135). 
O narrador de Vizinho, Vizinha entrelaça as histórias, mas não há o encontro pessoal, vivo. Essas pessoas estão separadas por seus segredos. Mais uma vez, o discurso evidencia que cada um tem a sua vida, mesmo lado a lado, um não conhece o outro e talvez, por isso, tornem-se desassossegados, como quer o nome da rua onde moram.

Expõe-se, a partir disso, o seguinte programa narrativo: $\mathrm{S}$ inicial $\rightarrow$ actante não tem companhia, está, portanto, disjunto do objeto valor; ele tem o querer fazer-se conjunto, mas não sabe como; o obstáculo é a própria condição da modernidade: cidade grande, falta de confiança, vida privada, individualização. Os actantes são ambos os protagonistas.

O programa narrativo sofre interferência quando surgem sujeitos que serão destinadores (doadores de competência), assim a rotina é quebrada, quando um traço comum une as personagens. Um elemento da vida dos dois vizinhos é descrito e, por esse elemento comum, apesar das inúmeras diferenças, parece que a união é possível graças à criança ${ }^{147}$ : "Ele tem uma sobrinha quase da idade do neto dela. Ela tem um neto dois dedos menor que a sobrinha dele".

As crianças os unem: "Outro dia, a sobrinha do vizinho fez uma visita. Justo no dia em que o neto veio passar o dia com a vizinha".

Por esse traço comum, as idades dos vizinhos são também reveladas. Eles já tiveram uma vida em família ou atarefada. Agora, encontram-se, no momento em que os filhos seguiram suas vidas; no trabalho, já cumpriram seus compromissos. I sso não é dito, é inferido. Eles estão sozinhos e sem preocupações com a sobrevivência. Podem, portanto, conviver, mas a cidade grande Ihes impõe barreiras. Reiterase a leitura sobre a condição da modernidade.

O dia da visita desses destinadores não é igual aos outros, por isso, os apartamentos estão completamente transformados para receber os ilustres visitantes, cada um do seu lado. Do lado esquerdo: desenhos na parede, bandeirinhas, balões e tapete vermelho; do lado direto: bolo,

${ }^{147} \mathrm{O}$ auxiliar (destinador), sujeito que doaria a competência, é fi adiante, essa cobertura discursiva será analisada mais detida 
sorvete, balas, cabana, skate... Cada um recebe à sua maneira. Até o corredor parece respirar novos ares, há mais cores quentes em seus traços, predominantemente amarelo e vermelho, a expressão da subjetividade no emprego dessas técnicas como gerador do sentido aponta para a construção de personagens, cada personagem é caracterizado pelo conteúdo, mas também pela expressão ${ }^{148}$. A felicidade pode ser notada na decoração da casa, nas expressões faciais (no caso do homem, ele faz a barba, a mulher se fantasia). As cores se alteram e a quantidade de objetos no cenário também.

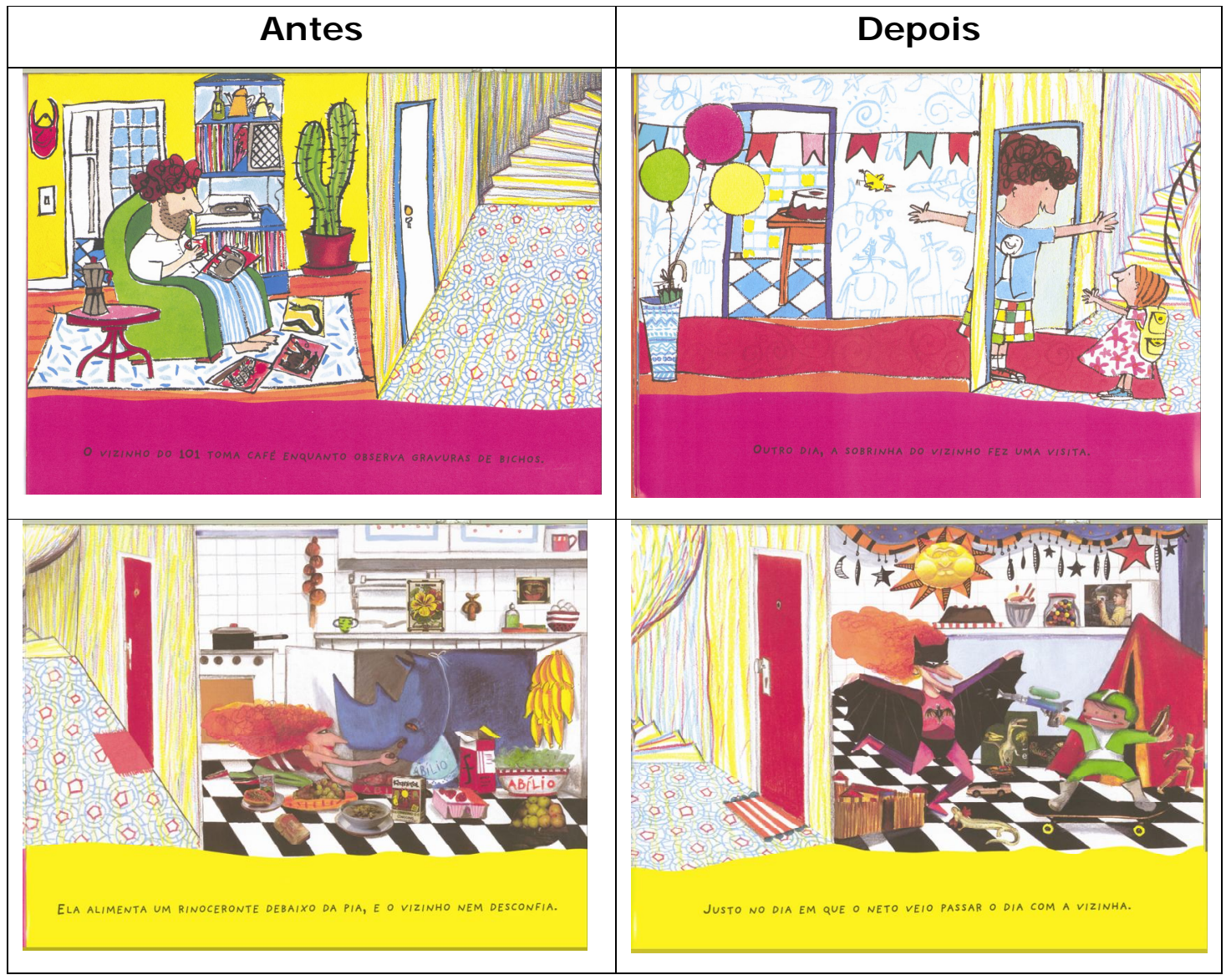

${ }^{148}$ Este dado é importante na avaliação de uma obra dada às criancac e tamhém ım elemento enriquecedor no trabalho com a obra em sa demonstrado no capítulo final deste estudo. 


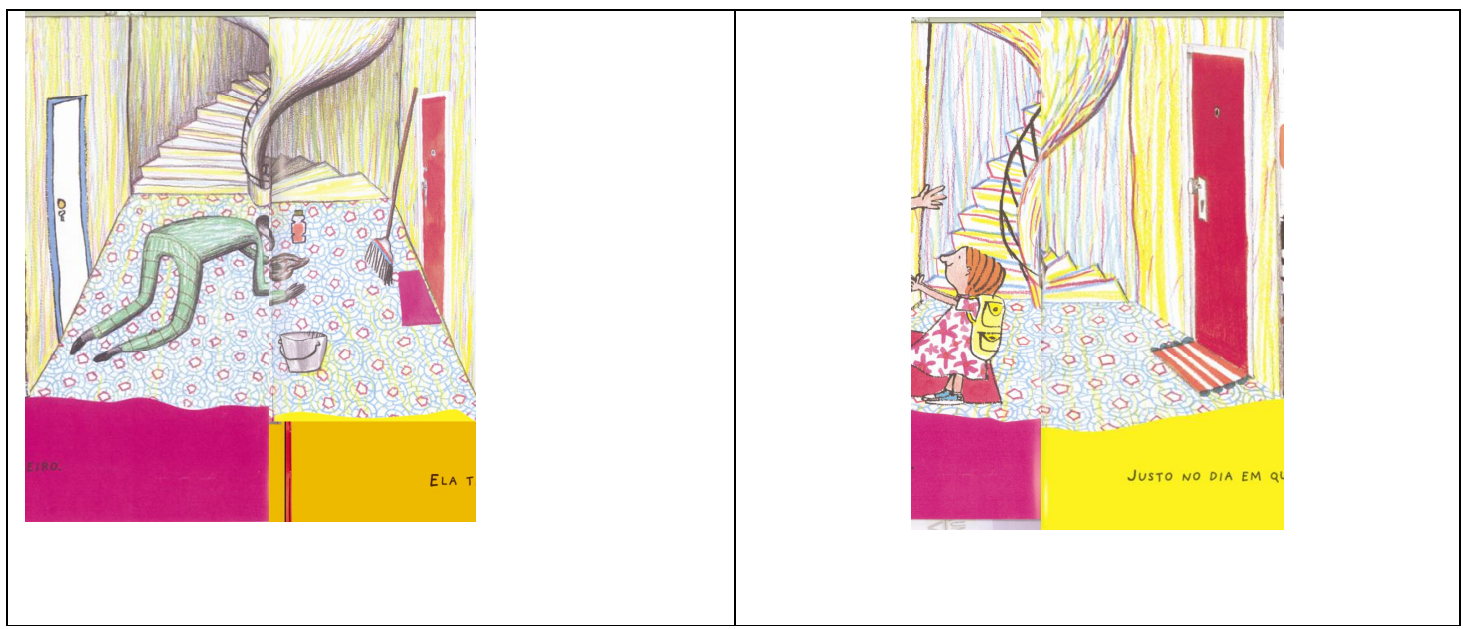

Figura 3.97 - Antes e depois da visita

Mesmo com a visita, a rotina das personagens não se altera por completo: "Quatro e quarenta: o vizinho saiu com o canário. A sobrinha espreita. Vinte para as cinco: a vizinha levou o relógio ao conserto. O neto observa".

A novidade está na presença dos visitantes, antes, os apartamentos ficavam vazios durantes o passeio dos vizinhos, agora, há gente e gente curiosa, inquieta, desassossegada para estabelecer novas relações. Essas personagens, sobretudo, são destituídas de convenções, de imposições sociais e, por isso, ousam, são livres para brincar e fabular:

Acontece que cada um inventa a sua cidade, como refúgio e evasão. Não cabe mais viver apenas na realidade, ou buscar principalmente a emancipação. Diante dos contrapontos trabalho e alienação, diversidade e desigualdade, comunidade e sociedade, modernidade e pós-modernidade, utopia e nostalgia, nada melhor do que a fabulação (IANNI, 2000, p. 137).

Eis a confusão na fabulação da gente pequena. As legendas ocupam o espaço do cenário, os objetos da vizinha entram no apartamento do vizinho. Os objetos desse entram no apartamento daquela. A brincadeira está rolando. Este é o ponto alto da narrativa. 
Nada possui lugar fixo, compartimentado; tudo se cria, vive, a imagem parece "quase" sangrada na página, não fosse os espaços das legendas:

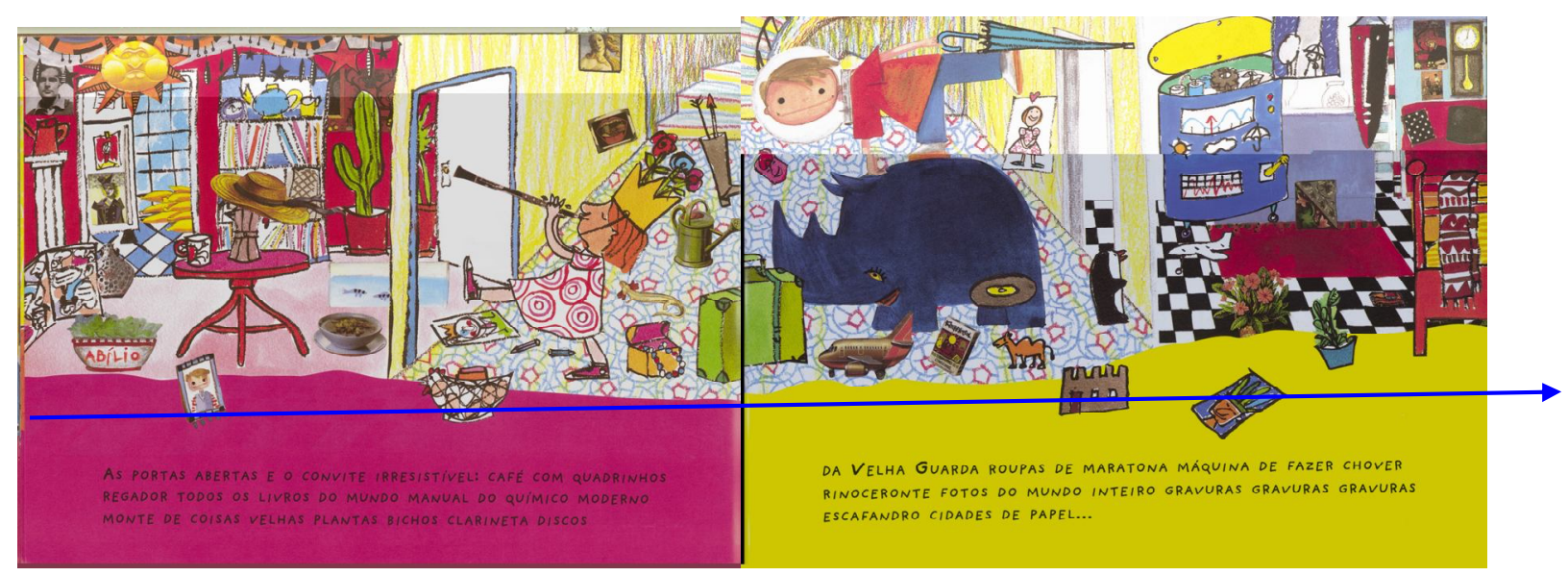

Figura 3.98 - Espaços invadidos

Assim como os objetos já não têm dono, o texto também foi completamente embaralhado. Nada mais tem lugar. Palavra e imagem se unem para mostrar a junção dos mundos: "As portas abertas e o convite irresistível: café com quadrinhos regador todos os livros do mundo manual do químico moderno monte de coisas velhas bichos clarineta discos da velha guarda roupas de maratona máquina de fazer chover rinoceronte fotos do mundo inteiro gravuras gravuras gravuras escafrando cidade de papel...."

$\mathrm{O}$ que faltou, sintaticamente, às sentenças? Pergunta-se. A vírgula, justamente, o sinal gráfico apresentado no título com a função de separar as palavras. A vírgula é um sinal que pertence ao sistema verbal, no entanto, como sinal gráfico, também pode ser tomado pela visualidade (palavra é imagem). É um muro que separa os mundos, assim como a disposição do cenário: Vizinho, Vizinha.

Contudo, onde estavam as personagens desassossegadas, as personagens título desta narrativa? Elas não participaram da festa. Enquanto as crianças não tiveram medo do contato e extrapolaram a brincadeira revelando os segredos que nem mesmo se deram con 
adultos estavam ausentes, ou seja, a intenção de doar competência a fim de que os sujeitos realizassem a performance não aconteceu. $O$ silêncio invade o ambiente e dança. O programa narrativo é frustrado, a sanção é negativa, e os protagonistas permanecem inalterados.

Ao longo da narrativa verbal, a vírgula não aparece, os períodos são sempre simples. Quando o programa narrativo não se cumpre, pela primeira vez, o sinal gráfico parece no texto: "Depois que a sobrinha e o neto foram embora, o silêncio ensaiou meia dúzia de passos de dança".

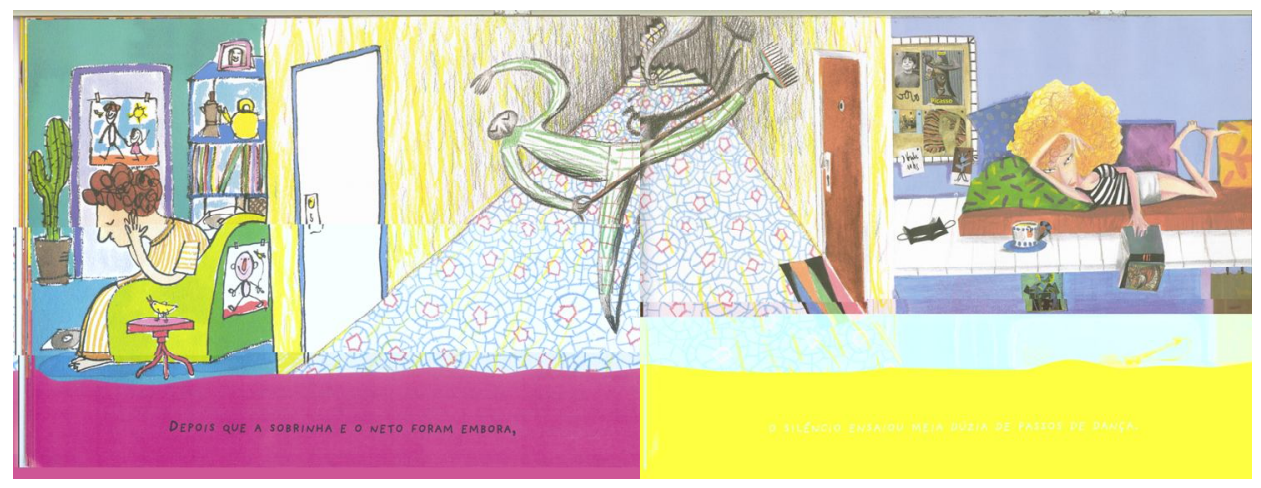

Figura 3.99 - A volta à rotina

Os apartamentos ficam espremidos em seus cantos quase escorregando da página dupla ${ }^{149}$, diminui o número de cores utilizadas, as expressões faciais e corporais revelam o desanimo e a frustração, as legendas voltam ao lugar, e o faxineiro, ao seu corredor, agora, até sua sombra cabe no hall, que se alarga e é preenchido apenas pelas cores predominantes amarelo e preto. As quentes que nutriam as paredes no momento da expectativa da visita desaparecem e cedem lugar ao preto/sombreado. Por todos esses elementos, é enfatizado o estado de ânimo das personagens, o vizinho triste de um lado, a vizinha triste de outro.

${ }^{149}$ Vale destacar que toda história acontece em página dupla. [ outro, a Vizinha, narrativas "quase paralelas": sintaxe espacia 
$\mathrm{Na}$ cena seguinte: "Enquanto toma café, o vizinho imagina as coisas que existem do outro lado".

"Qualquer dia desses ele convida a vizinha para entrar" (nova expectativa).

No tapete dela, está escrito "Bem-vindo" - um sinal de que ele será bem recebido reforçado pela legenda: "se ele convidar, ela aceita". (Porém, fica para outra história). As cores e a postura novamente se alteram e criam o efeito de tensão - movimento corporal de ação, mas outra força os detém.

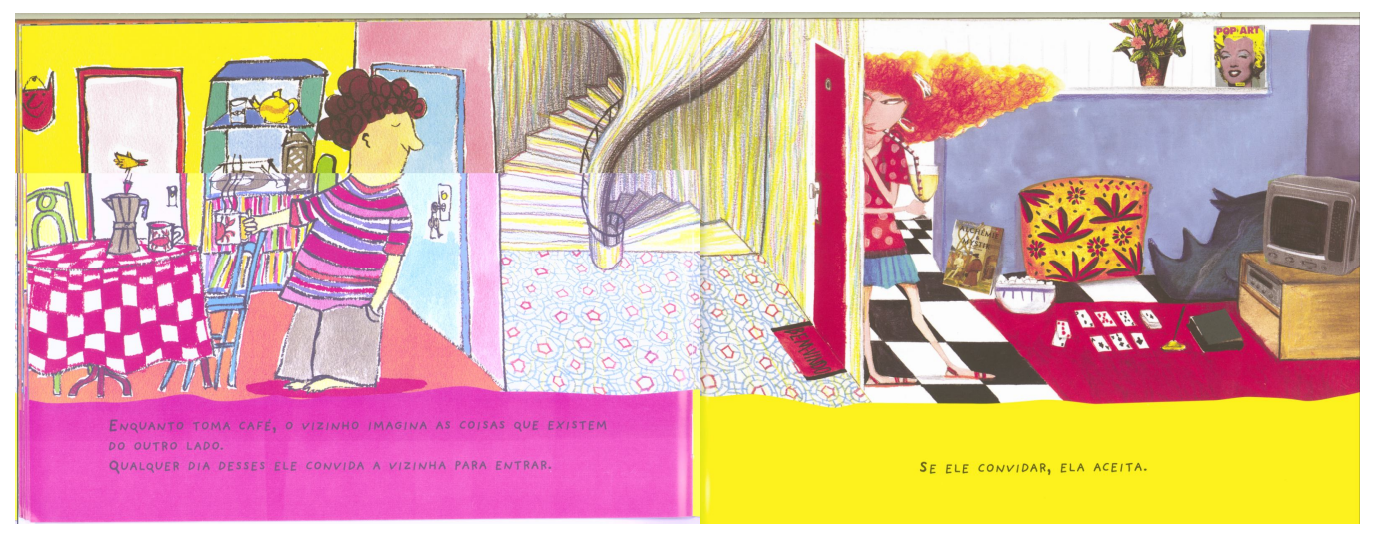

Figura 3.100 - Nova expectativa

A imposição da vida moderna ganhou este round. A narrativa não tem final feliz, apesar da tentativa das crianças e de uma esperança no fim do túnel. Vale pontuar que o auxílio, que poderia ter sido dado pelos destinadores, não é reconhecido como tal e, por isso, não há doação de competência. Os protagonistas não têm capacidade para reconhecer nos entes queridos a figura do auxiliar narrativo. Então, resta a expectativa de um dia poder concretizar o sonho da junção e a aquisição do objeto valor.

Assim, depois de dissecar a narrativa, cabe à análise propor a discussão sobre algumas estratégias utilizadas por este objeto-livro que são fundamentais à investigação que se propõe, pois a instância discursiva impõe a reflexão sobre os seguintes aspectos: a instauração de debreagem enunciva nos dois sistemas semióticos; 
destinadores como crianças; a tematização da ausência de relações na sociedade contemporânea, pois vale refletir acerca da relevância do assunto para o público-leitor criança e suas possíveis relações intertextuais; e, finalmente, o interdiscurso entre a maneira de narrar dos quadrinhos com legendas, balões, quadros que obedecem à subjetividade e a maneira de narrar da obra em questão. Além disso, a imposição da leitura linear versus simultânea definindo o gênero livro-álbum.

\subsubsection{O Encontro no Discurso}

Foi afirmado, no item anterior, que o discurso do narrador se estabelecia em: ele, lá, e, de fato, as legendas (sistema verbal) apresentam exatamente esta aspectualização, como é possível comprovar pelos exemplos a seguir: "Quem passa pela rua do Desassossego, número 38, nem percebe, mas.....; o vizinho coleciona discos da velha guarda; ela ainda vai aprender a tocar clarineta; ele inventou uma máquina de fazer chover; qualquer dia desses ele convida a vizinha para entrar". A aspectualização de pessoa - na terceira pessoa do singular - e de espaço - na rua do desassossego - instaura o narrador objetivo, que não se envolve com o enunciado, gerando efeito de sentido semelhante, como já apontado, ao discurso científico. As imagens também apresentam o discurso objetivado, em que o ele, o lá (instâncias de pessoa e espaço) validam o discurso, isso pode ser assistido a partir das cenas-exemplo que surgem: 


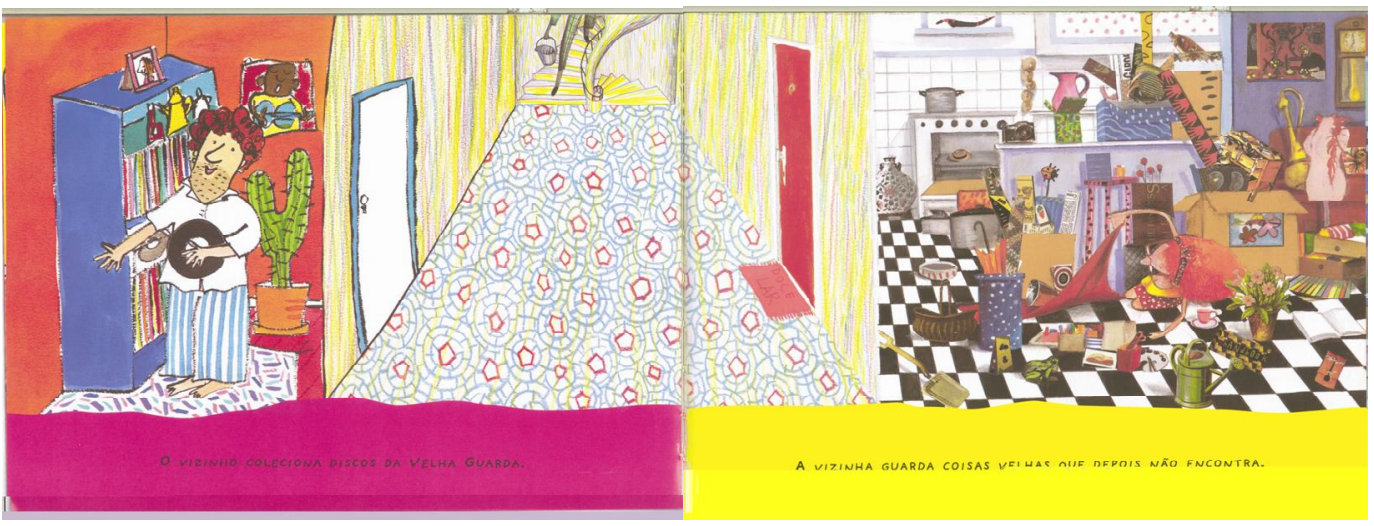

Figura 3.101 - Debreagem enunciva

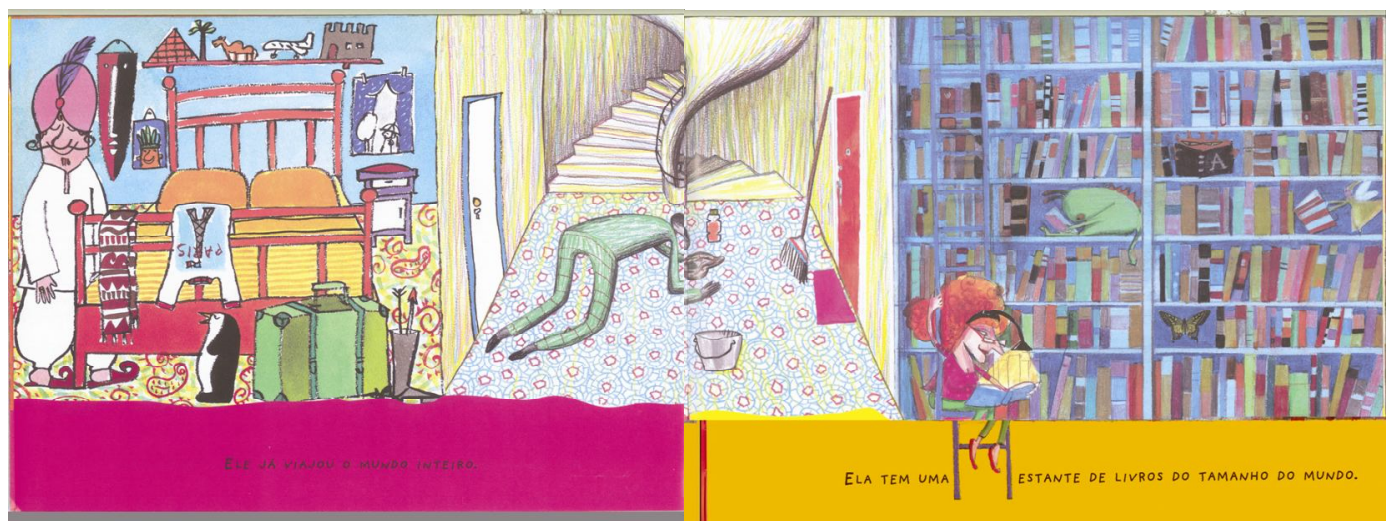

Figura 3.102 - I nstauração do ele, lá, algures

Nas cenas, os atores não dirigem olhos para o enunciatário, cada um, reiterando o tema da individualidade, vive em seu mundo, cada um tem seu estilo, seus objetos, seus segredos. Cabe ao narrador da narrativa visual apresentar, da forma mais objetiva possível, a cena da realidade.

Contudo, a manipulação de estilos diferentes, seja pelo traço, pela técnica ou pela materialidade empregada, confere subjetividade aos personagens. Ressalta-se que não há subjetividade ao narrar os fatos, ao expor a situação, mas na construção da personagem, o que é revelado pela materialidade - técnica, traço, disposição dos objetos, cores:

O artista nunca começa desde o início precisamente como artista, isto é, desde o início não pode operar apenas com elementos estéticos. Duas leis guiam a nhra do arto. a loi da personagem e a lei do autor, uma lei 
da forma. Onde o artista opera desde o início com grandezas estéticas tem-se uma obra feita, vazia, que não supera nada e, no fundo, não cria nada de axiologicamente ponderável. A personagem não pode ser criada do início ao fim a partir de elementos puramente estéticos, não se pode "fazer" a personagem, esta não seria viva, não iríamos "sentir" a sua significação estética. O autor não pode inventar uma personagem desprovida de qualquer independência em relação ao ato criador do autor, ato esse que a afirma e enforma (BAKHTIN, 2003, p. 183).

Bakhtin questiona a criação da personagem como algo fundamental à arte literária, pois, por meio dessa representação, o autor veiculará ideologia, e seu material é o próprio estilo, pois o modo de fazer, também, revela a ideologia:

[...] os únicos caminhos possíveis para a renovação da palavra ideológica - a palavra com seu tema intacto, a palavra penetrada por uma apreciação social segura e categórica, a palavra que realmente significa e é responsável por aquilo que diz (BAKHTIN, 1981, p. 196).

O trabalho em equipe, proposto por esta obra, revela um mundo construído e totalmente individualizado, tão individualizado que a enunciação procurou separá-lo completamente. Por meio da expressão, os estilos utilizados para a composição das personagens personalizam as imagens: na própria caracterização da personagem, mas também por seu ambiente (apartamento), objetos, maneira de se comportar, gostos, e isso se prolonga até a porta do apartamento, que metonimicamente personifica o morador. Normalmente, nos edifícios, as portas são individualizadas apenas com objetos, aqui material e cores presentificam a individualidade do morador. As características expressivas das personagens são: 


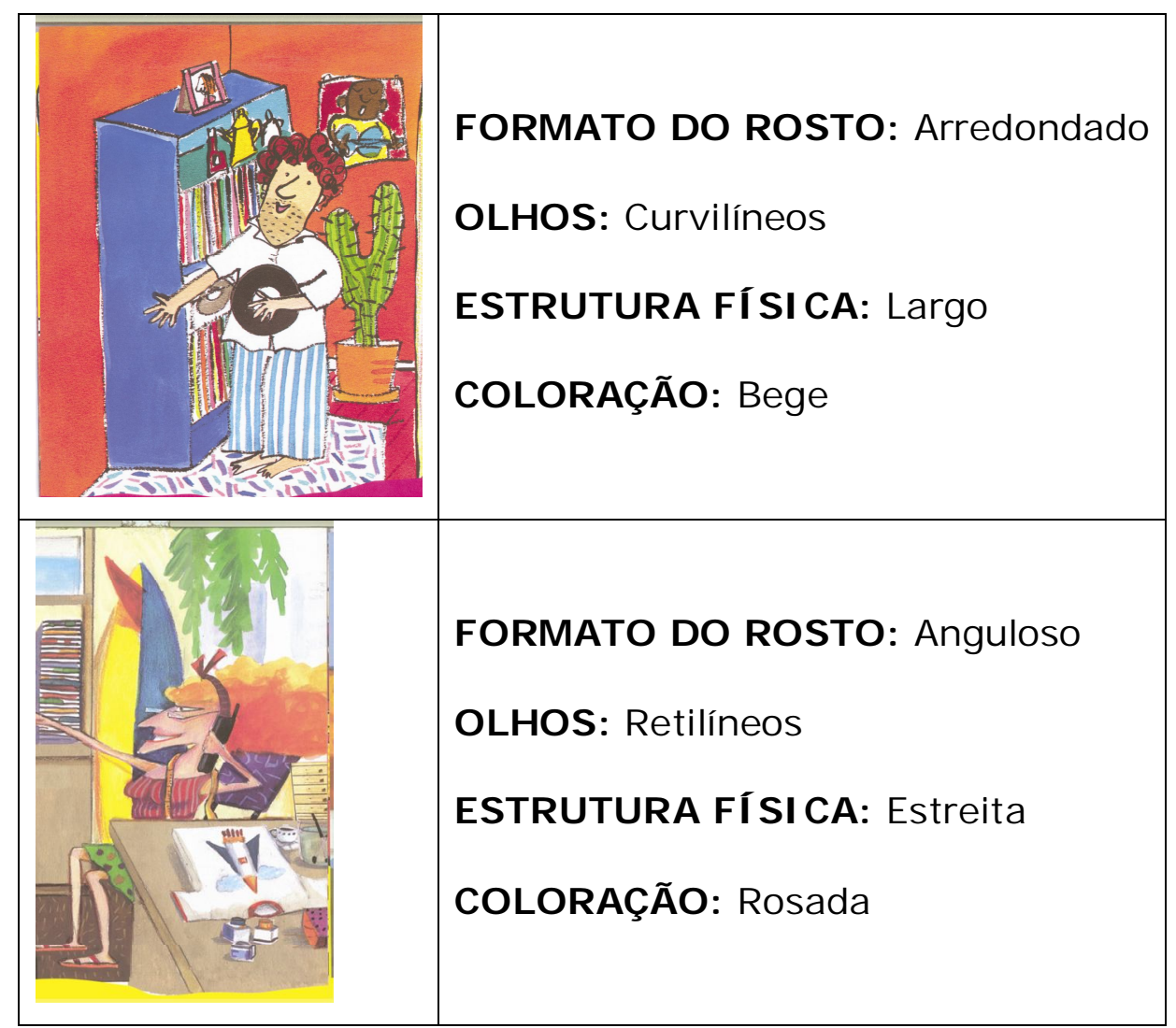

Figura 3.103 - Construção das personagens

Mais uma vez, é válida a comparação deste projeto gráfico com a representação dramática (teatro, televisão, cinema), em que diferentes atores constroem personagens que vão interagir na narrativa, o cenógrafo organiza os objetos em cena, o figurinista elabora a vestimenta das personagens, assim, em equipe, elaboram o espetáculo.

A obra Vizinho, Vizinha traz à cena literalmente uma situação cotidiana e o faz de maneira a gerar o efeito de sentido de que não houve interferência daquele que narrou, buscou-se o distanciamento, para que o leitor-enunciatário pudesse formar a sua opinião sobre a condição da modernidade e também pudesse sentir $\mathrm{O}$ isolamento. $\mathrm{O}$ teórico russo, mais uma vez, corrobora a idéia apresentada: 
[...] interpretar significa compenetrar-se do objeto, olhar para ele com os próprios olhos dele, renunciar à essencialidade da nossa própria distância em relação a ele; todas as forças que condensam de fora a vida se afiguram secundárias e fortuitas, desenvolve-se uma profunda descrença em qualquer distância (2003, p. 187-188).

Além da integração entre os sistemas visual e verbal na instauração de um narrador do discurso distanciado, outro aspecto a ser destacado diz respeito à figurativização da criança como possibilidade de aproximação dos dois universos - Vizinho, Vizinha. As crianças estão "enformadas" conforme o estilo do adulto a que se refere:

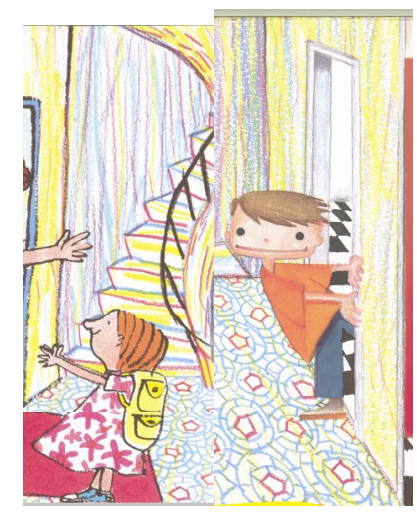

Figura 3.104 - As crianças

Entretanto, isso não desautoriza a aproximação. Independentemente de convenções, as crianças se misturam, mesclam-se. Elas bagunçam a vida destes adultos, mas eles não se dão conta. O mundo da criança também está separado do mundo adulto, apesar da tentativa. A partir dessa observação, configura-se a oposição adulto (segredo) versus criança (verdade), relacionando as oposições narrativas e discursivas.

Talvez seja necessária uma ressalva, visto que os protagonistas, no final da narrativa, revelam o desejo de aproximação, quer dizer que, de alguma maneira, as crianças alteraram a situação inicial. Cabe perguntar quem será mais forte: a imposição da modernidade nas arandes cidades ou a criança com sua ação libertária e libertadora. Ati 
oposição mais abstrata liberdade versus opressão, sendo aquela eufórica e essa disfórica.

Outro ponto a ser destacado é que os textos geram o efeito de sentido de objetividade, sem, contudo, refletir um traço totalmente realista, ou melhor, pela tematização, a realidade é revelada. $\mathrm{Na}$ expressão, ela é abandonada, então, o encontro do universo da criança com a obra dar-se-á pelo plano da expressão. Será pela via sensível que a criança entrará na narrativa. O conteúdo é "pesado", em princípio, mas necessário, visto que a criança não pode ser alijada (nem alienada) da realidade em que está inserida.

As imagens guardam a sua subjetividade, não importando o traço realista em proporções, cores ou disposição das figuras na cena. As técnicas empregadas reforçam esta afirmação:

En general, se puede afirmar que los álbumes realistas ayudan al reconocimiento del mundo interior y del de los demás $y$, en cierto modo, favorecen la imitación, los álbumes con representaciones planas buscan la profundidad acentuando la interiorización de las ideas $y$, por tanto, se dirigen a la inteligencia del lector. [...]

Los álbumes planos se centran más en el "qué" sucedió y renuncian a querer engañarnos con sensaciones de profundidad para intentar que lleguemos a una comprensión mayor de las cosas, a que captemos la densidad de lo real (GONZALEZ e ZAPARÍ N, 2005, p. 12).

Pela subjetividade, o discurso conduz o enunciatário à realidade objetiva, própria ao discurso científico. Tendo em vista a leitura proposta, afirma-se a pertinência da temática abordada pela obra Vizinho, Vizinha. Para reforçar a atualidade do tema, lembra-se de outras duas obras literárias voltadas ao público-criança, a saber: Avós (original em português galego), de Chemas Heras (texto) e Rosa Osuna (ilustrações), e outra já citada por este trabalho de tese - El hilo de la vida (que foi traduzido no Brasil): 


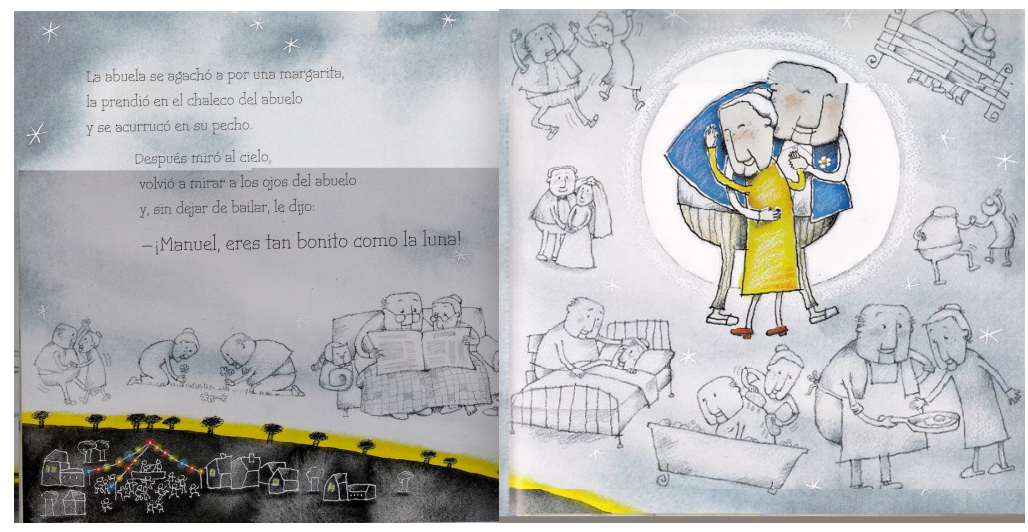

Figura 3.105 - Los abuelos
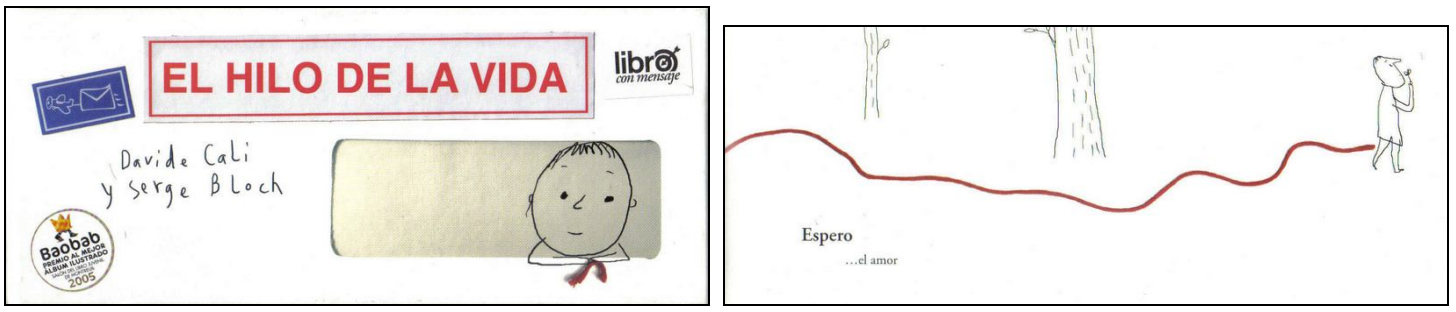

Figura 3.106 - Capa de El hilo de la vida Figura 3.107 - Miolo de El hilo de la vida

Essas são obras literárias em que a temática das relações humanas entre pessoas que já têm uma história vem à cena. Tais produções reforçam a idéia da convivência, da vida, da morte, das lembranças. O idoso é figurativizado em suas relações, e essa abordagem é muito importante em uma sociedade que, a todo momento, busca a juventude, ou seja, são livro-álbuns que valorizam o amor ou, como no caso da obra analisada, a falta de liberdade para se aventurar nesta etapa da vida, a opressão social diante das relações humanas. São obras que, com humor, aliam poesia e ensinamento, condição determinante na valorização de um livro para crianças.

O humor também fica a cargo da expressão que se aproxima das histórias em quadrinhos, a relação interdiscursiva, neste caso, dá-se pela relação com este outro gênero do discurso, que, pela simultaneidade na apreensão da imagem, pode usar e abusar de outras histórias ou sugestão de histórias. 
Na obra Chiquita Bacana e outras pequetitas, Ângela Lago propõe uma narrativa principal e inúmeras micronarrativas no visual. Em Vizinho, Vizinha, há a principal, que foi explorada ao longo da análise que se apresenta, uma coadjuvante, encenada pelo faxineiro, e micronarrativas expostas pelas gravuras nas paredes. Estas micronarrativas exigem relações intertextuais e existem somente graças à técnica da colagem:

En la historia del arte, después de los primeros collages se produjo un paso más cuando, a base de una superposición de imágenes que no fuera una mera yuxtaposición, se intentaba desdoblar el espacio y aprovechar la profundidad de campo mental (GONZALEZ e ZAPARíN, 2005, p. 13).

Enquanto o objeto-livro impõe a leitura linear, a saber, da esquerda para a direita, de cima para baixo; os quadrinhos e os livroálbuns são condicionados pela leitura do virar das páginas, mas, assim que a página dupla se abre, ele as lê como se estivesse diante de um quadro, de um objeto planar que cria e recria condições de tridimensionalidade na obra dada, de modo a alcançar, pela estratégia da justaposição de estilos, a poeticidade. Abaixo, destacam-se algumas referências a outros artistas; no apartamento da vizinha, há inúmeras menções a obras de arte ${ }^{150}$ :

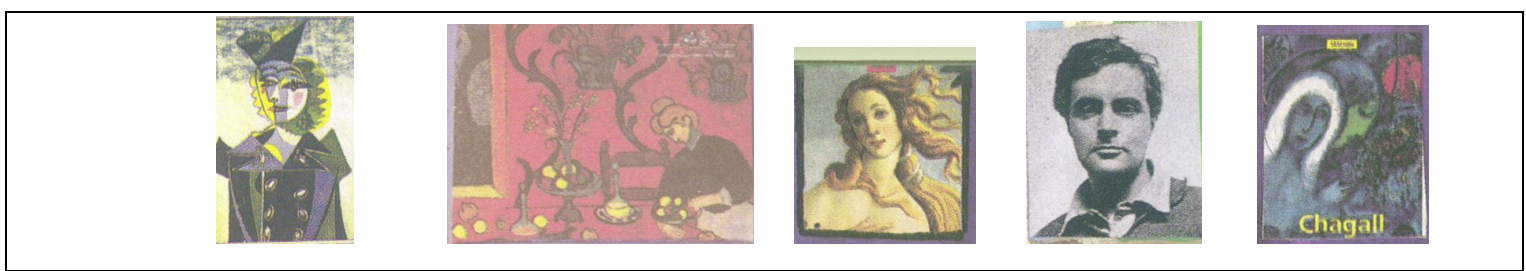

Figura 3.108 - Citações pontuais

${ }^{150}$ Esta é uma forma de citação que será explorada no próximo c 
Assim sendo, vislumbra-se na obra analisada um projeto gráfico criativo, que apresenta um processo de criação com reflexos no enunciado e, portanto, impregnado de sentido, afirmando o caráter de poeticidade deste livro-álbum:

Nuestra época, signada por el predominio de la imagen visual, impone al niño contemporáneo una cultura en la que lo icónico resulta decisivo. El inventario de imágenes almacenadas por cada uno de nosotros en ese archivador insondable sería único en cada caso específico. Constituiría el resultado de experiencias y oportunidades diferentes, sería la suma de nuestra existencia, estaría marcado por el contexto sociocultural en que nos desenvolvimos, por la incidencia de los medios de difusión masiva (la televisión, los periódicos, las revistas, la publicidad), por las horas que estuvimos frente a las pantallas de los cines y la naturaleza de los fotogramas que vimos proyectados en ellas, por los museos y galerías que recorrimos y, naturalmente, por los libros que leímos o simplemente hojeamos, por las imágenes gráficas que nos salieron al encuentro desde sus páginas (ANDRICAì N, 2001, p. 1). 


\section{DESENROLANDO FIOS}

As fronteiras de um livro nunca são bem definidas: por trás do título, das primeiras linhas e do último ponto final, por trás de sua configuração interna e de sua forma autônoma, ele

fica preso num sistema de referências a outros livros, outros textos, outras frases: é um nó dentro de uma rede.

(Michel Foucault)

Percebe-se a necessidade de desenrolar um pouco mais os fios do tecido que se apresentam. Para isso, colocam-se em foco duas questões que perseguiram as análises com maior insistência.

A primeira delas diz respeito às citações, sejam de textos verbais, visuais ou de discursos. Sobre esse conceito, pretende-se formalizar como elas são feitas na literatura infantil contemporânea e ainda marcar que este é um recurso amplamente utilizado e deve ser tratado pela mediação.

A segunda questão se refere à estratégia de se voltar para o próprio código, trazendo a enunciação para o enunciado ou, em outros termos, vindo a metaficção à cena.

A partir dessa estratégia, tem-se o intuito de ampliar o que foi apresentado ao longo das análises e propor mecanismos de identificação, a fim de que a mediação possa trabalhar nessa abordagem, por meio da literatura infantil contemporânea.

\subsection{A I NTERTEXTUALI DADE COMO UMA ESTRATÉGI A LiteráRI A: UM FIO ESSENCI AL}

Aflige o ser humano, nos tempos contemporâneos, o mundo interligado, as redes conectadas, os padrões globalizados. Tudo acontece ao mesmo tempo agora, como cantam e contam os artistas neste tempo e lugar. O século XXI tem como característica os avanços tecnológicos e, com isso, a quebra de fronteiras e a aproximação de distâncias, graças às conexões on-line. Os textos, de maneira geral, reflet $\epsilon$ 
O diálogo tem espaço garantido nas manifestações textuais, sejam elas verbais ou visuais, ontem e hoje. O contato entre obras se estabelece e é inerente à linguagem, segundo alguns teóricos, como Bakhtin, antes mesmo desta corrida tecnológica. Entretanto, este fenômeno lingüístico é ainda mais evidente hoje, e teorias que corroboram tal idéia vêm promovendo um debate sobre a pós-modernidade do conceito, como observa Hutcheon (1991):

O leitor é obrigado a reconhecer não apenas a inevitável textualidade de nosso conhecimento sobre o passado, mas também o valor e a limitação da forma inevitavelmente discursiva desse conhecimento (p. 167).

Esse diálogo passa a ser importante, então, para aqueles que estudam os textos/discursos, e a literatura infantil é campo fértil à reflexão, visto que ela é utilizada também como forma de preparação do leitor literário.

A abordagem faz-se intratexto e extratexto, esta última relação entendida como o contexto de inserção do discurso, esse recurso torna-se fundamental para o trabalho com a ampliação do repertório do leitor (p. 42).

Pensar sobre o leitor-criança, neste momento, é importante. Como ele estabelece as relações entre obras, como adquire repertório, como identifica a personagem? As histórias clássicas - conto de fadas, contos de animais, fábulas, lendas - são adquiridas ao longo do tempo pelo contador de histórias, pelas referências em livros, na escola, no contato com o colega e, hoje, por meio das novas tecnologias. No cinema, por exemplo, a personagem Gato-de-Botas pode ser admirada no filme Shrek. Esse procedimento ajuda a compor o repertório na infância e também na vida adulta. As referências são, portanto, inevitáveis e essenciais.

Norma Discini, em Intertextualidade e o conto maravilhoso, como detalhado na análise de Fita Verde no cabelo: nova velha estória,propõe uma tipologia para assimilação do texto-base, a saber: apropriação, paródia, assimilação e estilização (2003), ou aindí 
títulos dos capítulos da obra da autora: a desistória, a contra-história, a paráfrase e a estilização (idem). Por essa perspectiva, a pesquisadora analisa obras que são chamadas genericamente de releituras. As obras recebem este nome, porque independentemente da forma de apropriação, seja pela negação ou pelo puro recontar, tomam o texto-base como um todo narrativo. Subvertem ou apropriam-se do começo, do meio e do final da trama narrativa. Toda estrutura e esquema narrativos são trazidos à tona para cumprir um novo propósito, às vezes, com uma nova roupagem discursiva ou com alterações no percurso narrativo. Estas modificações, por vezes, alteram o nível fundamental da obra, transformando a essência do texto, seja modernizando, pensariam alguns, ou contextualizando, uma vez que as histórias viajam quase sempre por terras distantes ${ }^{151}$.

A partir dessa tipologia, é plausível identificar obras que fazem referências intertextuais, aludem a outros textos não com o intuito de recontá-los, como aquelas analisadas por Discini, mas como forma de ampliar o sentido da narrativa ou do discurso, sem, no entanto, estarem atreladas a um texto-base. Melhor, na tipologia, que se desenvolve, o termo texto-base perde lugar, visto que não interessa, necessariamente, o texto do qual surge a nova obra, mas a alusão a ele nela identificada.

Isto posto, ainda, interessa demonstrar como tais contatos são possíveis na literatura infantil, ou seja, quais são os tipos de citação propostas pelo gênero em questão.

Assim, na tipologia que se propõe, a primeira maneira de contato entre textos é aquela sobre a qual se debruçou Discini, ou seja, a releitura. Não é possível passar por este tipo sem destacá-lo, pois são inúmeras obras que se apropriam de um texto-base para (re)contá-lo de maneira a subverter, negar, estilizar uma história em um outro texto. Recebe o nome, neste estudo em desenvolvimento, de releitura, pelas características explicitadas. O exemplo que se apresenta para demonstrar a idéia é Cântico dos cânticos, de Angela Lago, pois já no título há a

\footnotetext{
${ }^{151}$ Norma Discini analisa as seguintes obras: Chapeuzinho Vermelhn de Perraılt. Chapeuzinho Vermelho e o Lobo Torturador, de Alberto Berqu de Chico Buarque; e Fita Verde no cabelo: nova velha estória 
retomada do texto bíblico. Lago reconta por imagens a história do rei Salomão e da camponesa que estão apaixonados.

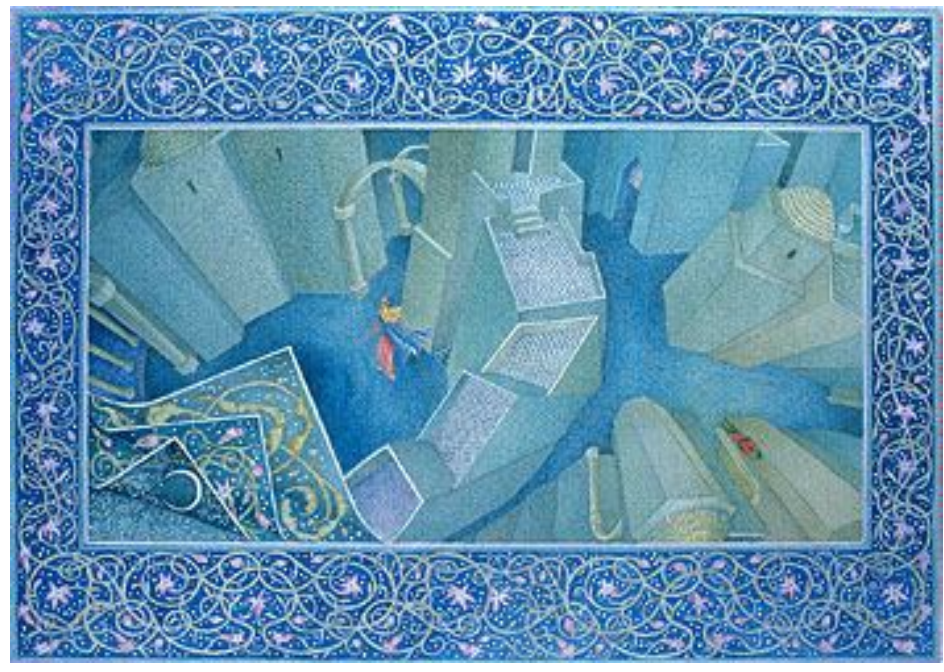

Figura 4.1 - Cântico dos cânticos

Outra forma de contato se dá quando o autor do texto em questão apenas cita, pontualmente, uma outra obra. Não é objetivo recontar o texto-base, mas fazer uma alusão a outra obra, convocando o leitor a estabelecer relações. Neste caso, há o abandono total da idéia de textobase. O que se percebe nesta forma de contato é o acréscimo de sentido na medida em que leva o leitor a acionar seu repertório. Assim, identificase que a função dessa estratégia é ampliar o repertório do leitor. A literatura infantil cumpre seu papel como formadora do leitor literário, como ressaltado por Colomer (2003):

As interrogações artísticas pós-modernas se dirigem a explorar o que acontece quando se confrontam mundos distintos, quando se violam as fronteiras entre realidades e categorias diferentes. O resultado desta busca foi o aumento da autoconsciência na arte em geral e na literatura em particular, uma exploração dos limites e possibilidi tradição que as conforma (2003, p. 10 
A primeira obra-exemplo oferecida à analise é $\mathrm{O}$ menino mais bonito do mundo, de Ziraldo, em que, inicialmente, o recontar do mito bíblico é destacado como proposta. O capítulo retomado é aquele referente ao nascimento do Homem - Adão e Eva. Este caso, no entanto, ilustra não só a releitura, como demonstrado, da mesma forma que a última cena da obra também contempla outra forma de citação, neste caso, mais pontual e como estratégia para ampliar o repertório do leitor, bem como para introduzi-lo no mundo das artes plásticas. Isso porque "Eva", a mulher dos desejos do personagem de Ziraldo, aparece sobre a forma de O nascimento da Vênus, de Botticelli, ou seja, há uma citação do artista italiano. Nesta cena, o repertório do leitor é acionado e a relação se estabelece pontualmente, agregando sentido no nível discursivo quando surge uma figura de outro discurso. Neste exemplo, considera-se a intertextualidade como a recontextualização de uma figura do discurso. A Vênus da obra $O$ nascimento da Vênus é personagem em um novo contexto. Ela é transportada para uma nova narrativa e até, como é possível identificar pelo traço e material empregados, não é a mesma, mas uma, se é que é pertinente, uma paráfrase.

Outro exemplo desta forma de citação, já analisado por este trabalho, é com relação ao cenário narrativo, em Fita Verde no cabelo, em que a arquitetura colonial é colocada como figura discursiva em um novo contexto, a saber, o cenário mineiro de Guimarães Rosa. 


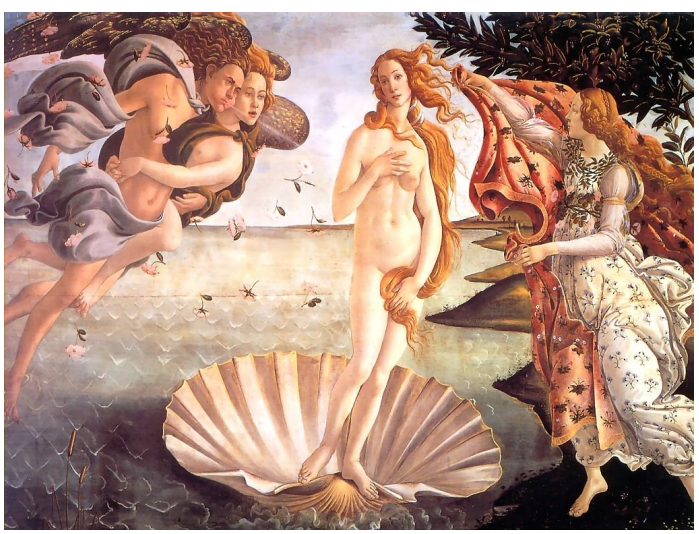

Figura 4.2 - 0 nascimento da Vênus, de Botticelli

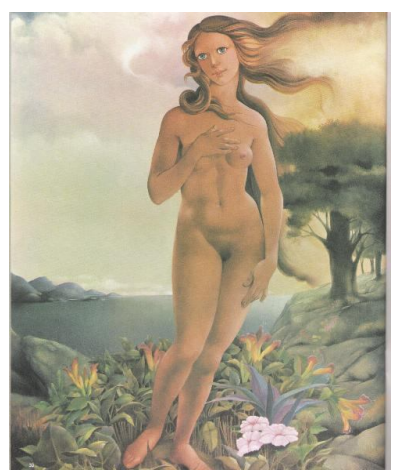

Figura 4.3 - Eva, de Ziraldo

A segunda forma é mais evidente no texto visual. Afirma-se isso, pois seria necessário outro estudo para verificar esta ocorrência também em um texto estritamente verbal, mas, talvez seja possível arriscar que a simultaneidade do sistema visual é que proporcione este tipo de citação a da narrativa coadjuvante. Explica-se que, nesta expressão, pode-se perceber uma narrativa principal e também outras coadjuvantes ${ }^{152}$.

Esta coexistência narrativa pode trabalhar com o recontar um texto-base, mas esta não é a narrativa principal, ou seja, não era intenção a releitura, e sim uma forma de citação não pontual, visto que ela tem um desenvolvimento próximo ao texto-base. Como em Chiquita Bacana e outras pequetitas, que apresenta algumas narrativas coadjuvantes, por exemplo, Chapeuzinho Vermelho, Joãozinho e o pé-de-feijão, A bela adormecida, entre outras.

${ }^{152}$ Como apresentado na análise da obra Vizinho, Vizinha. 


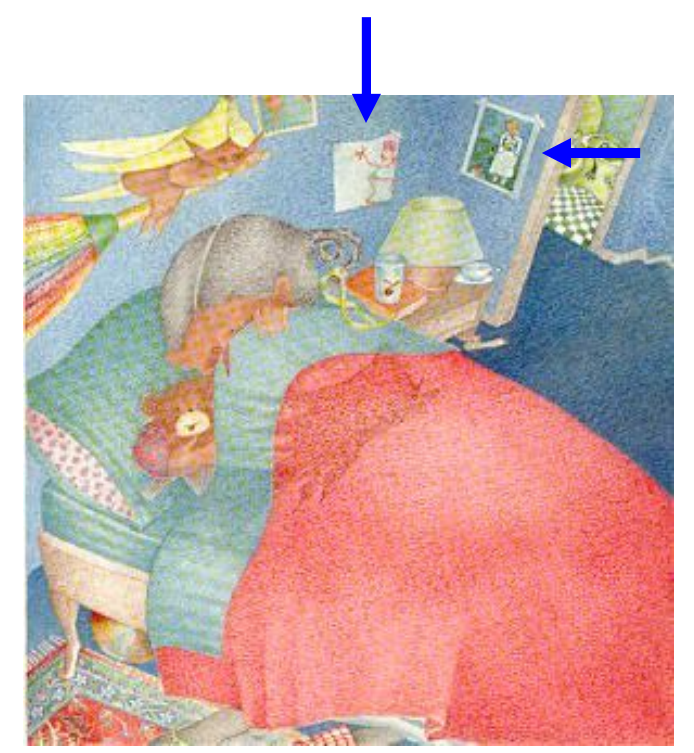

Figura 4.4 - Chiquita Bacana e outras pequetitas - Joãozinho e o pé de feijão - Obra de Picasso

Além da possibilidade de retomar um texto-base e fazer dele uma narrativa coadjuvante, a citação pode remeter a outra história ou outro quadro e além disso, desenvolver um percurso paralelo. A obra exemplo é Vizinho, Vizinha. Nela, o cenário da Vizinha é povoado por referências que não têm lugar fixo, ora estão de um lado, ora de outro; não é possível, neste caso, identificar um percurso desenvolvido pela "personagem citada", mas, assim como em Chiquita Bacana e outras pequetitas, os objetos (quadros, desenhos) personificam-se e observam como a história das personagens principais vai seguir: são, portanto, expectadores e, por isso, podem ser associados a uma "personagem observadora" da cena, mas que não é narrador. Denomina-se esta forma de citar: citação coadjuvante, como demonstrado pelos exemplos: 


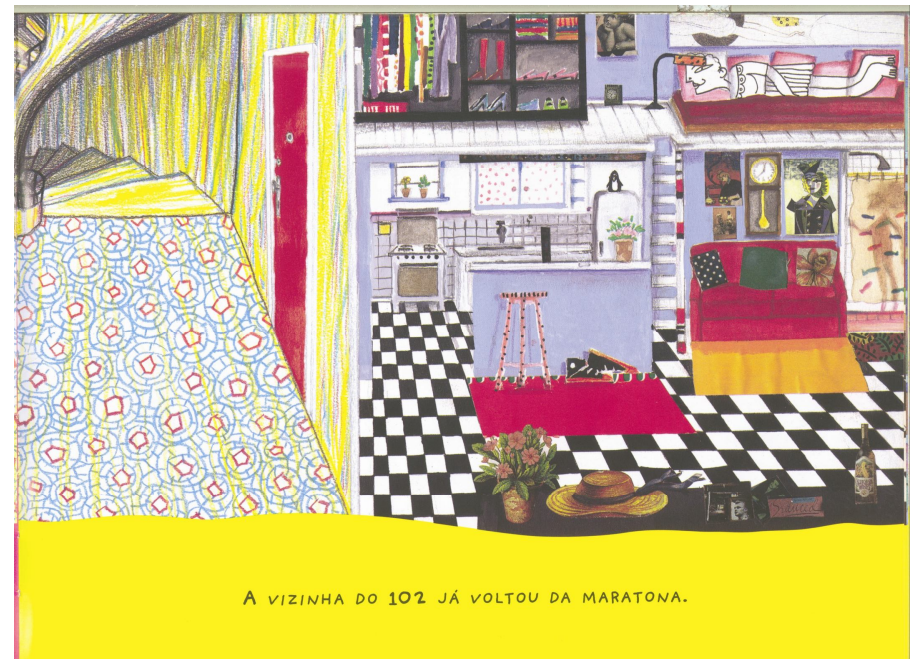

Figura 4.5 - Apartamento da Vizinha povoado de histórias
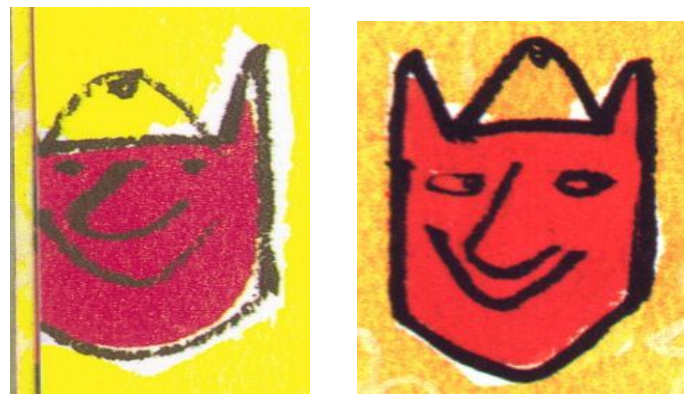

Figura 4.6 - Máscaras observando

Outra forma de citar é aquela em que a referência é deixada ao acaso na cena, como novamente em Vizinho, Vizinha - ou seja, pela técnica da colagem, mas não só, o artista organiza o espaço de maneira a fazer referências. Esta maneira de citar recebe o nome de citação pontual. Observa-se:
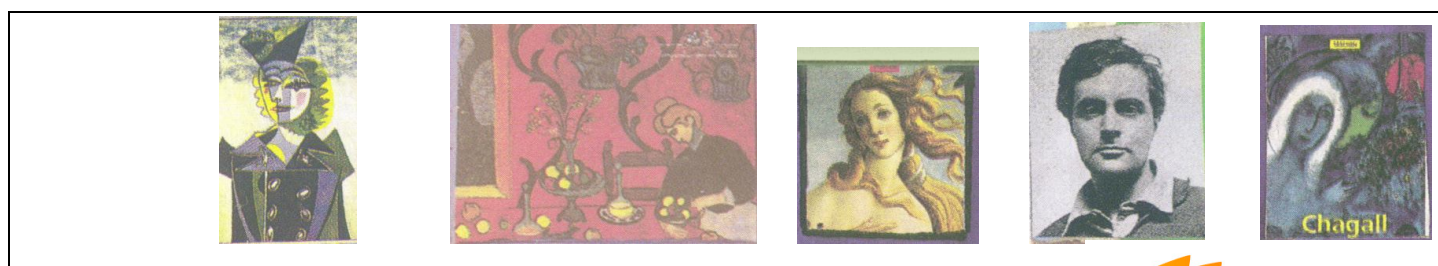

Figura 4.7 - Referências intertextua 
Finalmente, no quinto caso, há o contato não entre obras propriamente, mas entre maneiras de fazer. Uma determinada obra não recupera o texto-base, senão o discurso, o estilo de fazer de um dado artista. Seria a retomada de estilo. Uma maneira de fazer ao estilo de Picasso ou Van Gogh. Ricardo Azevedo propõe esta forma de contato na obra Menino que sentia mil coisas, que trata do desenvolvimento de um menino e cujas ilustrações recuperam maneiras de fazer de diferentes autores. Picasso é o artista retomado pela ilustração apresentada como exemplo. Verificam-se os recortes, a cor azul e as sobreposições características do artista espanhol. Além disso, a contracapa da obra apresenta a intenção de retomar o estilo dos referidos artistas - citação mostrada e marcada:
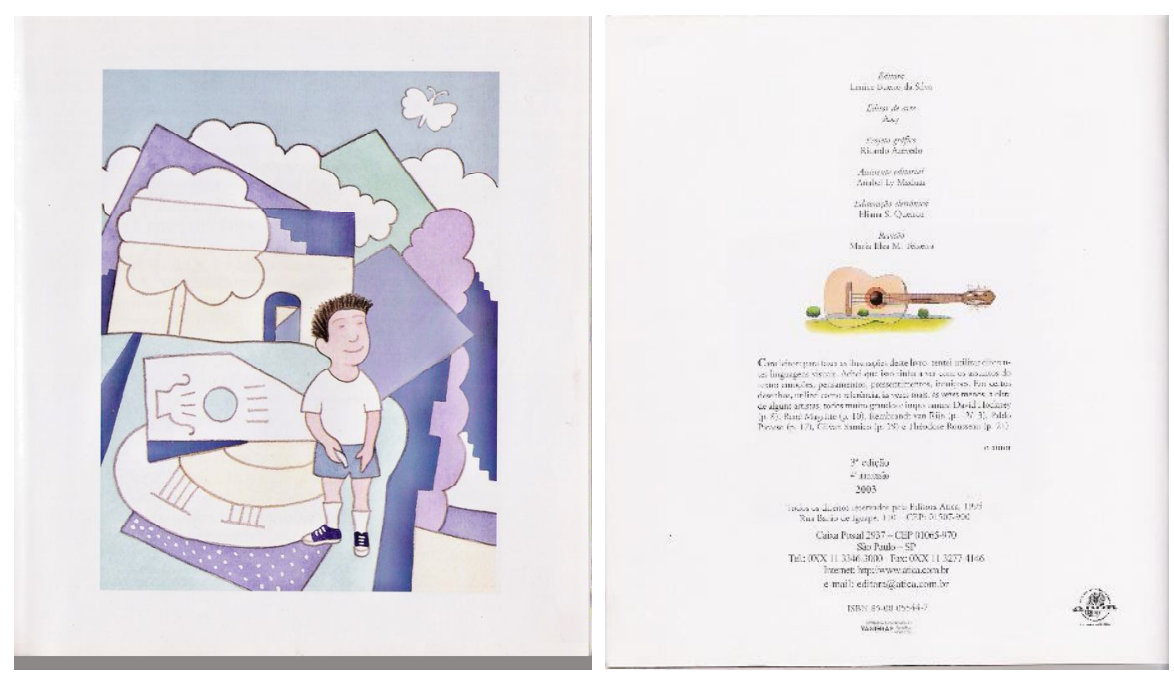

Figura 4.8 - Ricardo Azevedo

A obra Griso, o unicórnio, já citada anteriormente, que utiliza o mesmo recurso do exemplo apresentado, não pode ser esquecida. Também outras analisadas por este estudo se valem da estratégia descrita: Jardins, Desertos, Fita Verde no cabelo, no contexto brasileiro, e 
Bacelar, nas obras O dinossauro, A sereiazinha e Sebastião, em referência a Chagall e Trnka, no cenário português.

E, ainda, em Timor Lorosae: A ilha do sol nascente, em que André Letria (artista português), em citação mostrada, mas não marcada, faz a relação com Ar Penck, demonstra-se:

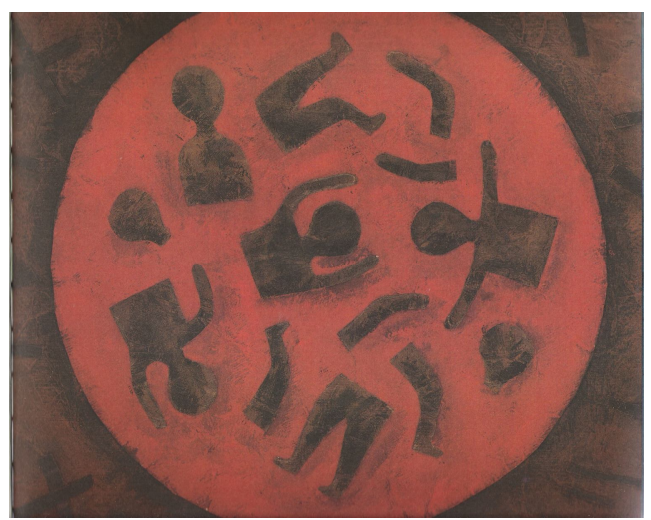

Figura 4.9 - André Letria

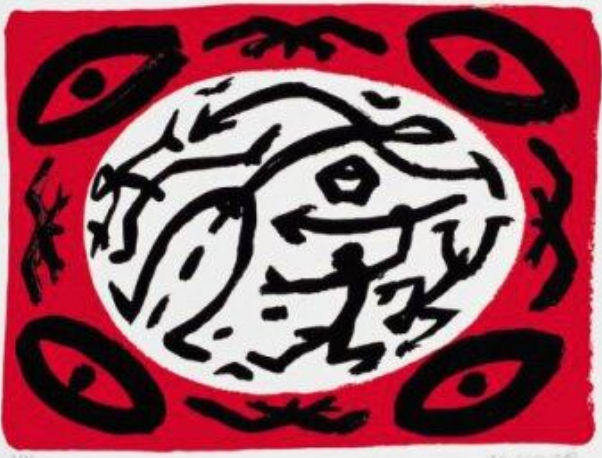

Figura 4.10 - Ar Penck

Revela-se, pois, que este recurso discursivo é uma forma de a criança acionar o seu repertório, recuperando de maneira estética uma qualidade que deve ser abordada nas relações didático-pedagógicas. A literatura infantil se firma mais uma vez, e de maneira comprovada, entre aqueles objetos artísticos que têm a intertextualidade como um recurso estético, afirmando-se o valor literário.

Assim, sistematiza-se a tipologia proposta para a relação entre textos/discursos:

1) Releitura (recontar ao longo de todo o livro uma história já conhecida - paráfrase, paródia, estilização, apropriação).

2) Citação recontextualizada (quando um elemento narrativo é tirado de seu contexto para viver uma nova história). 
3) Citação coadjuvante (recontar uma história conhecida como narrativa coadjuvante).

4) Citação pontual (cita-se uma "figura discursiva conhecida", elemento narrativo, como técnica de colagem).

5) Interdiscurso (conta uma nova história a partir da maneira de fazer do outro).

A intertextualidade ou interdiscursividade são também mecanismos que levam à metaficcionalidade, como discutido por Colomer (2003). A autora catalã denomina intertextualidade produtiva, e esse procedimento une um fio ao outro.

\section{O livro-álbum metaficcional - outro fio fundamental}

A literatura infantil nasce do desejo de levar o leitor ao universo desconhecido da aventura seja por mar, por terra, pelos ares. Seria uma expressão longe da perspectiva da reflexão sobre o próprio código, esse tema tão complexo e reflexivo deveria (ou estaria) à margem de tal expressão, se for considerado o público. Afirma-se, então, que esse não seria um tema caro à literatura infantil em princípio. Antes, interessariam mecanismos de linguagem, em que a imaginação fosse acionada, e os efeitos catárticos, no sentido aristotélico, fossem atingidos. Pretender-seia, nesta expressão, o enunciado enunciado e não e enunciação enunciada. Interessaria, sobretudo, apagar as marcas da enunciação para fazer emergir o mundo da ficção. Contudo, nos tempos modernos, ou até pós-modernos, impõe-se outro tipo de reflexão e relação com o mundo. Esta maneira de enfrentar o mundo já foi antecipada pelos precursores.

Alice no país das maravilhas, de Lewis Carroll, representando a literatura universal em meados do século XIX, e Monteiro Lobato, a brasileira do início do século XX, alteraram o estatuto da literatura infantil, como é amplamente identificado pelos críticos: 
Desta perspectiva podem interpretar-se muitas obras clássicas de literatura infantil, como Alice no país das maravilhas, repletos de exigências de leituras impossíveis de serem realizadas pelo destinatário infantil, mas que ao contrário, deram condições para a evolução da literatura para crianças ao abrir caminho para novos modelos narrativos. Assim, por exemplo, a partir de Carroll, o novo modelo foi imitado através de formas muitos mais compreensíveis para crianças, embora menos valorizadas pela crítica, e passou a constituir um modelo usual para leitores crianças (COLOMER, 2003, p. 165).

As obras de tais autores precursores alteraram este "efeito de ficcionalidade" para voltarem-se ao próprio código. Carroll e Lobato criaram personagens similares - Alice e Emília questionavam, cada uma ao seu modo, o ficcional, o contar ilusório e, "brechtianamente", tomaram, de alguma maneira, as rédeas da história. Temperamentais, impunham suas necessidades. O próprio Lobato reflete sobre a independência de Emília:

Muito interessante o que se passou com meus livros para crianças. Os personagens foram nascendo ao sabor do acaso e sem intenções. Emilia começou uma feia boneca de pano, dessas que nas quitandas do interior custam 200 reis. Mas rapidamente evoluiu, e evoluiu cabritamente - cabritinho novo - aos pinotes. Teoria biológica das mutações. E foi adquirindo uma tal independência que, não sei em que livro, quando the perguntaram: "Mas que você é, afinal de contas, Emília?" ela responde de queixinho empinado: "Sou a independência ou morte!" E é. Tão independente que nem eu, seu pai, consigo dominá-la. Quando escrevo um desses livros, ela me entra nos dois dedos que batem as teclas e diz o que quer, não o que eu quero que ela seja. Fez de mim um "aparelho", como se diz em linguagem espírita (Lobato, 1946, p. 341).

Com isso, pensa-se que a metaficção pode ser encontrada na literatura infantil contemporânea, pois questionar o código, figurativizar os problemas de linguagem é um mote freqüente nas obras de literatura infantil, negando o senso comum apresentado no início da reflexão. Assim, é possível afirmar que essa expressão apresenta os mesmos recursos, lida com os mesmos mecanismos discursivos oferecidos pela 
literatura voltada ao público adulto e, por isso, constitui-se como um agente formador do leitor literário.

A partir da definição de Fokkema, conclui-se sobre a pósmodernidade da literatura infantil contemporânea:

No pós-modernismo, a ênfase posta no código é ainda mais clara do que nos textos modernistas. Em certos casos, a questão de saber como deve ser contada uma história é mais importante que a própria história (FOKKEMA, [s.d], p. 72).

Tomando um caso exemplar, A bela borboleta, de Ziraldo, revela a metaficção, bem como a intertextualidade ${ }^{153}$ produtiva como recurso metaficcional, pois na medida em que se cita e o leitor é conduzido a acionar seu repertório o código já está enunciado.

Em A bela borboleta, de Ziraldo e Zélio, esse recurso de linguagem se concretiza. A citação é recontextualizada, pois, como já apresentado, a personagem foi transferida: Gato-de-Botas, Bela Adormecida, Alice e outras personagens são retirados de seus contextos originais e transportadas para um novo (a narrativa d' A bela borboleta).

Neste livro, as personagens das narrativas do passado "sacodem a poeira" e vêm lutar por uma causa comum: a leitura. De certa maneira, os personagens do baú vêm à tona como forma de reafirmar a necessidade de não deixar morrer as histórias do passado ou do presente.

Além da intertextualidade, o projeto gráfico impõe a reflexão acerca do próprio objeto-livro, visto que a borboleta está aprisionada no meio do livro, ela está presa pelos grampos e as personagens das histórias tradicionais têm a missão de salvá-la, para isso acontecer, o leitor deve movimentar as páginas do objeto-livro, ou seja, ler.

${ }^{153}$ Termo utilizado por COLOMER (2003). 


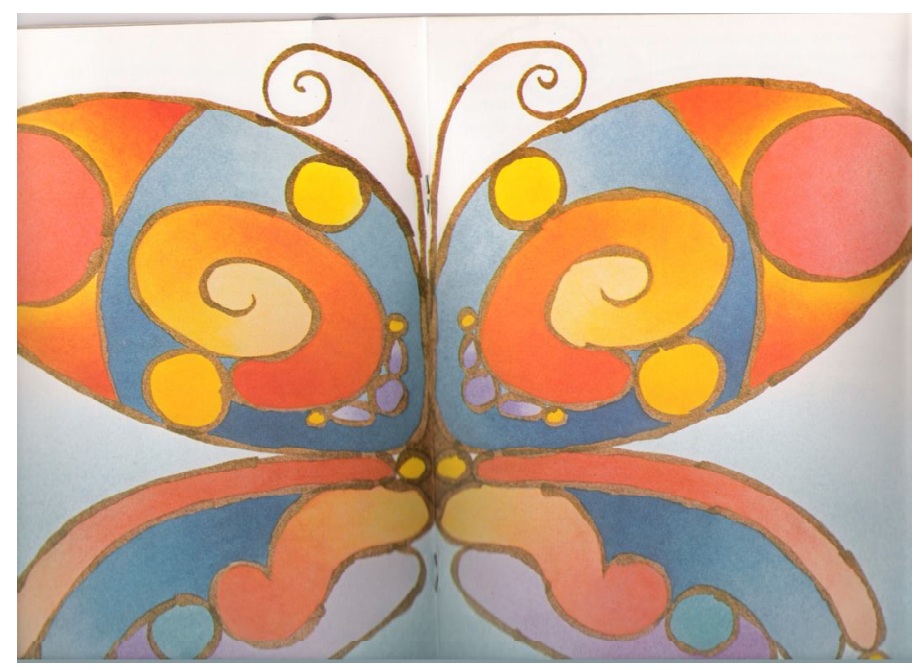

Figura 4.11 - A bela borboleta - grampos

As referências aos recursos gráficos são, na obra, o momento de volta ao código. Pára a ficção e entra a realidade. Estamos em um livro, constata-se! Este recurso pode também ser observado nas obras analisadas ao longo do estudo, por exemplo: Jardins, Desertos (intertextualidade produtiva), Fita Verde no cabelo (figuras acabadas - em processo e ambigüidade - metaficção) e nas portuguesas, em especial, Sebastião, em que, pela técnica da colagem, volta-se ao próprio código. Ainda, os exemplos que seguem:

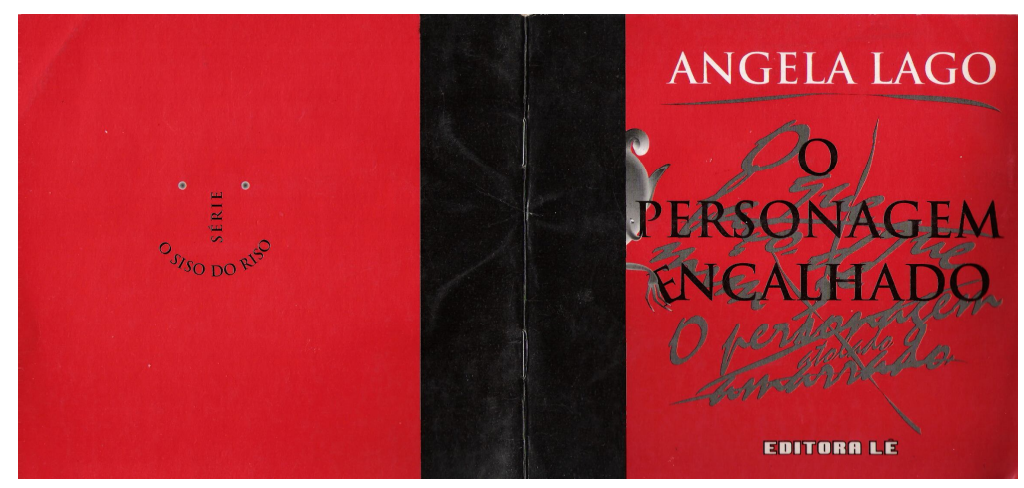




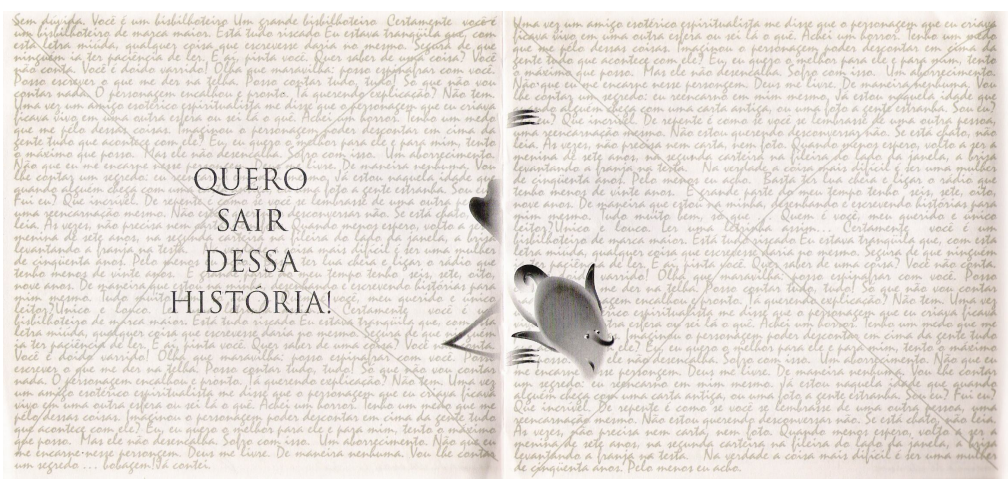

Figura 4.12 - O personagem encalhado
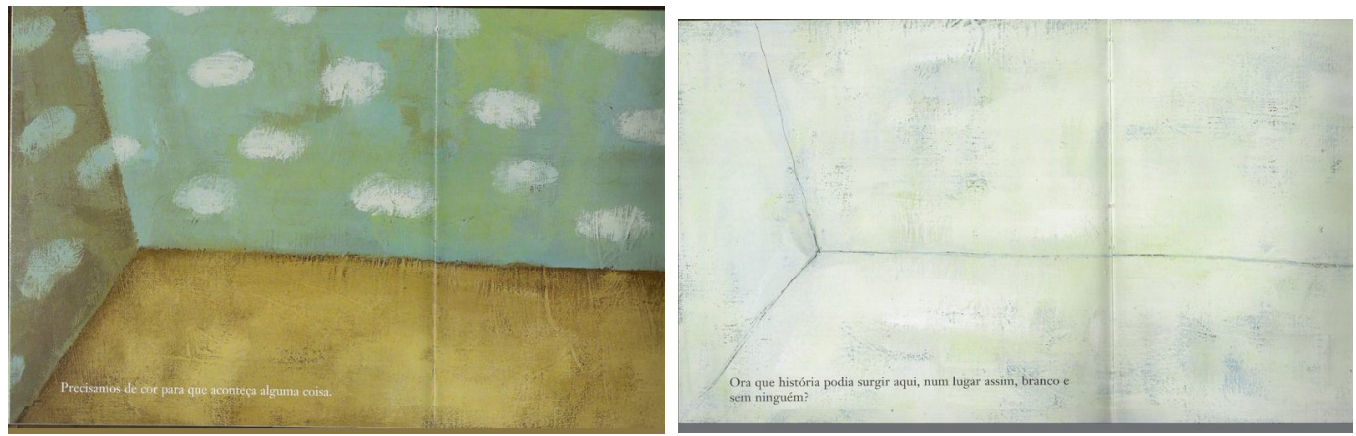

Figura 4.13 - André Letria - História de um Segredo

Como ocorre com grande parte da arte pós-modernista, o olho é estimulado a completar a forma por si mesmo; tal contra-expectativa nos instiga para sermos espectadores ativos, e não passivos (HUTCHEON, 1991, p. 54).

O leitor, nas obras citadas, não é passivo. Ele deve responder a quatro tarefas fundamentais: a primeira, envolver-se na trama narrativa; a segunda, reconhecer as citações; a terceira, refletir sobre o próprio código; e a quarta, preencher os espaços vazios. O leitor que cumpre seu papel é um sujeito ativo na leitura e, assim, o pretendido pela narrativa do pós-modernismo. Como aponta Silva-Díaz:

Es frecuente también que estos experimentos literarios transgredan las barreras entre lo que está dentro de la historia (el argumento) y lo que está fiıra lla citıarión comunicativa, el soporte), producien 
lector. Pues, por lo general, estamos acostumbrados a leer narraciones convencionales, el personaje, el narratario o la página permanecen en su debido lugar. [...]

Es así como en algunas obras pueden advertirse las características que se han señalado como propias de las obras postmoderna: rechazo al realismo, revelación de los mecanismos que construyen la ficción, conciencia lingüística, juego, intertextualidad productiva y una voluntad de producir la perplejidad en el lector o de hacerle participar en la construcción de la obra. Estas carcteristicas postmodernas se acumulan en las obras metaficcionales hasta el punto en que los términos postmodernismo y metaficción se utilizan como equivalentes (2005, p. 9).

Por meio da sensibilização do sujeito-leitor, sem "cair" em um "moralismo", em um "didatismo", a obra contemporânea alerta o leitor e o faz consciente a respeito das estratégias de interação.

A linha mais comum dos estudos de literatura infantil e juvenil é a de tentar aproximar-se das formas de operar na prática. Aprender a localizar a ideologia implícita nas obras de ficção é importante para, por exemplo, os setores educativos, que têm que ensinar às crianças e aos adolescentes a ler sem ficar a mercê daquilo que lêem (COLOMER, 2003, p. 119).

Evidenciar a metaficcionalidade das obras é um procedimento presente na literatura infantil contemporânea que, por isso, deve ser explorado pelos mediadores. 


\section{CONCLUSÃO}

\section{A SI TUAÇÃO DO PROJ ETO GRÁFI CO DOS LI VROS I NFANTI S CONTEMPORÂNEOS EM PORTUGAL E NO BRASI L: ATANDO AS LI NHAS E DESENHOS}

Depois de apresentar os autores Manuela Bacelar e Roger Mello, de realizar análises de suas obras com o objetivo de expor os seus projetos gráficos, bem como de discutir sobre a insistência intertextual e metaficcional na literatura infantil contemporânea, para finalizar a apresentação da investigação realizada, é necessário colocar foco na discussão comparativa e assim evidenciar a situação do projeto gráfico do livro infantil em Portugal e no Brasil.

Para isso, há que considerar critérios que dizem respeito ao conteúdo e à expressão. Assim sendo, propõe-se um trajeto que destacará os seguintes itens: a capa e o material, as técnicas plásticas empregadas, o papel organizador do projeto gráfico, as abordagens temáticas e as estratégias para a formação do leitor literário.

Segue, portanto, a apresentação dos critérios de aproximação entre os projetos gráficos.

\section{A capa e o material}

A primeira observação envolve aquele elemento que é mais aparente no projeto gráfico, a capa. Mais precisamente a qualidade do material que envolve o objeto-livro, assim como o efeito de sentido gerado pela estratégia adotada. A preocupação é com a "embalagem" da obra. Essa é considerada um convite à leitura, visto que a capa é o primeiro agente de mediação entre leitor e leitura. 
A partir da análise das capas, é fundamental pensar sobre os mecanismos de comunicação, que aproximam o leitor da leitura, cumprindo, com isso, o papel designado.

Para a semiótica discursiva, as estratégias de manipulação do Destinador obedecem aos seguintes procedimentos, conforme esclarece Barros (1999, p.33):

a) por sedução - imagem positiva do destinatário (quer-fazer);

b) por intimidação - valores negativos (dever-fazer);

c) por provocação - imagem negativa do destinatário (dever-fazer);

d) por tentação - valores positivos (quer-fazer).

Tendo em vista as diversas capas dos livros infantis, pode-se afirmar que, predominantemente, salvo algum caso em que se lança mão da ironia ${ }^{154}$, apenas duas estratégias de manipulação são utilizadas, a saber: por sedução e por tentação. A partir dessa perspectiva teórica, analisa-se, particularmente, o caso das capas dos livros infantis que atuam de maneira geral, a partir das seguintes relações (capa - miolo):

1. relação metonímica (por tentação): aquela em que a personagem ou o enredo são pontuados, mas não totalmente revelados. Neste caso, a imagem é destacada do miolo, a capa tem uma imagem especial, que especifica algum elemento narrativo (personagem, tempo, espaço, narrador, enredo);

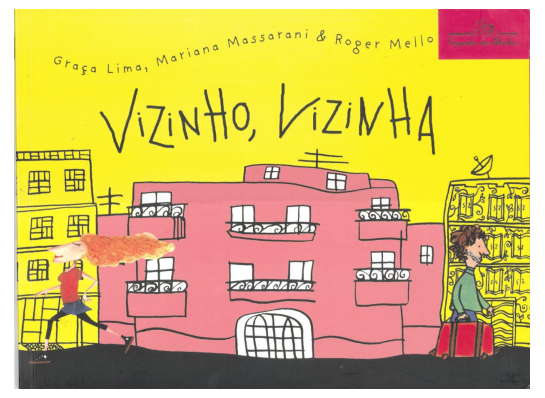

Figura 5.1 - Relação metonímica

\footnotetext{
${ }^{154}$ A obra adulta Bartleby, o escrivão - Uma história de procedimento de provocação quando diz na embalagem: comprar" (MELLVILLE, 2005).
} 
2. relação anafórica (por tentação): aquela em que uma imagem do miolo aparece na capa, antecipando um fato ou situação narrativa. Difere da anterior, pois a imagem da capa é a mesma que aparece no miolo;

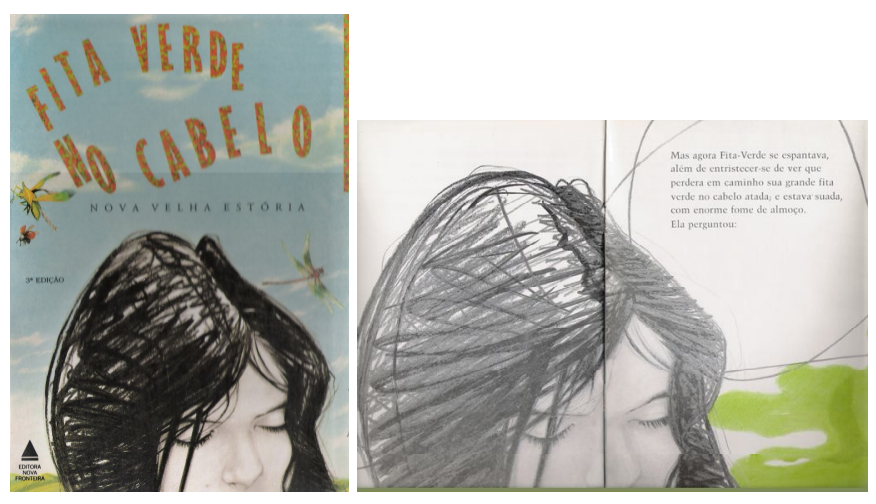

Figura 5.2 - Relação anafórica

3. relação determinante de gênero (por sedução): aquela em que a capa apresenta o gênero ao qual a obra remete. Essa modalidade valoriza a habilidade do leitor em acionar o seu repertório;

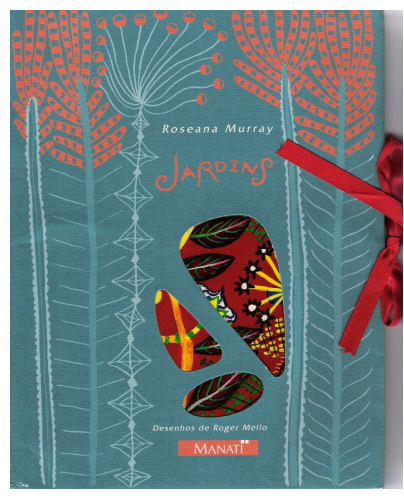

Figura 5.3 - Relação determinante de gênero 
4. relação enigmática (por sedução/por provocação): aquela em que a capa propõe um enigma que será desvendado ao longo da leitura. Essa pode ser considerada provocativa, no entanto, a desvalorização do destinatário é modalizada;
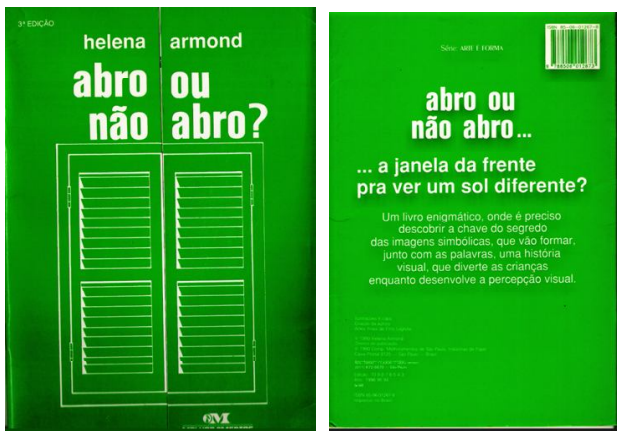

Figura 5.4 - Relação enigmática

5. relação formal (por sedução/por tentação): aquela na qual a capa apresenta apenas o título da obra e, por vezes, o autor ou autores, sem haver imagem, conforme capa dura de A sereiazinha.

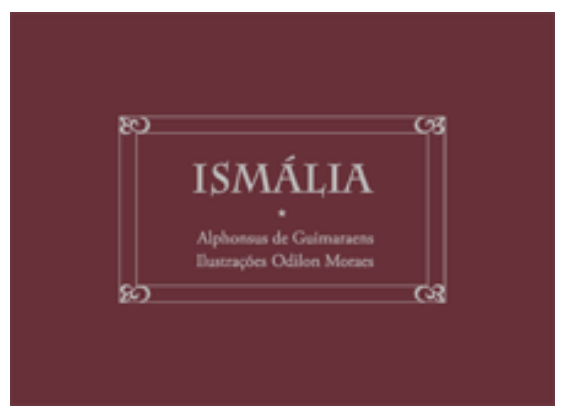

Figura 5.5 - Relação formal 
Estas funções são utilizadas pelos dois países em questão e também por capas de livros em geral ${ }^{155}$. O ponto de divergência entre elas está no material empregado e como esse material gera sentido.

A capa é um componente expressivo no projeto gráfico, pois é ela quem convida, quem seduz o leitor para a leitura e, portanto, essa estratégia pode levar à identidade daquele projeto gráfico.

Por exemplo, enquanto em Portugal a capa é dura, no Brasil, é mole. Ainda, neste contexto brasileiro, faz-se restrição ao número de cores utilizadas, e o papel, por vezes, é de gramagem mais baixa. Não se pode, contudo, afirmar que o livro infantil brasileiro seja, por oposição ao português, mais acessível ao leitor de baixa renda, já que a opção pela capa mole reduziria o custo e por isso seria mais acessível; pelo contrário, neste contexto, há implicações sociais - de escolarização e de políticas públicas - determinantes da distância entre criança e livro. Entretanto, não é pertinente dizer que o livro infantil brasileiro tenha qualidade inferior do ponto de vista plástico. O que há são caminhos e opções distintos, e isso resulta de contextos com histórias e valores diferentes e, quem sabe, com influências artísticas e culturais distintas.

Essa discussão é importante, visto que é raro, se não inexistente, o intercâmbio das publicações dos livros infantis entre esses dois países que têm a língua portuguesa em comum. Como pondera Natércia Rocha:

A circulação de livros entre Portugal e o Brasil nunca foi fácil nem satisfatória, mas sempre tem permanecido como um sonho que, uma vez por outra, se aproxima de uma realidade desejada. O fantasma dos acordos ortográficos e das variantes vocabulares é uma constante nas tentativas já efectuadas $^{156}$ (2001, p. 167).

\footnotetext{
${ }^{155}$ Conforme apresentado por: TREVISAN, C. A construção da identidade das editoras pelas $1^{\text {as }}$. capas: Record e Cosac Naify. São Paulo, 2008. Dissertação (Mestrado em Comunicação e Semiótica). Pontifícia Universidade Católica de ৎãn Paııln

${ }^{156} \mathrm{~A}$ obra de Natércia Rocha, Breve História da Literatura para cri edição actualizada até ao ano 2000 - é anterior ao acordo ortog 
Mesmo quando existe o diálogo entre as publicações desses países, é válido observar que a obra, no outro país, obedecerá aos padrões impostos por aquele contexto mercadológico, social e cultural. Por isso, é freqüente que o material da capa seja alterado, por exemplo: quando a obra A maior flor do mundo, de José Saramago, ilustrada por João Caetano, foi publicada no Brasil pela Cia das Letrinhas, ganhou capa mole, sendo que, originalmente, era apresentada em capa dura. Nesta obra, em particular, a opção pela capa mole não alterou o modo de ler e, portanto, a significação dela. Contudo, em outra situação, quando ao editar, na obra Cena de Rua, de Ângela Lago, a editora venezuelana Ekaré optou pela capa dura, isso implicou na perda do mecanismo da dobra do livro que, pelo movimento das páginas, criava dois efeitos: o movimento da personagem principal e o efeito de profundidade no cenário.

Ressalta-se, ainda, a questão da mudança de ilustração; na publicação brasileira da obra de José Saramago e em outras, manteve-se o ilustrador da obra original, mas existem casos em que um ilustrador "local" dialoga com o texto verbal estrangeiro, como no caso de Chapeuzinho Amarelo, de Chico Buarque, que foi publicada em Portugal com a interessante ilustração de André Letria ${ }^{157}$, conforme se apresenta, por exemplo, na capa abaixo:

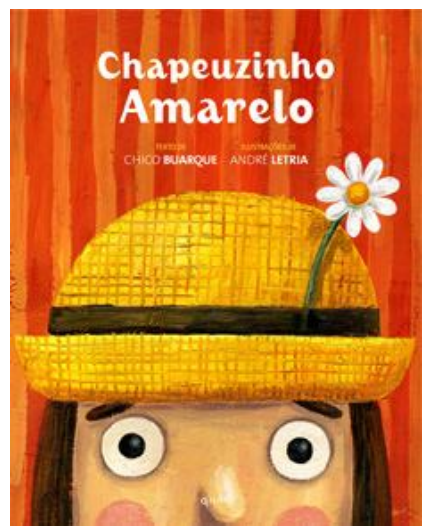

Figura 5.6 - Edição portuguesa

\footnotetext{
${ }^{157}$ Não é proposta deste estudo investigar esta situação, investigativo bastante interessante.
} 
Enfatiza-se, também, que a obra envolvida pela capa dura produz o efeito de formalização, efeito de uma obra valorizada, os chamados "livros para presente" (ou "livro de oferta"), como é comum em solo europeu.

No Brasil, esta prática não é comum; no entanto, a editora Cosacnaif vem apostando nesta estratégia mercadológica. Em suas obras para crianças, tem imprimido um novo conceito quanto à publicação dos livros infantis brasileiros. As obras Lampião \& Lancelote, de Fernando Vilela, No longe dos Gerais, de Nelson Cruz e Conto de escola, de Machado de Assis, com ilustrações de Nelson Cruz, são exemplos disso.

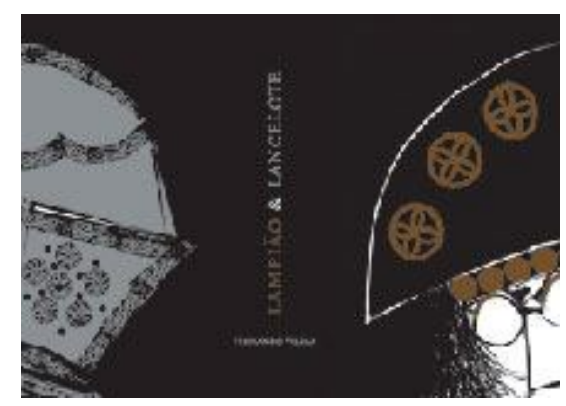

Figura 5.7 - Lancelote \& Lampião

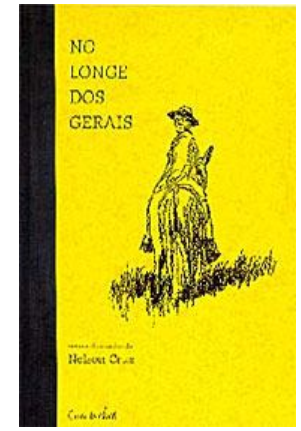

Figura 5.8 - No longe dos Gerais

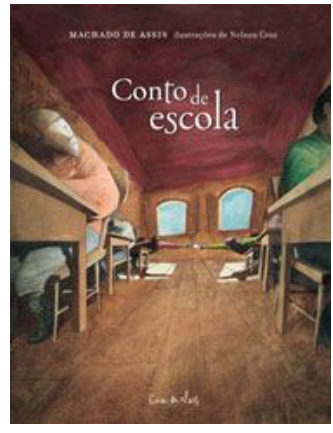

Figura 5.9 - Conto de escola

Além da capa, a qualidade do papel empregado também é importante. Nota-se que os três livros portugueses analisados apresentam-se em papel couché ou de alta gramagem. Não há variação na escolha do papel devido à qualidade de impressão alcançada e essa opção corrobora com a capa dura e a perspectiva de uma apresentação mais "tradicional", em que a diversificação do tipo de papel não é considerada. Por esse padrão editorial, age-se como se houvesse uma certa "imposição", uma norma a ser seguida para a publicação das obras infantis, garantindo a qualidade da impressão.

No cenário brasileiro, a situação é diferente, visto que a opção por papel vergê, papel de gramagem baixa, papel de $c$ 
elemento partícipe do projeto gráfico, constituindo-se como aspecto significante e auxiliar na produção do sentido. As obras Jardins e Desertos $^{158}$, de Roger Mello e De Morte! e Charadas Macabras, de Ângela Lago são exemplos desta contribuição do papel como elemento expressivo do projeto gráfico:
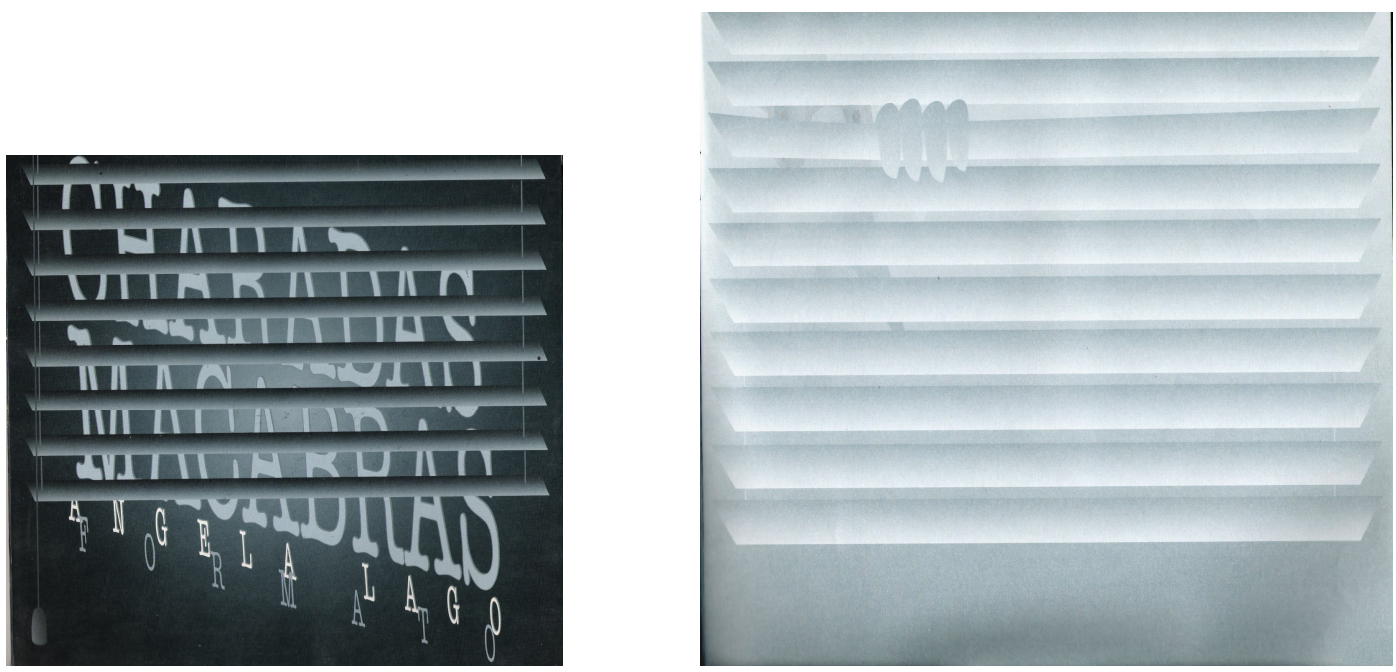

Figura 5.10 - Charadas macabras

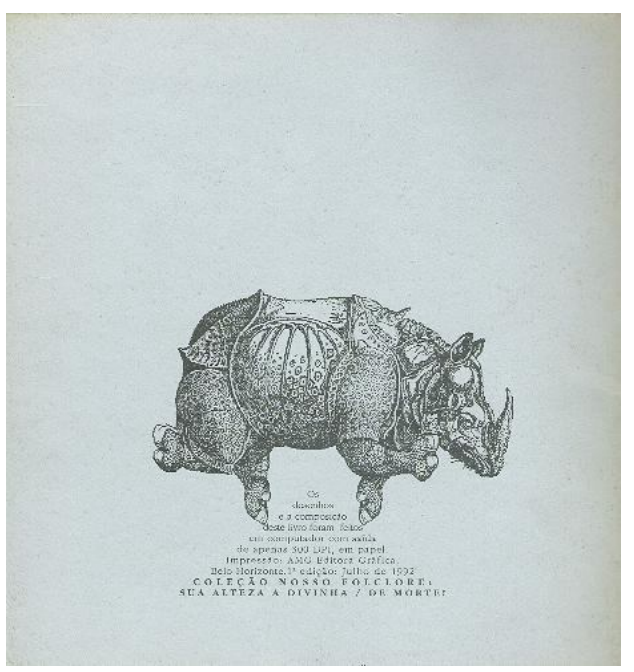

Figura 5.11 - De morte!

\footnotetext{
${ }^{158}$ Como apresentado em análise anterior.
} 
É importante ressaltar, mais uma vez, que o artista responsável pelo projeto gráfico, que pode ou não ser o produtor das imagens, articula a materialidade dos componentes do livro de maneira que todos, em conjunto, comunguem para contar a história e isso produz um efeito de sentido coerente, ou não, com a proposta do projeto gráfico.

Assim, esquematiza-se:

\begin{tabular}{|l|l|l|}
\hline \multicolumn{2}{|c|}{ Tabela 5.1 - A CAPA E O MATERI AL } \\
\hline & \multicolumn{1}{|c|}{ Portugal } & \multicolumn{1}{c|}{ Brasil } \\
\hline \multirow{2}{*}{$\begin{array}{l}\text { 1) Estratégias } \\
\text { de Manipulação }\end{array}$} & $\begin{array}{l}\text { Por sedução/Por } \\
\text { tentação: } \\
\text { Metonímica, anafórica, } \\
\text { determinante do gênero, } \\
\text { enigmática e formal }\end{array}$ & $\begin{array}{l}\text { Por seduço/Por } \\
\text { tentação: } \\
\text { Metonímica, anafórica, } \\
\text { determinante do gênero, } \\
\text { enigmática e formal }\end{array}$ \\
\hline \multirow{2}{*}{ 2) Capa e Papel } & Dura/papel couché fosco & $\begin{array}{l}\text { Mole/papel diversificado } \\
\text { de acordo com a proposta } \\
\text { do projeto. }\end{array}$ \\
\hline
\end{tabular}

\section{As técnicas plásticas empregadas}

Nas análises das obras dos artistas Manuela Bacelar e Roger Mello, evidenciaram-se, em cada livro, as técnicas empregadas, como: óleo, aquarela, marcador em pastel ou nanquim, lápis de cor, preenchimento de cor pelo computador, colagem, entre outros. Cada uma das técnicas constituía, de certa maneira, como foi demonstrado, se não o estilo do artista, pelo menos a identidade daquele projeto gráfico. Observando as produções para crianças nos dois cenários eleitos, o que há é a diversidade de técnicas empregadas. Contudo, é possível reconhecer tendências. 
Em Portugal, a técnica da colagem é recorrente, ocupando grande parte das estantes das livrarias; a outra parte é ocupada por imagens que empregam técnicas pictóricas. Abaixo, demonstra-se a afirmação:

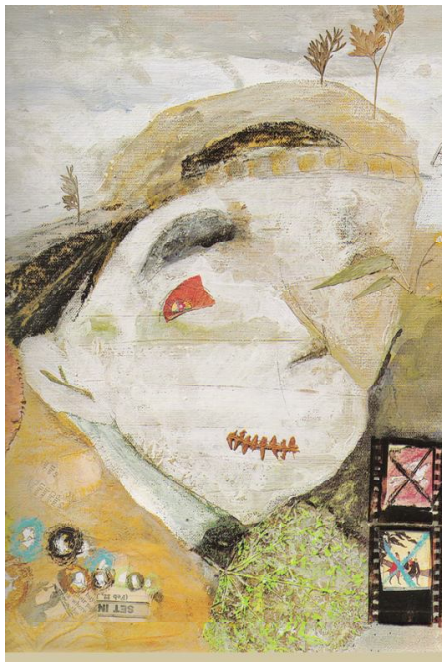

Figura 5.12 - A maior flor do mundo

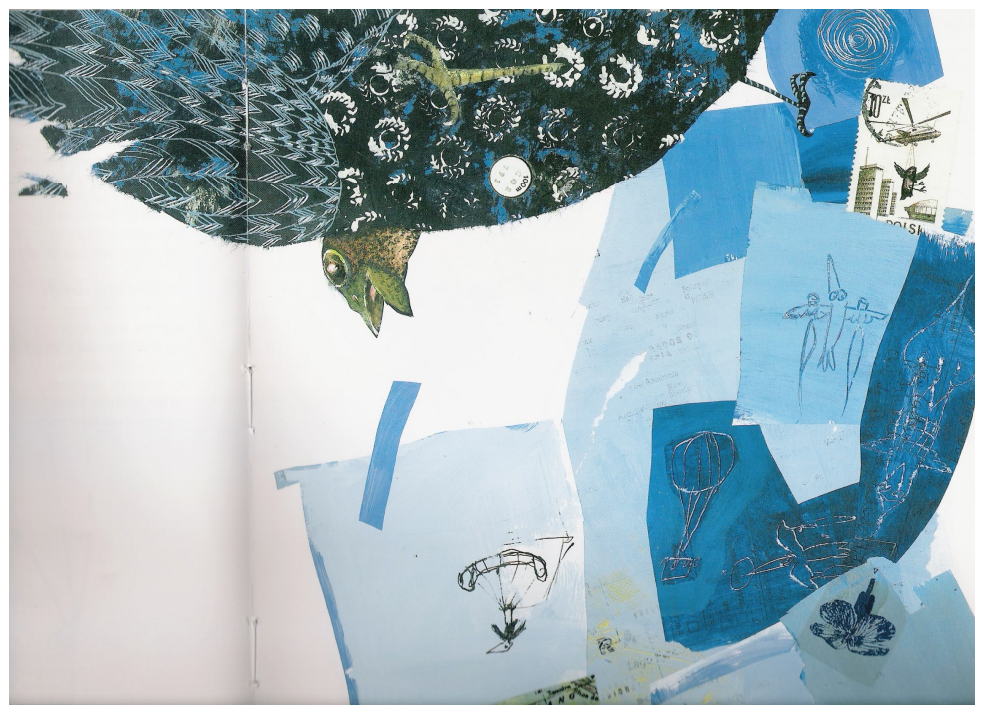

Figura 5.13 - Palavra para lavra

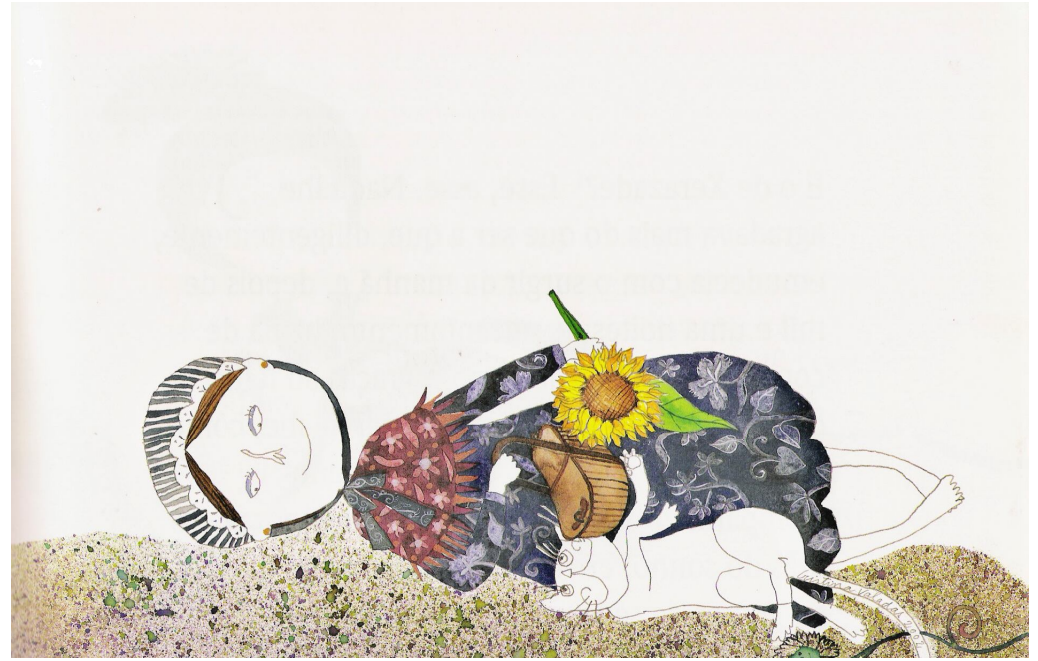

Figura 5.14 - O perfume do sonho, na tarde 


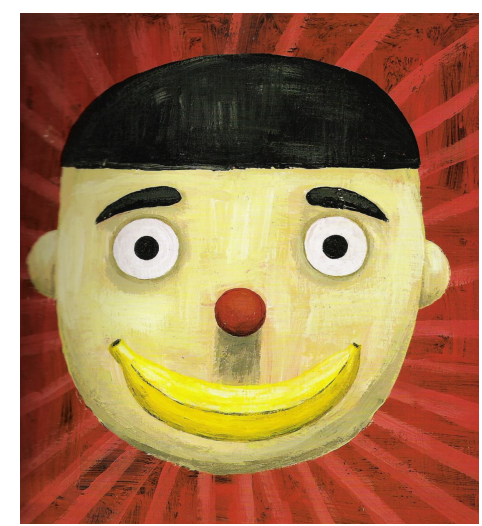

Figura 5.15 - André Letria

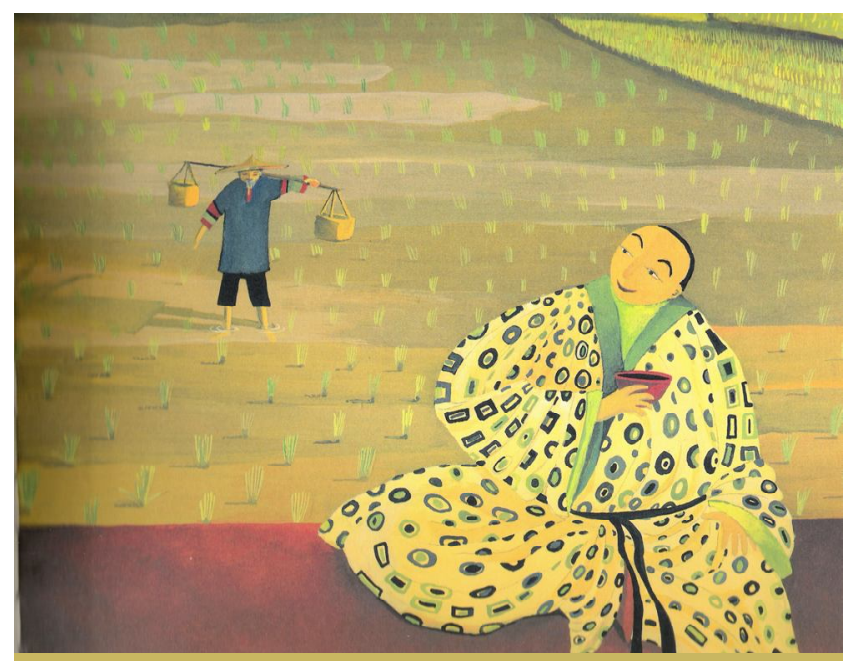

Figura 5.16 - Danuta Wojciechowska

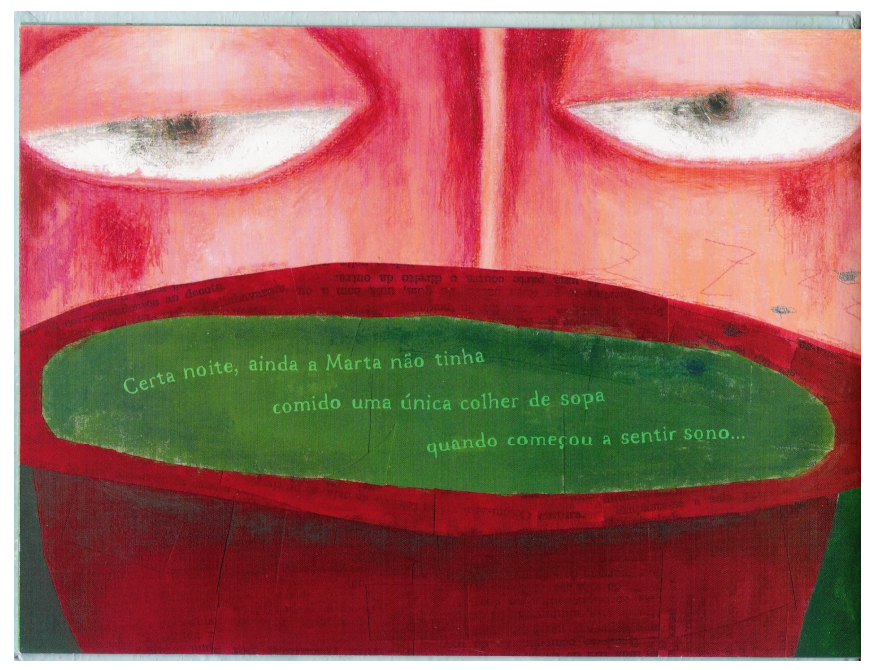

Figura 5.17 - Marta Torrão

No Brasil, há o fascínio no emprego da tecnologia, e os artistas, cada vez mais, apropriam-se do computador como ferramenta e, muitas vezes, associada à prática de tinta e papel. Seguem as imagens que confirmam a afirmação. Pode-se afirmar que, no Brasil, a tendência é gráfica, enquanto em Portugal, pictórica: 


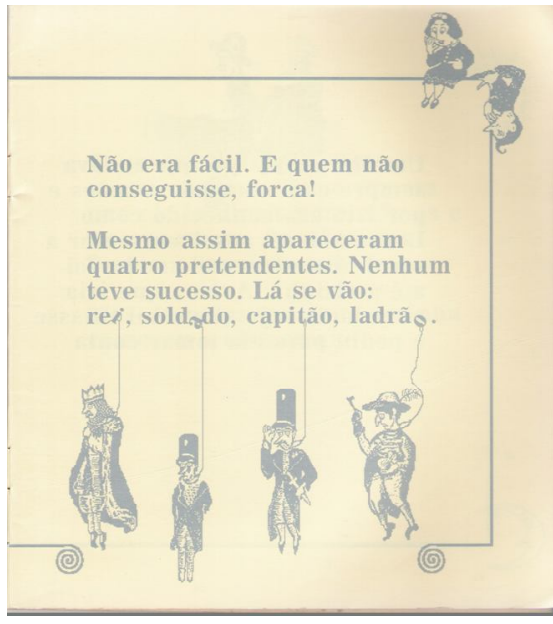

Figura 5.18 - Sua alteza, a divinha

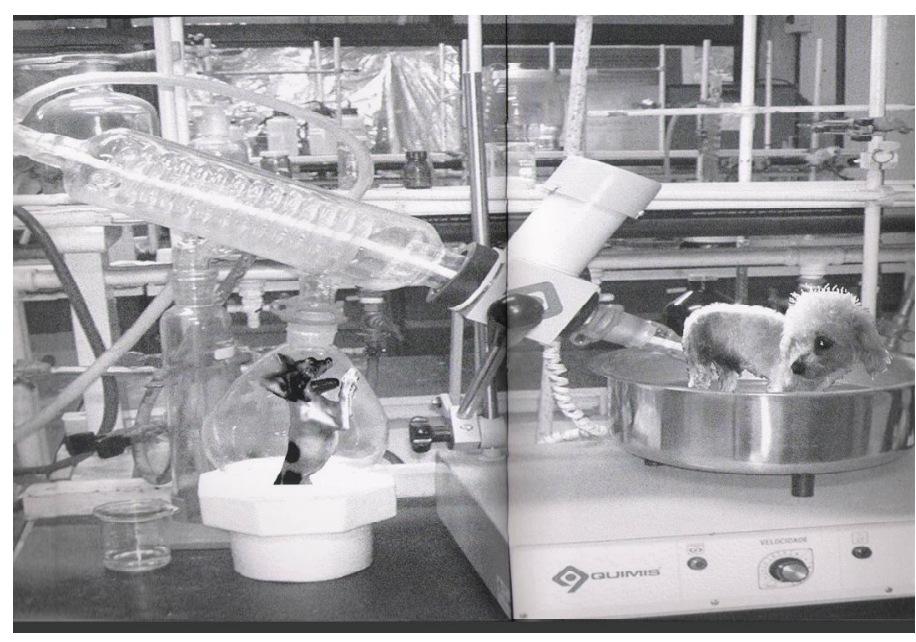

Figura 5.19 - A raça perfeita

Outro aspecto de divergência entre os projetos é em relação ao estilo (como expressão da individualidade). Como apontado por Rui Oliveira durante as análises, o "modo de fazer" é determinado pela proposta da obra, no entanto, tomando como exemplo dois artistas que não foram analisados, a saber: André Letria e Ângela Lago, para assim dar maior credibilidade ao argumento, já que estende a amostragem, o que se nota é um estilo (individual) mais pré-marcado em Portugal, enquanto no Brasil, o estilo é "camaleão", ou seja, transforma-se a partir da concepção do livro-objeto:
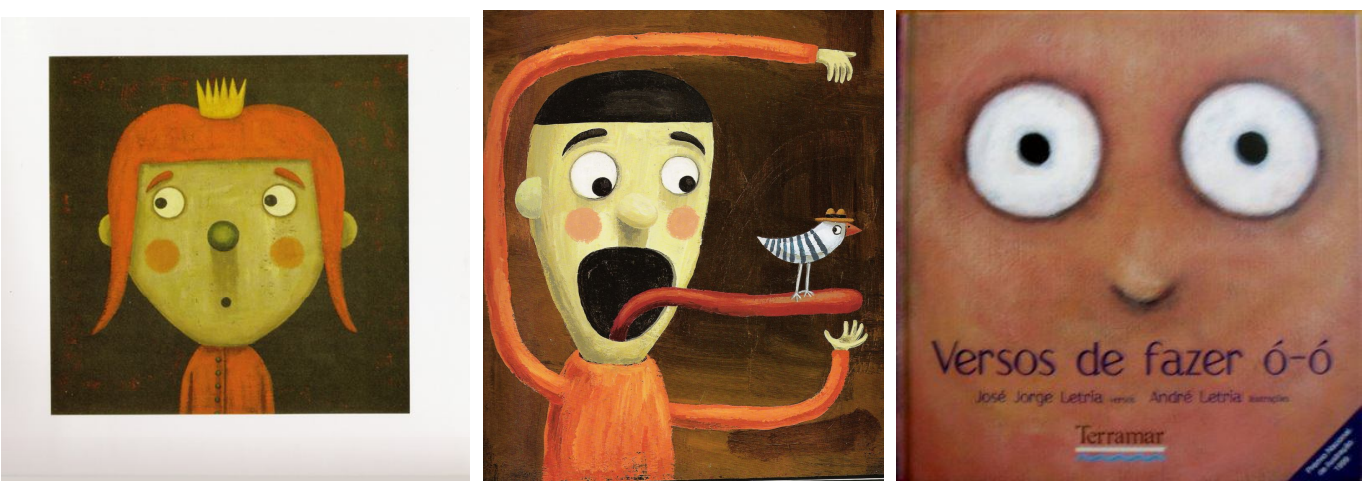

Figura 5.20 - André Letria 

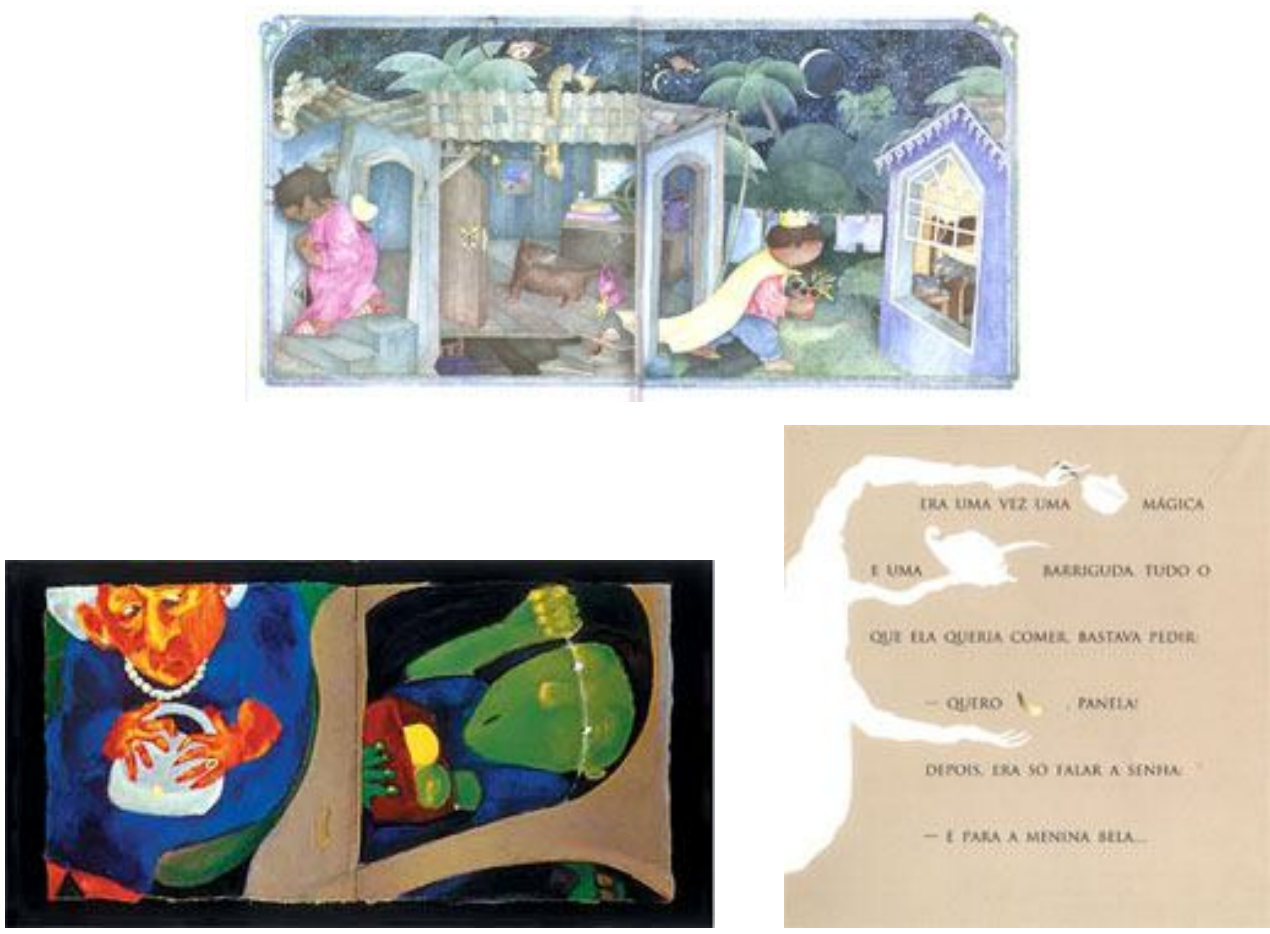

Figura 5.21 - Angela Lago

Assim, esquematiza-se:

\begin{tabular}{|l|l|l|}
\hline \multicolumn{3}{|c|}{ Tabela 5.2 - As técnicas plásticas empregadas } \\
\hline & \multicolumn{1}{|c|}{ Portugal } & \multicolumn{1}{c|}{ Brasil } \\
\hline 1) Técnica & Pictórica & Gráfica \\
\hline 2) Estilo & $\begin{array}{l}\text { Individualidade mais } \\
\text { marcada }\end{array}$ & $\begin{array}{l}\text { Individualidade menos marcada } \\
\text { (adequação ao projeto) }\end{array}$ \\
\hline
\end{tabular}

\section{O papel organizador do projeto gráfico}

Além desses critérios, outro aspecto a ser considerado por este estudo comparativo é a relação entre os produtores dos textos, a saber: o autor do texto verbal, o autor do texto visual e o aut 
como anteriormente pontuado, são considerados como enunciadores do discurso. Sendo assim, observa-se uma realidade distinta nos dois países: em Portugal, a tendência é produzir projetos cujas mídias contem histórias paralelas, enquanto no Brasil, a tendência se apropria do conceito de livro-álbum.

É evidente que, em função da diversidade das obras produzidas para crianças, é possível identificar exemplos de: livros-ilustrados, livrosálbum e livros de imagem em ambos cenários, contudo, há predominância no Brasil do livro-álbum e, em Portugal, do livro-ilustrado.

No Brasil, para demonstrar a afirmação, citam-se as seguintes obras, dentre outras, que utilizam palavra e imagem para produzir a narrativa: Chiquita Bacana e outras pequetitas, Sua Alteza a divinha, de Ângela Lago; Flicts, $\mathrm{O}$ menino mais bonito do mundo, $\mathrm{O}$ menino quadradinho, O menino maluquinho e A bela borboleta, de Ziraldo; Nós, A bruxinha e os 80 docinhos e 0 problema do Clóvis, de Eva Furnari; A casa do meu avô e O homem no sótão, de Ricardo Azevedo, Griso, o unicórnio e Vizinho, Vizinha, de Roger Mello ${ }^{159}$.

Em Portugal, em pesquisa de campo, foi possível localizar os seguintes livros-álbum: A flor de um mês, de José Jorge Letria e imagens de André Letria; A história de um segredo, de Paulo Cotrim e imagens de André Letria; O dinossauro, de Manuela Bacelar; Come a sopa, Marta!, de Marta Torrão; A maior flor do mundo, de José Saramago e imagens de João Caetano; entre outros. Já livros-ilustrados são inúmeros: A Sereiazinha, de Hans Christian Andersen e imagens de Manuela Bacelar; Os ovos misteriosos, de Luisa Ducla Soares e imagens de Manuela Bacelar, Silka, de Ilse Losa e imagens de Manuela Bacelar; Timor Lorosae: a ilha do sol nascente, de João Pedro Messéder e imagens de André Letria, entre outros.

Com isso, não se quer dizer que o livro-álbum tenha qualidade superior à do livro ilustrado, a intenção é apenas pontuar que o livro-

${ }^{159}$ Vale pontuar que existem muitos outros dos mesmos auto autores e ilustradores. 
álbum possibilita a exploração do projeto gráfico como um todo de sentido, em que as mídias se intercomunicam, já no livro-ilustrado, podem-se valorizar os recursos da palavra e os recursos da imagem, mas as mídias têm caminhos paralelos.

A partir disso, segue-se o percurso comparativo para explicitar a motivação dessa situação em cada um dos espaços problematizados pela discussão apresentada.

No Brasil, a história em quadrinhos foi, no início da década de 50, rechaçada pela educação, mas não pelos artistas, pelo contrário, muitos artistas plásticos se aventuraram por elas e, por esse atalho, tornaram-se autores infantis. Cada autor, obviamente, tem seu percurso, mas pode-se dizer que a produção dos quadrinhos, cartoons, charges fizeram escola no Brasil e que a literatura infantil brasileira é, claramente, influenciada por essa linguagem, como apresentado nas análises, caracterizando a aproximação com o livro-álbum e também com o estilo gráfico, tratados no item anterior.

Em Portugal, não se percebe a influência tão evidente dos quadrinhos ${ }^{160}$. Normalmente, o produtor de imagens para o livro infantil tem um trabalho paralelo como artista plástico, e não gráfico. As imagens abaixo sustentam a afirmação:

${ }^{160}$ Esse é uma dado que aponta para a ausência de artistas com a dınla vncarãn e nara a inexistência de equipes de trabalho. A equipe formada para em quadrinhos contribui para essa vivência como demonstrac 


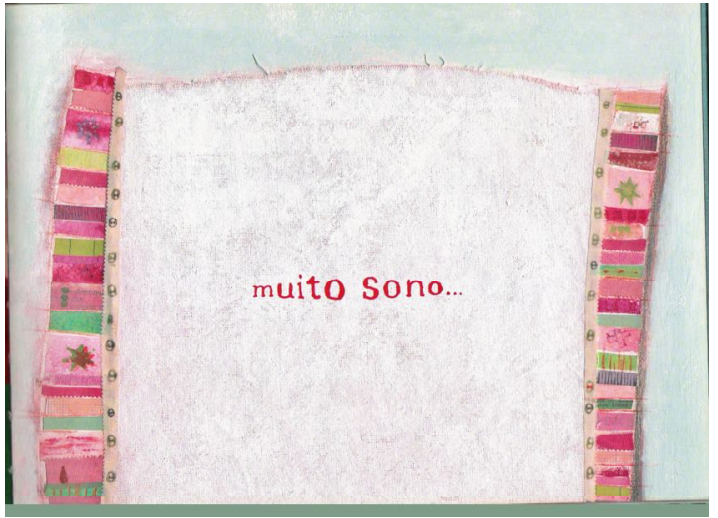

Figura 5.22 - Marta Torrão

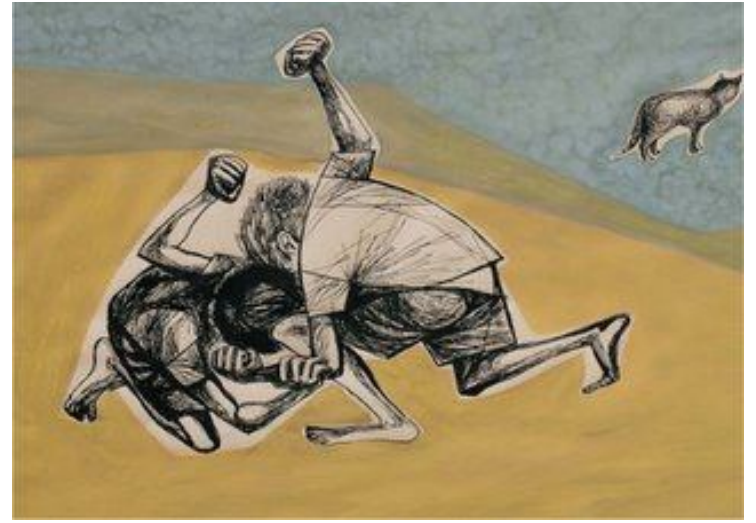

Figura 5.23 - Maria Kheil

Em território português, o artista produz uma tela que vai ser impressa; já no Brasil, a técnica passa pela confecção de uma "boneca", como explica Guto Lins:

Com a boneca do livro é possível testar a influência real de cada página comparativamente. O objetivo da boneca é simular o produto cada vez mais próximo da realidade. Nesta fase planeja-se o projeto gráfico e as ilustrações quase que simultaneamente, definindo "movimento de câmera" e "closes" e o ritmo de todo o livro. O projeto gráfico além de determinar as manchas gráficas, define as respirações e os espaços em branco necessários (2004, p. 62).

Ao projetar as imagens no espaço do livro, o artista é levado a pensar sobre este suporte, bastante distinto de uma tela, o quadro. Como se observa nas imagens a seguir: 


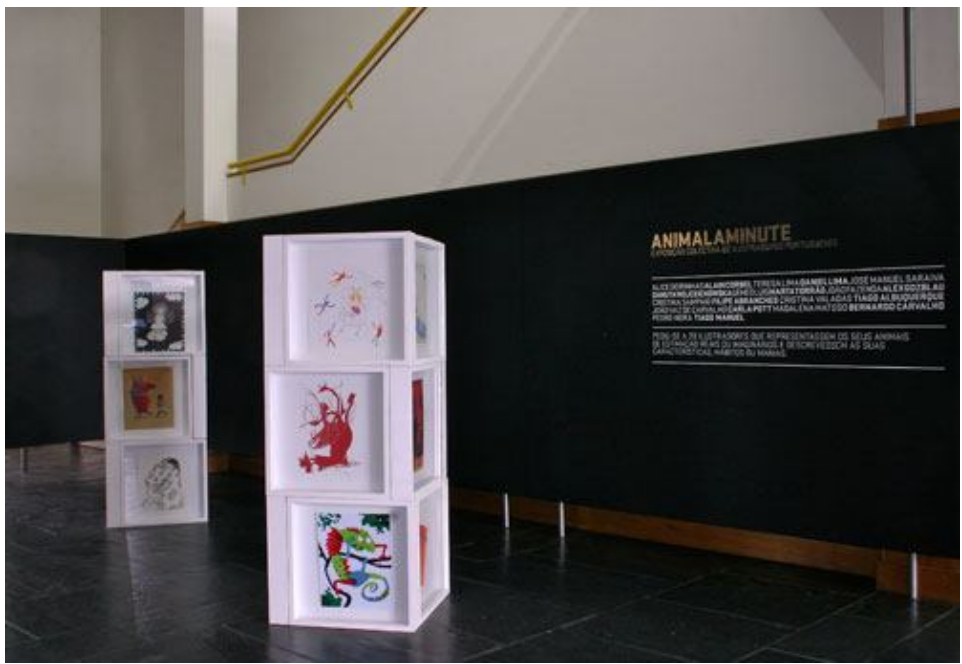

Figura 5.24 - A exposição, em Portugal - imagem de Gemeo Luis

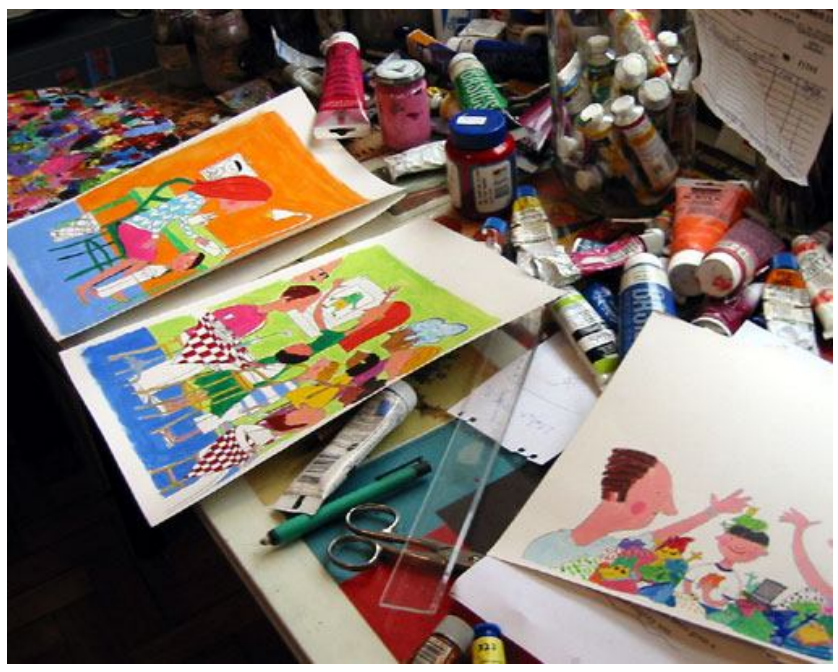

Figura 5.25 - A “boneca” - no Brasil - imagem da obra de Graça Lima

Da explicação apresentada por Guto Lins, é possível extrair outro critério divergente entre as expressões visuais da literatura infantil, a saber: o "movimento de câmera" e os "closes". No Brasil, este recurso é utilizado de maneira bastante diversa, imprimindo movimento às imagens - Chiquita Bacana e outras pequetitas e Cena de rua, de Ângela Lago, são exemplos de que o recurso é radicalmente exploradc 
apresentado nas imagens abaixo, a opção é pela estaticidade das imagens. Destaca-se, no entanto, neste cenário, a obra de Gêmeo Luis, que trabalha com esculturas de papel nas quais o movimento é constante. Esse exemplo é uma exceção.

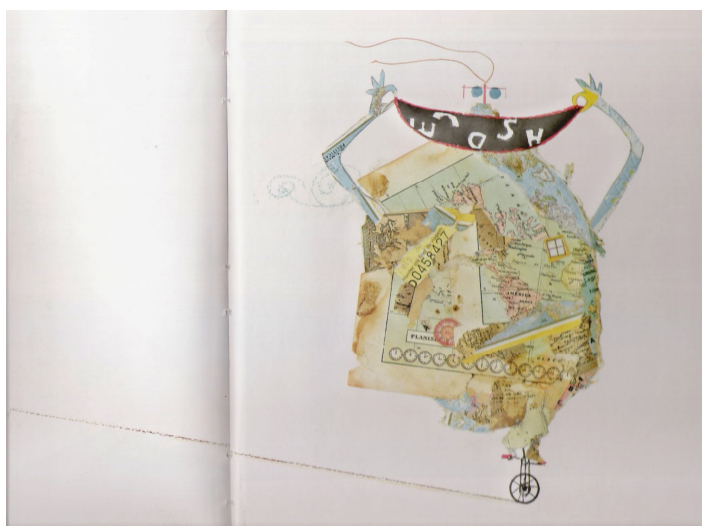

Figura 5.26 - J oão Caetano

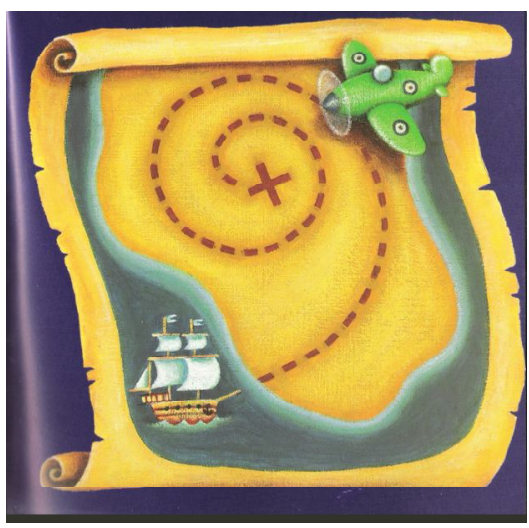

Figura 5.27 - André Letria

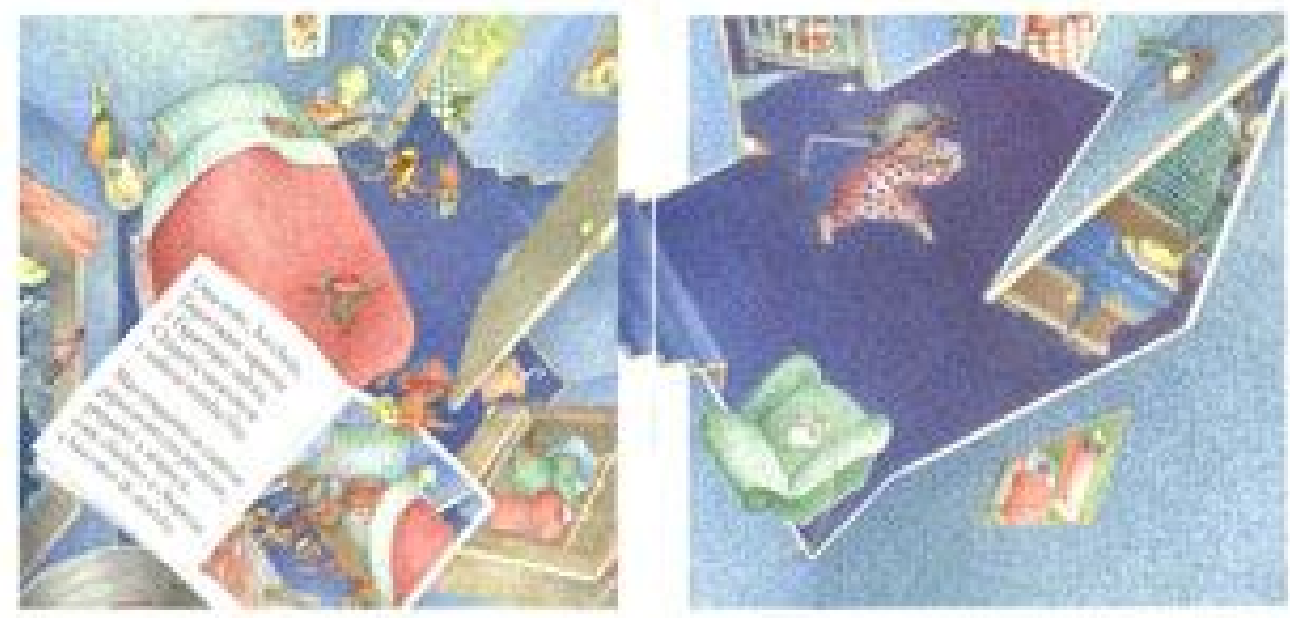

Figura 5.28 - Angela Lago 

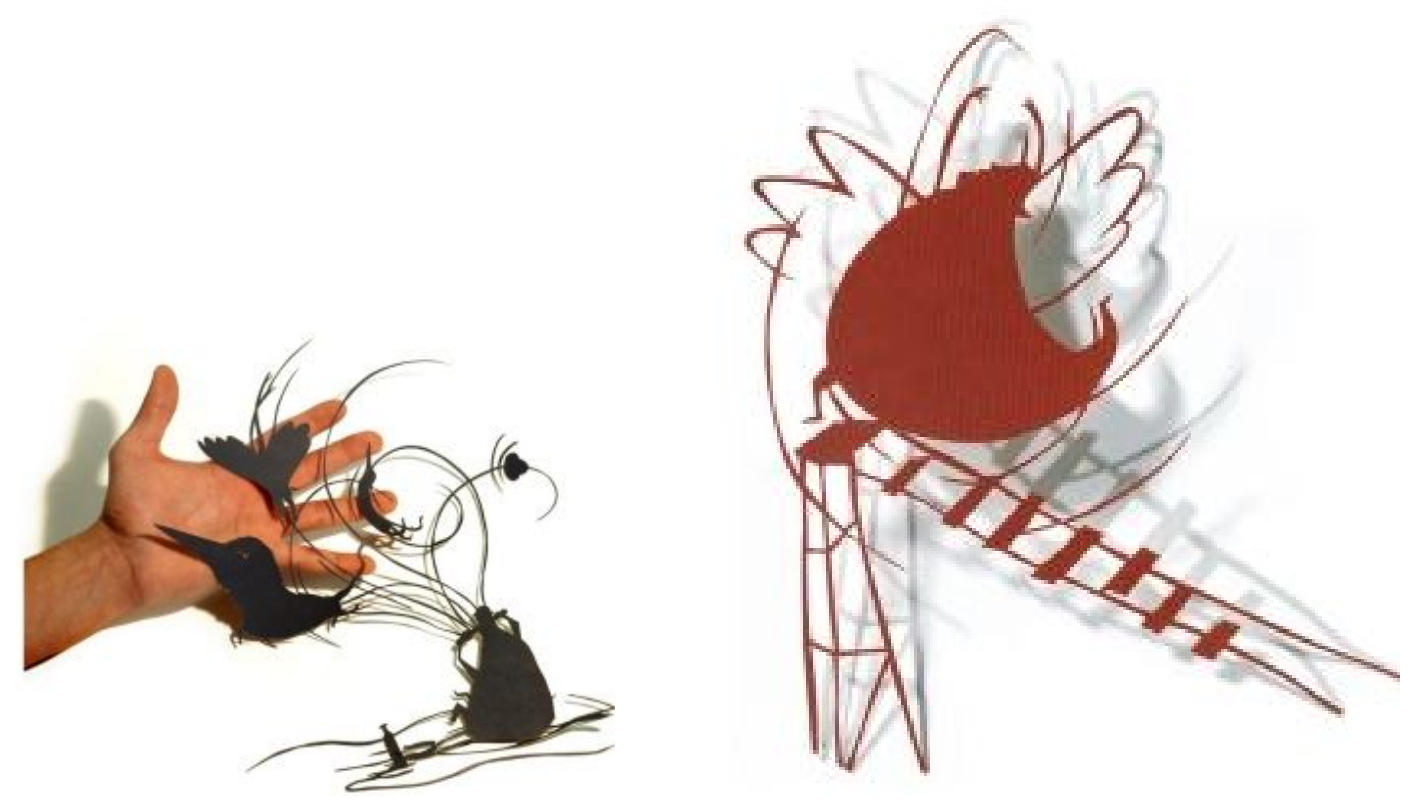

Figura 5.29 - Gemeo Luis

Tendo em vista os diversos recursos empregados, observa-se que as diferentes expressões artísticas - cinema, quadrinhos, artes plásticas encontram campo fértil para esse diálogo no livro para crianças. A imagem faz do livro infantil um objeto para todos os sentidos. É evidente que a palavra, com sua força poética, fratura o tempo e sinestesicamente atua sobre o corpo do sujeito, afinal, o que a literatura infantil pretende é justamente formar o leitor literário e, portanto, é fundamental destacar a força da palavra em si e dos recursos expressivos próprios aos discursos literários em geral, como abordado por Colomer (2003), em A formação do leitor literário, quando a estudiosa pontua que a função da literatura infantil é apresentar a arte literária às crianças, com suas variações e complexidades. Silva-Díaz (2005) também segue esse princípio ao abordar o álbum metaficcional como uma tendência da literatura infantil atual ${ }^{161}$.

A criança, contudo, como foi ponderado ao longo das análises, tem os sentidos à flor da pele e seu tempo obedece a um ritmo diferente - o

\footnotetext{
${ }^{161}$ Ambas propostas citadas farão parte das discussões sobre
} literatura infantil. 
ritmo para os pequenos é acelerado, imediato, dada à urgência em conhecer o mundo. Muitas vezes, esse tempo é difícil de ser partilhado pelo adulto. O mundo está repleto de estímulos, e à criança cabe o esforço de percebê-los. O livro, ainda, é concorrente direto dos estímulos do mundo e mais um estímulo dado à criança. Por isso mesmo, não pode (ou não poderia) ser um objeto neutro, desinteressante. Deve, sim, oferecer uma "vitamina doce e saudável" para os sentidos, e, por essas características, o entrecruzar de sistemas semióticos tem no livro infantil um ambiente extremamente favorável ao seu desabrochar. Contrariamente ao que se pensava no passado, em que a palavra própria ao livro infantil era a dos manuais escolares, hoje, a função da literatura para crianças é introduzir o leitor no rico universo poético-literário. Então, deve-se afastar, o máximo possível, o livro dos manuais escolares e aproximá-lo da arte em todas as suas formas e expressões.

Assim, esquematiza-se:

\begin{tabular}{|l|l|l|}
\hline \multicolumn{3}{|c|}{ Tabela 5.3 - Técnicas plásticas empregadas } \\
\hline & \multicolumn{1}{|c|}{ Portugal } & \multicolumn{1}{c|}{ Brasil } \\
\hline 1) Gênero & Livro-ilustrado & Livro-álbum \\
\hline 2) Influências & Arte pictórica & $\begin{array}{l}\text { Histórias em } \\
\text { quadrinhos }\end{array}$ \\
\hline 3) Procedimentos & Tela - impressão & Boneca \\
\hline 4) Efeito & Estaticidade & Dinamicidade \\
\hline
\end{tabular}

Entretanto, nem só de expressão e experimentos vive o livro dados às crianças. Passa-se, pois, ao conteúdo. 


\section{As abordagens temáticas}

Estabelecer padrões no que diz respeito ao conteúdo literário é bastante difícil, pois a vida em sentido amplo está repleta de "histórias" e estímulos que merecem ser contados:

O estilo artístico não trabalha com palavras, mas com elementos do mundo, com valores do mundo e da vida; esse estilo pode ser definido como um conjunto de procedimentos de informação e acabamento do homem e do seu mundo, e determina a relação também com o material, a palavra, cuja natureza, evidentemente, deve-se conhecer para compreender tal relação. $\mathrm{O}$ artista trata diretamente com o objeto enquanto momento do acontecimento do mundo - e isso determina posteriormente (aqui, é claro, não se trata de ordem cronológica, mas de hierarquia de valores) a sua relação com o significado concreto da palavra enquanto elemento puramente verbal do contexto, determina o uso do elemento fonético (imagem acústica), do emocional (a própria emoção tem relação axiológica com o objeto, está orientada para o objeto e não para a palavra, embora o objeto também possa ser não dado sem levar em conta a palavra, do pictural, etc. (BAKHTIN, 2003, p. 181).

Apesar de a vida ser rica em histórias, é possível destacar as temáticas recorrentes nos livros infantis contemporâneos de Portugal e do Brasil e ainda refletir sobre aquilo que Colomer aponta como ideologia das produções infantis atuais ${ }^{162}$.

Partindo do ponto de vista apresentado, é plausível concluir que em Portugal a temática da própria História Nacional é uma constante; são exemplos disso: A flor de um mês, de José Jorge Letria e André Letria; Timor Lorosae - a ilha do sol nascente, de João Pedro Messéder e André Letria; A história de um segredo, de Paulo Cotrim e André Letria; Sebastião, de Manuela Bacelar e até O dinossauro (de Bacelar), que foi analisada por este estudo, pode ser lida como uma metáfora do território

\footnotetext{
${ }^{162}$ Conforme referido no capítulo 4.
} 
português, como uma Jangada de Pedra; só que neste caso, Portugal sai para "visitar" outros países e depois volta à sua condição original.

No Brasil, há enorme diversidade de abordagens. Existem obras com temáticas regionais: Caçadores de aventuras, Daniel Munduruku e Inez Martins (il.), Catando piolhos, contando histórias, Daniel Munduruku e Matè (il.), Histórias que o povo conta, Ricardo Azevedo, Contos de bicho do mato, de Ricardo Azevedo. Também, a condição do homem contemporâneo se tornar tema, como em Vizinho, Vizinha. Posto isso, é difícil apontar uma temática recorrente. No entanto, desde Ziraldo ${ }^{163}$, o livro se volta para o próprio livro, em procedimento metaficcional, e essa acaba sendo uma abordagem recorrente em território nacional. Os exemplos dessa abordagem são: A bela borboleta, de Ziraldo; O problema do Clóvis, de Eva Furnari, O personagem encalhado, de Ângela Lago, entre outros.

Surge, então, o livro-álbum metaficcional como terreno fértil à experimentação, para alcançar o objetivo exposto:

Não por casualidade as fronteiras profissionais entre os ilustradores, pintores, publicitários, desenhistas de humor ou de quadrinhos, etc., tornaram-se permeáveis nos últimos tempos e os álbuns converteram-se em um campo propício à experimentação artística (COLOMER, 2003, 130).

Se investiga-se a produção gráfica, deve-se abordar alguns aspectos que necessitam avaliação no momento de escolha do livro, tendo em vista que o que se pretende é a formação de um leitor literário, como afirma Silva-Díaz (2005):

Aún cuando proponen una lectura distanciada las obras metaficcionales involucran activamente a sus lectores en la producción de sentido. Los lectores de metaficción se adentran en un mundo ficcional que se reconoce como tal, y que, activa sus conocimientos acerca de las convenciones

${ }^{163}$ Muitas vezes, Monteiro Lobato utiliza recursos que o fazem, pós-contemporaneidade, com em Memória de Emília, para cit 
literarias instándoles a resolver las contradicciones y a interactuar críticamente con la formulación que el texto realiza sobre la naturaleza y el funcionamiento de lo literario. De esta manera se amplía su experiencia de la literatura (2005, p.21).

Assim, esquematiza-se:

\begin{tabular}{|c|c|}
\hline \multicolumn{2}{|c|}{ Tabela 5.4 - Abordagens temáticas } \\
\hline Portugal & Brasil \\
\hline História Nacional & Metaficcionalidade \\
\hline
\end{tabular}

\begin{tabular}{|l|l|l|}
\hline \multicolumn{2}{|c|}{ Tabela 5.5 - Comparativo das características da literatura infantil } \\
contemporânea \\
\hline Capa & \multicolumn{1}{|c|}{ Portugal } & \multicolumn{1}{c|}{ Brasil } \\
\hline & $\begin{array}{l}\text { Metonímica, anafórica, } \\
\text { determinante do gênero, } \\
\text { enigmática e formal }\end{array}$ & $\begin{array}{l}\text { Por sedução/Por tentação: } \\
\text { Metonímica, anafórica, } \\
\text { determinante do gênero, } \\
\text { enigmática e formal }\end{array}$ \\
\hline Papel & Dura/ papel couché fosco & $\begin{array}{l}\text { Mole/ papel diversificado } \\
\text { de acordo com a proposta } \\
\text { do projeto }\end{array}$ \\
\hline Técnica & Pictórica & $\begin{array}{l}\text { Gráfica } \\
\text { Individualidade menos } \\
\text { marcada (adequação ao } \\
\text { projeto) }\end{array}$ \\
\hline Gênero & $\begin{array}{l}\text { Individualidade mais } \\
\text { marcada }\end{array}$ & Livro-álbum \\
\hline Influência & Aivro-ilustrado pictórica & Historias em quadrinhos \\
\hline Criação & Tela - impressão & Boneca \\
\hline Temática & História Nacional & Metaficcionalidade \\
\hline
\end{tabular}




\section{Estratégias para formação do leitor literário}

Unindo conteúdo e expressão, o objetivo da literatura infantil é, como pontuado no item anterior, introduzir o leitor no universo das artes literárias que, como todo o código, lança mão de algumas estratégias. Então, é tarefa da literatura infantil formar o leitor de maneira que ele desenvolva habilidades para transitar livremente pelo território das letras.

Posto isso, é plausível enumerar as qualidades literárias que um álbum metaficcional apresenta, para assim verificar se ele leva à formação do leitor literário, tal como quer. Colomer (2003), em estudo sobre a formação do leitor literário, observa que os álbuns obedecem a um sentido que mescla o conhecido com o desconhecido, pois para que o leitor decodifique a mensagem do texto ele deve ter pontos de familiarização para instaurar mecanismos de desfamiliarização; cita ainda Whalen-Levitt (1984, apud Colomer, 2003) e sua classificação das maneiras mais freqüentes com as quais os álbuns jogam com as convenções:

a) Violação do sentido comum da visão do mundo, com imagens impossíveis na realidade, do tipo das escadas enlaçadas de Moebius.

b) Manipulação do ponto de vista ao propor perspectivas alternadas.

c) Camuflagem das imagens em outros objetos, ressaltando suas relações de semelhança e diferença.

d) Alusões a outras obras de arte, como, por exemplo, quadros famosos (2003, p.107).

Além dos aspectos literários, não pode se perder de vista que o livro-álbum impõe uma reflexão que vai além das estratégias do conteúdo (que se dá tanto pelo texto verbal quanto pelo texto visual), passa também pela expressão; essa implicação atribui uma complexidade ainda maior ao livro infantil: 
Longe da idéia de uma amável literatura para crianças pequenas, o álbum produziu as maiores tensões educativas e estéticas da produção infantil e, em lugar de oferecer-se como o tipo de livro mais simples, resultou em um dos gêneros mais complexos da literatura para crianças e jovens, já que utiliza simultaneamente duas formas de arte, a plástica e a linguagem, e porque implica dois receptores, as crianças e os adultos. A necessidade de inter-relacionar os conhecimentos críticos do âmbito literário e da imagem parece, pois, absolutamente incontestável no campo da literatura infantil (COLOMER, 2003, p. 105).

Seguindo o percurso imposto no início do estudo que ora se apresenta, pontua-se esquematicamente os critérios de avaliação que seriam pertinentes de serem considerados no momento de escolha de um livro infantil:

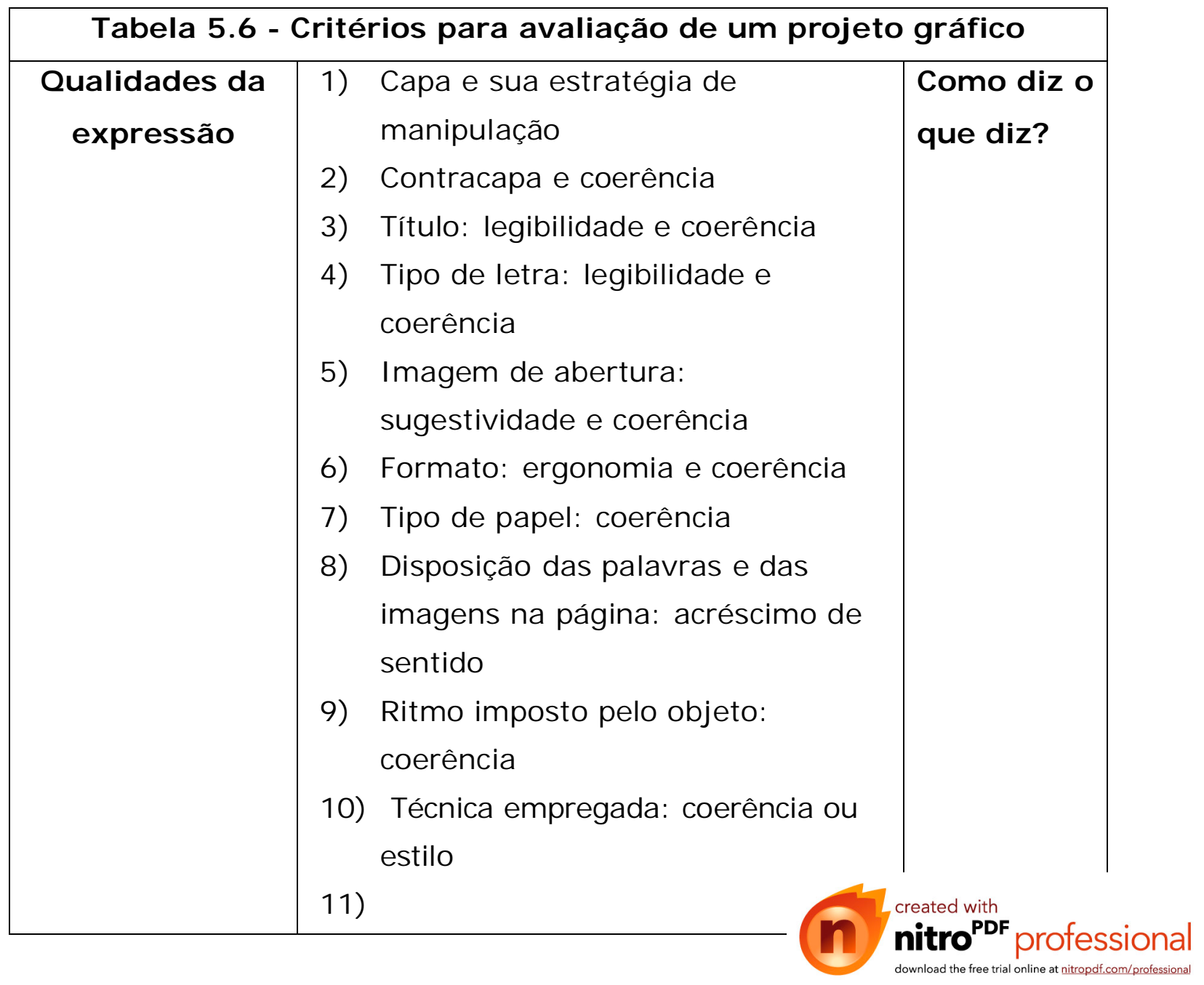




\begin{tabular}{|c|ll|l|}
\hline $\begin{array}{c}\text { Qualidades do } \\
\text { conteúdo }\end{array}$ & 1) & Atende ao objetivo proposto & O que diz? \\
& 2) & Recorre às habilidades diversas & \\
3) & Aciona e amplia o repertório do & \\
& leitor & \\
4) & Estabelece relação \\
& coerente/criativa - capa e miolo & \\
& 5) & Utiliza recursos intertextuais & \\
6) & Recorre a outras expressões & \\
& artísticas & \\
& 7) & Atende à ideologia desejada & \\
\hline
\end{tabular}

A partir desses apontamentos, cabe ao mediador interrogar sobre as suas intenções e contrapor aquilo que a obra apresenta, pensando sobre os seguintes aspectos:

\section{Propostas para a mediação:}

a) Investigar e detalhar os discursos e objetivos sociais;

b) Relacionar as habilidades interpretativas entre a obra e as diferentes mídias;

c) Alimentar a leitura com outros textos;

d) Promover diálogos entre leitores e entre diferentes expressões;

e) Promover leituras silenciosas;

f) Aceitar os livros "da moda" e ser sensível ao campo de interesse, buscando ampliá-lo;

g) Dotar os leitores de habilidades para sentirem-se donos da leitura;

h) Apresentar livros coerentes com a proposta desejada. 
A partir dessa proposta, é possível tecer relações entre os distintos sistemas semióticos, identificar as vozes discursivas e ponderar sobre o ato da leitura voltada ao próprio código. Com este tecido em mãos, cabe ao mediador confeccionar os leitores literários que estão por aí ou que virão.

Clavo mi remo en el agua Llevo tu remo en el mío Creo que he visto una luz al otro lado del río

Oigo una voz que me llama casi un suspiro Rema, rema, rema-a Rema, rema, rema-a

(Jorge Drexler) 


\section{REFERÊNCI AS BI BLI OGRÁFI CAS}

ABRAMOVICH, F. O estranho mundo que se mostra às crianças. São Paulo: Summus, 1983.

$\overline{1} \overline{9} \overline{9} \overline{.}$

- Literatura infantil: gostosuras e bobices. São Paulo: Scipione,

AGUILAR, G. H. Figuras y estratégias: em torno a una semiótica de lo visual. Madrid: Siglo XXI editores S/A, 1994.

ALBERGARIA, L. Do folhetim à literatura infantil: leitor, memória e identidade. Belo Horizonte: Lê, 1996.

AMARAL, M. L. Criança é criança: literatura infantil e seus problemas. Petrópolis: Vozes, 1983.

AMARI LHA, M. Estão mortas as fadas? Petrópolis: Vozes, 1997.

ANDERSEN, H. A sereiazinha (ilustrações Manuela Bacelar). Trad. Ribeiro da Fonseca. Edições Afrontamento: Porto, 1995.

ANDRICAÌN, S. "El libro infantil: un camino a la apreciación de las artes visuales". Revista cuatrogatos - revista de literatura infantil, o․ 8, octubre-diciembre, 2001.

ARAÚj O, E. A construção do livro: princípios da técnica de editoração. Rio de Janeiro: Nova Fronteira/I NL, 1986.

ARIZPE, E.; STYLES, M. Lectura de imágenes. Trad. María Vinós Zelaya. México: Fondo de Cultura Económica, 2004.

ARMAS, J. D. "Estrategias de desbordamiento en la ilustración de libros infantiles". In: VIANA, MARTINS \& COQUET (Org.). Leitura, literatura infantil e ilustração - investigação e prática docente. Braga: Centro de Estudos da Criança - Universidade do Minho, 2003.

ARMOND, H. Abro ou não abro?. São Paulo: Melhoramentos, 1990.

ARROYO, L. A literatura infantil. São Paulo: Melhoramentos, 1968.

AZEVEDO, R. Menino sentindo mil coisas. São Paulo: Ática, 2003. . Um ano danado de bom!. São Paulo: Moderna, 1997.

BACELAR, M. O dinossauro. Edições Afrontamento: Pc 
. Sebastião. Edições Afrontamento: Porto, 2005.

. Bernardino. Edições Afrontamento: Porto, 2005.

BAJOUR, C.; CARRANZA, M. El libro álbum, una deuda en la literatura infantil argentina. Revista Eletrónica I maginaria, [s.d.].

BAKHTIN, M. Estética da criação verbal. São Paulo, Martins Fontes, 2003.

BAMBERGER, R. Como incentivar o hábito da leitura. São Paulo: Ática, 1995.

BAPTISTA, C.; PENTAGNA, R. Contos por encanto por enquanto ...: uma experiência com literatura infanto-juvenil. Petrópolis: Vozes, 1995.

BARROS, D. L. P. Teoria Semiótica do texto. São Paulo: Ática, 2003.

; Fiorin, J (Org.). Dialogismo, polifonia, intertextualidade. São Paulo: EDUSP, [s.d.].

- Teoria do discurso: fundamentos semióticos. São Paulo: Humanitas/FFLCH, Usp, 2002.

BARTHES, R. O óbvio e o obtuso. Lisboa: Edições 70, 1982.

BASTOS, G. A escrita para crianças em Portugal. Lisboa: Caminho, 1997.

BATTUT, E. El gato que sonríe... . [S.I.]: Editorial Kókinos, [s.d.].

BENJ AMI N, W. Reflexões: o brinquedo, a criança e a educação. São Paulo: Summus, 1987.

BETTELHEIM, B. A psicanálise dos contos de fadas. Rio de Janeiro: Paz e Terra, 1978.

BORGE, J.L. Ficciones. México: Fondo de Cultura Econômica, 1998.

BROWNE, A. Willy, o mágico. São Paulo: Martins Fontes, 1997.

BRUNEL, P.; CHEVERL, Y. (Org.). Compêndio de literatura comparada. Trad. Maria do Rosário Monteiro. Lisboa: Edições Fundação Calouste Gulbenkian, 2004.

CALADO, I. A utilização educativa das imagens. Porto: Editora Porto, 1994. 
CALVINO, I. Seis propostas para o próximo milênio. São Paulo: Companhia das Letras, 1990.

CALVINO, I. Sobre o conto de fadas. Lisboa: Teorema, 1999.

CAMARGO, L. Ilustração do livro infantil. Belo Horizonte: Lê, 1995.

CANDIDO, A. Literatura e Sociedade. São Paulo: Editora Nacional, 1976.

CATER, B. Libros de información: del placer de saber al placer de leer. Caracas: Banco del Libro, 2001.

CERRILLO, P.; PADRINO, J. Presente y futuro de la literatura infantil. Cuenca: Ediciones de la Universidad de Castilla-La Mancha, 2000.

. (Coord.). La literatura infantil en el siglo XXI. Cuenca: Ediciones de la Universidad de Castilla-La Mancha, 2001.

CERVERA, J. Teoría de la literatura infantil. Bilbao: Edições Mensajero, [s.d.].

CHARTIE, R. Cultura escrita, literatura e história: conversas de Roger Chartie com Carlos Aguirre Anaya, Jesús Anaya Rosique, Daniel Goldin e Antonio Saborit. Porto Alegre: ARTMED, 2001.

COELHO, N. A literatura infantil. História, teoria e análise didática. São Paulo: Ática, 1993. $\overline{1} \overline{9} \overline{1} \overline{1}$

. Panorama histórico da literatura infantil/juvenil. São Paulo: Ática, . O conto de fadas. São Paulo: Ática, 1987.

COLLARO, A. Projeto gráfico: teoria e prática da diagramação. São Paulo: Summus, 2000.

COLOMER, T. et alii. El libro: álbum - invención y evolución de un género para niños. Caracas: Banco del Libro, 1999.

COLOMER, T. et. alii. El papel de la mediación en la formación de lectores. Buenos Aires: Fondo de Cultura Económica, 2005, p. 9-29.

COLOMER, T. Introducción a la literatura infantil y juvenil. Madrid: Síntesis Educación, 1999.

A formação do leitor literário: narrativa infantil e juvenil. São Paulo: Global, 2003. 
- Introducción a la literatura infantil y juvenil. Madrid: Sintesis Educación, 1999.

. (Org.). Siete llaves para valorar las historias infantiles. Madrid: Fūūāación Germán Sánchez Ruipérez, 2002.

CORTEZ, M. Diálogo intersemiótico na literatura infantil de Ziraldo, Eva Furnari e Angela Lago. São Paulo, 2001. Dissertação (Mestrado em Semiótica e Lingüística Geral) - Faculdade de Filosofia Letras e Ciências Humanas, Universidade de São Paulo.

COTRIM, J. História de um segredo (ilustrações André Letria). Edições Afrontamento: Porto, 2002.

CREPALDI, G. Pintura siglo XX. [S.I.]: Electa, 2001.

CUNHA, M. A. A. Literatura infantil. São Paulo: Ática, 1969.

DACOSTA, L. O perfume do sonho, na tarde (ilustrações Cristina Valadas). Porto: ASA, 2004.

DANSET-LEGER. "Aspects de la lecture d'une image". In: L'enfant et les images de la littérature enfantine. Liége: Pierre Mardaga, [s.d.].

DICIONÁRIO da pintura moderna. Trad. Jacy Monteiro. São Paulo: Hemus, 1991.

DINORAH, M. O livro infantil e a formação do leitor. Petrópolis: Vozes, 1995.

DIOGO, A. Literatura infantil - História, teoria, interpretações. Porto: Porto Editora, 1994.

DURAND, M.; BERTRAND, G. L'image dans le livre pours enfants. Paris: L'ecole Sarl, 1975.

ESCARPIT, D. "Lectura del libro de imágenes por los más pequeños". In: THIBAULT-LAULAN, A. M. Imagen y comunicación, Valencia: Editor Fernando Torres, 1973.

. "La ilustración del libro infantil: un arte ambiguo". In: Peonza, no. 51 , p. 22-29, 1999.

. (Ed.) L' enfant, l'image et le récit. Paris: Mouton Editer, 1977.

ESCARPIT, R. A revolução do livro. Trad. M. I. Rolim. Rio de Janeiro: Fundação Getulio Vargas/INL, 1976. 
ESPINOZA, G. Explora y juega con la ilustración: una guía para aprender a narrar con imágenes. Caracas: Banco del Libro, 2004.

FERLAUTO, C. O tipo da gráfica, uma continuação. São Paulo: Edições Rosari, 2002.

$\overline{2} \overline{0} \overline{0} \overline{1}$.

; JANH, H. O livro da gráfica. 3. ed. São Paulo: Edições Rosari,

FIORIN, J. L. Elementos da análise do discurso. São Paulo: Contexto, 2004.

- As astúcias da enunciação: as categorias de pessoa, espaço e tempo. São Paulo: Ática, 2002.

FLOCH, J. Alguns conceitos fundamentais em Semiótica geral. Documentos de Estudo do Centro de Pesquisas Sociossemióticas - 1. São Paulo: Centro de Pesquisas Sociossemióticas, 2001.

"Semiótica plástica e linguagem publicitária". Trad. José Luiz Fiorin. In: Significação, ano VI, 1987. . Indentités Visuelles. Paris: P.U.F., 1995.

"Imagens, signos, figuras. A abordagem semiótica da imagem". In: Cruzeiro Semiótico, n. 3, Porto, 1985.

FOKKEMA, D. Modernismo e pós-modernismo. Lisboa: Vega Universidade, [s.d.].

GARCIA, F. G. "Cómo leer el álbum ilustrado". In: CLIJ, doc. 146, junio, 2002.

GÓES, L. P. Introdução à literatura infantil. São Paulo: Pioneira, 1989.

Melhoramentos, 1991.

GOMES, J. A. "Manuela Bacelar: da ilustração ao álbum". In: Solta Palavra (CRILIJ), boletim n. 6, dezembro, 2004.

. "O conto em forma (to) de álbum: primeiras aproximações". Revista Malasartes, Porto, n.12, novembro, 2003.

- Literatura para crianças e jovens: alguns percursos. Lisboa: Caminho, 1991. 
. Da nascente à voz: contributos para uma pedagogia da leitura. Lisboa: Caminho, 1996.

GONZÁLEZ, L. D.; ZAPARAí N, L. "Entusistas de la fusión - Aproximaciones al lenguaje de los álbumes". In: CLIJ (Cuadernos de Literatura infantil y Juvenil). Barcelona, n. 184, año 18, julio/agosto, 2005.

álbumes" "Cubistas agradecidos n. 180, año 18, marzo, 2005.

. "Optimistas y nostálgicos anglosajones - Aproximaciones al lenguaje de los álbumes". In: CLIJ (Cuadernos de Literatura infantil y Juvenil). Barcelona, n. 179, año 18, febrero, 2005.

"Aproximaciones al lenguaje de los álbumes". In: CLIJ (Cuadernos de Literatura infantil y Juvenil). Barcelona, n. 178, año 18, enero, 2005.

GREIMAS, A. J. Da Imperfeição. Trad. A. C. de Oliveira. São Paulo: Hacker Editores, 2002.

; COURTÉS, J. Dicionário de semiótica. São Paulo: Cultrix, [s.d.].

HALL, S. A identidade cultural na pós-modernidade. Rio de Janeiro, DP\&A, 2004.

HELD, J. "As relações texto/figuras nos livros e álbuns para crianças". In: Jolibert \& Gloton. O poder de ler. Porto: Civilização, 1978, p.143.

. O imáginario no poder: as crianças e a literatura fantástica. Trad. Carlos Rizzi. São Paulo: Summus, 1980.

HERAS, C. Abuelos. Braga: Kalandraka, 2006.

HONRADO, A. Palavra para lavras (ilustrações João Caetano). Porto: Campo das Letras, 2002.

HUCTEON, L. Poética do pós-modernismo. Rio de Janeiro: I mago, 1991.

IANNI, O. Enigmas da modernidade-mundo. Rio de Janeiro: Civilização Brasileira, 2003.

JESUALDO. A literatura infantil. São Paulo: Cultrix, [s.d.].

J OLIBERT, J.; GLOTON, R. O poder de ler. Trad. Emília Bessa. Porto: Civilização, 1978. 
JOLY, M. A imagem e a sua interpretação. Lisboa: Edições 70, 2003.

KHÉDE, S. S (Org.). Literatura infantil: um gênero polêmico. Porto Alegre: Mercado Aberto, 1986.

. Personagens da literatura infanto-juvenil. São Paulo: Ática, 1990.

LAGO, A. Charadas macabras. Belo Horizonte: Formato, 1994.

. Cântico dos cânticos. São Paulo: Paulinas, 1992.

. O personagem encalhado. Belo Horizonte: Lê, 1995.

. A banguelinha. São Paulo: Moderna, 2002.

; LOTUFO, G. A raça perfeita. Belo Horizonte: Formato, [s.d.].

. De Morte!. Belo Horizonte: RHJ, 1992.

. Sua alteza a divinha. Belo Horizonte: RHJ, 1990.

$\overline{1} 9 \overline{8} \overline{.}$

- Chiquita Bacana e as outras pequetitas. Belo Horizonte: Lê,

LAJOLO, M. Do mundo da leitura para a leitura do mundo. São Paulo: Ática, 1993.

; ZILBERMAN, R. Literatura infantil brasileira. História e histórias. São Paulo: Ática, 1985.

LANDOWSKI, E. "Para uma semiótica sensível". In: Eduacação e Realidade, Porto Alegre: Universidade Federal do Rio Grande do Sul, Faculdade de Educação, n. 2, v. 30, p. 93-106, jul/dez, 2005.

$\overline{2} \overline{0} \overline{0} \overline{2}$

. Presenças do outro. Trad. M. Amazonas. São Paulo: Perspectiva,

. "Viagem às nascentes do sentido". In: I. Assis Silva. Corpo e Sentido. São Paulo: Edunesp, 1997.

; FIORIN, J. L. O gosto da gente, o gosto das coisas: abordagem semiótica. São Paulo: EDUC, 1997.

A sociedade refletida: Ensaios de Sociossemiótica I. Trad. E. Brandão. Campinas: EDUC-Pontes, 1991. 
LETRIA, J. Letras \& Letria (ilustrações André Letria). Lisboa: Dom Quixote, 2005.

Ambar, 2002.

O menino eterno (ilustrações Danuta Wojciechowska). Porto:

LIMA, G. Dissertação de mestrado. O designe Gráfico do livro infantil brasileiro, a década de 70 - Ziraldo, Gian Calvi, Eliardo França. PUC-RJ.

LINS, G. Livro infantil? - projeto gráfico, metodologia e subjetividade. Rio de Janeiro: Rosari, 2003.

LOBATO, M. A Barca de Gleyre. São Paulo: Brasiliense, 1946.

LOURENÇO, E. A morte de Colombo - metamorfose e fim do Ocidente como mito. Lisboa: Gradiva, 2005.

b) O labirinto da saudade. Lisboa: Gradiva, 2005.

LUCAS, F. "Ideologia e literatura infantil". In: Colóquio/Letras. Revista bimestral, Lisboa, n. 84, março, 1985.

MAIA, G. "Manuela Bacelar: um sol para as histórias escritas". In: Solta Palavra (CRILIJ), boletim n. 6, dezembro, 2004.

. "Entrelinhas: quando o texto também é ilustração". In: VIANA; MARTINS; COQUET (Org.). Leitura, Literatura infantil e ilustração: investigação e prática docente. Braga: Centro de Estudos da Criança Universidade do Minho, 2003.

3-8, dezembro, 2002.

. "O visível, o legível e o invisível". In: Malasartes, Porto, n. 10, p.

MANGUEL, A. Lendo imagens: uma história de amor e ódio. Trad. R. Figueiredo et alii. São Paulo: Companhia das Letras, 2001.

. Uma história da leitura, Trad. P. M. Soares. São Paulo: Companhia das Letras, 1997.

MARTíN, A. "Historias de las lecturas infantiles - Las aleluyas - Primera lectura y primeras imágenes para niños - siglos XVIII - XIX". In: CLIJ (Cuadernos de Literatura infantil y Juvenil). Barcelona, n. 179, año 18, febrero, 2005.

MARTINS, M. H. Crônica de uma utopia. São Paulo: Brasiliense, 1989.

. (Org.). Questões de linguagem. São Paulo: Can+arta 1 nnn 
MARTINS, W. A palavra escrita: História do livro, da imprensa e da biblioteca. São Paulo: Ática, 1998.

MEI RELES, C. Problemas de literatura infantil. 3. ed. Rio de Janeiro: Nova Fronteira, 1984.

MELLO, A. M. L de; TURCHI, M. Z.; SILVA, V. M. T. Literatura infantil: prosa \& poesia. Goiânia: Editora da UFG, 1995.

MELLO, R. A flor do lado de lá. São Paulo: Global, 2004.

Vizinho, Vizinha (ilustrações Roger Mello, Mariana Massarani e Graça Lima). São Paulo: Companhia das Letrinhas, 2002.

MERLEAU-PONTY, M. Fenomenologia da percepção. Trad. C. A. R. de Moura. 2. ed. São Paulo: Martins Fontes, 1999.

MERLEAU-PONTY, M. Palestras. Lisboa: Edições 70, 2002.

. O olho e o espírito. Lisboa: Vega, 2004.

MESQUITA, A. (Org.). Pedagogias do imaginário - Olhares sobre a literatura infantil. Porto: ASA, 2002.

MÉSSEDER, J. Timor Lorosae: a ilha do sol nascente (ilustrações André Letria). Porto: Ambar, 2001.

MOYA, A. Shazan! (ilustrações Roger Mello). São Paulo: Perspectiva, 1977.

MURRAY, R. Jardins (ilustrações Roger Mello). Rio de Janeiro: Manati, 2001.

. Desertos. Rio de Janeiro, Objetiva, 2006.

NECYK, B. J.; CIPINIUK, Alberto. PONTIFÍCIA UNIVERSIDADE CATÓLICA DO RIO DE JANEIRO Departamento de Artes. Texto e imagem: um olhar sobre o livro infantil contemporâneo. 2007. Dissertação (Mestrado em Artes) - Pontifícia Universidade Católica do Rio de Janeiro, Rio de Janeiro, 2007.

OLIVEIRA, A. C. de. "Visualidade, entre significação sensível e inteligível". In:

Eduacação e Realidade, Porto Alegre: Universidade Federal do Rio Grande do Sul, Faculdade de Educação, n. 2, v. 30, p. 107-122, jul/dez, 2005. 
OLIVEIRA, M. A. "A literatura infantil e a interação participativa da criança com a obra" In: PENTEADO, H. (Org.). Pedagogia da comunicação: teorias e práticas. São Paulo: Cortez, 1998.

. Leitura prazer: interação participativa com a literatura infantil na escola. São Paulo: Paulinas, 1996.

OLIVEIRA, R. Como vejo a arte de ilustrar e as intenções do meu trabalho. Disponível em <www.docedeletra.com.br/ruideoliveira>. Acesso em: 15 dez 2006.

PACHECO, E. D. (Org.). Comunicação, educação e arte na cultura infantojuvenil. São Paulo: Edições Loyola, 1991.

PADILHA, D. Percepções do ser: o endereçamento da poesia de Cecília Meireles e Roseana Murray. Disponível em: $<w w w . a l b . c o m . b r / a n a i s 16 / s e m 08 p d f / s m 08 s s 10 \_02 . p d f>$. Acesso em: 28 JUL 2008.

PADRINO, J. Formas y colores, la ilustración infantil en España. Cuenca: Ediciones de la Universidad de Castilha-La Mancha, 2004.

PAES, J. P. Poesia para crianças: um depoimento. São Paulo: Editora Giordano, 1996.

PALO, M. J.; OLIVEIRA, M. R. D. Literatura infantil: voz de criança. São Paulo: Ática, 1992.

PAZ, O. Signos em rotação. São Paulo: Perspectiva, 1976.

PERROTI, E. Confinamento cultural. Infância e leitura infantil. São Paulo: Summus, 1990.

PFRONM, S. N. (Org.). O livro na educação. São Paulo: Primor/Nec, 1974.

PI NTO, J. B. Pontos de literatura infantil. São Paulo: FTD, 1967.

PIRES, M. História da literatura infantil Portuguesa. Lisboa: Veja, 1983.

PLATÃO, F.; FIORIN, J. Para entender o texto. São Paulo: Ática, 1999.

POIZAT, C. Máquinas. Braga: Kalandraka, 2000.

REIS, C.; LOPES, A. Dicionário de narratologia. Coimbra: Almedina, 2002.

ROCHA, N. Breve história da literatura para criança edição actualizada até o ano 2000. Lisboa: Caminho, 
RODRIGUES, C. A função da ilustração e do texto no desenvolvimento perceptivo da criança em contacto com a literatura infantil. Braga: Universidade do Minho, 1987.

ROSA, G. Fita Verde no cabelo: nova velha estória (ilustrações Roger Mello). Rio de Janeiro: [s.n.], 1992.

SÁ, D. A literatura infantil em Portugal. Braga: Franciscana, 1981.

SALEM, N. História da literatura infantil. São Paulo: Mestre J ou, 1959.

SALISBURY, M. Ilustración de libros infantiles: como crear imágenes para su publicación. Trad. J ofre Homedes. Barcelona: Acanto, 2005.

SANCHES, M. R. (Org.). Deslocalizar a Europa. Lisboa: Cotovia, 2005.

SANDRONI, C. S. A criança e o livro. São Paulo: Ática, 1987.

SANTOS, B. S. Pela mão de Alice - o social e o político na pósmodernidade. Porto: Afrontamento, 1994.

- A cor do tempo quando foge: crônicas (1985-2000). Porto: Áfrontamento, 2001.

SARAIVA, A. A cultura em Portugal: teoria e história. Lisboa: Livraria Bertrand, 1981.

SARAMAGO, J. A maior flor do mundo (ilustrações João Caetano). São Paulo: Companhia das Letrinhas, 2001.

SCHITTER, I. La otra lectura: la ilustración en los libros para niños. Buenos Aires: Lugar Editorial, 2005.

SERRA, E. (Org.). 30 anos de literatura para crianças e jovens: algumas leituras. Campinas: Mercado de Letras, Associação de Leitura do Brasil, 1998.

SERRÃO, J. Dicionário de História de Portugal. Porto: Livraria Figueirinha, 1985.

SHAVIT, Z. Poética da literatura para crianças. Trad. Ana Fonseca. Lisboa: Caminho, 2003.

SILVA, E. T. Leitura na escola e na biblioteca. Campinas: Papirus, 1995. 
SILVA-DíAZ, M.C. La metaficción como un juego de niños: una introducción a los álbumes metaficcionales. Caracas: Banco del Libro, 2005.

SISTO, C. Ver de ver meu pai (ilustrações Roger Mello). Rio de janeiro: Nova Fronteira, 1994.

SMOLKA, A. L. B. A criança na fase inicial da escrita. São Paulo: Cortez, 1999.

SUARI, N. Mirando cuentos. Lo visible e invisible en las ilustraciones de la literatura infantil. Barcelona: Laertes, 2004.

TEIXEI RA, L. Entre dispersão e acúmulo: para uma metodologia de análise de textos sincréticos. In: Gragoatá - Revista do Programa de PósGraduação em Letras, Niterói, n. 16, p.229-242, 1o. semestre/2004.

. As cores do discurso. Niterói: EDUFF, 1996.

TORRÃO, M. Come a sopa, Marta!. Lisboa: O Bichinho do Conto, 2004.

TORRES, E. Palabras que acunan: cómo favorecer la disposición lectora en bebés. Caracas: Banco del Libro, 2003.

TRAÇA, M. O fio da memória: do conto popular ao conto para crianças. Porto: Porto Editora, 1992.

TSCHICHOLD, J. Ensaios sobre tipografia e estética do livro. Cotia, SP: Ateliê Editorial, 2007.

VALERY, P. Variedades. (Org. e Trad.) J oão Alexandre Barbosa. São Paulo: Iluminuras, 1999.

VELOSO, R. A obra de Aquilino Ribeiro para crianças. Porto: Porto Editora, 1994.

VILARDI, R. Ensinando a gostar de ler e formando leitores para a vida inteira. Rio de Janeiro: Qualitymark, 1999.

VILCHES, L. La lectura de la imagen - prensa, cine, televisión. Barcelona, Paidós I bérica, 1995.

WENSELL, U. “El papel de las ilustraciones en la difusión de los libros para niños". In: CERRILLO, P.; PADRINO, J. Presente y futuro de la literatura infantil. Cuenca: Ediciones de la Universidad de Castilla-La Mancha, 2000.

YUNES, E.; PONDÉ, G. Leitura e leituras da literatur FTD, 1989. 
ZILBERMAN, R. (Org.). A produção cultural para a criança. 4. ed. Porto Alegre: Mercado Aberto, 1990.

_-_-_- A literatura infantil na escola. São Paulo: Global, 1994.

$\overline{1} 989$.

. Estética da recepção e História da Literatura. São Paulo: Ática,

ZIRALDO. O menino quadradinho. São Paulo: Melhoramentos, 1989.

. Flicts. São Paulo: Melhoramentos, 1969.

- O menino mais bonito do mundo (ilustrações Samir Mattar e Marina Apoena). São Paulo: Melhoramentos, 1983.

; ZÉLI O. A bela borboleta. São Paulo: Melhoramentos, 1980. 